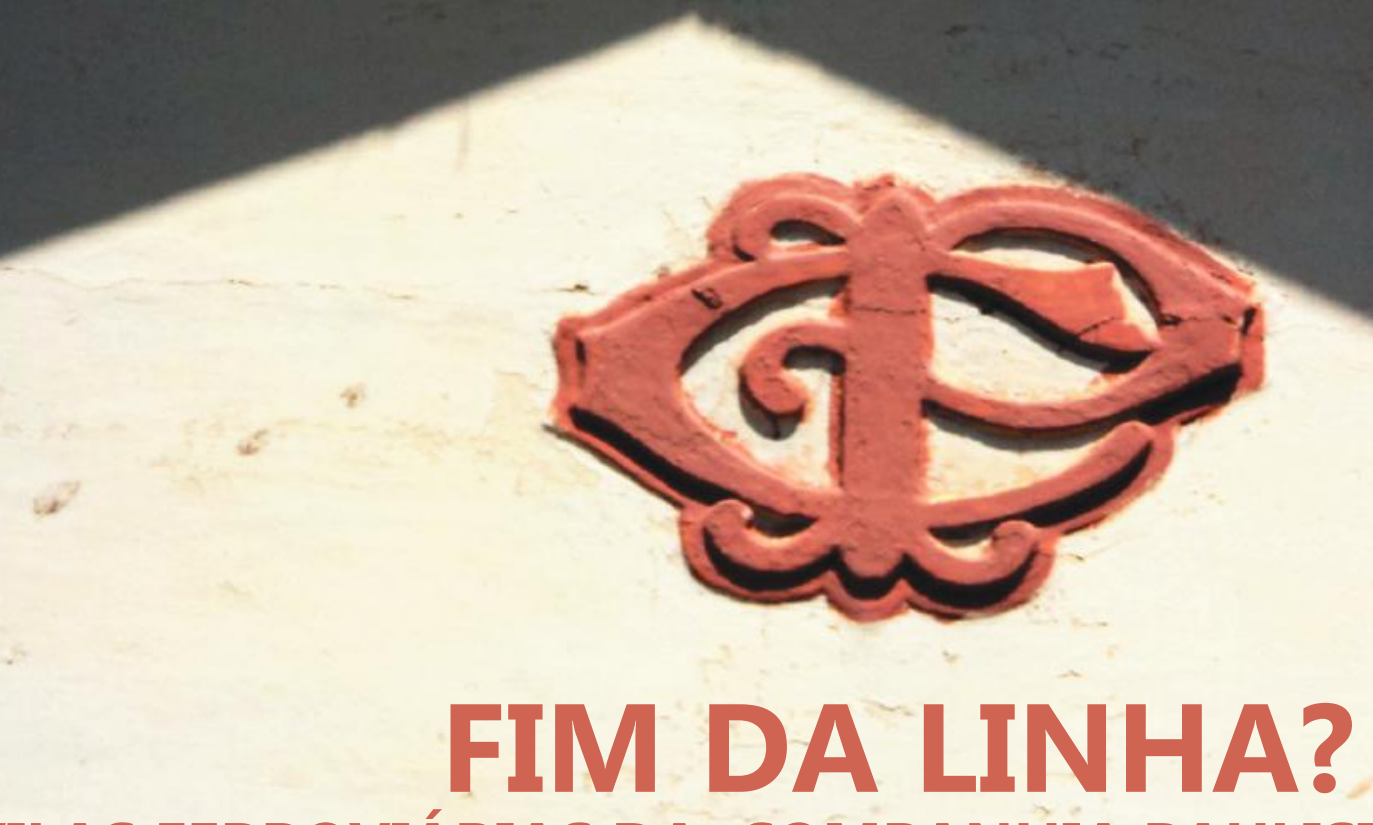

VILAS FERROVIÁRIAS DA COMPANHIA PAULISTA (1868-1961): UMA INVESTIGAÇÃO SOBRE HISTÓRIA E PRESERVAÇÃO

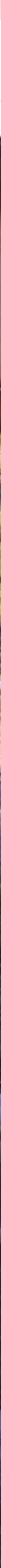


LUCIANA MASSAMI INOUE

FIM DA LINHA?

\title{
VILAS FERROVIÁRIAS DA COMPANHIA PAULISTA (1868-1961): UMA INVESTIGAÇÃO SOBRE HISTÓRIA E PRESERVAÇÃO
}

\author{
Tese apresentada à Faculdade \\ de Arquitetura e Urbanismo da \\ Universidade de São Paulo para \\ obtenção do título de Doutor em \\ Ciências \\ Área de Concentração: História \\ e Fundamentos da Arquitetura e \\ Urbanismo
}

Orientadora: Profa. Dra. Maria Lucia Caira Gitahy

\section{SÃO PAULO}

\section{6}

EXEMPLAR REVISADO E ALTERADO EM RELAÇÃO À VERSÃO ORIGINAL, SOB RESPONSABILIDADE DO AUTOR E ANUÊNCIA DO ORIENTADOR.

$O$ original se encontra disponível na sede do programa 
AUTORIZO A REPRODUÇÃO E DIVULGAÇÃO TOTAL OU PARCIAL DESTE TRABALHO, POR QUALQUER MEIO CONVENCIONAL OU ELETRÔNICO, PARA FINS DE ESTUDO E PESQUISA, DESDE QUE CITADA A FONTE.

E-MAIL DA AUTORA: lumassami@gmail.com

Capa:

Diagramação: Luciana Massami Inoue

Imagens: Emblema da Companhia Paulista em uma edificação; Linha de trem em Itirapina; Casas de vilas ferroviárias de Dois Córregos, Rincão, Brotas, São Carlos e Jaú. Fotos: Luciana Massami Inoue, 2013.

Inoue, Luciana Massami

I58f Fim da linha? vilas ferroviárias da Companhia Paulista (1868-1961): uma investigação sobre história e preservação / Luciana Massami Inoue. -- São Paulo, 2016.

324 p. : il.

Tese (Doutorado - Área de Concentração: História e Fundamentos da Arquitetura e do Urbanismo) - FAUUSP.

Orientador: Maria Lucia Caira Gitahy

1.Patrimonio cultural 2.Ferrovias (Preservação) 3.Vilas operárias 4.Paisagem cultural I.Título

CDU 725.31 
Nome: INOUE, Luciana Massami

Título: Fim da Linha? Vilas Ferroviárias da Companhia Paulista (1868-1961): uma investigação sobre história e preservação

Tese apresentada à Faculdade de Arquitetura e Urbanismo da Universidade de São Paulo para obtenção do título de Doutor em Ciência.

Área de Concentração: História e Fundamentos da Arquitetura e Urbanismo

Orientadora: Profa. Dra. Maria Lucia Caira Gitahy

Aprovado em:

\section{Banca Examinadora:}

Prof. Dr. Instituição:

Julgamento: Assinatura:

Prof. Dr. Instituição:

Julgamento: Assinatura:

Prof. Dr. Instituição:

Julgamento: Assinatura:

Prof. Dr. Instituição:

Julgamento: Assinatura:

Prof. Dr. Instituição: Assinatura: 
A meus pais, que me ensinaram o respeito pelos antepassados e a importância dos estudos.

E à memória dos ferroviários das inúmeras vilas ferroviárias espalhadas pelo Brasil e a todos os trabalhadores manuais de ontem e de hoje, nem sempre lembrados, que fazem rodar muitas máquinas e casas, fazendo possíveis muitos trabalhos intelectuais. 


\section{AGRADECIMENTOS}

À minha orientadora Profa. Dra. Maria Lucia Caira Gitahy, que tem acompanhado desde a iniciação científica na graduação desta faculdade, e me ensinou o "be-a-bá" da pesquisa. Agradeço não apenas sua orientação, mas sua dedicação, apoio e amizade durante todos estes anos (como o tempo voa, Malu! Foram vinte anos que trabalhamos juntas!)

À Fundação de Amparo à Pesquisa do Estado de São Paulo (FAPESP) pela concessão da bolsa de doutorado e pelo apoio financeiro para a realização desta pesquisa (No. Processo FAPESP: 2013/23935-5).

Aos Professores Prof. Dra. Teresa da Silva Lopes, da University of York (Reino Unido) e Prof. Dr. Paul Meurs da TU Delft University (Holanda) que possibilitaram a visita técnica, e permitiram que eu pudesse conhecer mais de perto o patrimônio industrial e ferroviário e formas de preservar nos diferentes países.

Às professoras supervisoras na monitoria PAE (Programa de Aperfeiçoamento de Ensino), Profa. Dra. Beatriz Kühl, na disciplina de Técnicas Retrospectivas, e novamente Prof. Dra. Maria Lucia Gitahy, na disciplina de Fundamentos à Crítica da Arquitetura e do Urbanismo, ambas disiciplinas ministradas na graduação.

Às professoras da Banca de Qualificação, novamente Prof. Dra. Beatriz Kühl e Prof. Dra. Telma de Barros Correia, pelos comentários e sugestões à presente tese.

Aos professores das diversas disciplinas cursadas durante o curso de pós-graduação, que de alguma forma e de outra contribuíram para as reflexões da presente tese: Prof. Dr. Carlos Lemos, Profa. Dra.Maria Lucia Bressan Pinheiro, Profa. Dra. Ana Lúcia Duarte Lanna, Prof. Dr. Paulo César Garcez Marins, Profa. Dra. Beatriz Piccoloto Bueno, Prof. Dr. Dante Teixeira Martins.

Ao Prof. Dr. Rodrigo Toledo, da UNESP Araraquara, filho de ex-ferroviário e ex-residente de Rincão, que gentilmente acompanhou-me em uma visita de campo à mesma.

Aos bibliotecários da FAU-USP, em especial Maria José Polletti. Aos funcionários dos arquivos visitados, Museu Ferroviário de Jundiaí e em especial ao staff do National Railway Museum, pela atenção e dedicação.

Ao pessoal do grupo de pesquisa HSTTFAU, liderado pela Profa. Dra. Maria Lucia Gitahy, por ter escutado o que eu vinha pesquisando e ajudando com comentários, em especial Fernando Atique e Cristina de Campos.

Aos colegas da pós-graduação que conheci durante este percurso, em especial, Agnes Helena Chiuratto, Ana Lúcia Saad, Ângela Rodrigues, Clara Carvalho e Esdras Arraes.

À Virgínia Pereira, pela amizade e a ajuda na revisão do Abstract.

Ao Inácio, pelo companheirismo e pela companhia nas visitas de campo de Brotas à Crewe!

E a todos que de alguma forma contribuíram a esta pesquisa: muito obrigada! 


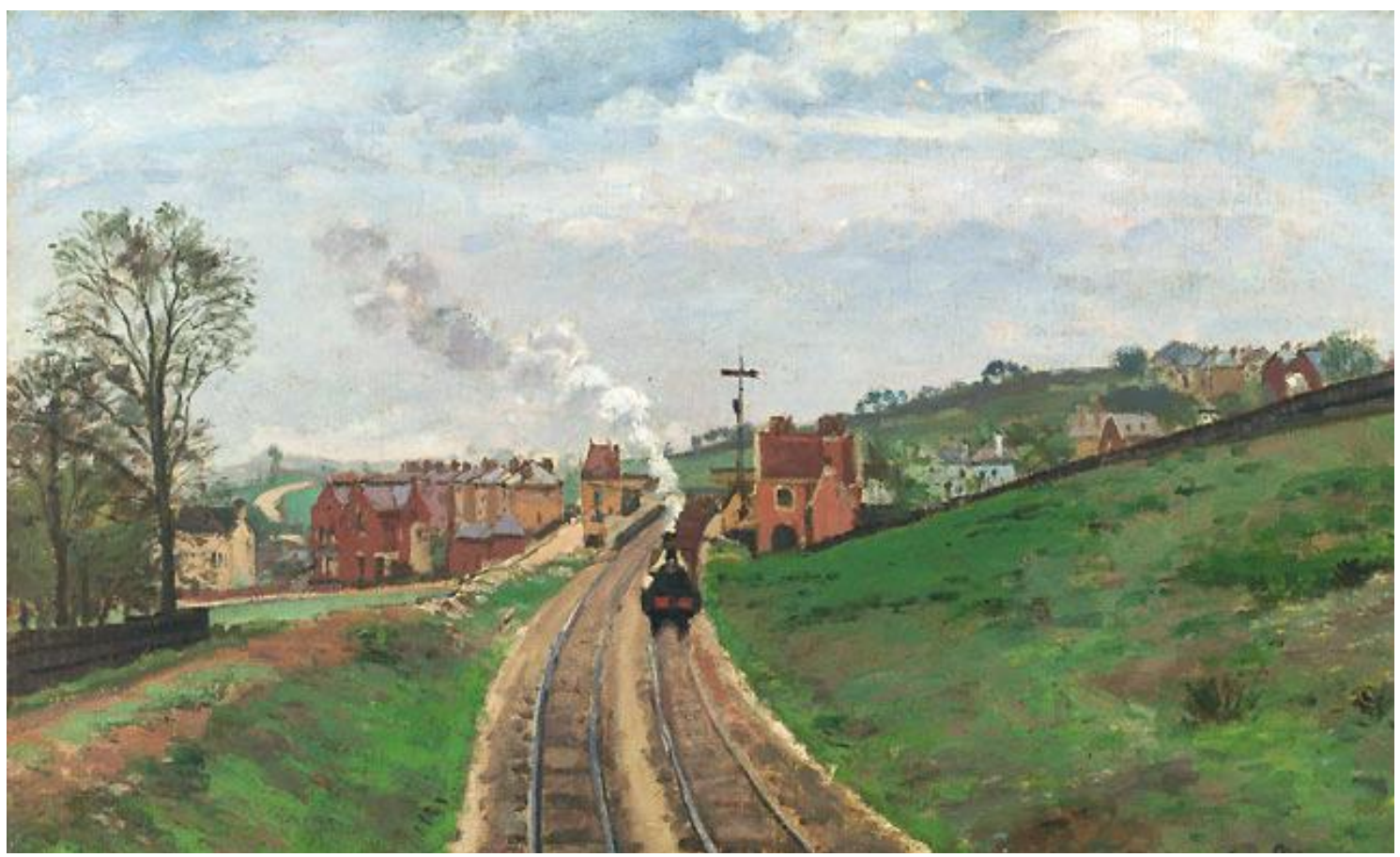

Camille Pissarro - Lordship Lane Station, Dulwich, 1871. In <https://www. wikiart.org/en/camille-pissarro/lordship-lane-station-dulwich-1871>. Acesso em out 2016.

"Happy are those who see beauty in modest spots where others see nothing. Everything is beautiful, the whole secret lies in knowing how to interpret it." Camille Pissarro 1830-1903 In BILLSON, Peter. Derby and the Midland Railway. Derby: Breedon 1996.)

"Les plus grandes production de l'architecture sont moins des oeuvres individuelles que des oeuvres sociales; plutôt l'enfantement des peuples en travail que le jet des hommes de génie ; le depôt que laisse une nation; les entassements que font les siècles; le résidu des évaporations successives de la societé humaine; en un mot, des espèces de formations. " Victor Hugo (epígrafe do item 2 ROSSI, Aldo 1966. P. 162) 


\title{
RESUMO
}

\author{
INOUE, L. M. Fim da Linha? Vilas ferroviárias da Companhia Paulista (1868- \\ 1961): uma investigação sobre história e preservação. 2016. 324 f. Tese \\ (Doutorado) - Faculdade de Arquitetura e Urbanismo, Universidade de São \\ Paulo, São Paulo, 2016.
}

O propósito desta pesquisa foi estudar a história social das vilas ferroviárias da Companhia Paulista e contribuir para a discussão sobre a preservação das mesmas. Dentre as diversas companhias ferroviárias espalhadas pelo estado de São Paulo, elegeu-se a Companhia Paulista, a primeira formada com capital nacional e com grande penetração geográfica, política, econômica e social. E dentre as suas vilas, foram escolhidas somente seis como estudo de caso - Itirapina, Brotas, Dois Córregos, Jaú, São Carlos e Rincão - ainda não analisadas, e que apresentavam um número considerável de casas e se localizavam geograficamente próximas, no "coração" do estado de São Paulo. O recorte temporal é o da própria Companhia que inicia-se em 1868, e termina em 1961, como empresa privada. Como métodos empregados a pesquisa utilizouse de fontes primárias - especialmente os Relatórios da Companhia Paulista - e como fontes secundárias, houve duas vertentes que se procurou conjugar: uma referente às vilas ferroviárias, a Companhia Paulista e seus trabalhadores e, outra vertente referente às questões de preservação. Foram de fundamental importância as visitas de campo às respectivas cidades, na verificação do estado de conservação, sua morfologia urbana e a aplicabilidade de propostas pensadas para sua preservação. Igualmente importantes foram às visitas técnicas realizadas para analisar e comparar o encaminhamento dado ao patrimônio industrial ferroviário e urbano nos diferentes países. As vilas ferroviárias tomadas de maneira isolada, parecem ser insignificantes, contudo, ao estudar a história social da Companhia Paulista e principalmente a de seus trabalhadores, as vilas passam a adquirir outro significado. Desse modo, o valor das vilas ferroviárias é melhor entendido com a apreciação dos processos históricos mais amplos. Um dos caminhos possíveis encontrados para a re-significação encontra apoio no conceito de paisagem cultural, assim como no conceito de áreas de conservação ou conservação integrada. Os conceitos se complementam e ambos auxiliam a gestão do patrimônio. E a partir do conceito de áreas de conservação, encontra-se a leitura morfotipológica. Ao invés de uma leitura estilística das vilas ferroviárias, optou-se por fazer tal leitura, mais ligada ao tecido urbano, aliada é claro, à investigação da história social destes espaços, que acreditamos que dá sustentação e significação para uma política de preservação, na busca de encontrar o caráter do lugar, e ao mesmo tempo conectar o passado à dimensão contemporânea que devem ter as políticas de preservação. Espera-se assim ter cumprido com os objetivos, de valorizar novamente as vilas ferroviárias e o mundo do trabalho dentro da história e das políticas de preservação.

Palavras-chave: patrimônio, ferrovias, vila operária, paisagem cultural. 


\section{ABSTRACT}

\section{INOUE, L. M. End of the line? Railway Worker Villages of Companhia} Paulista (1868-1961): a research about history and preservation. 2016. 324 fl. PhD Thesis. Faculty of Architecture and Urbanism, University of São Paulo, São Paulo, 2016.

The aim of this research was to study the social history of the railway worker villages of the "Companhia Paulista" and to contribute to the discussion about their preservation. Among many railway companies spread in the São Paulo state, the "Companhia Paulista" was chosen because it was the first company to be founded with national capital and due to its geographical, political, economic and social influence. Among its villages, only six of them were chosen as cases of study - "Itirapina", "Brotas", "Dois Córregos", "Jaú", "São Carlos" e "Rincão" - villages not yet analysed, which showed a considerable number of houses and were located geographically close to each other, "in the heart of" São Paulo state. The time frame of the research was given by the company life time itself, with start in 1868 and end in 1961 as a private enterprise. The methods employed were the investigation of primary sources - especially the "Companhia Paulista" annual reports - and secondary sources, which were divided into two parts that we sought to combine: one refers to railway worker villages, the "Companhia" and its workers, and the other one refers to the preservation issues. The field visits to the aforementioned cities were important for the verification of their conservation status, their urban morphology as well as for the analysis of the applicability of the proposals to their preservation. The technical visits made were similarly important to analyse and compare the solution given to the industrial railway and urban heritage in different countries. Taken into an isolated view, the railway villages seem insignificant, however, as we study the accompanying social history of the "Companhia Paulista" and mainly of its workers, the villages acquire a whole new meaning. Thus in this way, the value of the railway worker villages is better understood with the analysis of broader historical processes. One of the possible ways found to the "re-meaning" is supported by the cultural landscape concept as well as the concept of conservation areas or integrated conservation. The concepts complement one another and both help in the heritage management. From the concept of conservation areas, the morphotypological analysis emerges. Instead of a stylistic analysis of the railway worker villages, we preferred the present type of analysis, more related to the "urban fabric" and connected to the investigation of the social history of these places, which we believe sustain and give meaning to the preservation policies, in the search of the "character of the place", while at the same time trying to connect the past to the contemporary dimension, which should have the preservation policies. We hope that with this research we have accomplished the following purposes: once again give value to the railway worker villages and the associated world of labour inside history and inside the preservation policies.

Keywords: heritage, railways, worker villages, cultural landscape 


\section{LISTA DE MAPAS}

Mapa 1 - Rede ferroviária brasileira .................................................................. 4

Mapa 2 - Linhas e vilas ferroviárias da Companhia Paulista.................................p. 7

Mapa 3 - Distribuição, localização e identificação dos bens tombados pelo IPHAN considerados patrimônio industrial no Brasil........................................................... 57

Mapa 4 - Mapas da evolução ferroviária de São Paulo e do roteiro do café.........p. 79

Mapa 5 - Carta ferroviária em 1901.................................................................p. 87

Mapa 6 - Mapa do Estado de São Paulo e carta ferroviária em 1901.................p. 87

Mapa 7 - Mapa das principais rodovias do Estado de São Paulo - década de 1990...p. 97

Mapa 8 - Mapa das linhas da Companhia Paulista em 1938............................p. 132

Mapa 9 - Mapa das linhas da Companhia Paulista em 1954...........................p. 133

Mapa 10 - Implantação de Jaú............................................................................p. 155

Mapa 11 - Mapa de Brotas................................................................................. 155

Mapa 12 - Implantação de Dois Córregos..............................................................p. 158

Mapa 13 - Implantação de Rincão......................................................................... 158

Mapa 14 - Mapa de Itirapina........................................................................... 159

Mapa 15 - Implantação de Itirapina....................................................................... 159

Mapa 16 - Mapa de São Carlos, Vila Morumbi...................................................p. 160

Mapa 17 - Implantação de São Carlos................................................................p. 160

Mapa 18 - Implantação de casa de turma …......................................................p. 169

Mapa 19 - Rincão: Foto aérea do município e arredores......................................p. 230

Mapa 20 - Rincão: Foto aérea do município e área do complexo ferroviário.....p. 230

Mapa 21 - Rincão: limite do complexo ferroviário e principais edifícios.................p. 233

Mapa 22 - Complexo ferroviário de Rincão: Principais tipologias residenciais.....p. 234

Mapa 23 - Complexo ferroviário de Rincão: usos dos edifícios...............................p. 268

Mapa 24 - Complexo ferroviário de Rincão: Traçado viário......................................p. 268

Mapa 25 - Complexo ferroviário de Rincão: Logradouro ......................................p. 272

Mapa 26 - Complexo ferroviário de Rincão: "Monumentos"..................................p. 274

\section{LISTA DE TABELAS}

Tabela 1 - Quantitativo de imóveis transferidos para a União na Região Sudeste .....p. 4 Tabela 2 - Bens tombados pelo IPHAN relacionados a conjuntos urbanos/vilas e ao

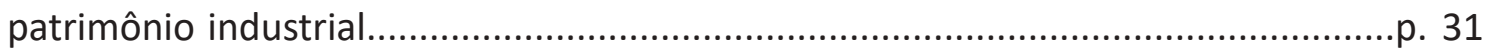

Tabela 3 - Bens tombados pelo CONDEPHAAT relacionados a conjuntos urbanos/vilas e 
ao patrimônio industrial

p. 32

Tabela 04 - Bens tombados pelo CONPRESP relacionados a conjuntos urbanos/vilas e ao patrimônio industrial.

p. 34

\section{LISTA DE GRÁFICOS}

Gráfico 1 - Porcentagem de termos em voga nos documentos de políticas de patrimônio cultural internacional. p. 68

Gráfico 2 - Imigrantes transportados gratuitamente pela Companhia Paulista entre 1883 à 1909

p. 128

\section{LISTA DE FIGURAS}

Figura 1 - Capa do folheto do Bournville Trust.

p. 72

Figura 2 - Capa do folheto do New Earswick.

p. 72

Figura 3 - Página do folheto de aplicação para uma casa na vila de New Earswick.......p. 73 Figura 4 - "Cena de família de Adolfo Augusto Pinto", 1891, do pintor Almeida Júnior. p. 82

Figura 5 - Desenho de maio de 1843, extraído de um diário de ferroviário/ cozinhando na lareira...... .p. 172

Figura 6 - Página do Bromborough Pool Conservation Area Guidance Leaflet.....p. 207

\section{LISTA DE FOTOGRAFIAS}

Foto 1 - Prancha encontrada no Museu Ferroviário de Jundiaí..... p. 13

Foto 2 - Detalhe da foto 1: Carimbo da prancha p. 13

Foto 3 - Detalhe da foto 1: outra data encontrada.....

Foto 4 - Detalhe da foto 1: planta p. 14

Foto 5 - Detalhe da foto 1 : fachada frontal. p. 14

Foto 6 - Detalhe da foto 1 : fachada lateral p. 14

Foto 7 - Detalhe da foto 1 : corte p. 14

Foto 8 - Planta de uma casa da vila ferroviária de Campinas. p. 14

Foto 9 - Vila ferroviária de Jaú: casa encoberta pelo muro p. 16

Foto 10 - Vila ferroviária de Jaú: a mesma casa sem o muro p. 16

Foto 11 - Uma das tipologias de casa da vila operária de Port Sunlight. p. 18

Foto 12 - Conjunto de casas da vila operária de Bromborough Pool. p. 18

Foto 13 - Visão geral de uma das ruas da vila operária de Saltaire p. 18 
Foto 14 - Conjunto de casas de uma das tipologias de New Earswick p. 19

Foto 15 - Visão geral de uma das ruas da vila ferroviária de Swindon. p. 19

Foto 16 - Casas de uma das tipologias de Swindon. p. 19

Foto 17 - Uma das ruas de Crewe. p. 19

Foto 18 - Uma das ruas de Derby...... p. 19

Foto 19 - Vila ferroviária de Itirapina. p. 23

Foto 20 - Foto atual da estação de Itirapina. p. 23

Foto 21 - Foto atual de uma das casas da vila ferroviária de Itirapina. p. 23

Foto 22 - Foto de Brotas e estações próximas. p. 23

Foto 23 - Foto atual da estação de Brotas. p. 24

Foto 24 - Foto atual de uma das casas da vila ferroviária de Brotas. p. 24

Foto 25 - Foto da estação e da vila ferroviária de Dois Córregos. p. 24

Foto 26 - Foto atual da estação de Dois Córregos.

Foto 27 - Foto atual das casas da vila ferroviária de Dois Córregos..... p. 24

Foto 28 - Foto atual da estação de Jaú. p. 25

Foto 29 - Foto atual das casas da vila ferroviária de Jaú. p. 25

Foto 30 - Casa da vila ferroviária de Jaú. p. 25

Foto 31 - Foto atual da estação de São Carlos. p. 25

Foto 32 - Foto atual de uma das casas da vila ferroviária de São Carlos. p. 25

Foto 33 - Fotos da estação de São Carlos. p. 26

Foto 34 - Foto atual da estação de Rincão. p. 26

Foto 35 - Foto atual de uma das tipologias da vila ferroviária de Rincão. p. 26

Foto 36 - Fotos da estação e casas da vila ferroviária de Rincão. p. 26

Foto 37-Placa que se encontra na Vila dos Ingleses (São Paulo Railway), São Paulo-SP. p. 38

Foto 38 - Edifício da escola abandonada na Vila Maria Zélia. p. 41

Foto 39 - Alguns exemplos de descaracterização de edifícios da Vila Maria Zélia........p. 41

Foto 40 - Alguns exemplos de descaracterização de edifícios da Vila Maria Zélia........

Foto 41 - Vila Economizadora.

Foto 42 - Alguns exemplos de mudanças de caixilhos da Vila Economizadora.......p. 42

Foto 43 - Alguns exemplos de mudanças de caixilhos da Vila Economizadora.....p. 42

Foto 44 - Casa da vila ferroviária de Itirapina.

Foto 45 - Casa da vila ferroviária de Brotas.....

Foto 46 - Casa da vila ferroviária de Dois Córregos.....

Foto 47 - Casa da vila ferroviária de Jaú. 
Foto 48 - Casa da vila ferroviária de São Carlos

Foto 49 - Casa da vila ferroviária de Rincão.

Foto 50 - Foto de uma das páginas da publicação feita pela comunidade de Cricklewood: Resident's Community Association (RCA). p. 73

Foto 51 - Foto de uma das páginas da publicação feita pela comunidade de Cricklewood: Resident's Community Association (RCA). p. 73

Foto 52 - Inauguração da estação de Campinas (1872) . p. 80

Foto 53 - Retrato de Adolpho Pinto. p. 82

Foto54-Fotos dorio Mogy Guassú e suas pontes. .p. 100

Foto 55 - Locomotiva a vapor da Companhia Paulista .p. 102

Foto 56 - Locomotiva a vapor da marca Baldwin da Companhia Paulista .p. 102

Foto 57 - Locomotiva elétrica da Companhia Paulista .p. 102

Foto 58 - Locomotiva a diesel da Companhia Paulista .p. 102

Foto 59 - Locomotiva a vapor e carro de 1a . classe da Companhia Paulista..... .p. 102

Foto 60 - Carro Pullman da Companhia Paulista. .p. 103

Foto 61 - Interior de um carro Pullman da Companhia Paulista. .p. 103

Foto 62 -Carro trem "R" da Companhia Paulista. .p. 103

Foto 63 - Interior de um carro trem "R" da Companhia Paulista. p. 103

Foto 64 - Interior de um carro de madeira de 1‥ classe da Companhia Paulista. p.103

Foto 65 - Interior de um carro de madeira de 2a. classe da Companhia Paulista. .p. 103

Foto 66 - Interior de um carro restaurante (em aço) da Companhia Paulista..... .p. 104

Foto 67 - Interior de um carro restaurante (em aço) da Companhia Paulista..... .p. 104

Foto 68 - Carro de transporte de presos da Companhia Paulista. .p. 104

Foto 69 - Interior de um carro de transporte de enfermos. p. 104

Foto 70 - Trem frigorífico na estação de São Carlos .p. 104

Foto 71-Conselheiro Antônio Prado e Edmundo Navarro. .p. 105

Foto 72 - Diversas fotos dos hortos florestais de Rio Claro e Loreto .p. 105

Foto 73 - Diversas fotos do horto florestal de Rio Claro. .p. 105

Foto 74-Francisco Paes de Monlevade. .p. 106

Foto 75 - O fundador (Francisco Antônio de Souza Queiroz)e os presidentes da Companhia Paulista. p. 110

Foto 76 - Foto atual da estação de Anápolis e do morro do Cuscuzeiro..... .p. 113

Foto 77-Conselheiro Antônio da Silva Prado. .p. 115

Foto 78-Modelo de casa de empregados e ferroviários. p. 116 Foto 79-Primeiros Chefes de Seções. 
Foto 80-Engenheiros residentes de 1918........................................................p. 118

Foto 81 - Escritório central: Adolpho Pinto e funcionários......................................p. 120

Foto 82 - Francisco Paes Monlevade e família............................................................p. 120

Foto 83-Jayme Pinheiro de Ulhôa Cintra...................................................................p. 120

Foto 84-Oficina de Jundiaí e funcionários................................................................p. 121

Foto 85-Pessoal nos depósitos de locomotivas.......................................................p. 122

Foto 86 -Lavadores de carros, pintores, torneiros e pessoal de estação......................p. 122

Foto 87-Lavadores de carros............................................................................... 122

Foto 88-Examinadores de veículos e outros...........................................................p. 122

Foto 89-Mestres de Linhas...............................................................................p. 122

Foto90-Turmasem serviço.................................................................................p. 122

Foto 91-Pessoal do armazém e outros......................................................................p. 122

Foto 92 - Pessoal de estação: guardas, ajudantes, praticantes e telegrafistas .............p. 123

Foto 93-Portadores de diversas estações............................................................... p. 123

Foto 94-Chefes de estações.................................................................................. 123

Foto 95-Chefes efetivos e substitutos de estações.................................................p. 123

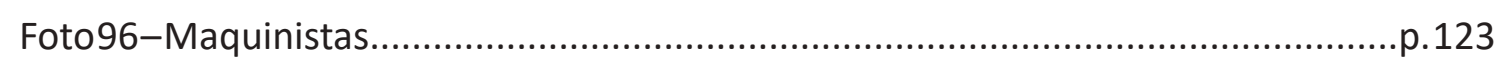

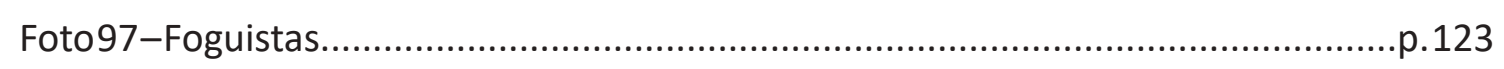

Foto 98-Diretoria da Companhia Paulista............................................................p. 124

Foto 99-Sede da Companhia Paulista, na rua São Bento (São Paulo).........................p. 125

Foto 100 -Eletrificação do trecho de Jundiaí à Campinas.........................................p. 126

Foto 101 -Subestação elétrica de São Carlos.........................................................p. 126

Foto 102-Subestação elétrica de Rincão..............................................................p. 126

Foto 103 -Salto de Monjolinho e Usina elétrica da Companhia Paulista.....................p. 127

Foto 104-Sociedade Beneficente dos Empregados da Companhia Paulista (1918)...p. 130

Foto 105-Cooperativa da Companhia Paulista.......................................................p. 131

Foto 106-Trabalhadores da Baldeação.................................................................. 131

Foto 107-Operação de Baldeação de Gado na estação de São Carlos........................p. 131

Foto 108 - Escola ferroviária de Rio Claro - sala de aula.............................................p. 140

Foto 109-Escola ferroviária de Rio Claro-interior da oficina....................................p. 140

Foto 110 -Escola ferroviária de Rio Claro-interior da oficina....................................p. 140

Foto 111 -Escola ferroviária de Rio Claro-interior da oficina...................................p. 140

Foto 112 -Escola ferroviária de Jundiaí-edifício da oficina.......................................p. 142

Foto 113 -Escola ferroviária de Jundiaí-interior da oficina......................................p. 142

Foto 114-Escola ferroviária de Jundiaí-interior da oficina......................................p. 142 
Foto 115 - Escola ferroviária de Jundiaí-instrutores .p. 143

Foto 116-Escola ferroviária de Jundiaí-aluno p. 143

Foto 117-Escola ferroviária de Jundiaí-aluno .p. 143

Foto 118-Escola ferroviária de Jundiaí-aluno .p. 143

Foto 119-Escola ferroviária de Jundiaí-aluno .p. 143

Foto 120-Escola ferroviária de Rio Claro-aluno. .p. 144

Foto 121 - Escola ferroviária de Jundiaí - quadro da 7ạ. turma formada em 1945. p. 144

Foto 122 - Casas construídas através CAP pela Companhia Sorocabana..... .p. 151

Foto 123 - Relógio da estação de Dois Córregos .p. 154

Foto 124 - Casa da vila ferroviária de Dois Córregos .p. 154

Foto 125 - Casa da vila ferroviária de Jaú .p. 154

Foto126-Vila operária deSaltaire.

Foto 127 - Foto antiga da casa do chefe da estação de Jaú

Foto 128 - Foto antiga da casa do chefe da estação de Jaú

Foto 129 - Foto atual da casa do chefe da estação de Jaú. p. 162

Foto 130 - Foto atual da casa do chefe da estação de Jaú

Foto 131 - Casa do chefe da subestação elétrica de Dois Córregos..... p. 163

Foto 132 - Casa do chefe da subestação elétrica de Rincão p. 163

Foto 133 - Casa do Mestre de Linha de Itirapina. p. 163

Foto 134 - Banda do Curso de Ferroviários em desfile. p. 164

Foto 135 - Time de futebol da Companhia Paulista.... p. 164

Foto 136 - Fachada de casa ("porta e janela") em linha, em Rincão. p. 167

Foto 137 - Casas "em linha", em Itirapina. p. 167

Foto 138 - Casas geminadas em Brotas. p. 167

Foto 139 - Casas geminadas em Dois Córregos. p. 167

Foto 140 - Casa isolada no lote em Jaú. p. 167

Foto 141 - Casa isolada no lote, casa de chefe de estação, em Jaú .p. 167

Foto 142 - Conjunto de casas geminadas em Dois Córregos. p. 168

Foto 143 - Casas geminadas com muros frontais baixos em Dois Córregos p. 168

Foto 144 - Casa de turma da CP, no ramal São Carlos e Santa Eudóxia p. 169

Foto 145 - Casa de turma da CP p. 169

Foto 146 - Casa de turma da CP. .p. 169

Foto 147 - Foto atual de casa de turma em Pederneiras, da CP. p. 169

Foto 148 - Chaminé de uma das casas em Rincão. p. 171

Foto 149 - Entrada da alameda ou back-alley em Swindon. p. 173 
Foto 150 - Back-alley em Swindon .p. 173

Foto 151 - Projeto de casa proletária proposto pelo engenheiro Everardo Backheuser. p.174

Foto 152 - Anexo externo em casa da vila ferroviária de Rincão. p. 174

Foto 153 - Anexo externo em casa da vila ferroviária de Jaú. p. 174

Foto 154 - Foto da vila ferroviária de Rincão e a caixa d'água. .p. 175

Foto 155 - Caixa d'água em ferro fundido de Rincão. p. 175

Foto 156 - Forro em madeira de uma das casas em Rincão .p. 175

Foto 157- Assoalho em madeira de uma das casas em Rincão. .p. 175

Foto 158 - Casa em madeira da Companhia Sorocabana em Ourinhos. .p. 176

Foto 159-Casa em madeira da Companhia Paulista em São Carlos. .p. 176

Foto 160 - Casa em tijolo aparente da Companhia Paulista em São Carlos.

Foto 161 - Casa do chefe da subestação elétrica de Rincão. .p. 178

Foto 162 - Uma das tipologias da vila ferroviária de Rincão. p. 178

Foto 163 - Casa em estilo Art-Déco, próxima à subestação elétrica em Dois Córregos p. 180

Foto 164 - Casa em estilo Art-Déco, próxima à subestação elétrica em Dois Córregos. p. 180

Foto 165- Vila ferroviária de Swindon. p. 192

Foto 166-Vila ferroviária de Derby. .p. 192

Foto 167-Foto geral do complexo ferroviário e oficina de Crewe-1895.

Foto 168 - Foto atual de Crewe p. 193

Foto 169- Foto atual de Crewe p. 193

Foto 170 - Arquivo do National Railway Museum, em York. .p. 205

Foto 171 - Um dos galpões de exposição do National Railway Museum, em York. .p. 205

Foto 172 -Fila da entrada do National Railway Museum, em York. p. 205

Foto 173 - Arquivo do Museu Ferroviário de Jundiaí.. p. 205

Foto 174 -Sala de exposição do Museu Ferroviário de Jundiaí. p. 205

Foto 175-Sala de exposição do Museu Ferroviário de Jundiaí. p. 205

Foto 176-Cartaz do encontro de ferromodelismo em São Carlos p. 211 Foto 177 -Ferromodelistas reunidos próximos ao armazém de São Carlos Foto 178 - Edifício que a Associação de Preservação Ferroviária Brotense pretende utilizar como sede. p. 211

Foto 179 - Rincão: casas da subtipologia B1 - fachada frontal. p. 236

Foto 180 - Rincão: casas da subtipologia B1 - fachada lateral. p. 236 
Foto 181 - Rincão: casas da subtipologia B1 - anexo com banheiro e tanque.......p. 236

Foto 182 - Rincão: casas da subtipologia B1 - detalhe da chaminé.........................p. 236

Foto 183 - Rincão: casas da subtipologia B1 - corredor de acesso........................p. 236

Foto 184 - Rincão: casa da subtipologia B1 - fachada lateral em 2013 .......................p. 237

Foto 185 - Rincão: casa da subtipologia B1 - fachada lateral em 2016........................p. 237

Foto 186 - Rincão: subtipologia B2 - visão geral da quadra.....................................p. 240

Foto 187 - Rincão: subtipologia B2 - visão geral da quadra....................................p. 240

Foto 188 - Rincão: subtipologia B3 - fachada frontal............................................p. 244

Foto 189 - Rincão: subtipologia B3 - janela original.............................................p. 244

Foto 190 - Rincão: subtipologia B3 - fachada frontal...............................................p. 244

Foto 191 - Rincão: subtipologia B4 - fachada frontal................................................p. 248

Foto 192 - Rincão: subtipologia B4 - visão geral das casas.......................................p. 248

Foto 193 - Rincão: subtipologia B4 - fachadas modificadas.....................................p. 248

Foto 194 - Rincão: subtipologia B4 - fachadas modificadas........................................ 248

Foto 195 - Rincão: subtipologia B5 - fachada original..............................................p. 253

Foto 196-Rincão: subtipologia B5 - fachada modificada.........................................p. 253

Foto 197-Rincão: subtipologia C1 - fachada frontal ...............................................p. 257

Foto 198 - Rincão: subtipologia C1 - fachadas......................................................... 257

Foto 199 - Rincão: subtipologia C1 - fachada posterior e quintal.............................p. 258

Foto 200 - Rincão: subtipologia C1 - visão geral da rua ...........................................p. 258

Foto 201 - Rincão: subtipologia C2 - visão geral da rua ..........................................p. 262

Foto 202 - Rincão: subtipologia C2 - fachada frontal...............................................p. 262

Foto 203 - Rincão: casa do chefe da estação ........................................................p. 264

Foto 204 - Rincão: planta da casa do chefe da estação................................................. 264

Foto 205-Rincão: subestação elétrica e casa do chefe............................................p. 266

Foto 206 - Rincão: calçada em tijolos....................................................................... 269

Foto 207 - Rincão: calçada revestida em arenito.....................................................p. 269

Foto 208 - Rincão: foto aérea de parte da vila ferroviária.......................................p. 272

Foto 209-Rincão: entrada da estação....................................................................p. 273

Foto 210 - Rincão: esplanada da estação............................................................... 273

Foto 211 - Rincão: caixa d'água que abastecia a vila ..............................................p. 273

Foto 212 - Rincão: subestação elétrica em 2013...................................................p. 275

Foto 213 - Rincão: subestação elétrica em 2016 ......................................................p. 275

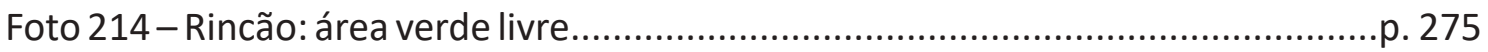

Foto 215 - Rincão: visão geral da rua ....................................................................... 275 
Foto 216 - Rincão: placa da Rua dos Ferroviários p. 276

Foto 217 - Rincão: casos de alterações na volumetria e na fachada...... p. 277

Foto 218 - Rincão: casos de alterações na volumetria e na fachada...... p. 277

Foto 219 - Rincão: desenho e poesia em homenagem à cidade

p. 279

\section{LISTA DE SIGLAS}

ABPF

Associação Brasileira de Preservação Ferroviária

ALL

América Latina Logística

APT

Abertura de Processo de Tombamento

BNDES

Banco Nacional do Desenvolvimento Econômico e Social

CAP

Caixa de Aposentadoria e Pensões

CIVVIH International Committee on Historic Towns and Villages

CM Companhia Mogiana

CP Companhia Paulista

CPEF Companhia Paulista de Estradas de Ferro

CFESP Centro Ferroviário de Ensino e Seleção Profissional

CNRC Centro Nacional de Referência Cultural

CONDEPHAAT Conselho de Defesa do Patrimônio, Histórico, Arqueológico, Artístico e Turístico

CONDEPACC Conselho de Defesa do Patrimônio Artístico e Cultural de Campinas

CONPRESP Conselho Municipal de Preservação do Patrimônio Histórico, Cultural e Ambiental da Cidade de S. Paulo

DARF Documento de Arrecadação das Receitas Federais

DNER Departamento Nacional de Estradas de Rodagem

DNEF Departamento Nacional de Estradas de Ferro

DNIT Departamento Nacional de Infraestrutura de Transportes

DPH Departamento do Patrimônio Histórico (órgão da Secretaria Municipal da Cultura do Município de São Paulo)

EFS Estrada de Ferro Sorocabana

FEPASA Ferrovia Paulista S. A.

FERROBAN Ferrovia Bandeirantes S. A. 


\begin{tabular}{|c|c|}
\hline FNPM & Fundação Nacional Pró-Memória \\
\hline TEO & Tombamento Ex-Officio \\
\hline IAP & Instituto de Aposentadoria e Pensões \\
\hline IBAMA & Instituto do Meio Ambiente e dos Recursos Naturais Renováveis \\
\hline IGC & Instituto Geográfico e Cartográfico do Estado de São Paulo \\
\hline IBDF & Instituto Brasileiro de Desenvolvimento Florestal \\
\hline ICMBio & Instituto Chico Mendes de Conservação da Biodiversidade \\
\hline ICOM & International Council of Museums \\
\hline ICOMOS & International Council on Monuments and Sites \\
\hline ICCROM & $\begin{array}{l}\text { International Centre for the Study of the Preservation and Restoration of } \\
\text { Cultural Property }\end{array}$ \\
\hline IDORT & Instituto de Organização Racional do Trabalho \\
\hline IPHAN & Instituto do Patrimônio Histórico e Artístico Nacional \\
\hline OEA & Organização dos Estados Americanos \\
\hline $\mathrm{PCH}$ & Programa Integrado de Reconstrução das Cidades Históricas \\
\hline RFFSA & Rede Ferroviária Federal S. A. \\
\hline RCPEF & Relatório da Companhia Paulista de Estradas de Ferro \\
\hline SENAI & Serviço Nacional de Aprendizagem Industrial \\
\hline SEPLAN & Secretaria do Planejamento \\
\hline SESC & Serviço Social do Comércio \\
\hline SESI & Serviço Social da Indústria \\
\hline SESP & Serviço de Ensino e Seleção Profissional \\
\hline SHU & Sítio Urbano Histórico \\
\hline SPU & Superintendência do Patrimônio da União \\
\hline SPR & São Paulo Railway \\
\hline SPHAN & Serviço do Patrimônio Histórico Artístico Nacional (1937-1946) \\
\hline $\mathrm{TICCIH}$ & $\begin{array}{l}\text { The International Committee for the Conservation of the Industrial } \\
\text { Heritage }\end{array}$ \\
\hline UNESCO & United Nations Educational, Scientific, Cultural Organization \\
\hline
\end{tabular}




\section{SUMÁRIO}

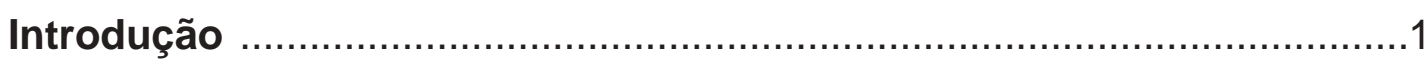

Capítulo 1 - Preservação das vilas ferroviárias ....................................27

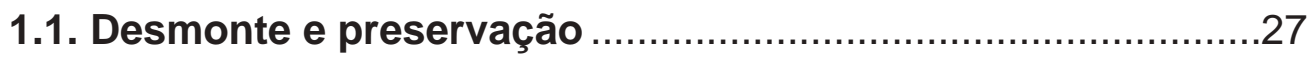

1.2. Órgãos de preservação e patrimônio industrial ferroviário ...45

1.3. Instrumentos de preservação e patrimônio industrial ferroviário..................................................... 59

Capítulo 2 - A Companhia Paulista e suas vilas ferroviárias................78

2.1. Café, ferrovias e cidades ……..............................................

2.2. Companhia Paulista e seus trabalhadores ……....................99

2.3. Cidades, trabalhadores e vilas ferroviárias ........................154

Capítulo 3 - A Paisagem cultural ferroviária e as áreas de

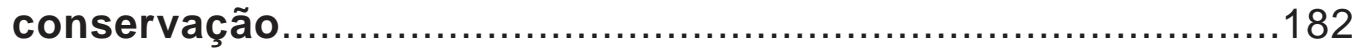

3.1. Paisagem cultural ferroviária ……......................................183

3.2. Preservação, patrimônio urbano e áreas de conservação..192

3. 3. 0 caso concreto das vilas ferroviárias escolhidas .............202

Capítulo 4 - Um ensaio de leitura morfotipológica da vila ferroviária

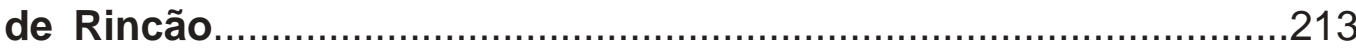

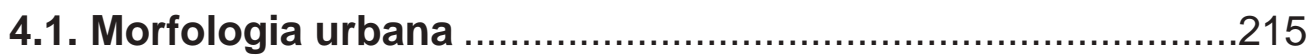

4.2. Morfologia urbana, paisagem e "genius loci" ....................219

4.3. Métodos e leitura morfotipológica da vila ferroviária de

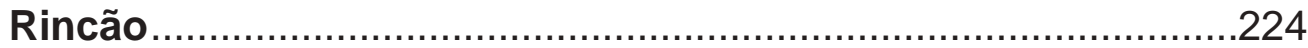

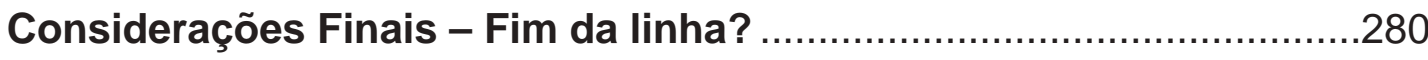

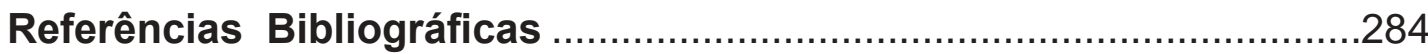

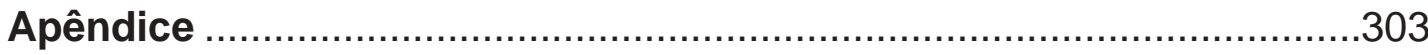




\section{Introdução}

\section{O título}

O título surgiu ao encontrar um certo saudosismo quando comentava com as pessoas acerca do meu objeto de estudo no doutorado: "Ai que pena que acabou..." "Ai, eu tinha um tio / um avô no interior que morava numa dessas vilas...”. A verdade é que há muitos estudos sobre as ferrovias, inclusive realizados por pesquisadores descendentes de ex-ferroviários. Por inclinações pessoais tenho grande apreço pela história, e me dava pena, ao realizar as visitas de campo ver muitas estações e vilas ferroviárias abandonadas. Quis me utilizar do trocadilho das linhas do trem e ao mesmo tempo indagar: será mesmo o "fim da linha"? É o fim das vilas ferroviárias? Não há mais esperança para estas vilas ferroviárias e o fim delas será a demolição? Ao início desta pesquisa, indagou-se sobre o estado de preservação destas, e ao mesmo tempo, sobre a questão de sua preservação junto aos órgãos de preservação do patrimônio. Seriam as vilas meritórias de preservação? Haveria alguma forma de preservá-las de maneira eficaz?

\section{A questão problema}

Recortou-se um conjunto de vilas ferroviárias de uma das várias companhias ferroviárias, com escolha da Companhia Paulista, para estudá-las dentro do patrimônio industrial e do complexo ferroviário, para melhor evidenciar seu estado de conservação atual no quadro das políticas de preservação e apontar caminhos para a mesma. A preservação das vilas ferroviárias apenas faria sentido dentro do problema da re-significação e valoração. A valoração artística ou de excepcionalidade (critérios estes que também foram questionados ao longo deste trabalho), não se aplicariam ao caso, pois o objeto de estudo se enquadra no que se chama de "arquitetura modesta". Dentre recortes e leituras possíveis deste rico objeto de estudo, a presente investigação sustenta-se fortemente na pesquisa histórica, dos fundamentos sociais da arquitetura e do urbanismo, sobretudo a história social e urbana, que subsidia a questão da preservação. As vilas ferroviárias tomadas de maneira isolada, parecem ser insignificantes, contudo, ao estudar a história 
social da Companhia Paulista e principalmente a de seus trabalhadores, as vilas passam a adquirir outro significado. Desse modo, o valor das vilas ferroviárias é melhor entendido com a apreciação dos processos históricos mais amplos. Um dos caminhos possíveis encontrados para a re-significação encontra apoio no conceito de paisagem cultural, assim como no conceito de áreas de conservação ou conservação integrada. Acredita-se que tais conceitos complementam-se e auxiliam a gestão do patrimônio.

\section{Metodologia: escolha do tema e recortes}

A questão problema foi melhor perfilada, a partir do próprio estabelecimento do estado da arte, pela revisão bibliográfica dos dados empíricos acompanhada da exploração do projeto de pesquisa. Neste processo, identificou-se e recortou-se um objeto relevante para o debate em curso. Os dados empíricos foram coletados durante as visitas de campo realizadas, nas quais se constatou o estado de abandono dos complexos ferroviários. Em alguns casos, uma atenção maior foi dada à estação, com proposição de uso administrativo ou cultural, em detrimento das vilas ferroviárias. Como algumas das estações, as vilas ferroviárias sofreram demolições e descaracterizações em várias cidades, chegando muitas vezes a ser impossível identificá-las como um complexo ferroviário. Pela revisão bibliográfica, pode-se constatar a ênfase dada às estações e o silêncio conferido às vilas ferroviárias na historiografia arquitetônica e urbanística, com raras exceções. No campo da preservação, entender o complexo ferroviário, e não apenas um edifício isolado, como a estação, é recente. Na prática, este entendimento só começa entre o final da década de 1980 e início da década de 1990. Deste modo, a presente pesquisa procurou entender o silêncio tanto na historiografia como no campo do patrimônio, e ver como as pesquisas históricas podem colaborar no processo de preservação das vilas ferroviárias dentro do contexto atual do patrimônio industrial ferroviário.

\section{Origem do Tema}

O tema de pesquisa surgiu de minha trajetória acadêmica e profissional. Com relação à trajetória acadêmica, quis dar continuidade à história da habitação para o trabalhador, tratado na dissertação de mestrado defendida em 2010, nesta mesma faculdade, denominada “A iniciativa privada e o mercado formal de habitação para o trabalhador na 
cidade de São Paulo, 1942 - 1964”, elaborada na área de pesquisa Fundamentos Sociais da Arquitetura e do Urbanismo. Naquele trabalho, procurei estudar o referido período histórico, social e econômico, principalmente salários e custo de vida, e como tais fatores impactaram a habitação para o trabalhador, bem como identificar as frentes de investimento da iniciativa privada na habitação para o trabalhador. Com relação à trajetória profissional, trabalhei entre 2010 e 2013 no setor de Gestão Patrimonial, da Superintendência do Patrimônio da União no estado de São Paulo, órgão ligado ao Ministério de Planejamento, Orçamento e Gestão, especificamente com a regularização fundiária das casas que eram geridas pela extinta RFFSA, ou seja, as vilas ferroviárias das várias companhias existentes no estado de São Paulo. Constatei, além dos problemas fundiários envolvidos, o abandono deste rico patrimônio industrial.

Em 2007, por meio da Medida Provisória $n^{\circ}$ 353, de 22 de janeiro, posteriormente convertida na Lei $\mathrm{n}^{\circ} 11.483 / 2007$, regulamentada pelo Decreto $\mathrm{N}^{\circ} 6.018$ de 22 de janeiro de 2007 extingue-se a Rede Ferroviária Federal S. A.. A partir de tal lei, parte do patrimônio da extinta RFFSA foi transferida para o DNIT - Departamento Nacional de Infraestrutura de Transportes, e parte transferida para a SPU - Superintendência do Patrimônio da União. Os chamados bens móveis (trilhos, dormentes, equipamentos, etc...) e os bens imóveis operacionais foram transferidos para o DNIT, e os bens imóveis não operacionais foram transferidos para a SPU. Dentre estes bens imóveis não operacionais, encontram-se terrenos comerciais e residenciais, estações ferroviárias desativadas, benfeitorias como armazéns, caixas d'água, e residências. Esta transferência de bens, pelo menos no que tange à SPU, está sendo realizada gradativamente pelo que se denominam Termos de Transferência. Uma vez vistoriados, tais imóveis são recebidos nas respectivas regionais da Superintendência, e passam ser de propriedade e gestão da União. Ainda que transferidos de forma gradativa, houve uma transferência massiva de imóveis ao que se chamou de Carteira Imobiliária. À região Sudeste brasileira coube a maior parte desta transferência de imóveis, logicamente, por encontrar-se nesta região a maior parte da malha ferroviária brasileira construída. É o que se pode depreender rapidamente ao olhar o mapa abaixo, e também no quadro resumo dos imóveis transferidos. 


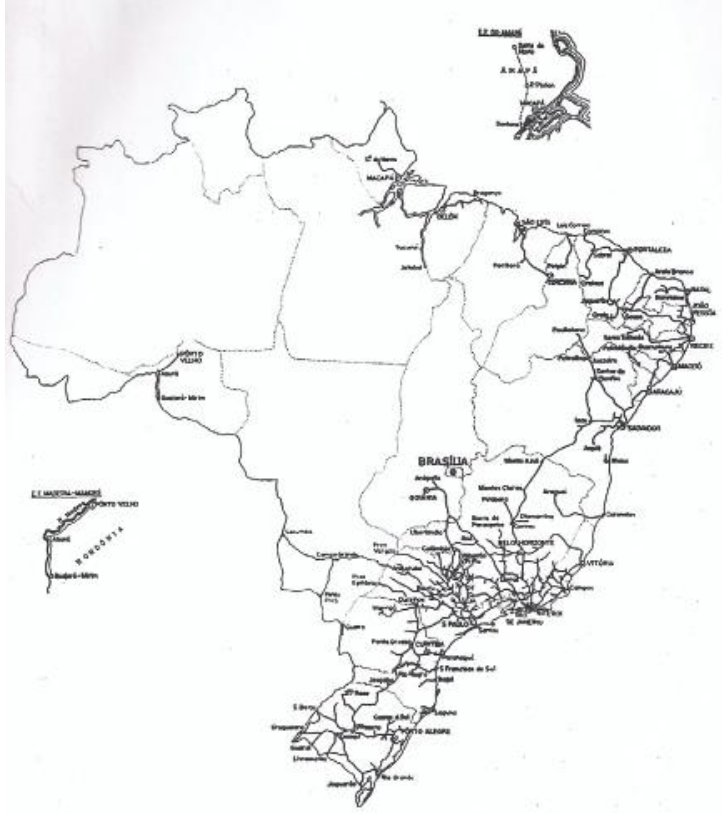

Mapa 1 - Rede Ferroviária brasileira. Fonte: SANTOS, R. 1961:24 apud: MINAMI, 1994,

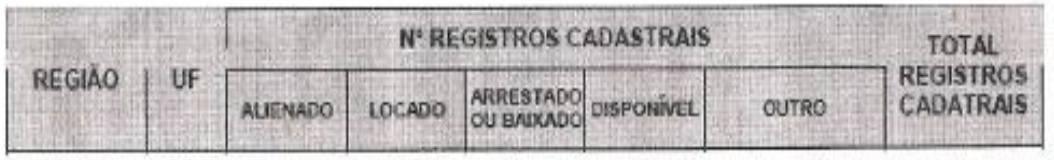

Tabela 1 Quantitativo de imóveis transferidos para a União na Região Sudeste Fonte: SPU-SP

Dentro desta carteira imobiliária, de imóveis alienados e locados no estado de São Paulo, um breve levantamento (e excluindo-se os bens imóveis comerciais) registra 343 contratos de bens alienados residenciais e 5.550 contratos de bens locados residenciais. Portanto, aproximadamente 6.000 imóveis residenciais alienados e locados no estado de São Paulo, e é dentro deste universo documental, que esta tese teve que trabalhar e, portanto, fazer um recorte selecionando alguns conjuntos de apenas uma Companhia.

Com relação à preservação deste patrimônio ferroviário, a Lei 11.483/2007 também contempla este aspecto, e o artigo $9^{\circ}$ é inteiramente dedicado ao IPHAN. Transcreve-se a seguir tal artigo:

Art. 9o Caberá ao Instituto do Patrimônio Histórico e Artístico Nacional - IPHAN receber e administrar os bens móveis e imóveis de valor artístico, histórico e cultural, oriundos da extinta RFFSA, bem como zelar pela sua guarda e manutenção.

$\S 1^{o}$ Caso o bem seja classificado como operacional, o IPHAN deverá 
garantir seu compartilhamento para uso ferroviário.

$\S 2^{o}$ A preservação e a difusão da Memória Ferroviária constituída pelo patrimônio artístico, cultural e histórico do setor ferroviário serão promovidas mediante:

I - construção, formação, organização, manutenção, ampliação e equipamento de museus, bibliotecas, arquivos e outras organizações culturais, bem como de suas coleções e acervos;

II - conservação e restauração de prédios, monumentos, logradouros, sítios e demais espaços oriundos da extinta RFFSA.

$\S 3^{\circ}$ As atividades previstas no $\S 2^{\circ}$-deste artigo serão financiadas, dentre outras formas, por meio de recursos captados e canalizados pelo Programa Nacional de Apoio à Cultura - PRONAC, instituído pela Lei $n^{\circ} 8.313$, de 23 de dezembro de 1991.

\section{Recortes espacial e temporal}

Por que a Companhia Paulista? A maior parte da malha ferroviária brasileira encontra-se na região sudeste, mais especificamente entre Minas Gerais e São Paulo. Dada a grande quantidade de companhias ferroviárias paulistas, e a grande gama de 6000 imóveis residenciais, necessitávamos escolher uma companhia, e ainda, na própria Companhia algumas destas vilas ferroviárias.

Pela bibliografia existente, observou-se que há poucos estudos referentes às vilas ferroviárias e os existentes referem-se à Vila de Paranapiacaba, construída pela companhia ferroviária São Paulo Railway. Sendo a Vila de Paranapiacaba a mais estudada, consequentemente, há mais estudos da companhia ferroviária que a construiu, a São Paulo Railway, que em parte era formada por capital inglês e parte por capital nacional, apesar de ser conhecida no meio ferroviário como a "Inglesinha". Assim, quisemos escolher uma companhia ferroviária, inteiramente nacional e, estudar suas vilas ferroviárias. A companhia escolhida foi Companhia Paulista, a primeira a ser constituída com capital brasileiro em 1868, resultado da união de fazendeiros, cafeicultores do estado, depois dela vieram outras, como a Mogiana e a Sorocabana, entre outras, e a última a ser encampada pelo Estado, em 1961. Interessante notar como apenas a história da Companhia Paulista já poderia originar uma tese relativa ao patrimônio industrial, dada a quantidade de informações de suas iniciativas pioneiras, o que Segnini(1982) chama de complexo agroindustrial, no qual a ferrovia possui um papel predominante. Observa-se, por exemplo, o fato de ser fluvial em seu princípio, pouco mencionado nos trabalhos lidos; a primeira a eletrificar seus trilhos em 1922; a primeira a estabelecer um horto florestal para o fornecimento de madeira para substituir o carvão importado, e também pelas empresas subsidiárias que 
possuía como a CAIC - Companhia Agrícola de Imigração e Colonização, e a Companhia Frigorífica, em Barretos. Além é claro, de conhecidos personagens históricos que circularam tanto pela Companhia Paulista, como pelos meios políticos e técnicos, para mencionar alguns: Antônio Prado e figuras da engenharia brasileira como Adolfo Pinto e Antônio Francisco de Paula Souza. Assim, a ampla leitura sobre a história da Companhia Paulista, poderia nos fazer perder o foco da pesquisa, que são as vilas ferroviárias.

Uma vez escolhida a Companhia Paulista, continuamos com um outro recorte. Uma fonte utilizada inicialmente foi Morais (2002), um dos poucos estudos sobre as vilas ferroviárias paulistas, que tratou dos núcleos, vilas e conjuntos de casas construídas pelas companhias que compunham a FEPASA: Companhias Sorocabana, Paulista, Mogiana, Estrada de Ferro Araraquara e Estrada de Ferro São Paulo - Minas. Vale lembrar que do seu estudo permanecem ausentes outras duas grandes ferrovias do estado de São Paulo, a Estrada de Ferro Noroeste e a Estrada de Ferro Central do Brasil, que certamente possuíam vilas ferroviárias ao longo de suas linhas. Segundo Morais (2002:119), as ferrovias da FEPASA possuíam 5752 casas construídas (número muito próximo ao que foi fornecido pela SPU), e chegando a atuar em 210 municípios. Ainda segundo Morais (2002:152), apenas a Companhia Paulista construiu um total de 1612 unidades, e as vilas ferroviárias estiveram presentes em 62 municípios. Morais (2002), analisa os municípios de Jundiaí, Barretos, Bauru, Bebedouro, Campinas, Cordeirópolis e Marília. Na presente pesquisa preferiu-se escolher as vilas ferroviárias e cidades não analisadas por Morais (2002), e por outros autores como Ghirardello (2002) e Soukef Junior (2005), estes últimos estudaram Bauru. Além disso, não fizeram parte desta pesquisa as cidades onde havia o entroncamento com outras companhias ferroviárias, pois sabia-se que nos entroncamentos a quantidade de casas era sempre maior. Quis-se averiguar cidades nas quais o impacto foi produzido apenas pela Companhia Paulista. Também não foram escolhidas as cidades em que a Companhia Paulista possuía oficinas, como Jundiaí e Rio Claro, pois já se sabia de antemão que eram locais que possuíam forte concentração de trabalhadores e, portanto, uma grande quantidade de casas. Na amostragem realizada por Morais (2002), chamou-nos a atenção as cidades localizadas no “coração" do estado de São Paulo que não eram entroncamentos, nem oficinas, e possuíam grande quantidade de casas, aproximadamente mais de quarenta unidades. Ao longo da pesquisa, descobriu-se que a considerável quantidade de unidades habitacionais, deve-se aos locais de armazéns reguladores de café, muitos deles construídos pelo governo federal na década de 1920, nos terrenos da Companhia 
Paulista; ou locais de baldeação, entre linhas eletrificadas e não-eletrificadas; ou troca de bitolas, de métricas para as de $1,60 \mathrm{~m}$. Além de excluir-se os entroncamentos e locais de oficina, utilizamos de mais dois critérios na escolha das cidades e vilas ferroviárias dentro do universo de 62 municípios: a) uma quantidade razoável de casas, pois dado o estado de abandono e descaracterizações do patrimônio ferroviário, temia-se não encontrar nenhuma amostra para analisar. b) a proximidade das vilas ferroviárias por questões logísticas da pesquisa.

Assim, entre as vilas elencadas e graficamente representadas por Morais (2002, ver mapa abaixo), escolhemos inicialmente seis, que não foram estudadas pelo autor, e por apresentarem um número considerável de casas, a saber: Itirapina (91 casas), Brotas (44 casas), Dois Córregos (92 casas), Jaú (52 casas), e São Carlos (44 casas), Rincão (54 casas). Ao longo da pesquisa, e através do cruzamento de fontes pode-se verificar a divergência de alguns números. Segundo dados da Inventariança da RFFSA e Superintendência do Patrimônio da União (SPU), os números são os seguintes: Itirapina (94 casas), Brotas ( 9 casas), Dois Córregos (42 casas), Jaú (24 casas), e São Carlos (34 casas), Rincão (72 casas). Nota-se uma diferença para menor na maioria dos casos, com exceção de Itirapina e Rincão, que apresentaram um número maior de unidades. A divergência dos números deve-se a demolições ou ao método de inventário das casas. Em Rincão, através

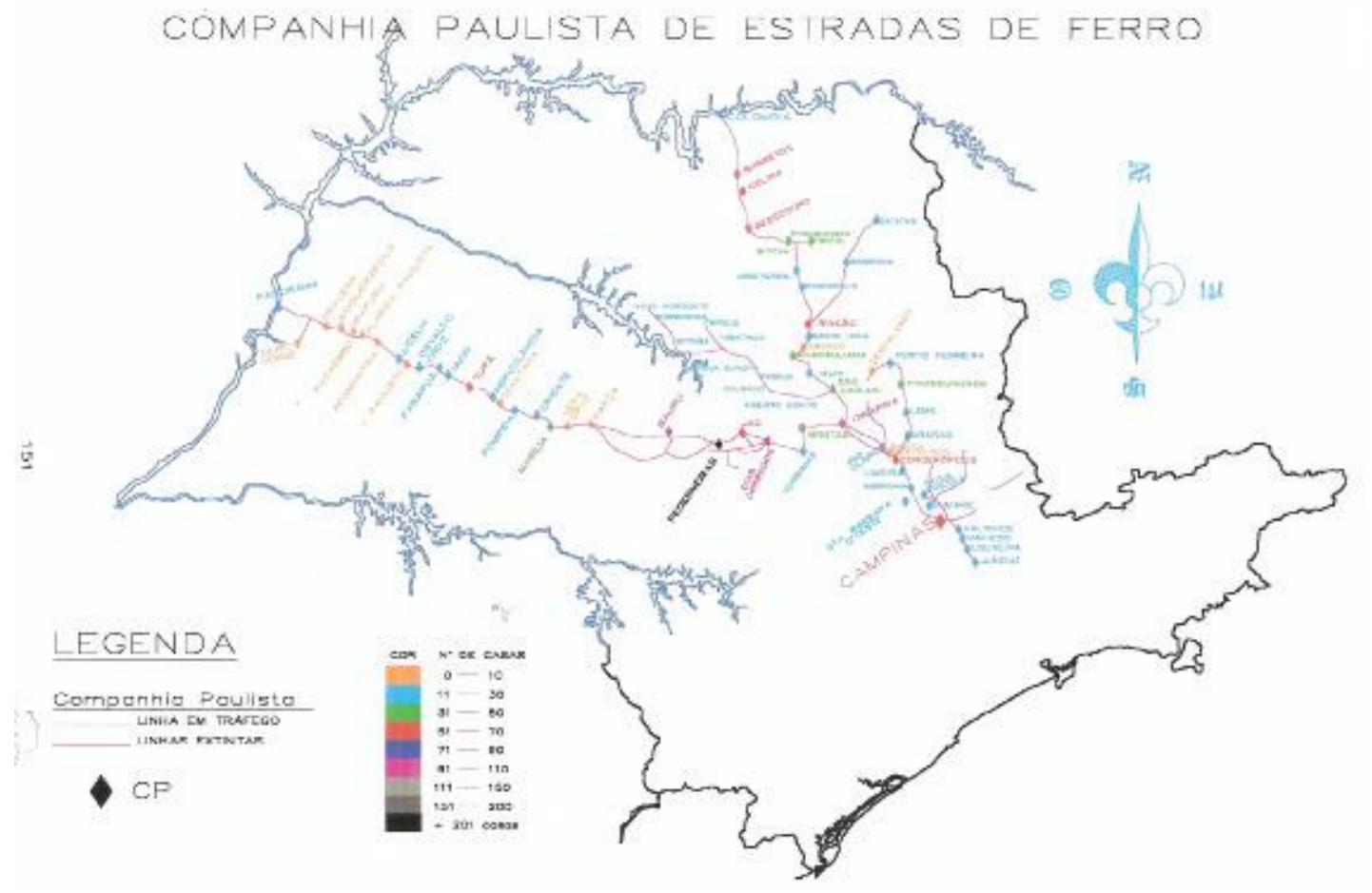

Mapa 2 - Linhas e vilas ferroviárias da Companhia Paulista. FONTE: MORAIS, 2002. p.151 
da leitura dos Relatórios da Companhia Paulista, pode-se constatar que a vila chegou a apresentar 120 unidades.

Nestas vilas ferroviárias, procurou-se, a partir do estudo histórico e sociológico, realizar uma leitura morfotipológica (CARNEIRO \& MILET, 2002)1, auxiliando na re-significação e construção de uma paisagem cultural ferroviária, com vistas a uma política e gestão de preservação. Recorda-se que nenhuma delas é objeto de tombamento ou de qualquer tipo de instrumento de preservação atualmente. Tal leitura espacial foi escolhida por dois motivos: primeiro, são vilas, e não se tratando de um edifício isolado, fazem parte do tecido urbano; e segundo, por fazerem parte do que chama de arquitetura modesta, não caberia uma leitura estilística das casas das vilas ferroviárias. Apesar da simplicidade destas, foi possível identificar em algum momento, por exemplo, em Dois Córregos, a influência do Art-Decó em algumas delas. Segundo Kühl (1998, p. 173), os edifícios das estações da Companhia Paulista são "edifícios bem resolvidos, representativos da arquitetura da época e com boa qualidade de construção, apesar de, em sua maioria, não possuírem qualidades estéticas excepcionais". Foram construídas em estilos classicizantes, art nouveau, art decó ou mesmo neogótico. Diferentemente das estações, chegamos à conclusão de que as vilas ferroviárias, por servir ao interesse econômico da companhia e pertencer ao que se chama "mundo do trabalho", não tenham recebido tratamento arquitetônico diferenciado, e por falta de tal tratamento aliado à sobrevaloração artística (que como veremos, possui raízes históricas) durante certo período, os órgãos de preservação, também ficaram ausentes nas políticas de preservação. Desse modo, ao invés de uma leitura estilística das vilas ferroviárias, optou-se por fazer uma leitura morfotipológica, mais ligada ao tecido urbano, ou seja, observando-se a implantação, as diferentes tipologias, as formas e materiais das casas, a hierarquia dos espaços e outras características que conformem uma paisagem industrial ferroviária, aliada é claro, à investigação da história social destes espaços, que acreditamos que dá sustentação e significação para uma política de preservação.

No aspecto referente à preservação, a Vila de Paranapiacaba, é a única vila ferroviária tombada em nível federal, ou seja, pelo IPHAN (Instituto do Patrimônio Histórico e Artístico Nacional), inscrita no livro Histórico de tombo em 2008 e, recentemente indi-

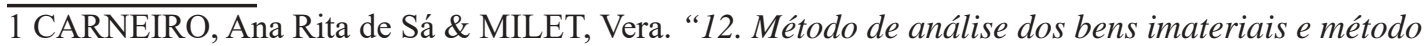
de leitura da imagem de uma área urbana para sua reabilitação - Ana Rita Sá Carneiro e Vera Milet" in JOKILEHTO, Jukka et al. Gestão do Patrimônio Cultural Integrado. UFPE/ Centro de Conservação Integrada Urbana e Territorial. Programa de Pós-Graduação em Desenvolvimento Urbano. Recife: Ed. Universitária da UFPE, 2002. 
cada a integrar a lista do patrimônio mundial, pela UNESCO. O tombamento também é ratificado pelo CONDEPHAAT (Conselho de Defesa do Patrimônio, Histórico, Arqueológico, Artístico e Turístico), órgão de preservação estadual. Há complexos ferroviários tombados pelo IPHAN e em nível estadual pelo CONDEPHAAT, a partir do final dos anos 1980, sendo o primeiro destes complexos a própria Vila de Paranapiacaba, mas nenhuma inscrita nos livros de tombo como "Vila Ferroviária". Recentemente, em 2013, foi tombada em nível municipal a vila ferroviária de Campinas 2013; e como Campinas, deve haver outros tombamentos pelos municípios paulistas. O que se pretende evitar é que, ao elevar-se a Vila de Paranapiacaba a patrimônio nacional, e quase mundial, acabe-se por obscurecer a existência das demais vilas ferroviárias. O presente estudo, vem reforçar que a construção de vilas para seus trabalhadores, era procedimento comum a todas as companhias ferroviárias, e indagar se, como a Vila de Paranapiacaba, as outras merecem ser preservadas. Considera-se pertinente a pergunta de que se deva preservar ou não, especificamente para as vilas ferroviárias escolhidas, pois não se trata de "patrimonializar" tudo, conforme levanta Choay (2006, p. 237)², porém também não se deve tomar a posição oposta, isto é, não é o caso de destratar o patrimônio e demoli-lo. Manter certo grau de reverência em relação aos monumentos e lugares, conforme há muito tempo apontado por Ruskin e Riegl, é necessário; em um mundo em que tudo se tornou descartável e, ao mesmo tempo, em um mundo preocupado com a sustentabilidade dos ambientes. Uma vez verificado que merecem ser preservadas, aponta-se uma forma de preservação.

Um outro aspecto que se quer evidenciar, ainda relacionado à questão da preservação, é que o tombamento e a indicação a patrimônio nacional ou mundial, não livra os bens tombados de problemas de gestão. A própria Vila de Paranapiacaba é exemplo disto. Parece pertinente aqui citar o exemplo dado por Meneses (2010) ao recordar o que poeta e escritor Carlos Drummond de Andrade escreveu no Jornal do Brasil quando Ouro Preto ganhou o título de Monumento Mundial: "Qualquer dia Ouro Preto vira monumento interplanetário e continuará com os mesmos problemas.". (MENESES, 2010, p. 30). ${ }^{3}$

$\overline{2} \quad$ “(...) qual é o fundamento em que repousa a conservação do patrimônio histórico arquitetônico num mundo que se muniu de recursos cientificos e técnicos para guardar na memória e interrogar seu passado sem a mediação de monumentos ou de monumentos históricos reais? Com efeito, quer se trate das funções econômicas e dos recursos de entretenimento oferecidos pelo patrimônio na sociedade de lazer, quer se trate de valores cognitivos, pedagógicos e artísticos, nenhuma das motivações institucionalmente reconhecidas ou reivindicadas permite interpretar o fervor com o qual o culto patrimonial é celebrado e se difunde no mundo inteiro." (CHOAY, 2006, p. 237)

3 MENESES, Ulpiano Toledo Bezerra de. O campo do Patrimônio cultural. Conferência Magna. In: I Fórum do Patrimônio Cultural. Sistema Nacional do Patrimônio Cultural: Desafios, estratégias e experiências para uma nova gestão. Brasília: IPHAN, 2010. p. 25-39. 
Além dos problemas levantados pelo autor no texto, arrisco a dizer que os problemas são de gestão do patrimônio. Foi observado através de visitas a algumas vilas operárias tombadas na cidade de São Paulo (Vila Maria Zélia, Vila Economizadora), que o tombamento não garante as descaracterizações. É importante garantir a conservação e gestão destes lugares. Recordamos que tombamento, preservação, conservação e gestão possuem matizes distintos, ainda que sejam relacionados.

Há ainda uma polêmica em torno dos bens tombados: se transformá-los em áreas culturais, ou dar uma nova função aos mesmos. No caso, das vilas ferroviárias, a polêmica é ainda maior, dado o déficit habitacional brasileiro. Valeria a pena mantê-las com a função original residencial? Pode-se detectar que algumas vilas operárias tiveram seu uso transformado para hotéis, ou seja, um uso turístico. Às estações, geralmente é dado um uso cultural ou turístico. Foi visto que, com o turismo e a sustentabilidade, as questões do patrimônio foram revisitadas. Seria correto propôr uma mudança de uso? Haveria o que alguns autores identificam como a chamada "gentrificação", que ocorre ao revitalizar-se uma área degradada? Porém, nem em todos casos de revitalização ou preservação há "gentrificação". Há modos de envolver a população local e, ao mesmo tempo, garantir uma preservação eficaz?

Desta maneira, a verificação do estado atual de conservação de algumas vilas operárias e ferroviárias levou ao questionamento das políticas de preservação atuais. Procurou-se contrastar a política de preservação brasileira com a política de preservação de outros países. Em resumo, a presente pesquisa indaga o modo de preservação das vilas ferroviárias estudadas, especialmente sob três aspectos: a) o sistema de valoração atualmente utilizado pelas políticas de preservação brasileiras; b) a gestão do patrimônio cultural e; c) a sustentabilidade econômica destes bens.

Com relação ao marco temporal, vale lembrar, que por se trabalhar com questões relativas ao patrimônio, estaremos trabalhando com diversas temporalidades. Há assim, um tempo referente à existência da Companhia Paulista como empresa privada, que se inicia em 1868 e termina em 1961. Há uma temporalidade posterior, a qual chamaremos “tempo da preservação". É nestas diferentes temporalidades que esta tese se estrutura. Partimos do presente, do estado atual da preservação destas vilas ferroviárias; recorremos à história (construiu-se esta história, com enfoque nos aspectos econômicos, sociais e urbanos, e cientes dos limites desta construção e recorte) para dar um novo significado ao objeto escolhido. A re-significação desta parte do patrimônio industrial ferroviário para o 
presente e com vistas ao futuro destas vilas, justifica este procedimento. Poderá parecer óbvio, porém não o é: acredita-se que para uma política de preservação eficaz, esta conexão das temporalidades - passado, presente e futuro - é extremamente necessária.

Cabe falar em recorte temporal propriamente, quando analisamos a história da Companhia Paulista como empresa privada, entre 1868 e 1961. Apesar da longa existência, de quase um século, julgou-se importante manter estas balizas temporais. Estudos econômicos e sociais anteriores, e das vilas operárias, e o foco na vida dos trabalhadores ferroviários ajudaram, não apenas na leitura dos espaços, como também a estabelecer algumas periodizações dentro deste longo percurso da Companhia Paulista.

Com relação ao futuro e à preservação das vilas ferroviárias, além de re-significar, propõe-se uma associação de dois conceitos: o de paisagem cultural e o conceito de áreas de conservação. Ambos os conceitos não são novos, porém, pela bibliografia estudada, raras vezes, são vistos de maneira conjugada. Sabe-se das vantagens e das desvantagens do conceito de paisagem cultural. Portanto, para suprir as desvantagens deste conceito, sobretudo referentes, aos limites e aspectos de gestão, propõe-se uní-lo ao conceito de áreas de conservação. Neste último conceito, sem esquecer da multidisciplinariedade que exigem os estudos do patrimônio e do urbano, sublinha-se a questão da re-utilização dos espaços urbanos, não apenas segundo o uso cultural, mas também levar em conta o tecido urbano, seguindo uma tendência mundial de aliar os estudos do patrimônio ao planejamento urbano. Para auxiliar na conservação destas áreas, estabelecendo diretrizes para eventuais guias de transformação, recomenda-se a leitura morfotipológica destes espaços. Ao final deste trabalho, fizemos um ensaio para uma das vilas ferroviárias, e a vila escolhida é a de Rincão, por apresentar grande diversidade de tipologias e subtipologias, e com poucas descaracterizações.

Tais recortes, tanto espacial (limitando-se as seis vilas ferroviárias) como temporal (a história da Companhia Paulista como empresa privada), fizeram-se necessários dada a magnitude tanto empírica quanto analítica das questões em pauta. Contudo, acredita-se que as conclusões a que chegamos com o presente trabalho, e principalmente a metodologia utilizada, fundamentada na pesquisa histórica, utilização do conceito de paisagem cultural associado a aspectos de gestão e áreas de conservação, com a leitura de seus espaços através da leitura morfotipológica, podem vir a ser extrapoladas para outras vilas ferroviárias dos outros municípios do estado de São Paulo onde atuou a Companhia Paulista. Acredita-se que, fazendo-se as necessárias adaptações, a metodologia de 
trabalho poderá ser empregada inclusive para vilas constituídas por outras companhias ferroviárias.

\section{Metodologia}

A pesquisa constituiu suas análises, a partir da revisão bibliográfica e dos dados empíricos, obtidos em visitas de campo. É necessário lembrar que existem duas vertentes bibliográficas que se procurou conjugar: uma referente às vilas ferroviárias, a Companhia Paulista e seus trabalhadores e, outra vertente bibliográfica referente às questões de preservação.

Para a revisão bibliográfica das vilas ferroviárias e da Companhia Paulista, utilizou-se das fontes secundárias, ou seja, a bibliografia existente sobre as ferrovias, e especialmente as vilas ferroviárias. E como fontes primárias, utilizamos os Relatórios da Companhia Paulista, a Revista Ferroviária, os arquivos da Superintendência do Patrimônio da União (SPU), Inventariança da extinta Rede Ferroviária Federal (RFFSA) e o Museu Ferroviário de Jundiaí. Por esta revisão bibliográfica das fontes secundárias, tivemos duas importantes constatações: a primeira, a de que existem muitos estudos sobre as ferrovias e estações, mais ainda são poucos os estudos específicos sobre as vilas ferroviárias. E a segunda constatação, a leitura dos espaços das vilas ferroviárias não poderia ser mais rica senão através dos estudos de cunho sociológico, e aqui, gostaria de destacar o trabalho de Segnini (1982). Há também uma forte relação entre as vilas ferroviárias e vilas operárias, e a obra a ser destacada é a de Correia. Quanto às fontes primárias pesquisadas, utilizamos os Relatórios da Companhia Paulista, já visitados por autores como Saes, Grandi e Segnini, respectivamente para estudos do ponto de vista econômico e social. Há poucas informações sobre as vilas, porém, pudemos detectar algumas, como a datação da maior parte das casas da vila ferroviária de Rincão, e que a construção de armazéns reguladores de café em terrenos da Companhia Paulista, em 1922, demandaram mais construção de casas nas vilas. Outra fonte primária utilizada foi a Revista Ferroviária, cujos artigos dão um panorama sobre as ferrovias nacionais, e inclusive internacionais, entre 1940 e 1960, informando por exemplo, sobre a crise ferroviária, os planos nacionais de viação, a pressão pela estatização e a criação da Rede Ferroviária Federal S. A., com posições favoráveis e contra tal criação. Interessante notar e ressaltar, que a Companhia Paulista foi a primeira a reunir capital nacional, e a última de administração privada a sobreviver 
às encampações.

Também foram consultados os Arquivos da Inventariança da Rede Ferroviária Federal S. A. e o Museu Ferroviário de Jundiaí (antiga oficina da Companhia Paulista). Infelizmente, parece que há pouco cuidado com o material, e arrisca-se a dizer, pouca exploração histórica destes arquivos. Sublinha-se que há ainda um rico material a ser pesquisado e, ao mesmo tempo um grande patrimônio industrial em risco. No Arquivo da Inventariança da Rede Ferroviária Federal S. A., foram encontradas apenas plantas em escalas ampliadas (escalas 1:200, 1:500, 1:1000), ou seja, apenas escalas de implantação das vilas. Não foi encontrada nenhuma planta antiga de qualquer casa de vila. Há inven-

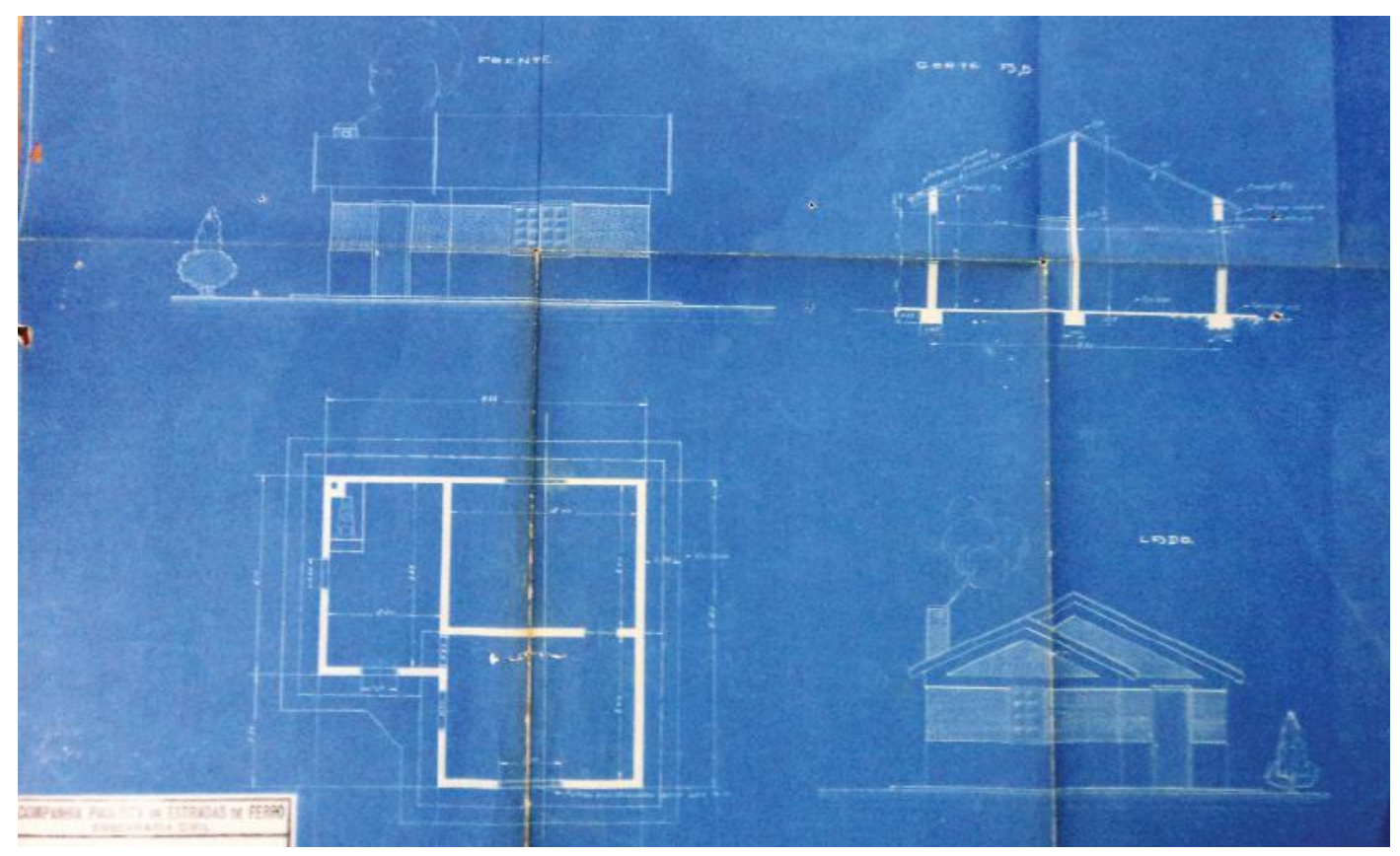

Foto 1 - Prancha encontrada no Museu Ferroviária de Jundiaí
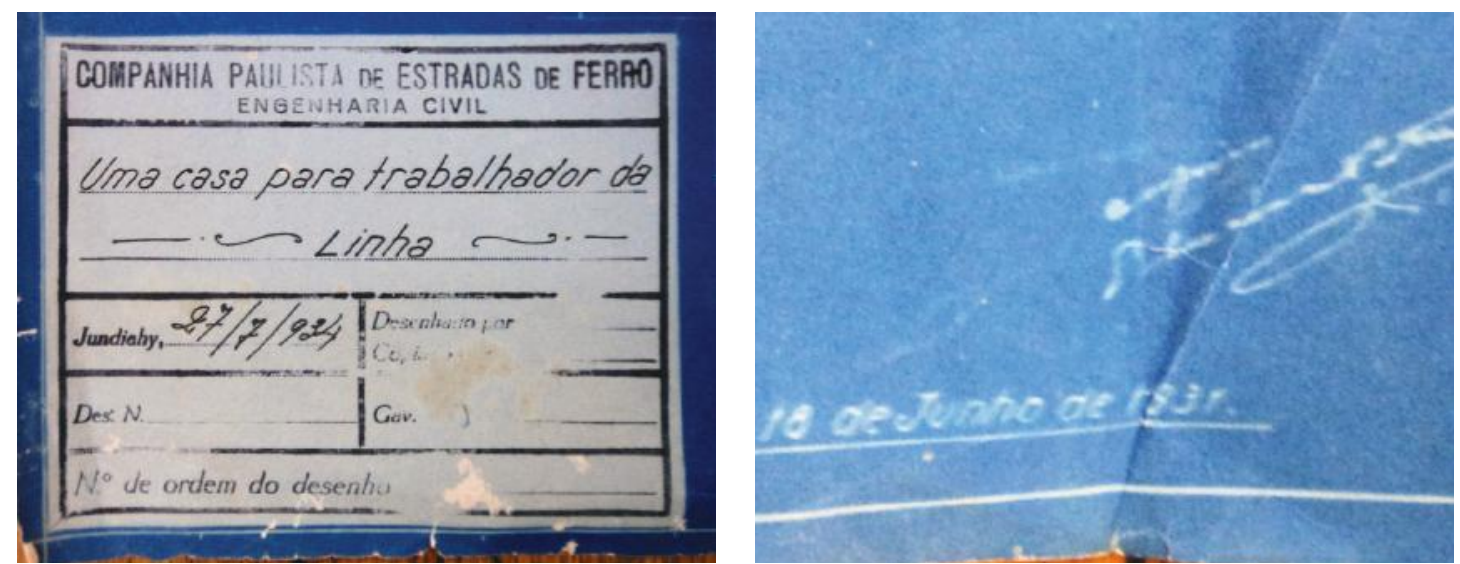

Foto 2 - Detalhe da foto 1: Carimbo da

Foto 3 - Outra data encontrada (1931) prancha (1934) 


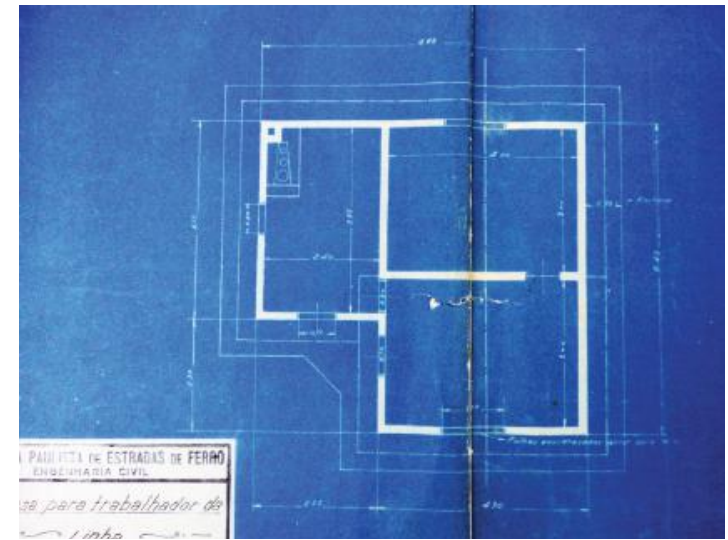

Foto 4 - Detalhe da foto 1: Planta. Fonte: Museu Ferroviário de Jundiaí

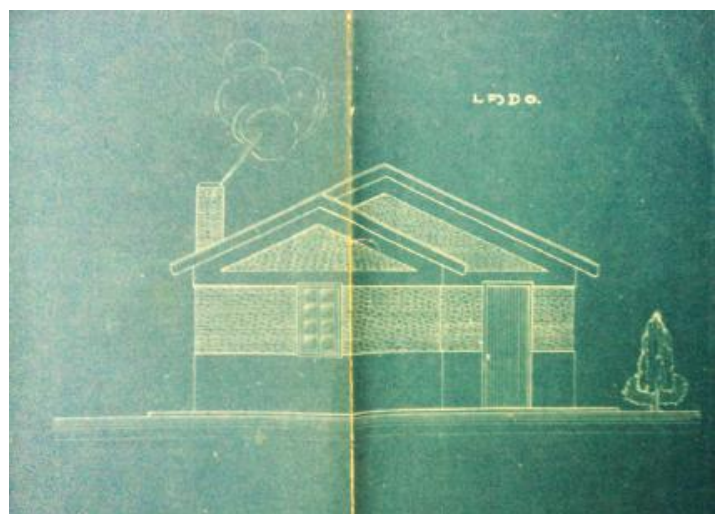

Foto 6 - Detalhe da foto 1: Fachada lateral. Fonte: Museu Ferroviário de Jundiaí

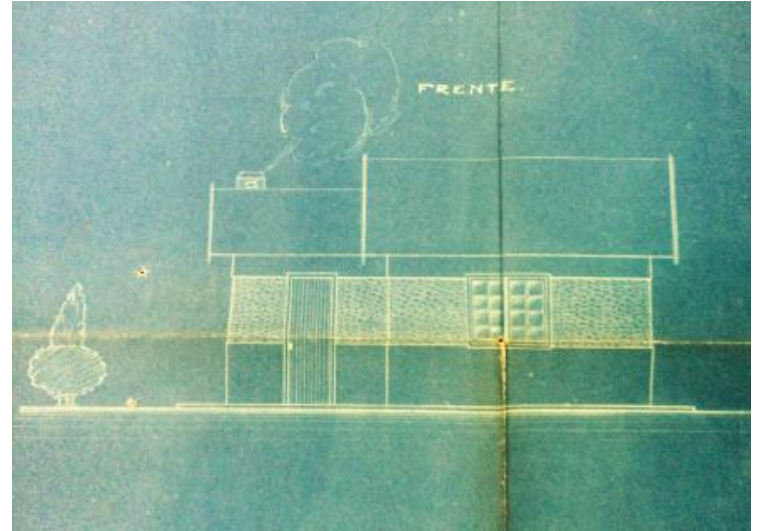

Foto 5 - Detalhe da foto 1: Fachada frontal. Fonte: Museu Ferroviário de Jundiaí

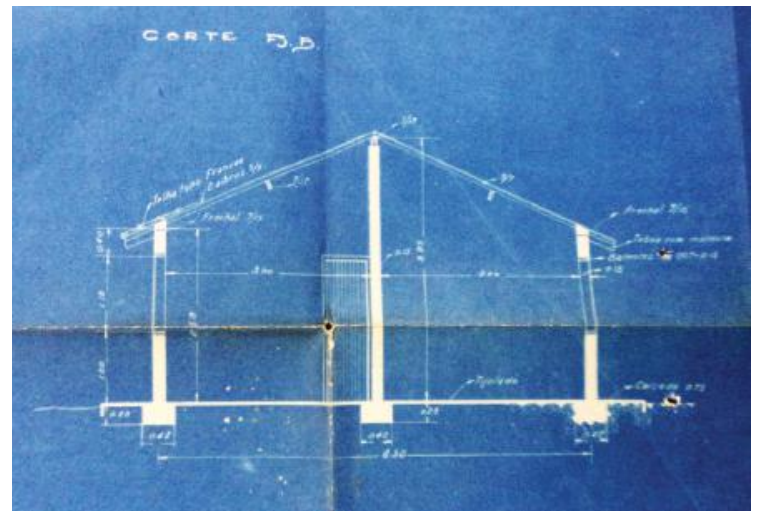

Foto 7 - Detalhe da foto 1: Corte. Fonte: Museu Ferroviário de Jundiaí

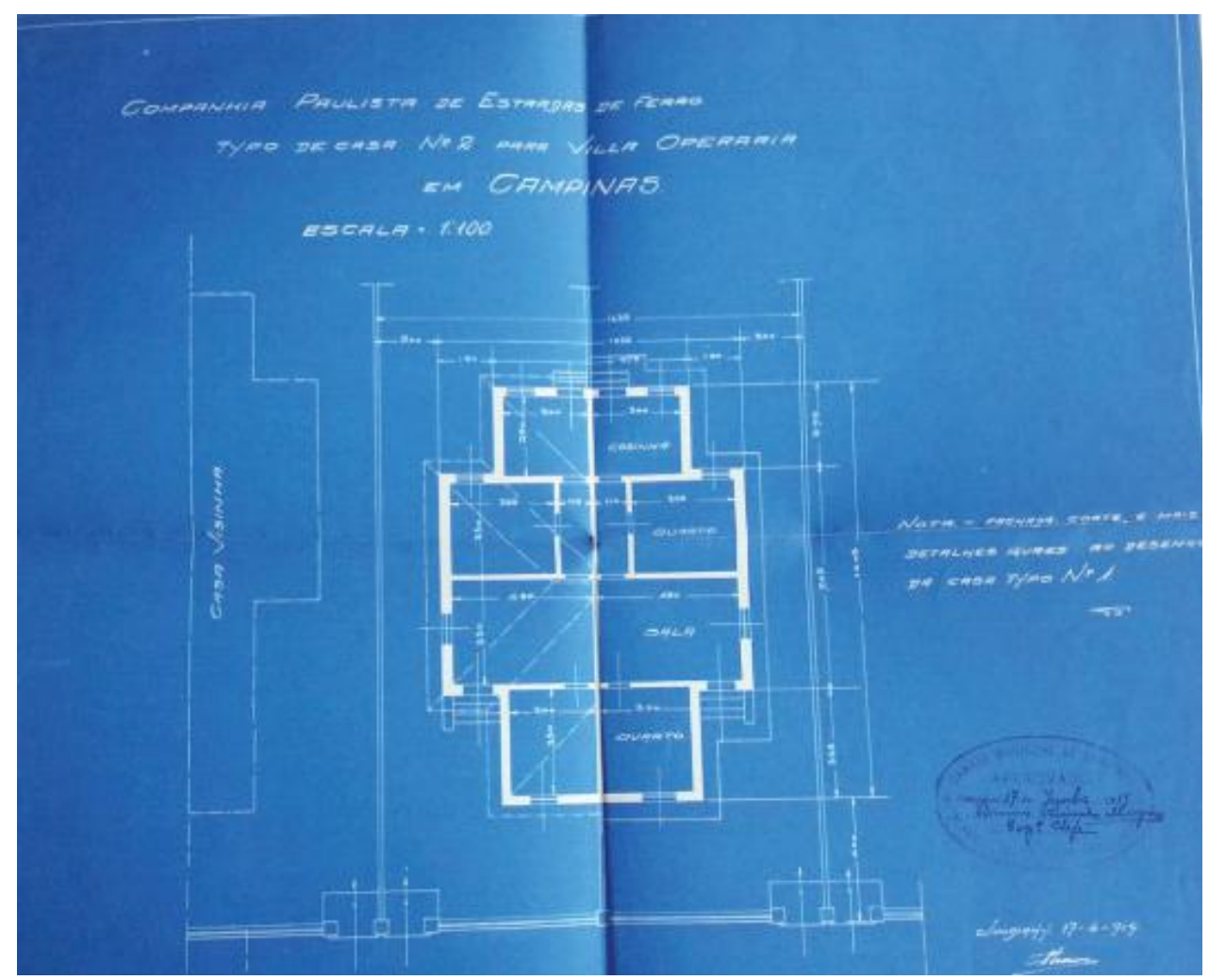

Foto 8 - Planta de uma casa da vila ferroviária de Campinas. Fonte: Arquivo Municipal de Campinas 
tários mais recentes realizados por uma empresa terceirizada, assim como o relatório da PLANART, que está na biblioteca da FAU-USP, cujo responsável técnico foi o Prof. Nestor Goulart Reis Filho, contratado pela FEPASA, com vistas a um projeto de restauro, porém nunca realizado. O que chama a atenção no Relatório da PLANART é a identificação das vilas ferroviárias dentro do complexo ferroviário, e note-se que estes estudos são de 1978. E os tombamentos das estações como complexos ferroviários são mais recentes, do final dos anos 1980 e início dos anos 1990 em diante. Ainda sobre as fontes primárias, um engenheiro da Inventariança informou que há algum material da Companhia Paulista, no bairro da Móoca, como por exemplo, as fichas dos ex-ferroviários, mas estão inacessíveis aos pesquisadores, por questões de manuseio e saúde, pois são frágeis e estão com bolor.

No Museu Ferroviário de Jundiaí, apesar da grande quantidade de material que à primeira vista pode-se observar na biblioteca, os registros são pouco sistematizados e organizados. Há muitas plantas de máquinas locomotivas e vagões. Foi encontrada aí, uma única planta de uma casa de turma, datada de 1934, não assinada, apenas traz no carimbo: “Seção de Engenharia". Assim, fica difícil comprovar se a vila era projetada pela Seção de Engenharia e replicada por outras cidades, apenas adaptando-se a implantação. Tudo leva crer que sim, pela simplicidade do programa e dos estilos, e por haver nos relatórios da Companhia, alguns dados pela Seção de Linhas e Edifícios, que terá seu nome alterado para Seção de Engenharia. Não se acredita em uma hipótese da contratação de um arquiteto para a construção das vilas, como existem alguns exemplos de algumas estações, cujo projeto poderia envolver um arquiteto convidado. Outra planta encontrada, foi de uma casa da vila ferroviária de Campinas. O carimbo data de 1919. ${ }^{4}$

É entre estas lacunas de informações, que conseguimos encontrar aqui e acolá, documentos sobre as vilas ferroviárias, e remontar a sua história. E, na falta de fontes primárias, as visitas de campo às cidades, foram de fundamental importância. As visitas de campo foram relevantes para uma primeira apreensão da inserção destas na malha urbana e para averiguar seu estado atual de conservação, além da leitura morfotipológica destes espaços. Em cidades como Itirapina, Dois Córregos, Brotas e Rincão, como não houve um crescimento expressivo da cidade, a identificação das vilas foi fácil. Porém em cidades como Jaú e São Carlos, a identificação, se não fossem registros anteriores obtidos por Morais (2002) ou Termos de Transferência da Superintendência do Patrimônio da União, seria difícil a identificação. No caso de Jaú, a construção de muros dificulta

$4 \quad$ Uma hipótese é a de que as plantas eram esenhadas pela Companhia Paulista e aprovadas nas respectivas cidades. 
a visibilidade das casas. No caso de São Carlos, a causa da dificuldade em identificar a vila foi a demolição, e também a heterogeneidade de tipologias e materiais das casas, não conformando um conjunto. Assim comprova-se como as fontes primárias, a revisão bibliográfica e as visitas de campo complementam-se. Não seria possível a leitura destes espaços sem as

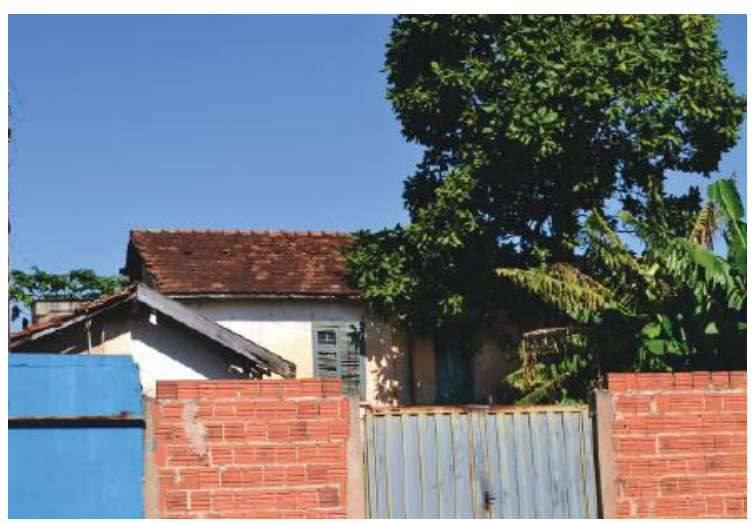

Foto 9 - Vila ferroviária de Jaú - casa encoberta pelo muro. Fonte: autora, 2012 fontes primárias e secundárias. Ao mesmo tempo, foi verificado como os dados empíricos jogam nova luz às fontes escritas e vice-versa.

Para a questão de patrimônio, partiu-se dos trabalhos de Kühl (1996, 2000 e 2010), e outros que tratam da questão do patrimonial industrial como Soukhef Jr (2010), Vichnewski (2004), e para as questões relativas ao patrimônio urbano, Rufinoni (2009) e Vitorino (2008). Para

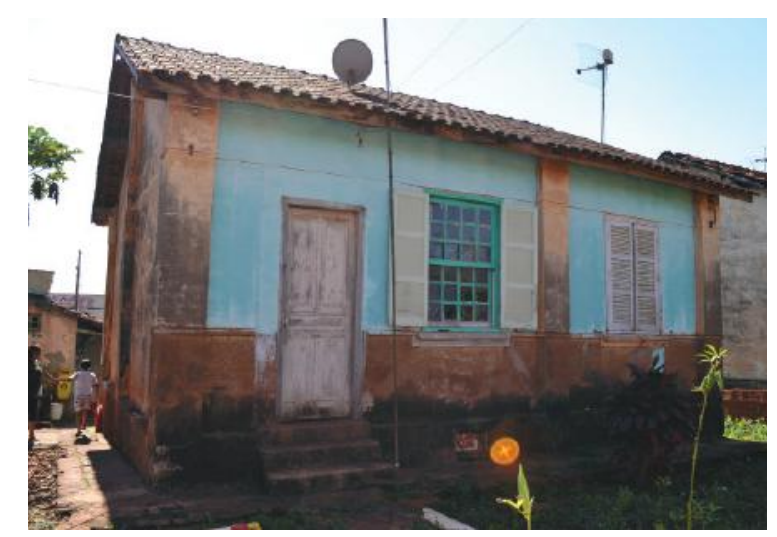

Foto 10 - Vila ferroviária de Jaú - a mesma casa sem o muro. Fonte: autora, 2012 compreensão das políticas de preservação brasileiras foram importantes as leituras dos trabalhos de Sant'Anna (1995), Rodrigues (2000), Fonseca (2005) e Chuva (2009), e para a compreensão das diferenças entre as políticas brasileiras e estrangeiras não poderíamos deixar de citar Choay (2006) e Gouveia \& Miceli(1985). Para o conceito de paisagem cultural, apoiamo-nos no trabalho de Ribeiro (2007). Também foram de grande importância a leitura de cartas patrimoniais, além da carta relativa ao patrimônio industrial - Niznhy Tagil (2003). Foi feita uma análise das cartas patrimoniais, verificando como se deu o alargamento do conceito de patrimônio de objeto isolado para o de patrimônio urbano. Também neste sentido foi de grande importância a leitura do artigo de Colenbrader, Roders \& Veldpaus (2013). Além disso, durante as visitas técnicas realizadas ao Reino Unido e Holanda, foi possível tomar contato com outra bibliografia, sobretudo em língua inglesa, e descobrir uma outra maneira de organizar e gerir o patrimônio. 
Para a compreensão das áreas de conservação, foram importantes as visitas realizadas para conhecer as vilas operárias e ferroviárias inglesas, e para a coleta de novas referências bibliográficas. Já no projeto de pesquisa foi proposto um estudo comparativo com outras vilas ferroviárias e também tomar conhecimento do encaminhamento dado para o patrimônio ferroviário em outros países. Por serem países que iniciaram antes a construção de ferrovias, e ainda utilizarem muito da sua malha ferroviária pelo que temos notícia, é de se estranhar que tenham sofrido processo de abandono, porém há casos, como foi citado por Kühl (1998, p. 233). As visitas técnicas foram no sentido de averiguar o estado de conservação. Por terem um grande histórico de preservação tanto teórico como prático, foi muito interessante estudar tais casos internacionais, e refletir, considerando as distâncias e circunstâncias, a aplicabilidade de tais experiências aos casos brasileiros.

Foram duas as visitas técnicas realizadas durante o doutorado: uma ao Reino Unido e outra aos Países Baixos. No Reino Unido, visitamos algumas vilas operárias, ferroviárias e o Ironbridge, com o intuito de observar o seu estado de conservação, e também visitamos o National Railway Museum. O National Railway Museum possui um convênio com a Universidade de York, a responsável por este convênio atualmente é a Profa. Dra. Teresa da Silva Lopes, que me recebeu. As vilas operárias visitadas foram as de Port Sunlight, Bromborough Pool, Saltaire e New Earswick, localizadas na região do antigo centro industrial da Inglaterra, e as vilas ferroviárias visitadas foram as de Swindon, Crewe e Derby. Após a visita, pode-se resumir a quatro, as descobertas ou contribuições desta visita: a primeira delas, e a que a aproxima das vilas ferroviárias brasileiras, é que é possível estabelecer algumas semelhanças entre vilas brasileiras e inglesas: no processo de formação das vilas, no paternalismo existente entre patrões e empregados, na hierarquia do trabalho especializada nas vilas, nas diferentes tipologias e programas. As demais descobertas são mais contrastes do que semelhanças, com relação à realidade brasileira, sobretudo, no que diz respeito à preservação.

A segunda descoberta foi verificar a existência de planos das áreas de conservação, com exceção de Crewe, para todas as vilas. No Reino Unido, quanto ao patrimônio industrial, inclusive o ferroviário, apesar das demolições na década de 1960, movimentos preservacionistas ganham força no início da década de 1990. O Planning Act, da mesma época, volta a estabelecer as áreas de conservação. Os planos de conservação não necessariamente são elaborados pelo poder público. Podem ser elaborados, por exemplo, por escritórios de arquitetura ou paisagismo, e protocolados nos councils ou municipalidades. 
Estas experiências sugeriram um maior aprofundamento do que vem a ser tais áreas, ganhando destaque em nossas pesquisas, até apresentá-las como conceito complementar ao de Paisagem Cultural.

A terceira descoberta foi a da existência dos trusts e de como a questão do patrimônio é encarada pelo Estado e pela sociedade civil. Assim, esta outra questão foi aprofundada pela pesquisa, discutindo-se no primeiro capítulo, a existência de modelos de preservação, como colocados por Choay (2006). No Reino Unido, o órgão de preservação English Heritage funciona mais como um conselheiro, fiscalizador e subsidiário, dos trusts que levam a cabo o trabalho de restauro e manutenção. A forma de encarar o patrimônio em geral, pela sociedade, é bastante diferente da sociedade brasileira. Há menos centralização e mais participação da sociedade, inclusive financeiramente. E não se teme o que se chama de propriedade privada. Um dos maiores trusts ingleses, o National Trust, compra inúmeras propriedades para sua conservação. Há uma grande diferença de entendimento, se formos comparar, a sociedade brasileira e a inglesa, do papel do Estado na cultura. Para os ingleses, nem tudo o que é público deve necessariamente vir do Estado, e nem tudo que é cultura deve ser chancelado e patrocinado pelo Estado.

E a quarta descoberta foi o National Railway Museum, que obviamente contrasta com, por exemplo, o nosso Museu Ferroviário de Jundiaí. Chama a atenção a estrutura do museu; o estabelecimento de um convênio com a Universidade de York para continuar as pesquisas de seus acervos e materiais; a imensa quantidade de materiais sejam estes, arquivos,

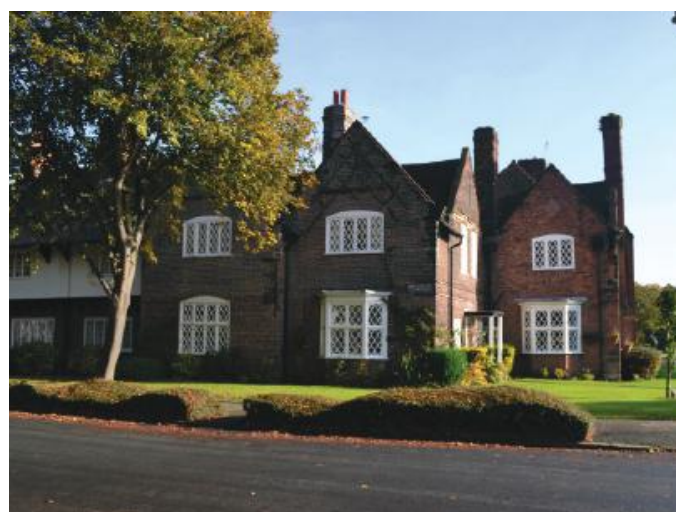

Foto 11 - Uma das tipologias de casa da vila operária de Portsunlight. Fonte: autora, 2014

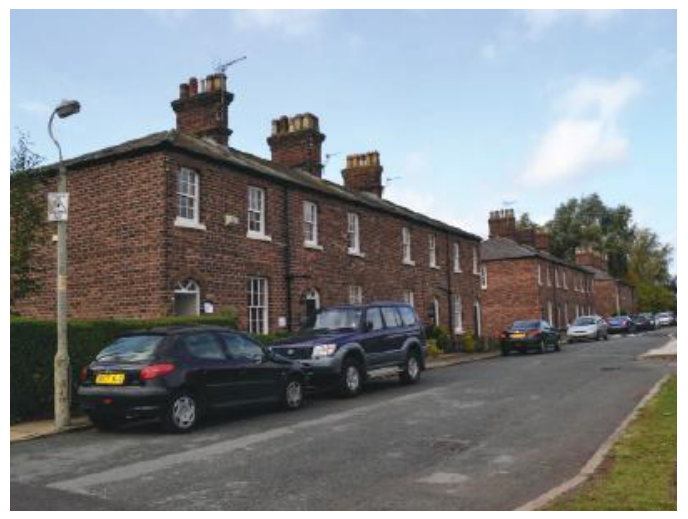

Foto 12 - Conjunto de casas da vila operária de Bromborough Pool.

Fonte: autora, 2014

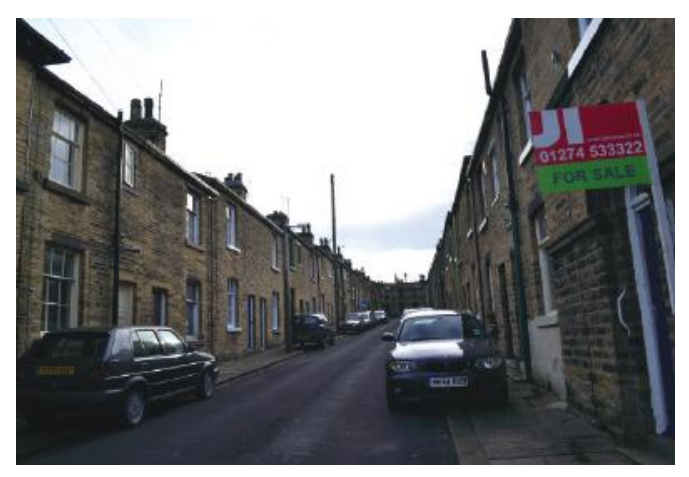

Foto 13 - Visão geral de uma das ruas da vila operária de Saltaire.

Fonte: autora, 2014 


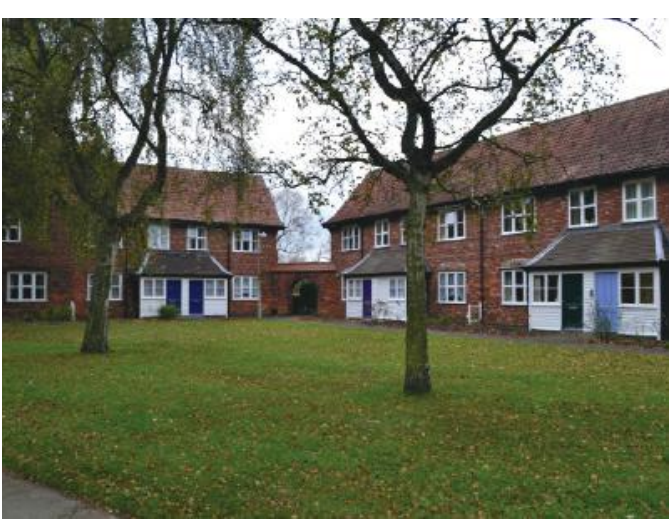

Foto 14- Conjunto de casas de uma das tipologias de New Earswick Fonte: autora, 2014

máquinas e locomotivas expostas; a maneira atrativa como estão apresentados tais bens patrimoniais aos visitantes, e também a quantidade de visitantes que recebe semanalmente.

Na sequência à visita ao Reino Unido, visitamos os Países Baixos, onde fui recebida pelo Prof. Dr. Paul Meurs, professor do Departamento de Patrimônio e Ambiente Construído, da Faculdade de Arquitetura e Urbanismo, da Universidade de Delft. O departa-

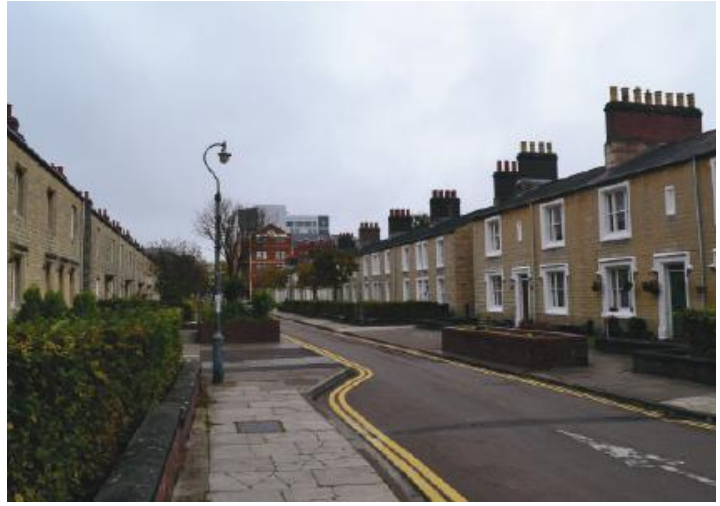

Foto 15- Visão geral de uma das ruas da vila ferroviária de Swindon. Fonte: autora, 2014

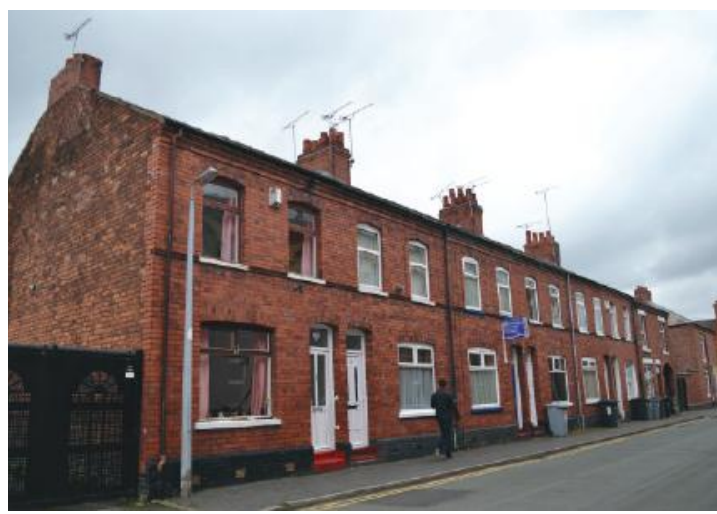

Foto 17 - Uma das ruas da vila ferroviária de Crewe. Fonte: autora, 2014

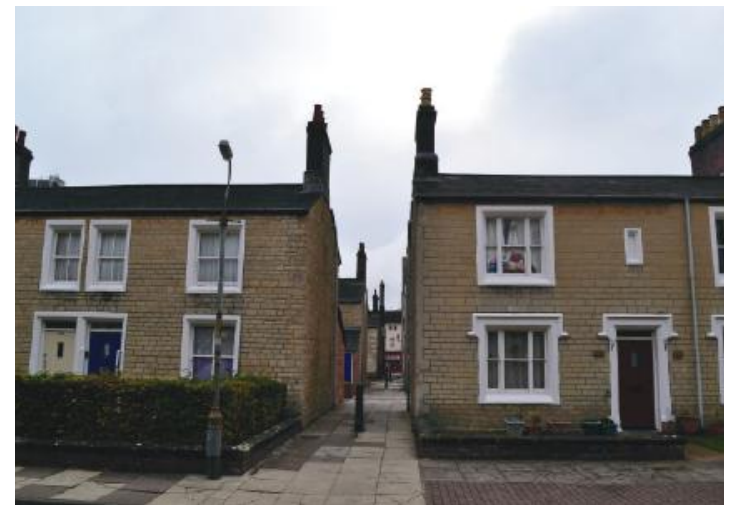

Foto 16 - Casas de uma das tipologias de Swindon. Fonte: autora, 2014

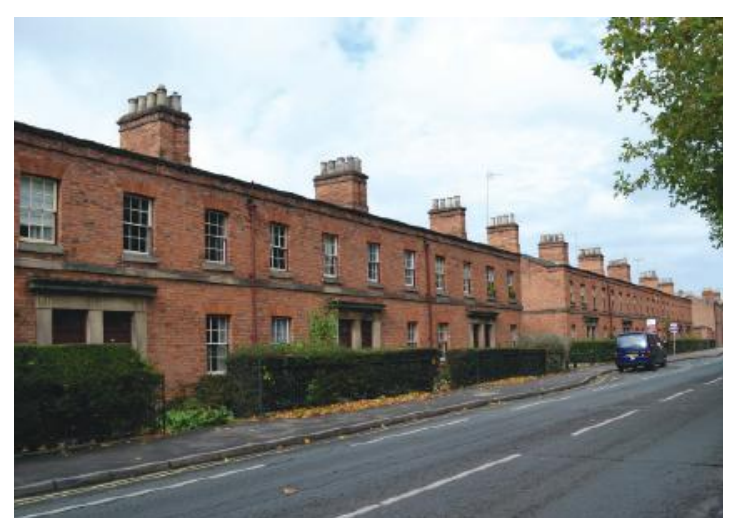

Foto 18 - Uma das ruas da vila ferroviária de Derby. Fonte: autora, 2014

mento de patrimônio possui o seguinte nome: RMIT - Restoration, Modification, Intervention and Transformation. Encontrou-se uma explicação do nome do departamento, em uma publicação de 2006, dada pelo Prof. Dr. Jo M. J. Coenen, que estruturou o departa- 
mento:

A constante intervenção, modificação e transformação do ambiente construído necessita novas abordagens pelos arquitetos e planejadores em sua profissão. Isto também implica que políticas de conservação deveriam seriamente considerar a mudança integrada, não apenas como ameaça, mas um fato natural como também uma oportunidade positiva. Na Delft University esta percepção resultou na criação do RMIT.(...). ${ }^{5}$

E em seguida explica cada um dos conceitos ligados ao departamento:

(...) I have rearranged the content of the discipline of restoration into three main domains: Modification, at scale levels extending from material to building. Intervention from the level of the single building to the building complex and Transformation extending from the level of the building complex to the silhouette of the town or village as a whole and to the entire landscape. The three, MIT, form the body of the discipline of Restoration. (...)" (COENEN in MEURS \& VERHOEF 2006, p. 199)

Este aspecto da mudança e de transformação do patrimônio, bastante ligado ao planejamento urbano, talvez seja o que mais impressionou das palestras e das aulas que pude frequentar em Delft. Aliás tais aspectos de mudança, como algo positivo para o patrimônio, está em consonância com a carta patrimonial denominada "Princípios de Valleta", do ICOMOS, de 2011, ainda pouco difundida nos meios de brasileiros. Porém, não é só a mudança pela mudança. Há nas aulas de Delft, como no ambiente holandês de maneira geral, a questão do re-uso, do refurbishment, o reaproveitamento dos edifícios. Ao mesmo tempo, não existe uma contraposição entre a prática projetual e a história e os valores do lugar. Para a mudança, existe valoração, escalas de intervenção, para assim, estabelecer os guias de transformação. Há um equilíbrio entre passado, presente e futuro. Se pudesse resumir tal visita técnica, eu destacaria: re-uso, dimensão contemporânea do patrimônio e o patrimônio estreitamente ligado ao projeto do edifício e planejamento urbano.

A intervenção é pensada e voltada para adaptar os edifícios a novos usos, para assim conservar os edifícios, com a conservação entendida como novo uso. Uma questão importante ligada ao re-uso dos edifícios holandeses, é a situação do patrimônio holandês e a gestão deste patrimônio. Segundo Meurs (S.D.) ${ }^{6}$, os Países Baixos possuem 50.000

\footnotetext{
$\overline{5}$ Minha tradução - COENEN in MEURS \& VERHOEF 2006, p. 197.

6 MEURS utilizou como fonte de dados: Erfgoed Nederland, Jaaroverzicht Monumenten, archeologie en Cultuurlandschap 2010, Amsterdam 2011.
} 
edifícios considerados patrimônios naturais, 50.000 edifícios considerados patrimônios municipais, 500 edifícios são patrimônios regionais, 450 vilas históricas e paisagens urbanas, 1400 lugares arqueológicos e 9 lugares que são patrimônios mundiais (World Heritage Sites, incluindo Wadden Sea e Willemstad, em Curaçao). Há ainda um número de 'paisagens valiosas" ("valuable landscapes" conhecidas como Belvedere areas) e um extensivo sistema de parques nacionais. Diante deste imenso patrimônio, é quase que impossível gerir, e até os órgãos não estão mais propensos a inventariar, "listar" ou "tombar" mais nada, pelas dificuldades de gestão.

A saída encontrada para tantos edifícios tombados é a re-utilização destes. Os novos usos dados aos edifícios são os mais variados, e a nova função é dada com vistas às qualidades e necessidades locais, e ao desenvolvimento que se queira dar ao local. Dessa maneira, é muito mais uma visão do patrimônio ligada ao planejamento urbano. Os holandeses já sabem o que possuem, já passaram a fase do inventário, o problema agora para eles é cuidar, conservar e para isto, dar uma nova destinação, pois sabem o valor de uso que tal patrimônio possui. O refurbishment, o aproveitar o existente e assim evitar o desperdício, liga-se também às questões econômicas, e atualmente se une à questão da sustentabilidade ambiental. Aliás, é muito comum ultimamente, unir o patrimônio à questão da sustentabilidade ambiental, e à qualidade ambiental cada vez mais ligada ao ambiente urbano. Assim, revela-se a dimensão contemporânea do patrimônio, não se contrapondo patrimônio e desenvolvimento, como também, não se une patrimônio à ideia de tecido "museal" (ou congelamento) e não há tampouco um simples estabelecimento de áreas. Há uma cuidadosa avaliação do lugar, das suas pré-existências, enfim, da valoração e do equilíbrio que este trabalho de valoração exige para o estabelecimento dos guias de transformação.

Outra lição aprendida da Holanda foi a maneira de ver concretizada a equipe multidisciplinar, importante para os trabalhos de patrimônio. O escritório de Prof. Paul Meurs, possui não apenas arquitetos como historiadores em sua equipe. Além disso, o escritório faz o trabalho de intermediação entre os órgãos de preservação, municipalidades e empresas. Acredito que este tipo de conexão, raramente é feito no Brasil, ou pelos menos, nos meios de acadêmicos. Nestes últimos, a crítica é dirigida aos órgãos de preservação, quanto a critérios de tombamento e preservação ou à morosidade dos processos, ou então a crítica é dirigida aos especuladores imobiliários que vem demolindo as construções antigas, tombadas ou não. Dificilmente, encontra-se uma posição mais conciliadora, entre 
as duas esferas, pública e privada, ou então, soluções mais propositivas.

Os exemplos e lições aprendidos na Inglaterra e na Holanda, talvez não sejam aplicáveis ao Brasil. Nossas estruturas e mentalidades são diferentes, contudo, pode-se introduzir mudanças, e tais exemplos, por suas diferenças e pelos estranhamentos produzidos, podem iluminar o tratamento do patrimônio brasileiro. Um pouco do pragmatismo inglês e holandês pode nos ser salutar, bem como a aproximação do patrimônio ao planejamento urbano e à sociedade. A diferença leva a refletir se não se pode organizar de outras maneiras a preservação das vilas ferroviárias no Brasil.

Esta tese se estrutura na articulação de diferentes temporalidades: partimos do presente, do estado atual da preservação das vilas ferroviárias onde se conforma o primeiro capítulo; para entender a importância destas vilas ferroviárias analisadas, abordadas no primeiro capítulo. Para a compreensão histórica destas vilas ferroviárias, reconstruímos e analisamos tal passado, segundo alguns recortes, em especial os aspectos sociais, econômicos e urbanos, elaborados no capítulo segundo. E, finalmente, com tal passado analisado, volta-se a re-significar as vilas, que são pensadas hoje e com vistas ao futuro, já que se apresenta uma proposta de preservação através da articulação de dois conceitos, a paisagem cultural ferroviária e as áreas de conservação,

Esperamos ter cumprido com os objetivos, de valorizar novamente as vilas ferroviárias e o mundo do trabalho dentro da história e das políticas de preservação. E esperamos que, após a leitura do presente trabalho, a memória transcenda a Vila de Paranapiacaba como único exemplar de vila ferroviária. E que o leitor, ao viajar pelo interior de São Paulo, possa ele mesmo, identificar na paisagem, além da estação, umas casinhas pequeninas, e que se lembre que nelas moraram os ferroviários, que fizeram funcionar muitos dos trens que circularam por este interior. 


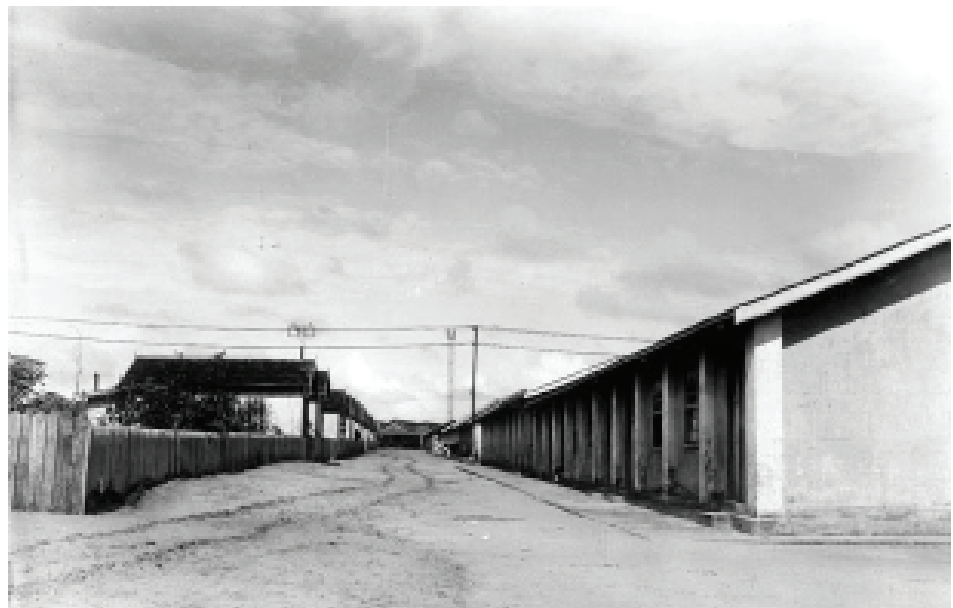

\section{ITIRAPINA}

Foto 19 - Vila

ferroviária de Itirapina.

Fonte: Museu

Ferroviário de Jundiaí.

$\mathrm{s} / \mathrm{d}$.

Foto 20 - Foto atual

da estação de Itirapina.

Fonte: autora, 2013.

Foto 21 - Foto atual de uma das casas da vila ferroviária de Itirapina.

\section{9}
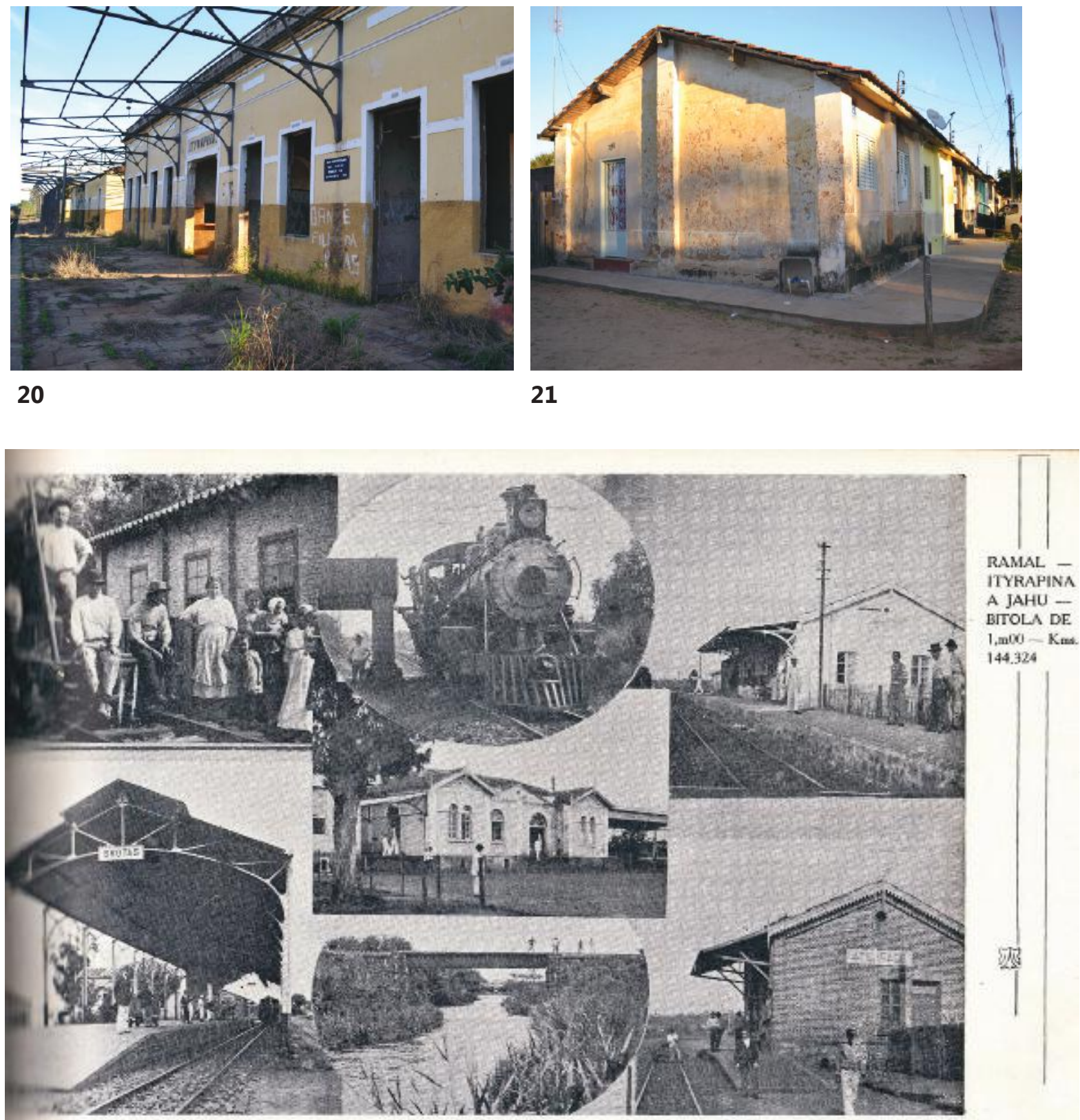

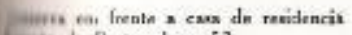
fouth its Blechas, kims 52
Loccmntiva Iomando s gas Ponte sobre o Rio Jueare
Estagño de Campo Alegre, kme. 20. insmgurada em 1.7-1885 Alerrado, posto telegrsphico, $\mathrm{km}$. 42 . 


\section{BROTAS}

Foto 22 (pág. anterior) - Foto de Brotas e estações próximas. Fonte: Álbum Ilustrado da CP, 1918. Foto 23 - Foto atual da estação de Brotas. Fonte: autora, 2013.

Foto 24 - Foto atual de uma das casas da vila ferroviária de Brotas. Fonte: autora, 2013.
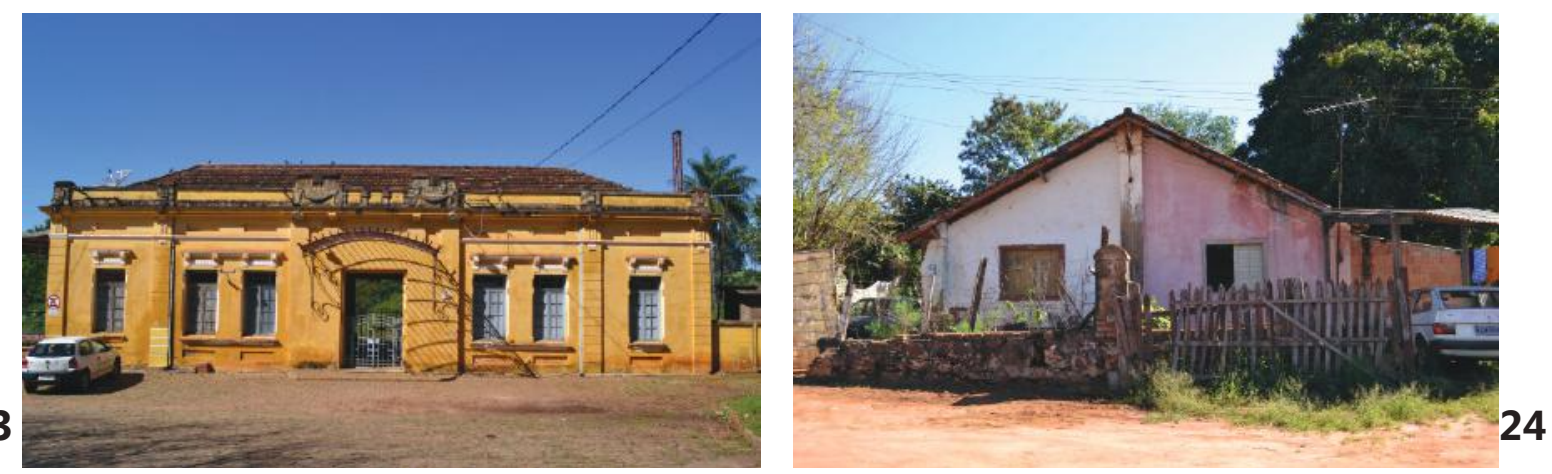

- RAMAL - IYRAPINA A JAHL - BITOIA DE Im,00 - Km. 144,324
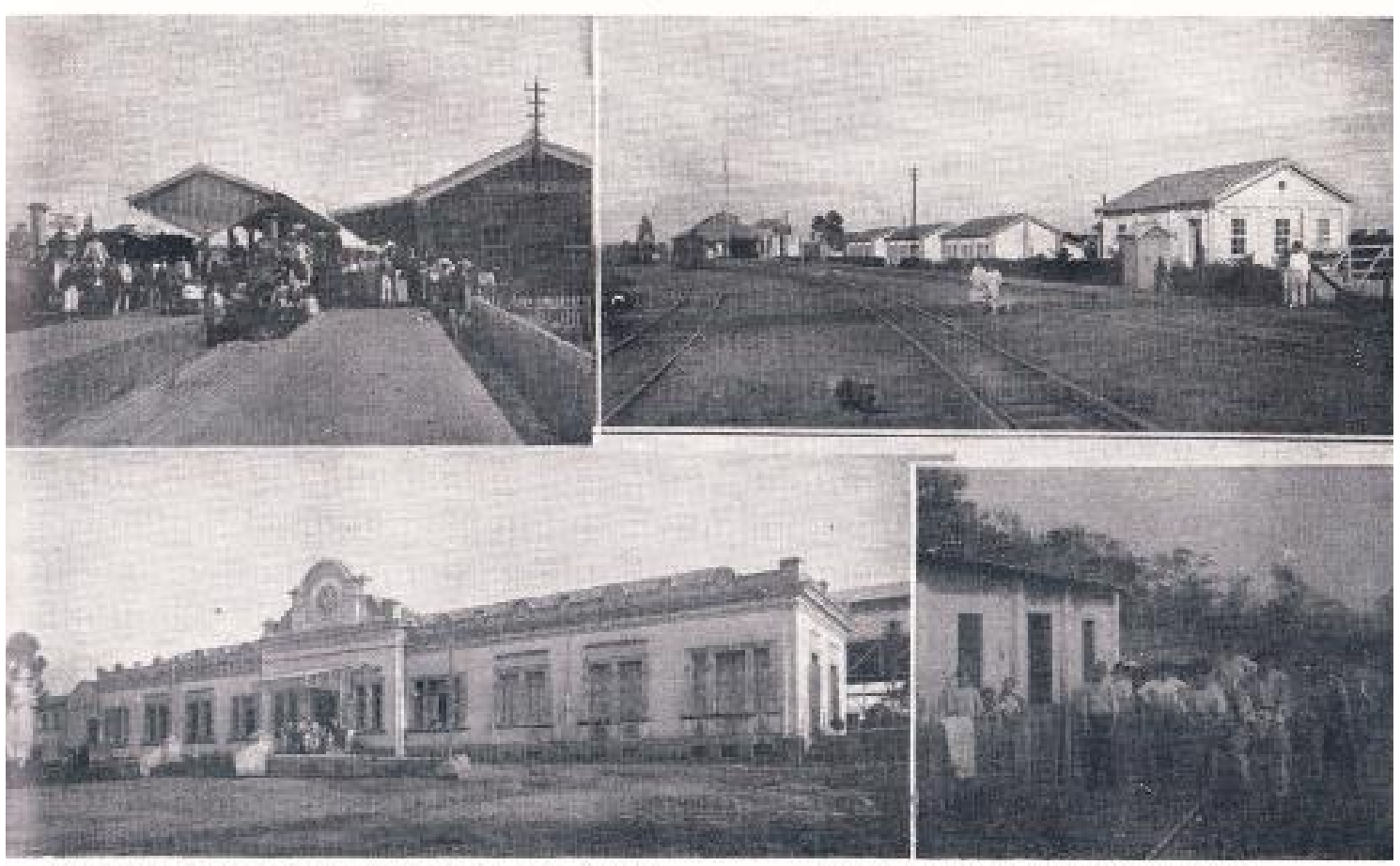

25

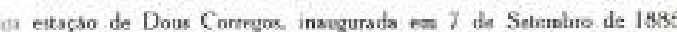

Estaço e casas de emprezados da Componhia

Aclual oleşio de Dous Corregos, km. 112

Cunurva junto í case do mexideneis

\section{DOIS CÓRREGOS}

Foto 25 - Foto da estação e da vila ferroviária de Dois Córregos. Fonte: Álbum Ilustrado da CP, 1918. Foto 26 - Foto atual da estação de Dois Córregos. Fonte: autora, 2013.

Foto 27 - Foto atual das casas da vila ferroviária de Dois Córregos. Fonte: autora, 2013.
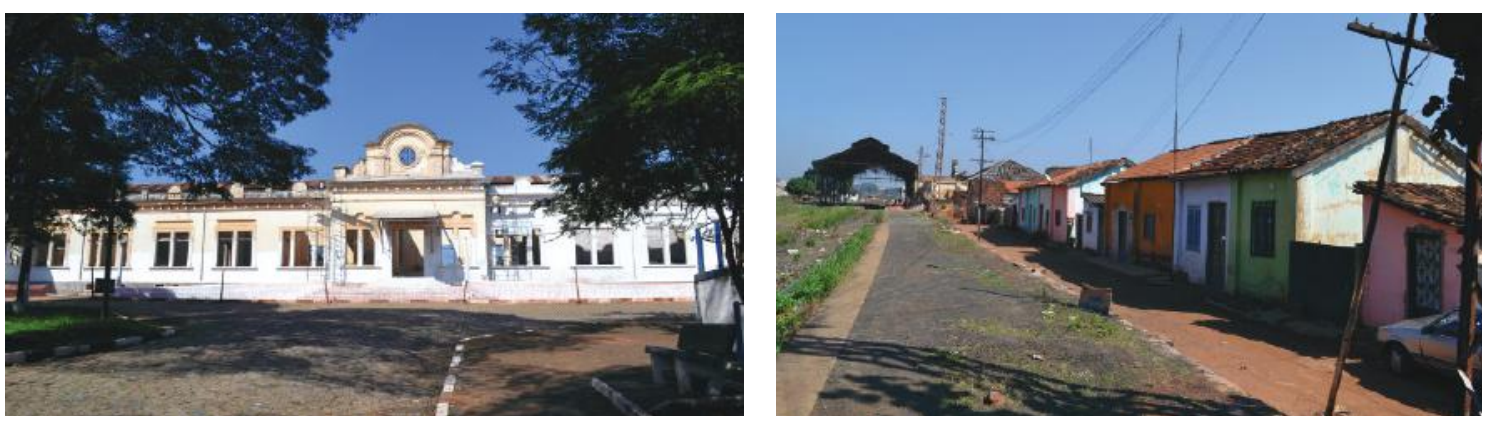

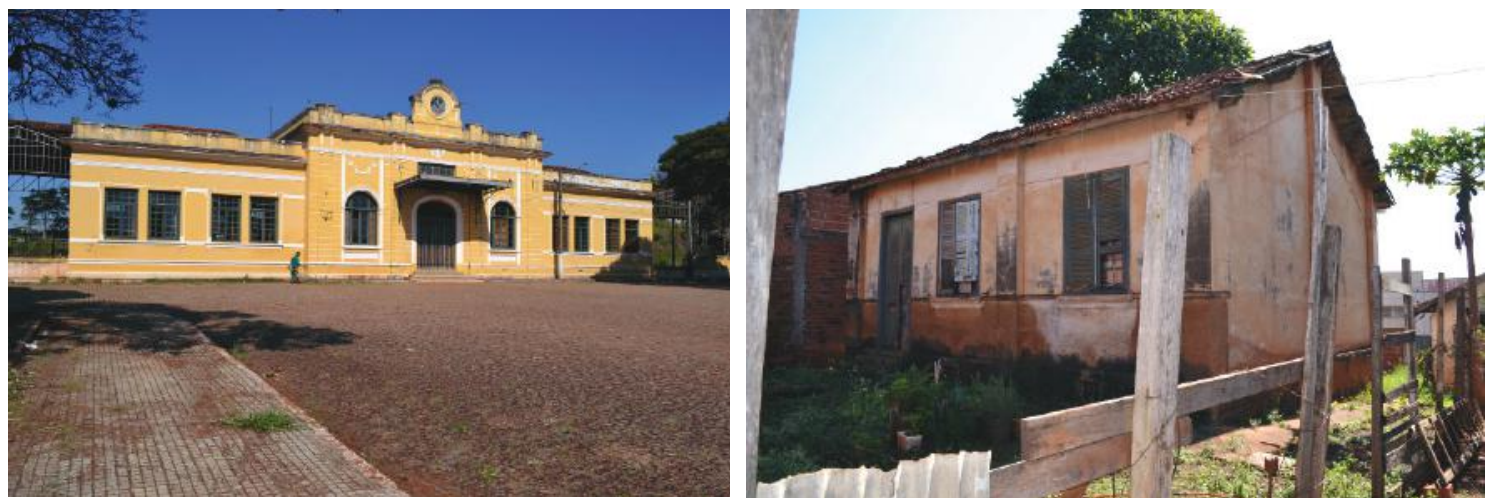

JAÚ

Foto 28 - Foto atual da estação de Jaú. Fonte: autora, 2013.

Foto 29 - Foto atual de uma das casas da vila ferroviária de Jaú. Fonte: autora, 2013.

Foto 30 (foto abaixo) - Casa da vila ferroviária de Jaú. Fonte: Museu Ferroviário de Jundiaí, s/d.

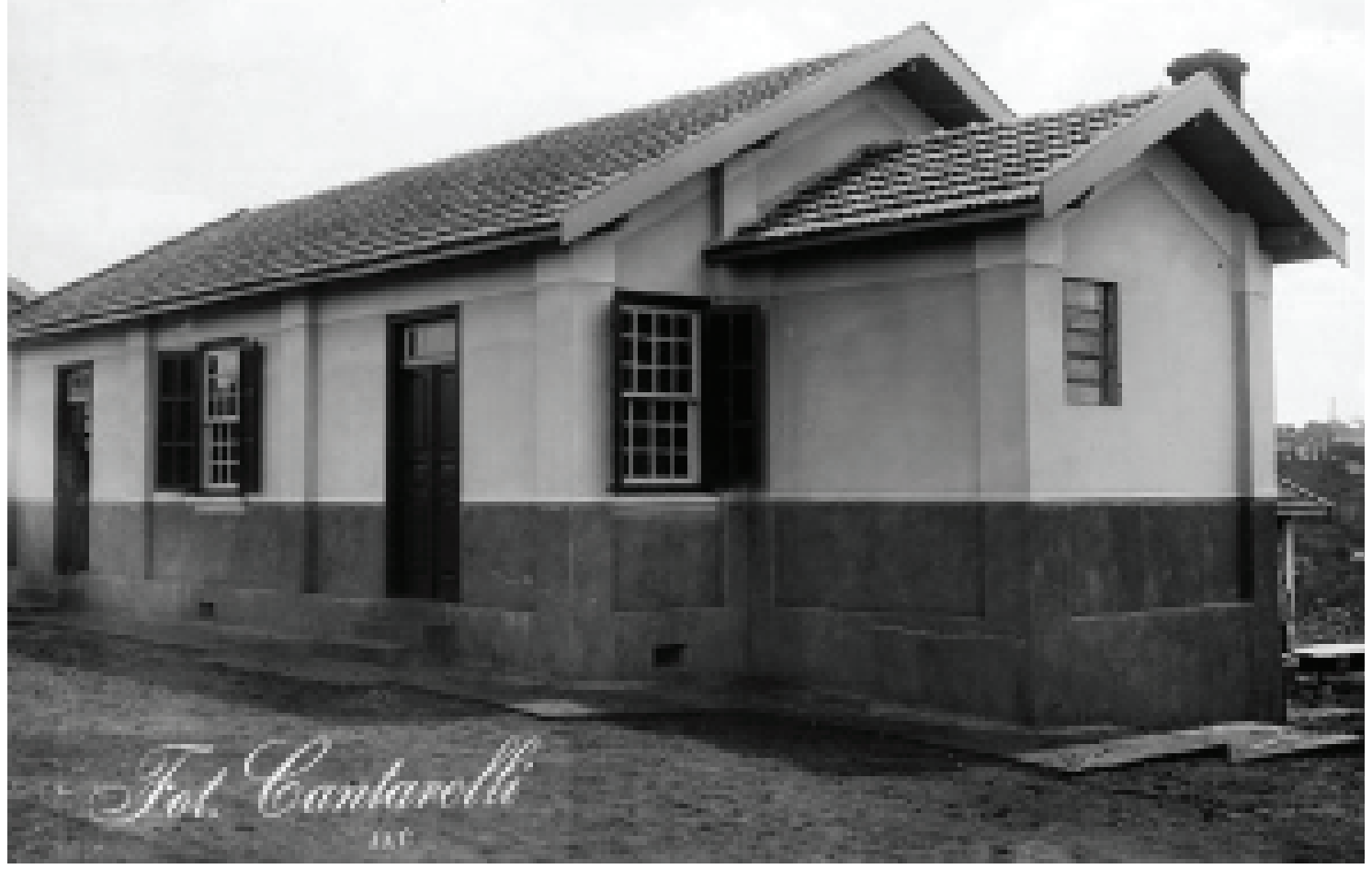

31
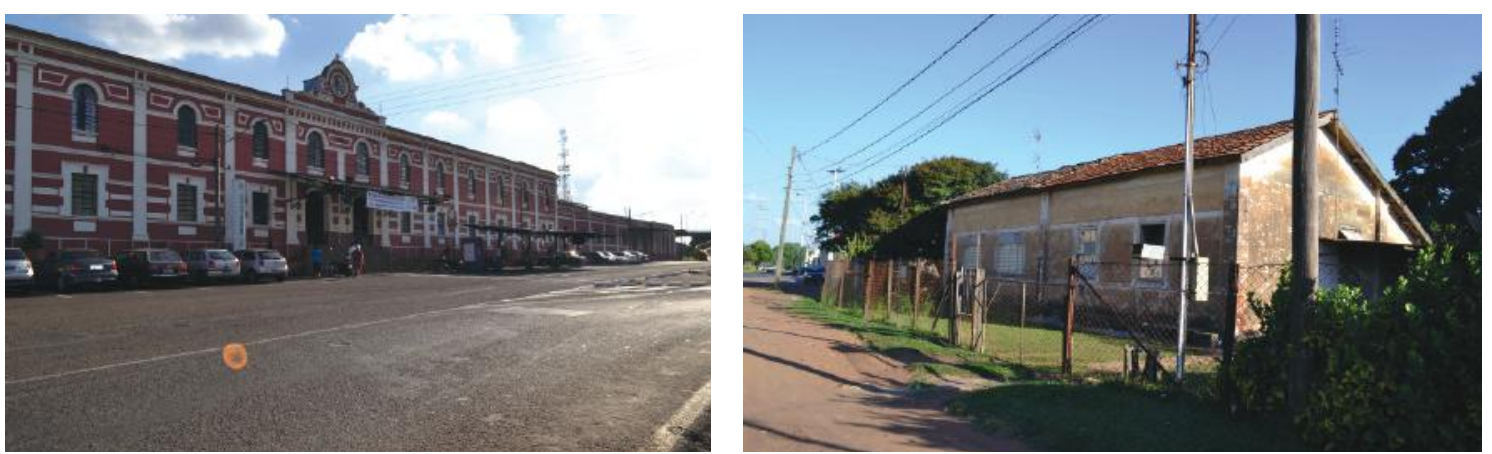

\section{SÃO CARLOS}

Foto 31 - Foto atual da estação e da vila ferroviária de São Carlos. Fonte: autora, 2013.

Foto 32 - Foto atual da de uma das casas da vila ferroviária de São Carlos. Fonte: autora, 2013.

Foto 33 (próx. pág.) - Foto da estação de São Carlos. Fonte: Álbum ilustrado da CP, 1918. 


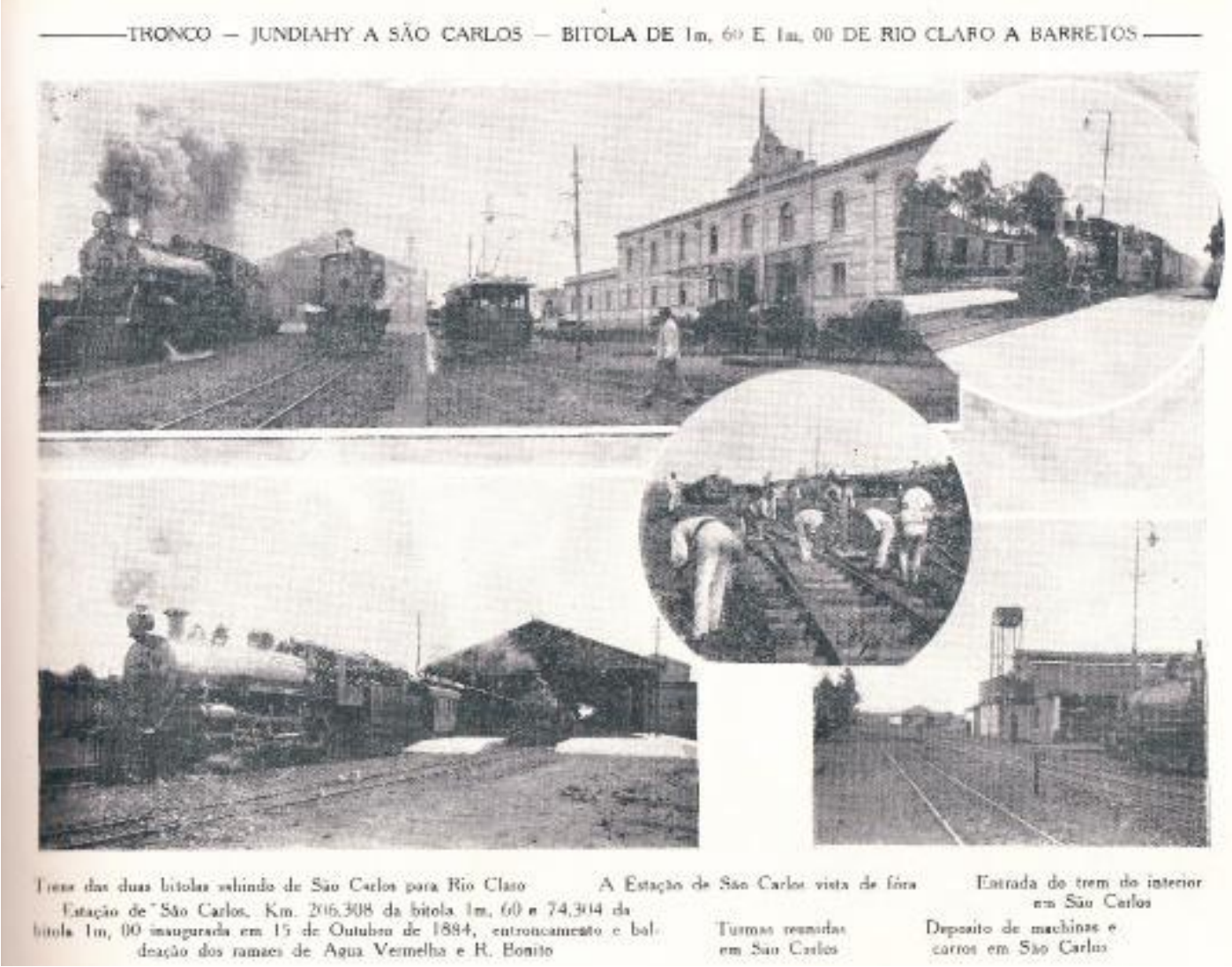

RINCÃO

Foto 34 - Foto atual da estação de Rincão. Fonte: autora, 2013.

Foto 35 - Foto atual de uma das tipologias da vila ferroviária de Rincão. Fonte: autora, 2013.

Foto 36 - Fotos da estação e casas da vila ferroviária de Rincão. Fonte: Álbum Ilustrado da CP, 1918.
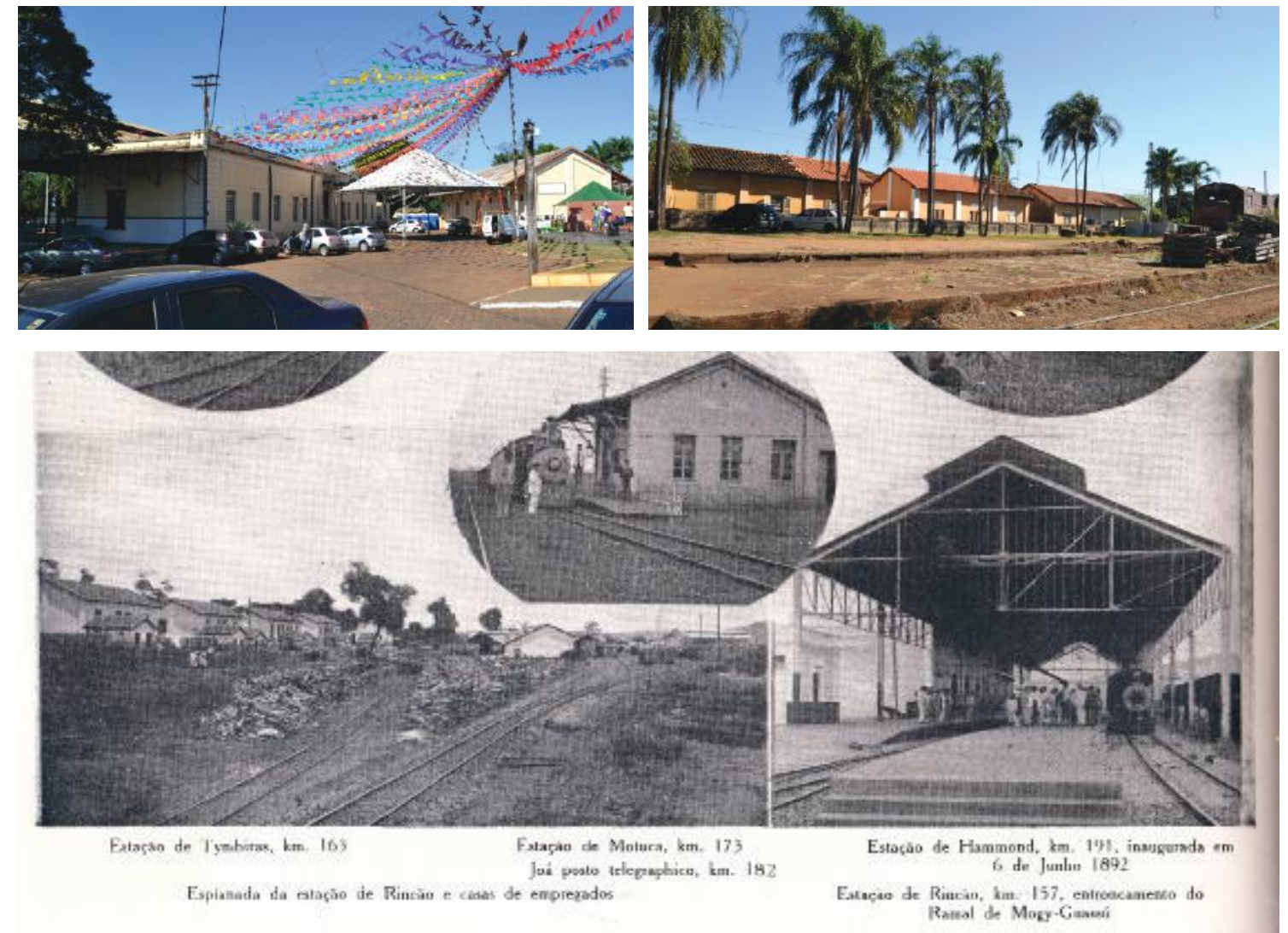


\title{
Capítulo 1 - Preservação das vilas ferroviárias
}

\author{
(...) uma lei não basta. Hoje isso é patente. \\ A preservação dos monumentos antigos \\ é antes de tudo mentalidade. (CHOAY, \\ 2006, p. 149)
}

Antes de mais nada, gostaríamos de evidenciar que as vilas ferroviárias fazem parte de um importante patrimônio industrial. Processos históricos paralelos podem ser identificados quanto às vilas operárias brasileiras, como ocorre com as inglesas no tocante tanto aos processos de formação, como de desmonte. Contudo, entre a preservação das vilas operárias brasileiras e inglesas, há uma grande diferença. Neste capítulo, verificaremos como as vilas ferroviárias estão sendo consideradas no processo de preservação, indagando-se inclusive sobre a política e os instrumentos de preservação existentes.

\subsection{Desmonte e preservação}

Segundo Correia (2004b), já há casos de desmonte das fábricas desde o final do século XIX, como o da Real Fábrica de Ipanema, porém a maior parte das vilas operárias iniciam seu processo de desmonte na década de 1920, que se intensifica na década de 1980. Esta última intensificação, "está associada à difusão de ideias neoliberais e de práticas como a terceirização de segmentos da produção, em um quadro de reestruturação industrial." (CORREIA, 2004b, p. 164). Os autores Correia e Gunn (2004), sempre recordam que, apesar do desmonte de inúmeras vilas operárias, também núcleos fabris continuaram a ser criados no Brasil após 1930, inclusive com a participação de empresas do Estado, como as mineradoras, e a partir de 1950 continuam a ser criadas, mas com menor intensidade. No caso das vilas ferroviárias, o desmonte coincide com a decadência do café e das ferrovias, com a concorrência rodoviária. As ferrovias paulistas iniciam-se no final do século XIX e muitas delas acompanham o declínio do café, o principal produto transportado. Portanto, acabam arrefecendo já na década de 1930, somado à concorrência rodoviária com o início na mesma década de 1930 que se intensifica em 1950.

A Companhia Paulista é fundada em 1868, sua primeira estação é a de Jundiaí, 
e alcança seus primeiros 45 quilômetros de ferrovia, com a inauguração da estação de Campinas, em 1872. A partir daí, segue num crescendo de extensão, segundo dados dos Relatórios da Companhia Paulista: alcança 1023km, em 1899; 1245km em 1917, permanecendo sem grandes variações até 1931, quando atinge 1466km de linha. Na década de 1940, possui a extensão de $1511 \mathrm{~km}$, seguindo sem variações, até que em 1947, alcança a extensão de $1852 \mathrm{~km}$. Na década seguinte, 1950, possui $2071 \mathrm{~km}$ de linha, chegando à extensão, até onde se pode contabilizar com a pesquisa, de $2155 \mathrm{~km}$. Algumas considerações devem ser feitas sobre a extensão: esta se deve não só a expansão territorial do cultivo de café, como também a construção de linhas duplas, por exemplo, a duplicação de linhas entre Itirapina e Campinas (1947); e as aquisições de outras empresas ferroviárias, das quais destacamos a compra da Rio Claro Railway Company, em 1892. Destaca-se este ramal, pois é o ramal entre Itirapina a Jaú, cidades escolhidas como objeto de estudo. Apesar da sua existência e crescimento mesmo após o ciclo do café, há o arrefecimento da construção das estações e vilas após 1930. Entretanto, pode-se localizar ainda alguma de construção de casas em 1950.

O fim da Companhia Paulista, como empresa privada, deu-se em 1961, encampada pelo governo estadual. Na década seguinte, é criada a FEPASA - Ferrovia Paulista S/A, criada pelo decreto estadual $n^{\circ} 10.410$, de 28.10.1971, que incorpora Companhia Paulista de Estradas de Ferro e mais quatro grandes ferrovias do Estado de São Paulo, a Ferrovia Sorocabana; a Ferrovia Araraquarense; a Ferrovia Mogiana; parte da Estrada de Ferro São Paulo - Minas, com a formação de uma única empresa. Os bens imóveis e móveis passam então a ser administrados pela FEPASA. Enquanto isto, foi criada a Rede Ferroviária Federal S. A. (RFFSA) mediante Lei N 3.115, de 16 de março de 1957, e pela reunião de 18 ferrovias regionais, estas, em sua maioria, de capital privado. Em 2007, por meio da Medida Provisória ${ }^{\circ} 353$, de 22 de janeiro, posteriormente convertida na Lei $\mathrm{n}^{\circ}$ 11.348/2007, regulamentada pelo Decreto $N^{\circ} 6.018$ de 22 de janeiro de 2007 extingue-se a Rede Ferroviária Federal S. A. . A partir de tal lei, parte do patrimônio da extinta RFFSA foi transferida para o DNIT - Departamento Nacional de Infraestrutura de Transportes, e parte transferida para a SPU - Superintendência do Patrimônio da União. Os chamados bens móveis (trilhos, dormentes, equipamentos, etc...) e os bens imóveis operacionais foram transferidos para o DNIT, e os bens não operacionais foram transferidos para a SPU. Dentre estes bens imóveis não operacionais, encontram-se terrenos comerciais e residenciais, estações ferroviárias desativadas, benfeitorias como armazéns, caixas d'á- 
gua, e residências, ou seja, as casas das vilas ferroviárias. Esta transferência de bens, pelo menos no que tange à SPU, está sendo realizada gradativamente pelo que se denominam Termos de Transferência. Uma vez vistoriados, tais imóveis são recebidos nas respectivas regionais da Superintendência, e passam ser de propriedade e gestão da União. À região Sudeste brasileira coube a maior parte desta transferência de imóveis, logicamente, por encontrar-se nesta região a maior parte da malha ferroviária brasileira construída.

O desmonte das vilas operárias deve-se a causas variadas: que vão desde expansão das fábricas (Fábrica de Cerveja Cia. Antárctica Paulista; Eucatex; Vila Gessy; Vidraria Santa Marina - CORREIA, 2004b, p. 167), requerendo a demolição de parte das vilas operárias para sua ampliação; a falência da fábrica, ou a mudança ou terceirização do centro de produção, e consequente venda das vilas operárias, tudo relacionado às mudanças nas relações de trabalho e capital. Recorda-se que, assim como a construção de uma fábrica, a de uma vila operária pode ter ocorrido em várias etapas, e no desmonte pode ocorrer o mesmo. A sede da fábrica pode permanecer, e somente ser desfeita a vila. Outra causa de desmonte apontado por Correia (2004b, p. 165), é a Lei do Inquilinato, de 1942, que congelou aluguéis, dificultou o despejo de inquilinos e fez com que algumas empresas se desfizessem das casas das vilas. Um caso de desmonte interessante apontado por Correia (2004b, p. 165) é o seguinte:

Já em 1938, o engenheiro-arquiteto Rubens Porto testemunhava a destruição de duas vilas operárias de fábricas na Gávea e em Laranjeiras, no Rio de Janeiro, atribuindo o fato à alta valorização dos terrenos por elas ocupados, os quais estariam sendo loteados para venda. (PORTO, 1938, p. 59)

Tal exemplo, aponta o desmonte devido à valorização dos terrenos. É o que mais tem-se visto atualmente na cidade de São Paulo, onde bairros de antiga tradição operária são desfeitos, com consequente demolição das casas operárias, como Móoca e Lapa, que tem dado lugar a novos empreendimentos imobiliários.

Em geral, os casos dos desmontes das vilas operárias assumem três formas: a) a venda das casas para os antigos operários; b) aluguel aos mesmos ou a terceiros; e c) a demolição, se bem que neste último caso, antes do processo de demolição, algumas vezes tenham passado pela venda. No caso das vilas das várias companhias ferroviárias, pode-se encontrar as três formas de desmonte acima citados. Algumas estações, juntamente com suas vilas ferroviárias, foram vendidas aos municípios, um exemplo é a Vila de 
Paranapiacaba, que pertenceu a São Paulo Railway, e foi alienada ao município de Santo André. Outro exemplo é vila ferroviária de Rincão, objeto de nosso estudo, que foi vendida à prefeitura.

No caso das ferrovias, parte das estações e terrenos foram vendidos ou foram feitas concessões às empresas de logística como a América Latina Logística (ALL). Esta empresa, no estado de São Paulo, está subdivida em Malha Oeste, Malha Sul, e Malha Paulista, esta última que cobre a maior parte do estado. Com o nome de Ferroban, assumiu o controle de operações da malha paulista da Rede Ferroviária Federal S.A, antiga FEPASA, em $1^{\circ}$ de janeiro de 1999, por 30 anos. Tais imóveis são considerados como operacionais pela Lei $\mathrm{n}^{\circ} 11.348 / 2007$, regulamentada pelo Decreto $\mathrm{N}^{\circ} 6.018$ de 22 de janeiro de 2007, que se extingue a Rede Ferroviária Federal S. A. (RFFSA). As linhas são utilizadas para a carga, enquanto muitas das estações não são utilizadas e encontram-se abandonadas. As vilas ferroviárias muitas vezes são consideradas bens imóveis, e assim pertencem, desde a extinção da RFFSA, à Superintendência do Patrimônio da União. Algumas das casas, bens não operacionais, portanto sob gestão da Superintendência do Patrimônio da União (SPU) estão em terrenos operacionais, sob a administração do Departamento Nacional de Infraestrutura de Transporte (DNIT), e concedidas às empresas de logística. Desse modo, fica complicada a solução fundiária das vilas ferroviárias.

Também na Superintendência do Patrimônio da União (SPU), as estações são os objetos mais procurados para a cessão às prefeituras municipais, que muitas vezes não querem resolver o conflito fundiário existente nas vilas ferroviárias, com raras exceções. As vilas ferroviárias da Companhia Paulista passaram a ser administradas pela Superintendência do Patrimônio da União, e os aluguéis dos bens imóveis passaram a ser cobrados por esta. Por enquanto, o impasse acima mencionado, entre os bens não-operacionais (vilas ferroviárias) sobre os terrenos, bens operacionais; somado à falta de celeridade do Patrimônio da União levam a um não posicionamento quanto à forma para resolver a questão da propriedade das vilas. Se incorporadas ao Patrimônio da União, como vem ocorrendo com as estações (e não as vilas), e depois cedidas às administrações diretas, como os municípios; ou ainda se as casas serão vendidas diretamente aos ocupantes, sem passar pelo processo de incorporação. O processo de incorporação é um trabalho penoso pois os funcionários encontram dificuldades para encontrar os mapas dos terrenos das ferrovias e a cadeia sucessória. Além disso, o que se alega no Patrimônio da União, é que, por falta de funcionários, não há como proceder ao leilão dos mais de 4000 contratos de 
aluguéis ainda vigentes. A questão é que neste "limbo" fundiário que se encontram as casas, alguns moradores, antes ex-ferroviários ou descendentes de ex-ferroviários, têm a esperança de conseguir a casa própria; outros, dada a morosidade nas soluções, já abandonaram as casas, que foram ocupadas irregularmente por terceiros. Se antes havia estudos sociológicos com relatos dos antigos ferroviários ou filhos de ex-ferroviários, estes estudos não podem ser mais feitos atualmente, pois a maior parte das casas já estão ocupadas por pessoas sem qualquer relação com a ferrovia.

Em seu estudo sobre as vilas operárias, Correia (2004b), paralelamente ao desmonte também apresenta os conjuntos fabris preservados. Há edifícios preservados em nível federal, nível estadual e municipal. Correia (2004b) registra as várias vilas operárias e seu estado de uso e preservação. Um dos primeiros bens mais antigos do patrimônio industrial seria a Real Fábrica de São João do Ipanema, que foi tombada pelo IPHAN em 1964, inscrito no livro Histórico. Teve diversos usos, até ser cedido para o IBAMA, em 1992, sendo uma Unidade de Conservação do ICMBio. Quanto aos bens do patrimônio industrial ferroviário, procurou-se verificar como estão inseridas as vilas ferroviárias nos órgãos de preservação em seus três níveis, federal estadual e municipal. Reuniu-se dados de modo esquemático na tabela a seguir. Ainda uma explicação acerca da tabela: além de procurar entre os órgãos, bens do patrimônio industrial e ferroviário, procuramos incluir os conjuntos urbanos ou vilas, excluindo-se os centros históricos. A explicação é que no processo de questionamento, as vilas ferroviárias, sendo um conjunto ou parte do tecido urbano, não sendo tombadas como estações, poderiam estar em alguns destes tombamentos. Contudo, como se verá a seguir, também estão ausentes nesta classificação.

Tabela 2 - Bens tombados pelo IPHAN relacionados a conjuntos urbanos/vilas e ao patrimônio industrial

\begin{tabular}{|c|c|c|c|c|}
\hline & & IPHAN & ANO & $\begin{array}{l}\text { LIVRO DE } \\
\text { TOMBO }\end{array}$ \\
\hline conjuntos & 1 & Conjunto Arquitetônico e Urbanístico da Aldeia de Carapicuíba & 1940 & $\begin{array}{l}\text { H/Arq, etn, } \\
\text { psg }\end{array}$ \\
\hline \multirow[t]{2}{*}{$\begin{array}{l}\text { urbanos e/ } \\
\text { ou vilas }\end{array}$} & 2 & $\begin{array}{l}\text { Remanescentes da Antiga Vila Colonial, particularmente a Igreja Matriz, } \\
\text { compreendendo as obras de talha e imagens antigas de São Vicente }\end{array}$ & 1955 & $\mathrm{H}$ \\
\hline & 3 & Conjunto Histórico e Paisagísitco da Cidade de Iguape & 2011 & $\begin{array}{l}\text { H/Arq, etn, } \\
\text { psg }\end{array}$ \\
\hline
\end{tabular}




\begin{tabular}{|c|c|c|c|c|}
\hline \multirow{15}{*}{$\begin{array}{l}\text { patrimônio } \\
\text { industrial e } \\
\text { ferroviário }\end{array}$} & 1 & Área onde se enccontram os remanescentes da Real Fábrica de Ipanema & 1964 & $\mathrm{H}$ \\
\hline & 2 & $\begin{array}{l}\text { Estação da Luz (SPRailway) } \\
\text { Conjunto de edificacốes da Companhia Paulista de Estrada de Ferro em Jundiaí }\end{array}$ & 1976 & $\mathrm{BA} / \mathrm{H}$ \\
\hline & 3 & (CP) & 2004 & BA \\
\hline & 4 & Estação Ferroviária de Mayrink (EFS) & 2004 & BA \\
\hline & 5 & Vila Ferroviária de Paranapiacaba (SP Railway)** & 2008 & $\mathrm{H}$ \\
\hline & & LISTA DO PATRIMÔNIO CULTURALFERROVIÁRIO & & \\
\hline & 1 & Vários edifícios da estação de Cruzeiro (Rede Sul Mineira de EF) & 2007 & $\begin{array}{l}\text { não tem } \\
\text { indicação }\end{array}$ \\
\hline & 2 & Antiga subestação de Sumaré (CP) & 2008 & de livro \\
\hline & 3 & Estação ferroviária de São José do Rio Preto (EFA) & 2009 & \\
\hline & 4 & Antiga estação ferroviária de Avaré (EFS) & 2014 & \\
\hline & 5 & Estação ferroviária de Ribeirão Preto (CP) & 2014 & \\
\hline & 7 & Casa Estação Ferroviária Cachoeira Paulista & 1977 & INDEFERIDO \\
\hline & 8 & Estação ferroviária de Guaratinguetá (EFCB) & 1980 & INSTRUÇÃO \\
\hline & 9 & Estação ferroviária de Dois Córregos & 2014 & INSTRUÇÃO \\
\hline & 10 & Acervo da Ex-RFFSA no Museu Ferroviário de Jundiaí & 2014 & INSTRUÇÃO \\
\hline
\end{tabular}

FONTE: Lista dos bens tombados (1938-2015) in http://portal.iphan.gov.br/uploads/ckfinder/arquivos/2016-09-16_Lista\%20 Bens\%20Tombados.pdf. E Acesso em 03 out 2016. E informações colhidas com técnico do IPHAN, em entrevista de outubro de 2016.

*considerou-se apenas os bens tombados pelo IPHAN no estado de São Paulo

** a partir de 2015, a Vila de Paranpiacaba passa a integrar uma lista chamada de conjuntos urbanos tombados

Tabela 3 - Bens tombados pelo CONDEPHAAT relacionados a conjuntos urbanos/ vilas e ao patrimônio industrial

\begin{tabular}{|c|c|c|c|c|}
\hline & & CONDEPHAAT & ANO & $\begin{array}{c}\text { LIVRO DE } \\
\text { TOMBO }\end{array}$ \\
\hline \multirow{9}{*}{$\begin{array}{l}\text { conjuntos } \\
\text { urbanos e/ } \\
\text { ou vilas* }\end{array}$} & 1 & Aldeia de Carapicuíba e Igreja de S. João Batista (tomb. Ex-officio) & 1974 & $\mathrm{H}$ \\
\hline & 2 & Remanescentes da Vila Colonial e Porto de Naus (São Vicente) & 1982 & $\mathrm{H}$ \\
\hline & 3 & Vila Economizadora & 1981 & $\mathrm{H}$ \\
\hline & 4 & Vila Maria Zélia & 1983 & $\stackrel{H}{\text { Arg etne }}$ \\
\hline & 5 & Bairro dos Jardins (São Paulo) & 1986 & psg \\
\hline & 6 & Unidades Habitacionais de Picinguaba - Vila caiçara (Ubatuba) & 1990 & $\begin{array}{l}\text { Arq, etn e } \\
\text { psg } \\
\text { Arq, etn e }\end{array}$ \\
\hline & 7 & Bairro do Cafundó (Salto de Pirapora) & 1990 & $\begin{array}{l}\text { psg } \\
\text { Arq, etn e }\end{array}$ \\
\hline & 8 & Bairro do Pacaembú (São Paulo) & 1991 & psg \\
\hline & 9 & Vila ltororó & 2005 & $\mathrm{H}$ \\
\hline
\end{tabular}




\begin{tabular}{|c|c|c|c|c|}
\hline \multirow{12}{*}{$\begin{array}{l}\text { patrimônio } \\
\text { industrial }\end{array}$} & 1 & Real Fábrica de São João de Ipanema (Iperó) & 1974 & $\mathrm{H}$ \\
\hline & 2 & Usina Hidrelétrica de Corumbataí (Rio Claro) & 1982 & $\mathrm{H}$ \\
\hline & 3 & Edifício da Fábrica de Tecidos São Luís (Itu) & 1983 & $\mathrm{H}$ \\
\hline & 4 & Indústrias Reunidas Matarazzo (São Paulo) & 1987 & $\mathrm{H}$ \\
\hline & 5 & Edifício de Manufaturas de Tapetes Santa Helena (Jacareí) & 1991 & $\mathrm{H}$ \\
\hline & 6 & Indústrias Reunidas Matarazzo (Marília) & 1993 & $\mathrm{H}$ \\
\hline & 7 & Cervejaria Paulista (Ribeirão Preto) & 2007 & $\mathrm{H}$ \\
\hline & 8 & Fábrica Santa Adélia ( Tatuí) & 2008 & $\mathrm{H}$ \\
\hline & 9 & Fábrica Swift/Armour (São José do Rio Preto) & 2008 & H \\
\hline & 10 & Indústrias Têxteis São Martinho (Tatuí) & 2008 & $\mathrm{H}$ \\
\hline & 11 & Complexo do gasômetro e Casa das Retortas ( São Paulo) & 2010 & $\mathrm{H}$ \\
\hline & 12 & Complexo industrial Carioba & 2013 & H \\
\hline \multirow{10}{*}{$\begin{array}{c}\text { patrimônio } \\
\text { industrial } \\
\text { ferroviário }\end{array}$} & 1 & Estação de Bananal & 1974 & $\mathrm{H}$ \\
\hline & 2 & Estação de Santa Rita do Passa Quatro (CP) & 1981 & $\mathrm{H}$ \\
\hline & 3 & Estação da Luz (São Paulo - SPRailway) & 1982 & $\mathrm{H}$ \\
\hline & 4 & Estação do Brás (São Paulo - SPRailway) & 1982 & $\mathrm{H}$ \\
\hline & 5 & Estação Barracão em Ribeirão Preto (CM) & 1982 & $\mathrm{H}$ \\
\hline & 6 & Estação de Guaratinguetá (EFCB) & 1982 & $\mathrm{H}$ \\
\hline & 7 & Estação de Cachoeira Paulista (EFCB) & 1982 & H \\
\hline & 8 & Estação de Campinas (CP) & 1982 & $\mathrm{H}$ \\
\hline & 9 & Estação de Descalvado (CP) & 1987 & $\mathrm{H}$ \\
\hline & 10 & Estação de Mairinque (EFS - projeto de Victor Bubugras) & 1987 & $\mathrm{H}$ \\
\hline \multirow{21}{*}{$\begin{array}{c}\text { patrimônio } \\
\text { industrial } \\
\text { ferroviário }\end{array}$} & 11 & Estação de Rio Claro (CM) & 1987 & $\mathrm{H}$ \\
\hline & 12 & Complexo Ferroviário de Paranapiacaba (SPRailway) & 1988 & $\mathrm{H}$ \\
\hline & 13 & Rotunda do município de Cruzeiro (Rede Sul Mineira de EF) & 1989 & H \\
\hline & 14 & Estação Júlio Prestes (EFS) & 2000 & $\mathrm{H}$ \\
\hline & 15 & Conjunto da Estação Ferroviária Franco da Rocha (São Paulo - SPRailway) & 2011 & H \\
\hline & 16 & Conjunto da Estação Ferroviária de Jaraguá (São Paulo - SPRailway) & 2011 & $\mathrm{H}$ \\
\hline & 17 & Conjunto da Estação Ferroviária de Rio Grande da Serra (SPRailway) & 2011 & $\mathrm{H}$ \\
\hline & 18 & Complexo da Estação Ferroviária de Várzea Paulista (SPRailway) & 2011 & $\mathrm{H}$ \\
\hline & 19 & Conjunto da Estação Ferroviária de Caieiras (São Paulo - SPRailway) & 2012 & $\mathrm{H}$ \\
\hline & 20 & Conjunto da Estação Ferroviária de Perus (São Paulo - SPRailway) & 2012 & H \\
\hline & 21 & Conjunto da Estação Ferroviária de Ribeirão Pires (SPRailway) & 2012 & $\mathrm{H}$ \\
\hline & 22 & Conjunto da Estação Ferroviária de Andradina (EFNOB) & 2012 & $\mathrm{H}$ \\
\hline & 23 & Conjunto da Estação Ferroviária de Louveira (CP) & 2012 & $\mathrm{H}$ \\
\hline & 26 & Conjunto da Estação Ferroviária Araçatuba (EFNOB) & 2012 & $\mathrm{H}$ \\
\hline & 27 & Complexo da Estação Ferroviária de Botucatu (EFS) & 2012 & $\mathrm{H}$ \\
\hline & 28 & Complexo da Estação Ferroviária de Sumaré (CP) & 2013 & $\mathrm{H}$ \\
\hline & 29 & Conjunto da Estação Ferroviária de Piraju (EFS - Projeto de Ramos de Azevedo) & 2013 & H \\
\hline & 30 & Conjunto da Estação Ferroviária de Piratininga (CP) & 2013 & $\mathrm{H}$ \\
\hline & 31 & Conjunto da Estação Ferroviária de Valinhos & 2013 & $\mathrm{H}$ \\
\hline & 32 & Estação ferroviária de Piquete & 2014 & $\mathrm{H}$ \\
\hline & 33 & $\begin{array}{l}\text { Complexo da estação ferroviária de Cruzeiro (Rede Sul Mineira de EF) } \\
\text { Antigo sistema de funicular de Paranapiacaba e seus remanescentes na Serra do } \\
\text { Mar }\end{array}$ & $\begin{array}{l}2015 \\
2015\end{array}$ & $\begin{array}{l}\text { não tem } \\
\text { indicação de } \\
\text { livro }\end{array}$ \\
\hline
\end{tabular}
outubro de 2016. 
* não incluímos nesta lista os centros históricos de Bananal, Cananéia, Iguape, Iporanga, Itu, Santana do Parnaíba, São Luís do Paraitinga e São Sebastião.

**O Horto e Museu Edmundo Navarro de Andrade (Rio Claro) pertencente à Companhia Paulista de Estradas de Ferro, foi tombada em 1979, inscrito no Livro Arqueológico, etnográfico e paisagístico.

***BA - Belas Artes, $\mathrm{H}$ - Histórico, Arq, Etn, psg - Arqueológico, etnográfico e paisagístico

****CP -Companhia Paulista CM - Companhia Mogiana EFNOB - Estrada de Ferro Noroeste do Brasil EFS - Estrada de Ferro Sorocabana SPRailway - São Paulo Railway

Tabela 4 - Bens tombados pelo CONPRESP relacionados a conjuntos urbanos/vilas e ao patrimônio industrial

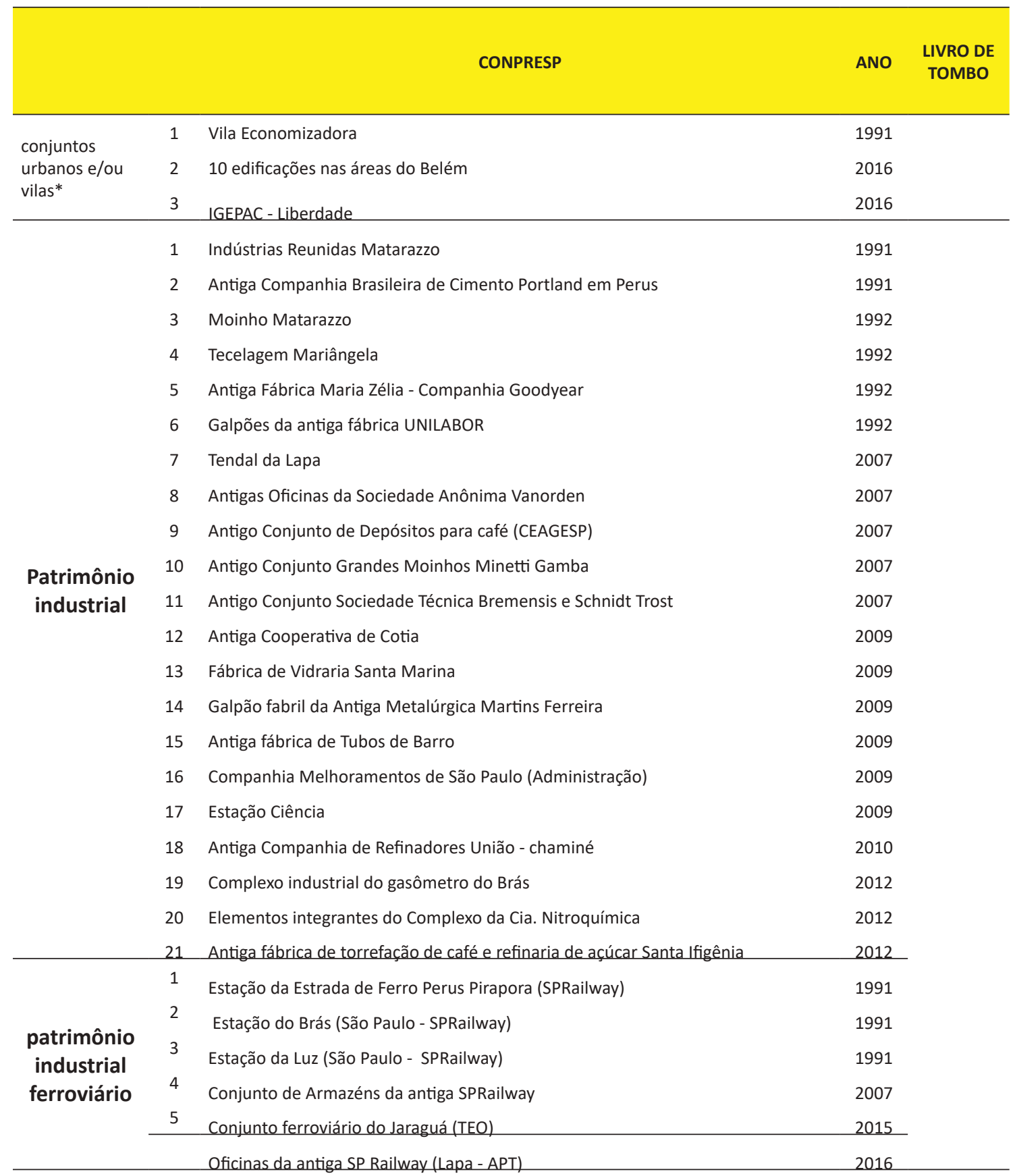




\footnotetext{
* Sobre a lista de bens tombados, como a busca pelo site da CONPRESP não é muito prática, utilizamos como fonte RODRIGUES (2011:101). A lista tem como data limite o ano de 2010. Na ocasião, havia 10 lugares relacionados ao patrimônio industrial com abertura de processo de tombamento (APT), entre eles a Estação Júlio Prestes, cujo processo foi aberto em 1992. Também nesta fonte, não considerava o livro em que o bem foi inscrito.

**Há que se considerar para a cidade de São Paulo, as antigas Z8-200 (das lei de zoneamento de 1975, 1978 e 1984) , como também as ZEPEC (Zonas Especiais de Preservação) estabelecidas pelos Planos Diretores Estratégicos de 2002 e 2014 , que podem abarcar zonas que incluem bens relacionados ao patrimônio industrial

*** Esta lista foi atualizada em 2016. De 2013 à 2016, o site do DPH mudou e facilitou a pesquisa, as resoluções de tombamento bem como de abertura de processos de tombamento (APT) estão publicadas na íntegra. http://www.prefeitura.sp.gov.br/ cidade/secretarias/cultura/conpresp/legislacao/resolucoes/index.php?p=1137. Acesso em 03 out 2016.
}

Várias observações podem ser inferidas desta tabela. Com exceção da Real Fábrica de Ipanema, cujo tombamento é de 1964 no IPHAN, e 1974 no CONDEPHAAT, a maior parte dos bens que integram o patrimônio industrial foram reconhecidos primeiro no CONDEPHAAT. Por exemplo, o tombamento da estação de Bananal é de 1974 e a maior parte dos tombamentos na década de 1980, e depois no IPHAN e no CONPRESP, cujos tombamentos datam da década de 1990. Há um maior número de bens tombados nos órgãos estadual e municipal, além da inclusão da preservação nos planos diretores municipais.

A maior parte dos tombamentos do patrimônio industrial ferroviário referem-se a bens isolados, especificamente estações, com exceção do tombamento recente do conjunto das edificações da Companhia Paulista em Jundiaí, que foi incluída no livro de tombo de Belas Artes somente, em 2004 e recentemente a Vila Ferroviária de Paranapiacaba, também considerada sítio urbano, incluída no livro de tombo do IPHAN em 2008. No CONDEPHAAT, os complexos ferroviários, com exceção da Vila de Paranapiacaba cujo tombamento é de 1988, são vistos como tais, isto é, com a inclusão além das estações, os armazéns e as vilas ferroviárias apenas em 2011, data dos primeiros tombamentos que levam o nome "conjunto da estação ferroviária".

Na tabela referente ao IPHAN, pode-se observar que, em São Paulo, com exceção da aldeia de Carapicuíba, que provavelmente, guarda relação com o período colonial e os remanescentes da Vila colonial de São Vicente, o tombamento de Iguape é recente. Com respeito aos bens relacionados à habitação, as casas tombadas, geralmente pertencem a um personagem ilustre, não se faz menção a nenhuma outra vila ferroviária, além da Paranapiacaba, nem mesmo a uma vila operária, quando se sabe que há alguns tombamentos em nível estadual e municipal. Pode-se questionar outros aspectos desta pequena amostragem: os conjuntos arquitetônicos foram inscritos em ambos livros Histórico e Arqueológico/Etnográfico/Paisagístico; outros apenas em livro Histórico, como a Vila 
Ferroviária de Paranapiacaba; e outros apenas nos livros de Belas Artes como a estação ferroviária de Mayrink e o conjunto de edificações da Companhia Paulista de Estrada de Ferro em Jundiaí; e outros em ambos livros de Belas Artes e Histórico, como foi a Estação da Luz. O que leva um bem ser inscrito em um livro e em outro não? Quais são estes critérios de valores histórico e artístico que estão sendo colocados?

Após a lei federal No. 11.483/2007, cujo art. $9^{\circ}$ incumbe especificamente o IPHAN de "receber e administrar os bens móveis e imóveis de valor artístico, histórico e cultural, oriundos da extinta RFFSA, bem como zelar pela sua guarda e manutenção."1; o órgão federal para estabelecer um procedimento administrativo específico para valoração, gestão e administração dos bens do Patrimônio ferroviário, cria a Portaria No. 407, de 21 de dezembro de 2010. É através desta portaria que é criada a Lista do Patrimônio Cultural Ferroviário. Também através dela, e para atender a demanda de aproximadamente 52.000 bens imóveis, 31.400 metros lineares de acervo documental, 118.000 desenhos técnicos, 74.000 itens bibliográficos e outros bens móveis ainda não calculados que na época estavam espalhados pelos escritórios regionais da inventariança da ex-RFFSA ${ }^{2}$, que o patrimônio ferroviário ganha um destaque maior frente ao patrimônio industrial. Se não houvesse uma lei federal que demandasse, acredita-se que tampouco o patrimônio ferroviário ganharia atenção nos órgãos, a não ser pela urgente demanda. Segundo Finger (2013), foi realizado um inventário de varredura pelo IPHAN, onde foram identificadas oito mil edificações, restando por identificar os bens móveis, bibliográficos e documentais, e deste universo, até outubro de 2013, 450 (quatrocentos e cinquenta) bens foram incorporados à Lista do Patrimônio Cultural, “cuja responsabilidade pela gestão foi, na maior parte dos casos, repassadas aos órgãos muncipais por meio da celebração de Termos de Compromisso". Com relação à gestão destes bens, resta saber se de fato, quantos são e se estes Termos de Compromisso têm funcionado na prática e como é feito o acompanhamento do IPHAN aos órgãos municipais.

A portaria não discute a questão da valoração, e em entrevista recente parece que a questão do valor nacional ainda é critério no dia a dia do órgão. Com relação aos critérios de seleção para os bens integrarem a Lista do Patrimônio Cultural Ferroviário, eles parecem ser muito vagos, ficando difícil a análise e o estabelecimento de procedimentos

1 Lei No. 11.483 , de 31 de maio de 2007, que fala da extinção da RFFSA.

2 Dados segundo o artigo: CAVALCANTI NETO, J. R. ; CARNEIRO, F.G.; GIANNECHINNI, A. C.. "Avanços e desafios na preservação do patrimônio ferroviário pelo Instituto do Patrimônio Histórico e Artístico Nacional” in VI Colóquio Latinoamericano sobre Recuperação e Preservação do Patrimônio Industrial. São Paulo, TICCIH/Faculdade Belas Artes, julho, 2012. 
pelos técnicos, por exemplo, o que diz o Art $4^{\circ}$., inciso I:

Art. $4^{o}$ São passíveis de inclusão na Lista do Patrimônio Cultural Ferroviário os bens móveis e imóveis oriundos da extinta RFFSA:

I - Que apresentarem correlação com fatos e contextos históricos ou culturais relevantes, inclusive ciclos econômicos, movimentos e eventos sociais, processos de ocupação e desenvolvimento do País, de seus Estados ou Regiões, bem como com seus agentes sociais marcantes; (...)

Passando-se para a tabela do CONDEPHAAT, pode-se ver que a estação de Bananal foi uma das primeiras a serem tombadas juntamente com a Real Fábrica São João de Ipanema, em 1974. Contudo ainda como edifício isolado, e seguem-se a ela outros tombamentos de estações na década de 1980. O tombamento de conjuntos ferroviários só irá ocorrer a partir de 2011. Ainda que tenha havido tombamentos de vilas operárias, como Vila Economizadora e Vila Maria Zélia desde a década de 1980, assim como outros tombamentos de bairros na mesma década, como o Bairro dos Jardins (1986), em São Paulo; a Vila Caiçara de Picinguaba em Ubatuba, em 1990; e o Bairro do Pacaembú, em São Paulo em 1991. A partir das tabelas, pode-se indagar porque estas estações foram tombadas e não outras, ou porque tais complexos e não outros, quais foram os critérios utilizados?

Segundo entrevista recente com técnico do CONDEPHAAT, que trabalha no órgão desde 2009, havia um grande número de processos acumulados de pedidos de tombamento de estações, aproximadamente 600 (seiscentos) processos. Para dar vazão a esta demanda, optou-se por fazer o estudo de uma linha, a São Paulo Railway, que serviu de modelo, e as próximas linhas estudadas foram da Companhia Sorocabana, depois Mogiana e por último a Companhia Paulista. Nem todos os pedidos de tombamento são aceitos, os critérios utilizados foram: a) principais pontos das linhas: entroncamentos, marcos-zero, pontos terminais (pontas-de-trilho) e transposições (serras, rios etc.); b) existência de conjuntos ferroviário-industriais com legibilidade favorável, preferencialmente íntegros ou quase íntegros; c) identificação de paradas que desempenharam papel relevante em processos históricos, sociais e econômicos de caráter regional, estadual ou nacional; d) conjuntos e/ou obras que apresentem técnicas, arquitetura e/ou engenharia de caráter especial; e) conjuntos inseridos preferencialmente em linha-tronco e/ou ramais de expressividade econômica ou social regional/estadual; f) consideração da classe operacional da estação; g) estado de caracterização e/ou conservação favorável à preservação. Nota-se, portanto, a preferência por conjuntos mais que por bens isolados. Desse modo, fica difícil 
pelos critérios acima definidos, obter-se o tombamento de, por exemplo, casas de turma, ou linhas férreas. Ainda assim, houve o tombamento, bastante recente, de 2015, do antigo sistema de funicular de Paranapiacaba e seus remanescentes na Serra do Mar.

Uma obra ausente das tabelas: a Vila Inglesa, e que pertenceu a São Paulo Railway, localizada no município de São Paulo, não está na relação nem do IPHAN, nem do CONDEPHAAT. Existe uma placa em frente à ela, mas não se afirma se ela é tombada, apenas que afirma que pertence à família Moreau (uma das ramificações da família Aguiar de Andrada) que preservou o imóvel e denomina "imóvel particular de interesse cultural”. No entanto, encontra-se dentro da área envoltória de preservação da Estação da Luz. Recentemente, em 2012, foi aberto o processo de tombamento.

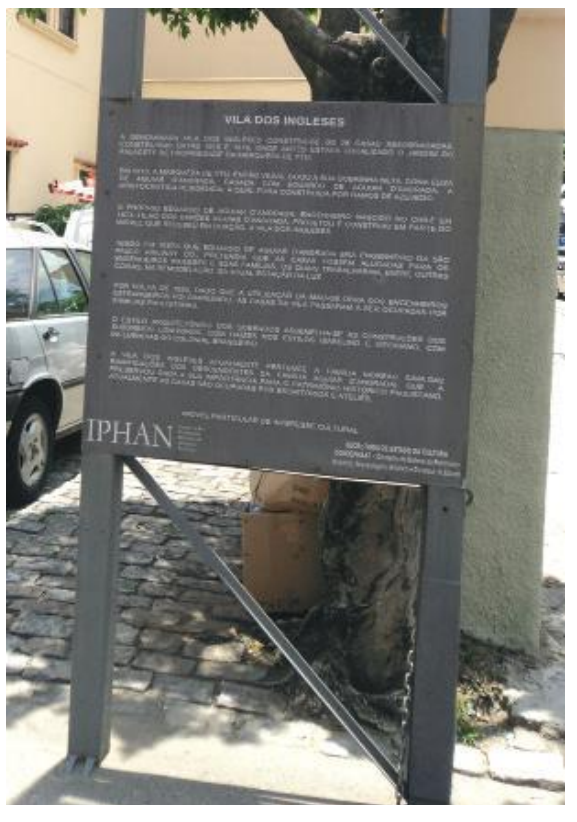

Foto 37 - Placa que se encontra na Vila dos Ingleses (São Paulo Railway), São Paulo - SP.Fonte: autora, 2013 DEPHAAT, um dado interessante, que só se pode detectar ao conhecer a história da Companhia Paulista. Existe o tombamento do Horto e Museu Edmundo Navarro de Andrade (Rio Claro), em 1979, e inscrito no Livro Arqueológico, Etnográfico e Paisagístico. Este Horto Florestal foi iniciativa da Companhia Paulista de Estradas de Ferro para a produção de madeira para substituir o carvão, e também para o fornecimento de dormentes. O Horto leva o nome do engenheiro agrônomo, Edmundo Navarro de Andrade, responsável não apenas pelo Horto Florestal de Rio Claro, mas pelos outros treze espalhados pelo estado de São Paulo, conforme dados do Relatório da Companhia Paulista e afirmação de Segnini (1982, p. 64). O primeiro horto florestal é o de Jundiaí, de 1904. É interessante que apenas este tenha sido tombado, parecendo faltar uma visão sistêmica destes bens.

Em nível municipal, a capital do estado possui o CONPRESP - Conselho Municipal de Preservação do Patrimônio Histórico, Cultural e Ambiental da Cidade de S. Paulo, criado em 1985 e fundação oficializada em 1988. Segundo o site ${ }^{3}$, o órgão "é obrigado a tombar todos os bens previamente protegidos nas demais instancias: federal elou estadual. A este tombamento dá-se o nome de ex-officio ou TEO.”. As Resoluções de Abertura

3 www. prefeitura.sp.gov.br/cidade/secretarias/cultura/conpresp/organização/index.php?p=4321. Acesso em 09 novembro de 2015. 
de Processo de Tombamento (APT) antecedem aos estudos de tombamento e visam proteger imediatamente o bem para que não seja destruído, mutilado, demolido ou alterado parcialmente. Ainda no mesmo site, há dois comentários interessantes: "Algumas resoluções antigas não consideravam a Área Envoltória do bem a ser delimitada, obrigando a emissão de resoluções exclusivas visando a regulamentação destas áreas. A partir de 1990, o entorno passou a ser definido no texto legal da Resolução de Tombamento.” E ainda o seguinte trecho:

O trabalho do CONPRESP está interligado ao do DPH - Departamento do Patrimônio Histórico, órgão da Secretaria Municipal de Cultura, criado pela Lei $n^{\circ} 8.252$ de 21/05/1975 e cujas atribuições são a identificação, proteção e fiscalização do patrimônio cultural e natural da cidade. O DPH e o CONPRESP são, portanto, órgãos autônomos, interdependentes e responsáveis pela preservação cultural e ambiental no Município, que trabalham em conjunto, ora instruindo os processos de tombamento, ora deliberando sobre eles. O DPH também atua como órgão técnico consultivo ao CONPRESP em seus despachos decisórios.

Pode-se dizer que a relação que citamos acima dos bens tombados pelo IPHAN e CONDEPHAAT são ratificados pelo CONPRESP. A pesquisa dos bens tombados no site do CONPRESP não é muito fácil, pois a busca não é por nome ou rua, mas por inscrição municipal. Contudo pela legislação, especificamente entre as Resoluções ${ }^{4}$ é possível ver a relação de bens tombados ou com abertura de processos de tombamento, e recentemente pode-se ter acesso as resoluções na íntegra, por ano, o que facilita a pesquisa. Entre aquelas vilas tombadas pelo CONDEPHAAT, temos a Vila Economizadora, que sofreu um tombamento ex-officio em 1991, junto com vários outros bens imóveis; e em 1992 é tombada a Vila Maria Zélia, que depois sofre algumas alterações em 1995. Além destas vilas operárias, pode-se talvez encontrar vilas dentro dos complexos industriais tombados pelo CONPRESP: por exemplo, Cia Brasileira de Cimento Portland (1992), moinho Matarazzo e Tecelagem Mariângela (1992); Companhia Antártica (ainda não tombada, apenas APT - Abertura de Processo de Tombamento - 2007); Vidraçaria Santa Marina (2009), juntamente com outros imóveis na Lapa; Complexo da Cia Nitroquímica (apenas APT, 2012) e Complexo Industrial do Gasômetro do Brás (2012). As vilas operárias também podem ser encontradas em sua área envoltória, contudo, este tema merece um estudo aprofundado. Há ainda outros complexos industriais citados por Rodrigues (2011),

4 "o documento dispositivo normativo emanado de um órgão colegiado, registrando uma decisão ou ordem na instância de sua área de atuação, expressa em Lei." FONTE: site CONPRESP. 
porém, além da maior quantidade de bens tombados em relação aos órgãos estaduais e federais, não vemos diferenças qualitativas no que diz respeito ao tratamento dado aos bens do patrimônio ferroviário e de conjuntos urbanos. Sobre o patrimônio ferroviário, encontram-se tombados apenas os bens da São Paulo Railway: três estações, um conjunto de armazéns da São Paulo Railway (2007), um tombamento ex-officio do conjunto ferroviário do Jaraguá (2015), uma ratificação do tombamento do CONDEPHAAT, e abertura do processo de tombamento (APT) do conjunto de oficinas da São Paulo Railway (2015). Nota-se novamente que primeiro foram tombadas as estações, como bens isolados, e o tratamento como complexos ferroviários é recente, apenas a partir de 2007, ainda assim não se sabe se houve o tratamento das vilas ferroviárias neste conjunto. Quanto ao tombamento de conjuntos urbanos ou vilas, parece que algumas mudanças foram introduzidas no DPH, pois são recentes os tombamentos de 10 edificações nas áreas do Belém (área com forte tradição industrial, cuja resolução de tombamento é de 2016) e a resolução IGEPAC/Liberdade, também de 2016. Tal resolução é uma atualização do Inventário Geral do Patrimônio Ambiental, Cultural e Urbano de São Paulo, realizadas pelo DPH e publicados no Caderno do IGEPAC-Liberdade (1987). Parece que os estudos de bairros estão sendo ressuscitados no órgão.

Ao destacar-se os bens tombados da Companhia Paulista nas três esferas de preservação temos: no IPHAN, o tombamento do conjunto de edificações da Companhia em Jundiaí, inscrito em 2004, no livro de Belas Artes, e mais recentemente integram a chamada Lista do Patrimônio Cultural Ferroviário: Antiga Subestação de Sumaré (2008) e Estação Ferroviária de Ribeirão Preto (2014). No CONDEPHAAT, temos (entre parênteses, o livro de tombo e ano da inscrição): a Estação de Santa Rita do Passa Quatro (Histórico - 1981), Estação de Campinas (Histórico - 1982); Estação de Descalvado (Histórico 1987); conjunto da Estação Ferroviária de Louveira (Histórico - 2012); conjunto da Estação Ferroviária de Piratininga (Histórico - 2013) e conjunto da Estação Ferroviária de Valinhos (2013). Estes três últimos tombamentos, bastante recentes, devem contemplar as vilas ferroviárias. Nota-se que a partir de 2015, no CONDEPHAAT os tombamentos não têm indicação do livro. Como se pode observar, as vilas ferroviárias objeto de nosso estudo - Itirapina, Dois Córregos, Brotas, Jaú, São Carlos e Rincão - não estão tombadas em nenhum órgão de preservação, com exceção da estação ferroviária de Dois Córregos, que há um processo aberto em 2014, e em instrução no IPHAN. Também não estão contemplados em nenhuma área de preservação de nenhum plano diretor (onde há) 
de suas respectivas cidades. Apenas, novamente Dois Córregos, que estabeleceu muito recentemente uma lei - lei 4166, de 13 de janeiro de 2016 - que cria o Museu Ferroviário de Dois Córregos. Sabe-se que a Vila Ferroviária de Campinas, da Companhia Paulista, conhecida como Vila Ponte Preta, teve um processo aberto de tombamento em nível municipal, pelo CONDEPACC (Conselho de Defesa do Patrimônio Artístico e Cultural de Campinas) em outubro de 2004, e concluído após dez anos em 2014.

Com relação à conservação e preservação das vilas operárias, como também em outros edifícios, observa-se que o tombamento não garante a preservação. No Brasil, o instituto do tombamento não é bem compreendido pela sociedade, e os proprietários não o vêem com bons olhos. Assim, "as intenções de tombamento de partes destes sítios desativados acabaram colaborando para um rápido desmonte e abandono do patrimônio construído, como foi observado nos casos da Fábrica Carioba e da Fábrica São Martinho." (CORREIA, 2004b). No caso da fábrica Carioba, houve dificuldades para seu tombamento nos órgãos técnicos, poderes municipais e estadual, e

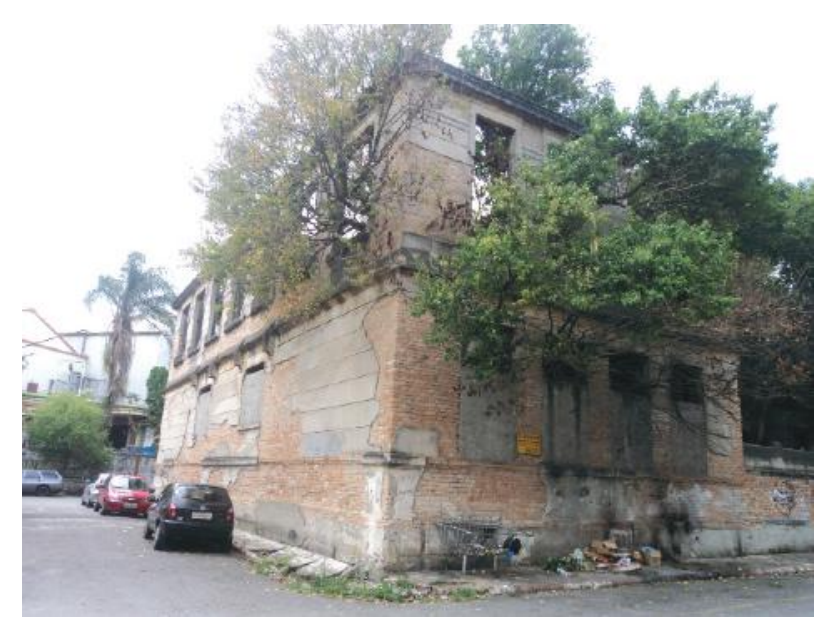

Foto 38 - Edifício da escola abandonada na Vila Maria Zélia. Fonte: autora, 2012.
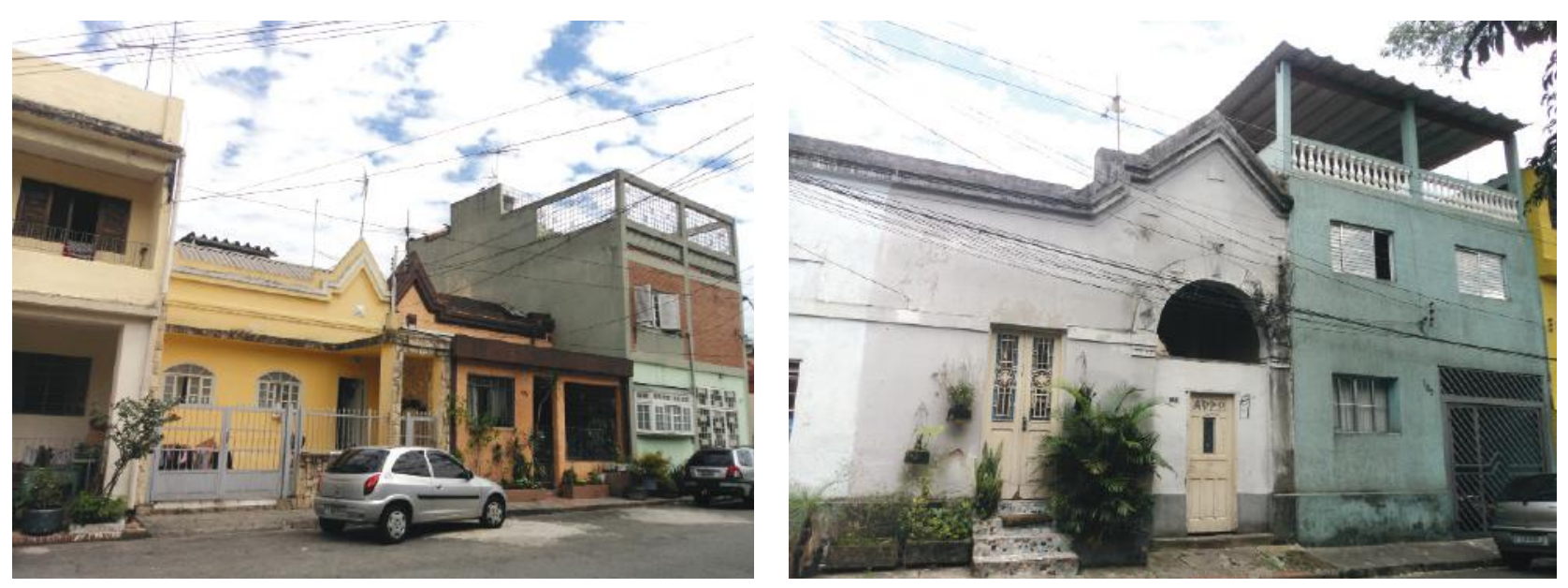

Fotos 39 e 40 - Alguns exemplos de descaracterização de edifícios da Vila Maria Zélia. Fonte: autora, 2012.

demora da tomada de decisões dos poderes públicos: “(...) os proprietários avançaram na destruição de casas e prédios. Amparados no direito de propriedade, desfizeram uma 
41

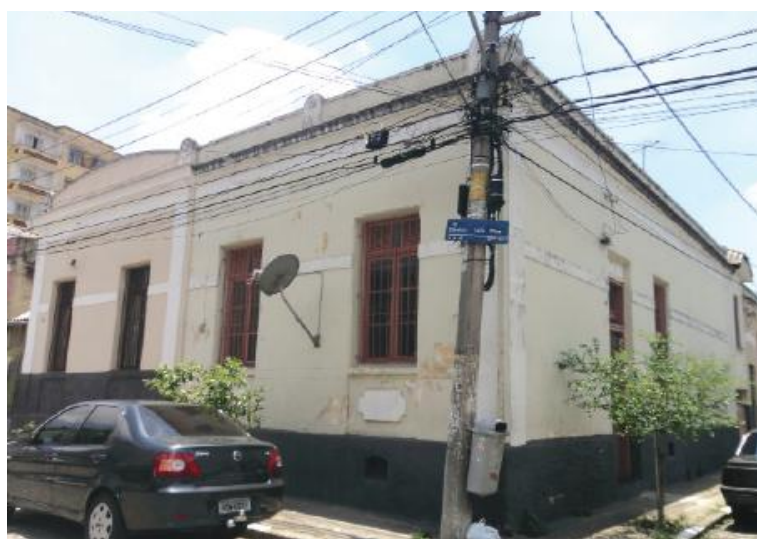

42

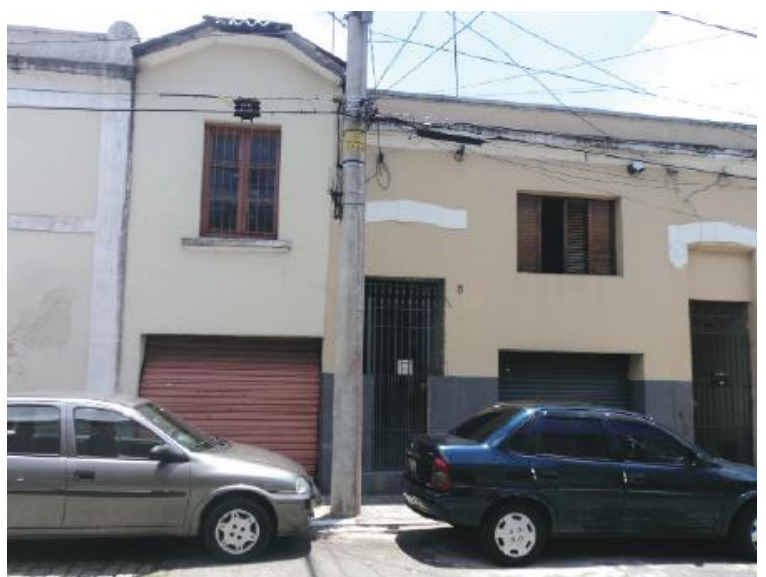

43

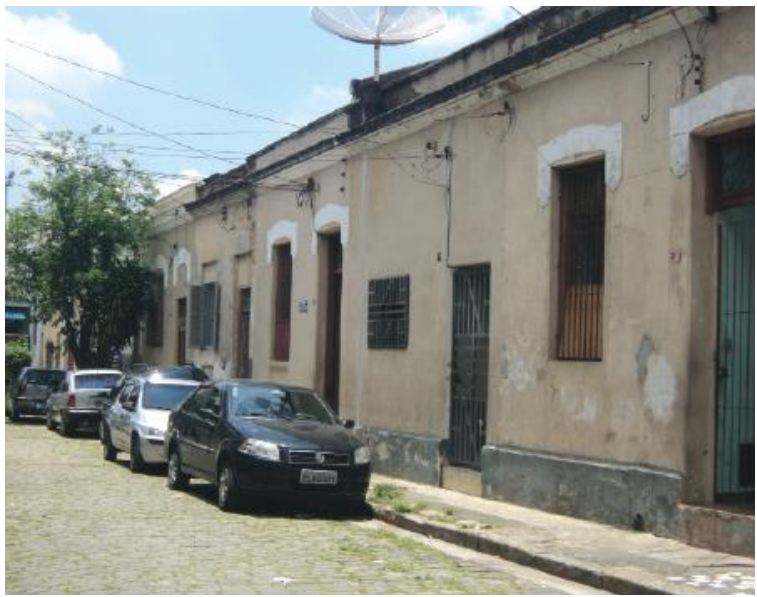

Fotos 41, 42, 43 - Vila Economizadora, e alguns exemplos de mudanças de caixilhos da Vila Maria Economizadora. Fonte: autora, 2012. comunidade e desmancharam uma trama urbana, substituída por um pequeno grupo de prédios desconectados que, abrigando arquivo histórico e museu, tentam recuperar pela história um lugar desfeito.”. (CORREIA, 2004b, p. 233; 245). Por vezes, as demolições e descaracterizações dos edifícios, devem-se à morosidade no reconhecimento do bem como patrimônio, assim como na conclusão do processo de tombamento. Ou ainda, há falta de fiscalização. As descaracterizações podem ser constatadas em recentes visitas às vilas operárias tombadas pelo CONDEPHAAT e ratificadas pelo CONPRESP na cidade de São Paulo, a Vila Maria Zélia e a Vila Economizadora Paulista.

No caso das vilas ferroviárias da Companhia Paulista, com relação ao estado de conservação, quando não demolidas, elas também se encontram descaracterizadas. A menor das vilas pesquisadas é a de Brotas com apenas 9 (nove) casas, sendo que na amostragem de Morais (2002) possuía 44 casas. A divergência de números neste caso, não se deve apenas à contagem ou amostragem, mas à demolição ou venda ao longo do tempo. Talvez a mais descaracterizada, e impossível até de reconhecer como conjunto, é a Vila de São Carlos, com 34 casas. Em outra vila ferroviária, em Jaú, por causa da construção de muros, tornou-se difícil a visibilidade das casas. Tanto em São Carlos como em Jaú, por serem cidades maiores, o tecido urbano das vilas sofreu grandes modificações. A que apresenta melhor estado de conservação entre as vilas ferroviárias é a de Rincão, além 
de apresentar muitas tipologias e considerável quantidade de casas. Foi uma das maiores vilas, chegando a 120 casas, e hoje possui 72 casas, contudo, é a que ainda apresenta melhor estado de conservação. Atualmente, segundo a visita de campo realizada, ela possui em realidade 209 casas.

44
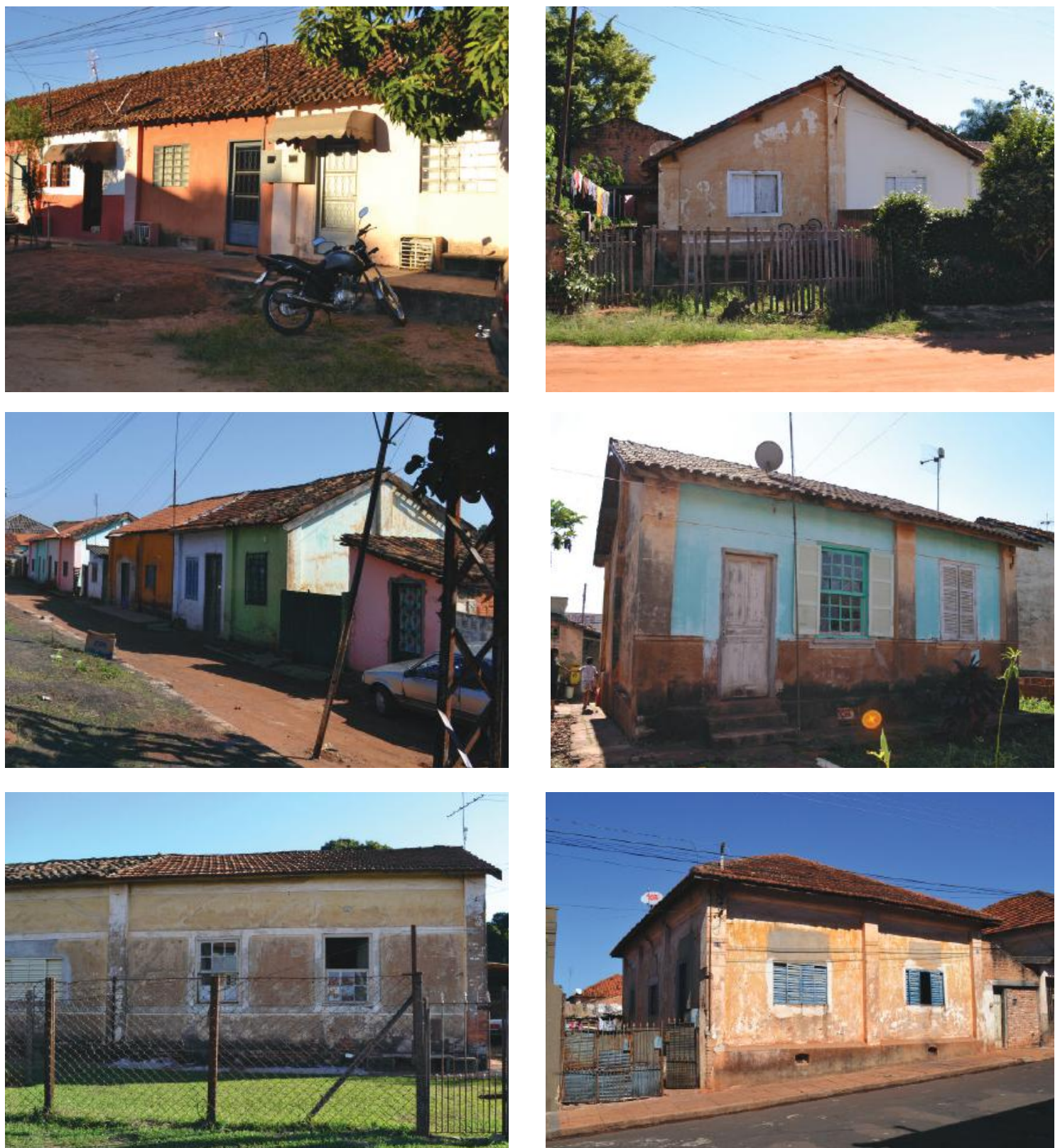

Fotos 44, 45, 46, 47, 48, 49 - Casas das vilas ferroviárias de Itirapina, Brotas, Dois Córregos, Jaú, São Carlos e Rincão.Fonte: autora, 2012.

Outra questão que se coloca, com relação às vilas ferroviárias, é que quando não demolidas, muitas delas encontram-se ocupadas, algumas por descendentes dos ex-ferroviários, geralmente filhos, porém a maior parte delas ocupadas por pessoas sem relação com a 
ferrovia. Sem dúvida, é importante resolver a questão fundiária e conservar o uso habitacional. Nem sempre as vilas operárias foram vendidas a seus operários. Por exemplo, as vilas operárias da Companhia Hidrelétrica do Estado de São Paulo (CESP) erguidas para a construção das usinas hidrelétricas de Barra Bonita e Bariri foram transformadas em hotéis. ${ }^{5}$ Seria ético e socialmente justo que tais vilas operárias fossem transformadas em hotéis? A famosa New Lannark, de Robert Owen, foi transformada em hotel. Algumas vezes, o turismo pode contribuir para gerar renda e para não tornar a vila uma cidade "fantasma". Como exemplo, temos Biribiri (MG), que se tornou local turístico, na rota dos turistas que vão à Diamantina. O turismo às vezes, é mal visto por alguns, afugentando a população local, porém às vezes, pode ser uma opção para a gestão e manutenção dos locais. Muitos projetos que envolvem revitalização de tecidos urbanos, com investimentos em áreas degradadas, podem gerar processos de gentrificação. Outras vezes, estes projetos envolvem tão bem a comunidade local, que acabam integrando os moradores. Assim, dependerá de cada caso, a escala da cidade, a localização dos bens patrimoniais e, no caso de tecidos urbanos a serem preservados, deve ser observado onde estão inseridos, analisar a população local, as necessidades da cidade para proceder eficazmente a preservação. A questão colocada aqui é a do uso, se mantê-lo ou transformá-lo; e ainda, de que maneira o uso pode garantir a conservação.

Como será visto no capítulo seguinte, a história mostra a importância das ferrovias na economia brasileira, e principalmente na configuração do território paulista, a estreita ligação das ferrovias e do café, da riqueza de uma única ferrovia, que foi a Companhia Paulista (imaginem-se as outras companhias que não fazem parte deste estudo), seus engenheiros, diretores e seus ferroviários. Comenta-se ainda a relação das vilas operárias e das ferroviárias, toda a transformação da legislação trabalhista, e a relação das teorias de organização científica com a educação e a moradia dos trabalhadores. Por toda esta história social, somada à presença ainda hoje de atores sociais, tais como moradores, ex-ferroviários, pesquisadores, associações de ferroviários, apaixonados por ferrovias, acredita-se que as vilas ferroviárias sejam um lugar de memória bastante forte. Porém, todos os edifícios da Companhia Paulista devem ser preservados ou somente alguns? Além de critérios de tombamento, quais critérios de preservação adotar? Quais as formas de obter uma preservação eficaz? E como garantir que a população original permaneça, além disso, reconheça e usufrua? Estas e outras questões são o que se gostaria de aprofundar ainda neste trabalho.

5 Para saber mais ver VIANNA, M. (2004). 


\section{2. Órgãos de preservação e patrimônio industrial ferroviário}

Não iremos fazer aqui análise das políticas de preservação dos órgãos brasileiros como já o fizeram: Chuva (2009) para o órgão de preservação federal, o IPHAN, analisando-o entre 1930 e 1940; Fonseca (2005) analisando o IPHAN de 1930 até 1990 e também Sant'Anna (1995) que também analisa o órgão federal até a década de 1990. Já para a análise da política de preservação estadual, o CONDEPHAAT (Conselho de Defesa do Patrimônio Histórico Arqueológico, Artístico e Turístico) temos o trabalho de Rodrigues (2000), que analisa o órgão desde sua fundação em 1969, até 1987. Com relação ao CONPRESP, (Conselho Municipal de Preservação do Patrimônio Histórico, Cultural e Ambiental, criado em 1985, com instalação definitiva em 1989), há um trabalho que trata do patrimônio industrial na cidade de São Paulo, e portanto, cita o órgão municipal que é Rodrigues (2011) analisando-o até 2010, não especificamente a política de preservação, exceto em alguns momentos. No presente trabalho, procuramos relacionar tais trabalhos sobre as políticas dos órgãos de preservação e o patrimônio industrial, especificamente ferroviário e procurar aprofundar as questões levantadas na epígrafe anterior, sobretudo com relação à valoração, aos critérios e ao funcionamento dos nossos órgãos de preservação, e como compreender neste contexto, as vilas ferroviárias, objeto de nosso estudo.

Com base nos autores acima citados, pode-se afirmar que foi a tardia inclusão dos bens referentes ao patrimônio industrial, que em sua maioria possuem uma estética própria e são pertencentes ao período em que predominou o ecletismo. Fogem em tudo ao que era considerada, ao primeiro período do IPHAN, denominado por Fonseca (2005) como a "fase heróica", na qual a maior parte dos bens tombados pertencia à arquitetura do período colonial, as arquiteturas de "pedra e cal" que tanto estimava o arquiteto Lúcio Costa. Também foge ao que se enquadra na arquitetura militar e religiosa, conforme lembra Chuva (2009, p. 270-1) em seu estudo. Há ainda a questão do valor nacional, que era identificada pelos técnicos do patrimônio, como a arquitetura resultante da miscigenação do português, do negro e do índio. Arquiteturas indígenas ou destinadas aos escravos, como os quilombos, ficavam à margem deste valor, como também as arquiteturas dos imigrantes europeus. A arquitetura eclética, por ser uma arquitetura "europeizante", fi- 
cava assim também à margem deste valor nacional. Porém, os técnicos, em sua maioria arquitetos, conseguiram por exemplo, tombar desde muito cedo, exemplos da arquitetura modernista no Brasil. Ou o que se considerava a "boa arquitetura", segundo os técnicos, portanto um juízo estético bastante questionável e discricionário, apelando ao valor artístico de bens isolados. Assim, muito da arquitetura ferroviária que possui o estilo eclético ficou à margem do tombamento do IPHAN, pois não se enquadrava na arquitetura nacional, nem no valor estético determinado pelos técnicos. Tais tipos de valorações só sofreram questionamento na década de 1960, no IPHAN, mesmo assim, com pouco efeito no processo de trabalho do órgão.

Este tipo de valoração - dividir os bens entre históricos e artísticos - e o tombamento daqueles com um valor nacional, além do procedimento centralizador do processo de “patrimonialização", não é algo característico nosso. Segundo Choay (2006, p. 148):

Essa legislação confirma a centralização, a unidade e a coerência da política francesa de conservação dos monumentos históricos, que se vê em seguida dotada de meios de ação próprios. De acordo com a tradição centralizadora da França, ela não deixou de funcionar como modelo em outros países em que o papel do Estado era menos preponderante e a descentralização era parte da tradição (Alemanha, Itália). $\mathrm{Na}$ Inglaterra, a intervenção do Estado na administração e conservação dos monumentos históricos só aconteceu tardiamente, com o Ancient Monuments Protection Act, de 1882, e permanece reduzida.(CHOAY, 2006, p.148)

Na França, a questão do valor nacional tem origem com a Revolução Francesa, durante a qual os bens do clero e da Coroa, passaram ao Estado revolucionário, e foram os Comitês revolucionários que criaram uma estrutura de conservação centralizada, e que "haveria de se tornar, até a recente descentralização dos poderes do Estado em nível regional, a característica da gestão francesa dos monumentos históricos.”. (CHOAY, 2006, p. 119). O patrimônio ficava a cargo dos Inspetores, e estes tinham o poder de tombar os bens. O patrimônio era dividido em duas categorias: bens móveis e imóveis. Os bens móveis ficavam em depósitos e depois eram transformados em museus abertos ao público, carregado de espírito enciclopedista, cuja função era servir de instrução à nação, e: “Essa pedagogia é concebida, de imediato, em escala nacional." (CHOAY, 2006, p. 101). Vicp d'Azyr na Comissão Provisória das Artes, em 1792 e 1793: “constitui o exemplo de uma nova figura, pela primeira vez prática, das relações fecundas entre as ciências naturais e o estudo dos monumentos históricos. Em matéria de arquitetu- 
ra, a ficha-padrão, estabelecida meio século mais tarde sob a direção de Mérimée, não será mais precisa que a da seção XI da Instruction." (CHOAY, 2006, p. 115). Portanto, esta estrutura de funcionamento francesa, com seus bens divididos, entre bens móveis e imóveis, a figura do inspetor, a ficha de inventário, não é por acaso, que encontramos o mesmo modelo centralizador no Brasil.

Não se deve esquecer sobretudo, que a questão do patrimônio é uma questão de valoração, e que tal valoração sofre mudanças com a história, e muitas vezes tal valoração é conflitiva, e passa por processos políticos. $\mathrm{O}$ valor nacional tão caro aos franceses, e que também o foi aos brasileiros, é silenciado na teoria de valores de Riegl (1858-1905), publicado em seu livro "O culto moderno dos monumentos", de 1903. Choay (2006, p. 117) considera este silêncio revelador pois:

Riegl raciocina enfocando o monumento histórico, noção que prevaleceu por todo o século XIX e até a década de 1960, e não enfocando o patrimônio: este último conceito, forjado para designar bens pertencentes à nação e aos quais se pode aplicar um novo tipo de conservação, deixa, em parte, de ser pertinente e cai em desuso quando a Revolução chega ao fim. Na França revolucionária, foi o valor nacional que legitimou todos os outros, dos quais é indissociável, e a cujo conjunto hierarquizado ele comunica seu poder afetivo. (CHOAY, 2006, p. 117)

Atualmente, em que a tarefa de preservação dos monumentos brasileiros também foi descentralizada entre os órgãos estaduais e municipais, o valor nacional também pode ser questionado, como já levantado por Fonseca (2005, p. 229): “O fato é que, com a criação de órgãos estaduais e municipais de preservação, extingue-se o papel supletivo que a SPHAN antes exercia, tornando-se, por outro lado, a cada dia mais importante discutir o que a instituição entende atualmente como bem de valor nacional."

Ao lado do valor nacional, outro valor que merece ser questionado, e por muito tempo foi critério para tombamento no Brasil, e de certa maneira ainda continua-se sendo utilizado, é o valor excepcional. Tal valor faz-se necessário, por exemplo, para inclusão dos bens na lista de Patrimônio Mundial da Unesco. Choay (2006, p. 207), em uma nota de rodapé comentando sobre os critérios da UNESCO, questiona tal valor: " $O$ valor excepcional é um critério vago, difícil de aplicar." 6 . Além disso, tal valor confronta com

6 Porém, aqui não iremos entrar questão do valor excepcional e da lista do patrimônio mundial, apenas fazer um comentário. Recentemente, a Vila Ferroviária de Paranapiacaba foi indicada para integrar a lista do patrimônio mundial. A indicação pode ter motivações políticas e financeiras, já que desde que foi tombada apresenta problemas de conservação, e uma vez integrada na lista da UNESCO, facilita a propaganda turística e a captação de recursos. Ao integrar a lista também, pode obscurecer o valor das demais vilas ferroviárias. Não que a vila não mereça a indicação, porém gostaríamos de ressaltar que o procedimento de construção de vilas ferroviárias era comum a todas as companhias da época. 
outro valor já levantado por Ruskin, no século XIX, o "pitoresco" e a arquitetura "modesta". A valoração dos monumentos e lugares continua sendo um problema. Segundo Choay, a questão da valoração foi brilhantemente abordada por Riegl, contudo traz novos problemas. Riegl ao dar proeminência do valor de ancianidade aos bens, o que equivaleria ao valor de reverência de Ruskin, leva a que "todo objeto do passado pode ser convertido em testemunho histórico sem que para isso tenha tido, na origem, uma destinação memorial." (CHOAY, 2006, p. 26). Desse modo, tudo pode ser convertido em monumento histórico. Porém, entre a teoria e a prática, há um interstício, e Choay não aborda esta lacuna, pois o alargamento do conceito de patrimônio, só ocorrerá a partir da década de 1960, o marco simbólico é a Carta de Veneza de 1964. Tal alargamento dos monumentos históricos é ao mesmo tempo, cronológico, geográfico e tipológico. ${ }^{7}$ Outra questão que contribui para o alargamento do conceito de patrimônio é o conceito de memória: as memórias não são mais nacionais, podem ser coletivas, mas também individuais, de pequenos grupos, o que contribui para o surgimento dos chamados "novos patrimônios". O domínio patrimonial não são mais edifícios individuais, mas bens imateriais, conjuntos urbanos e até cidades inteiras. Um dos problemas decorrentes deste alargamento, apontado por Choay (2006, p. 27) é a conservação incondicional: "Em contrapartida, uma vez que se insere em um lugar imutável e definitivo num conjunto objetivado e fixado pelo saber, o monumento histórico exige, dentro da lógica desse saber, e ao menos teoricamente, uma conservação incondicional."

A atribuição de valores ainda é conflitante, e acrescentar a palavra cultural ${ }^{8}$ que,

7 "Paralelamente, impõe-se uma expansão tipológica do patrimônio histórico: um mundo de edifícios modestos, nem memoriais, nem prestigiosos, reconhecidos e valorizados por disciplinas novas como a etnologia rural e urbana, a história das técnicas, a arqueologia medieval, foram integrados ao corpus patrimonial. Contudo, o aporte mais considerável de novos tipos se deve à transposição do muro da industrialização e à anexação, pela prática conservatória, que se apoiam, no todo ou em parte, em técnicas de construção novas: (...)" (CHOAY, 2006, p.209)

8 “(...) A palavra 'cultura' se difunde a partir dos anos 1960. Símbolo de sua fortuna, a criação de um ministério para assuntos culturais, que logo se torna 'da Cultura', é um modelo que não tarda a ser adotado pela maioria dos países europeus e a atravessar os mares. Malraux cria as Maisons de la Culture [Casas da Cultura], ao passo que a 'cultura' se diversifica: culturas minoritárias, cultura popular, cultura do pobre, cultura do corriqueiro..." (CHOAY, 2006, p. 210). A questão da cultura é um tema de debate à parte, com merecimento de ser aprofundado, chegando inclusive a incluir-se no campo antropológico e filosófico. Por exemplo, encontrou-se o seguinte trecho da filósofa Arendt, quando Tenca (2002, p. 40) falava no tempo livre dos trabalhadores: "A palavra cultura - palavra e conceito - é de origem romana. A palavra 'cultura'orgina-se de colere - cultivar, habitar, tomar conta, criar e preservar - e relaciona-se essencialmente como trato do homem com a natureza, no sentido do amanho e da preservação da natureza até que ela se torne adequada à habitação humana. Como tal, a palavra indica uma atitude de carinhoso cuidado e se coloca em aguda oposição a todo esforço de sujeitar a natureza à dominação do homem. Em decorrência, não se aplica apenas ao amanho do solo, mas pode designar outrossim o 'culto' aos deuses, o cuidado com aquilo que lhes pertence.(...) Conjuntamente, cultura no sentido de tornar a natureza um 
de certa forma, engloba os vários outros valores, em que se camuflam, porém não se apagam os conflitos. Ao extrapolar o patrimônio ao campo do urbano, pode-se dizer que muitos outros valores entrarão em conflito, além de históricos, artísticos, entrarão em cena: o valor de uso confundido com o valor econômico, valores éticos, valores psicológicos, valores afetivos, etc... Assim, o problema dos órgãos de patrimônio e restauradores urbanos, será de equilibrar tais valores em seus processos de registro, inventário e intervenção.

Todos os autores brasileiros anteriores citados analisam os órgãos de patrimônio, tendo a maior parte deles, como marco temporal a década de 1990. Talvez seja a hora de analisar os órgãos de patrimônio brasileiros nas últimas duas décadas. Fugiria ao nosso escopo, mas seria um interessante trabalho a ser realizado, pois já se passaram mais vinte anos. Desde a década de 1990, parece que além do alargamento do patrimônio, abrangendo questões sociais, como também em relação a grandes áreas, sob o conceito de paisagem cultural, a cultura mescla-se ao meio ambiente. Alguns artigos internacionais apresentam a relação entre sustentabilidade e patrimônio. Todo este processo de alargamento do conceito de patrimônio, do questionamento de alguns critérios, foi sentida também no Brasil, em maior ou menor grau, nos órgãos de preservação brasileiros.

No órgão federal, com a saída de Rodrigo Melo Franco de Andrade e a entrada de Aloísio Magalhães, houve uma mudança de enfoque dos bens de "pedra e cal", para a expansão de bens móveis e imateriais, sendo o artesanato um deles. Aloísio de Magalhães, com a criação do Centro Nacional de Referência Cultural (CNRC), criado em 1975, busca quebrar a dicotomia entre cultura erudita e cultura popular, até busca inspiração no ante-projeto de Mário de Andrade. Porém neste último, ainda se mantinha a dicotomia, e para o primeiro: “expressões da cultura popular deviam ser apreciadas de uma outra ordem de valores que não a que presidia à prática de preservação exercida pelo SPHAM, adequada aos bens móveis e imóveis de excepcional valor histórico e artístico.”. (FONSECA, 2005, p. 178). As manifestações populares, como o artesanato não eram vistas de maneira estática, mas com uma dimensão contemporânea (FONSECA, 2005, p. 167), e assim: "A noção de cultura popular foi ampliada de modo a abranger tanto as manifestações populares tradicionais quanto suas intersecções com o mundo industrial e urbano. Ficava de fora, apenas, a cultura de massa." (FONSECA, 2005, p. 172). Foram feitos

lugar habitável para as pessoas e cultura no sentido de cuidar dos monumentos do passado ainda hoje determinam o conteúdo e o significado que temos em mente ao falarmos de cultura" (ARENDT, 1972, p. 265-6) “Esse lar terreno somente se torna um mundo no sentido próprio da palavra quando a totalidade das coisas fabricadas é organizada de modo a poder resistir ao processo vital consumidor das pessoas que o habitam, sobrevivendo assim a elas. Somente quando essa sobrevivência é assegurada falamos de cultura..." (ARENDT opus cit. p. 263) 
muitos projetos no CNRC, como Estudo multidisciplinar do Caju, Museu ao Ar Livre, em Orleans, Santa Catarina, "Levantamentos de Documentação sobre o Brasil”.

Com a morte súbita de Aloísio Magalhães, em 1982, nenhum destes projetos chega a se efetivar como uma política de preservação. Cria-se um conflito de critérios entre os técnicos da geração "da pedra e do cal", sendo o "valor excepcional" o mais questionado, e os técnicos do CNRC, que passam a ser corpos técnicos paralelos e independentes, e não conjugados em uma proposta de trabalho comum. O CNRC foi transformado em Fundação Nacional Pró-Memória, (FNPM) criou conceitos como referência, dinâmica cultural, indicadores culturais, contextos culturais especificos, etc., que segundo Fonseca (2005, p. 201):

(...) embora tenham se tornado moeda corrente nos programas $e$ projetos culturais produzidos durante a década de oitenta, continuavam obscuros, mesmo dentro da FNPM. Faltou elaborá-los, em termos de seu potencial cognitivo e de sua utilização, através da discussão e divulgação de trabalhos e ações que demonstrassem, na abordagem de problemas especificos, como eram entendidos e operacionalizados.

Dois anos antes da criação do CNRC, em 1973, foi criado junto à Secretaria do Planejamento- SEPLAN-, o Programa Integrado de Reconstrução das Cidades Históricas, mais conhecido como PCH, que também foi incorporado ao IPHAN. Esta última iniciativa nasceu do resultado das reuniões de governantes que resultaram nos documentos Compromisso de Brasília e de Salvador, respectivamente em 1970 e 1971, alinhados com as Normas de Quito de 1967. Buscam alinhar planos de valorização monumental com planos de desenvolvimento nacional para as cidades históricas. Tal desenvolvimento nacional foi ligado principalmente à indústria do turismo. Segundo Fonseca (2005, p. 162):

A criação do PCH veio suprir basicamente a falta de recursos financeiros e administrativos do IPHAN, continuando a cargo dessa instituição a referência conceitual e técnica. Propiciou, por outro lado, a criação, durante as décadas de 70 e 80, de órgãos locais de patrimônio e elaboração de legislações estaduais de proteção, abrindo caminhos efetivos para a descentralização.

No entanto, as críticas dirigidas ao IPHAN não se limitavam a suas carências operacionais. Também em termos conceituais, a ênfase dada aos monumentos da cultura do colonizador tornava problemática, nos anos 70, uma identificação social mais abrangente com o patrimônio. (...)

E assim, em São Paulo, deu-se a criação do CONDEPHAAT, Conselho de Defesa do Patrimônio Histórico, Arqueológico, Artístico e Turístico, em nível estadual, em 
1969, e do CONPRESP, Conselho de Preservação Municipal do Patrimônio Histórico, Cultural e Ambiental, no município de São Paulo, criado em 1985, e efetivado em 1989. A grosso modo, com algumas variações, também replicam o modo de trabalho do órgão central. Os tombamentos do IPHAN são ratificados ex-officio por estes dois órgãos. Por exemplo, podemos verificar que nos órgãos estadual e municipal há um maior número de tombamentos com relação ao patrimônio ferroviário. Porém os tombamentos são ainda de estações, isto é, de edifícios ou conjuntos isolados.

Segundo Rodrigues (2000, p. 80 - 86), entre 1975 e 1982, começa a se notar algumas mudanças, depois de um seminário realizado por Varinne-Bohan, "o órgão estadual adotaria novos objetos de proteção e o patrimônio também passaria a ser entendido em sua dimensão urbana. Tratava-se de um momento em que a sociedade começava a perceber a importância da memória e da preservação como um direito social." Há uma aproximação com os órgãos de planejamento urbano e "se passou a valorizar também aspectos sócio-culturais que compõem os remanescentes físicos, possibilitando incorporar edificações mais recentes. ”. Mesmo no órgão municipal, há uma aproximação entre a preservação e os órgãos de planejamento urbano.

Quando havia a figura de um Rodrigo Melo Franco de Andrade, ou então um Aloísio Magalhães no comando de uma política de preservação federal, fácil era identificar por quais caminhos a política de preservação brasileira trilhava. Porém agora, ao analisar o site do IPHAN, a impressão não é tão nítida. Há órgãos que cuidam dos tombamentos de bens imóveis, e outros que cuidam dos bens móveis. Ainda funcionam com os livros de tombo, a única forma prevista pela lei de 1937, que de lá para cá, não foi alterada. Algumas discussões sobre o uso de novos conceitos como o de "paisagem cultural", criado pela UNESCO em 1992, e introduzida no IPHAN pela Portaria $\mathrm{N}^{\circ} 127$, de 2009, ainda está em experimentação, assim como o chamado "tombamento participativo". Segundo o I Fórum Nacional do Patrimônio Cultural, organizado pelo IPHAN em 2009, há ainda mais desafios e experiências a serem testadas com o tempo, do que uma efetiva política de preservação.

Nota-se que, por maior que tenha sido a evolução das teorias de restauro e por mais que os princípios das cartas patrimoniais sejam sabidos e difundidos, observa-se uma visível distância entre a teoria e a prática nos órgãos de preservação em seus diferentes níveis, federal, estadual e municipal. Houve uma "descentralização" do órgão federal, com a criação de órgãos estaduais e municipais, porém não há uma definição clara das 
funções de cada órgão, o que acaba criando conflito de competências, desperdício de profissionais, com sobreposição de funções, nas diferentes esferas, e um dos exemplos é o inventário. Além do subaproveitamento e falta de coordenação, a falta de técnicos é sentida desde o início de todos os órgãos até os dias atuais. ${ }^{9}$ Apesar da falta de técnicos, o inventário do patrimônio ferroviário, é tratado simultaneamente pelos três órgãos, sem haver delegação, ou divisão de tarefas. A pergunta que fica é: mas não se trata do mesmo patrimônio ferroviário? O procedimento de inventário é o mesmo, e os critérios de tombamento utilizados, diferentes. Se ainda estamos na fase de inventário, o que dizer da gestão dos imóveis? Na entrevista ao técnico do IPHAN, questionado sobre a gestão, citou-se apenas a chamada Portaria Interinstitucional No. 1, de setembro de 2011, assinada entre o IPHAN e a SPU. Contudo, nota-se que esta gestão está muito mais relacionada à destinação dos imóveis, e é muito mais teórica que prática. ${ }^{10}$ No CONDEPHAAT, o tombamento é tratado em um setor e a gestão por outro. Segundo o técnico do tombamento, quase que inexiste uma política de gestão. Nota-se que o patrimônio ferroviário não está sendo tratado de maneira sistêmica e ordenada. Pelo quadro de tombamentos ferroviários, ainda ficam pendentes questões: por que o órgão federal insiste em tombar apenas estações, sendo a indústria ferroviária um verdadeiro complexo? Por que tais estações e não outras? Enquanto não houver um alinhamento entre os órgãos de preservação nas três esferas, federal, estadual e municipal, e a divisão de tarefas, assim como equipes técnicas em trabalho multidisciplinar, fica difícil preservar o patrimônio. São problemas portanto de governança e gestão, e da definição de uma política de preservação eficaz.

Quanto à questão da valoração, a posição de Choay, como de outros franceses

9

Uma tese de doutorado da FAU-USP, em 2009, que estuda o CONDEPHAAT, aponta para a falta de coordenação e diretrizes de atuação do órgão, atendendo apenas aos pedidos de tombamento: "Sob outro enfoque, no entanto, o atendimento ao balcão também pode ser visto como uma falta de política do órgão, que só atende à demanda e responde apenas quando provocado, ao invés de pré-definir suas próprias linhas de atuação e política pública. Esta crítica ao alertar para o sobrepeso do 'balcão' aponta a necessidade do órgão estabelecer suas diretrizes de atuação e sua política." (PRATA, 2009, p. 79)

10 Por exemplo, no tempo que trabalhei na SPU, não vi acontecer o descrito no art. 12, da Portaria que diz: "Art. 12 O IPHAN, por intermédio da Coordenação Técnica do Patrimônio Ferroviário, fornecerá a lista de imóveis declarados como de interesse, no prazo de 30 (trinta) dias a contar da publicação desta Portaria, em atenção ao art. $\underline{7}^{\circ}$ do Decreto $n^{\circ}{ }^{\circ}$ 6.018, de 2007, para destinação por meio dos instrumentos de cessão elou entrega provisória pela SPU.

Parágrafo único. Os processos de destinação dos imóveis mencionados no caput serão iniciados no prazo de até 15 (quinze) dias contados a partir do recebimento da lista, e finalizados com a lavratura do respectivo instrumento em até 120 (cento e vinte) dias, prorrogáveis por mais 60 (sessenta) dias." O prazo acima não foi cumprido pelo menos na Superintendência da São Paulo. E o que mais ocorria eram casos do art. 13, o funcionamento somente por provocação: "Art. 13. Os Órgãos Centrais do IPHAN e da SPU declararão, mediante provocação, os casos excepcionais, os quais terão procedimentos e prazos diferenciados." 
como Chastel e Babelon, parece ser profundamente cética em relação aos "novos patrimônios". Sobre estes dois últimos autores, segundo Fonseca (2005, p.74):

(...)Valores como monumentalidade, singularidade e excepcionalidade são consideradas por eles como fundamentais para despertar o 'sentido do patrimônio'. Mas, ao criticarem a aplicação de critérios etnográficos para a seleção de bens patrimoniais, e ao defenderem o sentido do sagrado como 'o único possível em uma época de agnoscitismo' esses autores deixam de levar em conta a inescapável dimensão política da questão, reforçando, por outro lado, sua dimensão ideológica.

O patrimônio industrial, no qual está inserido o patrimônio ferroviário, entra neste alargamento tipológico do patrimônio mencionado anteriormente. Choay (2006) afirma que a seção do patrimônio industrial francês da Comissão Superior dos Monumentos Históricos, iniciou-se em 1986. Dado o ceticismo dos autores acima mencionados quanto aos "novos patrimônios", cabe ainda falarmos sobre patrimônio ferroviário? Dado o atual contexto internacional e brasileiro, constata-se que a abertura para os "novos patrimônios" é um caminho sem volta, porém cada Estado-nação precisaria vê-lo de forma sistêmica e buscar ordená-lo, em uma política de preservação ligada ao ordenamento do território.

No tratamento das vilas ferroviárias, poderíamos propor o aprofundamento de seu estudo e o questionamento de sua preservação através do conceito de "arquitetura menor" ou "arquitetura modesta", ou pelo caminho do patrimônio industrial. Acredito que os dois caminhos sejam viáveis. No campo teórico, a questão da "arquitetura menor" ou "arquitetura modesta" é já anunciada por Ruskin, e depois absorvida ao falar do ambiente, nos escritos de Gustavo Giovannoni, e nas cartas patrimoniais. Na Carta de Veneza, em seu primeiro artigo, ela é mencionada: “art. 1 - A noção de monumento histórico (...) Estende-se não só às grandes criações, mas também às obras modestas, que tenham adquirido, com o tempo, significação cultural." Noções como de vizinhança aos monumentos históricos, já se encontram presentes na Carta de Restauro de Atenas de 1931, cuja elaboração contou com a participação de Gustavo Giovannoni, e as palavras "sítios urbanos" e "paisagens" também se encontram na Recomendação de Paris, de 1962. Com relação ao patrimônio industrial, as vilas ferroviárias caberiam perfeitamente. Segundo Pozzer (2007, p. 218), o patrimônio industrial tem origem na arqueologia industrial: 
do século XX e seus primeiros trabalhos foram desenvolvidos na Inglaterra. Porém, muito antes já havia existido interesse pela proteção dos remanescentes industriais, que em geral foi disperso e buscou valorizar diferentes aspectos da industrialização e pareciam atuar de formas diferentes adequando-se às necessidades locais, sobretudo no continente europeu. Os primeiros passos da arqueologia industrial na busca por uma maior valorização do patrimônio industrial foram dados na década de 1950, porém, foi apenas a partir da década de 1960 que a disciplina começou receber contornos mais precisos no que se refere à sua constituição como disciplina. (POZZER, 2007, p. 218)

Como se vê na afirmação acima, é na década de 1960, com o surgimento concomitante dos "novos patrimônios", que a arqueologia aproxima-se do patrimônio industrial, resultado da aproximação da história com a arqueologia, que, por sua vez, são resultados dos movimentos da Nova História, ligada da Escola dos Annales e da Nova Arqueologia. (POZZER, 2007, p. 246). O autor enumera outros dois grandes marcos do patrimônio industrial: um em 1968, quando foi construído o primeiro museu de arqueologia industrial no Reino Unido, o Ironbridge Museum, cujo nome refere-se a primeira ponte construída em ferro, em 1779. O local é um verdadeiro conjunto de museus, localizado na área onde se descobriu a produção de aço utilizando-se o coque. Outro marco importante para o patrimônio industrial, foi 1978, por ocasião do III Congresso Internacional para a Conservação dos Monumentos Industriais em Estocolmo, foi criado o The International Comittee for the Conservation of Industrial Heritage (TICCIH), que é a organização internacional responsável por promover a preservação, conservação, investigação, documentação, pesquisa e interpretação do patrimônio industrial. Foi em uma destas reuniões do TICCIH, em 2003, na Rússia, na cidade de Nizhny Tagil, que foi redigida uma carta, considerada a "Carta do Patrimônio Industrial”, na qual são apresentadas a definição, os valores, a importância da identificação, da proteção, da manutenção e conservação dos bens ligados ao patrimônio industrial. Tal carta menciona que: "os exemplos mais significativos e característicos devem ser inventariados, protegidos e conservados, de acordo com o espírito da Carta de Veneza, para uso e benefício do presente e do futuro.". E em nota de rodapé da Carta de Patrimônio Industrial, menciona-se que devem ser incluídas, além da Carta de Veneza, a Carta de Burra (1980) e a Recomendação R(90)20 do Conselho da Europa. Portanto, tal carta é complementar e em consonância às cartas patrimoniais internacionais. Como definição de patrimônio industrial tem-se:

O patrimônio industrial compreende os vestígios da cultura industrial que possuem valor histórico, tecnológico, social, arquitetônico ou científico. Estes vestígios englobam edifícios e maquinaria, oficinas, 
fábricas, minas e locais de processamento e de refinação, entrepostos
e armazéns, centros de produção, transmissão e utilização de energia,
meios de transporte e todas as suas estruturas e infra-estruturas assim
como os locais onde se desenvolveram atividades sociais relacionadas
comas indústrias, tais como habitações, locais de culto ou de educação.
(TICCIH. Carta do Patrimônio Industrial, 2003, p. 3 grifo nosso)

Assim, com esta carta, ficam contempladas todas as vilas operárias, e obviamente as vilas ferroviárias, objeto de nosso estudo. Um último aspecto que gostaria de comentar é que nesta carta, fica estabelecida a questão da periodização, amplamente debatida anteriormente. Segundo a Carta de Patrimônio Industrial:

O período histórico de maior relevo para este estudo estende-se desde os inícios da Revolução Industrial, a partir da segunda metade do século XVIII, até aos nossos dias, sem negligenciar as suas raízes pré e proto-industriais. Para além disso, apoia-se no estudo das técnicas de produção, englobadas pela história da tecnologia. (idem)

Para o objeto de nosso estudo, o patrimônio ferroviário, não restam dúvidas. No Brasil, segundo Vichnewski (2004) o estudo e a investigação do patrimônio industrial iniciaram-se com a difusão da disciplina da arqueologia industrial, durante a década de 1970. O autor afirma que Warren Dean (1976) inaugura os estudos de arqueologia industrial, com a publicação nos "Anais de História, da Universidade Estadual Paulista, em Assis, o artigo - A Fábrica São Luiz de Itu: um estudo de arqueologia industrial." (VICHNEWSKI, 2004, p. 31-2). Apesar do primeiro tombamento relativo ao patrimônio industrial ser anterior a esta data, em setembro de 1964:

foi tombado pelo SPHAN, hoje IPHAN, o primeiro complexo funcionante para exploração e fabricação de ferro no Brasil - a Real Fábrica de Ferro São João do Ipanema - que esteve em atividade até o final do século XIX. (...)Essa fábrica estudada foi a primeira a empregar o vapor como energia na província de São Paulo. As atividades da fábrica foram iniciadas em dezembro de $1869 .{ }^{11}$

Vichnewski (2004) comenta ainda que igualmente, na Europa e no Brasil, a disciplina arqueologia industrial caminhou paralelamente com a história da técnica, cujo

11 VICHNEWSKI (2004, p. 35) cita também os seguintes tombamentos do IPHAN: a Fábrica de Ferro Patriótica, em Ouro Preto, Minas Gerais, tombada em junho de 1938, que, hoje se encontra em ruínas; a Fábrica de Vinho Tito Silva, em João Pessoa, Paraíba, tombada em agosto de 1984, aberta à visitação ao público; a Fábrica Santa Amélia, de São Luís, Maranhão, tombada em julho de 1987, que conserva ainda toda a estrutura do edifício próxima das condições originais. Sobre a Fábrica de Ferro Patriótica, talvez o autor não deve considerá-la como primeiro tombamento do patrimônio industrial, pois está tombada por pertencer à cidade histórica de Ouro Preto, e não pelo fato de pertencer ao patrimônio industrial. 
estudo foi levado por autores como Ruy Gama, Júlio Katinsky, Andrey Schlee, entre outros, e na década de 1980 cita vários estudos sobre os engenhos de açúcar. Um último dado citado por Pozzer (2007), sobre o patrimônio industrial, em 2003: “um pequeno mas ativo grupo fundou, nas dependências da Escola de Sociologia e Política, na cidade de São Paulo" o Comitê Brasileiro de Preservação do Patrimônio Industrial, composto por profissionais de diversas áreas e membros da comunidade. (MENEGUELLO \& RUBINO, 2004, p. 1 apud POZZER, 2007, p. 252-3).

Assim, depois desta rápida apresentação da formação dos estudos sobre patrimônio industrial no panorama internacional e nacional, com abordagem do patrimônio industrial no órgão de preservação federal, temos o trabalho de Kempter (2010, p. 277). Segundo as tabelas e gráficos apresentados por esta autora, dos 1051 bens tombados pelo IPHAN desde seus inícios até 2010, incluindo-se os bens móveis e integrados, imóveis e arqueológicos (nas suas diversas classificações sítios urbanos, edificações, equipamentos urbanos e infraestrutura, jardins históricos e parques, paisagens naturais, ruínas, etc.), tem-se apenas 36 bens considerados patrimônio industrial, inclusive os engenhos. Destes, 11 bens pertencem ao patrimônio ferroviário. Dos 36 bens considerados patrimônio industrial, 7 estão localizados no estado de São Paulo, e 4 deles são patrimônio ferroviário. 


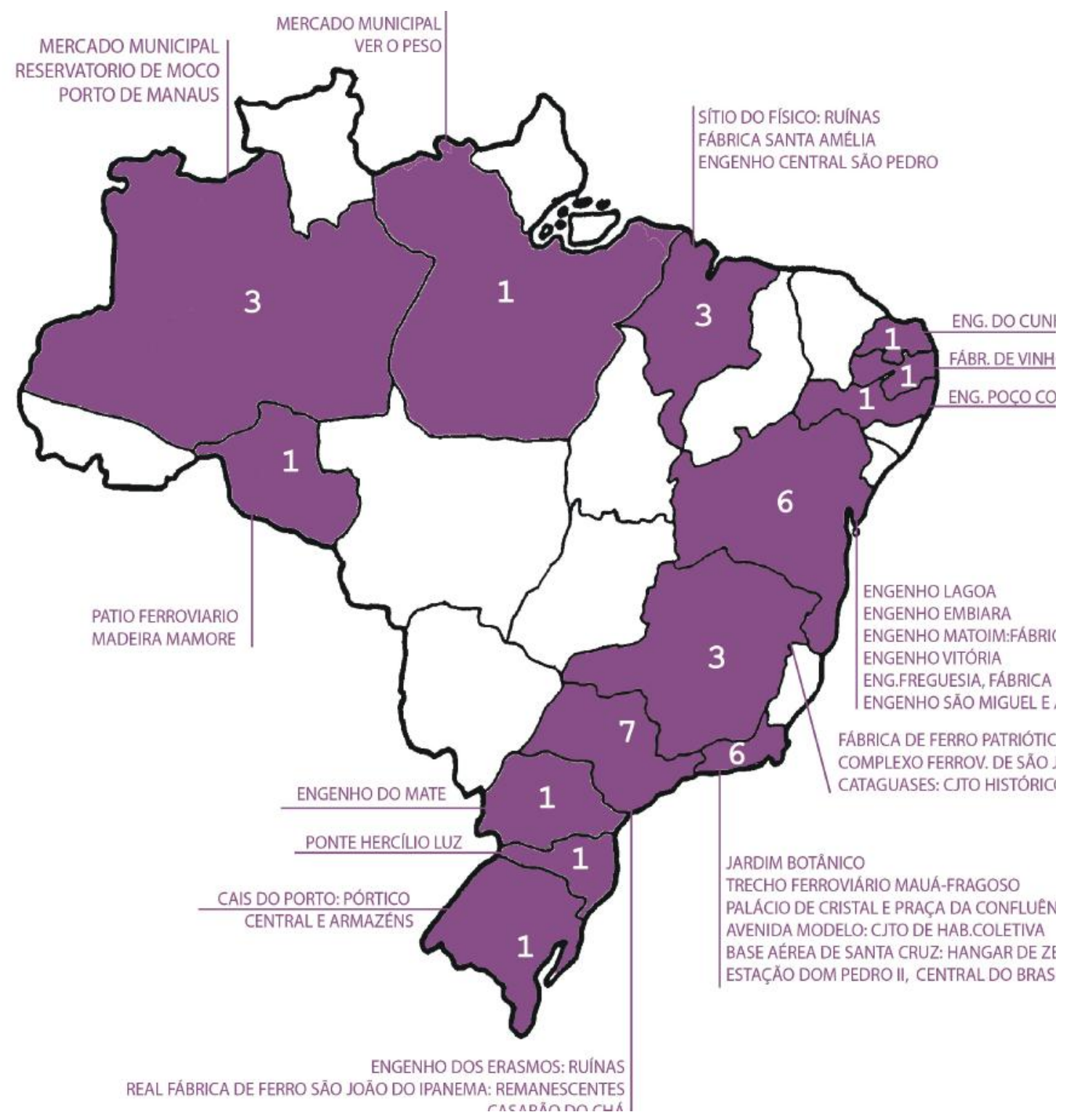

Mapa 03 - Distribuição, localização e identificação dos bens tombados pelo IPHAN considerados patrimônio industrial no Brasil. Fonte: KEMPTER (2010, p. 277)

Deste quadro, podemos inferir que são relativamente poucos os bens levantados pelo órgão federal, e se comparados aos imóveis existentes, referentes às diversas companhias ferroviárias, listadas pela Inventariança da antiga Rede Ferroviária Federal. Vale lembrar que apenas no estado de São Paulo, existiram sete grandes empresas ferroviárias, além da Companhia Paulista, são elas: a Estrada de Ferro Sorocabana, a Companhia Mogiana, a São Paulo-Railway, a Estrada de Ferro Araraquara, a Estrada de Ferro São Paulo Minas, a Estrada de Ferro Noroeste do Brasil e a Estrada de Ferro Central do Brasil, que também atravessava o estado de São Paulo. Se apenas na Companhia Paulista, há muito material e pesquisa realizada, e ainda assim material a ser pesquisado, nos arquivos do 
Museu de Jundiaí ou na Móoca, com histórias preciosas para serem contadas, imaginem-se em cada uma destas ferrovias.

Outro ponto importante que se deve ressaltar: o patrimônio industrial, conforme posto pela Carta de Nizhny Tagil refere-se a todo um complexo. E isto foi muito bem lembrado por Kühl (2013, p. 35):

Isso, como mencionado, diz respeito não apenas às estações, com seu mobiliário, equipamentos, plataformas, abrigos e passarelas, mas a todo o conjunto de construções e de elementos que colaboram para a configuração do complexo sistema relacionado às ferrovias que também inclui sua articulação com a cidade e com as unidades de produção - como (figuras 8 a 10) os locais de trabalho com os próprios instrumentos de trabalho, oficinas, armazéns, depósitos de locomotivas e vagões, giradores, casas de máquinas, cabinas de sinalização e, ainda, residências, a própria linha com seus trilhos, dormentes, lastro, elementos de sinalização, taludes, aterros e demais obras-de-arte a ela associadas. Além disso, diz respeito também a tradições, saberes e formas de sociabilidade que não tem sido objeto de estudos mais sistemáticos; ou seja, é todo um complexo que colabora na caracterização do patrimônio ferroviário. São esses elementos que configuram linhas, redes, pátios ferroviários, que repercutem nas cidades e no próprio território, que têm de ser preservados de modo articulado, para serem apreendidos em sua complexidade. Entretanto, isso não significa preservar tudo indistintamente, como será mostrado adiante.

E apesar dos esforços e iniciativas do IPHAN e do CONDEPHAAT, a preservação ainda é limitada e insuficiente. Creio que uma das limitações, além da já mencionada forma de organização dos órgãos de preservação, talvez seja a legislação, que separa os bens imóveis e os bens móveis. No caso do patrimônio ferroviário, não se fala ainda de bens móveis integrados, como por exemplo, as locomotivas e os vagões, os relógios das estações, como se fala dos bens móveis integrados para a arquitetura religiosa. Não é necessário lembrar que há muito trabalho a ser realizado, não apenas com relação ao patrimônio ferroviário, que até tem merecido ações do IPHAN. Vale lembrar que o patrimônio ferroviário é apenas um subsistema do patrimônio industrial. Imaginem-se os outros bens industriais, que estão sendo pouco contemplados: minas, portos, fábricas de bens de consumo, etc. Por estas constatações, nota-se que o patrimônio industrial não é visto de forma sistêmica. Há vários problemas em não se trabalhar desta maneira, cita-se apenas um deles: a demora em reconhecer este patrimônio resulta na perda, inclusive na falta de registro dos bens. Outros problemas referem-se ao entendimento para comunicar e gerir 
tais bens em uma forma de preservação eficaz, e de maneira articulada entre os órgãos de patrimônio.

Apesar do exposto sobre o patrimônio industrial e ferroviário, justamente pela existência de múltiplas e variadas formas de patrimônio e pela questão de valoração, pode-se ainda levantar a seguinte pergunta: será possível uma outra entrada que não o patrimônio industrial para o caso das vilas ferroviárias? Como por exemplo: memória dos trabalhadores, paisagem urbana, história habitacional? Ainda que houvesse, dado o corpus teórico bastante consolidado, a representatividade da linha de pesquisa, e inclusive o caráter interdisciplinar do patrimônio industrial, esta é uma linha bastante adequada para a pesquisa das vilas ferroviárias dentro do patrimônio industrial ferroviário. Quanto à questão da "arquitetura modesta", esta permanece ao tratar-se juntamente a questão do patrimônio industrial no âmbito do patrimônio urbano, como o fez Rufinoni (2009). Talvez uma outra forma de tratar a questão seria dentro de um conceito bastante em voga que é o de paisagem cultural, como veremos adiante.

Aqui trata-se de dar uma visão sistêmica deste patrimônio, pois como vimos, não está sendo tratado desta forma, e ao não ser visto sistemicamente, traz inúmeros problemas de preservação. Além da perda, conforme apontamos anteriormente, traz o desgaste na maneira de trabalhar e gerir, resultando em problemas de inventário (todos os órgãos em todos os níveis fazendo desgastantes inventários com poucos funcionários), em conflitos de estabelecimentos de critérios, conflitos de competências na conservação. Enfim, em problemas de gestão deste patrimônio. Nesta perspectiva, considera-se, por enquanto, adequado considerar a questão dos complexos ferroviários, dentro do patrimônio industrial.

\subsection{Instrumentos de preservação e patrimônio industrial ferroviário}

Em algumas vistorias pelo interior do estado, é possível observar que muitas das construções ferroviárias encontram-se ou em ruínas ou invadidas, aguardando posicionamento da União e dos órgãos de conservação e preservação, nas suas diversas instâncias federal, estadual e municipal. Vimos ainda que as demolições e descaracterizações dos edifícios industriais, devem-se à morosidade do reconhecimento do bem como patrimô- 
nio, assim como à morosidade na conclusão do processo de tombamento, ou ainda, por falta de fiscalização. Também foi observado que o tombamento tampouco é bem compreendido pela sociedade. Principalmente os proprietários de imóveis, não o vêem com bons olhos. O tombamento é muitas vezes confundido com uma forma de "congelamento", de edifícios e bairros ou outras áreas, tanto é assim que, por outro lado, há pedidos de tombamento de bairros pelos próprios moradores ou associação de moradores, a fim de evitar a construção de edifícios altos nos mesmos.

Há ainda na sociedade brasileira a confusão entre tombamento e preservação, inclusive dentro do próprio IPHAN. Há no site do IPHAN, no item sobre "Perguntas frequentes”, as seguintes perguntas: “O tombamento preserva?”, “O tombamento é a única forma de preservação?"12 A resposta fornecida pelo IPHAN é ambígua e genérica, com uma aproximação ainda muito mais teórica do que prática. Vejam-se duas das respostas do IPHAN:

O Tombamento é a única forma de preservação?

Não. A Constituição Federal estabelece que é função da União, do Estado e dos Municípios, com o apoio das comunidades, preservar os bens culturais e naturais brasileiros. Além do Tombamento, existem outras formas de preservação. $O$ inventário é a primeira forma para o reconhecimento da importância dos bens culturais e ambientais, por meio do registro de suas características principais. Os Planos Diretores também estabelecem formas de preservação do patrimônio, em nível municipal, por intermédio do planejamento urbano. Os municípios devem promover o desenvolvimento das cidades sem a destruição do patrimônio. Podem ainda criar leis especificas que estabeleçam incentivos à preservação.

O Tombamento preserva?

Sim. O Tombamento é a primeira ação a ser tomada para a preservação dos bens culturais, na medida que impede legalmente a sua destruição. No caso de bens culturais, preservar não é só a memória coletiva, mas todos os esforços e recursos já investidos para sua construção. A preservação somente se torna visivel para todos quando um bem cultural se encontra em bom estado de conservação, propiciando sua plena utilização. ${ }^{13}$

Na teoria, sabe-se que o tombamento não é a única forma de preservação, contudo, na prática cotidiana, é o instrumento legal mais utilizado. No texto, menciona-se o inventário como outra forma de preservação. Citam-se os planos diretores como uma

\section{2}

Disponível em: <http://portal.iphan.gov.br/portal/montarPaginaSecao.

do? id=100\&sigla=Institucional\&retorno=paginaPerguntasFrequentes $>$ Acesso em 10/06/2013 20:31.

$13<$ http://portal.iphan.gov.br/portal/montarPaginaSecao.

do? $\mathrm{id}=100 \&$ sigla $=$ Institucional\&retorno=paginaPerguntasFrequentes $>$ Acesso em 10/06/2013 20:31. 
terceira forma de preservação, porém a articulação entre os órgãos de preservação, nas três esferas, e com os municípios ainda é difícil, e na prática, nem sempre se dá. Que a sociedade deve participar da preservação, isto está claro, para garantir sua eficácia. Existem pedidos de tombamento pela população sim, como participação da população nos inventários também. Porém, a articulação entre os órgãos de preservação, administrações diretas federais, municipais e estaduais e sociedade, ainda está para ser realizada. A impressão que se tem é que há várias experiências em diversos lugares, mas não há um denominador comum que se traduza em uma política de preservação efetiva, em que o órgão federal delega funções aos órgãos de preservação estaduais e municipais. Dado os equívocos quanto aos termos, nos órgãos de preservação e na sociedade, acredita-se que vale a pena, aprofundar cada um deles: tombamento, preservação, conservação e gestão.

Sobre o tombamento, lembra-nos Fonseca (2005, p. 180) na introdução de um de seus capítulos, recorrendo ao jurista brasileiro Helly Lopes Meirelles, um dos principais doutrinadores do Direito Administrativo: “As expressões 'Livros do Tombo'e 'tombamento' provêm do Direito Português, onde a palavra 'tombar' significa 'inventariar', 'arrolar' ou 'inscrever' nos arquivos do Reino guardados na 'Torre do Tombo'”. Cada país tem sua maneira de arrolar estes bens em uma lista ${ }^{14}$, algumas mais simples, outras mais complicadas. Por exemplo, o Brasil possui quatro livros para os bens materiais e para os bens imateriais temos os registros (estes últimos de origem mais recente). Tal procedimento para os bens materiais foi nos dado pelo Decreto-lei $\mathrm{n}^{\circ} 25$, de 30 de novembro de 1937, e até hoje segue um dos principais instrumentos jurídicos para a preservação. Para deixar clara a diferença entre a preservação e o tombamento, recorre-se a outro autor do Direito Administrativo:

Preservação é o conceito genérico. Nele podemos compreender toda e qualquer ação do Estado que vise conservar a memória de fatos ou valores culturais de uma Nação. É importante acentuar este aspecto já que, do ponto de vista normativo, existem várias possibilidades de formas legais de preservação. A par da legislação, há também as atividades administrativas do Estado que, sem restringir ou conformar direitos, caracterizam-se como ações de fomento que têm como consequência a preservação da memória. Portanto, o conceito de preservação é genérico, não se restringindo a uma única lei, ou forma de preservação especifica. (CASTRO, 1991, p. 5)

Fica evidente assim, que a preservação, como um conceito mais genérico, aponta

14 O Estados Unidos tem uma lista única, e a França possui duas listas a dos classès e dos inscrits, que dependendo da lista de tombamento, possui uma forma de conservação e/ou intervenção. (MICELI\&GOUVEIA, 1985) 
que, se há vontade de preservar, não necessariamente é preciso uma lei. Ainda no campo legislativo, a autora afirma que, "O Decreto-lei 25, de 15 de novembro de 1937, é o mais conhecido instrumento legal pátrio de preservação, mas não é o único. (...)” (CASTRO, 1991, p. 6) e cita outras leis, como a Lei n. 3.924, de 26 de julho de 1961 para preservação de monumento arqueológicos e pré-históricos; e a Lei 4.845, de 19 de novembro de 1965 que proíbe a saída, para o exterior, de obras de arte e ofícios produzidos no País, até o final do período monárquico e ainda os instrumentos legais de planejamento urbano, que prevêem áreas de interesse cultural e ambiental. (CASTRO, 1991, p. 6). Sobre estes últimos, como ocorre com a preservação ambiental, dentro do planejamento:

Não se pode afirmar que esse tipo de preservação seja tombamento. Embora os efeitos possam ser praticamento os mesmos, limitando o direito de propriedade, impondo condiçães de uso e conservação do imóvel, o procedimento para a imposição da limitação é diverso, assim como podem ser diversos a competência, a forma, o motivo e a finalidade. (CASTRO, 1991, p. 8)

Há uma distinção com relação ao tombamento e o planejamento, ainda que ultimamente, devido ao alargamento do conceito de patrimônio dos edifícios isolados ao patrimônio urbano, e inclusive de vastas áreas de paisagens em que o ambiente e a cultura acabam por se mesclar, as práticas de conservação aproximam-se dos instrumentos de planejamento e de organização do território, e tais práticas são recomendadas pelas teorias e cartas de restauro internacionais.

Fica claro que a preservação é um conceito maior que o tombamento, sendo o tombamento apenas um dos instrumentos, pode haver outros instrumentos concorrentes para auxiliar na preservação. Passemos então a discutir o que é a conservação. Segundo Castro (1991), o principal efeito jurídico do tombamento é "a obrigação de conservar a coisa tombada.”. Em linhas anteriores já se havia mencionado que um dos problemas do culto aos monumentos histórico é sua conservação incondicional, apontado por Choay (2006, p. 27). Tanto é assim, que em alguns países, já adiantados no inventário e tombamento, não se quer tombar mais nada, pois já há muito o que conservar, manter e dar uma destinação. ${ }^{15} \mathrm{O} u$ então, que não se queira tombar, enquanto não se verificar a sustentabi15

Um exemplo, seria a Holanda. Segundo Meurs (S.D.), a Holanda possui 50.000 edifícios considerados patrimônios naturais, 50.000 edifícios considerados patrimônios municipais, 500 edifícios patrimônios regionais, 450 vilas históricas e paisagens urbanas, 1400 lugares arqueológicos e 9 lugares que são patrimônios mundiais (World Heritage Sites, incluindo Wadden Sea e Willemstad, em Curaçao). Há ainda um número de 'paisagens valiosas' ("valuable landscapes" conhecidas como Belvedere areas) e um extensivo sistema de parques nacionais. Outro autor holandês também chega a dizer que há aproximadamente 
lidade financeira ou a destinação do imóvel, como é o caso inglês.

Do ponto de vista jurídico brasileiro:

Conservar é proteger do dano, da mutilação e da descaraterização. Este é o conceito da própria lei (DL 25/37), disposto no seu art. 17. Com isso, a coisa tombada deve ser resguardada de qualquer ação de destruição opcional ou provocada. Não obstante, não é adequado entender a noção de conservação como de permanência absoluta, ou de completa inalterabilidade; ao contrário, se a coisa é, pela natureza, mutável, sua conservação importa proteger condições básicas que permitam a continuidade de suas características, segundo sua própria natureza. (...) (CASTRO, 1991, p. 77)

Fica claro que ao contrário do que está difuso na sociedade ou no imaginário popular - talvez até porque os próprios órgãos de preservação não definem adequadamente, por exemplo, "as condições básicas que permitam a continuidade das características dos bens" - conservar não é “congelar”. Aliás, as políticas de preservação deveriam ir além de uma política "museal” de patrimônio, estarem mais atentas para a dimensão contemporânea do mesmo, o que serve tanto para o edifício isolado, como para os conjuntos urbanos. Saindo do aspecto jurídico, e voltando ao lado mais conceitual e filosófico, Choay (2006, p. 149) afirma que:

Querer e saber 'tombar' monumentos é uma coisa. Saber conserválos fisicamente e restaurá-los é algo que se baseia em outros tipos de conhecimentos. Isso requer uma prática especifica e pessoas especializadas, os 'arquitetos dos monumentos históricos', que o século XIX precisou inventar.

Pode-se aproveitar a fala de Choay, e verificar que dentro do trabalho de preservação, existem vários procedimentos, conhecimentos e ações. Assim, o trabalho de inventariar e tombar, exige certo tipo de conhecimentos que não é o mesmo para o trabalho de

100.000 edifícios, aproximadamente $1.5 \%$ do total de edificações do país, são protegidos de uma maneira ou de outra. (VAN BEUSEKON, Jan Willem "The Future of Historic Inner Cities in the Netherlands" in DEBEN, L., SALET, W. \& VAN THOOR, M.T.(Eds.). Cultural heritage and the future of the historical inner city of Amsterdam. Amsterdam: Aksant Academic Publishers, 2004.) Segundo Pickard (1996, p. 286), o Reino Unido possui cerca de 500.000 bens tombados (listed buildings), aproximadamente 8000 áreas de conservação e cerca de 15.000 monumentos antigos (scheduled ancient monuments). Segundo Schmidt (2008, p. 124), segundo a fonte Denkmalschutz Informationen (1/2008,5), 1.377 .142 lugares de significância cultural foram listados na Alemanha em 2008, sendo 748.105 edifícios históricos e 565.696 lugares arqueológicos. Não há classificação de significado dos monumentos e a proteção aos edifícios é integral. A título comparativo: o patrimônio brasileiro, em nível federal, segundo Kempter (2010, p. 277), o IPHAN possuía entre bens móveis, imóveis e arqueológicos tombados, quando o livro foi escrito: apenas 1051 itens. Considerando este número total e descontando-se os bens móveis, chegamos ao número de 981 bens imóveis e sítios, ruínas e paisagens, não chegando, portanto, a um milhar. É uma pena, que neste arrolamento, foram desconsiderados os bens preservados em níveis estaduais e municipais. 
conservar e restaurar os monumentos, o que aqui chamaremos de intervenção. Se o trabalho de "patrimonialização", seja o inventário ou o tombamento, exige conhecimentos de valoração sobre os bens, o trabalho de intervenção exige outros:

A intervenção de restauradores especializados nos monumentos históricos exige não apenas conhecimentos seguros, históricos, técnicos, metodológicos. Ela implica também uma doutrina que pode articular de forma muito diferente esses saberes e esses savoir-faire, modificando os objetivos e a natureza da intervenção arquitetônica. A nova disciplina que se constituiu a partir da década de 1820, a conservação dos monumentos antigos, reconhece necessariamente os valores e os novos significados atribuidos ao monumento histórico. (CHOAY, 2006, p. 153)

Não se trata aqui de expôr todo o histórico das teorias da conservação dos monumentos antigos, que vão desde as aporias de restauração de matriz inglesa, representada por Ruskin, e a matriz francesa representada por Viollet-le-Duc, passando pelos teóricos italianos Gustavo Giovannoni e Camilo Boito, chegando a Cesare Brandi, pois já o fizeram vários autores, que podemos citar, como Choay (2006), e entre autores brasileiros Kühl (2008), e também critérios de intervenção fogem ao nosso escopo. São de interesse desta pesquisa, a partir do alargamento do patrimônio para o urbano, os trabalhos realizados por Choay (2006) e Rufinoni (2009), que repassam os mesmos teóricos mas sob o ponto de vista da gênese e corpus teórico para a intervenção do patrimônio urbano, pois, ao considerar as vilas ferroviárias, muitas delas fazem parte do tecido urbano das cidades.

Segundo Choay (2006, p. 178-9):

A noção de patrimônio urbano histórico constituiu-se na contramão do processo de urbanização dominante. Ela é o resultado de uma dialética da história e da historicidade que se processa entre três figuras (ou abordagens) sucessivas da cidade antiga. Chamarei essas figuras respectivamente de memorial, histórica e historial.

Resumindo muito brevemente estas três figuras: a memorial é representada por Ruskin, e também por William Morris, que combatem pela vida e pela existência da cidade ocidental pré-industrial (Choay, 2006, p. 182); a figura histórica, possui duas vertentes, uma com papel propedêutico representada por Camillo Sitte e outra com papel museal representada por Charles Buls, este último admirador do primeiro. Sitte possui uma visão “contrária à de Ruskin, e também à de Haussmann: a cidade antiga, tornada obsoleta pelo devir da sociedade industrial, nem por isso deixa de ser reconhecida e constituída 
em uma figura histórica original, que requer reflexão." (CHOAY, 2006, p. 182). Sitte escreve um livro em 1889, chamado Der Städtebau nach seinen künstlerischen Grundsätzen, traduzido para o francês "com o título já enganoso de L'Art de contruire les villes." (CHOAY, 2006, p. 182), no qual estuda a cidade antiga, a cidade barroca, e através do estudo das configurações espaciais, busca assim a beleza dos lugares. Por este motivo, Sitte é conhecido como o criador da morfologia urbana. Para Sitte, o papel das cidades do passado acabou, mas sua beleza plástica permanece. "Conservar os conjuntos urbanos antigos como se conservam os objetos de museu parece, por inscrever-se na lógica das análises do Städtebau. (...)” (CHOAY, 2006, p. 191). Charles Buls, prefeito de Bruxelas, não se limita a estudar a morfologia das cidades como Sitte, e resolve restaurá-las. Assim, ele restaura a praça histórica e reconstitui as partes que faltam. A terceira figura é a superação das precedentes, que é representada por Giovannoni, que atribui simultaneamente um valor de uso e um valor museal aos conjuntos urbanos antigos, integrando-os numa concepção geral da organização do território. Tais ideias estão em seu livro Vecchie città ed edilizia nuova, de 1931. Há ainda alguns autores, Colenbrader, Roders \& Veldpaus (2013), que entre Sitte e Giovannoni, apontam que é importante considerar Patrick Guedes, e seu livro Cities in Evolution, de 1915, em que afirma que para um bom tratamento da cidade, necessita-se um bom diagnóstico, introduzindo o conceito de survey da cidade pré-existente, relacionando assim o planejamento urbano e o patrimônio urbano.

Interessante notar que a questão da cidade ou bairro museal, quando se trata de preservar partes da cidade, não se encontra apenas no debate do século XIX, em que o desenvolvimento ou a Revolução Industrial surgia destruindo as cidades pré-industriais. A cidade ou bairro museal, pode ser encontrada também na forma como se dão os processos de preservação e de tombamento das cidades contemporâneas. Entender tombamento como única forma de preservação ou entender tombamento como "congelamento", é negar a dimensão contemporânea que possuem os monumentos. Choay (2006, p. 200) observa que ao permitir "a síntese das figuras reverencial e museal da conservação urbana (...) Giovannoni funda uma doutrina de conservação e restauração do patrimônio urbano.", que se pode resumir em três grandes princípios: o fragmento urbano antigo deve ser integrado a um plano diretor (piano regolatore) local, regional e territorial; depois o conceito de monumento histórico não deveria ser isolado do seu "ambiente", e terceiro "os conjuntos urbanos antigos requerem procedimentos de preservação e de restauração análogos aos que foram definidos por Boito para os monumentos." (CHOAY, 2006, p. 
201).

Giovannoni foi por um tempo negado, por questões ideológicas, pelo fato de sua produção dar-se no regime fascista e por sua oposição à arquitetura modernista, entretanto, recentemente ele foi resgatado do esquecimento por autores como Choay e Zucconi, entre outros. ${ }^{16}$ Os princípios do restauro urbano já contidos no livro de Giovannoni, serão mais tarde divulgados e conhecidos, nas áreas protegidas ou setores preservados ("secteurs sauvagardés") franceses da lei Malraux, de 1962 e no que se chama de "conservação integrada”, na Declaração de Amsterdã, de 1975 (CHOAY, 2006, p. 203), ou ainda as "conservation areas" inglesas, criadas pelas Civic Amenities Act em 1967, "que estipulava a designação, a ser realizada pelas autoridades locais responsáveis pelo planejamento urbano (...) Em tais áreas seriam preservadas tanto as edificações quanto as suas características arquitetônicas e paisagísticas.” (RUFINONI, 2009, p. 145). Tais “conservation areas" foram ratificadas pelo Planning (Listed Buildings and Conservation Areas) Act inglês de $1990 .{ }^{17}$ Tais princípios de áreas protegidas e de conservação integrada, isto é, considerar áreas de preservação nos planos diretores também foram introduzidos em alguns órgãos de preservação municipais brasileiros, sendo um dos exemplos a cidade de São Paulo. Inspirada nos "setores preservados franceses" e no Plano Regulador de Bolonha $(1964)^{18}$, que tentou integrar a preservação do centro histórico à solução de problemas urbanos sociais, como a moradia, e ainda tendo em consideração os compromissos de Brasília (1970) e de Salvador (1971), em 1974, “a Coordenação Geral de Planejamento (COGEP), da Prefeitura de São Paulo, hoje Secretaria Municipal de Planejamento (SEMPLA), iniciou o cadastramento das edificações e logradouros paulistanos a serem protegidos." (RODRIGUES, 2000, p. 71). Era uma época em que a cidade estava convulsionada pelas obras do metrô. Em tais "setores preservados" ou manchas, estavam incluídos "bens culturais significativos, dos diferentes períodos de desenvolvimento da cidade, classificadas como Z8-200, e sujeitas a medidas específicas incluídas na legislação de uso e ocupação do solo do município, a Lei $n$. 8.328/75." (RODRIGUES, 2000, p. 72). Tais áreas Z8-200, serão depois transformadas nas ZEPECs, Zonas Especiais de Preservação Cultural, da lei 13.885, de 25 de agosto de 2004, que estabelece normas complementares à lei 13.430, de 13 de setembro de 2002, que define

16 Para saber mais sobre o arquiteto italiano, ver: GIOVANNONI, Gustavo. Textos escolhidos. KÜHL, Beatriz (org.). Tradução: Renata Campello Cabral, Carlos Roberto M. de Andrade, Beatriz Mugayar Kühl. Cotia, SP: Ateliê Editorial, 2013.

17 Para saber mais sobre as “conservation areas”, ver PICKARD (1996, p. 214-42).

18 Para saber mais sobre o plano: CERVELATTI, Pier Luigi. Bolonia: política y metodologia de la restauración de centros históricos. Barcelona: Gili, 1976. 
o Plano Diretor Estratégico de São Paulo, este que passado os dez anos, foi revisto. As ZEPECs estão contempladas agora no novo Plano Diretor Estratégico, definidas pela lei 16.050, de 31 de julho de 2014.

Tais áreas de conservação, ligadas aos planos diretores e políticas de preservação municipais, parecem funcionar bem nos países europeus. Resta saber por que motivo lá fora estas áreas de conservação funcionam e por aqui não são tão comentadas, e verificar realmente se estas Z8-200 e ZEPECs tem contribuído à efetiva preservação. ${ }^{19}$ Porém, para isso, um estudo à parte precisaria ser feito, aprofundando no que dispõem as leis e as práticas. Rufinoni (2009) ao analisar as práticas de restauro urbanas, tanto italianas como o caso paulistano da Operação Consorciada Urbana, conhecida como Diagonal Sul, definida pelo Plano Diretor Estratégico de 2002, critica o distanciamento das teorias com relação a prática. Como também um “distanciamento perigoso entre a preservação do patrimônio e a cultura de projeto e de planejamento urbano, ou seja, a preservação e o restauro tem se afastado cada vez mais da produção arquitetônica e urbanística" (RUFINONI, 2009:297). Parece que as práticas das requalificações urbanas, muitas delas ocorridas a partir da Carta de Washington (1986), na década de 1980, foram apenas uma justificativa para a introdução de novos projetos, tanto com desconhecimento da cidade pré-existente e seus valores, como com o desconhecimento das teorias e recomendações das cartas patrimoniais, ou cada qual "segundo suas próprias (e desconexas) orientações” (RUFINONI,2009, p. 297). Há um certo distanciamento entre arquitetos e urbanistas e aqueles profissionais "conservacionistas", ou envolvidos com patrimônio ou preservação dos monumentos, como se queira chamar.

Tal distanciamento também é sentido na Alemanha, e menos na Dinamarca e nos Países Baixos, segundo Schmidt (2008, p. 135). Nestes últimos, por um lado, os profissionais da "preservação" dos órgãos públicos são muito benvindos como parceiros consultores, e de outro lado os arquitetos e urbanistas consideram as pré-existências, tanto do edifício como do tecido urbano em seus projetos. É uma tarefa difícil, porém possí-

19 Pelo que lemos das leis que estabelecem a Z8-200 e ZEPECs, elas parecem ser ainda genéricas, e não individualizadas como as áreas de conservação inglesas. As Z8-200 apenas estabelecem quais edifícios e conjuntos a serem preservados porém não dão diretrizes específicas para cada área. Já as ZEPECs reafirmam as áreas da Z8-200, e acrescentam outras áreas. Sobre parcelamentos e desmembramentos, a competência é da Secretaria de Planejamento, e somente depois fala-se em consulta à órgãos competentes de outras esferas, inclusive à Secretaria de Cultura e órgãos de preservação. Parece que ainda persistem conflitos de competências, desta vez entre o Planejamento e a Cultura: Por exemplo, que órgão fará a fiscalização? E ainda: os incentivos fiscais foram estabelecidos? E arrisca-se a dizer, que a grande diferença e a eficácia das áreas de conservação inglesas, é que esta não são um instrumento isolado, mas ligado a outros elementos que constituem a base do modelo anglo-saxão de preservação, que são: a sociedade civil organizada e os trusts. Ainda assim, os estudos da eficácia destas leis na prática, merecem ser aprofundados. 
vel, conciliar as forças dialéticas entre conservação e desenvolvimento. Na solução desta dialética, é que os ensinamentos de Giovannoni continuam sendo atuais, na "compreensão da cidade como documento e artefato cognitivo, como organismo vivo e dinâmico" (RUFINONI, 2013, p. 88). Segundo Colenbrader, Roders \& Veldpaus (2013, p. 12-3) ${ }^{20}$, a tendência de conciliar a gestão do patrimônio com o desenvolvimento urbano sustentável é necessária. A separação entre os caminhos da gestão do patrimônio e o desenvolvimento urbano ocorreu em 1930, no entanto, ainda não se uniram em caminho comum, apesar das tentativas e resultados positivos ao longo dos anos.

Depois de termos visto os matizes sutis das palavras, tombamento, preservação e conservação, gostaríamos de introduzir aqui um termo que é pouco utilizado no Brasil, a gestão do patrimônio. Em alguns países, fala-se em management. Aliás, o termo no contexto internacional foi se introduzindo aos poucos, assim como o termo sustentabilidade relacionado ao patrimônio, a partir da década de 1990, como se pode ver nos estudos de Colenbrader, Roders \& Veldpaus (2013), que produziram o gráfico abaixo, baseado em como os termos aparecem nos documentos internacionais de políticas de patrimônio cultural:

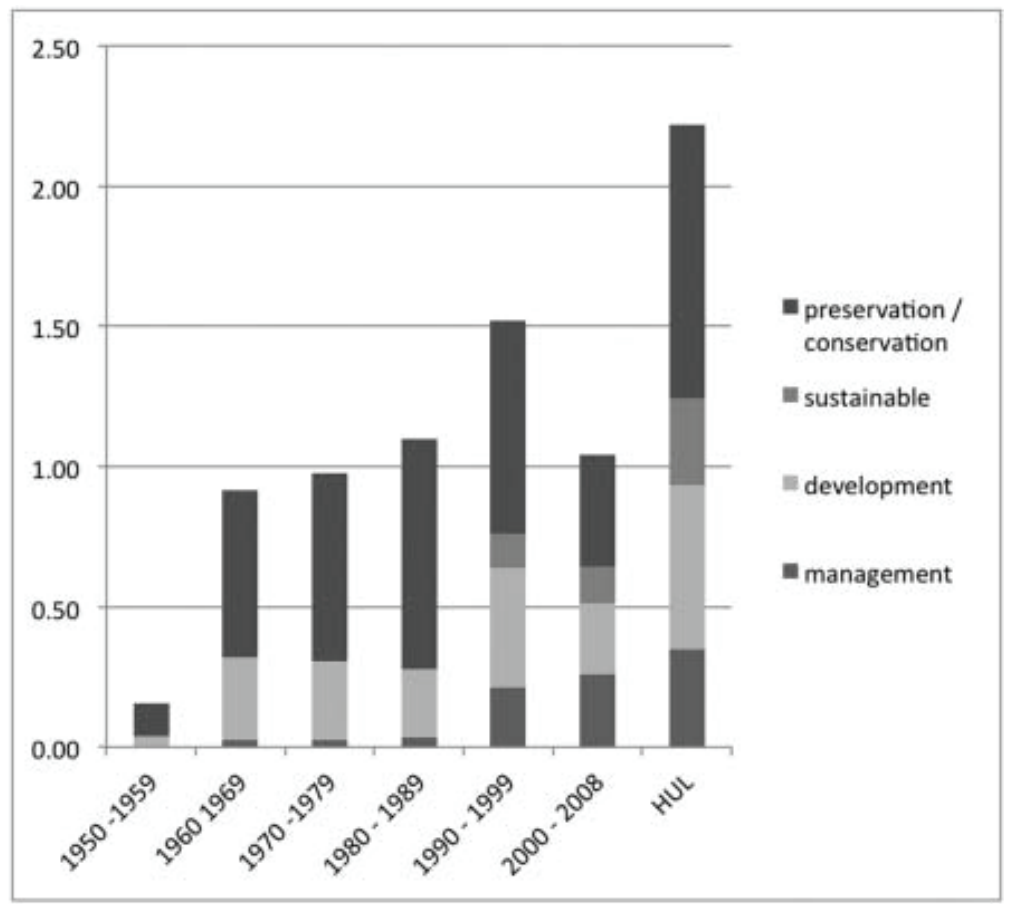

Gráfico 1 - Porcentagem de termos em voga nos documentos de políticas de patrimônio cultural international. Nota: HUL - Historic Urban Landscape. Fonte: COLENBRADER, RODERS \&

20 "The turn towards integrating heritage management with sustainable urban development is thus urgently needed. Although previous paragraphs show that theory is available, and the global policy documents also set, or follow, a trend towards management and development, in practice it seems much more difficult to establish such integration. This implies that the separate paths heritage management and urban development took in the 1930s, in practice, have not yet merged into a common path, despite attempts and positive results over the years." (COLENBRADER, RODERS \& VELDPAUS, 2013, p. 12-3) 
VELDPAUS, 2013.

No Brasil, fala-se em tombar, conservar e teorias de intervenção, e quando muito, em planos de manutenção. Gastam-se vultos de dinheiro para o restauro e a manutenção de um edifício, que em muitos casos é transformado em um museu, e geralmente utilizando-se os cofres públicos. Porém, pouco se pensa na sustentabilidade financeira e no valor ético deste tipo de restauro e de uso. No site do IPHAN, a palavra "gestão" é apenas entendida como contas públicas. Isto é, apenas o que se recebe e se gasta com a preservação. Num país, em que há carência e falta de recursos em áreas como educação e saúde, seria ético gastar tais recursos na restauração de um edifício para transformá-lo e mantê-lo com uso cultural, como museu? Pode-se justificar tal gasto em nome da cultura e da educação patrimonial. Porém não haveria outras formas de fazê-lo, com mais participação da sociedade civil? Fala-se atualmente em tombamento e inventários participativos, não poderiam haver formas de gestão participativa, inclusive financeiramente? Um dos exemplos, é o modelo anglo-saxão criado para o patrimônio, que não foi o implantado no Brasil, mas que funciona bem na Inglaterra e nos Estados Unidos. E o que basicamente diferencia o modelo francês do anglo-saxão é o poder de iniciativa e centralização da tarefa de preservação nas mãos do Estado, no caso francês, e a participação da sociedade civil na preservação, com pouca intervenção do Estado, no caso inglês. Choay (2006) já apontara para esta diferença, como também Fonseca $(2005 \text {, p. 249) })^{21}$

Aqui no Brasil, influenciado pelo modelo francês, a gestão inclusive em programa de grande envergadura, como foi o Monumenta $^{22}$, conforme observou Sant'Anna (1995),

21 "Em termos gerais, essas políticas desenvolveram conforme dois grandes modelos: o modelo francês, em que o poder de iniciativa se concentra no Estado, e o modelo anglo-saxão, em que a sociedade civil se organiza para participar dessa tarefa." (FONSECA, 2005, p. 249).

22 Além disso, mesmo em um programa desta envergadura, a política de preservação não é homogênea. Segundo Bonduki (2012, p. 22): "A atuação do Monumenta, no entanto, está longe de ser linear e homogênea. Ao longo dos mais de dez anos de aperfeiçoamento do programa, é possível identificar claramente uma tensão conceitual relativa à noção de sustentabilidade que se propôs como basilar. Essa noção oscila entre uma visão neoliberal, voltada para atividades econômicas fomentadas pelo mercado, com ênfase no turismo e na espetaculosidade do patrimônio, e uma visão mais associada às práticas e aos usos cotidianos dos moradores e usuários dos núcleos históricos - perspectiva em que o papel do Estado e da sociedade organizada é mais importante que o do mercado.". Bonduki (2012) neste livro parece ser defensor do programa Monumenta, apesar de não esconder as dificuldades do projeto, "levando vários anos para elaborar projetos, realizar licitações e viabilizar o início das obras. Além disso, a descontinuidade nas administrações municipais também prejudicou o andamento dos projetos.”(BONDUKI, 2012, p. 43). Apesar da propaganda realizada em torno ao projeto, veja-se o alcance: 26 cidades conveniadas, 1500 projetos, sendo que " 235 foram efetivamente realizados até a finalização formal do programa. As demais, não viabilizadas, poderão ainda ser executadas no âmbito do PAC das Cidades Históricas elou numa eventual $2^{a}$. etapa, se for solicitado um novo funcionamento ao BID."(BONDUKI, 2012, p. 49). E ainda, não se entrou no mérito de como as intervenções realizadas nos edifícios estão em acordo ou desacordo com 
ainda se encontra sob o patrocínio e com grande participação de investimento financeiro do Estado. Aliás, não somente a gestão, também o inventário, os processos de tombamento ficaram por muito tempo nas mãos do Estado. O IPHAN, ainda que seja uma autarquia, guarda certa autonomia, porém continua muito próximo ao Estado desde suas origens.

A autora francesa também observou, que em relação às associações de proteção britânicas, privadas e locais, mais algumas desvantagens na adoção do modelo francês. A primeira é que em seus inícios, os magros financiamentos do Estado, foram motivo para que o inspetor e a comissão fossem obrigados a sacrificar numerosos monumentos, "os salvos são em geral tirados aleatoriamente do uso e destinados ao mesmo tipo de 'visita' que os objetos de museu.” (CHOAY, 2006, p.148). Outras desvantagens são: a morosidade da burocracia e a "redução progressiva do papel ativo, estimulante e anticonformista dos voluntários, substituídos por funcionários - a comissão dos monumentos mantém apenas um poder consultivo e, em muitos casos, suas recomendações não são seguidas -, enfim, fraqueza maior, vazio doutrinal que constitui o contexto administrativo, técnico e jurídico dos procedimentos.” (CHOAY, 2006, p. 149)

Na Inglaterra, a intervenção do Estado na administração e conservação dos monumentos históricos só aconteceu tardiamente, com o Ancient Monuments Protection Act, de 1882, e permanece reduzida, segundo Choay (2006:148), mas depois foi complementada pelo Ancient Monument Act de 1900. Os precursores teóricos do movimento protecionista inglês foram Ruskin e Morris. Este último, fundou em 1877, a Society for the Protection of Ancient Buildings (SPAB). Um ano depois, ele já havia reunido uma documentação sobre 749 igrejas intactas. Choay (2006:147) cita outras associações com este mesmo sentido preservacionista: Church Building Society, que teve origem no movimento eclesiológico, ou associações arqueológicas como Oxford Architectural Society e Cambridge Camdem Society, de 1839, Cambridge Antiquariam, 1840 e British Archaeological Society, de 1843. Além destes tipos de associações, existem os chamados trusts "que norteadas por uma legislação especifica desempenham hoje um papel tão ou mais relevante do que a ação dos governos na área de conservação do patrimônio.” (GOUVEIA, 1985). Sem dúvida, um dos mais antigos trusts e bastante influentes atualmente na Inglaterra, e um dos maiores proprietários privados de terras da Inglaterra, é o National Trust for Places of Historic Interest or Natural Beauty, fundada em 1894. Segundo Gouveia (1985, p. 43-5):

O segredo do Trust parece residir no esquema local montado junto ao governo, permitindo a um proprietário doar ao Trust um edifício de as teorias de restauro e cartas patrimoniais. 
interesse arquitetônico ou histórico juntamente com uma soma (ou um outro imóvel que gere renda) destinada à formação de um fundo para a sua manutenção. Como o Trust é registrado como entidade de fins caritativos, nem a propriedade nem o capital ligado à sua manutenção podem ser gravados com impostos de transmissão. Além disso, a renda derivada do fundo inicial de manutenção do imóvel passa a ser livre de qualquer imposto. Com essa renda, o Trust mantém o prédio, seus objetos (móveis, pinturas, tapeçarias, etc.) e os jardins. Ao mesmo tempo, o Trust permite que o doador e lou seus herdeiros continuem morando na casa sem pagar aluguel, desde que o público tenha livre acesso aos jardins e às salas em certo número de dias por ano. Isto permite que os proprietários continuem tendo o usufruto da propriedade sem pagar o aluguel, impostos ou despesas de manutenção. E que as casas sejam abertas ao público sem se transformarem em museus, tendo ao mesmo tempo, sua manutenção garantida. Um outro artifício é a cooperação entre o governo e o Trust: impostos atrasados podem ser quitados com transferência de uma propriedade para o Tesouro, que por sua vez transfere a propriedade para o Trust que dá início às operações relatadas acima.

Ao contrário da Inglaterra, no Brasil, o proprietário de um bem tombado, recebe poucos incentivos fiscais, além da isenção do IPTU, para a manutenção e conservação dos edifícios. Na maior parte, é o proprietário quem deve arcar com os custos de conservação e restauro. Com relação a organização em sociedades, recentemente no Brasil há algumas iniciativas neste sentido, como a criação de associação de moradores requisitando tombamento de bairros, como os que requisitaram o tombamento do bairro dos Jardins e Perdizes na cidade de São Paulo; ou por exemplo, o Instituto de Preservação e Desenvolvimento do Vale do Paraíba (PRESERVALE), criado no Estado do Rio de Janeiro e “atualmente com 25 fazendas” (MARINS, 2013, p. 173), pois compram fazendas arruinadas e as restauram, e depois são transformadas em hotéis e abertas ao público, com grande sucesso financeiro e repercussão na imprensa nacional (MARINS, 2013, p.173174). Contudo, tais iniciativas, além de serem incipientes, não recebem incentivos fiscais, como os que existem na legislação inglesa.

São inúmeros os trusts existentes na Inglaterra, e com os mais variados objetos de preservação. Pickard (1996: 123) cita a existência do BPT, Building Preservation Trusts, que tem como missão inventariar os casos de edifícios tombados (listed buildings) em risco, isto é, abandonados, arruinados, para restaurá-los. São muitos os BPTs espalhados pelo Reino Unido, apenas os registrados no Architectural Heritage Fund (AHF) chegam a mais de cem. Outra forma de organização mencionada por Pickard (1996: 123) são as Association of Preservation Trusts (APT), formada em 1989, que tem como missão dar suporte aos trusts existentes como também para aqueles que querem formar um novo 
trust.

Em uma visita técnica recente às vilas operárias e ferroviárias e lugares relacionados ao patrimônio inglês, esta pesquisa encontrou trusts desde o início da formação das vilas e em funcionamento até os dias atuais, em Bournville (vila operária da fábrica de chocolates Cadbury, fundada em 1895 e com trust estabelecido em 1900) e New Earswick (vila operária da fábrica de chocolates de Joseph Rowntree - e desde 1988, propriedade da Nestlé - cujo trust foi estabelecido quase que concomitantemente à fundação da vila em 1902). Já o Port Sunlight Village Trust foi estabelecido
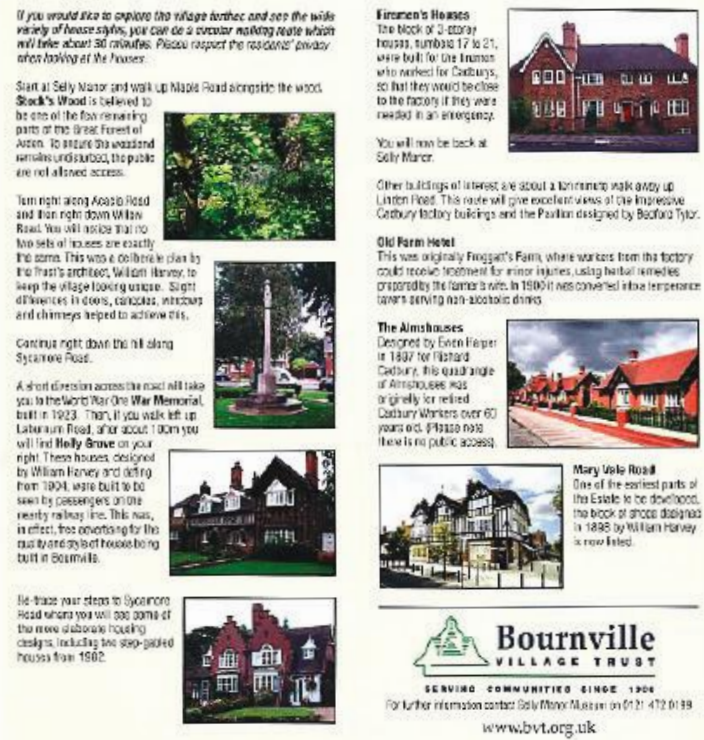
mais recentemente, em 1999, e a fundação da vila deu-se Figura 1 (acima) - Folheto do Bournville Trust. Fonte: Bournville Trust. Figura 2 (abaixo) - 2- Capa do folheto de New Earswick; Figura 3 (pág. seguinte) - Página do folheto de aplicação para uma casa em New Earswick, em várias línguas. Fonte: Joseph Rowntree Housing Trust.

em 1888, pertencen-

te à indústria Lever. Além dos cuidados com a manutenção e preservação das vilas, por exemplo, são distribuídas cartilhas de manutenção e critérios para reforma (caso do New Earswick Village Trust, que possui propriedades alugadas e vendidas, sob sua responsabilidade). Também é realizada a consulta junto aos moradores quanto ao uso a ser dado de edifícios abandonados dentro da vila, por exemplo, o celeiro de Bournville. Os trusts citados são importantes para a preservação de documentos relativos à

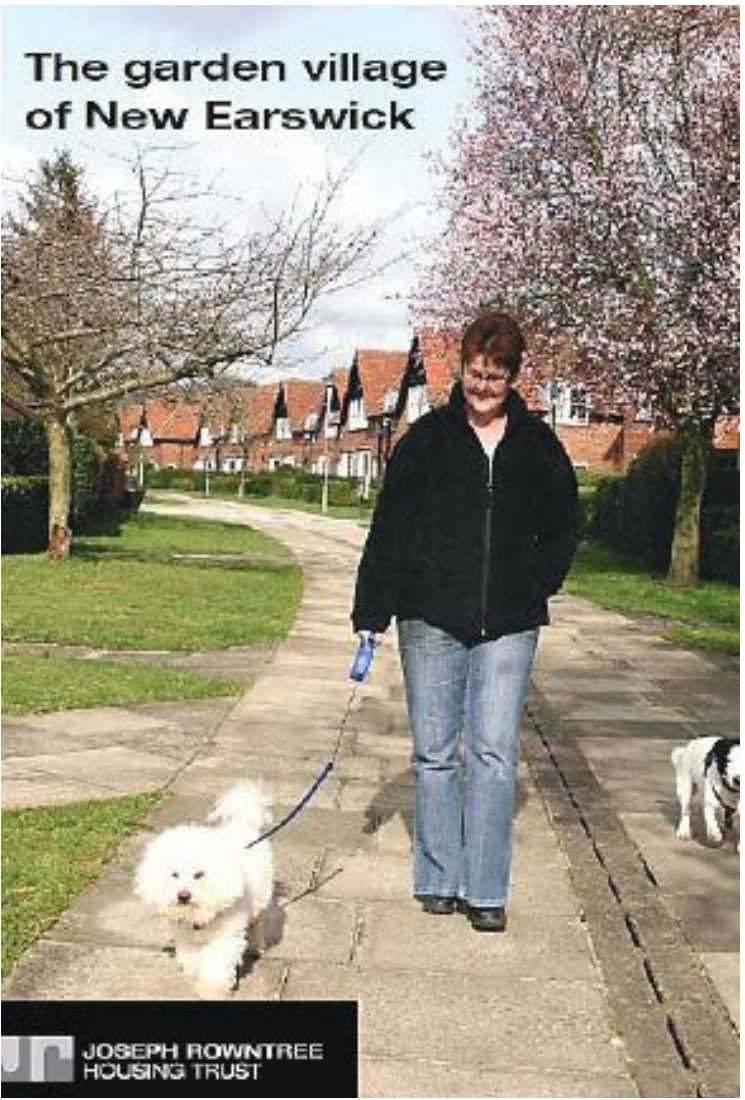


REGISTRATION FORM HOUSING REGISTER

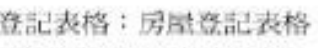

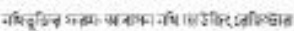

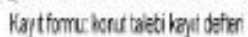

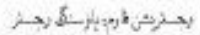

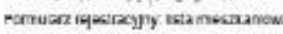

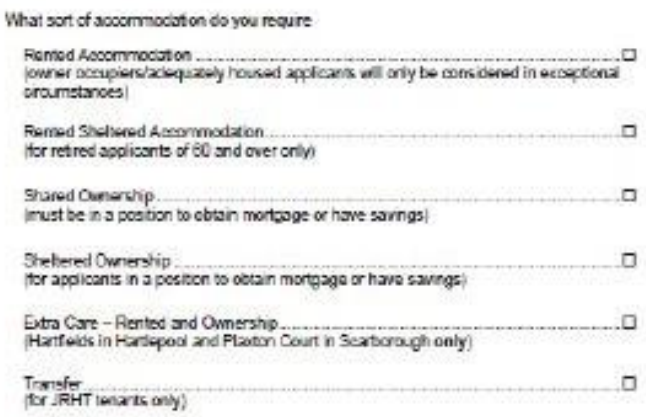

\section{JRHT}

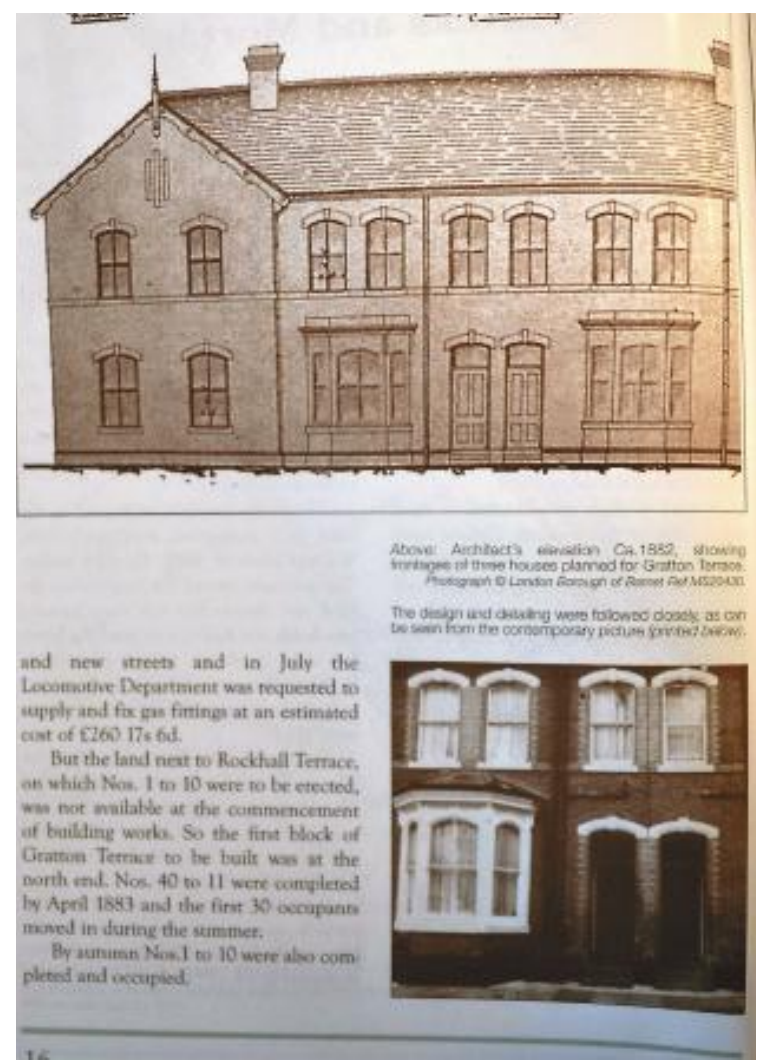

Fotos 50 e 51 - Foto de páginas da publicação feita pela comunidade de Cricklewood: Resident's Community Association (RCA). Fonte: London: Resident's Community Association, 2001. indústria e às vilas, como as plantas originais. Por exemplo, em New Earswick pode-se encontrar plantas originais de Barry Parker e Raymond Unwin. Outros dados importantes são: como os trusts são responsáveis pela perpetuação e por manter viva a história do lugar, através da divulgação das informações através dos sites ou dos museus, com facilidade se encontram os projetos das áreas de conservação e os relatórios anuais.

Um caso interessante de trust é o Bradford Property Trust, que comprou somente a vila operária (não a fábrica) de Saltaire, em 1933, e até onde sabemos, mais duas

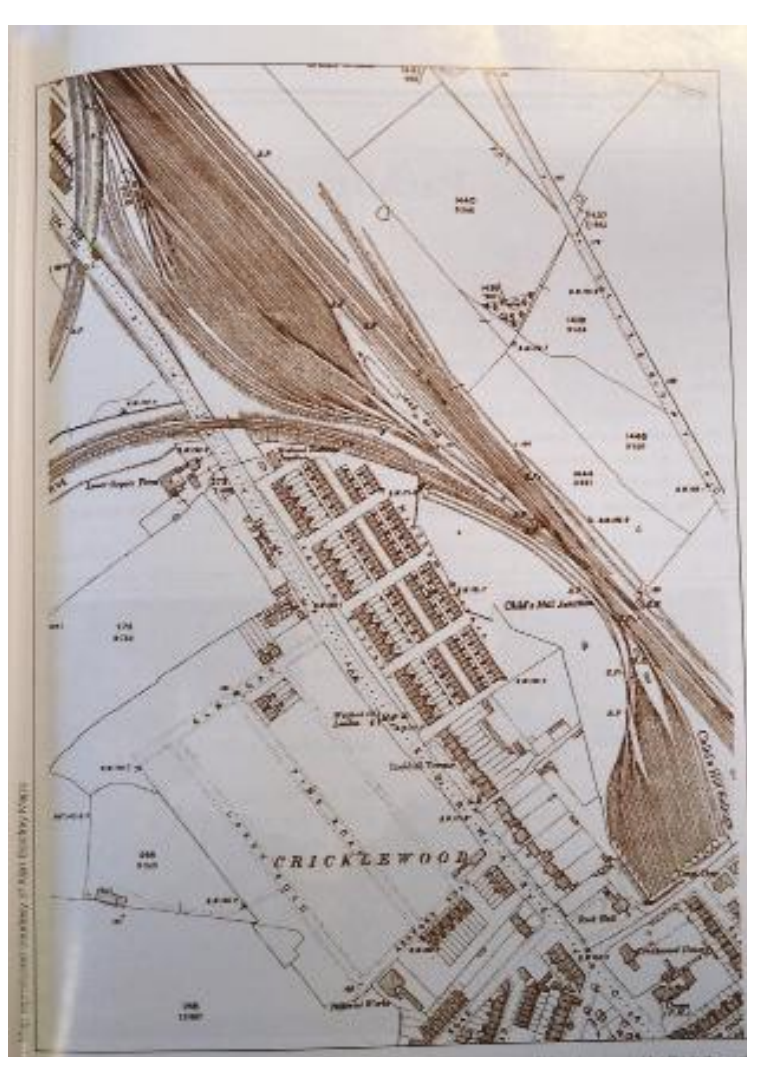

vilas ferroviárias a de Cricklewood e de Willesden, próximas a Londres, vendidas pela British Railway em 1964. Trata-se portanto, 
de um trust relativamente antigo, especializado em comprar vilas operárias, reformá-las e vendê-las. Além do Bradford Trust, a vila ferroviária de Cricklewood possui uma história interessante. Na década de 1960, para não de perder o sentido de comunidade, os moradores decidem fundar a Resident's Community Association (RCA), e esta, tenta obter do Barnet Council a reforma do edifício do Railway Institute. Apenas em 1998, o Railway Terrace de Cricklewood é declarado área de conservação. Nota-se neste exemplo, que a sociedade civil engajada, tanto através dos trusts como pela associação de moradores, e a existência de um apreço pelo lugar por muitos destes moradores, que eram ex-ferroviários. A preservação começa antes da lei, isto é, antes do lugar ser declarado área de conservação pela municipalidade.

Uma última questão que se pode colocar em relação aos trusts: não será um negócio lucrativo? Os trusts além dos incentivos fiscais que já vimos, recebem doações e fidelizações de voluntários, cobram ingressos aos lugares (o acesso é público, porém cobrado) e funcionam através de subvenções governamentais como o Heritage Lottery Fund. Seria o caso de verificar se são sustentáveis economicamente, e se rentáveis, através da análise de seus relatórios anuais. ${ }^{23}$

Nos Estados Unidos não há uma única política de proteção ao patrimônio, mas várias políticas de proteção, pois há vários bens patrimoniais, também mais próximo ao modelo inglês. O propósito da política de preservação é incentivar esta variedade. Pode-se dizer, que é uma "desorganização organizada", desorganização apenas aparente, e com incentivos para isso. Ao contrário, do que ocorre na política de preservação brasileira. A intervenção do governo federal norte-americano é limitada, embora eficaz, os motivos são dados novamente por Gouveia (1985: 47):

De um lado, porque boa parte do trabalho de preservação se encontra na esfera privada, em mãos de associações, grupos, empresas e indivíduos particulares. De outro, porque são as prefeituras e os governos estaduais que desempenham um papel predominante na construção de uma moldura legal favorável ou mesmo estimulante às atividades de preservação.

Quanto a este segundo aspecto, a designação de distritos históricos é uma prerrogativa da municipalidade, e está ligada ao planejamento urbano. Gouveia (1985:48) conta que a primeira lei de zoneamento preservacionista nos Estados Unidos, foi a partir da 
designação do distrito histórico de Charleston em 1930. Novamente, o que se vê aqui são as bases do modelo anglo-saxão de preservação: sociedade civil organizada, trusts e áreas de conservação, ligados ao planejamento urbano municipal.

Dois autores italianos Landriani \& Pozzoli (2014), analisam os modelos de gestão e governança utilizados na Itália e nos Estados Unidos para os organismos de preservação, sendo o da Itália, estatal e nos Estados Unidos baseado nas organizações não lucrativas, que eles chamam de NPOs (non profit organizations) ${ }^{24}$, incluindo-se fundações e associações, como os trusts ingleses. Os autores analisam os modelos dos dois países, segundo aspectos jurídicos e administrativos, e como casos concretos, eles analisam a Soprintenza Autonoma di Pompei, uma agência pública, e a Jeal Paul Getty Museum of Los Angeles, um museu administrado sob um único Trust. Como principais conclusões, os autores observam: diferença na dotação de recursos, a burocracia e o conflito de competências que existe em uma agência pública não na privada, o mesmo ocorrendo com a flexibilidade de governança e na transparência na divulgação da contabilidade. Os autores utilizam a palavra governança, quase que indistintamente com gestão, creio que se aplicam aos dois países, pois as duas formas estão ou concentradas na agência estatal ou concentradas nas organizações não lucrativas, com mínima interferência do Estado.

Tudo o que foi dito, faz-nos pensar se o modelo de gestão que temos no Brasil é o mais eficaz. Quis-se mostrar, assim, a relação entre Estado e sociedade nas questões do patrimônio, e em especial, apontar a existência de outras formas de organização diferentes das adotadas em nosso país. Procurou-se evidenciar também, e portanto, iniciamos a epígrafe com a frase de Choay (2006, p. 194): “(...) uma lei não basta. Hoje isso é patente. A preservação dos monumentos antigos é antes de tudo mentalidade."

Ao final deste capítulo, pode-se constatar que as vilas ferroviárias estiveram ausentes nas políticas levadas pelos órgãos de preservação, e que só recentemente são consideradas dentro do complexo ferroviário. Vimos que sua ausência se deve a critérios de valoração distintos definidos pelos órgãos de preservação em suas diversas instâncias. Foi visto também como este critério de valoração é cambiante, conforme o tempo e a sociedade. E arrisca-se a dizer que até hoje não é uma questão resolvida. O patrimônio industrial ferroviário, e de uma maneira geral, o patrimônio industrial, ainda é tratado de forma pouco sistêmica dentro dos órgãos de preservação, o que leva o tombamento de certas estações e complexos, em detrimento dos demais. Analisadas de várias maneiras,

24 O livro está em inglês. LANDRIANI, Loris; POZZOLI, Matteo. Management and Valuation of Heritage Assets. A comparative analysis between Italy and USA. NY, London: Springer, 2014. 
como arquitetura modesta ou memória ferroviária, dado o corpus teórico consolidado do patrimônio industrial, acredita-se que as vilas ferroviárias devem ser analisadas dentro desta última classificação. A entrada de análise "arquitetura modesta" justifica-se por tratarem-se de vilas e fazerem parte do tecido urbano. Portanto, podem ser também analisadas através do que se chama patrimônio urbano, o que não as incompatibilizam com a classificação patrimônio industrial ferroviário, que seria a principal. Ao aproximar o objeto de estudo do conceito de patrimônio urbano, aproxima-se a preservação e a gestão destes espaços pelo planejamento urbano. Mas considera-se de fundamental importância a leitura destes espaços pela morfologia urbana. Desta maneira, acredita-se que se conciliaria a questão da preservação das pré-existências urbanas e sociais, aliada à questão da introdução da mudança, de novos edifícios, enfim, equilibrando a questão da mudança e da continuidade dos tecidos urbanos.

Com relação aos instrumentos de preservação, tentou-se elucidar alguns dos termos que possuem matizes distintos, mas que na prática são colocados sob o único termo "patrimônio". Assim, quis-se deixar claro que tombamento não é mesmo que preservação, e que não é "congelamento" como supõe o senso comum, e ressaltar a dimensão contemporânea do patrimônio. A preservação é algo muito mais abrangente que o tombamento, este é apenas um dos instrumentos de preservação. Como outro instrumento de preservação pode-se citar o estabelecimento de áreas de conservação, junto aos planos urbanos. A preservação não deve ser apenas uma chancela do Estado e algo para especialistas, deve ser compartilhada com a sociedade, assim como a conservação e a gestão. Vimos que há basicamente duas matrizes de modelos de preservação, um francês - no qual o Estado estabelece o que vem a ser o patrimônio, e um anglo-saxão, no qual a preservação parte da sociedade para então ser chancelada pelo Estado. Parece que o nosso modelo deriva do modelo francês, e alterar tal mentalidade, de que a cultura e o patrimônio seja algo a cargo do Estado, e por ele conservado e gerido, não é fácil. Outro aspecto do patrimônio que se quis evidenciar foi a gestão.

Já aclarados os conceitos, volta-se ao objeto de pesquisa inicial, as vilas ferroviárias. Será que merecem ser todas preservadas? Tal questão só será respondida ao final, após a análise da história da Companhia Paulista. Será que merecem ser tombadas? Talvez nem todas necessitem de tombamento. Em qual dos livros? Prefere-se não responder a esta questão. Se se pudesse abolir os livros, e criar uma lista única de tombamento e incluir todos os bens dos diferentes estados e municípios, seria a nossa proposta. Fala-se 
em paisagem cultural, bens culturais, que abrangem aspectos materiais e imateriais do patrimônio, sendo que a existência de ambos são interdependentes, porém trabalha-se ainda em termos de registro e de tombamento de maneiras separadas. Parece um contrassenso, como aponta Meneses (2010, p. 31).

Se, como vimos, o tombamento não poupou as descaracterizações e nem o uso ajudou na conservação, pergunta-se: o problema está no tombamento? Ou o problema está no uso? A resposta é negativa para ambas as colocações. O problema não está no tombamento, o que vimos são problemas de gestão e fiscalização, e em como comunicar à sociedade o papel deste instrumento de preservação. O tombamento ainda parece ser o único instrumento sólido da sociedade brasileira para garantir a preservação e, neste sentido, deve ser valorizado e utilizado. Com relação ao uso, e ainda pendente a questão ética das transformações de uso como a de habitação em turismo, pode-se dizer que a alteração do uso deva ser dada primeiramente por um estudo aprofundado e multidisciplinar do bem cultural e do seu entorno, sejam estas pré-existências materiais ou sociais, levando em conta inclusive a sustentabilidade ambiental e econômica, para um eventual projeto de restauro ou revitalização. Dessa maneira, para questões de patrimônio urbano, é conveniente estabelecer áreas de conservação, aliando as questões de patrimônio e de planejamento urbano. Além disso, tendo em conta a dimensão contemporânea do patrimônio, além de simplesmente inventariar e tombar os bens, cabe estabelecer análises multidisciplinares que estabeleçam guias de transformação. E que tais áreas de conservação e guias de transformação sejam revistos de tempos em tempos, pois a cidade e a sociedade são cambiantes, e suas necessidades são diferentes para os diferentes tempos. 


\section{Capítulo 2 - A Companhia Paulista e suas vilas ferroviárias}

\subsection{Café, ferrovias e cidades}

As companhias ferroviárias em São Paulo foram fundadas com o objetivo de solucionar o problema da falta de transporte rápido e barato para o escoamento do principal produto agrícola da província, o café. Para resumir o "caminho do café", recorremos ao resumo feito por D'Alambert (1993, p. 6):

O café representou, nesse período, a principal fonte geradora de riqueza de São Paulo. Planta nativa da Etiópia, chegou ao Brasil pelas mãos do paraense Francisco Melo Palheta, em 1727. Dos cafezais do Pará saíram mudas e grãos para as capitanias do Maranhão, Amazonas e para as várias regiões do Nordeste. Em 1760, o Rio de Janeiro recebeu as primeiras sementes por iniciativa do Desembargador João Alberto Castelo Branco. Das terras fluminenses os cafeeiros expandiram-se para o Espírito Santo, Minas Gerais e Goiás, avançando concomitantemente em direção ao Vale do Paraíba, até atingir o solo paulista nas primeiras décadas do século XIX. Em 1900, praticamente toda a produção agrícola do estado encontrava-se voltada para o cultivo do café, principal fonte de divisas do país e criadora de um significativo excedente financeiro. São Paulo tornou-se o maior centro distribuidor de café, assumindo uma posição de grande relevo no cenário político e econômico do país

Comparando-se o Vale de Paraíba Paulista e a "marcha para o oeste": aquela economia baseava-se no "plantation" e na mão-de-obra escrava, exigiu dos fazendeiros, capacidade empresarial, além de terra, capital e mão-de-obra livre e assalariada ( $\mathrm{D}^{\prime}$ ALAMBERT, 1993, p. 7). Até 1850, havia ainda o cultivo de açúcar com o de café. Sem dúvida, o início das ferrovias deveu-se ao café, como atesta Saes (1981, p. 37) e outros autores que o antecederam. Foram poucas as ferrovias construídas cujo propósito inicial não fosse o escoamento do café, um exemplo delas é a Sorocabana, que surgiu para servir os produtores e comerciantes de algodão de Sorocaba. Seu fundador foi Luís Mateus Maylasky. Nada melhor que a caracterização feita por Caio Prado Júnior das ferrovias, citando por sua vez a Teodoro Sampaio, de que a rede de estradas de ferros paulistas era "como uma vasta mão espalmada" (SAES, 1981, p. 27), como podemos ver no mapa a seguir: 
A EVOLUCAO +ERROVIARIA IDE SAQ, PAUIO (II)
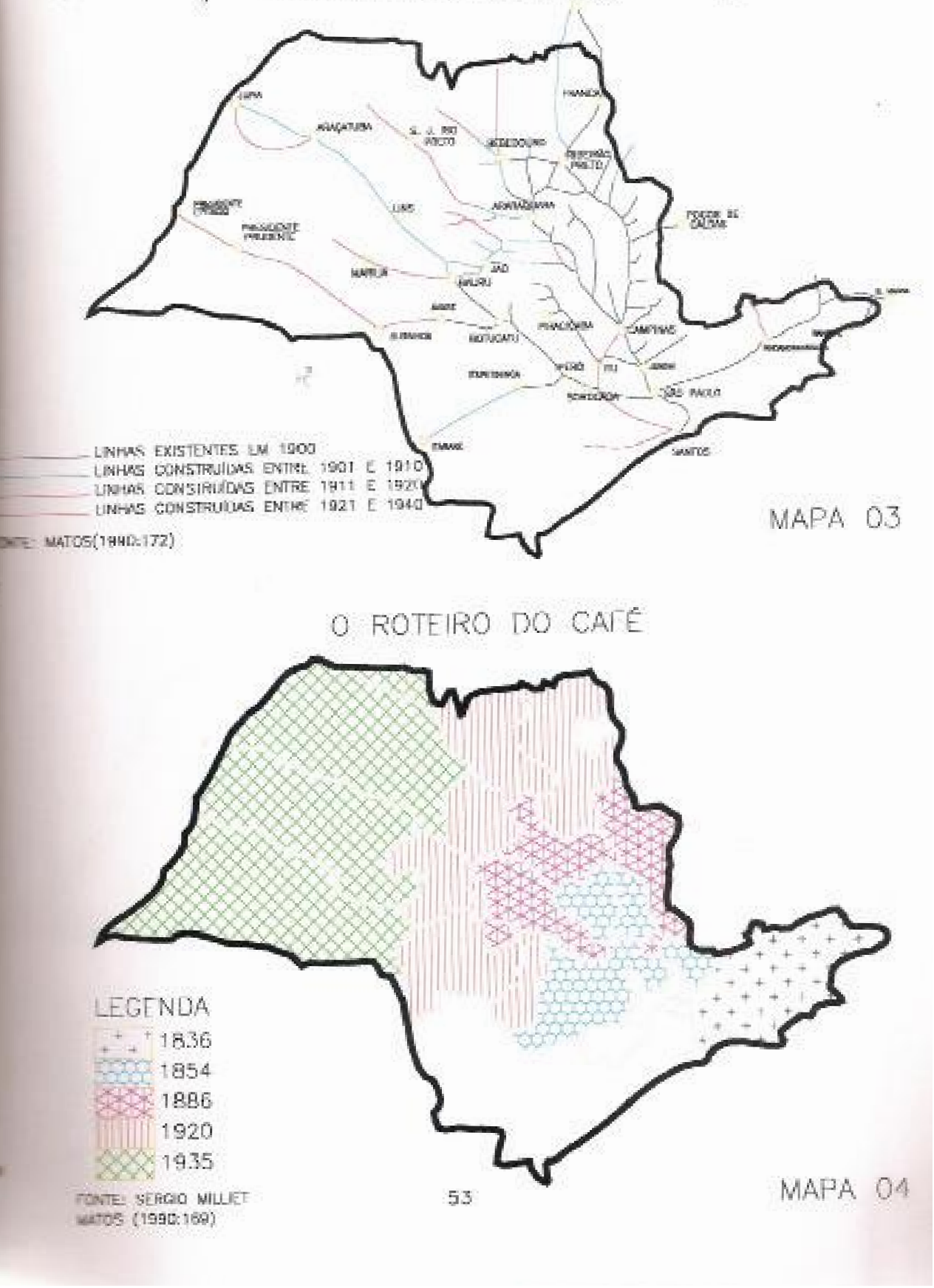

Mapa 4 -Mapas da evolução ferroviária de São Paulo e do roteiro do café. Fonte: MORAIS, 2002, p. 53

Acredita-se não ser necessário retomar toda a história das ferrovias, como já fizeram diversos autores. Assim, ficamos com uma pequena introdução sobre o início das ferrovias feita por Lanna (2002, p. 38): 
em movimento a primeira locomotiva ligando Manchester-Liverpool, promulgava-se no Brasil a Lei número 101, conhecida como Lei Feijó, que autorizava a criação de companhias, que visassem construir uma 'estrada de ferro da Capital do Império para as de Minas Gerais, Rio Grande do Sul e Bahia', com privilégio de uso garantido por 40 anos. Nesta mesma década, a firma santista de Aguiar, Viúva e filhos, associada a companhias inglesas, obteve concessão da Assembléia Provincial de São Paulo, para construir uma estrada ligando o porto de exportação. Mas, apenas em 1854, foram inaugurados os primeiros quilômetros de via férrea no Brasil. Foi necessário que se passasse quase outra década para que ferrovias fossem construídas para atender às pretensões político-econômicas estabelecidas nos anos 1830 .

A primeira ferrovia criada na província de São Paulo, a São Paulo Railway Company, foi inaugurada em 1867 e conectava as cidades de Santos, no litoral, com a de Jundiaí, no interior. Entretanto, as grandes propriedades de café estavam localizadas na região central da província, que naquela época se concentravam na região de Campinas. Os produtores de Campinas deveriam transportar sua produção até Jundiaí, seguindo depois para o porto de Santos. Para propiciar esta ligação da região produtora com a linha da São Paulo Railway é que nasce a segunda ferrovia da província de São Paulo, a Companhia Paulista, em 1868, com a intenção comunicar Jundiaí e Campinas, facilitando e barateando o transporte entre as duas cidades. Esta linha foi

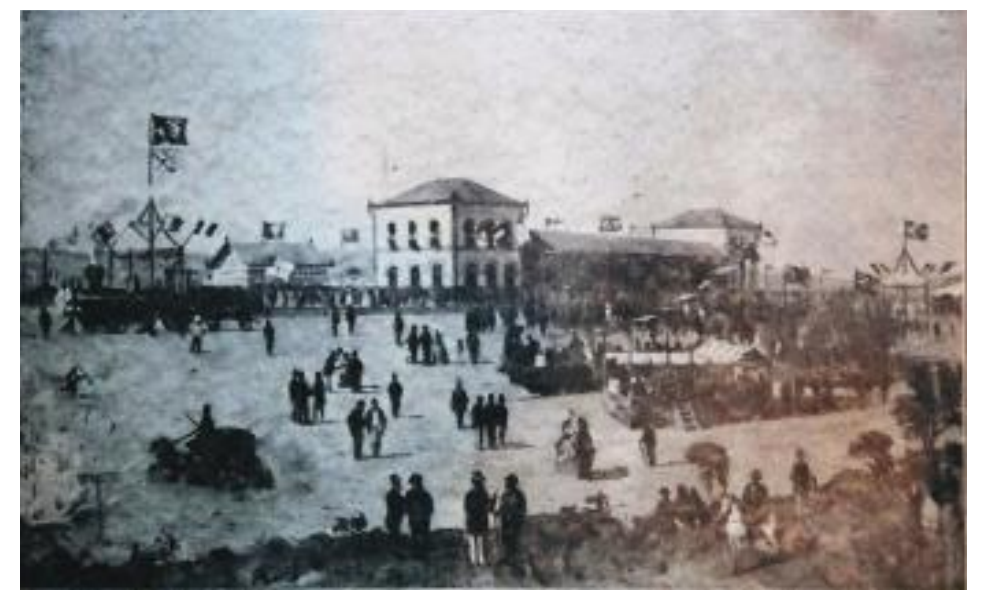

Foto 52 - Inauguração da estação de Campinas, 11 de agosto de 1872. Fonte: Relatório da Companhia Paulista, 1955. inaugurada em 1872.

A Companhia Paulista foi a primeira totalmente formada com capital nacional, sendo que os nove maiores acionistas eram brasileiros (SAES, 1979, p. 47) e sua iniciativa encorajou outros fazendeiros a organizarem companhias ferroviárias similares e, assim, resolverem seus problemas de transporte. Em 1870, surge a Companhia Ituana, seguida da Sorocabana (1871), situadas na mesma região da cidade de Campinas. A Companhia Ituana ligaria a cidade de Itu aos trilhos da São Paulo Railway em Jundiaí, ao passo que a Companhia Sorocabana construiria comunicação diretamente com a cidade de São Paulo. Anos depois, Ituana e Sorocabana entraram em negociação e permanece- 
ram como uma única empresa, a Companhia União Sorocabana e Ituana, posteriormente prevalecendo o nome Companhia Sorocabana. Em 1872 foi organizada outra companhia ferroviária, a Companhia Mogiana. Resultado da união de empresários e fazendeiros das cidades de Amparo e Mogi Guaçu, a Mogiana ligaria esta importante região produtora de café aos trilhos da Companhia Paulista em Campinas. A rápida expansão da Mogiana a levou até as terras da região de Ribeirão Preto, seguindo depois até o estado de Minas Gerais. Muitas outras companhias surgiram nesta virada de século, entretanto, as companhias Paulista, Mogiana, Ituana e Sorocabana foram as principais empresas de transportes ferroviários em São Paulo. Além delas há ainda, a Estrada de Ferro Araraquara (EFA 1886), a Estrada de Ferro São Paulo - Minas (SPM -1902) e a Estrada de Ferro Noroeste do Brasil (cujo primeiro trecho foi inaugurado em 1906 e ligava Bauru à estação Lauro Müller, no atual município de Guarantã).

Conforme afirmou Saes (1981, p. 67), “o desenvolvimento das vias férreas não obedeceu, a princípio, a um plano sistemático, foi comandado pelos interesses dos administradores, produtores e comerciantes de café.” E tal “multiplicidade de leis, federais e provinciais, com critérios distintos, será um problema quando das negociações para renovação de concessões, obtenção de direitos sobre novos trechos, pagamentos de juros e resgates de linhas pelo governo" (LANNA, 2002, p. 40).

Outro ponto que denota a falta de planejamento seria a diferença de bitolas entre as companhias ferroviárias: "A forma de desenvolvimento das linhas, ditada pelas necessidades imediatistas de fazendeiros do café, foi pouco racional. Havia variação de bitolas: a SPR e o tronco principal da Paulista tinham bitola larga (1,60 metros); e as demais linhas, bitola estreita (geralmente 1,00metro).(...)”(KÜHL, 1996, p. 135). Antonio Francisco de Paula Souza defendia o uso das bitolas estreitas, e antes dele havia publicações no mesmo sentido de Antonio Pereira Rebouças Filho (1871) também Bicalho (1876) (CAMPOS, 2007, p. 142). A bitola estreita também chamada bitola métrica, deveria ter em torno de 1,00 a 1,20m. A vantagem da Paulista era que em muitos trechos não precisava fazer a baldeação, pois tinha a mesma bitola que a São Paulo Railway, que detinha o monopólio do escoamento para o porto de Santos. Tal monopólio foi quebrado anos depois pela Companhia Sorocabana, a partir de 1937, que passou a ligar a cidade de Mairinque a Santos, porém já com o declínio da cafeicultura. Tal falta de planejamento poderia ser questionada, conforme faz Bernardini (2001) ao afirmar: 
moderno configurando uma atuação da elite que procurava estabelecer uma nova forma de produção organizada e instaurar uma ocupação que fosse intrinsecamente ligada ao desenvolvimento da cultura cafeeira. Reitera-se aqui que, antes mesmo que o planejamento se tornasse questão eminentemente ligada aos meios profissionais da engenharia, no meio urbano, com o sanitarismo, ele foi praticado sistematicamente por uma elite interessada em resolver os problemas econômicos de uma nova ordem ligada à produção cafeeira. Estes membros da elite, levaram a frente a ideia da ocupação territorial, ao mesmo tempo em que algumas cidades aumentavam sua importância como pontos de conexão para o desenvolvimento dessa economia. (BERNARDINI, 2001, p. 63).

Entende-se assim que o planejamento territorial esteve ligado aos interesses do produto que movia a economia, isto é, o café. A Companhia Paulista, nosso objeto de estudo, abarca desde o período monárquico até a República. O fato é que na fase final da Monarquia e no início da Primeira República, os mesmos atores sociais dominavam tanto a economia como a política. Assim, há pouca separação entre o Estado e a iniciativa privada, pois muitos políticos eram também proprietários de fazendas de café. Os engenheiros do século XIX e início do século XX eram por vezes, filhos de fazendeiros enviados para estudos

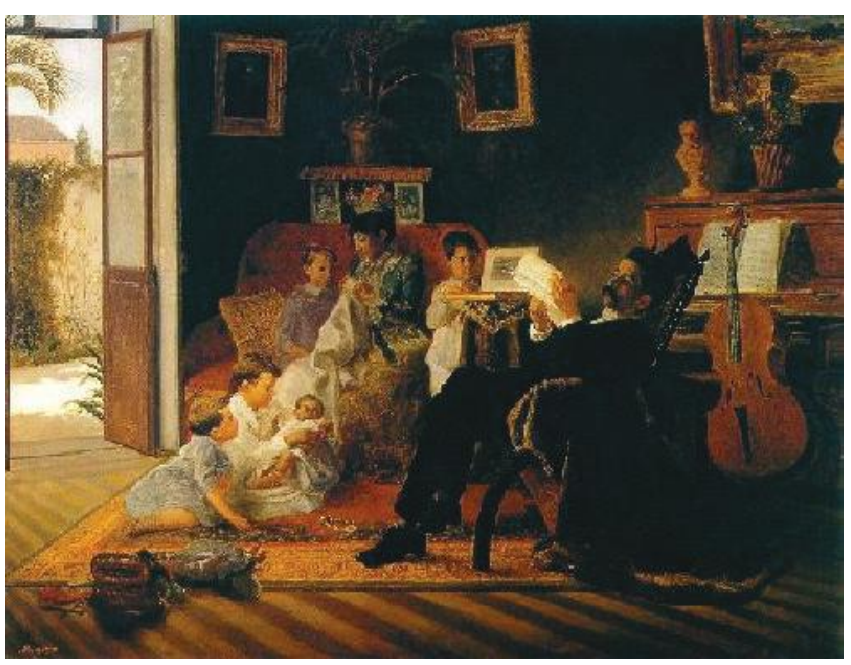

Figura 4 (acima) - "Cena de família de Adolfo Augusto Pinto", 1891, do pintor Almeida Júnior. Fonte: www.pinacoteca.org. br. Acesso em set. 2016.

Foto 53 - Retrato de Adolpho Pinto. Fonte: Álbum Ilustrado da Companhia Paulista, 1918.

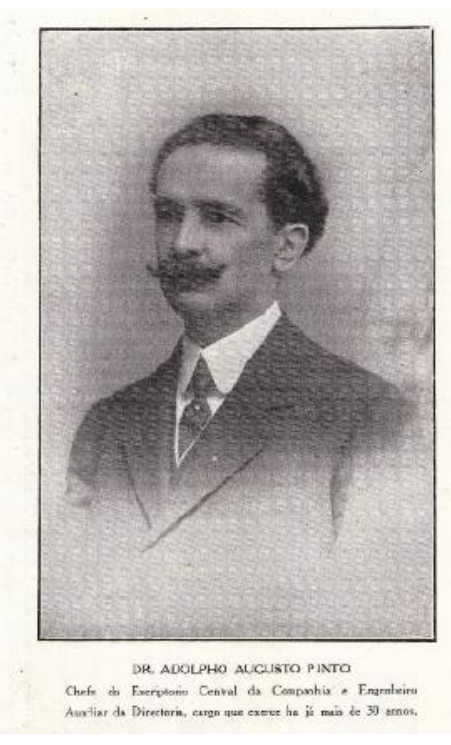
engenharia, na Europa ou nos Estados Unidos, e de volta ao Brasil, exerciam cargos na política e nos corpos técnicos. Dois destes casos, que pudemos detectar em nossos estudos, foram os engenheiros da Companhia Paulista,Antônio Francisco de Paula Souza ${ }^{1}$ e Adolpho Pinto.

1 O engenheiro ituano Antonio Francisco de Paula Souza (1843-1917) é muito conhecido por sua atuação junto à Escola Politécnica de São Paulo, como diretor, lente e pesquisador. Filho do Conselheiro Antonio Francisco de Paula Souza (1819-1866) e Maria Raphaela Aguiar de Barros (filha de Antonio Paes de Barros, Barão de Piracicaba). Estuda na Escola Politécnica de Zurich, depois transfere-se para 
Segundo a documentação pesquisada por Lanna (2002) sobre as companhias ferroviárias, não havia uma distinção entre a vida pública, profissional e pessoal, em todas as esferas:

Dos concessionários e dirigentes, passando pelos engenheiros, fiscais e empreiteiros, trabalhadores da construção e operação de negócio ferroviário - era toda uma rede de favores, roubos e negociatas que marcava o empreendimento ferroviário em si, assim como todas as atividades a ele relacionadas tais como empresas de colonização, regularização de títulos de propriedade da terra, aquisição de material de construção e rolante. (LANNA, 2002, p. 102).

Pode-se destacar outros dois eventos importantes que muitos autores, como Costa (1987) relacionam ao período estudado: a Lei de Terras de 1850 e a imigração. A política de imigração foi fomentada pelos próprios fazendeiros antes mesmo da lei de terras e da abolição da escravidão, com os núcleos coloniais, e é só depois que o Estado apropria-se de tais políticas, com a criação pelo governo federal da Inspetoria Geral de Terras e Colonização, em 1876. Segundo BERNARDINI (2001, p. 59):

Em julho de 1827, Visconde de São Leopoldo, ministro do presidente da província, já expedia uma portaria mandando proceder a uma exploração na província de São Paulo para o estabelecimento de núcleos coloniais. Em agosto, foi firmado o primeiro contrato para a introdução dos imigrantes em São Paulo. Este contrato foi firmado em Bremen (Alemanha) e estabelecia as obrigações e os benefícios concedidos aos imigrantes. Os imigrantes seriam sustentados por um ano e meio à custa da nação, receberiam gado, devendo entregálo na mesma espécie e valor no decurso de 4 anos e os terrenos que cultivassem ficariam sendo de sua propriedade. Os colonos seriam também isentos de quaisquer direitos e tributos.

Os primeiros 226 imigrantes que chegaram no porto de Santos eram em sua maioria alemães e fixaram-se nos "Campos de Guarapuava e a vila nova de Franca do Imperador'. Em 1828, quatro novos grupos chegavam ao porto de Santos, todos alemães totalizando 650 imigrantes. Para abrigá-los, o governo fundou o primeiro núcleo colonial entre as vilas de Itapecerica e Cotia. Ficaram ali provisoriamente, até que o governo pudesse alojá-los de forma definitiva. Para isso, foi fundada outra colônia na 'sertão do rio Negro' em 1828. Com o receio de embrenhar os colonos europeus em um sertão desconhecido, o Conselho do Governo da Província resolveu comprar terras e fundar a colônia de

Karlsruhe, Alemanha. Em 1868, Eng. Antonio Francisco de Paula Souza assume a Inspetoria de Obras Públicas da província de São Paulo. Depois parte para viagem aos Estados Unidos. Em 1871, retorna ao Brasil e torna-se engenheiro da Companhia Ituana, esta empresa foi criada em 1870, ligando Itu à Jundiaí, visando o escoamento de ferro da fábrica Ypanema. Antonio Paes de Barros, avô de Paula Souza, ocupou a presidência da Companhia. Em 1873, AF Paula Souza é convidado para ser o engenheiro-chefe da 3a. Seção a ser construída, ligando Campinas à Rio Claro, antes sob os cuidados do engenheiro-chefe Antonio Pereira Rebouças Filho (1839-1874). (CAMPOS, 2007: 55, 136). 
Santo Amaro, em 1829, onde se fixaram 91 famílias.

Após estas primeiras tentativas, o governo imperial suprimiu o subsídio aos colonos em 1830 e em dezembro do mesmo ano proibiu em todas as províncias do Império, despesas com a colonização estrangeira. Até 1876, o Serviço de Colonização e Imigração ficou paralisado.

São também conhecidas as iniciativas particulares, como as do Senador Vergueiro, que possuía terras na região de Limeira (Fazenda Ibicaba) ${ }^{2}$. Vergueiro chega a estabelecer uma empresa de imigração, a Vergueiro \& Cia, e à iniciativa deste seguiram-se outros fazendeiros ${ }^{3}$. E além do Senador Vergueiro, outros como Francisco Antonio de Souza Queiroz (ligado à Companhia Paulista); José Elias Pacheco Jordão (cuja família estava ligada à Companhia Ituana de Estradas de Ferro e mais tarde da Paulista), o comendador Antonio de Queiroz Telles, de Jundiaí. (SAES, 1979, p. 91 - 94). Além dos colonos alemães em São Paulo, Saes (1986, p. 91) identificou: "23 fazendas já participavam da experiência das colônias de parceria e o governo também fez experiências em Cananéia (1862), além de estabelecer 760 colonos norte-americanos nas cabeceiras do rio São Lourenço (Vale do Ribeira), na colônia chamadas de 'Nova Texas'.. Saes (1979, p. 95) cita como dois líderes do "imigrantismo", os irmãos Martinho Prado Júnior e Antônio Prado, grandes fazendeiros e dirigentes da Cia. Paulista de Estradas de Ferro. Este último foi deputado do partido Conservador.

Tais iniciativas particulares continuaram existindo mesmo depois da criação da Inspetoria Geral de Terras e Colonização em 1876, e da criação do órgão estadual em 1877, chamado Inspetoria Especial de Terras e Colonização de São Paulo, cuja chefia foi dada a Antônio da Silva Prado, "que se ofereceu gratuitamente para exercer o cargo". (BERNARDINI, 2004, p. 59) Em 1886, Antônio Prado “ocupando o cargo de Secretário da Agricultura, o desenvolvimento de núcleos colônias tomou novo impulso.”. (BERNARDINI, 2004, p. 59). Novamente, observa-se como os fazendeiros atuavam na política e nos órgãos governamentais. Quanto à Inspetoria Geral, esta passou a se chamar Delegacia da Inspetoria Geral de Terras e Colonização, em 1890, e no ano seguinte o governo a transferiu à Superintendência de Obras Públicas, separando-se desta em 1892. Em 1901,

$2 \quad$ cfr. COSTA $(1987$, p. 170).

3 "A grande expansão paulista para oeste (cafeeira e ferroviária), tendo ocorrido nos fins do século passado e nas duas primeiras décadas do século atual, livre, portanto, da conjuntura escravista, tem que ser associada ao movimento imigratório que marcou a paisagem humana, social e cultural de nosso Estado com as mais variadas etnias (predominando, a princípio, o elemento italiano) e levando o próprio governo a uma política de assistência ao imigrante através de 'núcleos coloniais' estabelecidos em diversas regiões do Estado.” (MATOS, 1981: 111) 
o Governo criou um projeto de lei providenciando os serviços de imigração e colonização. Nota-se como o café e os núcleos coloniais de imigração estavam conectados, e mais tarde, as próprias ferrovias, pois em 1882, passagens gratuitas são fornecidas aos imigrantes como meio de facilitar o deslocamento da mão-de-obra potencial. (SAES, 1981, p. 42). “A idéia de estabelecer colônias próximas às fazendas de café continuou existindo ainda em 1902, quando o Estado começou a investir também em outras culturas, além do café. (...)”(BERNARDINI, 2001, p. 61).

O fato é que café, imigração e ferrovias são processos inter-relacionados, porém não só. $\mathrm{O}$ excedente do café resultou no processo de industrialização, que num primeiro momento foi um complemento para a produção do café, como o estabelecimento de indústrias de algodão para a fabricação de sacas para o café. Daí a tríade café, ferrovias e industrialização apontada por autores tais como Dean (1971), Lemos (2001), Toledo (2004). Já Cano (1977) prefere denominar o conjunto como o complexo cafeeiro em São Paulo. Este complexo era composto por uma série de elementos que tinham como objetivo promover atividades que apoiassem as atividades econômicas ligadas ao café, como um novo sistema de transportes, dotar as cidades de uma estrutura capaz de apoiar as atividades produtoras no campo, estabelecimento de sistema bancário, dentre outros. $\mathrm{O}$ estabelecimento do complexo cafeeiro foi, segundo a tese de Cano (1977), fundamental para o sucesso da economia cafeeira que se implantava em São Paulo no final do século XIX. A economia cafeeira, concentrada praticamente no estado de São Paulo, possibilitou muitas outras formas de expansão do capital: como o estabelecimento de grandes indústrias, que em um primeiro momento até serviam ao café. Além disso, possibilitou o surgimento de companhias de energia elétrica e serviços urbanos, como saneamento, que em seu princípio nasceu por iniciativa de capitais locais, ligados ao café e à política, antes de serem vendidas, na década de 1920, a empresas estrangeiras como a canadense Light and Power Co. (MELLO \& SAES, 1985, p. 325). No mesmo sentido:

O crescimento das cidades de S. Paulo na segunda metade do século XIX abrira a possibilidade desse novo tipo de atividade-genericamente chamada de serviços urbanos. De início, encontramos empresas voltadas ao transporte urbano, à iluminação (à gás) das ruas, aos serviços de água e esgotos e de telefones. Já anotamos, em capítulo anterior, a existência de tais empresas para o ano de 1887. A década de 1890 e os primeiros anos do século XX apresentam, entretanto, rápido movimento de expansão desses serviços e mudanças significativas, em boa parte relacionados com o capital estrangeiro. Há, no entanto, duas linhas de desenvolvimento relevantes nesse período. Uma relativa às cidades do interior, em que alguns serviços são estabelecidos por meio 
de empresas de caráter local (quanto às atividades e quanto a seus proprietários); já em São Paulo (e em certa medida em Santos), há tanto uma tendência à formação de empresas de maior porte quanto outra ligada à penetração do capital estrangeiro nesses setores. (SAES, 1979, p. 167).

A economia cafeeira possibilitou também o capital financeiro, há o surgimento de diversos bancos nacionais e estrangeiros neste período. Ao mesmo tempo, o aumento destas atividades urbanas demanda obras de engenharia urbana, quer de saneamento, transportes e de energia elétrica, que por sua vez demandam tanto engenheiros, quanto trabalhadores. Daí os trabalhos de Bernardini (2004) e Campos (2007) que apesar de centrarem-se em figuras de engenheiros, ajudam a entender como estes atores circulavam entre as empresas ferroviárias, de saneamento e órgãos do governo referentes à agricultura, demarcação territorial e colonização. Também é possível notar como os fazendeiros também diversificavam seu capital em bancos e empresas de transporte, energia elétrica e saneamento.

Desse modo, a expansão do capital cafeeiro desencadeou outro processo, o da urbanização, transformando a fisionomia da provinciana capital paulista, como de outras cidades do interior e, a partir de certo momento, inclusive a criação de outras cidades com o impacto das ferrovias. É portanto, difícil dissociar os processos de imigração, criação de um mercado de terras, bem como a expansão da malha ferroviária, neste processo de urbanização.

Tendo analisado brevemente a tríade café, ferrovias e industrialização, e a relação desta tríade e a urbanização, gostaríamos com este novo tópico de entender a formação das cidades escolhidas, especialmente seus pontos em comum. Considera-se interessante entender a origem das cidades e a história da ferrovia para entender o impacto destas sobre as cidades.

Esclarecemos que São Carlos e Rincão constituem um ramal que passa por Araraquara, e faz a ligação com o estado de Minas. Por muito tempo, algumas das cidades como Jaú e Rincão, eram pontas de linha, portanto, foram locais de armazenamento ou carregamento. Itirapina e Dois Córregos chegam a quase uma centena de casas. Dois Córregos foi ponto de linha por algum tempo da Companhia Rio Clarense, e Itirapina um entroncamento de linhas e “(...) foi local de baldeação para importante ramal da Paulista, função que desapareceu com o alargamento da bitola do referido ramal.” (MATOS, 1981, p. 121). Itirapina passa então a ser uma bifurcação entre dois ramais, o anterior- 


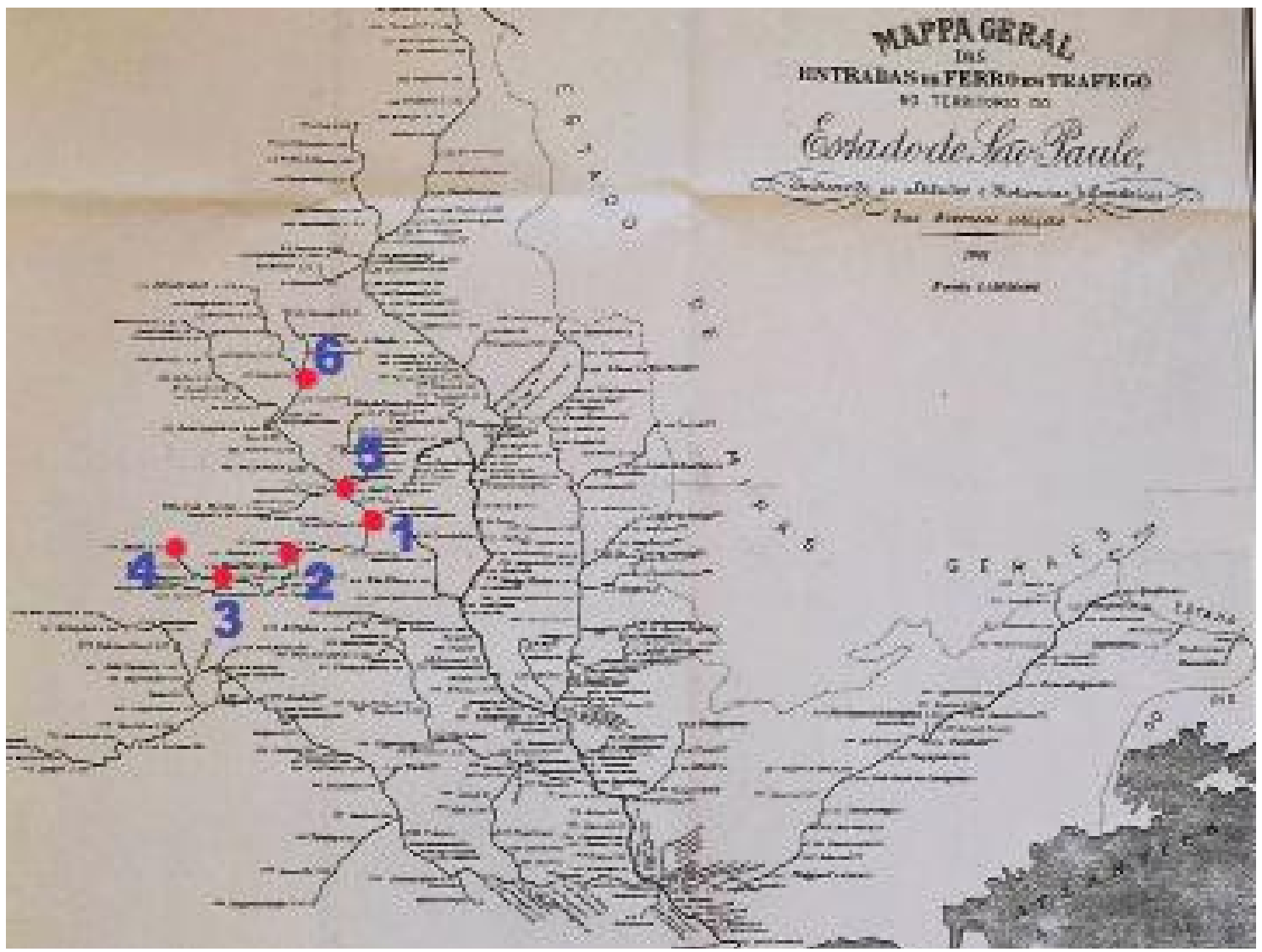

Mapa 5 - Carta ferroviária em 1901. Os números são a localização das cidades, objeto de estudo: 1 - Itirapina; 2 - Brotas; 3 - Dois Córregos; 4 - Jaú; 5 - São Carlos; 6- Rincão. Fonte: Relatório da Companhia Paulista, 1901.

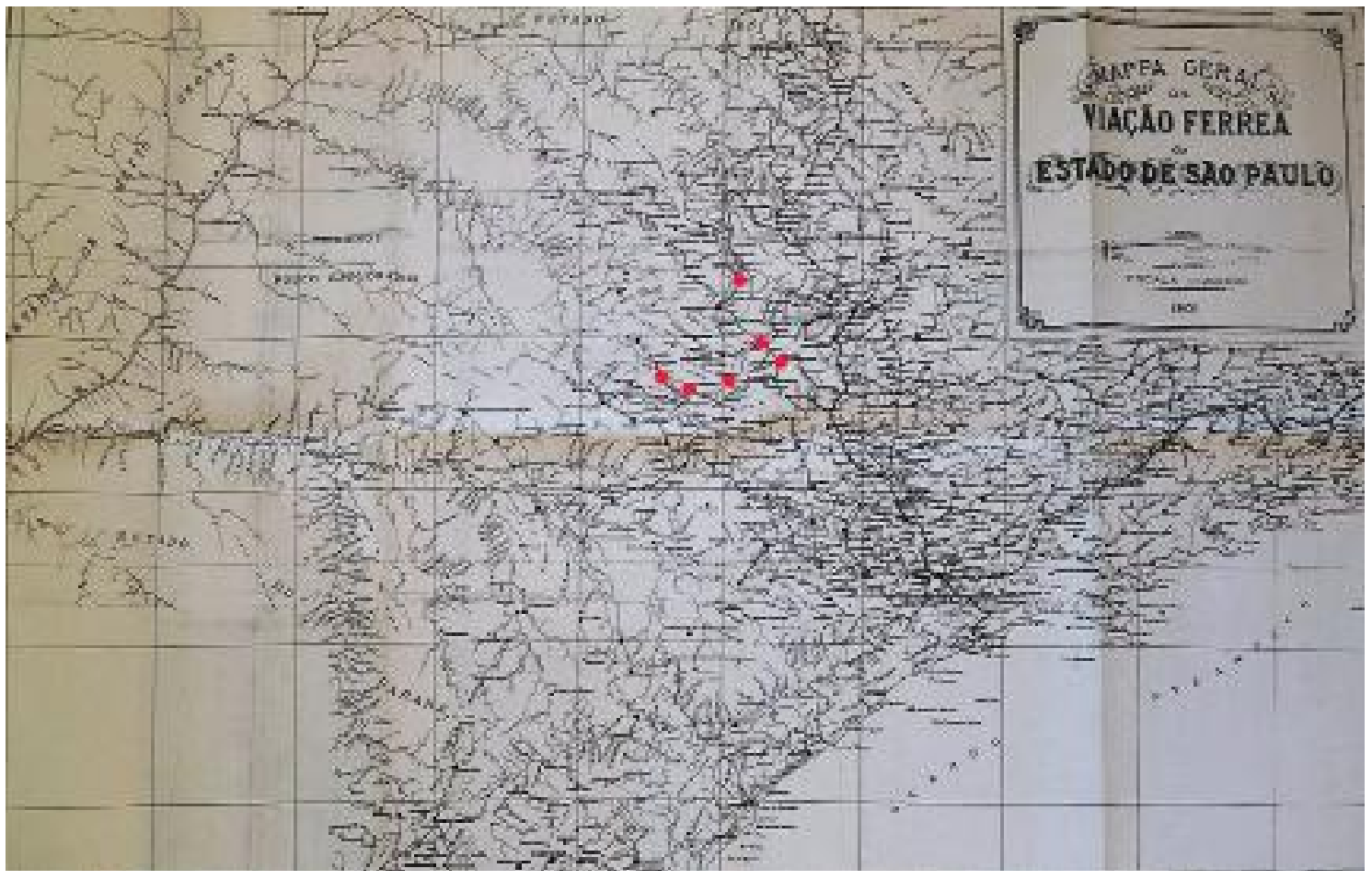

Mapa 6 - Mapa do Estado de São Paulo e carta ferroviária em 1901. Os pontos em vermelho são as cidades estudadas. Fonte: Relatório da Companhia Paulista, 1901. 
mente citado, que faz a ligação com Bauru, e que passa pelas cidades citadas na seguinte sequência: Brotas, Dois Córregos, Jaú - estes objetos de nosso estudo - e depois Pederneiras chegando em Bauru. Bauru, não faz parte de nosso estudo, mas é o entroncamento de três companhias ferroviárias - a Paulista, a Sorocabana e a Noroeste do Brasil, esta última realizando a integração com o Mato Grosso do Sul.

Verificou-se que invariavelmente elas remetam a suas origens indígenas. Muitos dos nomes são de origem tupi-guarani, como Itirapina e Jahú, e de fato, os tupi-guaranis e os caingangues ocuparam o território oeste paulista até o século XIX, tanto que na construção da estrada de ferro Noroeste do Brasil houve "ataques indígenas". A "pacificação" dos índios ocorre por volta de 1912, através dos trabalhos de Cândido Rondon. ${ }^{4}$ As informações históricas fornecidas pelas atuais prefeituras das cidades em estudo remontam à figura de um bandeirante ou posseiro, ou algum herdeiro de uma sesmaria, como foi o caso de Antônio de Arruda Botelho, Conde do Pinhal. Sobre estas figuras de tropeiros, bandeirantes ou posseiros a primeira ocupação espacial pode ter sido na forma dos chamados "ranchos". Sobre os "ranchos", descreve MATOS (1981, p. 31):

Elementos complementares às estradas, como os ranchos, constituem características importantíssima do sistema viário no interior do Brasil. A ausência de estalagens nas freguezias e vilas, ou a dificuldade de alojamento nas casas de fazendas, mesmo em se tratando de pessoas de qualidade (como ocorreu com os grandes viajantes e naturalistas estrangeiros) levavam os viajantes, tanto os rotineiros como os ocasionais, a lançar mão desse primitivo tipo de alojamento que os fazendeiros mandavam construir à margem das estradas. Todos muito precários.(...)

Quanto à variada gama de agentes sociais que remontam à origem das cidades do interior paulista, cita Matos (1981, p. 119), a figura do fazendeiro, ligado à propriedade agrícola, a do coronel, podendo ser este ligado à atividades comerciais, e:

da mesma maneira que as primeiras formas de ocupação da terra fizeram surgir o grileiro, falsificador de titulos de propriedade - uns e outros de tanta importância na paisagem humana de São Paulo e que vieram acrescentar novos valores à já tão rica e variada galeria de tipos característicos vinculados a atividades econômicas em nosso país. (MATOS 1981, p. 119)

A origem das cidades, mesmo antes da economia cafeeira, estava ligada à origem

4 "Deve-se notar, ainda, que esse é o ano da pacificação dos caingangues na Zona Noroeste pelo recém-criado SPI, Serviço de Proteção dos Índios e Localização dos Trabalhadores Nacionais. Esse órgão, que teve a colaboração de Cândido Rondon, depois de contatos pacificos com os indígenas, instala-se nas reservas de Icatu e Vanuire.” (GHIRARDELLO, 2002, p. 102) 
mineira, com os tropeiros vindos para o estado de São Paulo e vice-versa, ou o movimento denominado "monções", que foram expedições que atravessam a província para explorar as minas do Mato Grosso, estas desde a segunda metade do século XVII (SOUKEF JUNIOR, 2005, p. 129). Sobre a origem mineira já afirmou Monbeig, em 'Pionniers et Planteurs $^{\prime 5}$. Muitos destes aventureiros aí se estabeleceram e formaram pequenos núcleos. Outro fator que se deve levar em conta é que mesmo antes do café, existiu no interior paulista a cultura de açúcar. Conforme afirmou Saes (1979, p. 57-9): “O dinheiro dos fazendeiros de café, surgiu provavelmente do açúcar”, e ao mesmo tempo, um "processo contínuo de acumulação de terra durante a primeira metade do século XIX." Com o tempo, as fazendas ou engenhos de açúcar foram transformadas em fazendas de café. Foram encontradas duas afirmações no mesmo sentido:

No último quartel do século XVIII, dois fatores estimularão a criação de novos e mais distantes povoados: a política povoadora do Morgado de Mateus, que concede sesmarias até quase a metade do atual território paulista, e o cultivo de cana-de-açúcar que marcará o desenvolvimento das regiões de Campinas e Rio Claro. A exportação da produção açucareira possibilitará a acumulação do capital que será utilizado na formação das futuras lavouras cafeeiras, que cobrirão boa parte da província, a partir da segunda metade do século XIX. (SOUKEF JUNIOR, 2005, p. 129)

Para a afirmação acima, Soukef Junior, baseia-se em Matos (1981, p. 27), afirmando que através da economia do açúcar, vai se configurando já uma nova fisionomia para o território paulista, com a política povoadora de Morgado de Mateus, mediante a concessão de sesmarias e criação de freguesias. E ainda, a atividade tropeirista implicou em importantes alterações no sistema de transportes e comunicações, estabelecendo uma rede de caminhos, preferencialmente para o sul, próximo a Sorocaba, sede de famosa feira de muares.

Até aproximadamente 1840, o vale do Paraíba conservava a primazia da produção do café, e quando o oeste Paulista passou a oferecer condições melhores de produção, as fazendas de açúcar irão se transformar em fazendas de café. Ainda segundo Matos (1981, p. 39):

5 "Ao caracterizar o povoamento paulista nas regiões do oeste, nas áreas conhecidas por Alta Sorocabana, Alta Araraquarense e Alta Paulista, Pierre Monbeig não pode furtar-se a um valioso embasamento histórico, o que vem a tornar seu livro precioso não apenas na geografia, mas igualmente para a história de São Paulo. Nessa marcha do povoamento do Oeste, os mineiros, tanto quanto nas áreas centrais do Estado, tem papel preponderante. Os fatos lembrados pelo autor de 'Pioniers et Planteurs's sa expressivos: foi um mineiro, por exemplo, quem construiu o primeiro rancho em São José do Rio Preto (...)" (MATOS, 1981, p. 117) Outro exemplo, o mineiro de Pouso Alegre, José Teodoro e Botucatu. 
O vale do Paraíba conservava, ainda, em 1836, a primazia na produção do café, enquanto que a região de Campinas era fortemente açucareira. Vinte ou trinta anos mais tarde, um 'quadro estatístico' que porventura fosse elaborado, apresentaria uma situação totalmente diferente: o chamado 'Norte' decairia sensivelmente, enquanto que o centro-oeste, assumiria a liderança econômica da província. Liderança que virá a afirmar-se de maneira mais expressiva com a era ferroviária e com os movimentos de imigração e colonização, ambos na segunda metade do século, ocasião em que a velha vila de São Carlos, agora a denominação de Campinas restabelecida, fará jus ao título de 'capital agrícola de São Pauló.

Ainda nesta perspectiva comparativa entre as cidades, e consultando a bibliografia, percebe-se que a origem delas está relacionada às freguesias. A doação de terras era feita pela Coroa junto com um título nobiliárquico a uma pessoa. Este caso pode ser aplicado por exemplo, a São Carlos e ao Barão do Pinhal, Antônio Botelho. Além disso, por ser o Estado monárquico ainda unido à Igreja, a terra era ligada a esta. Desse modo, pode-se observar pela descrição das cidades que muitas delas resultam do que se chama "patrimônio". Isto é, há uma doação de parte da terra à Igreja para a construção da capela, e estas terras podem denominar-se "freguesia". O termo "freguesia" assim é associado à Igreja. Depois de algum tempo é elevada à condição de vila, ligada a algum distrito. Das cidades estudadas algumas estavam ligadas à Araraquara, como é o caso de Rincão. E conforme seu crescimento eram elevadas à categoria de cidades. É bastante ilustrativa a maneira como o site da prefeitura de Jaú, conta a sua origem:

Os habitantes já eram em número razoável, o que comportaria a criação de um patrimônio (Curato), onde se construiria uma Igreja, cemitério e alguns lotes urbanos para residência e comércio. Isto foi no segundo semestre de 1.851. A idéia da criação do Patrimônio foi bem aceita por todos, criou-se uma comissão para este fim, composta dos seguintes cidadãos: Tenente Manoel Joaquim Lopes, Francisco Gomes Botão, Bento Manoel de Moraes Navarro, Lúcio de Arruda Leme e ele, Capitão José Ribeiro de Camargo (os fundadores); as reuniões realizavam-se na casa de Lúcio de Arruda Leme, onde eram tratados os seguintes assuntos: $1^{\circ}$ ) localização do Patrimônio; $2^{\circ}$ ) denominação do mesmo; $3^{\circ}$ ) doação de área escolhida ao Bispado; $4^{\circ}$ ) escolha da Padroeira ou Padroeiro; $5^{\circ}$ ) derrubada da mata e arruamento.

E ainda sobre a doação de terras à Igreja:

"O tenente Manoel Joaquim Lopes e Francisco Gomes Botão assumiram
o compromisso de doarem, como de fato doaram ao Bispado, a área de
40 alqueires de terras, sendo 20 alqueires de cada, doação essa de fato,
pois a posse do terreno estava com a Igreja, não o direito, por não ter 
sido lavrada a escritura." ${ }^{6}$

Da bibliografia especializada, vimos que Marx (1989) estuda justamente o surgimento destas primeiras cidades, especialmente a cidade de São Paulo, comparando com outras cidades de colonização portuguesa e espanhola. Este processo de formação das cidades pode ser aplicado aqui a diversas cidades do interior paulista. Assim, afirma Marx (1989, p. 41):

(...) A partir dum povoado, que ostentou paulatinamente uma capela, obteve um cura, chegou afreguesia ouparóquia, ascendeu eventualmente a vila. Alcançou o status municipal, um governo correspondente a um, ainda que relativo, cuidado civil com a distribuição e definição dos usos do solo.(...)

Tal forma de fundar cidades apenas mudará com a Lei de Terras $1850^{7}$, quando a terra passa a ter fins especialmente especulativos, e com o advento da República, quando há a dissociação do Estado e da Igreja, ou seja, há a secularização ou a laicização do solo. Sobre este assunto também tratou Marx (1989, p. 38). ${ }^{8}$ Não apenas o solo foi laicizado, também os registros das terras e nascimentos, que antes eram feitos na Igreja. Por questões sanitaristas também os mortos e os cemitérios serão localizados fora do terreno das igrejas. Marx (1989, p. 41) cita ainda outros sinais de laicização como as alamedas e os parques públicos bem como os equipamentos urbanos sofisticados. O parque, por exemplo, não será mais o largo em frente à igreja.

Alguns autores observam a laicização de terras juntamente à expansão das ferrovias. Por exemplo, em Ghirardello (2002, p. 221):

Paralelamente e nos moldes comerciais do parcelamento rural, os núcleos urbanos serão loteados privadamente. Inexistiu nas novas cidades da Noroeste o antigo sistema de formação urbana, a partir de doações de terras à Igreja, o chamado patrimônio religioso, no qual o chão é aforado à Fábrica Paroquial. Um novo sistema se impõe dentro da lógica capitalista: a compra e venda livre da terra urbana fortalecida pela separação constitucional dos poderes entre a Igreja e Estado. Os povoados da Noroeste, portanto, não tiveram compromissos com o solo

6 Disponível em <http://www.jau.sp.gov.br/conhecajau_historia.php>. Acesso em: 13/06/2013 15:57.

7 Ver MARTINS, José de . "Frente Pioneira: contribuição para uma caracterização sociológica. " In Estudos Históricos. V. 10, pp. 33-41. Marília, 1971.

8 “(...) Com o advento da República - e somente com ele - desfaz-se a união da Igreja com o Estado. A secularização, iniciada ainda no século das luzes e tornada palpável em aspectos importantes na estruturação jurídica do império, se completa finalmente. Não haverá mais religião oficial nem determinados usos cerimoniais que compulsoriamente afetem a vida urbana. Para as questões da cidade, a alteração será pouca, apesar da laicização do Estado e do caráter mais do que laico das idéias e teorias urbanísticas vindas do hemisfério norte.” (MARX, Murilo, 1989, p. 38) 
sagrado e isso ficou fisicamente demonstrado em seu desenho orientado pela estrada de ferro.

Era interessante para os fazendeiros atrair pessoas e depois vender as terras, através dos já mencionados núcleos coloniais de imigrantes, como também através do fornecimento da passagem gratuita para imigrantes na Companhia Paulista desde 1882. Saes (1979) esclarece que o "imigrantismo" não se confunde com o movimento abolicionista, pois este último propunha fuga de escravos, o que desorganizaria a produção, enquanto que o primeiro "não era em si, anti-escravista”, a sua intenção era em primeiro lugar, evitar a desorganização da produção (SAES, 1979, p. 100). Esta forma de precaver-se da desorganização da produção, rendeu a liderança dos cafeicultores do oeste paulista em relação aos do Vale do Paraíba, pois:

propiciaria também a entrada em larga escala dos imigrantes europeus, especialmente italianos, seria o responsável, igualmente, pela formação de um início de classe média entre nós, nas zonas semi-urbanas ou já urbanizadas do interior, onde as cidades do café, mais que as do vale do Paraíba se multiplicariam, com tipos de população os mais diversificados. (MATOS, 1981, p. 27)

O perfil do fazendeiro do Vale do Paraíba e o perfil que adquire o fazendeiro do Oeste Paulista vão se distanciando, e com todos os inventos tecnológicos, sendo um deles a ferrovia, que aliada à expansão capital cafeeiro, transformam o fazendeiro do Oeste Paulista um empresário e homem urbano. Afirma também Saes (1979, p. 90):

(...) Entretanto, creio que nos anos 80, a se colocar a empresa ferroviária como núcleo desse movimento, se tem caráter distinto nessa 'urbanização': a ferrovia não só permite ao fazendeiro residir em São Paulo (e deslocar-se rapidamente para sua fazenda) como também abre a perspectiva de novas atividades, seja por sua forma de organização, seja pelas novas relações comerciais e financeiras que exige restabelecer.

A questão das terras também está ligada às ferrovias pela concessão de privilégios de zonas. As terras eram concedidas através de decretos, primeiramente federais e, aqui neste estudo, principalmente estaduais. A área concedida chegou a variar de 30 quilômetros para a construção das primeiras ferrovias, e no final da era ferroviária, 100 metros. Aproximadamente durante a década de 1890, não são necessários mais estímulos para a construção de ferrovias, pois sabe-se que é uma atividade rentável. Descobriu-se também que a região ocupada pelas cidades estudadas foi motivo de disputa entre as Companhias 
Paulista e Ituana. As estações das cidades estudadas foram construídas e inauguradas antes de 1892, data importante pois foi o ano da compra da Rio Claro Railway pela Companhia Paulista. Em nosso estudo, há portanto, um ramal que foi construída pela Estrada de Ferro Rio Clarense, depois adquirida pela Rio Claro Railway, e outro ramal construído pela própria Companhia Paulista. Tal disputa veremos mais detalhadamente adiante ainda neste capítulo, e importante, pois faz parte de um dos ramais onde estão localizadas as cidades de Itirapina, Dois córregos, Brotas e Jaú, cidades objeto de nosso estudo. O conflito na região começa entre 1879 e 1880, quando se discute a concessão do prolongamento da ferrovia a partir de Rio Claro, ponto atingido pela Companhia Paulista. ${ }^{9}$

A linha até Jaú foi construída pela Estrada de Ferro Rio Clarense, ao que tudo indica, tinha participação do Visconde de Rio Claro (José Estanislau de Oliveira) e seu genro Barão do Pinhal (Antônio Carlos de Arruda Botelho, casado com a filha do Visconde, Ana Carolina de Melo Oliveira). Tal empresa foi comprada, ainda na década de 1880, pela companhia com sede em Londres, Rio Claro Railway. E depois adquirida pela Companhia Paulista em 1892 (SAES, 1979, p. 132-4). Esta compra acarretou em dívidas que perduraram até 1930 para a Companhia Paulista. Adolpho Pinto que participou da compra, defende o investimento em História da Viação. Neste mesmo ano, a Companhia Paulista:

atingiu Jaboticabal, e iniciou a construção do ramal do Mogi-Guaçu, a partir de Rincão, no rumo das grandes fazendas que ali se abriam em férteis terrenos diabásicos; dessas, a mais importante - Guatapará - vai atrair também os trilhos da Mogiana. De São Carlos, tirou a Paulista dois ramais (Ribeirão Bonito e Areia Vermelha) e a grande fazenda de Santa Veridiana, dos Prados, foi atingida pelos trilhos até as linhas da Mogiana, nas proximidades de Casa Branca. Tratava-se, aqui, de uma 'linha de combate' (Adolfo Pinto) visando servir a uma zona já ocupada por outra estrada, pois a Mogiana, no seu prolongamento de

9 “(...) Esta, com prioridade para a nova linha, insiste no projeto que buscava Brotas e Jaú. Contra esse traçado levantavam-se importantes proprietários de São Carlos, Rio Claro e Araraquara que, ao verem a linha longe de suas propriedades, sentem-se prejudicados. O Governo Provincial age como árbitro da disputa; coloca-se, porém, como parte interessada pois Jaú e Brotas ficavam na direção 'natural' da linha da Companhia Ituana que contava com garantia de juros. A concessão do traçado preferido pela Companhia Paulista viria pois acarretar um ônus quase permanente ao Governo que não via condições de a Ituana se tornar rentável. Levanta-se ampla polêmica na imprensa (74): o Correio Paulistano (ligado a Antonio Prado, diretor da Paulista) e a Gazeta de Campinas defendem a Companhia Paulista (em nome dos interesses da Província) e acusam certos grandes proprietários defenderem interesses pessoais nessa polêmica. Em especial, o Visconde de Rio Claro é chamado de 'suserano deste feudo chamado Província de São Paulo', ao mesmo tempo em que então Presidente da Província, Laurindo Brito, é acusado de se curvar a interesses de grandes fazendeiros sob pretexto de defender a Companhia Ituana. Mantido, na concessão, o traçado por S. Carlos e Araraquara, a Companhia Paulista acaba por desistir de sua prioridade. Organiza-se outra Companhia - por Adolpho A. Pinto e Luiz. A. Pinto, embora pareça haver, por trás dos concessionários, a presença do Visconde de Rio Claro e do Barão do Pinhal, principais opositores à Companhia Paulista”. (SAES, 1979, p. 70) 
Casa Branca a Ribeirão Preto, invadira zona privilegiada da Paulista. (MATOS, 1981, p. 88)

A década de 1890 é repleta de fatos importantes. Nesta década, por exemplo, ocorre a fusão entre a Sorocabana e a Ituana. Em 1892, ocorre uma crise de transporte entre São Paulo e Santos. As companhias estudam um projeto de ligar o planalto ao litoral, e assim quebrar o monopólio da São Paulo Railway. Assim, a Cia. Mogiana e Sorocabana fazem projetos ligando ao porto de Santos, e a Companhia Paulista propõe a ligação de suas linhas ao porto de São Sebastião (SAES, 1979, p. 135). Em 1895, ocorre a duplicação da linha da São Paulo Railway, garantindo à Cia. inglesa o monopólio por mais tempo. Além disso, entre as décadas de 1890 e 1900, segundo Matos (1981, p. 88):

(...) O governo do Estado incentivava a imigração e continuava o rush das famílias do Estado do Rio e do vale do Paraíba, acentuando mais ainda com a crise da lavoura fluminense após a abolição. 'As zonas da Paulista e da Mogiana - lembra Sérgio Milliet - foram as que melhor aproveitaram a mão-de-obra do imigrante. Ao começar a imigração iniciava-se o seu desbravamento. E ao terminar este, embora outras regiões já se abrissem ao forasteiro, as conveniências de civilização instalada atraíram sempre o colono'(54). Por essas razões, são as duas estradas as que mais se desenvolvem. (...)

Nesta mesma década, os preços do café caíram no mercado internacional. Para o historiador Caio Prado Junior (1970), esta foi a primeira de uma série de dificuldades enfrentadas em consequência da superprodução, problema que seria solucionado somente na década de 1920 com a criação do Instituto do Café, que garantirá a estabilidade para o desenvolvimento do café através da interferência no mercado a favor dos produtores. O câmbio desfavorável e a desvalorização da moeda nacional afetaram as companhias ferroviárias, que dependiam de material importado para construir suas linhas. Em relatório enviado aos acionistas da companhia, em 1898, a diretoria explicava que era mais prudente suspender a construção do novo ramal que atravessaria o rio Tietê.

Com a estabilidade econômica e a retomada do crescimento da economia brasileira devido aos empréstimos internacionais feitos pelo presidente Campos Salles, a Companhia Paulista retoma seus projetos de expansão em 1901. Parte destes projetos foi a construção do ramal de Rincão, que impedia a passagem da Companhia Mogiana para a região de Bauru. Em 1901, os trabalhos do ramal entre Dois Córregos e Pederneiras transcorriam bem. Entretanto, o trecho mais complicado do novo ramal era a passagem do Rio Tietê. A ponte sobre este rio foi projetada pelos engenheiros da Companhia Paulista e construída em suas oficinas de Jundiaí. Esta ponte, em estrutura metálica e pilares de concreto, foi, 
por algum tempo, a mais extensa do estado de São Paulo. Foi oficialmente inaugurada em outubro de 1903 e o trecho final do ramal, Pederneiras e São Paulo dos Agudos, foi entregue ao tráfego da companhia em março de 1904. Neste ramal, a Companhia Paulista optou pelo uso da bitola métrica (1 metro), enquanto que seu tronco principal, entre Jundiaí e Rio Claro prevalecia o uso da bitola larga (1,60 metros).

Assim até 1900, muitas ferrovias foram construídas em função do café, sendo muitas vezes denominadas como ferrovias "cata-café". A partir desta data as ferrovias passam a ser de "cunho estratégico", ou segundo outros autores "plantadoras de cidades", e dessa maneira pretendia-se impulsionar a colonização/ocupação do interior do território. Até 1900, muitas das cidades do coração do Oeste Paulista eram pontas de linha: como Agudos (da EFSorocabana), Jaú e Jaboticabal (da Companhia Paulista) e Orlândia (da Mogiana). (MATOS, 1981, p. 91).

Adolpho Pinto e a diretoria da Companhia Paulista estavam imbuídos da certeza de que muitas das pequenas estações abertas na nova zona ferroviária logo se transformariam em cidades prósperas. Esta convicção no poder das ferrovias em disseminar cidades se explica pelo efeito que a chegada dos trilhos causou em muitas cidades paulistas. Nas décadas de 1870 e 1880, a chegada das ferrovias transformou o território. Novas cidades floresceram junto aos trilhos, como Rebouças (hoje Sumaré), e outras, como Rio Claro, São Carlos e Araraquara tiveram surto de desenvolvimento urbano quando as ferrovias rasgaram suas pacatas vilas. Não é sem razão que muitos autores afirmam que a ferrovia promoveu uma segunda fundação destas cidades.

Na zona da Alta Paulista, acredita-se que a companhia esperava repetir a mesma façanha e criar uma rede de cidades, cujo entreposto seria Piratininga. Desenvolver uma rede de cidades atreladas apenas a sua linha ferroviária pode ser considerada parte de uma estratégia da companhia para garantir um fluxo de fretes para o seu sustento. A atividade mais rentável dessas companhias ferroviárias brasileiras era o transporte de produtos agrícolas, assim, fomentar a abertura de novas frentes produtoras era gerar uma nova fonte de receita para a companhia (SAES, 1981).

Assim há outra pergunta a ser formulada: se a ferrovia trouxe mudanças, populacionais e simbólicas, e inclusive fundou cidades, como Bauru, contudo, muito diferente é afirmar que a ferrovia por si só é vetor de expansão da cidade. Somos favoráveis às afirmações de Soukef e Lanna ${ }^{10}$, que afirmam que cada caso deve ser analisado, não há

10 "Entretanto, a partir dos resultados aqui apresentados, não nos parece possível sustentar a ideia de consequências ou características comuns a todo este processo, nem mesmo quando referido à civilização do café ou a uma única linha, no caso a Paulista. As condições prévias, as particularidades de cada localidade 
generalizações. Somos próximos a esta posição, aliando a outro fator a ser apreciado como hipótese: a economia que sustentou a cidade após o declínio do café. De maneira geral, após o declínio do café, muito embora as ferrovias continuem existindo, transportando outros produtos inclusive industriais, e também pessoas, elas sofrem um longo processo de abandono, pois concomitantemente tem início uma política rodoviarista, cuja concorrência já se fazia sentir e inclusive foi discutida no Congresso de Engenharia e Legislação Ferroviárias em 1935. Com relação à indústria, considerando é claro que as ferrovias, são também empresas de cunho industrial e por tanto, parte do patrimônio industrial, houve a instalação de indústrias ao longo destas. Neste sentido, afirma MATOS (1981, p. 122):

Não poderíamos deixar de lado uma referência à contribuição das ferrovias para a paisagem industrial das regiões por elas servidas. Já desde o século passado as indústrias começaram a agrupar-se nas proximidades das vias férreas, muitas delas conseguindo desvios particulares para maior facilidade de circulação. Isso explica a concentração industrial em certos bairros de São Paulo (Brás, Ipiranga, Móoca, Lapa, Água Branca...), numa época em que os terrenos à margem das linhas ainda eram baratos e nos quais as condições topográficas facilitavam o estabelecimento de grandes fábricas. Assim, a ferrovia associada ao parque industrial veio a constituir-se uma imagem característica das cidades grandes. Tal fato é particularmente sensivel no eixo da Paulista, em que surgiram alguns centros industriais: Jundiaí, Campinas, Americana, Limeira, entre outros. Junto às linhas, estabelecem-se, também os grandes armazéns de café e cereais, os depósitos de combustiveis, numa configuração familiar e indicativa da aproximação de uma cidade de certa importância (...)

O fato é que a partir da década de 1950, diminuem-se os investimentos na rede ferroviária nacional e além disso, esta “(...) mostra-se insuficiente para atender o fluxo interno de bens intermediários, cuja demanda é suprida através da montagem de uma ampla malha rodoviária nacional estimulada, por sua vez, pelo desenvolvimento da indústria automobilística nacional.” (SOUKEF JUNIOR, 2005, p. 130)

interferiram de forma decisiva nos significados que a ferrovia trouxe para a organização do mercado de trabalho e do espaço urbano. Criando cidades como na Noroeste, definindo cidades industriais como em Jundiaí, fazendo parte da constituição de uma metrópole como em Campinas os impactos são inegáveis mas distintos. Criam e articulam novos eixos de crescimento nas cidades e entre elas, marcam a paisagem com seus edifícios e trabalhadores, com suas associações e greves, mas sempre de forma única. Não nos parece possível assumir a ideia de cidades que crescem por serem pontas de trilho ou de seu efeito multiplicador, a existência de um mercado interno de produtos e trabalho mais vigoroso e diversificado do que se possa supor, a constituição de regiões industrializadas e uma incrível variedade de modos de vida impõe a realização de outros trabalhos e pesquisas." (LANNA, 2002, p. 186). 


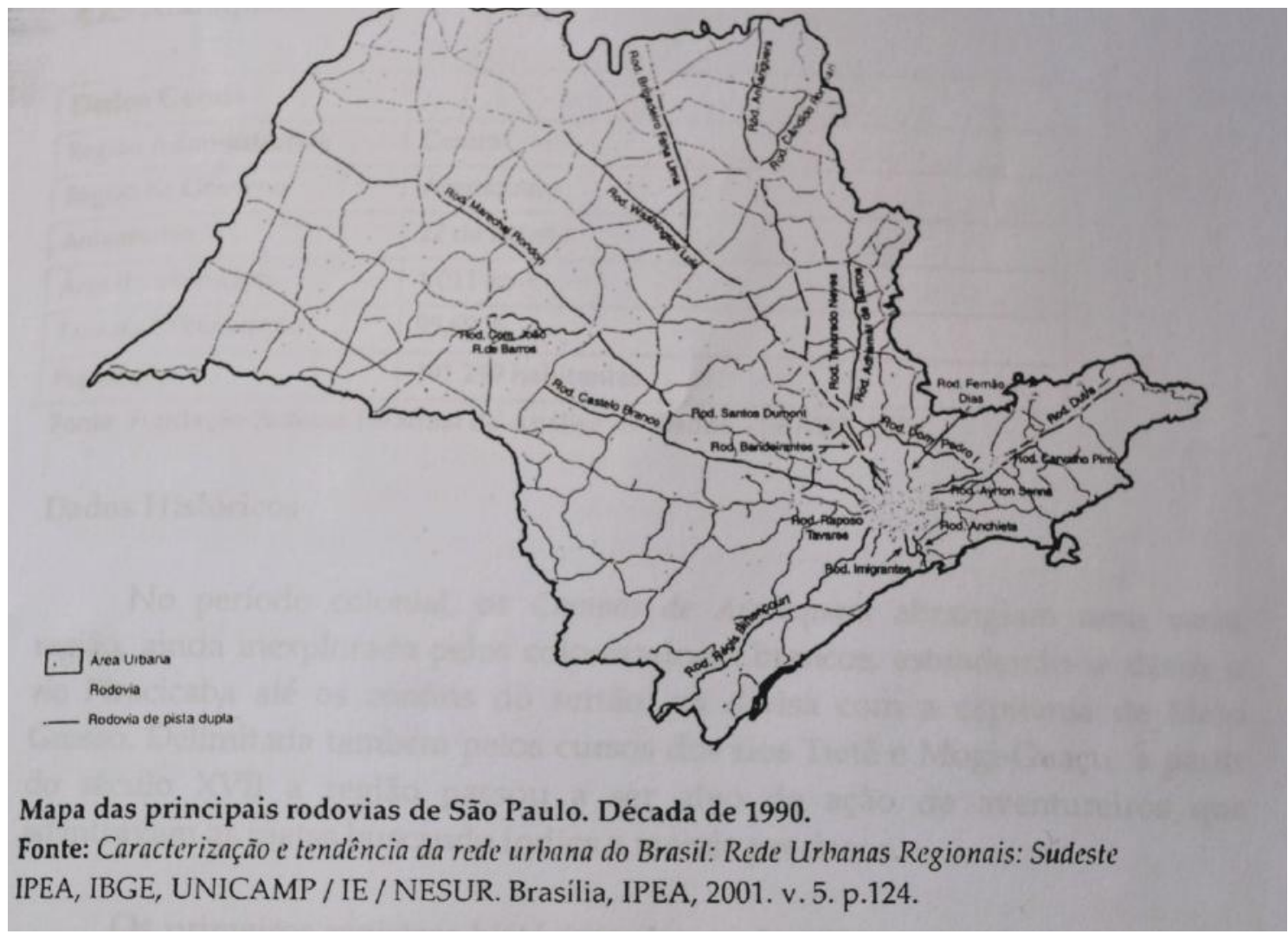

Mapa 7 - Mapa das principais rodovias do Estado de São Paulo - década de 1990. Fonte: IPEA, IBGE, UNICAMP/IE/NESUR, 2001. apud SOUKEF JUNIOR, 2005, P. 130.

Não cabendo generalizações sobre o impacto das ferrovias em cada cidade, encontramos em algumas das referências bibliográficas, Matos (1981, p. 121), Soukef Junior (2002), Pozzer (2007), Cruz (2007), os impactos da introdução da ferrovia , ou criando cidades, como foi o caso de Bauru, ou acarretando mudanças nas cidades ou vilas existentes. Porém, há peculiaridades nas cidades criadas pelas ferrovias diferentes das cidades existentes e impactadas pela mesma. Sabe-se que a ferrovia não transportou apenas mercadorias e pessoas - fazendeiros iam e vinham para São Paulo e para o interior; o mesmo com os imigrantes, mas transportou também ideias, valores e comportamentos ${ }^{11}$, estes últimos sobretudo urbanos, ao adentrar-se cada vez mais na Primeira República. Como parte de uma fábrica, ao redor das estações, instalaram-se armazéns, oficinas, pré-

11 "Além do prédio da estação a chegada da ferrovia significava a implantação de um conjunto novo de edificações como os armazéns, as oficinas, os escritórios e prédios administrativos, as residências de ferroviários que serão importante elemento na constituição de 'bairros operários'. Além disso, muitas casas comerciais, serviços de transporte e demais equipamentos urbanos são implantados ou incrementados com a ferrovia. Por fim todas as associações beneficentes e culturais, o maior fluxo de informações, a presença cotidiana dos correios e jornais implicam não só em novos espaços, mas também produzem um recorrente sentimento de 'pertencimento ao mundo', entendido como aquilo que ultrapassa a dimensão do local mas é a partir dele compreendido." (LANNA, 2002: 173) 
dios administrativos e casas para os seus trabalhadores. Vieram os trabalhadores da construção das linhas e das instalações.

A seguir, chegam seus funcionários: operários, médicos, engenheiros, funcionários administrativos, seguidos de todos aqueles que, de algum modo, poderiam se beneficiar dessa empreitada: comerciantes, prostitutas, advogados, agrimensores, bugreiros, etc. Consequentemente, o mercado local cresce e se diversifica com a criação de armazéns de secos e molhados, restaurantes, pensões, hotéis, casas de prostituição, bares, materiais de construção, serviços manuais entre outras atividades. (...) (SOUKEF JUNIOR, 2002, p. 213)

Estas mudanças em algumas cidades chegam a alterar o preço da terra, por causa da demanda por esta:

O primeiro indicador de que as coisas se alteravam foi o aumento do custo de vida, muito acima do que ocorria em outros lugares. O preço dos aluguéis, por exemplo, aumenta de forma impressionante. (...) $O$ rápido e progressivo aumento do valor da terra, a partir da chegada das ferrovias, gerará fortes atritos entre o poder púbico municipal, particulares e a Igreja, proprietária do chão de Bauru. (SOUKEF JUNIOR, 2002, p. 213)

No caso de Bauru, o impacto foi maior pois era o entroncamento de três ferrovias; outras vezes, o impacto causado por uma ferrovia pode ser maior que outra, no caso por exemplo de Campinas, conforme afirma Lanna (2002, p. 177):

A Paulista não teve em Campinas impacto semelhante ao ocorrido em Jundiai. Conforme demonstramos a transferência das Oficinas no início da década de 1890 foi fundamental para definir uma fisionomia industrial, operária e ferroviária para esta cidade. Não é sem significado que na grande greve de 1906 tenha sido Jundiai e não Campinas ou outra cidade qualquer cortada pela Paulista o palco central dos acontecimentos. A Mogiana marcou muito mais a cidade de Campinas do que a Paulista. (...) A ausência de oficinas reduz de forma significativa a demanda de trabalhadores.

Os autores que estudaram as ferrovias também são concordes em afirmar que em alguns casos a centralidade da cidade acaba mudando da igreja com a praça para o largo da estação. ${ }^{12}$ Este fato deve ser visto, repetimos, caso a caso, pois após as visitas 12 "Nas cidade pré-existentes, como é o caso daquelas cortadas pelas linhas da Companhia Paulista, podemos perceber uma reorientação dos movimentos de expansão que acabarão por unir a cidade da praça e da igreja com aquela marcada pela estação ferroviária. (...)As estações são também ícones urbanos importantes ao se contraporem aos largos e praças definidos pelos tradicionais marcos urbanos: a igreja e a administração pública. Mas seu entorno ocupado marcadamente pelo universo do trabalho e dos trabalhadores não faz parte dos discursos e intervenções da cidade belle époque." (LANNA, 2002, p. 171 173) 
realizadas, este fato não se verifica, exceção feita a Jaú, considerando o terreno da antiga estação onde hoje está o terminal rodoviário. O que se pode inferir deste fato, e assim as afirmações não se contrapõem, é que tal centralidade da estação em relação ao largo da igreja pode ter se dado no auge da época ferroviária, depois inclusive pode ter havido o deslocamento da estação para outro lugar, como foi o caso de Jaú, e hoje tal centralidade da estação, deixou de existir.

Depois ou concomitantemente à construção de todo este complexo ferroviário e movimento de mercadorias e pessoas, será a vez da chegada da infraestrutura urbana. Assim foi o que ocorreu em Bauru, que depois da ferrovia recebeu os serviços de telefone em 1901 e energia elétrica, em 1911, e como já se sabe os fazendeiros de café eram donos tanto das ferrovias como eram os primeiros investidores das empresas concessionárias de serviços urbanos. (SOUKEF JUNIOR, 2002, p. 238). O caso de Bauru, pode ser aplicado a várias cidades do interior paulista.

\subsection{Companhia Paulista e seus trabalhadores}

Antes de abordar a história da Companhia Paulista, cabe enfrentar o problema do recorte temporal, e como este foi resolvido neste trabalho. Dada a existência de quase um século da Companhia Paulista, como empresa privada de 1868 a 1961, foi necessário fazer certas periodizações, e sublinhar alguns fatos, tendo como base principalmente a história da Companhia Paulista, seus trabalhadores e as vilas ferroviárias.

Para a história das ferrovias no estado de São Paulo, é clássica a periodização feita por Pinto (1903), que cobre de 1830 a 1890, dividindo em quatro fases segundo os tipos de concessões federais feitas às companhias para a construção de estradas. A periodização complementar a esta, é a de Matos (1974) que inicia em 1890 e termina em 1940, dividindo em décadas, para ressaltar os eventos mais importantes: 1890 -1900; 1900-1910; 1910-1920 (década em que se consolida a conquista do "sertão desconhecido"), tendo a década de 1920 quase que completado o mapa das ferrovias, e a construção pela Sorocabana da linha Mairinque-Santos, quebrando o monopólio da São Paulo Railway. Matos aponta como fim da era ferroviária a década de 1940. (MATOS, 1974: 99 -100). Há ainda o trabalho de Martins (1995) que analisa os planos elaborados pelo governo federal e faz um comparativo das ferrovias federais brasileiras entre 1934 e 1956, no estado de São 
Paulo. Apenas a São Paulo Railway é analisada.

Para a periodização da Companhia Paulista do ponto de vista da empresa, temos os trabalhos de Saes e Grandi, que realizam recortes temporais complementares. Saes (1981) estuda a Companhia Paulista até a crise do café em 1930, e Grandi (2013) estuda a Companhia a partir de 1930 até 1961 quando ela foi encampada, lembrando que os trabalhos tem enfoque econômico. Além disso, descobriu-se que Grandi (2007) possui um trabalho anterior sobre a Companhia de Estrada de Ferro Rio Claro, entre 1880 a 1903. Os dois ramais, onde estão localizadas as vilas ferroviárias, objeto de nosso estudo, foram construídas pela Companhia Estrada de Ferro Rio Claro, que em 1888, foi comprada pelos ingleses denominando-se Rio Claro Railway, e adquirida pela Companhia Paulista em 1892. O ano 1903 foi escolhido por Grandi (2007), devido a um ramal férreo aberto paralelamente ao Rio Mogi-Guaçu. A navegação fluvial deixa de ser interessante para a Companhia Paulista, e é então desativada. Tendo como objeto de estudo as vilas ferroviárias, ao início de nosso trabalho, não se sabia se as casas foram construídas pela Companhia de Estrada de Ferro Rio Claro ou pela Companhia Paulista. Ao longo do trabalho, observa-se que assim como as estações sofreram mudanças (inclusive de lugar, devido às

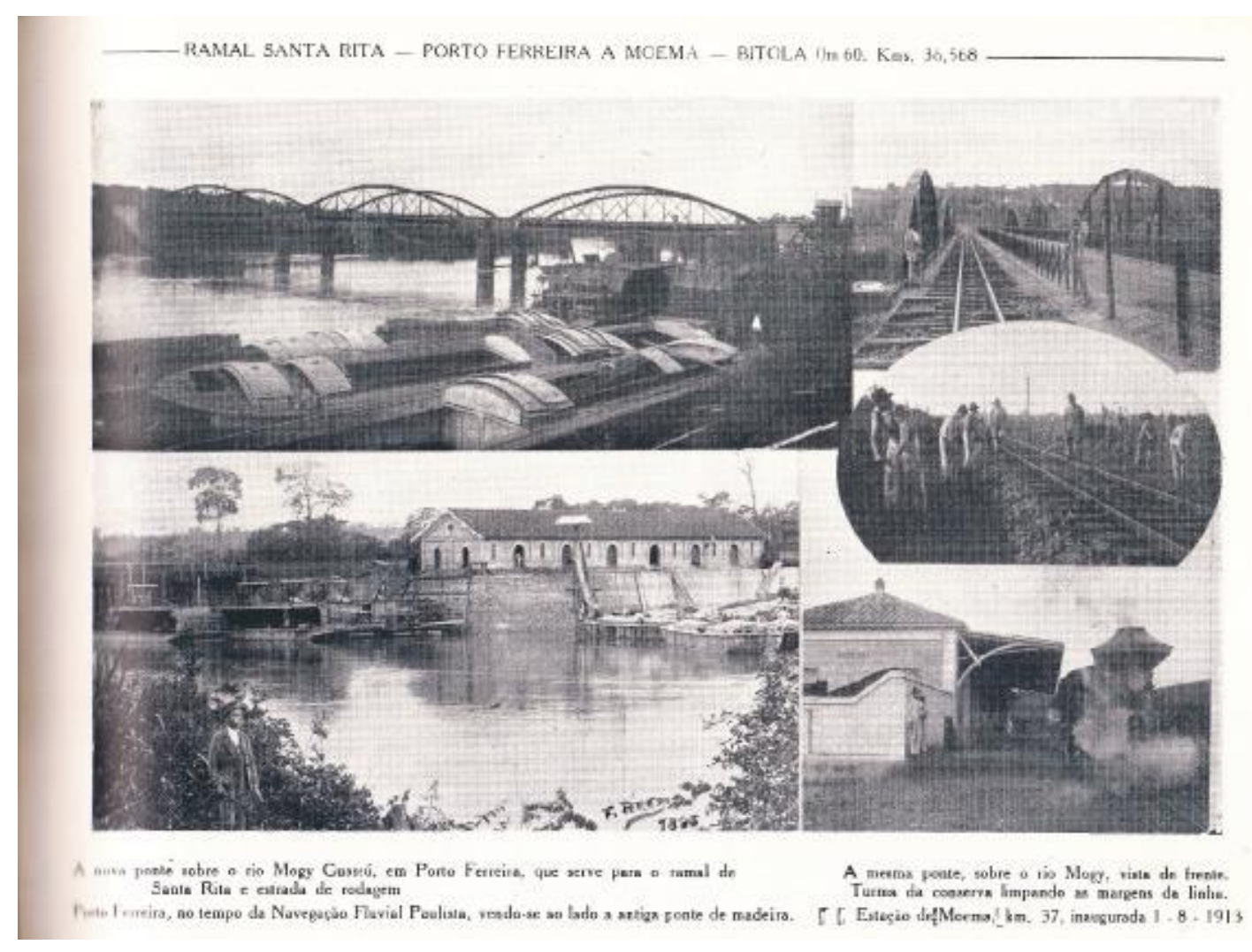

Foto 54 - Fotos do Rio Mogy Guassú e suas pontes. Fonte: Álbum Ilustrado da Companhia Paulista, 1901. 
retificações de traçado de linha), assim também as vilas ferroviárias podem ter atravessado várias fases. Além disso, com base nos relatórios da Companhia Paulista, tudo leva a crer que na década de 1920, por causa da construção de armazéns reguladores de café, as vilas ferroviárias objeto de nosso estudo foram construídas pela Companhia Paulista, apesar de pertencerem a cidades por onde passava a Companhia Estrada de Ferro Rio Claro.

Do ponto de vista dos trabalhadores da Companhia Paulista, temos o trabalho de Segnini (1982) que divide o largo período da companhia em três fases: a primeira fase (1868-1885), muito próxima à escravocrata, “caracteriza-se pela ausência de 'artifícios ofuscadores' aos olhos dos ferroviários, da lógica fundada na dominação contida na relação capital-trabalho(...)”; a segunda fase (1885 -1928), marcada pelo paternalismo nas relações de produção, "caracteriza-se à medida que as pressões exercidas sobre a burocracia pelos ferroviários, em busca de melhores condições de trabalho e de vida, não a manteriam mais alcançando seus objetivos de expansão e acumulação do capital se não modificasse seus instrumentos de dominação (...)”; e a terceira (1928-1961) “caracterizada pela reforma administrativa de 1928, dá-se como resposta 'cientifica' às necessidades crescentes, por parte do capital, do exercício da dominação sobre a mão-de-obra para obtenção de lucros em níveis máximos. (...)” (SEGNINI, 1982, p. 16), é a fase da Organização Racional do Trabalho e da Escola de Seleção e Formação, implantada por Roberto Mange, em 1934.

É ainda Segnini (1982) que aponta a Paulista como um complexo agroindustrial, deixando de ser simplesmente uma empresa de transportes, e "dentro deste complexo, a ferrovia foi sempre tida como sendo sua espinha dorsal, posto que dela surgiam os maiores lucros." (SEGNINI 1982, p. 82) Através da leitura dos relatórios da Companhia Paulista, Segnini (1982) enumera as inúmeras empresas por ela mantidas ${ }^{13}$. A Companhia Paulista foi constituída a princípio também como uma empresa fluvial, deixando de sê-lo em 1903; foi pioneira na eletrificação iniciada em 1922 (neste momento já uma empresa com presença de investidores estrangeiros); no transporte de passageiros utilizou vários tipos de vagões, importados dos Estados Unidos e da Inglaterra, e também fabricados nas oficinas de Jundiaí, como aparece nos relatórios da Companhia e é citado pelos entrevistados nas diversas pesquisas como: Pullman, Trem Azul, carros dormitórios, carros "R",

13 "Já não mais concentrava suas atenções somente no transporte ferroviário. Havia se tornado um complexo agro-industrial composto por um conjunto de empresas lucrativas em diferentes ramos - hortos florestais, oficinas mecânicas, frigoríficos, indústria de papel, colonização, transportes rodoviários, etc." (SEGNINI, 1982, p. 63) 
etc....

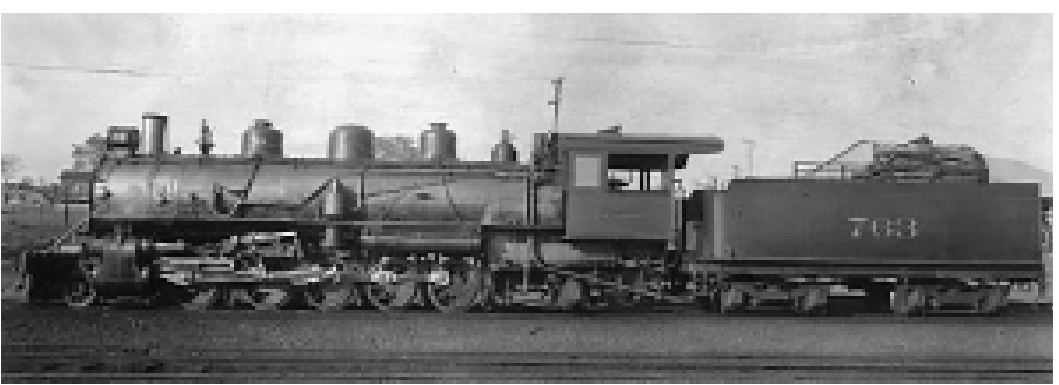

Foto $5 \mathbf{5}$ - Locomotiva a vapor da CP. Fonte: Museu Ferroviário de Jundiaí, s/d.

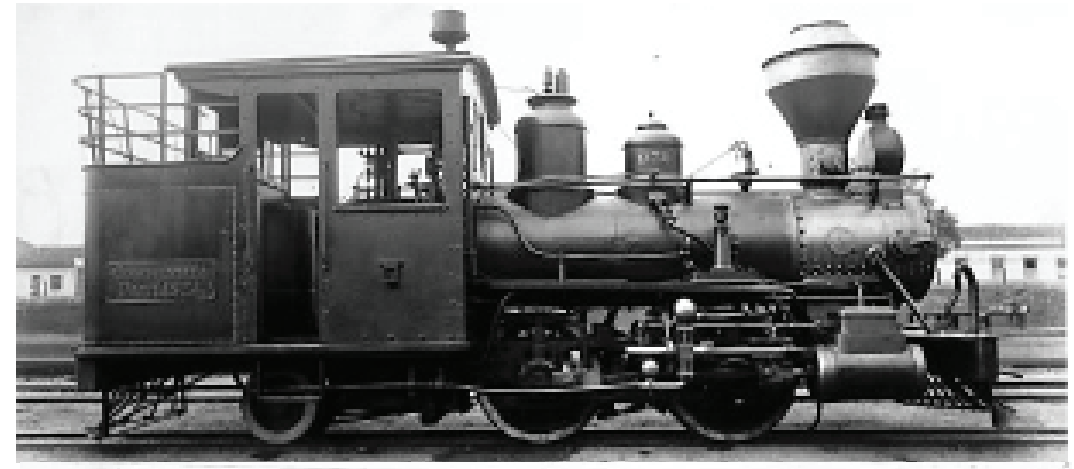

Foto 56 - Locomotiva a vapor da marca Baldwin pertencente à $C P$.

Fonte: Museu

Ferroviário de Jundiaí. s/d.

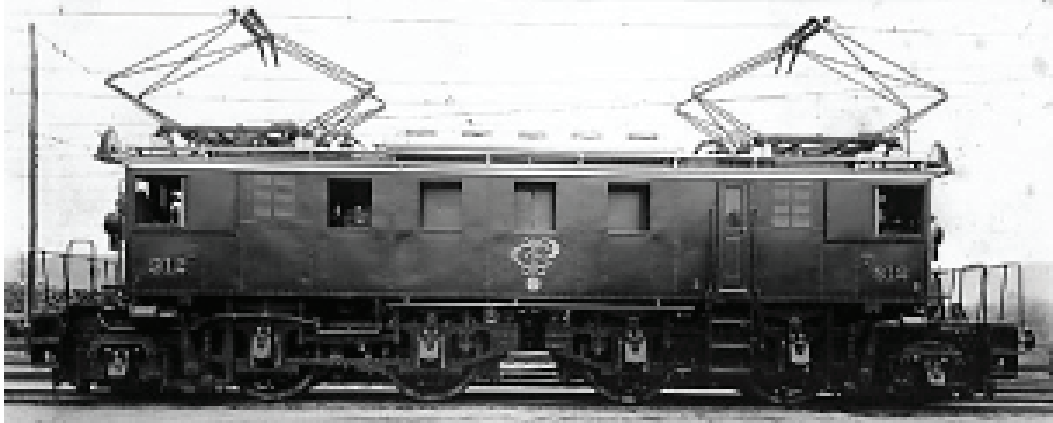

Foto 57 - Locomotiva elétrica $C P$. Fonte: Museu Ferroviário de Jundiaí. s/d.

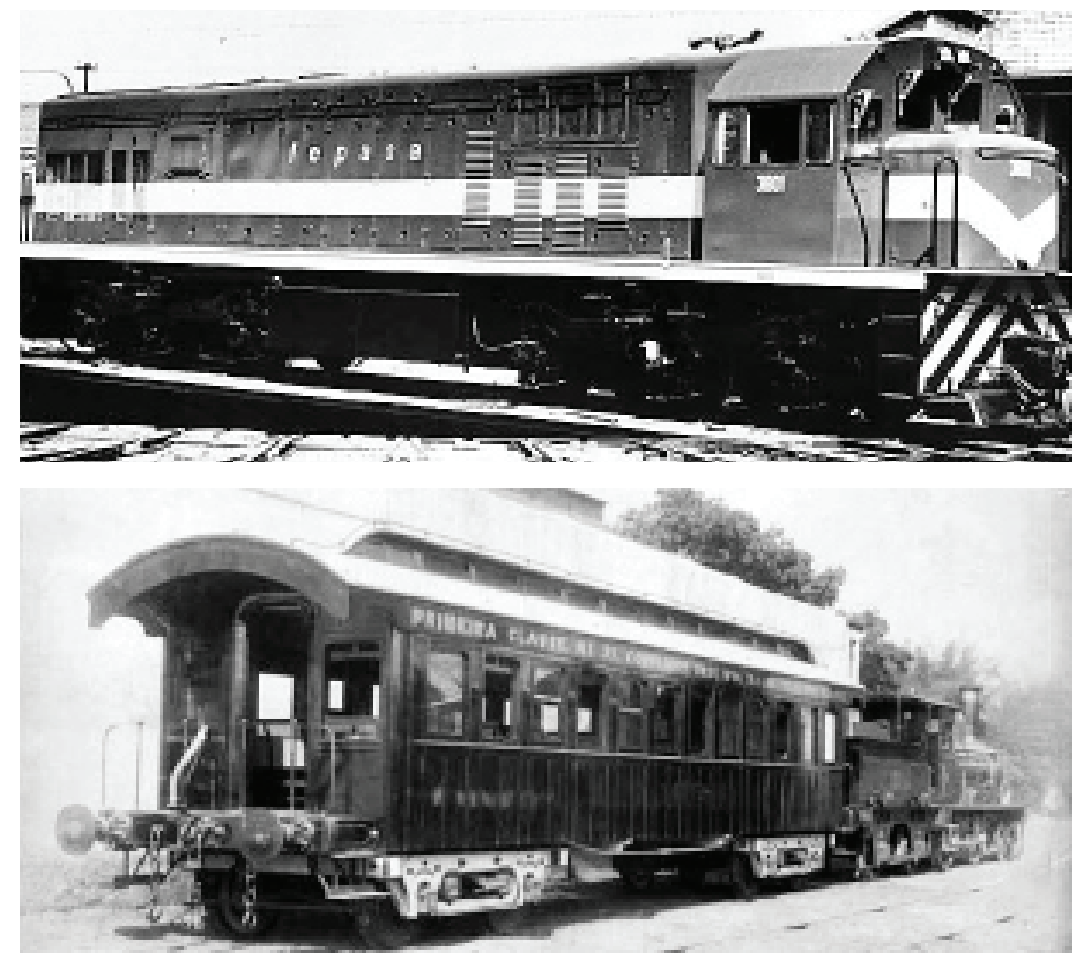

\section{Foto 58 -}

Locomotiva a diesel da CP.

Fonte: Museu Ferroviário de Jundiaí. s/d.

Foto 59 - Locomotiva a vapor e carro de 1 a. classe pertencente à CP. Fonte: Museu Ferroviário de Jundiaí. s/d. 


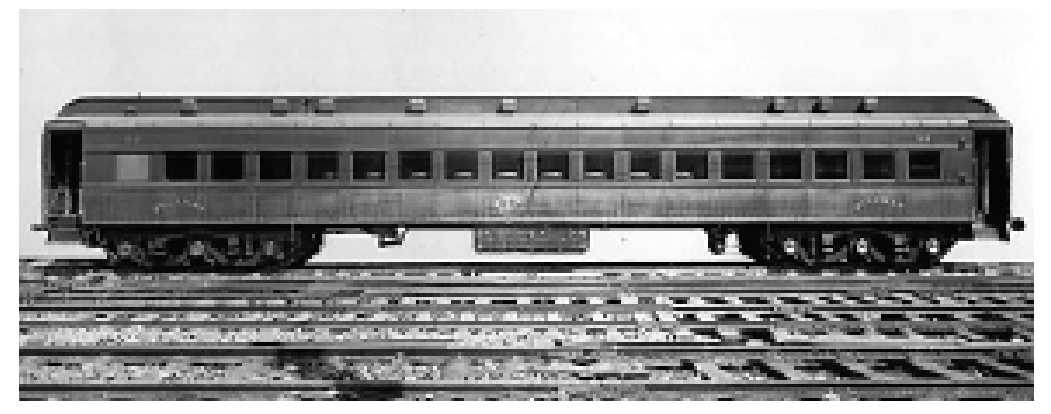

Foto 60 - carro Pullman da CP. Fonte: Museu Ferroviário de Jundiaí. s/d.

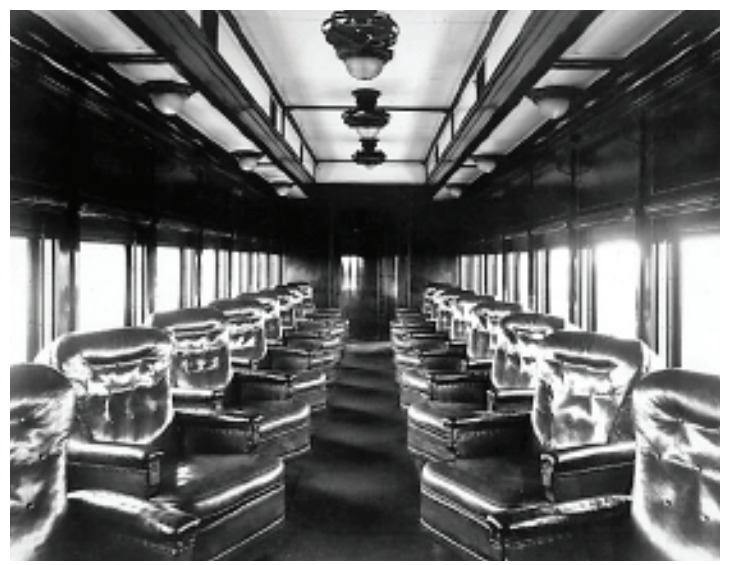

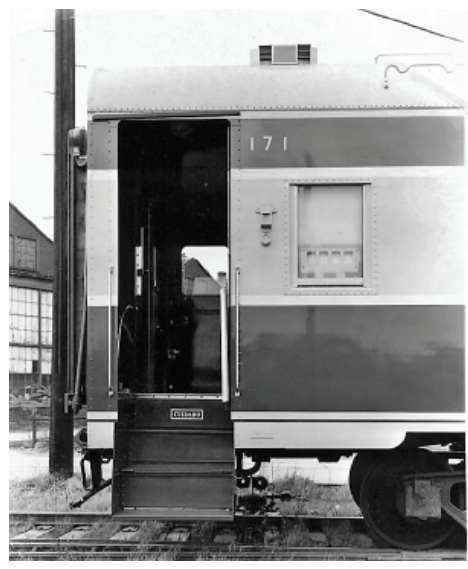

62

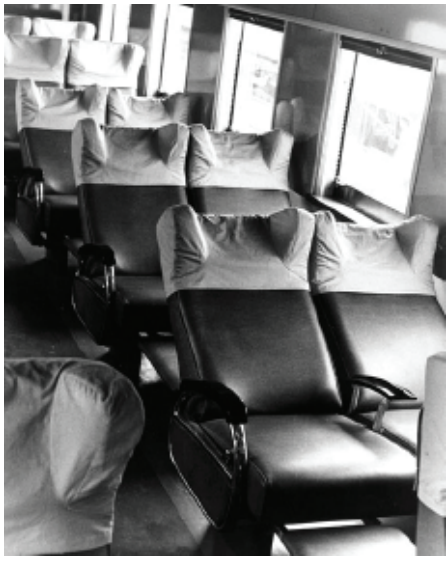

63
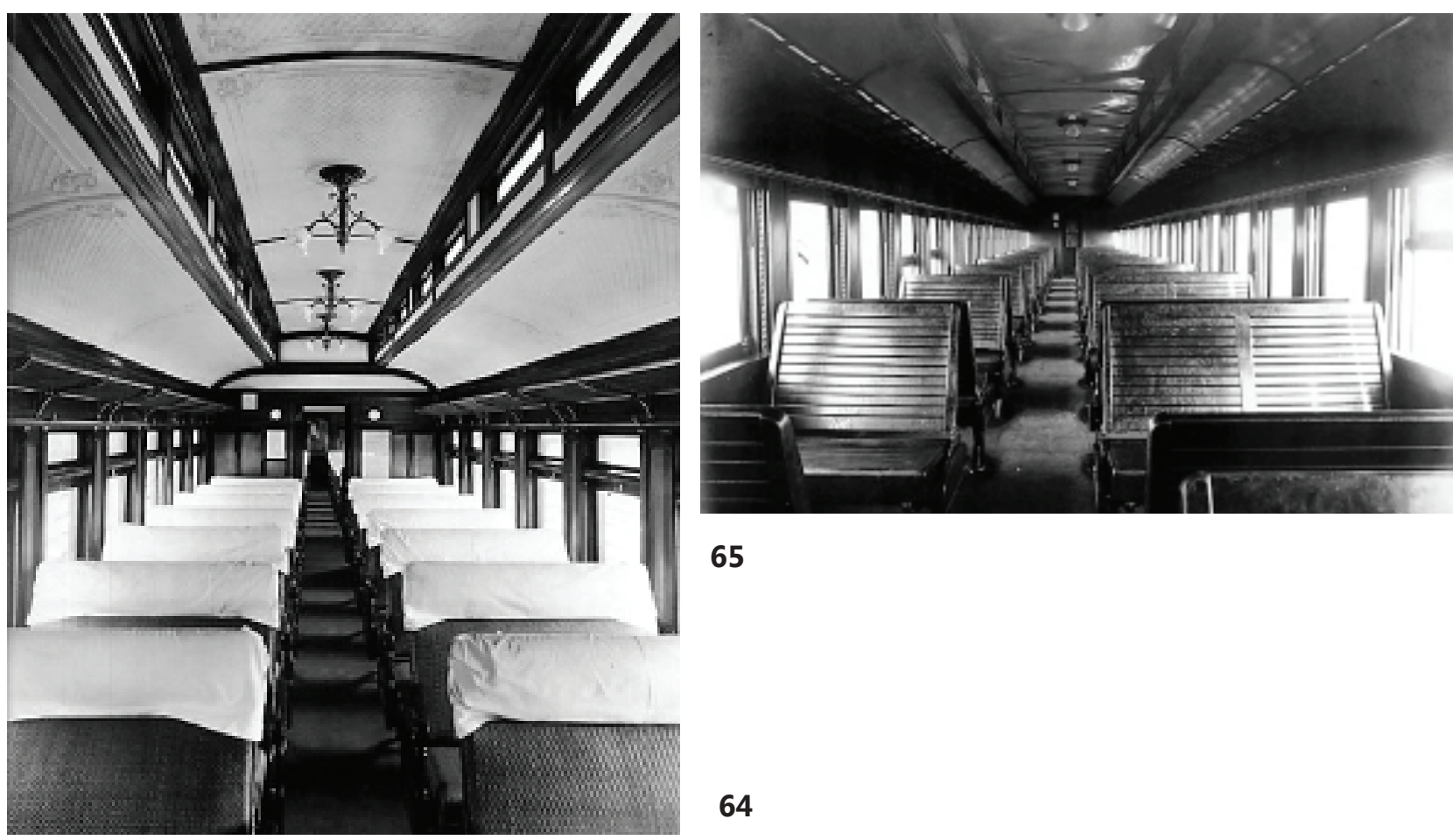

65

Foto 61 - Interior de um carro Pullman. Foto 62 - Carro trem "R". Foto 63 - Interior de um carro "R". Foto 64 - Interior de um carro de madeira de 1a. classe da CP. Foto 65 - Interior de um carro de madeira de 2a. classe da CP. Fonte: Museu Ferroviário de Jundiaí. s/d. 


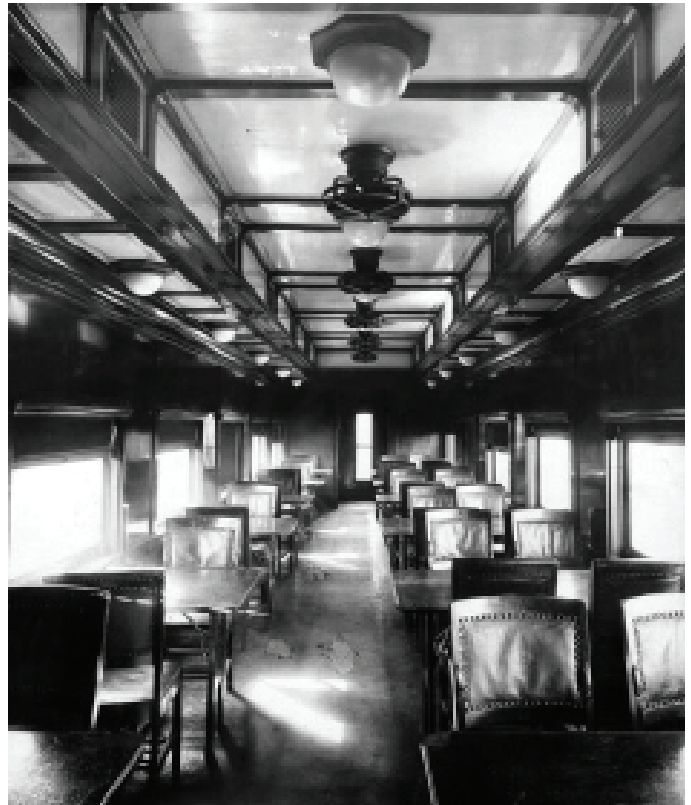

68
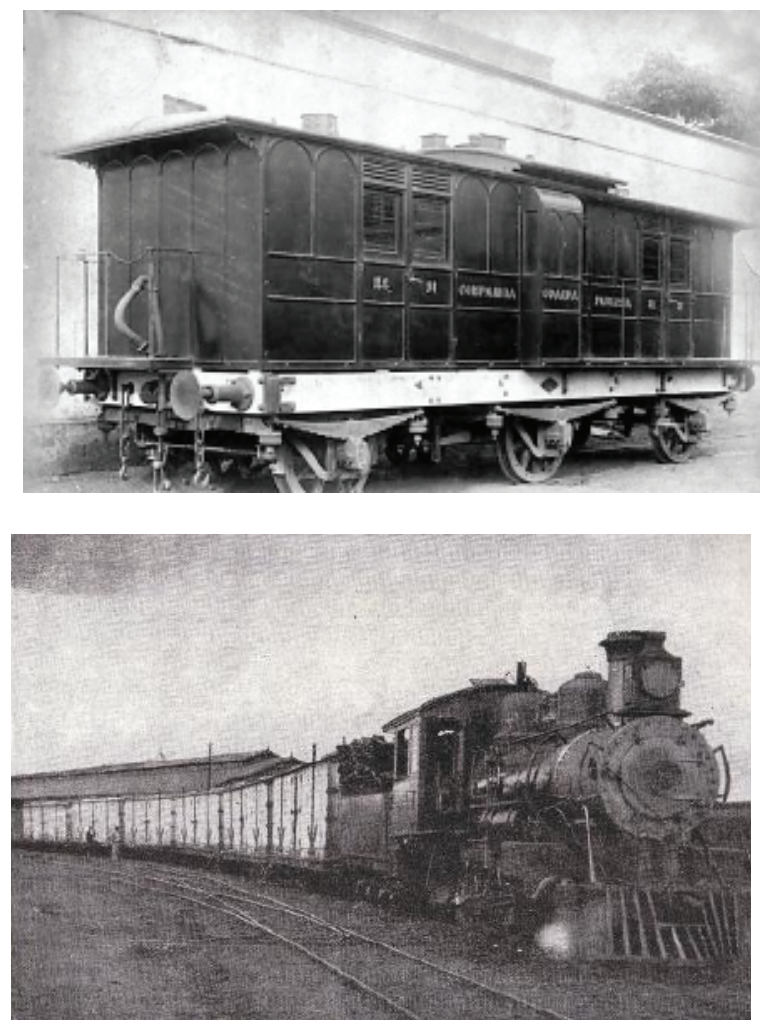

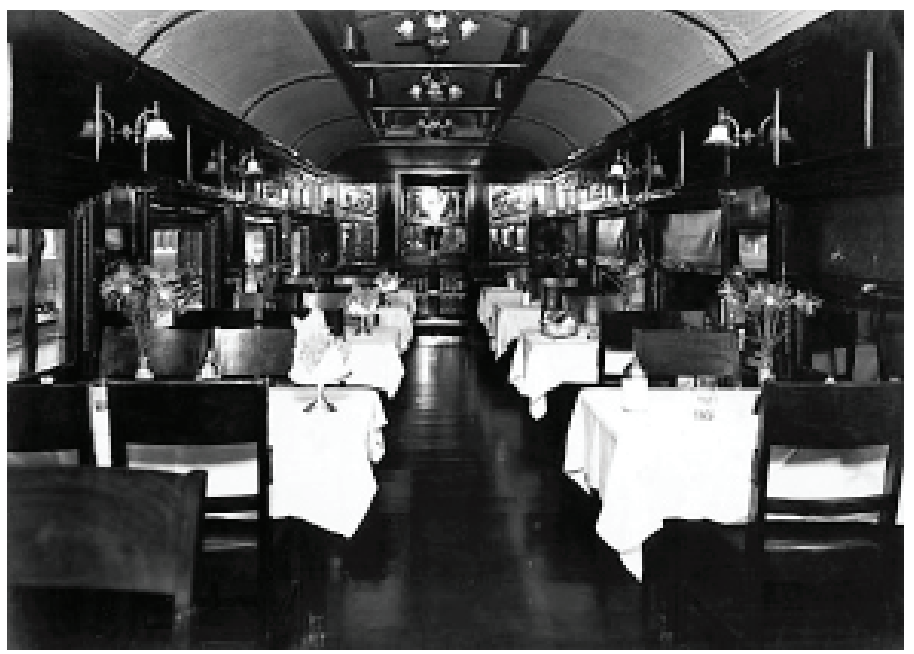

Fotos $\mathbf{6 6}$ e $\mathbf{6 7}$ - Interior de uma carro restaurante 67 (em aço) da CP. Fonte: Museu Ferroviário de Jundiaí. s/d.

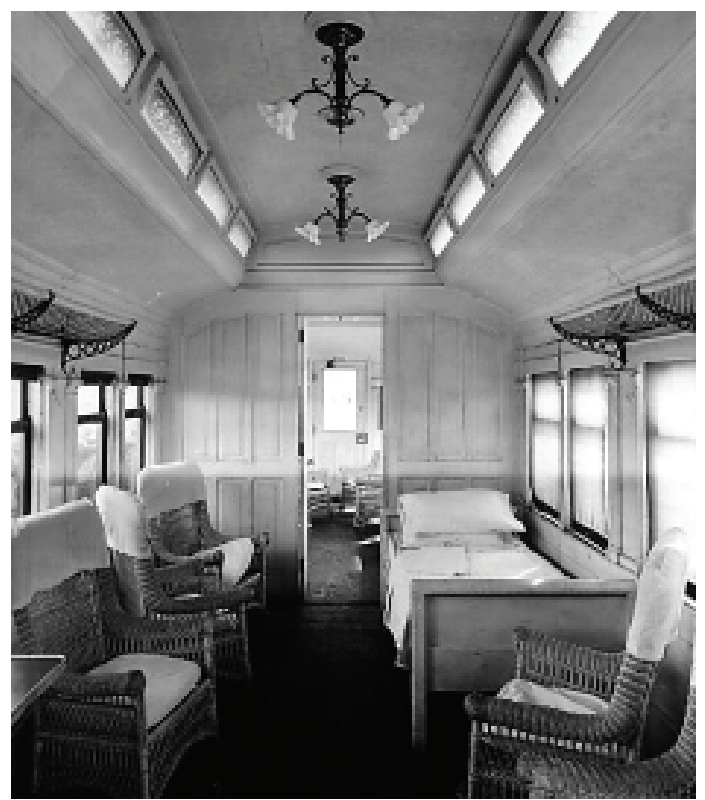

Foto 68 - Carro de transporte de presos. Foto 69 - Interior de um carro de transporte de enfermos Foto $\mathbf{7 0}$ - Carro frigorífico da CP. Fonte: Museu Ferroviário de Jundiaí. s/d.

Faz parte ainda deste pioneirismo a criação, em 1902, do Serviço Florestal ${ }^{14}$, com quatorze hortos florestais para cultivo de eucalipto, para fornecimento de lenha, dormentes e madeira para construção de vagões. Fazia parte ainda deste complexo agroindustrial,

14 "Em 1923, totalizava 3.522,9 alqueires distribuídos pelos hortos de Jundiaí, Boa Vista, Rebouças, Tau, Cordeiro, Loreto, Rio Claro e Camaquan. Neles se encontravam implantadas 8.506.000 árvores. Através delas, a Companhia assegurava aos acionistas uma renda de 85.000:000\$000, sem incluir terras, benfeitorias e semoventes. Chegou a possuir 14 hortos florestais, constituindo a maior pesquisa realizada, fora da Austrália, com eucalipto. (...)” (SEGNINI, 1982, p. 64) O responsável pelos hortos era o agrônomo Edmundo Navarro. 
um matadouro frigorífico em Barretos, criado através da Companhia Frigorífica e Pastoril, em 1909, e a participação também na Grace Paulista S. A. - Polpa e Papel, industrializando parte dos eucaliptos plantados em seus hortos florestais. ${ }^{15}$. Em 1928, criou a CAIC - Companhia de Agricultura Imigração e Colonização, cujo objetivo era colonizar terras, justificando a implantação dos trilhos, assim: "O comprador dava, inicialmente, a entrada de $20 \%$ e pagava o restante em quatro anos. Concomitantemente, a CAIC construía pequenos centros comerciais para aten-

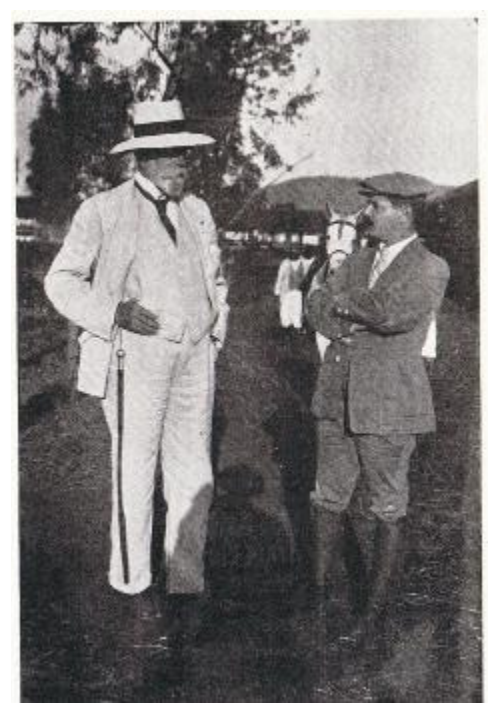
der estas propriedades rurais nascentes. Estes núcleos deram origem a cidades como Adamantina e Urânia, por exemplo." (SEGNINI, 1982, p. 66). Outra importante iniciativa nos anos 1920 , foi a criação de armazéns reguladores de café. Os armazéns foram construídos

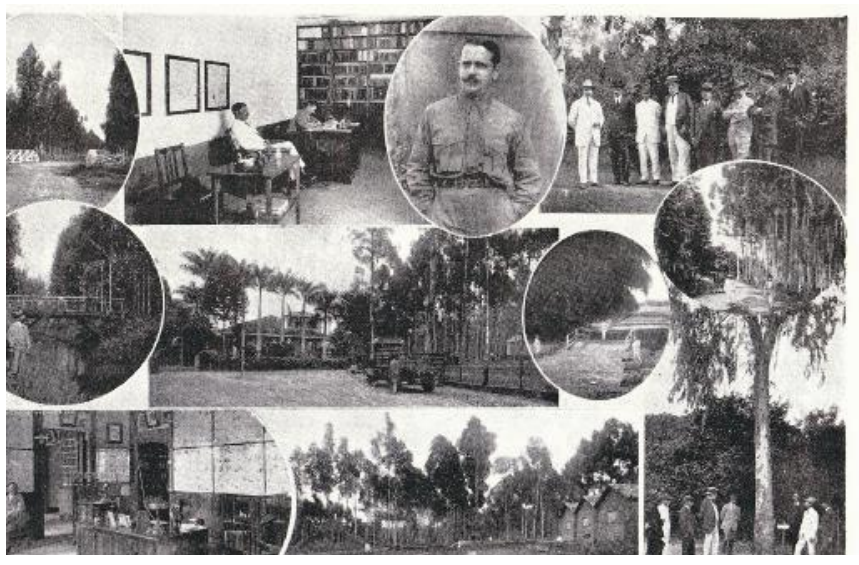
pelo Estado, mas em pontos de entroncamento ferroviário, escolhidos pela Paulista (SEGNINI, 1982, p. 66-7). A autora ainda aponta que outra forma de auferir lucros foi com a compra de pequenas vias férreas, que foram se tornando suas tributárias, como por exemplo, a Estrada de Ferro Morro Agudo, a de Monte Alto, a de Dourado e a de São Paulo-Goiás (SEGNINI, 1982). Todas estas iniciativas mereceriam um estudo aprofundado,

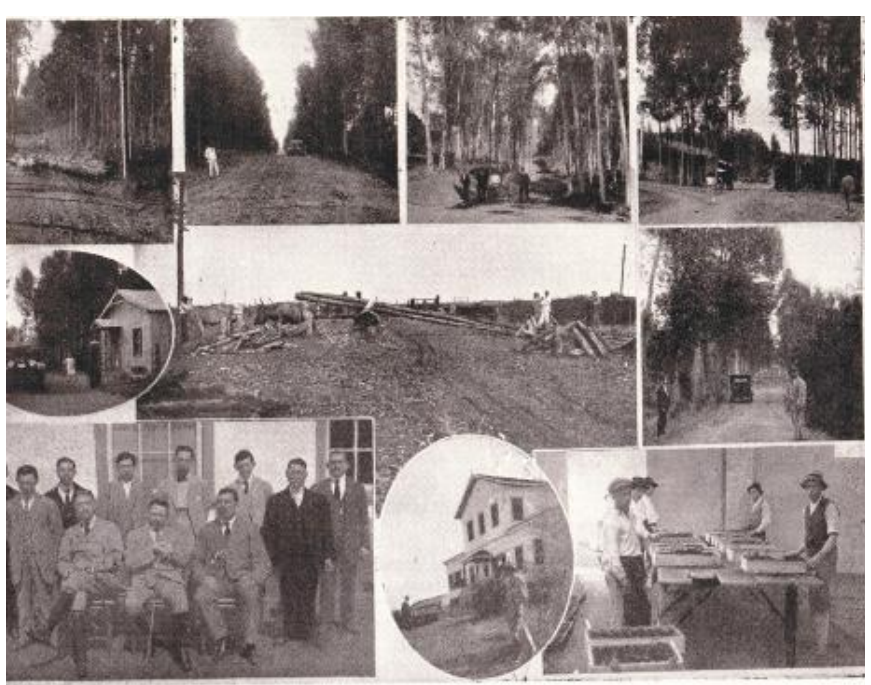

Foto 71 - Conselheiro Antônio Prado e Edmundo Navarro. Fotos 72 - Fotos diversas dos hortos florestais de Rio Calro e Loreto. Foto $\mathbf{7 3}$ - Fotos diversas do horto florestal de Rio Claro. Fonte: Álbum Ilustrado da CP, 1918.

\section{$15 \quad$ Ainda que não mencionado por}

Segnini, mas durante a pesquisa no Museu Ferroviário de Jundiaí, encontrou-se uma foto de uma pedreira. No relatório do ano 1912, fala-se de pedreiras, e nas vantagens da utilização dos lastros de pedra em relação as de terra. Resta saber, se também a Companhia Paulista possuía pedreiras para fornecimento de pedras para os lastros nos leitos dos trilhos. 
porém não fazem parte do escopo deste trabalho. Diante de toda esta riqueza, é temerário enveredarmos por outros caminhos, e perder de vista o objeto de nosso estudo: as vilas ferroviárias.

Sobre os trabalhadores ferroviários, há ainda o trabalho de Zambello (2005) que faz a periodização do ponto de vista do sindicalismo dos ferroviários da Paulista, dividindo em quatro fases: a) até 1929: Ligas Operárias e repressão dos governos da República, ligada às elites dos proprietários rurais e das estradas de ferro; b) 1930 - 1935: lideranças comunistas e da Federação Regional dos Ferroviários, greve de 1934 e prisão de suas lideranças; c) 1935 - 1954: mobilização dos comunistas e dos sindicatos, intervenções do DEOPS (Departamento de Ordem Social e Política) e intervencionismo ministerial. E 1961 - 1964: da encampação da Paulista até o golpe de Estado. Da periodização de Zambello (2005) ressalta-se a greve de 1906, parece ser a maior greve ferroviária acontecida na Companhia Paulista. Durou entre os dias 15 a 29 de maio, e ao longo destes dias conseguiu a adesão de outros trabalhadores de diversas companhias ferroviárias e também de outras empresas.

O motivo da greve na Paulista era o pedido de substituição de dois chefes, um deles o engenheiro Francisco Paes de Monlevade. Devido a política de modernização (com a compra de novas máquinas, a Companhia Paulista instituiu três feriados não pagos e inclusive demissões do pessoal das oficinas e manutenção de linhas) e o fim da obrigatoriedade de inscrição na Sociedade Beneficente, mal administrada pela companhia, segundo os grevistas. (FERREIRA, 2010, p. 122). Entre as reivindicações: excesso de trabalho, sobre-tempo (tempo de deslocamento da moradia até o local onde o trabalho seria executado)

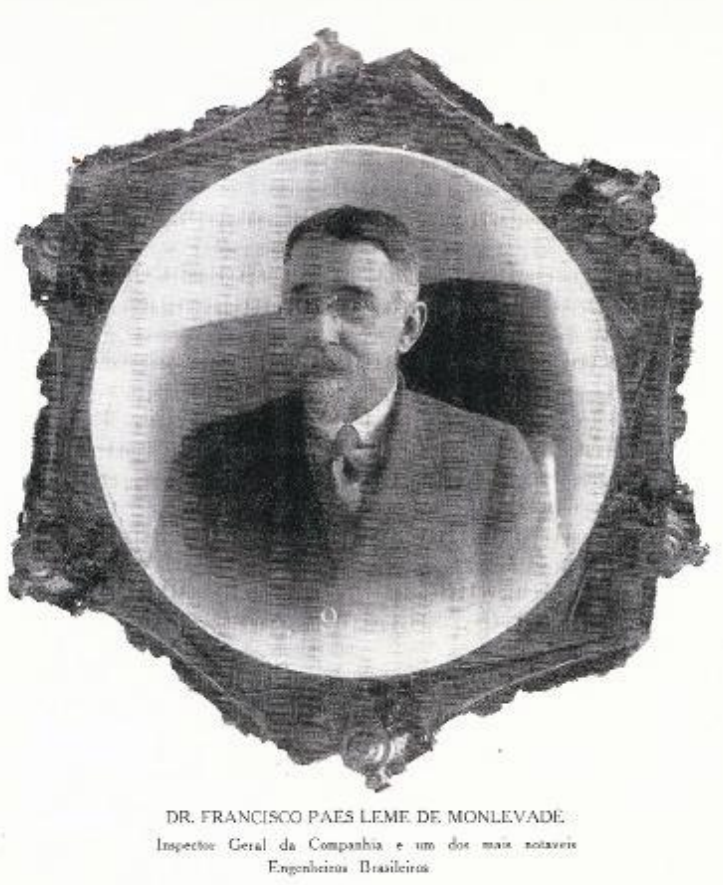

Foto 74 - Francisco Paes de Monlevade. Fonte: Álbum Ilustrado da CP, 1918. de trabalho não computado, rebaixamento de carreiras (ex: maquinista a foguista) (ZAMBELLO, 2005, p. 129). 
A repressão aos grevistas era feita pelo DEOPS - Departamento de Ordem Política Social paulista, iniciativa dos fazendeiros paulistas para reprimir as greves desde a década de 1910. Apesar de Zambello (2005) identificar somente no terceiro momento, o organismo atuou nas quatro fases por ele identificadas. Entre as décadas de 1950 a 1960, seguem-se interferências políticas nos sindicatos, numa política conhecida como peleguista; e coincide com o período de crise ferroviária, com enormes gastos de pessoal, e as ferrovias federais e estaduais com salários maiores que os da Paulista.

Desde 1951, o sindicato manifestou a intenção de lutar pela encampação da Paulista, justamente quando foi cogitada a estatização da Mogyana, pensando que assim, melhoraria a situação dos ferroviários. E assim, diante de pressão social, greves frequentes; pressão políticas, parece que a "encampação nasceu a partir de uma relação de dependência com a ideologia estadista.” (ZAMBELLO, 2005, p. 119). Alguns setores acreditavam que a solução para a crise ferroviária seria a administração federal que reuniria todas as ferrovias e da política rodoviarista em detrimento da ferroviária. Apesar dos saldos positivos (a única a sustentar esta posição frente a outras ferrovias deficitárias), cerca de $70 \%$ da receita da Companhia Paulista eram gastos com pessoal, além já de ter feitos empréstimos anteriormente para manter reaparelhadas e em perfeito funcionamento as suas linhas. Assim, a Companhia Paulista não resistiu, e foi encampada pelo governo estadual, depois de quase um século de existência.

Do ponto de vista das vilas ferroviárias, e tendo como referência estudos sobre as vilas operárias do período, a grosso modo, pode-se dizer, que três questões influenciaram a produção das mesmas, e dessa maneira, também as vilas ferroviárias. A primeira delas são as questões sanitaristas, dentro das quais vários atores sociais, políticos, engenheiros e médicos, formularam modelos do que deveria ser a "casa operária". A segunda questão é o tema da racionalização da habitação que, no Brasil, penetrou fortemente através do IDORT, Instituto de Organização e Racionalização do Trabalho. Paralelamente, a estas duas grandes questões, há a terceira questão: o debate da forma de acesso a esta moradia. Com relação a esta última questão, pode-se dizer que o Estado esteve sempre presente no debate, mas não em sua produção, e tal presença tornou-se cada vez mais forte a partir de 1940. Tal data coincide com a crise ferroviária e também a retirada da iniciativa privada, ou seja, das empresas, da produção das vilas operárias, ainda que tenham existido posteriormente a tal data.

É possível colocar marcos para a discussão destas três grandes questões. É cla- 
ro, que no mundo, tais questões estavam sendo debatidas desde os primeiros problemas trazidos pela Revolução Industrial, e que, de certa forma, o que era debatido internacionalmente, influenciou o Brasil. Em São Paulo, um destes marcos é o Primeiro Congresso Brasileiro de Habitação, de 1931, é citado por diversos autores entre eles: Carpintéro (1997), Segawa (2000), Correia (2004) e Bruna (2010), já que no mesmo, estavam concentrados os principais atores sociais e condensadas as primeiras ideias da "casa operária", que deveria ser econômica, higiênica e moral. Contudo, o debate e as formulações da casa operária ou a casa para o trabalhador não param por aí. Assim, um segundo marco seria a Jornada de Habitação Econômica, promovida pelo IDORT em 1941 Neste último evento, nota-se a presença dos industriais nos debates da moradia. $\mathrm{O}$ assunto é bastante aprofundado por Correia (2004). E paralelamente a estes dois marcos, está a reforma (não a sua criação, que é de 1923) das Caixas de Aposentadorias e Pensões em 1931, e no ano seguinte o Decreto-Lei 21.326, que aprova o regulamento para a aquisição ou construção de casas populares pelas Caixas de Aposentadorias e Pensões. Tais Caixas de Aposentadorias e Pensões serão transformadas nos Institutos de Aposentadorias e Pensões (IAP) em 1933, os quais em 1937, aprovam um novo regulamento para a aquisição de prédios destinados à moradia para as sedes e associados dos IAPs. Assim, chega-se ao Estado Novo, já com a ideologia da casa própria fortemente implementada. Com base nos temas da criação e reforma das Caixas de Aposentadorias e Pensões, respectivamente 1923 e 1931, e o da criação do IDORT, é que a bibliografia que versa sobre as vilas operárias, estabelece várias relações com a periodização estabelecida por Segnini (1982), sendo bastante elucidativa para nosso estudo.

A breve história da Companhia está baseada nos autores acima citados. Procurou-se relacionar a história das ferrovias, a história da Companhia Paulista, a história de seus trabalhadores e a história das vilas operárias, sublinhando-se fatos relacionados às vilas ferroviárias estudadas. Deste modo, resolveu-se adotar a seguinte periodização, em três fases: a) 1868 -1892, tendo como marcos a Criação da Companhia Paulista e a compra da Rio Claro Railway Company; b) 1892 - 1931, o ano de 1931 foi estabelecido como marco, pois além de englobar a fase chamada "paternalista" por Segnini (1982), tem-se inúmeras iniciativas pioneiras da Companhia na década de 1920, que vai até a crise do café entre 1930 e 1940. Ainda, 1931 é marcado pelo ano do Primeiro Congresso de Habitação Econômica e a reforma das Caixas de Aposentadorias e Pensões, que afetam a produção das vilas operárias em geral, e consequentemente as vilas ferroviárias. Segue-se com o 
terceiro período, c) 1931 - 1961, que engloba a crise ferroviária e a era da organização científica do trabalho, com a criação do IDORT, que afeta vários aspectos do trabalho e da vida do trabalhador inclusive sua moradia, que é tratada na Jornada da Habitação Econômica em 1941.

\section{8 - 1892: A criacão da Companhia Paulista e a compra da Rio Claro Company}

A Companhia Paulista foi a primeira totalmente formada com capital nacional, tendo como presidente Clemente Falcão de Souza Filho. Os nove maiores acionistas eram brasileiros, segundo Saes (1979, p. 47):

O primeiro relatório, aos acionistas da Companhia Paulista nos indica a existência de 25.000 ações distribuídas por 654 subscritores (32) número que por si só já nos parece significativo: não mais se tem a empresa individual, nem mesmo a empresa familiar e sim a grande empresa em sociedade (...) Embora individualmente nenhum acionista tivesse mais de 1000 ações (ou 4\% do total), os nove maiores acionistas assumiam mais de $20 \%$ do total. Eram eles: Barão de Itapetininga e Barão de Limeira (1000 ações cada); Barão do Cascalho e Barão de Piracicaba (600 cada); Barão do Rio Claro, Francisco A. Souza Queiroz, Luiz A. de Souza Barros, Martinho da Silva Prado e Nicolau Vergueiro $^{16}$ (500 cada). Se incluíssemos nesta relação irmãos e filhos destes acionistas com menor número de ações o total deveria subir a $30 \%$ ou mais do capital subscrito.

É muito interessante analisar as listas dos acionistas, nas quais existem verdadeiras árvores genealógicas, com nomes de mulheres e filhos dos fazendeiros do café. No princípio, são poucos nomes estrangeiros, um ou dois, de algum possível engenheiro, e inclusive de espólios ou doações à Igreja, pois aparecem nome de conventos e igrejas, com participações ínfimas. Por muito tempo, não houve bancos como acionistas. Saes 16 A seguir os nomes dos barões e suas origens: Barão de Itapetininga é Joaquim José dos Santos Silva (e Luiz Antonio de Souza Barros proprietários e capitalistas em São Paulo); Barão de Limeira é Vicente de Souza Queiroz e seu irmão Francisco A. de Souza Queiroz, filhos do Brigadeiro Luiz Antonio estiveram claramente ligados à economia açucareira e em vínculo estreito com a família Vergueiro; Barão do Cascalho é José Ferraz Campos, natural de Itu; Barão de Piracicaba é Antonio Paes de Barros, tido como um dos introdutores do café no Oeste paulista; Barão do Rio Claro é José Estanislau de Oliveira; Martinho da Silva Prado - fazendeiro de açúcar e de café; Os demais tem origem na agricultura de São Paulo, e participam da fase açucareira. (cfr.SAES, 1979, p. 48-9). Além disso, a primeira diretoria da CP figuram “além de Martinho Prado e Francisco A. de Souza Queiroz, três elementos mais ligados à cidade de São Paulo e à de Santos: Clemente Falcão de Souza Filho, Bernardo A. Gavião Peixoto e Ignácio Wallace da Gama Cochrane." (SAES, 1979, p. 48) “O Senador Souza Queiroz e seu cunhado, José Pereira de Campos Vergueiro, que em 1864 propôs uma nova alternativa à extensão a partir de Jundiaí. Para Vergueiro, seria importante que se construísse uma estrada de rodagem ligando Jundiaí a Rio Claro" (POZZER, 2007, p. 32) 
(1979, p. 210) fala de uma maior participação do capital estrangeiro, através dos bancos a partir de 1911. ${ }^{17}$
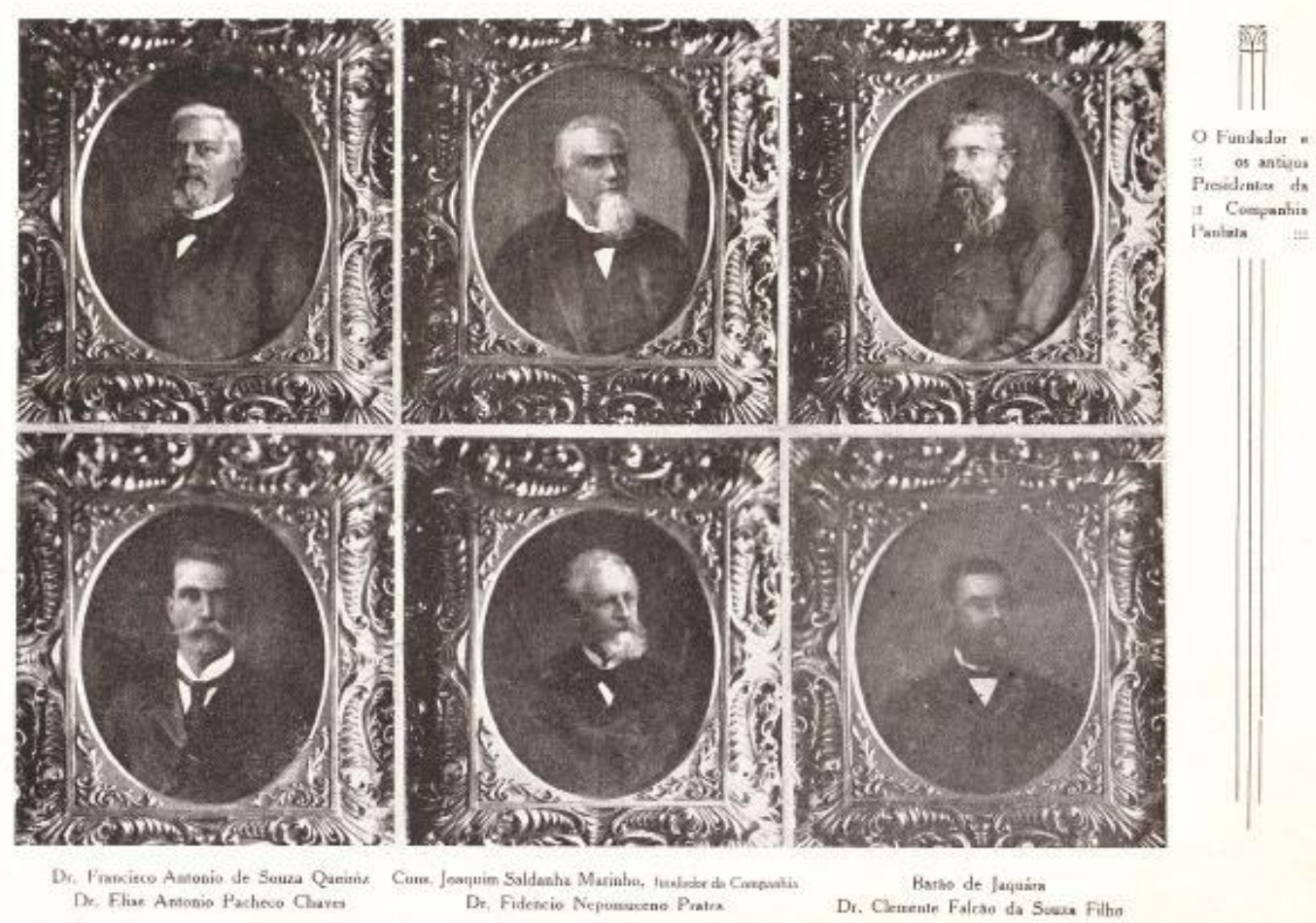

Foto 75 - O fundador (Francisco Antônio de Souza Queiroz) e os antigos presidentes da CP. Fonte: Álbum Ilustrado da CP, 1918.

É bastante apropriado o termo que Zambello (2005) utiliza para denominar estes agentes sociais como "fazendeiros-capitalistas diretores de ferrovia", porém convém lembrar, que antes de tudo eram capitalistas, assim o capital não se encontrava apenas nas fazendas de café, ou na ferrovia. No trabalho anterior, vimos que vários autores, por exemplo, Dean (1971) e Cano (1977), falam da presença destes fazendeiros na indústria, no comércio e nos bancos e Saes (1979, p. 34) afirma ainda: “(...) É certo, alguns fazendeiros podem ter passado à indústria sem a prévia experiência ferroviária (caso provável das fábricas do interior); a maior parte, no entanto, parece ter encontrado na ferrovia

17 “(...) Na Companhia Paulista, em 1905, há apenas três acionistas com mais de mil ações - Eduardo Prates (12.000); Banco do Comércio e Indústria de S. Paulo (10.570) e William Lidgerwood (13.995). Em 1909, Prates e Lidgerwood continuam a aparecer, mas o Banco Comércio e Indústria já não é registrado. Aparece, no entanto, o Banque de Paris et des Pays Bas em 45.000 ações. Em 1911, a mudança é completa: Prates tem apenas 4.000 ações, Lidgerwood não aparece entre maiores acionistas, que agora incluem: Banque de Paris et des Pays Bas (50.000), Empire Trust Co. de New York (55.000), Caisse Générale de Réports et de Dépots (22. 381) e Banca Francese e Italiana per l'America del Sud (13.031). Estas quatro instituições, inegavelmente relacionadas com Farquhar, detinham, por em 1911, 35\% do capital representado por 400.000 ações distribuídas entre 1771 acionistas.” (SAES, 1979, p. 210). 
o caminho de sua 'urbanização'." O certo é que os acionistas eram influentes economicamente, como em termos sociais, políticos e culturalmente. Conseguiram, na esfera política, concessões federais e estaduais de ferrovias. Culturalmente, pois alguns destes fazendeiros capitalistas diretores de ferrovias, enviaram seus filhos a estudar engenharia na Europa.

\section{$\underline{\text { A Companhia Rio Claro e a aquisicão pela Companhia Paulista }}$ $\underline{\text { em } 1892}$}

A criação da Companhia Rio Claro envolve questões interessantes como, a influências dos barões do café, a guerra pelas zonas de influência, a participação das figuras importantes da engenharia em seu traçado. Zambello (2005, p. 40-7) trata do projeto do traçado da Estrada de Ferro São Carlos do Pinhal entre 1880 e 1883, bem como Campos (2007), através da figura de Paula Souza um dos engenheiros responsáveis pela construção. Porém o estudo mais aprofundado sobre a Companhia Rio Claro é o de Grandi (2007). Seu trabalho abrange de 1880, ano de criação da Companhia até 1903, ano de desativação da navegação fluvial justamente por esta tornar-se desinteressante pela concorrência férrea no mesmo trecho. Pinto (1903) também justifica as vantagens da compra da Rio Claro Railway. É nestes autores que baseia- o relato a seguir.

Os donos da São Paulo Railway tinham a concessão imperial para ir até Rio Claro, mas não tinham interesse em fazê-lo (ZAMBELLO, 2005, p. 40), assim como ocorreu com a construção de Campinas, a construção foi cedida à Companhia Paulista, que estendeu suas linhas, em bitola larga (1,60 metros), até Rio Claro, com a inauguração da linha em 11 de agosto de 1876. Esta permanece ponta de linha da Paulista até 1884 (SOUKEF, 2005, p. 76-7). A partir de Rio Claro inicia-se a história da Companhia:

A história da Companhia E.F. Rio Claro vincula-se diretamente à questão do prolongamento da estrada de ferro da Companhia Paulista. Desde o contrato de 1873, firmado com o governo provincial, a Paulista detinha o direito de prolongamento além de seu ponto terminal, aberto ao tráfego em 1876 no município de Rio Claro. Porém, antes mesmo em 1873, o governo imperial encomendou estudos a respeito da viabilidade de implantação de uma via de comunicação entre as Províncias de São Paulo e Mato Grosso.(...) (GRANDI, 2007, p. 30)

O governo encaminhou tais estudos ao engenheiro Pimenta Bueno, traçado que “justificou a possibilidade de subir facilmente pelo vale do Rio Corumbatai, no sentido 
da interseção dos Rios Tietê e Mogi-Guaçu para se alcançar as cabeceiras do Rio Turvo, afluente do Rio Grande” (BUENO, 1876, p. 11 apud GRANDI, 2007, p.30) afirma que a Companhia Paulista não concordava com este traçado, e provocou um debate político entre aos anos de 1879 e 1880. A Companhia Paulista insistia no projeto em direção a Brotas e Jaú, contrariando interesses de fazendeiros de Rio Claro, São Carlos e Araraquara. ${ }^{18} \mathrm{O}$ fazendeiro mais influente na área era o Visconde de Rio Claro ou José Estanislau de Melo Oliveira, grandes proprietários rurais em Cuscuzeiro, antes Anápolis e atual Analândia. ${ }^{19}$ Quem fazia a defesa do traçado da Paulista era o então engenheiro da Companhia, Adolpho Pinto. Além disso:

A principal prerrogativa utilizada pela Paulista contra o projeto de concessão do governo se referia à questão da garantia de zona. Para a Paulista, a construção do traçado proposto prejudicaria o movimento de tráfego da linha férrea de Casa Branca da Companhia Mogiana e o de sua própria linha no ramal de Mogi-Guaçu (RCPEF, 1879, p. 53-55).

Novos traçados foram realizados, tanto pela Paulista, através do engenheiro-chefe Dr. Francisco Lobo Leite Pereira, e submetidos à apreciação do governo. Este, por sua vez, encarregou novos estudos ao engenheiro Eusébio Stevaux. Os estudos de Eusébio Stevaux foram apresentados pelo governo à Paulista, que recusou a proposta. Posteriormente, não houve interessados na concessão, fazendo com que o governo imperial publicasse editais de concorrência para a construção da ferrovia, mas desta vez "de acordo com o traçado Pimenta Bueno, compreendendo um ramal para Brotas, Dois Córregos e Jaú, mas em que se alterava a bitola de 1,60m para a de 1,00m.” (RCPEF, 1880, p. XVII apud GRANDI, 2007, p.38; PINTO, 1977, p. 65)

E assim, os dois principais fazendeiros da região Visconde de Rio Claro (José de Estanislau de Melo Oliveira) e seu genro Barão do Pinhal (Antônio Carlos de Arruda Botelho $)^{20}$ constituíram a Companhia Rio Claro, ambos integrantes do Partido Liberal, que assumiu o poder da Província de São Paulo em 1878. Segundo Grandi (2007, p. 41) esse fato contribuiu para que o governo da província aprovasse o traçado, de acordo com os interesses dos mesmos. Também Campos (2007, p.145-7) trata das questões políticas na determinação deste traçado. Um terceiro maior acionista, que também foi indicado para ocupar a presidência da primeira diretoria foi o Barão de Araraquara (DINIZ, 1975, 18 GRANDI (2007) recomenda em nota ver também SAES, 1981; MATOS, 1974; DEAN, 1977; MATOON Jr., 1971.

19 Provável homenagem à sua esposa Anna Brandina de Queirós Aranha de Arruda Botelho.

20 Mais sobre as biografias das duas figuras em Grandi (2007, p. 41-2) 
p. 839). O estatuto da Companhia de Estrada de Ferro Rio Claro foi aprovado através do decreto $\mathrm{n}^{\circ} 8639$ de 12 de agosto de 1882. Para as obras de construção da ferrovia foi encarregado o engenheiro Antônio Francisco de Paula Souza. ${ }^{21}$

O trajeto ferroviário traçado pelo próprio barão do Pinhal, que conhecia muito bem toda a região, tinha em determinados trechos condições naturais pouco favoráveis ao estabelecimento de uma linha férrea. Para se atingir o interior do planalto paulista pelo contorno do vale do Rio Corumbataí, o barão optou subir a serra pelo morro do Cuscuzeiro. (GRANDI, 2007, p. 45)

Este parece ser o traçado que passa por Analândia e chega a São Carlos do Pinhal, inaugurado em outubro de 1884. E, em janeiro do ano seguinte, alcança Araraquara (ZAMBELLO, 2005, p. 41) O traçado do edital de Rio Claro a Jaú foi entregue a outros dois engenheiros os irmãos Adolpho e Luis Augusto Pinto, e mais tarde transferida

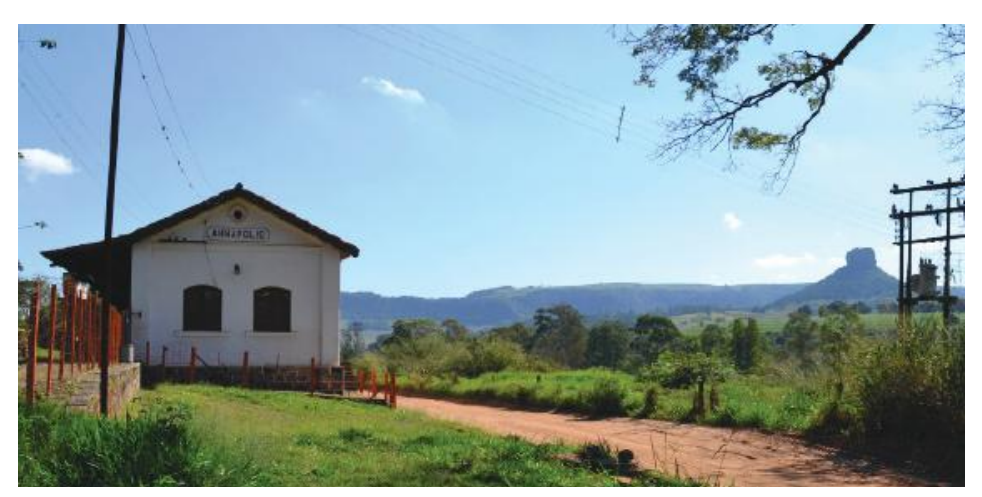

Foto 76 - Foto atual da estação de Anápolis e à direita da foto, observa-se o morro do Cuscuzeiro. Fonte: autora, 2012.

ao Conde do Pinhal.

\begin{abstract}
Em fins de setembro de 1886, a Companhia Rio Claro obteve a autorização para abrir o tráfego na seção entre Brotas e Dois Córregos, completando 231 quilômetros de operação de linha, tendo mais de 9 quilômetros concluídos, porém ainda não entregues ao tráfego, e 24 quilômetros em construção (SÃO PAULO, 1887:86). Sob um capital de 3.000 contos de réis representado pela linha em tráfego, a Companhia, após a conclusão de seus 264 quilômetros com a inauguração do último
\end{abstract}

21 Para saber mais sobre o engenheiro ver Campos, 2007: "Estabelecidos os contatos iniciais, a contratação de Paula Souza como engenheiro chefe da empresa ocorre março de 1881. A escolha do corpo técnico da empresa foi um consenso entre o engenheiro e o gerente, Antonio C. de Arruda Botelho, prevalecendo a opinião de Paula Souza. A contratação dos quadros técnicos e de camaradas (imigrantes, nacionais e ex-escravos alocados para serviços gerais), bem como a formação da empresa ferroviária começam em abril de 1881, quando Arruda Botelho entrega a quantia de 1 conto de réis. (1:000\$000) 'para as despesas de escritório, ferramentas e camaradas" (CAMPOS, 2007, p. 148) O mesmo engenheiro pede demissão do cargo em 1883. "A realização dessa estrada de ferro consolidou a carreira de Antonio Francisco de Paula junto ao setor ferroviário nacional, um projeto que se destacou, sem dúvida, pelo uso de novos materiais (concreto nas obras de arte) e tecnologias ferroviárias (os modernos freios westinghouse contemporâneos dessa estrada e o uso de locomotivas de uma conceituada firma norteamericana), mas o grande mérito deste projeto reside na introdução do método de levantamento topográfico pelo uso do Taqueômetro Cleps, cujo impacto se refletiria diretamente nas questões ligadas aos planejamento territorial, com obtenção de dados mais precisos acerca do território. Podemos inclusive afirmar que Paula Souza se torna referência para consultas acerca de topografia travando contatos com a comissão Geográfica e Geológica, na pessoa de Orville A. Derby e com Luiz Crulz, responsável por demarcar o quadrilátero para a construção da nova capital do Brasil no planalto central. Sua familiaridade com o método o faz publicar em 1895, Elementos de Taqueometria: cleps, descrição e uso prático deste instrumento (CAMPOS, 2007) 
trecho do ramal entre a estação D. Pedro II e a vila de Jaú, teve seu capital realizado elevado a 5.000 contos de réis. De modo a reforçar ainda mais a ideia de que a Companhia detinha uma excelente situação financeira, (...) (GRANDI, 2007, p. 58)

O ramal era altamente lucrativo, e atingiu a estação de Jaú em 18 de fevereiro de 1887. Além de ser uma região altamente lucrativa por causa do café, como no caso das outras ferrovias, o dinheiro foi investido em outras empresas, de serviços públicos, bancos e outras indústrias. Assim em 1889:

Do início da construção da estrada até o ano de 1889, a extensão total da ferrovia contabilizava 264 quilômetros, sendo 127 quilômetros na linha principal entre os municípios de Rio Claro e Araraquara, e 137 quilômetros no ramal que partia da estação Visconde de Rio Claro, no km 57 da linha principal. O ramal que atingia o município de Jaú continha 10 estações e a linha-tronco comportava 11, totalizando assim 21 estações ao longo da estrada de ferro. (RCPEF, 1888, p. 65)

Os dados da Companhia Rio Claro encontram-se nos Relatórios da Companhia Paulista, pois em 1888, a Paulista propõe uma fusão com a Rio Claro. Fizeram parte destes estudos os engenheiros Walter Hammond e Adolpho Pinto. Segundo Grandi (2007, p. 59) : "A partir da segunda metade da década de 1880, a Companhia Rio Claro passou a ser objeto de negociações entre diversos grupos nacionais e estrangeiros que manifestavam interesses em adquiri-la em função, principalmente, dos lucros que a localização estratégica da ferrovia garantia.”

A proposta de fusão foi recusada pela Companhia Rio Claro, que aceitou a proposta de compra pelos ingleses, transformando-a em 1888, em Rio Claro Railway. Ainda não se sabe os motivos da venda, já que a Companhia demonstrava ser lucrativa. Os historiadores apontam duas hipóteses:

Diniz observa que as incertezas provocadas pela conjuntura política, ao final da década de 1880, aliadas ao bom preço oferecido pelos investidores ingleses, são suficientes para explicar a venda da Companhia Rio Claro (1973:166). Dean já é mais enfático ao afirmar que o conde do Pinhal não tinha muito interesse em administrar a ferrovia (1977:54) (GRANDI, 2007:80)

O desinteresse em administrar a Companhia, manifesta-se depois da morte de seu sogro, o Visconde de Rio Claro, em 1884. Vendida a Companhia, o conde fundou o Banco de São Paulo e a Casa Comissária Arruda Botelho. (GRANDI, 2007, p. 81) Talvez o Barão do Pinhal tivesse mais interesse em bancos, pois, em 1891, funda o Banco União de São Carlos, que tinha na gerência seu genro Firminiano de Morais Pinto, ex-presidente 
da Companhia Rio Claro, e, no mesmo ano, funda o Banco de Piracicaba. (GORDINHO, 1985 , p. 88)

Malograda a tentativa de fusão, a Companhia Paulista volta à compra da Rio Claro Railway em 1892. A companhia, agora inglesa, recebeu também uma proposta da Mogiana por um preço superior ao da Paulista. Esta saiu vitoriosa por causa das garantias por ela oferecidas. A compra definitiva "foi assinada em São Paulo no dia 26 de março de 1892, mediante a autorização prévia do governo federal” (PINTO,1977, p. 200). Apesar da dívida contraída para a Paulista, que tardou em ser saldada devido a taxa de câmbio, assim justifica Adolpho Pinto a compra da Rio Claro, a aquisição foi vantajosa para a Paulista em termos de receita e de expansão ferroviária, e também segundo Grandi (2007, p. 109) para o aumento de fluxo populacional:

Durante o período de 1892 a 1903 a Seção Rio Claro apresentou a média de $40 \%$ de participação no transporte total de passageiros realizado pela Paulista. Não há dúvida de que essa expressiva participação no transporte de passageiros está diretamente vinculada ao fluxo de mãode-obra destinado ao trabalho nas lavouras.

As evidências sobre esta afirmação encontram-se, primeiro, na constatação do estabelecimento de importantes núcleos coloniais próximos ao ramal de Rio Claro, como os de Gavião Peixoto, Nova Paulicéia e Nova Europa e, segundo, no fato de que entre 1893 e 1897 São Carlos (município servido pelo ramal de Rio Claro) rivalizava com a região de Ribeirão Preto e São Simão como um dos principais destinos migratórios do Estado. Segundo Carlos Pacheco, durante esse mesmo período São Carlos recebeu em torno de dois terços dos imigrantes que se dirigiam para a quinta zona cafeeira de São Paulo, a região da Baixa Paulista

O ano de 1892 da compra da Rio Claro Railway pela Companhia Paulista, também coincide com a fusão da Sorocabana e Ituana. Nota-se que o crescimento das ferrovias está aliado a estas compras de pequenos ramais e à aquisição de zonas de privilégio. ${ }^{22} \mathrm{O}$ ano de 1892 para a Companhia Paulista é o ano que inicia a presidência de Antônio da Silva Prado que dura até o ano de $1928 .{ }^{23}$ Muito interessante o resumo que faz

22 Ou a invasão de zonas, o que alguns autores chegam a afirmar "linhas de combate" para qual companhia adquirisse primeiro a sua zona de privilégio. (PINTO, 1903 e MATOS, 1981:88).

23 Este período poderia ser até um bom recorte para um estudo aprofundado.

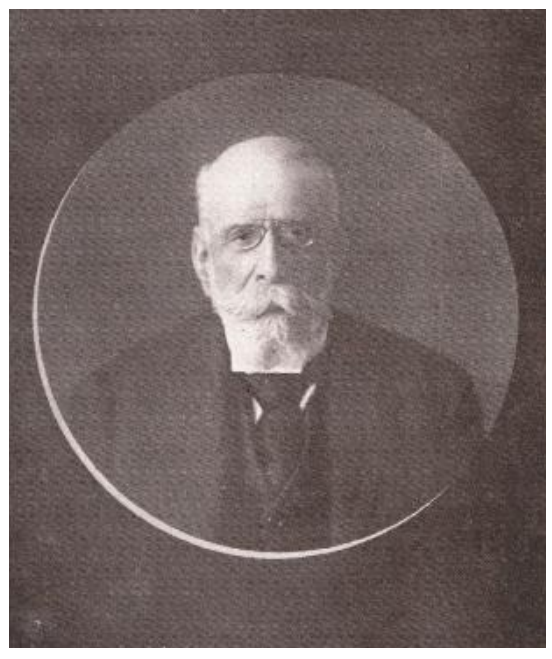

Foto 77 - Conselheiro Antônio da Silva Prado. Fonte: Álbum Ilustrado da CP, 1918. 
Zambello (2005, p. 47) da administração de Antonio da Silva Prado na Companhia Paulista, responsável por exemplo, pela compra de navios a vapor e eletrificação até Rincão. Grandi (2007) em seu estudo sobre a Rio Claro até 1903, mostra que a expansão da Companhia Paulista sobre a margem direita do Rio Mogi-Guaçu era para fazer concorrência com a Companhia Mogiana, e disputar o escoamento da produção dos municípios de São Simão, Ribeirão Preto e Sertãozinho, e também ramal este que justificou a extinção da navegação fluvial no Rio Mogi-Guaçu. Assim em 1903, a Companhia Paulista, deixa de ser fluvial.

Do ponto de vista dos trabalhadores, corresponde a primeira fase (1868-1885) determinada por Segnini (1982) como muito próxima a escravocrata, e “caracteriza-se pela ausência de 'artifícios ofuscadores' aos olhos dos ferroviários, da lógica fundada na dominação contida na relação capital-trabalho(...)”. Uma vez identificados que os ferroviários eram trabalhadores livres, pois por lei era proibido a construção das ferrovias utilizassem mão-de-obra escrava, seriam os ferroviários, ex-escravos ou imigrantes? É necessário diferenciar as várias seções e classes de funcionários das ferrovias, e quais deles habitavam as vilas ferroviárias. Apesar de Segnini (1982) referir-se às casas como "artifícios ofuscadores" da segunda fase da Companhia por ela periodizada, a construção de casas para seus trabalhadores existiu desde os seus inícios, como consta em Lanna (2002, p. 144), referindo-se uma das primeiras vilas ferroviárias da Companhia, em Jundiaí:

(...) A construção de casas para os trabalhadores, foi, como já mencionado, uma atividade desenvolvida pela empresa desde a sua fundação. Nos prontuários pesquisados temos que as casas construídas pela Paulista em Jundiai foram ocupadas por ajustadores, ferreiros, trabalhadores, escriturários, caldereiros. Nenhum destes cargos pertence aos patamares mais qualificados da Paulista. Talvez por isso, esta região da cidade ocupada por estes ferroviários tenha sido identificada com 'cortiço'

Afirma-se que as vilas operárias em geral, foram construídas para atrair e reter trabalhadores mais qualificados. No caso das vilas ferroviárias, também afirma-se que possam ter sido as primeiras vilas operárias brasileiras, o que pode ter

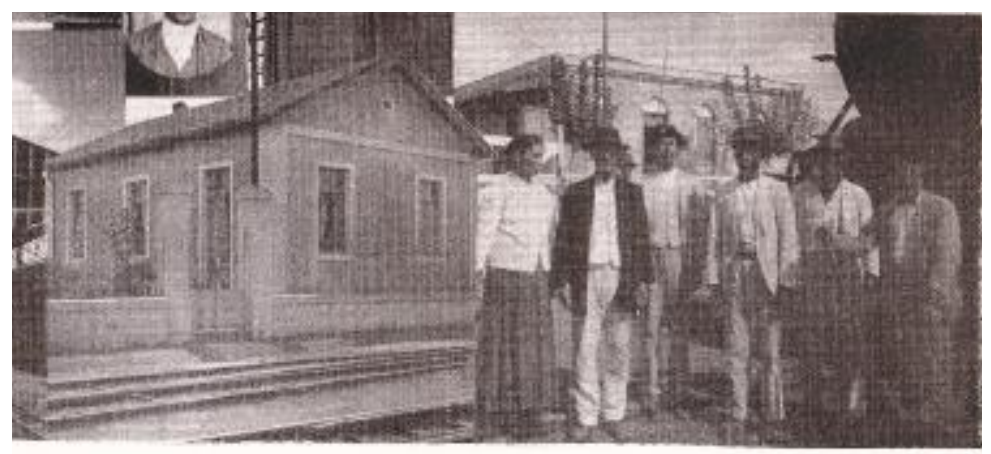

Foto 78 - Modelo de casa de empregados e trabalhadores ferroviários. Fonte: Álbum Ilustrado da CP, 1918. 
sido verdade no estado de São Paulo. O fato é que a demanda por mão-de obra no início da construção das ferrovias era grande, e não só por mão-de-obra qualificada, como pode ser visto na afirmação anterior. Além disso, a qualificação virá a posteriori com a Escola de Aprendizes e depois com a Escola de Ferroviários. A partir daí, as casas serão destinadas aos mais qualificados.

Em 1869, a Paulista era presidida por um engenheiro, Clemente Falcão de Souza Filho e um quadro de funcionários bastante restrito que não chegava a mais de 45 funcionários. Em 1870, a Companhia Paulista possuía 515 empregados, e em 1890, este número sobe para 1312. (LANNA, 2002, p. 122; 132) Quanto à questão de nacionalidade e raça, pode-se observar nas tabelas realizadas por Lanna (2002), a maior parte dos trabalhadores eram brasileiros e alguns estrangeiros. Interessante a observação que faz Segnini (1982, p. 37): “O anexo IV deste relatório traz indicações da presença de imigrantes alemães, de brasileiros e 'pretos'. A especificação da cor em lugar da nacionalidade, demonstra a ideologia da classe dominante na época - preto não tem pátria, é simplesmente preto, mão-de-obra a ser explorada (...)”. ${ }^{24}$ Não se pode afirmar que as tarefas que exigiam maior qualificação seriam ocupados pelos estrangeiros. ${ }^{25}$ Pela leitura dos relatórios da Companhia, foi visto que no princípio, entre os enge-

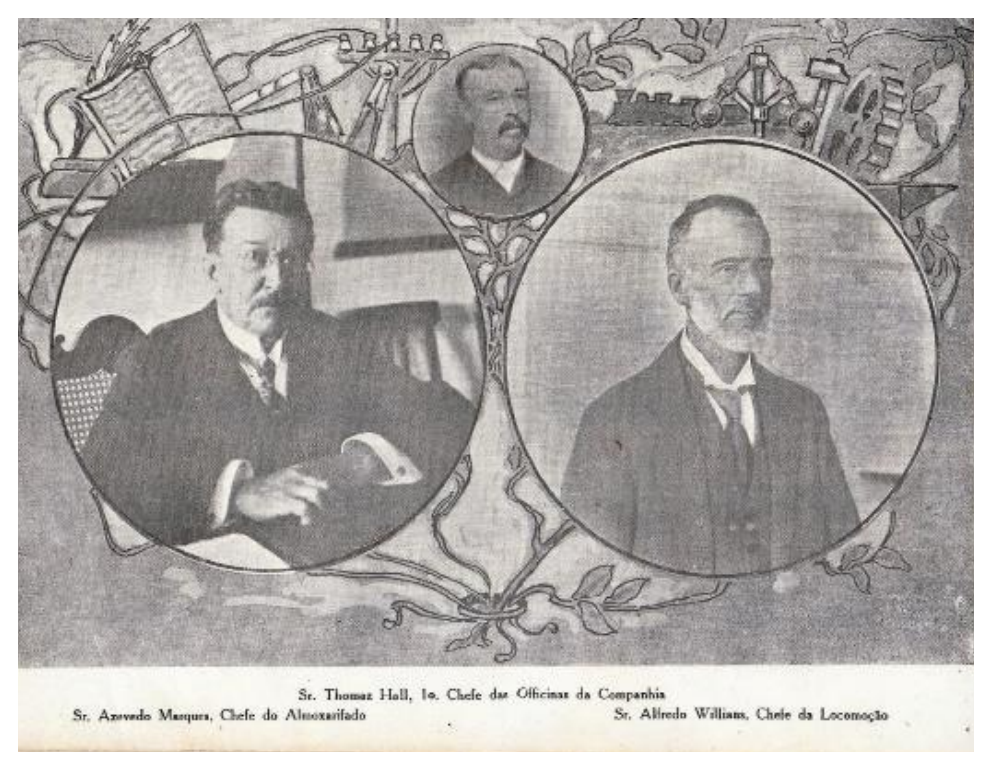

Foto 79 - Primeiros chefes de Seções. Esquerda: Azevedo Marques, chefe do Almoxarifado; centro: Thomas Hall, chefe das Oficinas; direita: Alfredo Williams, chefe da Locomoção. Fonte: Álbum Ilustrado da CP, 1918. nheiros ferroviários haviam engenheiros estrangeiros, mas depois foram substituídos por engenheiros brasileiros formados na Europa, e com a abertura da universidades e escolas de engenharia nacionais,

24 Sobre a presença de negros e a questão de raças nas ferrovias, baseado nas entrevistas com ferroviários das cidades de Rio Claro, Araraquara e São Carlos, e portanto de épocas mais recentes, talvez 1940 e 1950, ver Ferreira (2010). 
totalmente brasileiros. ${ }^{26}$ Há que se recordar que nas cidades estudadas não havia uma vila de engenheiros, poderia haver nas cidades com oficinas ou então uma e outra casa destinada ao engenheiro em cidades importantes. Isto parece se confirmar segundo a foto encontrada no livro de comemoração do cinquentenário da Paulista, em 1918. A foto intitulada "engenheiros residentes", aparece a foto de cada engenheiro, seu nome e as respectivas cidades em que residiam: Jundiaí, Dois Córregos, São Carlos, Araraquara e Jaboticabal.

Foto 80 -

Engenheiros residentes em 1918.

Fonte: Álbum Ilustrado da CP, 1918.

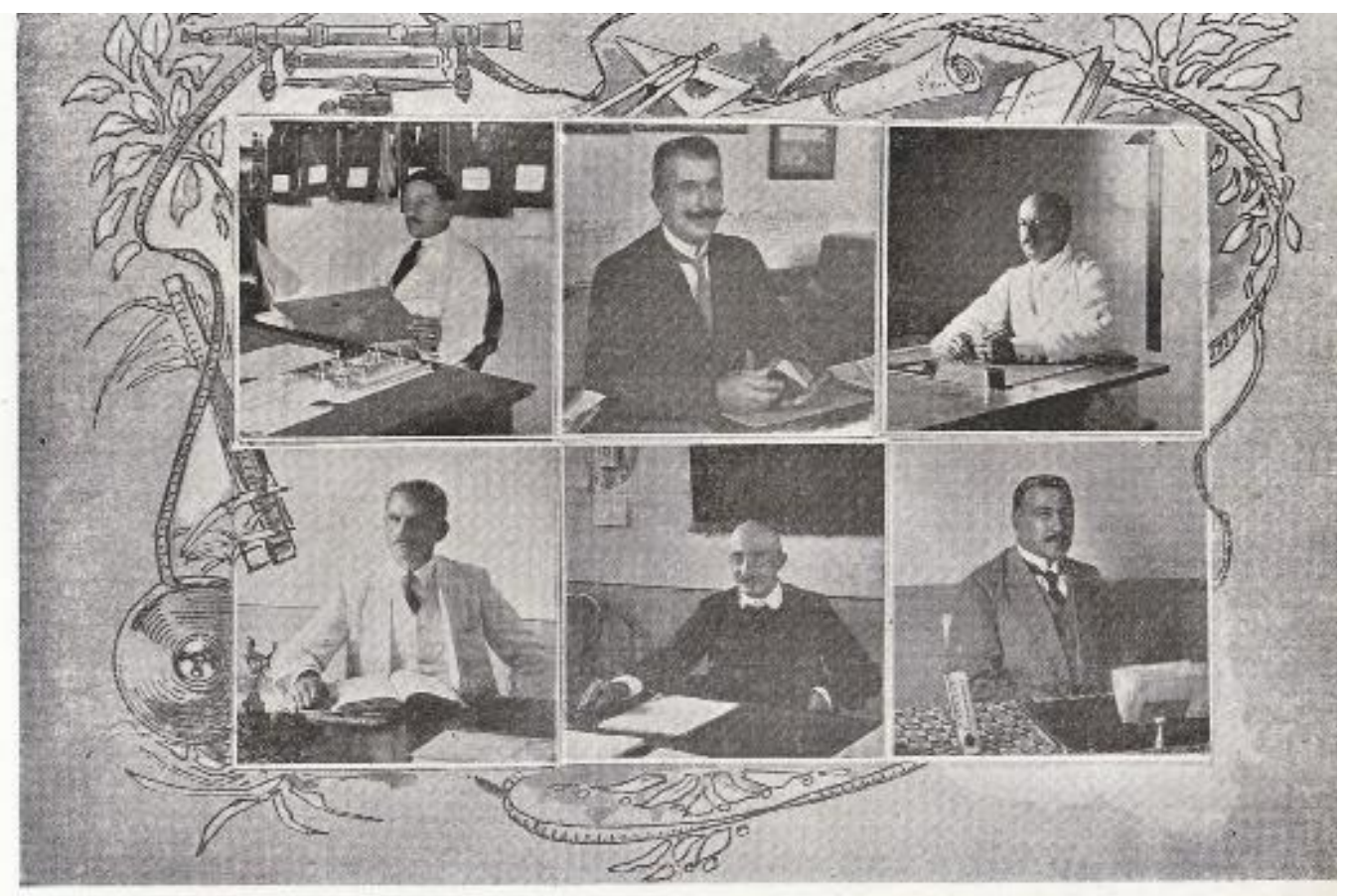

De. Plinio Moreiro Jundiahy Dr. Affoaso Piren Fleury, S. Catlos Dr. Joaquim da Fonieca Hedrizues. S. Carlos

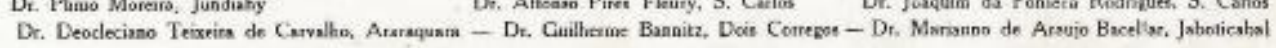

Muitas obras iniciais, de construção de linhas e estações, foram efetuadas por empreiteiras ${ }^{27}$, que empregavam os seus próprios trabalhadores ou contratavam a mão-de-obra local, que depois eram mantidas pela Companhia Paulista, pela Seção de Edifícios,

$26 \quad$ Neste sentido, colabora o seguinte depoimento de um ex-ferroviário: "Tinha um mestre geral na Paulista, um engenheiro inglês. Era um dos ingleses que tinha aí dentro. Tinha o Adam Gray, que era o chefe da oficina e tinha esse John Jones, que era o mestre-geral. Depois esse Gray, - eu nem cheguei a conhecer-ele morreu antes de a escola começar. (...)" (depoimento do Sr. Walter Lucke in Tenca, 2002, p. 110) (TENCA, 2002, p. 107, como também .Quadro de engenheiros/ agentes do Congresso de engenheiros de 1935.)

27 Sobre as empreiteiras comenta Lanna (2002, p.103): “ (...) A Companhia Paulista inicia a construção do trecho ligando Jundiaí a Campinas em 1870. Este foi dividido em três seções, supervisionadas pelo engenheiro-chefe, Viriato de Medeiros, e seus auxiliares, funcionários da Paulista. A construção estava a cargo de três empreiteiros - Ângelo Thomaz do Amaral, Heitor Rademaker Grunewald e João Pereira D. Faro - que subdividiam suas seções num total de 18 sub-empreiteiros. Vale destacar que foi a primeira vez que empreiteiros brasileiros se encarregaram da construção de uma estrada de ferro. Eram homens que firmavam contrato com a empresa ferroviária e contratavam, por sua conta, os trabalhadores da construção. A partir de 1874, os contratos firmados entre empreiteiros e a Paulista passaram a ter um fiador que depositava o valor de caução para garantir o início das obras e demais condições contratuais. " 
Linhas e Construção. Desse modo, é difícil ter informações sobre seus trabalhadores. Ghirardello (2002, p. 45) comenta que prisioneiros são enviados para a construção da Estrada de Ferro Noroeste. Talvez este não seja o caso da Paulista. Sobre os trabalhadores da construção, Lanna $(2002$, p.107, 108, 151) comenta que eram trabalhadores livres, a maioria brasileiros, e as condições das empreiteiras eram instáveis e precárias, com atrasos nos pagamentos e más condições de trabalho, e parece haver notícias de revolta dos mesmos.

Nas demais seções, os trabalhadores eram contratados e funcionários da Companhia Paulista. Talvez nos anos iniciais da Paulista, muitos trabalhos, mesmo de oficina, fossem terceirizados, e mais tarde, a Companhia incorporava tais oficinas ou construía suas próprias oficinas e capacitando seus trabalhadores. Um relato nesse sentido:

\section{(...) Henrique Faber, nascido em 1858, diz ter iniciado no quadro de funcionário da CPEF somente em 1906 como mestre de fundição. Contudo, afirma ter trabalhado para a Companhia Paulista muito tempo antes deste ano nas oficinas de fundição que, primeiramente eram de propriedade de seu pai e depois, passaram a ser sua (LANNA, 2002, p. 150)}

Pelas informações que temos através dos relatórios da Companhia Paulista, há as seguintes seções: I. Tráfego; II. Edifícios, Linhas e Construção; III. Locomoção e IV. Almoxarifado, todas as seções possuíam seus chefes, e estes subordinados ao Inspetor Geral, o mais alto cargo técnico da Companhia. Segundo Zambello (2005, p. 244):

As estradas de ferro brasileiras representaram a divisão de trabalho das estradas de ferro européias e estadunidenses. Tanto a Mogyana como a Paulista adotaram as mesmas divisões e subdivisões: inspetoria geral; contadoria; almoxarifado; tráfego; linha; e locomoção, sendo esta subdividida em escritório, oficinas e tração. Cada divisão concentrava sua hierarquia de trabalho.

O cargo de Inspetor Geral foi ocupado por figuras como Adolpho Pinto, Francisco Paes de Monlevade, Jayme Pinheiro de Ulhôa Cintra. Estes dois últimos foram, primeiramente, chefes de seção, e depois inspetores, e convidados a participar da diretoria. Tais chefes eram: "As 'cabeças pensantes' da administração, na Companhia Paulista, deveriam ser 'verdadeiros engenheiros', de acordo com a imagem construída pela diretoria. A esta 'casta' eram atribuídas as funções nobres da empresa (...)” (Relatório da Companhia Paulista $n^{\circ}$ 80, p. 30 apud SEGNINI,1982, p.74)

Na Seção de Tráfego, trabalhavam os maquinistas, foguistas (quando os trens 
eram a vapor) entre outros. Na Seção de Locomoção, encontram-se os responsáveis pelo funcionamento das locomotivas, e portanto, oficinas. Na Seção de Edifício, Linhas e Construção, os responsáveis pela construção e manutenção das linhas. Nesta última se-
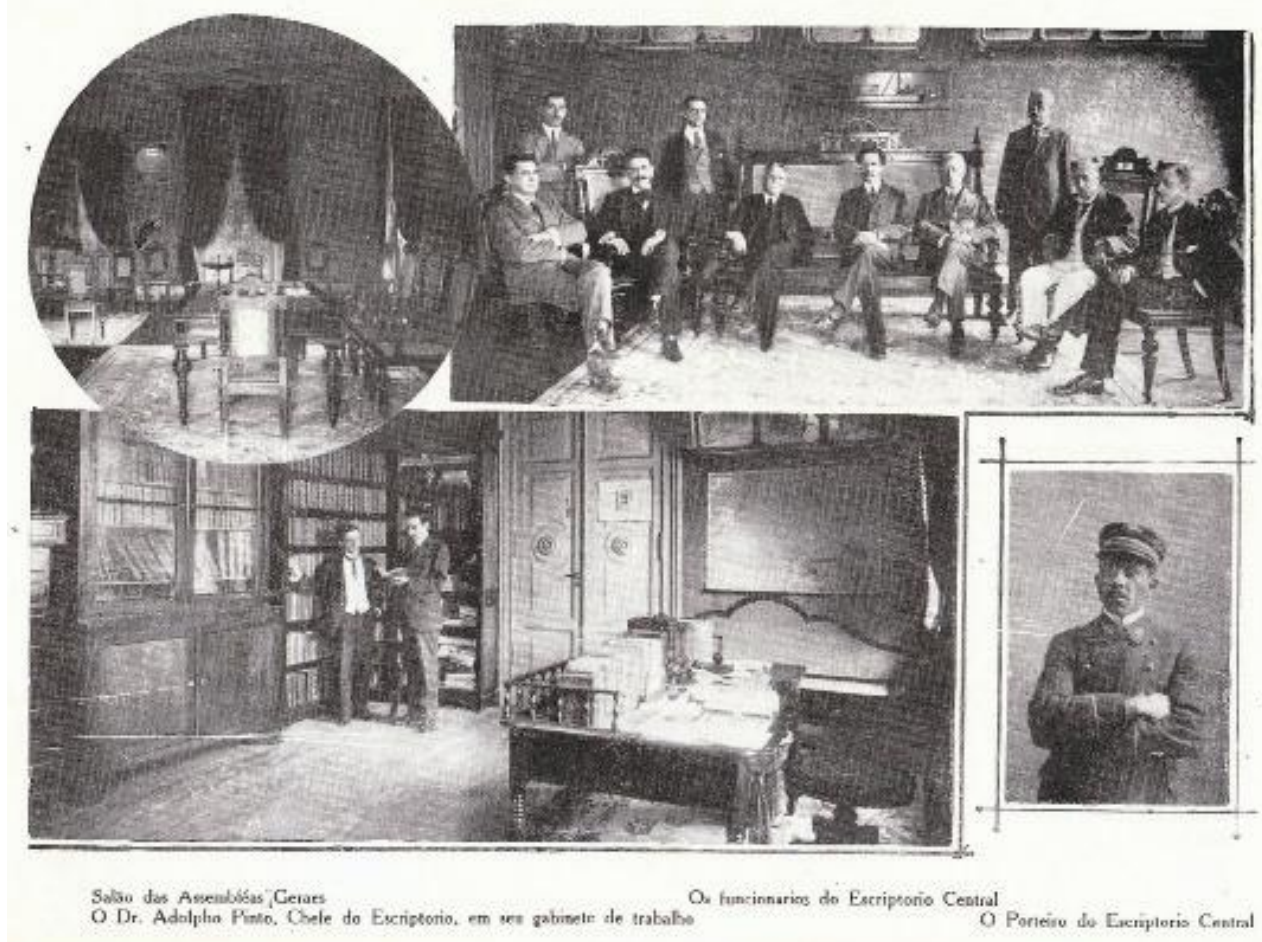

Foto 81 - Foto do escritório central. Acima à direita: Adolfo Pinto e funcionários.

Foto 82 -Francisco Monlevade e família.

Foto 83 - Terceiro da esquerda para direita: Jayme Pinheiro de Ulhôa Fonte: Álbum Ilustrado da CP, 1918.
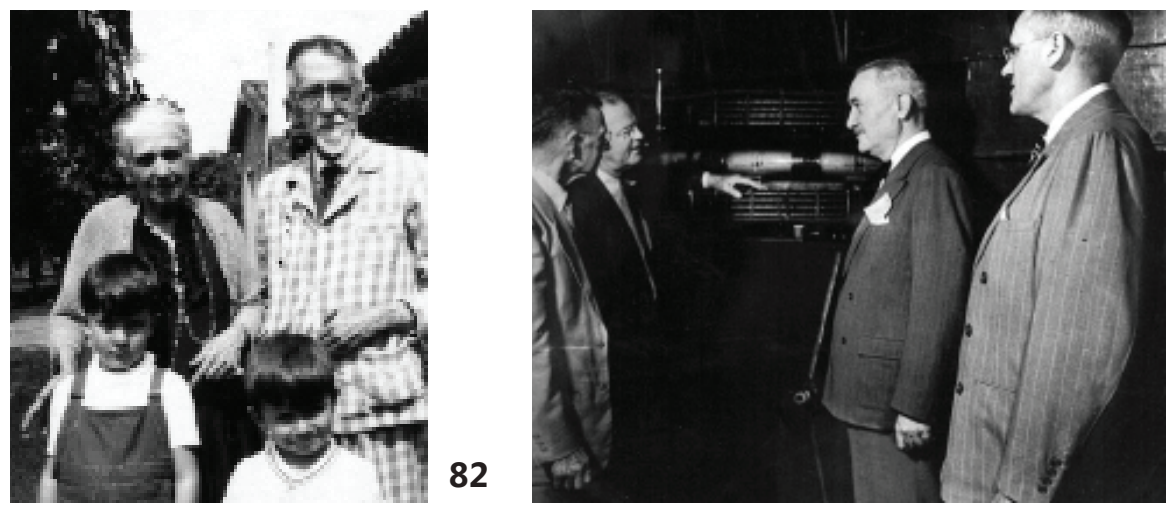

ção, estariam também os responsáveis pela construção das vilas ferroviárias, informação constatada nos relatórios da Companhia.

Tendo como objeto de estudo as vilas ferroviárias, não sabemos precisamente para trabalhadores de qual das três seções, Locomoção/Tração (pessoal de locomotiva, maquinistas), Linhas (feitores e mestres de linha) ou Tráfego (pessoal de estação, de trem, de movimento e de sinalização), eram dirigidas as vilas operárias, porém podemos fazer certas deduções, e inclusive há menções na bibliografia especializada neste sentido. As casas de turma eram dirigidas aos operários responsáveis pela manutenção de linhas, e 
portanto, estes pertenceriam à Seção de Linha. Grandes oficinas como Jundiaíi ${ }^{28}$ e Rio Claro, demandariam grande quantidade de trabalhadores responsáveis pela manutenção de máquinas, e portanto, pertencentes à seção de Locomoção, e a estes seriam dirigidas as vilas. Em cada estação, deveria haver um chefe de estação que seria responsável pelo tráfego, a este também era dirigida uma casa, que se destacava no conjunto por apresentar maiores áreas construída e livre. Em cada estação, os trabalhadores responsáveis pela

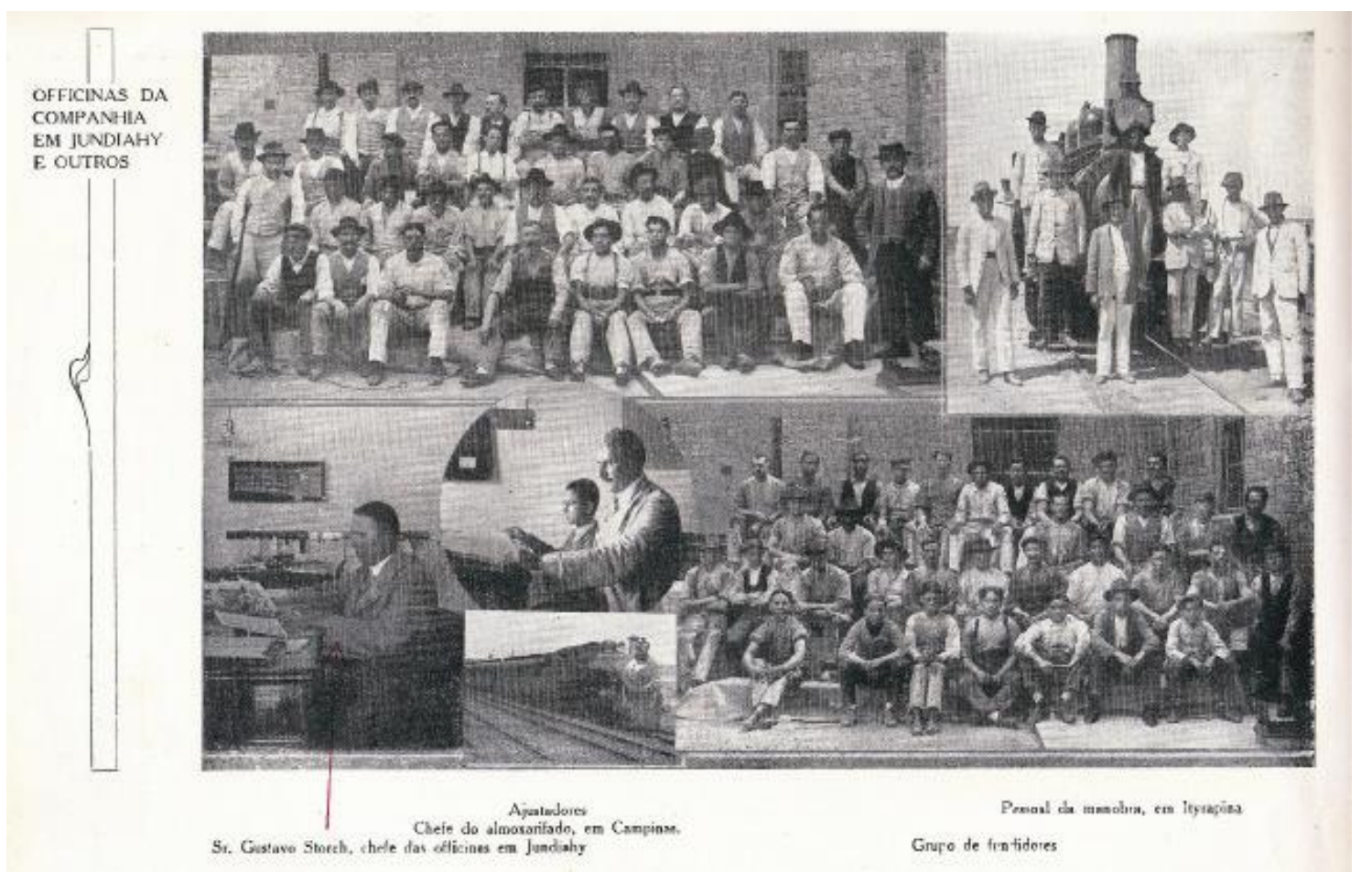

Foto 84 - Oficina de Jundiaí e funcionários. Fonte: Álbum Ilustrado da CP, 1918.

manutenção de máquinas (locomoção) e linhas, portanto, trabalhadores de cada uma das seções, receberiam casas das vilas. Sabe-se que os maquinistas eram um dos cargos mais

28 "Para reparação do mesmo material são dignas de especial menção as suas oficinas de Jundiahy e Rio Claro, principalmente as de Jundiahy, talvez as mais vastas e bem apparelhadas do Brasil, o que as tornam dignas de uma minuciosa descrição.(...) A construção d'estas oficinas, em substituição ás que primitivamente funccionaram em Campinas, foi iniciada em 1893, em terreno situado na parte baixa da cidade de Jundiahy, ao longo e junto do trecho inicial da linha férrea Paulista medindo a area total de 145.091 metros quadrados (...)". Pinto descreve as paredes de $40 \mathrm{~cm}$ de espessura, feitas de tijolos, e tesouras de cobertura feitas em aço, por segurança contra incêndio; fala do formato "dentes de serra" da cobertura para permitir boa iluminação natural. Para trabalhos noturnos havia iluminação elétrica. "Esta installação electrica também fornece luz a 40 casas para operários, que a Companhia Paulista possue em Jundiahy, na parte alta da cidade, e uma escola nocturna de aprendizes.” (PINTO, 1903, p. 105). A oficina possuía duas seções, uma para metais outra para madeira. A de metais, subdividia-se em cinco partes distintas: "fundição de ferro e bronze, a ferraria, a caldeiraria, a officina especial de machinas ferramenteas para tornear, aplainar e furar peças metallicas, e finalmente, a ajustagem e montagem de locomotivas. "(idem) A oficina para metais localizada na parte sul, e a de madeiras na parte norte, e por sua vez, subdividia-se nas seguintes oficinas: "serraria, carpintaria para carros, carpintaria para vagões e pintura de carros, toas ligadas entre si por linhas interiores de serviços e exteriores para manobras.” (PINTO, 1903, p. 111). 
altos da seção de tráfego, ao que almejavam os iniciantes da carreira, passando por diversos estágios. Será um maquinista depois transformado em chefe de estação? Caberia aqui mais investigação.

Uma última explicação com relação aos inícios das vilas ferroviárias: as casas eram construídas pela Companhia Paulista, em seus terrenos, obviamente, e alugadas aos
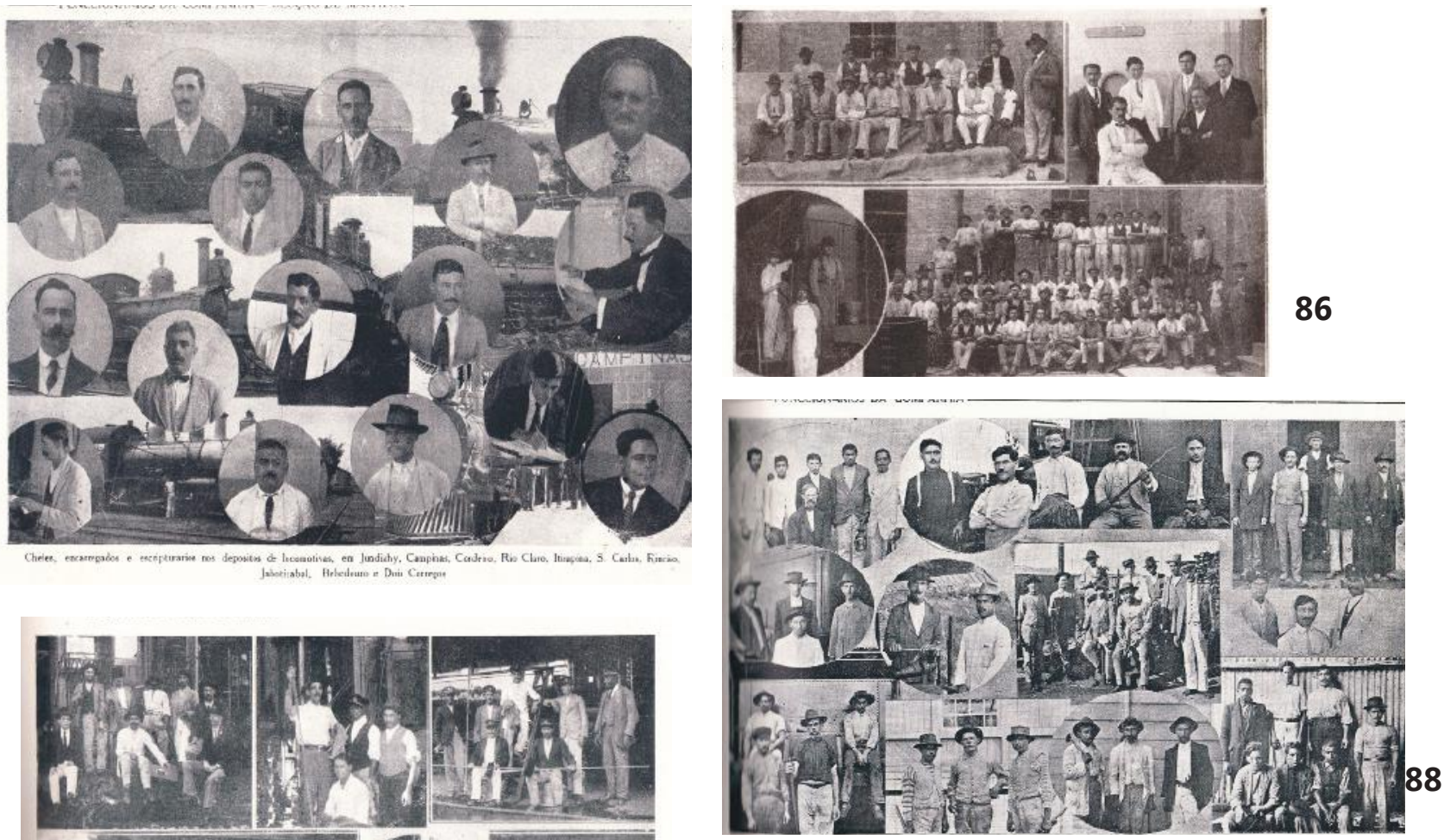

87
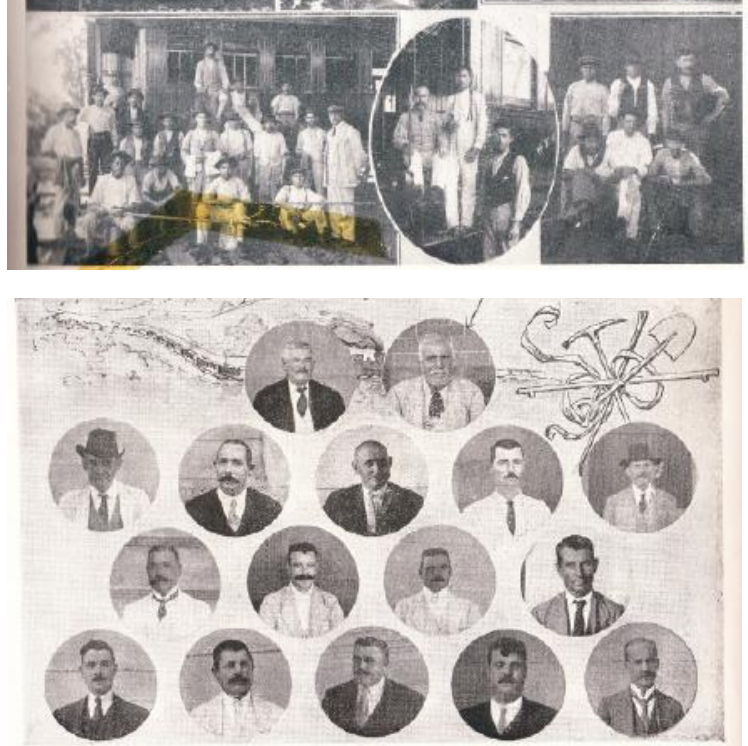

89

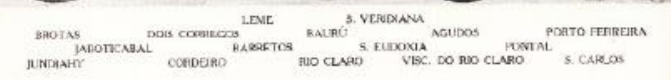

Foto 85 - Pessoal de depósito de locomotivas

Foto 86 -Lavadores de carros, pintores, torneiros e pessoal de estação. Foto 87 - Lavadores de carro. Foto 88 -Examinadores de veículos e outros. Foto 89 -Mestre de linhas. Foto $\mathbf{9 0}$ - Turmas em serviço. Foto 91 -Pessoal do armazém e outros. Fonte:
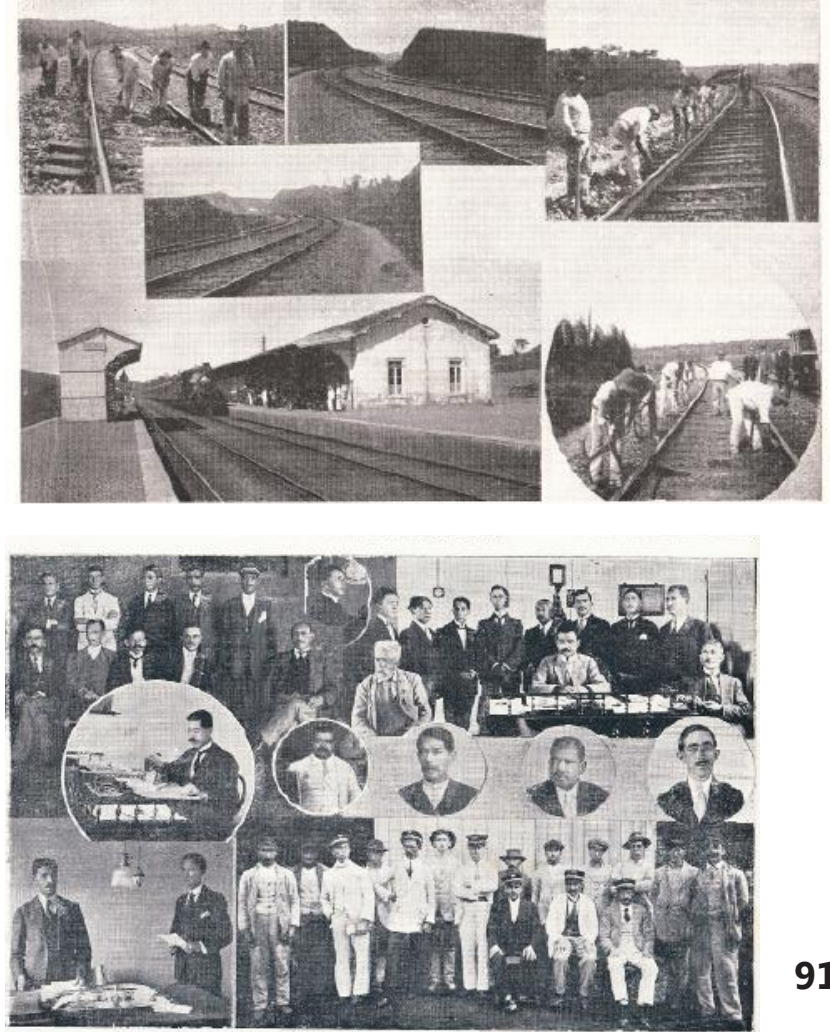
trabalhadores, descontados em sua folha de pagamento. "Desta forma, solucionava dois problemas: fixava o ferroviário ao seu local de trabalho, através da dependência que
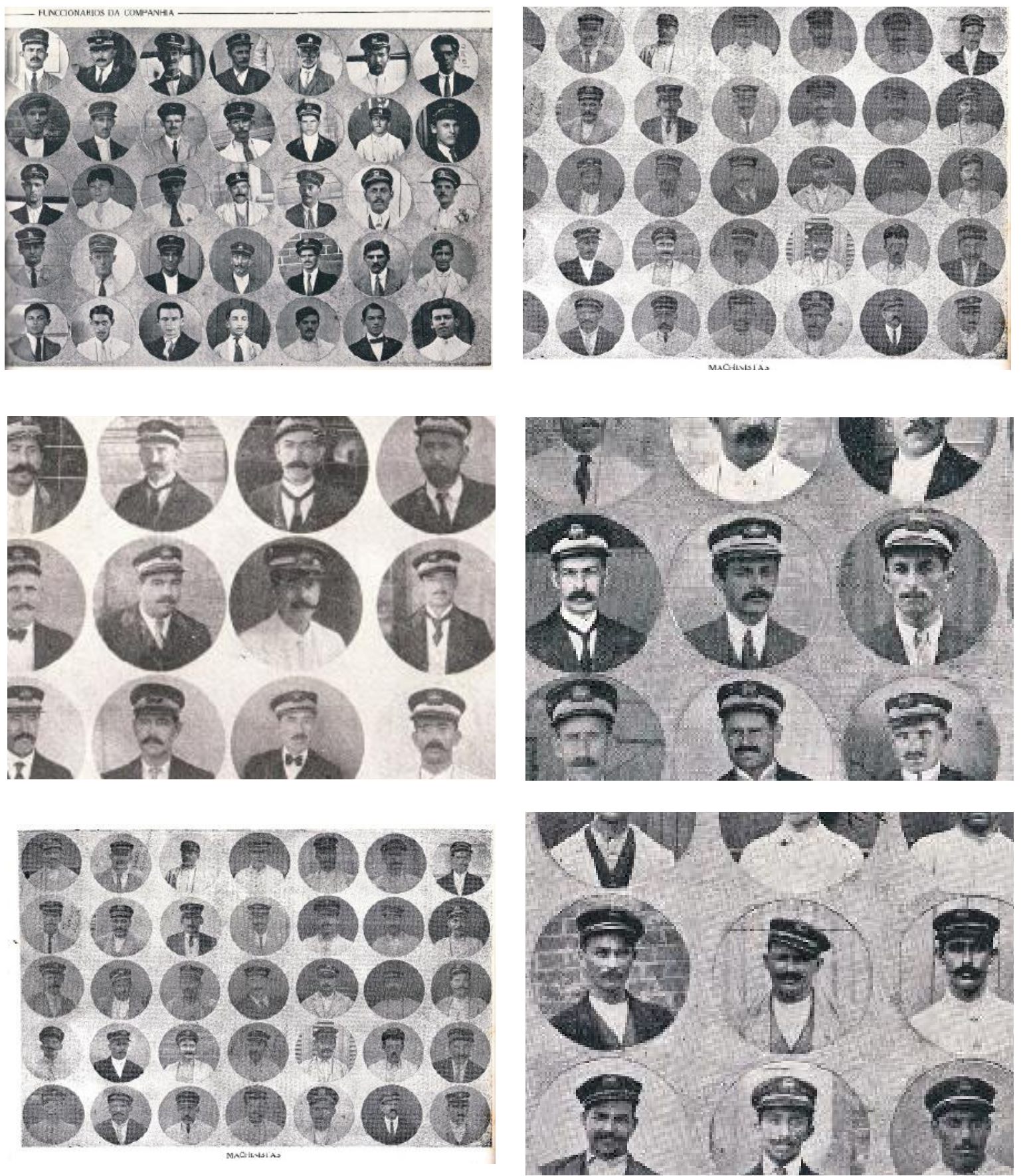

Foto 92 - Pessoal da estação: guardas, ajudantes, praticantes e telegrafistas. Foto 93 -Lavadores de carros. Foto 94 -Chefe de estações. Foto 95 -Chefes efetivos e substitutos de estações. Foto 96 -Maquinistas. Foto 97 - Foguistas. Fonte: Álbum Ilustrado da CP, 1918.

criava do mesmo com relação à moradia. Além disso, o patrimônio da empresa crescia através da valorização dos imóveis.”. (SEGNINI, 1982, p. 55). Veremos que a produção das vilas ferroviárias, e de modo geral vilas operárias, irá mudar com os tempos. 


\section{2 -1931 - A fase de expansão da Companhia da Paulista}

O início do século foi marcado pelos incentivos ferroviários. Talvez um dos acontecimentos importantes nesta década tenha sido a chegada das ferrovias a Bauru. As ferrovias competiam entre si para chegar primeiro à região, na conquista do interior e fazer a ligação com Santos. ${ }^{29}$

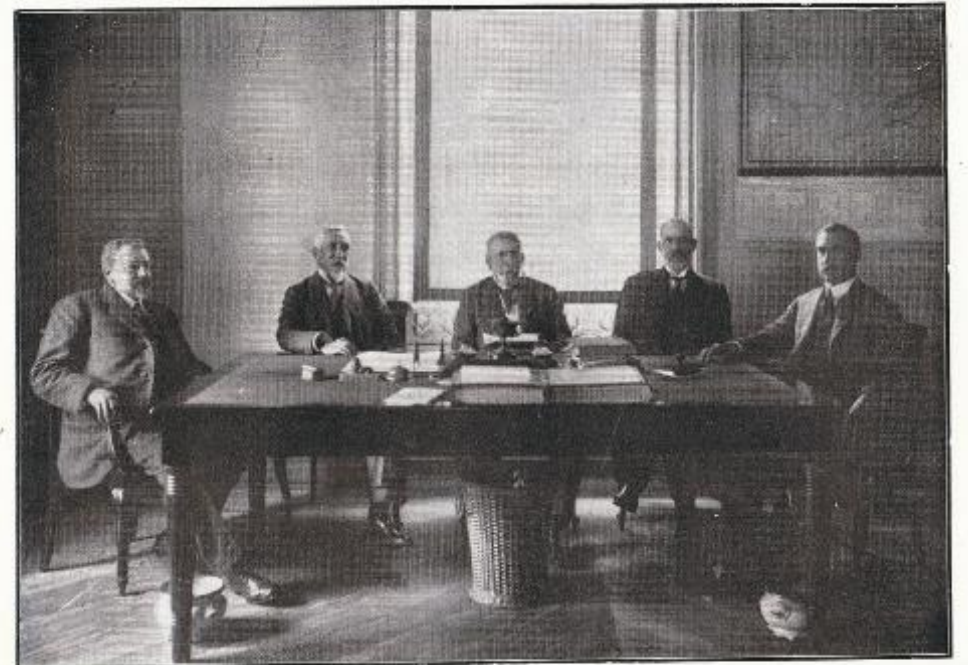

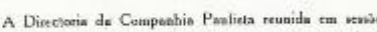

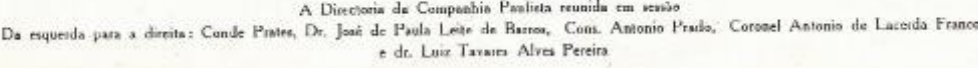

Foto 98 - Diretoria da Companhia Paulista.Fonte: Álbum Ilustrado da CP, 1918.

Antes de Bauru, a região do extremo era Agudos, onde ocorreu o cruzamento das linhas da Sorocabana e da Paulista em 1903. A primeira a chegar a Bauru, foi a Sorocabana em 01 de julho de 1905, havendo percorrido as cidades de Rubião Junior (1897), São Manuel (1888) e Lençóis (1898), enquanto que a Companhia Paulista, a partir de Itirapina avançou na direção de Brotas (1885) atinge Jaú (1887), Pederneiras (1903) e Agudos (1903) e finalmente Bauru (1910). Estas regiões eram as áreas mais férteis para o cultivo do café, por causa do solo. "Ali o governo do Estado ensaiara, no início do século, importante sistema de utilização da terra por meio de núcleos coloniais (Gavião Peixoto, Nova Paulicéia, Nova Europa...) e até a crise de 1929/1930 foi uma das maiores áreas produtoras." (MATOS, 1974, p. 95)

"Depois de muita pressão política, Bauru foi escolhida como ponta de lança dos trilhos da Estrada de Ferro Noroeste do Brasil" (SOUKEF JUNIOR, 2005, p. 212), em direção a Itapura. Matos (1974, p. 95) ao comentar a construção desta estrada, aponta o mérito dos trabalhos de levantamento geográfico feitos pela Comissão Geológica, que depois deu origem ao Instituto Geográfico e Geológico do Estado, chefiado por Orville Derby. E ainda, afirma o autor que muitas cidades tiveram início com a estação: "Ali, com efeito, a ferrovia precedeu o povoamento. Suas cidades, hoje todas muito importantes, praticamente tiveram início com a estação, ou até antes, com os barracões dos trabalhadores da estrada.”. (MATOS, 1974, p. 95)

29 Para saber mais sobre esta região, ver Matos (1974, p. 65) 
O interesse em conquistar cidades, era a garantia de zona de privilégio de exploração. Porém, alguns engenheiros pensavam na ligação entre o Pacífico e o Atlântico, um destes era Emílio Schnoor. ${ }^{30}$ Enquanto isso, a Paulista também "brigava” por outras frentes, "desviando suas linhas a partir de Rincão (a 30 quilômetros de Araraquara) e fazendo-as seguir pelo vale do Mogi-Guaçu, visou à zona de Bebedouro e Barretos, chegando seus trilhos à margem do rio Grande. (...)” (MATOS, 1974, p. 98). Como fatores importantes entre as décadas de 1910 a 1930, podemos destacar a chegada da ferrovia na cidade de Colômbia, no norte do estado, com vantagens relativas ao transporte de gado do triângulo mineiro. Para efetivar este transporte, mantém um transporte fluvial e estabelece um matadouro em Barretos, em 1909 e a vende em 1923 para uma sociedade inglesa chamada Brazil Meat Company. Além disso, “(...) A Companhia Paulista prolonga seus ramais além de Piratininga ${ }^{31}$ e conseqüentemente faz surgir grandes centros de população, como Marília em 1928. Prosseguindo, essa estrada atingirá Tupã nos próximos anos.”. (FERREIRA, 2010, p. 103) As demais companhias também avançam as suas linhas, afirmando Matos (1981, p. 99-100), que entre as décadas de 1910 e 1920, “quase se completa a carta ferroviária do Estado”.

Também por estas décadas concluem-se as obras do escritório central em São Paulo, próximo ao convento de São Bento (CAMPOS, 2007, p. 322). Este edifício é mencionado nos relatórios da Companhia Paulista, em 1895, referente à compra, e 1905, à conclusão do edifício. Este edifício mais tarde é demolido. Além deste edifício administrativo, a Companhia Paulista possuía duas oficinas, a de Jundiaí e a de Rio Claro. Em 1902, é iniciado o Serviço Florestal, para

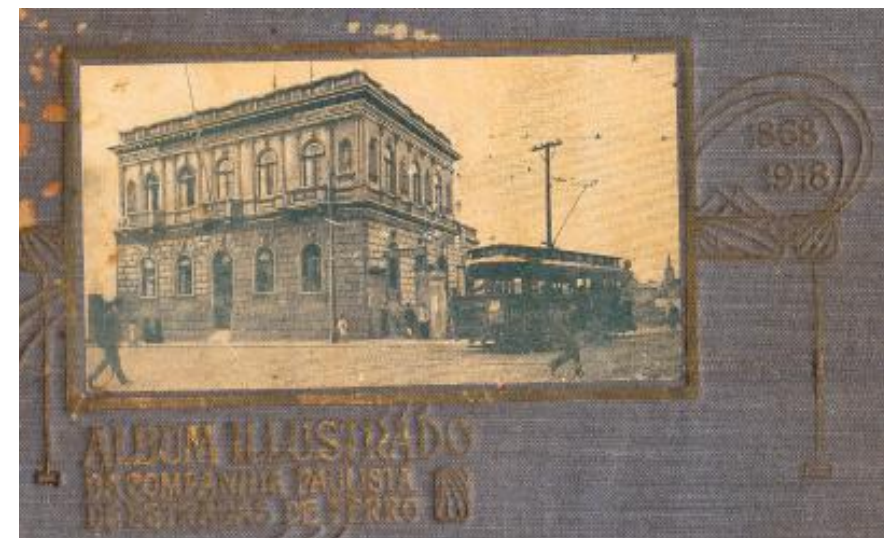

Foto 99 - Sede da Companhia Paulista, na rua São Bento. Fonte: Álbum Ilustrado da CP, 1918.

30 "O grande engenheiro aconselhava a ligação do Atlântico ao Pacífico. Os pontos de partida foram por ele criteriosamente considerados, do ponto de vista econômico e estratégico. Pareceu-lhe que, estando Santos ligado por via férrea a Jaú (pela Paulista) e a Agudos (pela Sorocabana), o traçado ideal aconselharia fazer desta última cidade (então denominada São Paulo dos Agudos) o ponto de partida da nova ferrovia. A articulação via Sorocabana oferecia a vantagem de uniformidade da bitola em percurso maior, o que não acontecia com a Paulista (...)” (MATOS, 1974, p. 96).

31 Cidade próxima à Bauru. Há um estudo de iniciação científica sobre a cidade de Piratininga: OLIVEIRA, Elisa Haddad de. Piratininga, a entrada da Alta Paulista: o projeto de um entreposto comercial e ferroviário no interior paulista, 1905-1908. Relatório Iniciação Científica/FAPESP, FAUUSP, 2011. 
produção de eucaliptos e outras espécies para fornecimento de lenha e substituição do carvão importado e para a utilização como dormentes.

Outro importante acontecimento que marca o pioneirismo da Companhia Paulista entre as décadas de 1910 e 1930, foi a eletrificação da ferrovia. Os estudos foram realizados pelo engenheiro Monlevade, desde 1919, como consta nos relatórios, e a inauguração do primeiro trecho, de Jundiaí a Campinas, ocorreu em 1922. A Companhia Paulista foi a pioneira na eletrificação, as quais seguiram-se a EF Central do Brasil (1922) e a Rede Mineira de Viação (1929) ${ }^{32}$. As demais companhias só iniciaram a sua eletrificação na década de 1940. Mais cara inicialmente, por causa dos serviços de infraestrutura, ao longo dos anos, a eletrificação rendeu economicamente para a Companhia Paulista, resistindo melhor aos altos preços dos combustíveis. Uma única ressalva que
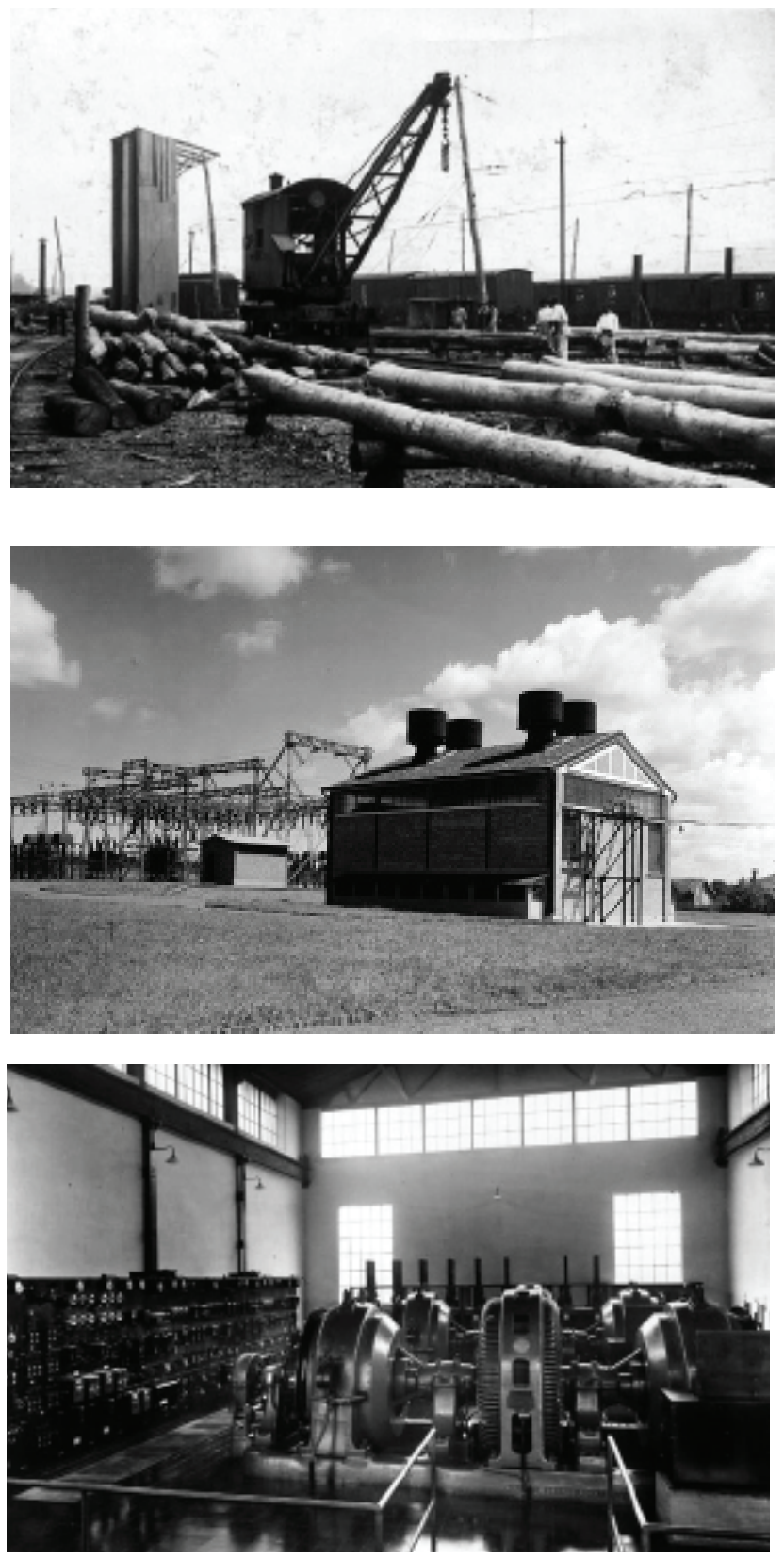

Foto 100 - Eletrificação do trecho de Jundiaí à Campinas. Foto $\mathbf{1 0 1}$-Subestação elétrica de São Carlos. Foto 102 - Foto interna da subestação elétrica de Rincão. Fonte: Museu Ferroviário de Jundiaí, s/d. poderia ser feita, pensando na Paulista como uma empresa com tantas iniciativas e investimentos, não ter tido ela própria a sua

32 Há uma tabela com as linhas eletrificadas in Martins (1995, p.320) “(...) Aos poucos sua rede elétrica foi se ampliando, estendendo-se até Rincão (na linha tronco) e até Cabrália (no ramal de Bauru). Outras estradas, como a Santos-Jundiaí, depois de encampada pelo governo federal, também eletrificaram suas linhas, o mesmo ocorrendo com a Sorocabana, que tem grande parte de seu tronco eletrificado. Algumas pequenas estradas eletrificadas devem ser citadas: a Campos de Jordão e o Ramal Férreo Campineiro, este suprimido há alguns anos. A aplicação dos motores Diesel às locomotivas fez com que as estradas não mais prosseguissem no seu programa de ampliação das redes elétricas. A partir de 1950, as ferrovias brasileiras entram na fase que poderíamos chamar de 'dieselização', com extraordinária vantagem sobre a tração elétrica, sujeita a frequentes interrupções.” (MATOS, 1981, p. 105). 


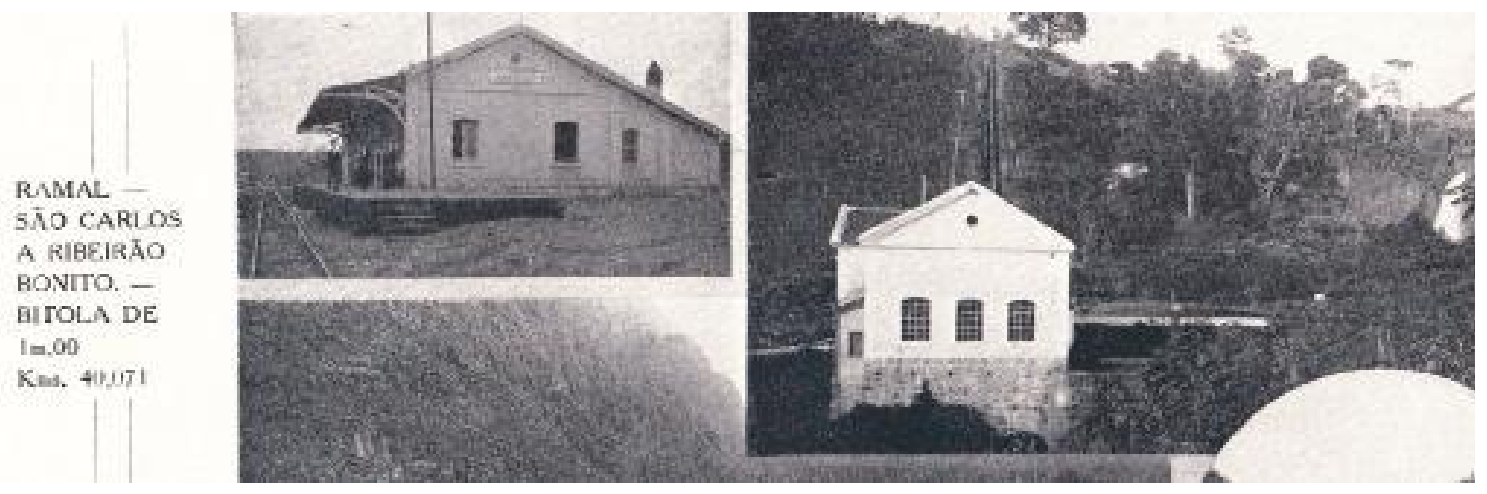

Foto 103 - À esquerda da foto, Salto de Monjolinho e Usina elétrica da Companhia Paulista. Fonte: Álbum Ilustrado da CP, 1918.

própria empresa de fornecimento de energia. ${ }^{33}$ As indústrias de tração (bondes) possuíam a própria produção de energia elétrica, e estavam dominadas por estrangeiros.

Ainda nos anos 1920, houve a criação de armazéns reguladores de café, construídos pelo Estado, mas em pontos de entroncamento ferroviário, escolhidos pela Paulista. Arrisca-se a dizer que já se entrevê a crise do café, pois havia já uma superprodução, e não se dava conta do seu escoamento, tendo que ser armazenada e regulada pelo Estado. A criação ou o aumento das casas de várias vilas ferroviárias, objeto de nosso estudo, como Itirapina, que possuía um armazém, são dessa década.

Outro evento importante é a criação em 1928 da CAIC - Companhia de Agricultura Imigração e Colonização, cujo objetivo era colonizar terras justificando a implantação dos trilhos. Já foi visto anteriormente, como a partir da Estrada de Ferro Noroeste, as ferrovias muitas vezes se antecipavam à criação de cidades. Seria um estudo interessante, se já não foi realizado, um estudo da CAIC e dos núcleos coloniais, de como atuavam em paralelo às ferrovias. Se não fosse um trabalho em conjunto com a imigração, poderia este negócio ser entendido, como um "braço imobiliário" da Companhia. Nos relatórios anuais da Companhia Paulista, não há uma menção explícita a estas atividades da empresa. Outro fato importante que vale lembrar novamente, é que desde 1882 até o final de sua existência, a Companhia Paulista fornecia transporte gratuito aos imigrantes, e os números são contabilizados ano a ano nos seus relatórios.

33 Segundo Saes (1979, p. 307): “No ano de 1920, o Anuário Estatístico de São Paulo registrava a existência de 58 empresas de energia elétrica (22), embora já fosse possível identificar que certas empresas eram dominadas por um mesmo grupo. Além da Light - São Paulo e da São Paulo Electric Co. (Sorocabana), ambas do grupo Light, já aparecia outra empresa estrangeira no setor: The Southern Brasil Electric Co. como acionista da Cia. Campineira de Tração e Luz (originada de duas empresas nacionais) e da Cia. Mogiana de Luz e Força (23), que tinha como diretores Alberto J. Byington, Mario E. Siqueira e Mario Sydow." 


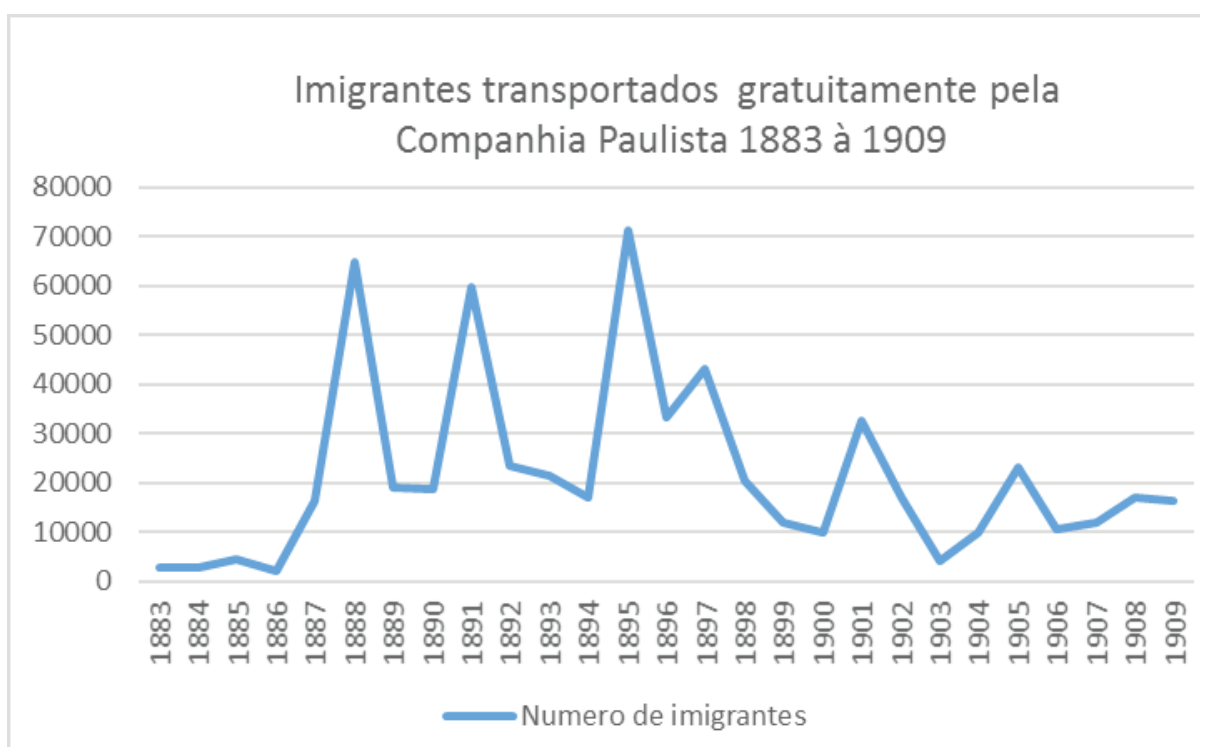

Gráfico 2 - Imigrantes transportados gratuitamente pela Companhia Paulista entre 1883 e 1909. Fonte: elaborado pela autora a partir dos dados do RCPEF (Relatórios da Companhia Paulista de Estradas de Ferro).

Além de construir novas linhas e ganhar frentes, a Paulista neste período e posteriores, foi responsável por adquirir outras companhias e estabelecer fusões. Assim também pertenciam à Companhia Paulista, além da Rio Claro, que já vimos anteriormente, a Estrada de Ferro São Paulo Goiás, Estrada de Ferro Dourados, Estrada de Ferro Barra Bonita, Estrada de Ferro Jaboticabal e a Estrada de Ferro Morro Agudo.

Outra iniciativa foi o trabalho de uniformização das linhas, de 1,00m (por exemplo, a maior parte das linhas da Companhia Rio Claro era de 1,00m) para 1,60m, este fato segundo Ferreira (2010, p. 105), deu-se a partir de 1914, possibilitando maior eficiência e economia, pois permitia o tráfego mútuo com a São Paulo Railway, detentora do privilégio de transportes de Jundiaí a Santos. O monopólio só foi quebrado em fins de 1920, com a construção pela Sorocabana, da ligação Mairinque - Santos, e de bitola métrica. A bitola de 1,60m, a mesma da São Paulo Railway evitava as baldeações. Este fato, leva a apontar também que uma das cidades, onde se encontra uma das vilas ferroviárias, Rincão, possuía grande número de casas, pois demandava grande número de trabalhadores, pois era final da rede eletrificada e por algum tempo da bitola de $1,60 \mathrm{~m}$, demandando baldeação. Segundo Matos (1981, p. 105):

Até 1930, apenas a linha tronco (Jundiaí - Colômbia) e os ramais e Piracicaba e Porto Ferreira possuíam a chamada 'bitola larga', sendo todos os demais trechos de 'bitola estreita'. A partir da década de 30 procedeu a grande empresa, aos poucos, ao alargamento da bitola em 
todo o ramal de Bauru, desde Itirapina até Panorama, às margens do rio Paraná. Idêntica medida foi tomada pela Araraquarense, em toda a sua linha tronco, o que lhe permitiu o tráfego mútuo com a Paulista, sem necessidade de baldeação em Araraquara.

A crise de 1929, e do principal produto de exportação brasileiro, o café, que motivou a construção de muitas ferrovias permite-nos eleger 1930, como o fim do período áureo das ferrovias brasileiras. Alguns autores, como Matos (1981, p. 105), preferem colocar a década de 1940: “A partir de 1940 assiste-se praticamente ao fim da era ferroviária. Não tendo sido reaparelhadas, nem corrigidos os seus erros básicos, não tiveram as ferrovias brasileiras condições para resistir à concorrência das rodovias.”. O fato é que a partir da década de 1930, começa a delinear-se outro tipo de política viária. Surge um presidente que afirma que "governar é abrir estradas", e aficionado pelos automóveis, provavelmente não se referia às ferrovias.

Em 1930, a Companhia Paulista possuía 1475 km de extensão chegando aos limites do estado de Goiás, e caminhando para alcançar os limites do estado de Mato Grosso do Sul, fato este alcançado com a inauguração da estação de Panorama, no extremo oeste, em 1950. A crise cafeeira afetou a Companhia, mas talvez devido aos seus outros investimentos, e a boa administração e aparelhagem, logo se recuperou e resistiu ainda por muito tempo.

Do ponto de vista dos trabalhadores, o período coincide o que Segnini (1982, p. 42), chama de segunda fase da Companhia Paulista (1885-1928), marcada pelo "paternalismo nas relações de produção", que:

revestiu-se de diferentes formas na Paulista. Entre elas destacamse a Sociedade Beneficente, Associação Protetora das Familias dos Empregados, Escola de Aprendizes, Cooperativas de Consumo, Construção de Casas para os Trabalhadores. Todas sob o controle e vigilância da empresa e permeadas pelos conflitos entre os ferroviários e os representantes do capital: a diretoria da empresa (SEGNINI 1982, p.42)

Segundo Ferreira (2010, p.119), as primeiras associações de operários eram mais assistencialistas, ou mutualistas que sindicais. Muitas empresas, por exemplo, possuíam sua Sociedade Beneficente, inclusive as Estradas de Ferro. A Sociedade Beneficente da Companhia Paulista foi fundada em 1895, e a objeção a ela foi um fator importante para a deflagração da greve de 1906 (LEME, 1986, p. 74 apud FERREIRA, 2010, p. 119). Depois a Associação/Sociedade Protetora das Famílias dos Empregados da Companhia 
Paulista, foi fundada no ano de 1904, que tinha a finalidade de fornecer às famílias dos sócios um pecúlio quando estes faleciam ou se acidentavam. Não se sabe se era uma iniciativa dos funcionários, segundo Ferreira (2010, p. 44-5). Zambello (2005, p. 100) afirma que já em 1901, trabalhadores possuíam “uma organização própria, como a Sociedade Beneficente dos Empregados em Locomotiva da Companhia Paulista das Estradas de Ferro, fundada por maquinistas e foguistas.”. Anos depois, em 1910, era criado o Fundo Especial de Pensões, com os mesmos objetivos. A reivindicação deste fundo, vinha dos funcionários desde 1908. Os valores de contribuição constam nos relatórios anuais da Companhia Paulista.

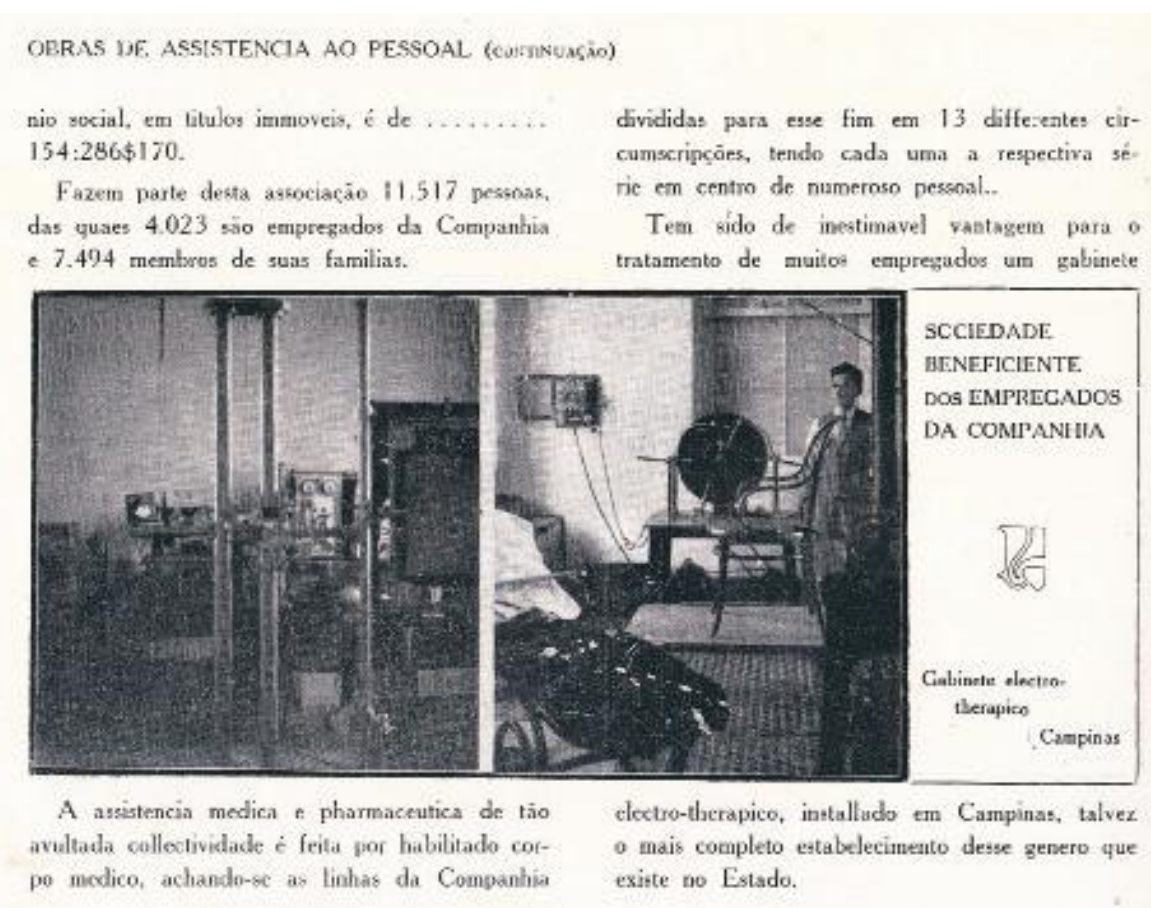

\section{Foto 104}

Sociedade

Beneficente dos Empregados da Companhia Paulista. Fonte: Álbum Ilustrado da CP, 1918.

A Escola de Aprendizes e a construção das casas de trabalhadores, neste primeiro período, não era uma questão de assistência social, mas de interesse econômico da própria empresa. Ela necessitava arregimentar e qualificar seus trabalhadores, daí a função da Escola de Aprendizes; fundada em 1901 segundo Pinto (1977, p. 111) ou 1903, segundo Segnini (1982, p. 46-7). Talvez as informações não sejam contraditórias, sendo a escola noturna descrita por Pinto (1977, p. 111) uma célula do que viria a ser a Escola de Aprendizes de 1903:

Em principio de 1901 foi installada junto às officinas uma escola nocturna para os aprendizes, cujo programa de ensino é o seguinte:

$1^{\circ}$ anno-Arithmetica pratica e desenho

$2^{\circ}$ anno - Elementos de geometria pratica e desenho

$3^{\circ}$ anno - Arithmetica theorica, geometria elementar e desenho $4^{\circ}$ anno - Mechanica pratica elementar, desenho de machinas, noções de physica e chimica. 
Este curso é obrigatório para todos os aprendizes, que têm revelado aproveitamento considerável e acima da expectativa. Das empresas de estradas de ferro do Brasil a única que deu este bello exemplo de interesse pela instrucção profissional de seu operários foi a Companhia Paulista.

A escola noturna, e também a Escola de Aprendizes funcionavam na oficina da Companhia Paulista em Jundiaí. O ambiente da oficina era importante, pois o saber transmitia-se no fazer, pelos empregados da própria oficina. Segundo Segnini (1982, p. 75): "A seleção era feita entre os próprios filhos dos ferroviários, garantindo, assim, a formação da 'família ferroviária', toda ela enquadrada na ideologia da empresa. (...)”. Os aprendizes muitas vezes não eram remunerados, porém este processo foi se tornando pouco rentável e moroso, porque mudara o perfil da própria Companhia Paulista, bem como das outras ferrovias, nas décadas seguintes.

As Cooperativas de Consumo, criadas em 1902, proporcionavam gêneros alimentícios e outras mercadorias (como tecido, utensílio doméstico, etc...) com preços acessíveis somente a seus funcionários, e estes poderiam pagar descontando na folha de pagamento. Havia cooperativas em Jundiaí, Campinas, Dois Córregos e São Carlos, e tudo leva crer que eram cidades que possuíam grandes armazéns. Os pedidos podiam ser realizados de qualquer cidade para as cooperativas, e estas despachavam para as cidades. As cooperativas foram fechadas quando a Companhia Paulista foi encampada

Foto 105 Cooperativa da Companhia Paulista.

Foto 106

Trabalhadores da baldeação. Foto 107 - Abaixo da foto, operação de baldeação de gado na estação de São Carlos. Fonte: Álbum Ilustrado da CP, 1918.

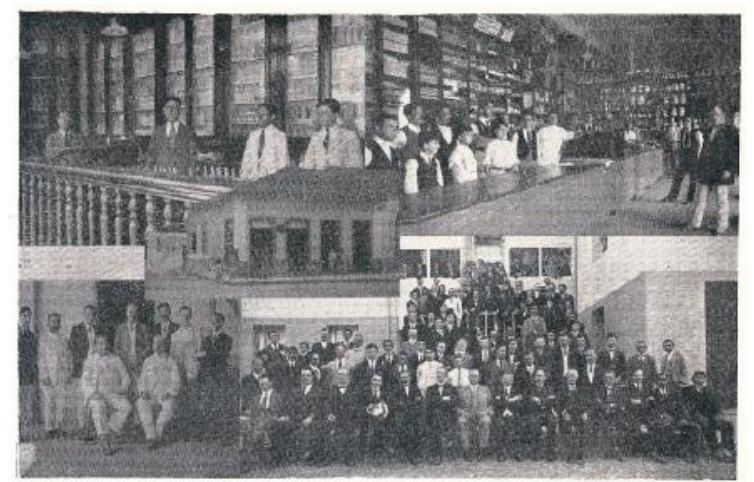

105

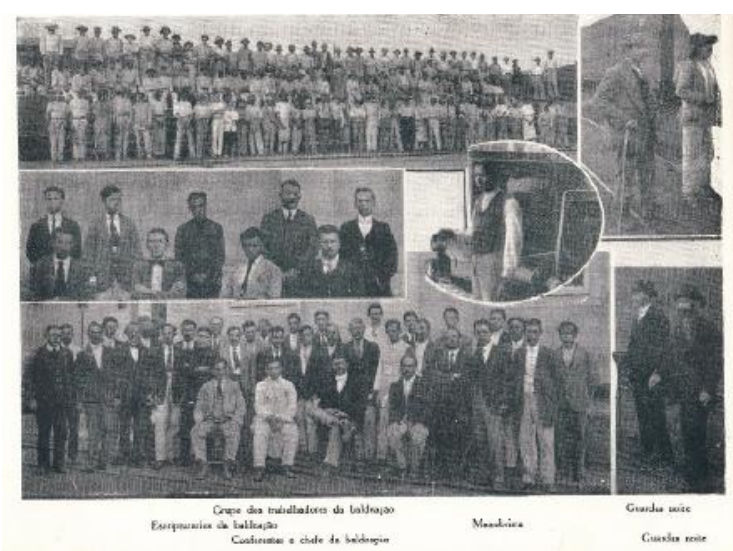

106

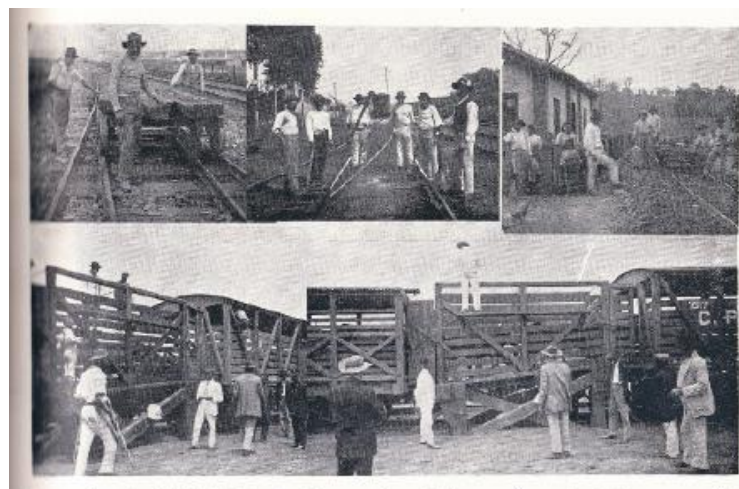


em 1961. Depoimentos de épocas mais recentes ${ }^{34}$, apontam que os funcionários apreciavam esta iniciativa pois os produtos comercializados eram mais baratos que na cidade.

Já foi visto que apesar de ser apontado por Segnini (1982) como um "artifício ofuscador" desta segunda fase, a construção de casas pela Companhia Paulista existiu desde o seu início. O acesso dos trabalhadores mais qualificados, qualificação também oferecida pela Companhia, foi o que mudou com o tempo. Além das oficinas, outro lugar de grande demanda, eram os entroncamentos de ferrovias, baldeação (por causa da diferença de bitolas) e armazéns. A criação de armazéns reguladores de café dá-se em 1922, época em que foram construídos pelo governo federal, nos terrenos da Companhia, justamente nas cidades objetos de estudo - Itirapina, São Carlos e Rincão - onde já havia o entrocamento entre bitolas estreitas e largas. Parece que após a construção de tais armazéns, contrataram-se mais trabalhadores, o que agravou o problema de habitação, como é apontado no relatório da Companhia, em 1924. De fato, foi aprovada pela Diretoria a construção de mais casas nas três cidades apontadas, e também em Araraquara.

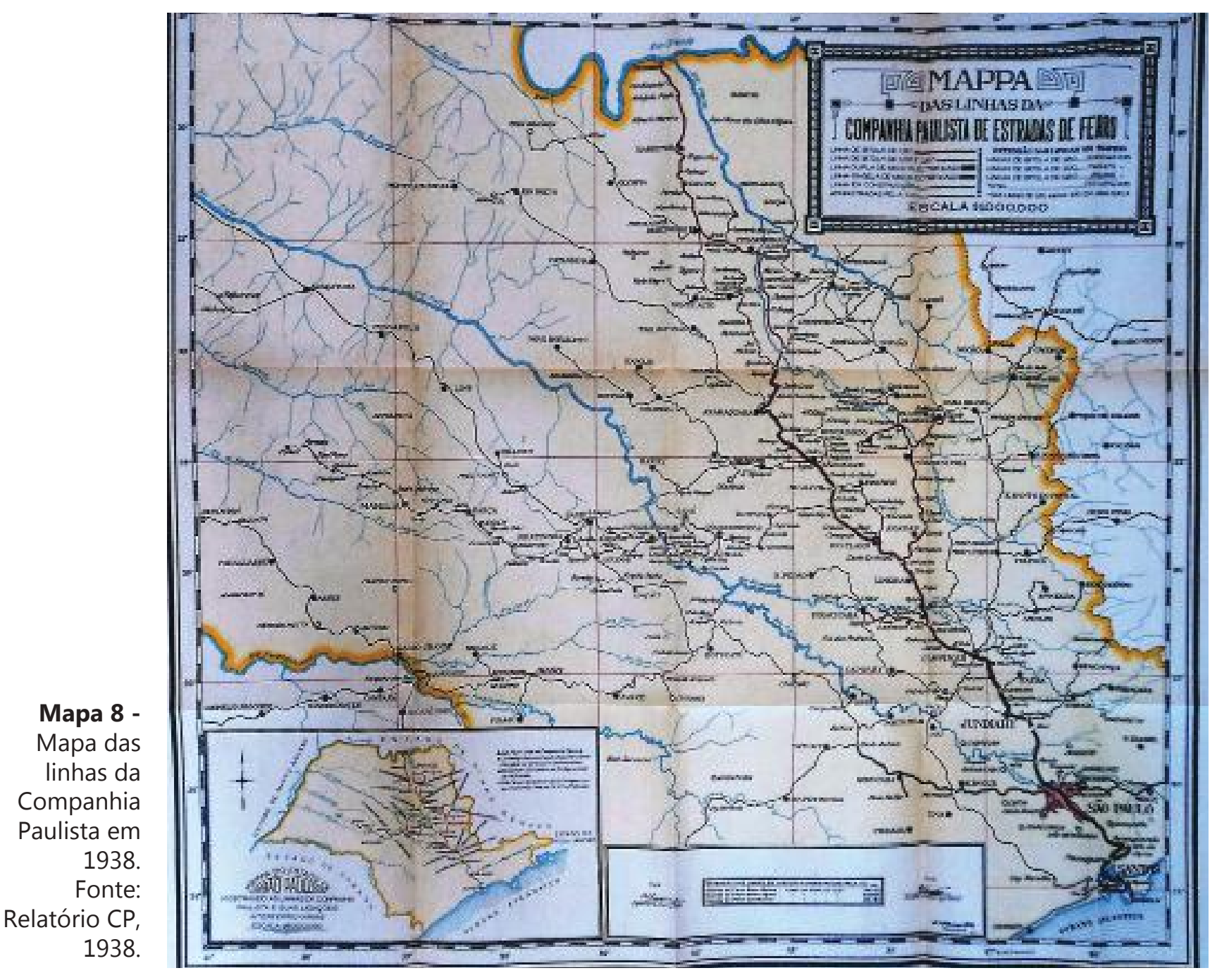

34 Depoimento do Sr. Carlos, em Ferreira (2010, p. 143) 


\section{A Companhia da Paulista entre 1931-1961: organizacão científica, fim da Companhia Paulista e das vilas ferroviárias}

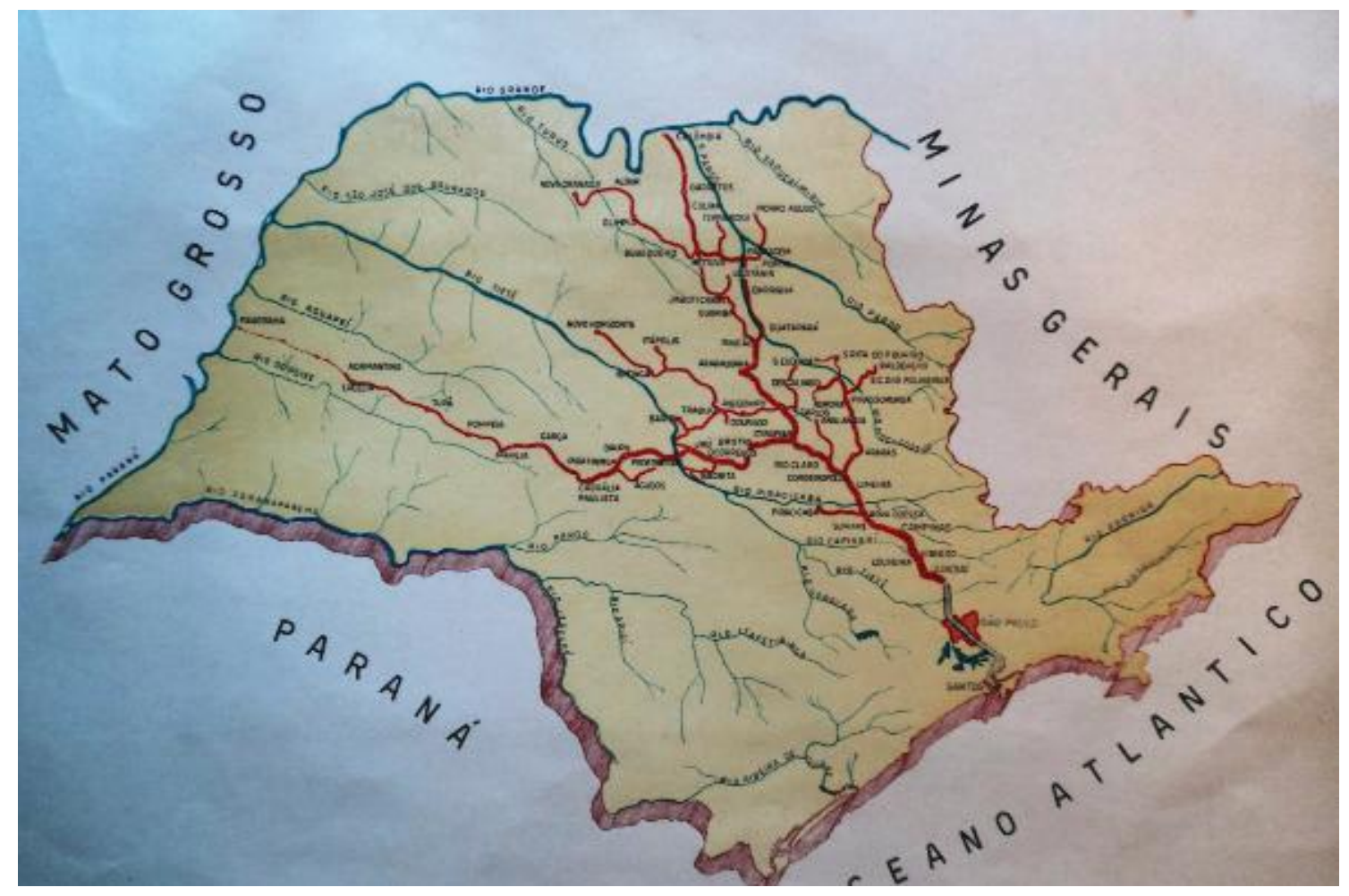

Mapa 9 - Mapa das linhas da Companhia Paulista em 1954. Fonte: Relatório CP, 1954.

Em geral, as décadas de 1930 ou 1940, são assinaladas como o fim da era ferroviária, pela crise do café e pela concorrência e política rodoviaristas. A concorrência rodoviária ${ }^{35}$ já se fazia sentir desde 1930, ainda que muitas ferrovias também oferecessem tal serviço de forma complementar. Além do café, é claro que as ferrovias transportavam outros tipos de mercadorias, porém, mesmo assim, o transporte destas foi-se perdendo para a concorrência do transporte rodoviário. Além disso, há várias explicações para o declínio das ferrovias, por exemplo, Saes (1981, p.182) tem duas hipóteses:

A problemática geral, acrescentamos duas hipóteses diretrizes. A primeira via a origem dos problemas das ferrovias nas próprias bases de seu estabelecimento: as estradas, que visavam servir à atividade exportadora, tinham o traçado definido pela diretriz 'áreas de

Já havia uma preocupação de concorrência no Congresso de Engenharia e Legislação Ferroviária em 1936, por exemplo: "2a . Commissão. "A Commissão resolveu, por indicação do muito illustre Eng. Arthur Pereira de Castilho, propor ao plenário que, como homenagem à memória do saudoso engenheiro Niepce da Silva, a brilhante these da sua autoria 'O papel das rodovias. Sua concurrencia com as ferrovias' e que em signal de respeito não foi discutida, seja publicada na íntegra nos annaes do Congresso." (1936, p. 206) 
produção-portos'. Tal fato limitava os fluxos potenciais de transporte e implicava em baixo grau de aproveitamento da capacidade instalada. Em conseqüência, notamos a baixa rentabilidade das empresas. A segunda hipótese responsabilizava a política administrativa das ferrovias - ou, talvez a administração política das empresas estatais pela virtual falência do sistema ferroviário (em especial, pelo número excessivo de empregados).

A evidência empírica, proporcionada pelo estudo das estradas de ferro Paulista, Mogiana e Sorocabana, nos aproxima da primeira hipótese, como já sugerimos no correr do trabalho.

O período de 1930 a 1961 houve três presidentes: Getúlio Vargas, Dutra e Juscelino Kubistchek, em cujas administrações foram elaborados dois Planos de Viação: o plano de viação de 1934 e o plano de viação de 1956. Apesar dos planos de viação elaborados por diversos engenheiros em diversas épocas, o plano de viação de 1934 é o primeiro plano de viação geral aprovado oficialmente. O plano vinha sendo elaborado desde 1931, quando "o Ministério da Viação e Obras Públicas tratou de formar uma comissão de alto nível para estudar a questão(...)” (MARTINS, 1995, p.100). Uma das figuras integrantes da comissão era o eng. Ferroviário Francisco Paes Leme de Monlevade, que foi da diretoria da Companhia Paulista. O plano de 1934 contemplou a complementariedade entre os vários tipos de transporte: marítimo, fluvial e rodoviário. Martins (1995, p. 10) aponta como falhas do Plano de 1934, as poucas inovações e os poucos investimentos. Não previa a fonte de recursos e faltava apoio da legislação vigente, pois "o Governo Federal não era o único que tinha o direito a legislar sobre a construção, os melhoramentos e a exploração dos transportes, por isso, sem regras e regulamentos uniformes o alcance dos objetivos do Plano estava comprometido, como, aliás previa a própria Comissão." (MARTINS, 1995, p. 108).

Paralelamente, no governo de Vargas, e final da década de 1930, começou o processo de encampação de empresas nacionais e estrangeiras, algumas reunidas na Inspetoria Federal de Estradas, órgão do Ministério da Viação e Obras Públicas encarregado de gerir as ferrovias e rodovias federais. "Esta Inspetoria deu origem, posteriormente, ao Departamento Nacional de Estradas de Rodagem - DNER e Departamento Nacional de Estradas de Ferro - DNEF. Esta, por sua vez, em 1957, daria origem à Rede Ferroviária Federal S.A. - RFFSA, empresa ligada ao Ministério dos Transportes." (SOUKEF JUNIOR, 2005, p. 100). Um exemplo de encampação é o da São Paulo Railway, cujo contrato de concessão findava em 1946. O período posterior, não é mais favorável para as ferrovias, segundo Martins (1995, p. 233): 
O período 1941 a 1951 chegava com intensas modificações no quadro da lucratividade das empresas ferroviárias brasileiras. Os estímulos gerados pela II Guerra Mundial e o refreamento da concorrência rodoviária, devido à falta de combustiveis, fizeram com que algumas empresas ferroviárias apresentassem superávits expressivos. Cessados tais estímulos ficaram os efeitos negativos do conflito mundial, relativos a não renovação de material importado, agravando o quadro de obsolescência e desgaste do material. Diante deste quadro, os déficits voltaram a surgir com uma força ainda maior do que no primeiro subperíodo estudado.

A Segunda Guerra Mundial atingiu várias economias e, no mundo, a partir da guerra, muitas ferrovias foram nacionalizadas para combater a crise, como nos Estados Unidos, França e Inglaterra. Algumas das nacionalizações foram exitosas, e outras nem tanto. Porém este movimento de nacionalização das ferrovias mundiais ${ }^{36}$ será usado como argumento pelos simpatizantes da nacionalização das ferrovias brasileiras, na criação da Rede Ferroviária Federal S. A.

Em 1951, foi elaborado outro Plano de Viação, porém não surtiu efeito (Martins, 1995, p. 312). Em 1956, já no governo de Juscelino Kubistchek, foram elaborados separadamente os Planos Rodoviário Nacional e Ferroviário Nacional. Os interesses do governo pendem para o setor rodoviário. Houve nesse meio tempo, a Comissão Mista Brasil - Estados Unidos, que avaliou os setores da economia brasileira, inclusive o de transportes. Depois desta Comissão, foram concedidos empréstimos através de bancos estrangeiros, especificamente o Export-Import Bank (Eximbank) e o BNDES para o reaparelhamento de várias ferrovias, porém eram muitas as obras a serem feitas. Além disso, segundo artigos da Revista Ferroviária da década de 1950, a discussão girava em torno dos crescentes déficits das ferrovias. Como causas apontadas, além da concorrência rodoviária, a falta 36 Há vários artigos sobre a nacionalização das ferrovias internacionais na Revista Ferroviária, como também o assunto é discutido por Martins (1995, p. 358): “A opção por uma empresa estatal que aglutinasse ferrovias federais positivamente não era nova, só para ficarmos em alguns exemplos, as encampações de ferrovias privadas na Áustria iniciou em 1851, enquanto seu sistema estatal começou a operar trinta anos mais tarde com a Kaiserlich und Koeniglich Staats Bahen, a KKSt. B; na Bélgica o sistema estatal começou a se expandir a partir de 1843 até a formação da Société Nationale des Chemins de Fer Belgique. Já a empresa estatal dinamarquesa foi formada em 1885. Na França onde o Estado sempre havia sido ativo na formação e desenvolvimento de ferrovias, formou a importante SNFC em 1938. Na Alemanha, cujo Estado também foi muito ativo no setor desde o início, teve sua primeira companhia unificadora de linhas férreas públicas após a I Guerra Mundial, sendo desde 1870 cinco estados administravam a maior parte das linhas (Prússia, Bavária, Saxônia, Hecklenburg e Hesse). A Grã-Bretanha, mãe das ferrovias, nacionalizou as mesmas em 1948, após o Estado haver forçado um grupamento das mesmas em 4 empresas no ano de 1923. Na Itália, após sucessivas encampações ocorridas a partir de 1865, formou seu sistema estatal unificado, em 1905. Os exemplos podem ser multiplicados à exaustão. O fato é que, positivamente, a unificação das ferrovias federais era inevitável, devido ao grande número de linhas administradas pelo Estado, bem como a experiência bem sucedida de outros países." 
de produção econômica das zonas servidas pelas rodovias, gerando o que se chama de ramais deficitários. Matos (1981, p. 30) aponta a lei 2.698, de 27 de dezembro de 1955, que autorizava a supressão destes ramais: "Só no Estado de São Paulo quase mil quilômetros de estradas foram suprimidas, abrangendo 27 trechos, de pequenas estradas, ou ramais das grandes empresas.” Assim, já na década de 1950, começavam a desaparecer os primeiros ramais ferroviários. A Rede Ferroviária Federal S. A. chegou a realizar um estudo segundo o qual, chegavam a $5.000 \mathrm{~km}$ os ramais deficitários. Neste período iniciou-se a política de substituição dos trilhos pelas rodovias, medida que foi polêmica.

Buscando uma solução para crise ferroviária, o então presidente da República, Getúlio Vargas, envia: “em 28 de abril de 1952, uma mensagem ao congresso nacional, acompanhando o Projeto $n^{\circ} 1.907$, de 1952, determinando a transformação das empresas ferroviárias da União e autorizando a constituição da Rede Ferroviária Federal S. A. (...)”.(MARTINS, 1995, p. 354) O projeto foi amplamente discutido nos meios técnicos, econômicos e políticos. Apoiado por uns, criticado por outros, assunto polêmico, cuja aprovação foi realizada somente no próximo governo, de Juscelino Kubistchek. O Congresso aprovou a transformação das empresas ferroviárias da União, na Rede Ferroviária Federal, através da lei n 3.115, em 16 de março de 1957. Mesmo com a criação da Rede Ferroviária Federal, os déficits ferroviários aumentavam. Uns culpavam a má administração da Rede Ferroviária Federal, na qual ao invés de técnicos, foram colocados apadrinhados políticos. O fato é que as despesas com pessoal consumiam grande parte das despesas das ferrovias, aliado, ao fato que o país atravessava um período de inflação.

É de 1940, a criação do salário mínimo, e de 1945, a Consolidação das Leis Trabalhistas. No entanto, a década de $1940^{37}$ é marcada pela estagnação da renda e pauperização dos ferroviários que estenderá também durante toda a década de 1950. Assim serão frequentes reivindicações por melhores salários, como também sobre o sobretempo ${ }^{38} \mathrm{e}$ inclusive a regulamentação da jornada de trabalho. Alguns autores afirmam que a encampação da Companhia Paulista foi motivada pela greve dos funcionários de 1961, reivindicando melhores salários como os da Sorocabana, que já era administrada pelo governo estadual. Zambello (2005, p. 189) afirma:

37 Em 1945, os salários estavam em torno de Cr\$ 745,00 a Cr\$760,00. (ZAMBELLO, 2005, p. 160).

38 "Um tema muito presente na memória do ferroviário é sua submissão ao sobre-tempo, como forma de garantia de subsistência (aluguel, alimentação e educação dos filhos) (...)” O sobre-tempo era mais concedido aos maquinistas. "Os gastos com a aplicação das leis sociais era a justificativa usada pelos donos das estradas de ferro para manter baixo os salários dos trabalhadores das estradas de ferro e limitar a contratação de mais maquinistas e foguistas (...)” (ZAMBELLO, 2005, p. 167) 
Foi no governo de Jânio Quadros que foi possível a encampação da Paulista, frustrada duas vezes no governo de Juscelino Kubitschek. Em 1961, Carvalho Pinto decretou a encampação da Paulista pelo Estado. A encampação significou o fim da Paulista e o fim do sindicalismo de oposição dos ferroviários da Paulista (...)

Apesar de em meio à crise ferroviária, ser a única empresa de propriedade privada e ainda apresentar saldos positivos, a Paulista dependia cada vez mais de subvenções estaduais (FERREIRA, 2010, p. 13). E assim, a Paulista registrou o seu fim como a primeira ferrovia de capital nacional, que foi também a última a resistir como de administração privada. A que, ao lado das empresas Sorocabana e Mogiana, as três empresas mais rentáveis do estado no período áureo do café e das ferrovias, segundo Saes (1981), teve o mesmo destino destas, que haviam sido encampadas anteriormente. A partir de 1961, a administração da Paulista passa ao governo do Estado, que em 1971, cria a FEPASA - Ferrovias Paulistas S. A., reunindo em uma única empresa cinco ferrovias: a Companhia Paulista, a Sorocabana, a Mogiana, a Araraquarense e a São Paulo-Minas. Também a partir de 1961, não existiram mais, grandes companhias como foi a Companhia Paulista de iniciativa privada. Somente ocorrerá a privatização das malhas e concessões realizadas a partir da década de 1990, com a chamada lei das concessões: Lei 8987/1995.

Enfocando os trabalhadores ferroviários, o período coincide com a que Segnini chama de terceira fase (1928-1961) "caracterizada pela reforma administrativa de 1928, dá-se como resposta 'científica' às necessidades crescentes, por parte do capital, do exercício da dominação sobre a mão-de-obra para obtenção de lucros em níveis máximos. (...) ’'(SEGNINI, 1982, p. 16). O fato utilizado pela autora para demarcar sua periodização em 1928 é o seguinte:

(...) de novembro de 1928 a 31 de outubro de 1929 contratava a Companhia Paulista o primeiro conjunto de máquinas 'Hollerith', procurando, assim, substituir o método antiquado de escrituração à mão e manuseio de documentos, pelo moderno, para a sua estatística mensal, serviços de relatórios e, atualmente, com o serviço de folhas de pagamento de toda a companhia, já organizado por esse sistema completamente racional.

Eis ai dois fatores que exemplificam a maneira mais prática de administrar e reorganizar racionalmente o trabalho ferroviário.

A despesa mensal de pessoal per capita da Companhia Paulista (parece incrível, mas é verdade) atinge atualmente Cr\$1.2000,00 (hum mil e duzentos cruzeiros). Há número muito elevado de pessoal em relação aо seu Tráfego e Oficinas. (SEGNINI, 1982, p. 89)

Os artifícios paternalistas da fase anterior são substituídos pela chamada "Organização Racional ou Científica do Trabalho". Desse modo, a Escola de Aprendizes juntamente com outras empresas ferroviárias será transformada na Escola de Ferroviários, 
em 1924, tendo à frente a figura de Roberto Mange ${ }^{39}$ que, alinhado às ideias tayloristas, fordistas, de racionalização e organização científica do trabalho ${ }^{40}$, em épocas posteriores, estará na fundação do IDORT (1931) e na organização das escolas CFESP (1934), SENAI $(1942)^{41}$ e SESI (1946). E a Sociedade Beneficente e a Associação Protetora das Famílias dos Empregados será transformada em lei federal. Darão lugar às Caixas de Aposentadorias e Pensões, que primeiro nasceu no âmbito dos ferroviários, e depois os benefícios ampliados a outras categorias de trabalhadores. Houve assim, cada vez mais forte participação e intervenção do Estado, principalmente no governo Vargas, com as empresas retirando-se do provimento destes benefícios, o que afetará a produção das casas.

Para entender a Escola dos Ferroviários, criada em 1924, é necessário entender a figura de Roberto Mange. Desde 1923, estava na organização do curso de Mecânica Prática ou Escola Profissional de Mecânica, no Liceu de Artes e Ofícios, convidado por Paula Souza.

(...) Essa Escola especializada, de orientação nova, escudada nos métodos de ensino profissional surgidos após a grande guerra, já possuía seu Serviço de Psicotécnica e também já trazia em si a semente de um centro de formação do pessoal ferroviário, pois, por acordo estabelecido com as principais Estradas do Estado (SPR, EFS, CP e $C M)$ cada uma destacou anualmente, por sua conta, dois aprendizes para virem a São Paulo frequentar um Curso de duração de 4 anos. (MANGE, 1941, p. 27)

As aulas práticas eram realizadas na oficina da Sorocabana, localizada no bairro da Lapa. Um ano depois, Roberto Mange estava à frente da organização da Escola de Ferroviários de 1924. Em 1927, a Estrada de Ferro Sorocabana elaborou um projeto de um curso de aprendizes, em Mairinque, com programa mínimo, e cursos de aperfeiçoamento de pessoas e provas psicotécnicas. As aulas começaram em 1930, sob o nome "Curso de Ferroviários de Sorocaba", o que Mange (1941, p. 29) aponta como o início do "Serviço de Ensino e Seleção Profissional” (SESP) da Estrada de Ferro Sorocabana. Roberto

39 "Roberto Auguste Edmond Mange nasceu no ano de 1885 em La Tour de Peilz, cantão de Vaud, na Suíça. Formou-se engenheiro mecânico em 1910 na Eidgenoessische Technische Hochschule - ETH, na cidade de Zurique, depois de passar alguns anos em Portugal, onde conclui a escola primária em 1899, e em Minden, na Alemanha, onde passou alguns anos no curso secundário. Iniciou sua carreira na empresa Brown-Boveri, tendo sido transferido para a sede da empresa, na Bélgica, em 1912 (Bryan, 1984). Em junho de 1913 chega a São Paulo a convite do engenheiro e empresário Antônio Francisco de Paula Souza, indo lecionar na Escola Politécnica, criada em 1894 'para resolver o problema da falta de mão-de-obra especializada, tanto para a indústria quanto para atender às próprias necessidades de crescimento da cidade e da expansão das ferrovias (...)'” (SENAI, 1991 apud TENCA, 2002, p.52) .

40 Tais idéias estava em circulação pelo mundo bem antes, e no Brasil, na década de 1920. Tenca (2002, p. 10,15,16) faz uma apreciação histórica de cada um dos conceitos.

41 No SENAI, Mange foi o primeiro diretor e ocupando o cargo até a sua morte, em 1955 (TENCA, 2002, p. 25) 
Mange participou de sua criação, influenciado por "uma viagem que fez à Alemanha, em 1929, 'a fim de conhecer os métodos racionais de aprendizagem e seleção profissional aplicados na Reichsbahn, um consórcio formado pela unificação de empresas ferroviárias daquele país"” (SENAI 1991:96 apud TENCA 2002, p. 53). Quando o SESP começou a funcionar, em 1931, oferecia dois cursos: o de Ferroviários, destinado a aprendizes e, para aqueles que já fossem funcionários, o de Aperfeiçoamento. (TENCA, 2002, p.3). Neste mesmo ano, 1931, era criado o IDORT, Instituto de Organização Racional do Trabalho $^{42}$, formado através de associação de industriais, da qual participavam também engenheiros, médicos e educadores (um dos sócios fundadores foi Roberto Simonsen, e Roberto Mange, estava presente como diretor técnico), órgão que foi responsável pela criação de muitas escolas profissionalizantes, como o SENAI (1942) e o SESI (1946). Roberto Mange também desenvolveu atividades junto com o educador Lourenço Filho, seu companheiro no IDORT, "especialmente no campo da psicotécnica, contribuíram para deixar sua marca no movimento escola novista brasileiro.”.(TENCA, 2002, p. 52)

Em 1934, o SESP torna-se o Centro Ferroviário de Ensino e Seleção Profissional (CFESP), ampliando a sua ação envolvendo, além das estradas de ferro paulistas, as de outros estados. É claro, que havia a participação do IDORT e da figura de Roberto Mange. Era então governador do estado de São Paulo, Armando Salles de Oliveira, que foi companheiro de Mange no IDORT. O CFESP contava com a adesão da Estrada de Ferro Araraquarense, Estrada de Ferro Campos do Jordão, Companhia Paulista de Estradas de Ferro (Jundiaí e Rio Claro), Companhia Mogiana de Estradas de Ferro (Campinas), Companhia Ferroviária São Paulo-Goiás (Bebedouro), Companhia Estrada de Ferro do Dourado, além da Estrada de Ferro Sorocabana. “O CFESP mantinha sob sua orientação cursos de formação e de aperfeiçoamento nas oficinas ferroviárias de Campinas, Araraquara, Rio Claro, Bebedouro e Jundiaí. Para empresas de menor porte, os serviços deveriam ser desenvolvidos com a participação de prefeituras locais.”. (SENAI, 1991 apud TENCA, 2002, p. 56). O CFESP era administrado por uma comissão superior composta de representantes das Secretarias da Viação e Obras Públicas, da Educação, da

42 "O IDORT, criado em 1931, embora já praticamente organizado em 1929, surge, com a bandeira da racionalização do trabalho, como a grande agência responsável, direta ou indiretamente, pela multiplicação de inúmeras outras voltadas para a busca da realização da acumulação do capital, pela intensificação da exploração do trabalho, numa ampla cruzada pela ocupação e controle do tempo do trabalhador. Essas instituições apareciam diretamente em estruturas governamentais ou em esferas privadas, sempre voltadas para a consolidação do exercício do poder político segundo a razão industrial. Apenas para exemplificar, quanto ao primeiro grupo pode-se destacar o DASP (Departamento de Administração do Serviço Público) estruturado no Estado Novo, em 1938. ” (TENCA, 2002, p. 20). 
Saúde Pública e das Estradas de Ferro, cabendo a chefia dos serviços um diretor nomeado por essa Comissão. (MANGE, 1941, p. 29)

Devido às ferrovias serem as únicas ou maiores empregadoras da região, e ainda a carreira de ferroviário fosse considerada promissora, com certo status social e econômico, o ingresso no curso era concorrido e alguns ferroviários consideravam a prova difícil. ${ }^{43}$ Além das provas, dava-se preferência ao parentesco. Isto é, aqueles que tinham alguém na família trabalhando nas ferrovias, perpetuando assim as gerações ferroviárias. Basicamente, as aulas eram em período integral, a parte da manhã dedicadas às aulas teóricas, como português e matemática, e a parte da tarde, às oficinas. Os alunos recebiam um pequeno salário.

\section{Foto 108 - Escola ferroviária de Rio Claro, sala de aula. Fotos 109, 110 e 11 - Escola ferroviária de Rio Claro, interior da oficina. Fonte: Museu Ferroviário de Jundiaí, s/d.}
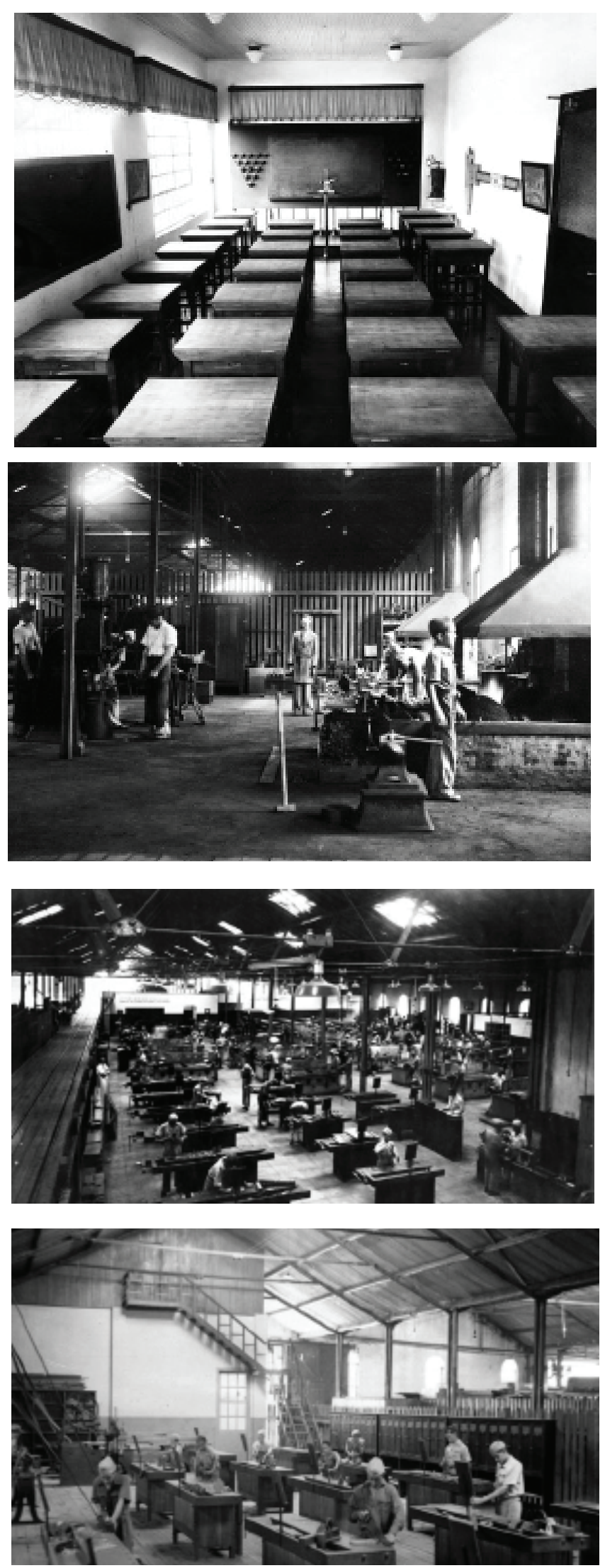

110

111

43 "Os candidatos eram submetidos a um processo de seleção bastante concorrido, que constava de avaliação de conhecimentos de português e matemática e de uma prova prática, que alguns entrevistados denominaram teste de aptidão e a maioria deles compara-a aos chamados psicotécnicos. Finalmente passavam por um exame médico.” (TENCA, 2002, p. 60). 
Em Rio Claro, durante alguns anos (1935 a 1939), as disciplinas teóricas foram desenvolvidas somente na Escola Profissional Secundária, mantida pelo governo do estado, e eram ministradas, no período da manhã, por professores daquela instituição mantida pelo poder público estadual. As aulas práticas aconteciam nas oficinas da Paulista, sempre no periodo da tarde. Aqui os instrutores eram oficiais da ferrovia, a maioria deles, no início, recrutados entre aqueles que tinham passado pela Escola Profissional. Aos poucos, a partir da formação da primeira turma, os instrutores da parte prática foram sendo selecionados entre os ex-alunos que apresentavam maior desempenho. O mesmo aconteceu com relação às disciplinas teóricas de conteúdo técnico. Depois de alguns anos o Curso passa a funcionar definitivamente nas oficinas, nos dois turnos, com todos os professores mantidos pela Companhia. (TENCA, 2002: 56)

A duração do curso era de três a quatro anos, e após estes anos, como se pode depreender do discurso acima, a garantia de emprego ao final era obtida pelos empregados. Através dos depoimentos realizados por Tenca (2002) pode-se ver o quanto era exigente o ensino. Interessante como aprendiam desenho geométrico, faziam o desenho de cada peça, tanto os alunos de Mecânica e de Marcenaria, e de como executavam tal desenho. Ao final do curso, cada aluno recebia uma caixa de ferramentas, por ele executada. Note-se o relato de um ex-ferroviário, sr. Renato Stabelini transcrito no trabalho de Tenca (2002, p. 214) :

Da turma toda, somente dois não entraram: o Tavares e o Turolla. Para esses o Dr. Pelágio deu a caixa de ferramenta. Quando a gente se formava já tinha a caixa de ferramenta: escala, graminho, esquadro, compasso, suta, esquadro " $T$ ", régua... Era a caixa de ferramenta prontinha. Cada seção recebia as ferramentas da seção dele. No $4^{\circ}$ ano o aluno preparava todas as ferramentas dele. O marceneiro fazia as caixas. E o ajustador tinha a caixa de ajustador, ferreiro era caixa para ferreiro, caldereiro era caixa para caldereiro e marceneiro era caixa de marceneiro. (...)

Três aspectos importantes presentes na filosofia das escolas profissionais de introduzida por Roberto Mange: formação racional para exercer postos de comando intermediários, a questão da disciplina e a tese defendida por Mange da "formação integral do homem trabalhador", afirmando que "era preciso juntar 'espírito e corpo', 'cabeça e mãos', 'instrução geral e aprendizagem profissional' para que o operário pudesse se tornar também um 'cidadão esclarecido"(MANGE, 1926 apud TENCA, 2002). Tal formação integral do trabalhador, relaciona-se com o que Segnini (1982) chama de "introjeção da moral patronal" no trabalhador, e que contribui por incutir o que se chama de "família ferroviária", termo este muito usado nos depoimentos dos ex-ferroviários, e tal conceito é que permeia os espaços das vilas ferroviárias, seja na disciplina desde o 
uniforme e a pontualidade do trabalho na ferrovia, como na manutenção das linhas como das casas, seja no tempo livre passado com outros ferroviários.

Sobre a formação para exercer postos de comando intermediários, de fato, foi assim, “(...) a partir dos anos quarenta, antigos encarregados, chefes, auxiliar de mestre geral e até mesmo geral foram sendo substituídos pelos egressos do Curso de ferroviários.”(TENCA, 2002, p. 74) Parece que esta característica era da Companhia Paulista, segundo Tenca (2002), diferenciando-se em relação ao taylorismo. De fato, a assunção de engenheiros a postos de comando, como diretoria e inspetoria geral, já

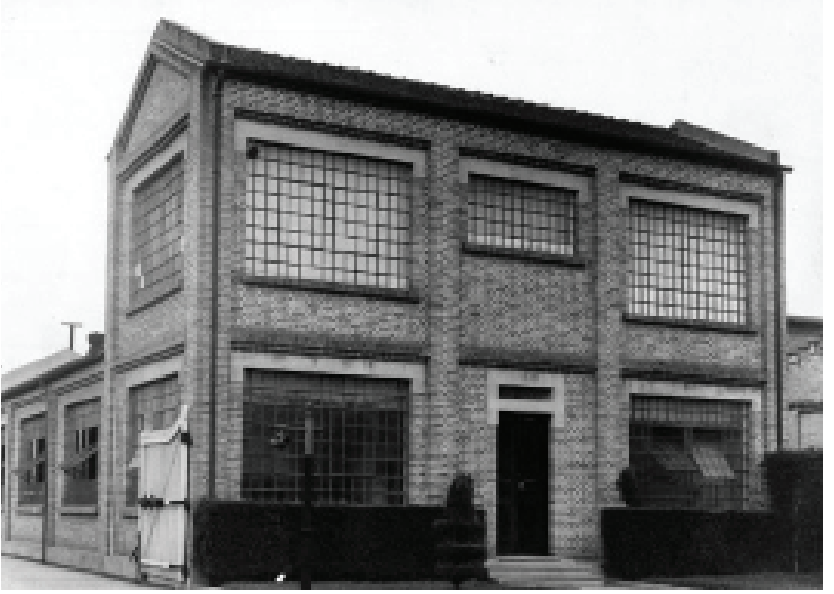
era verificada na Companhia Paulista, através dos exemplos de Francisco Monlevade e Jayme Cintra, que a princípio, não tinham nenhuma ligação de sangue ou parentesco com a primeira elite cafeeira, como o caso de Adolpho Pinto. Assim, este modelo é replicado para os postos intermediários, com os melhores alunos formados nas escolas sendo chamados a assumir tais postos. Temos alguns exemplos, extraídos do trabalho de
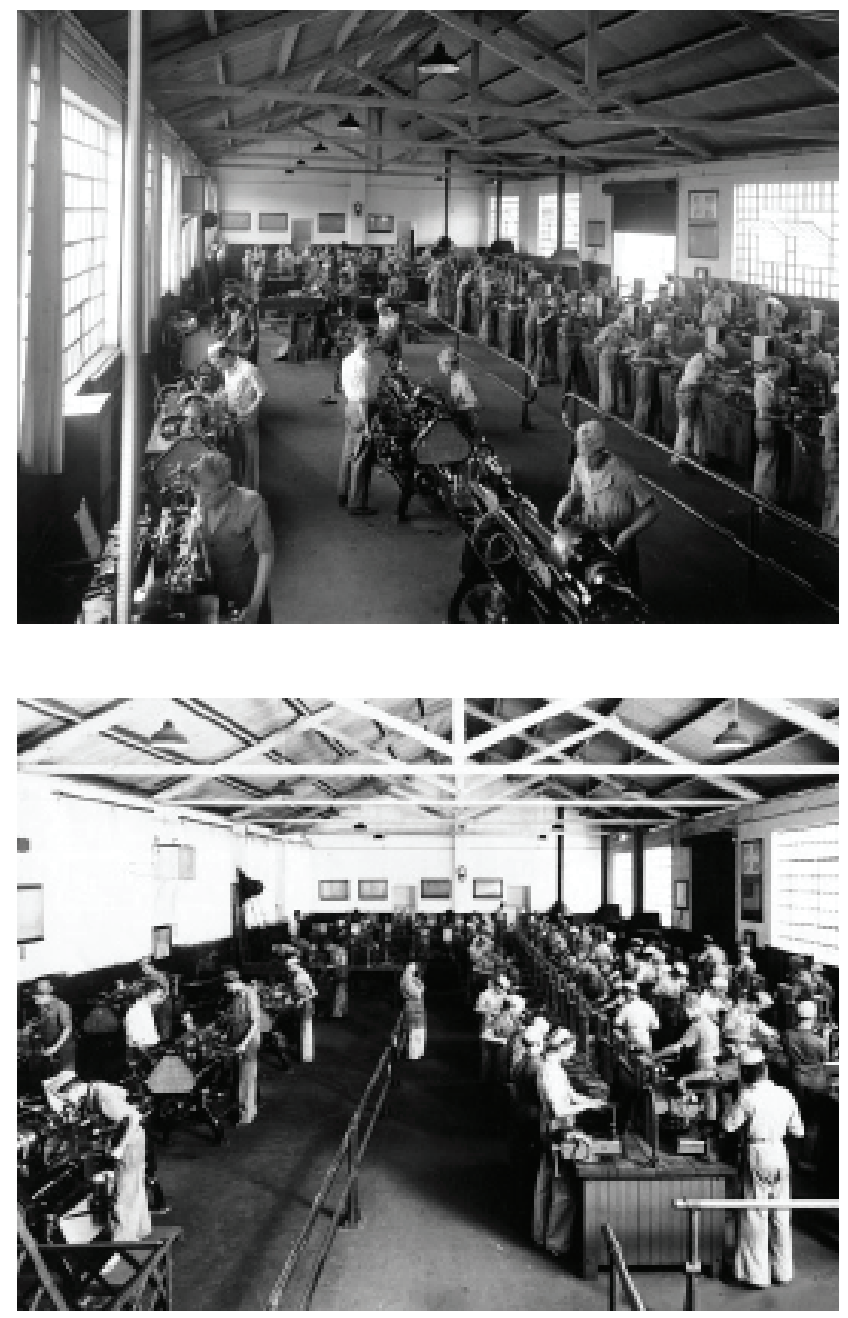

Foto 112 - Escola ferroviária de Jundiaí - edifício da oficina. Fotos $\mathbf{1 1 3}$ e $\mathbf{1 1 4}$ - Escola ferroviária de Rio Jundiaí - interior da oficina. Fonte: Museu Ferroviário de Jundiaí, s/d. Tenca (2002): Walter Lucke, chegou a mestre geral, tendo formação de marceneiro, era conhecido como o "teórico" pelos seus companheiros ferroviários, por seus bons conhecimentos de geometria e matemática. 


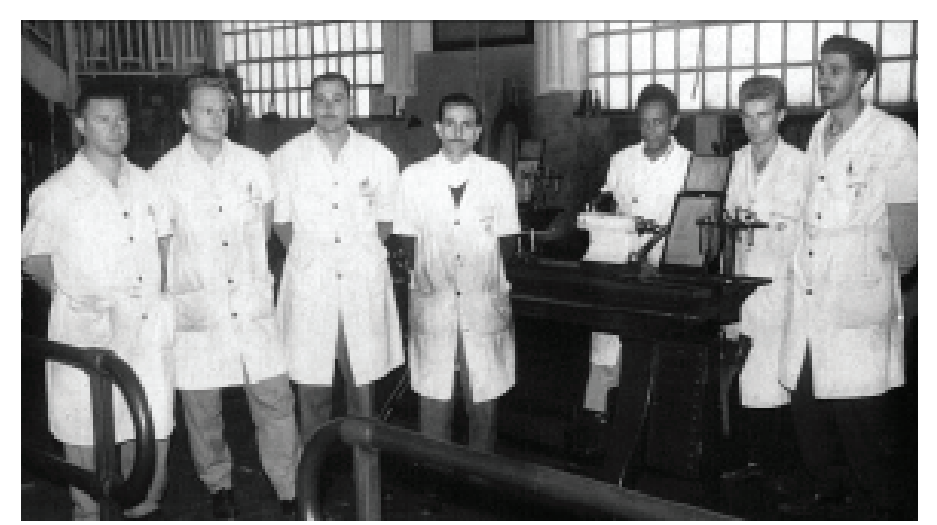

Foto 115 - Instrutores da Escola ferroviária de Jundiaí. Fonte: Museu Ferroviário de Jundiaí, s/d. co", tendo formação de ajustador

Deu aulas e ajudou a estruturar o curso de ferroviários da Paulista e inclusive depois do SENAI; André Serrano exerceu o cargo de auxiliar de mestre geral, penúltimo da hierarquia das oficinas, era conhecido pelos outros ex-ferroviários como o "práti-
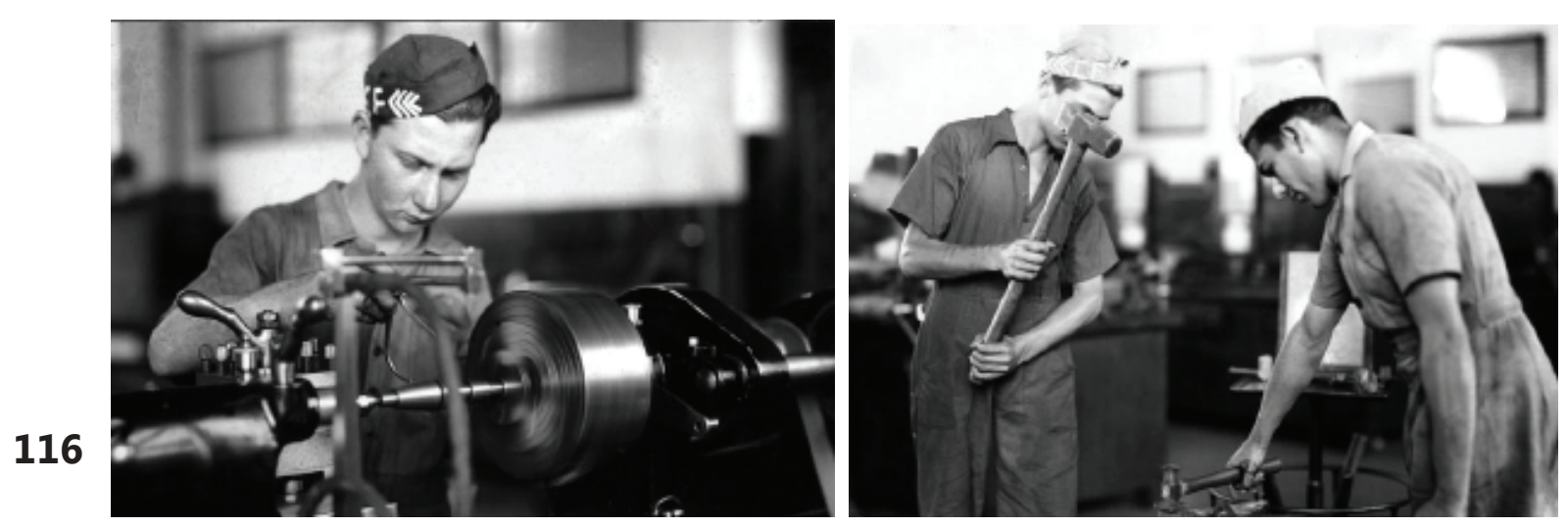

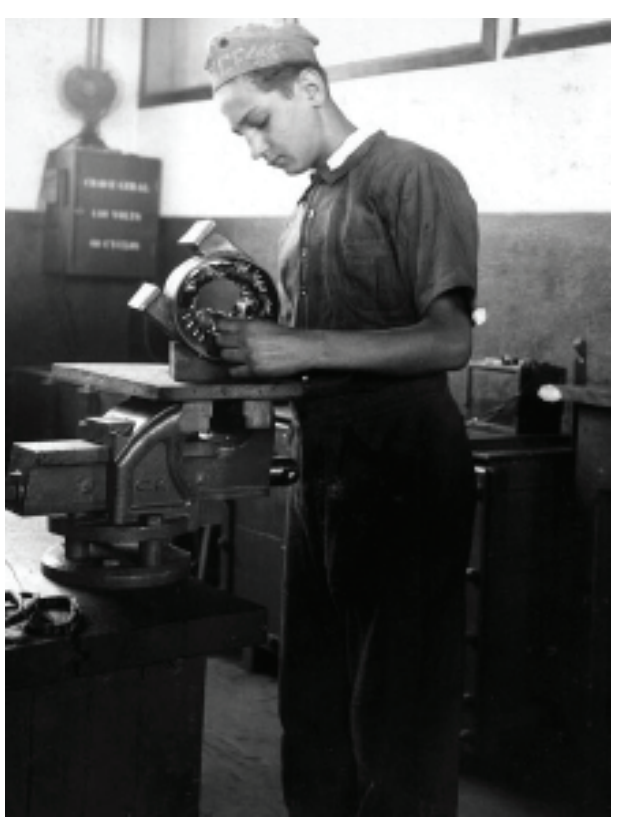

118

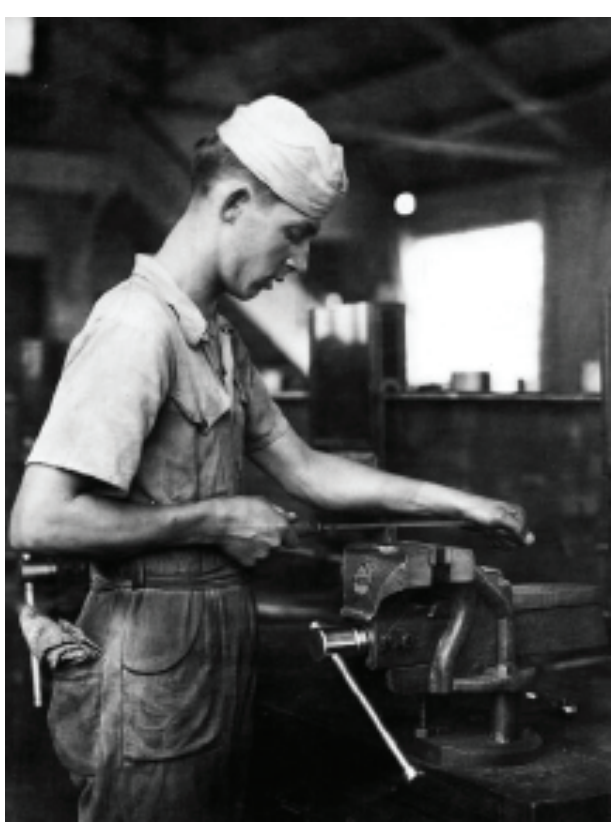

119
Fotos 116 à

119 - Alunos da Escola ferroviária de Jundiaí. Fonte: Museu Ferroviário de Jundiaí, s/d.

mecânico, gostava de adaptar as peças importadas.

Quanto ao aspecto disciplina, era exigido desde os tempos da escola, e segundo os relatos dos ex-ferroviários manifestava-se através do tempo e do uniforme. Atrasos nas 


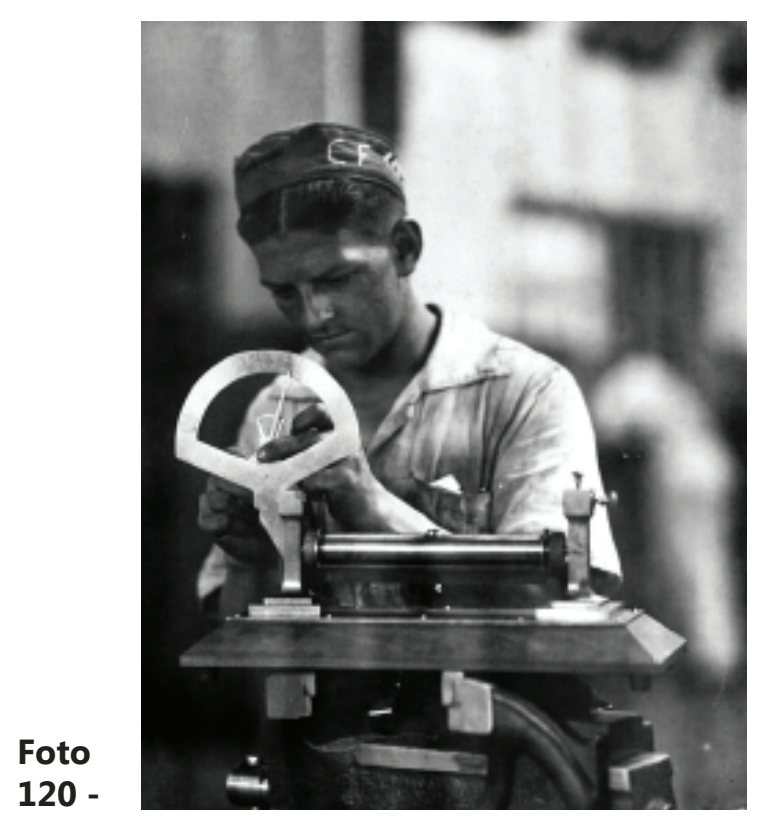

Aluno da Escola ferroviária de Rio Claro, instrutores.Fonte: Museu Ferroviário de Jundiaí, s/d. aulas e a falta de uniforme eram punidos. ${ }^{44} \mathrm{E}$ assim, durante o dia a dia da Companhia Paulista, o horário era cobrado, e atrasos eram multados. Havia um sistema de fiscalização distribuído aos diversos chefes das diversas seções. Os atrasos eram multados ou anotados, assim como outros tipos de mau comportamento numa folha chamada "Fé e Ofícios" (ZAMBELLO, 2005, p. 287). O apito e o relógio das estações são elementos muito importantes na ferrovia, e inclusive na paisagem. Havia o apito do trem e o apito das oficinas e estações, que eram utilizadas para a comunicação com os trabalhadores e inclusive para comunicar acidentes:

Eu acho que isso mudou, o trem decaiu foi por causa do horário. Foi por causa da falta de horário. [Naquela época], se acontecia um acidente, já era deslocada a turma que tinha nas oficinas, preparada para ir fazer o serviço de socorro. Quer dizer, tudo tomado nome, endereço, tudo da pessoa. Acontecesse qualquer coisa, a Paulista quitava tudo. Mas caía tudo lá. Já sabia, já tinha o número de apitos para cada tipo de acidente. Dois apitos, por exemplo, era descarrilamento. Três apitos, era um desastre muito feio. Às vezes dava dois, o responsável saia correndo, ia lá saber. Se era ligado aquele bloco, ele ia. De modo que em prazo de pouco tempo era resolvido. (depoimento de Clóvis Paes de

$44 \quad \mathrm{O}$ seguinte depoimento é ilustrativo: "O Curso tinha essa disciplina rigorosa. Nas oficinas, apitava, tocava a campainha, tinha que estar no seu lugar, u-ni-for-miza-do! Quando eu falo uniformizado, é com macacão, e o bibi. Era bibi, chamavam de bibi. Se não tivesse o bibi, ia embora para casa. (...) Perdia o dia. Quarenta faltas no ano (justificadas ou não justificadas), o aluno perdia o ano. Era jubilado. $O$ aluno podia entrar com atestado médico: não se aceitava. Quarenta dias de falta no ano, perdia o ano letivo.".(depoimento do Sr. Benedito Guilherme in TENCA, 2002, p. 161).

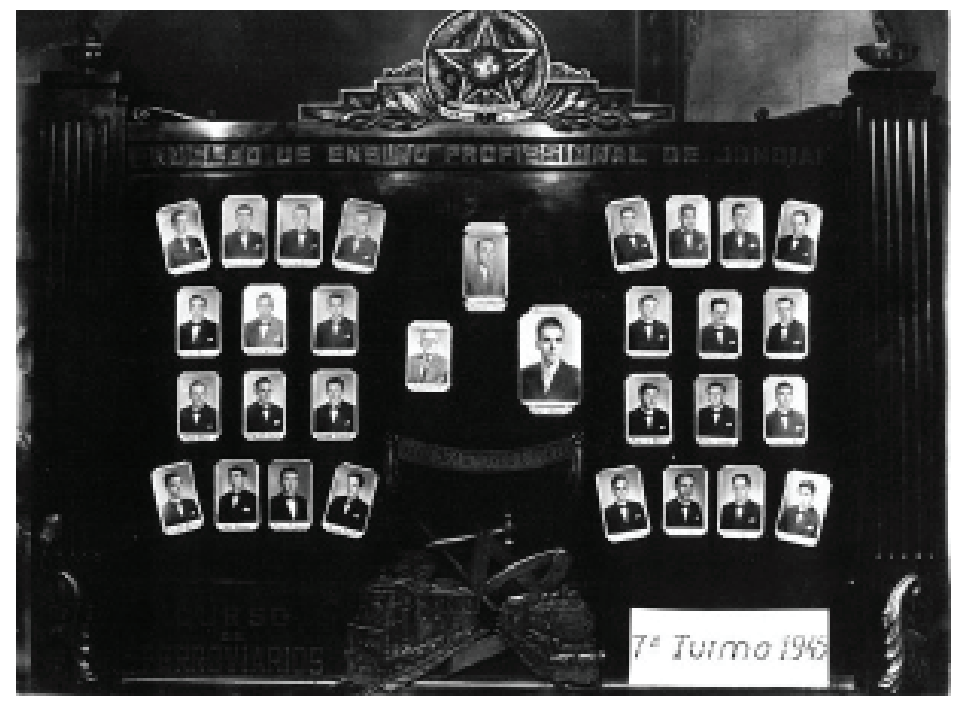

Foto 121 - Escola ferroviária de Jundiaí, quadro da 7a. turma formada em 1945. Fonte: Museu Ferroviário de Jundiaí, s/d. 
Oliveira in TENCA, 2002, p. 147)

Esta disciplina dos empregados no cumprimento dos horários, era motivo de eficiência da Companhia, e até mesmo de orgulho dos próprios trabalhadores, pois em alguns relatos, afirma-se que se podia saber as horas pelo apito do trem. Ainda relacionado ao tempo, encontra-se a curiosa tarefa do "chamador", responsável pela escala e de chamar os maquinistas e foguistas em suas casas. O uniforme além da disciplina, era também uma espécie de distinção, status que dava ser ferroviário, nos tempos áureos da ferrovia. Há uma descrição de um ex-ferroviário, Waldemar Raffa, que durante algum tempo foi presidente de sindicato, que reflete isso. (ZAMBELLO, 2005, p. 270). Todos estes aspectos eram cobrados da escola, incutindo os valores da Companhia Paulista, que eram: conforto, rapidez e segurança. ${ }^{45}$

Quanto ao aspecto da "formação integral" do trabalhador, defendida por Mange, alguns autores (SEGNINI, 1982:80) a entendem como a introjeção da "moral patronal" imposta aos trabalhadores. A própria ideia de "família ferroviária”, que aparece em vários relatos, parece contribuir com esta ideia de "formação integral”, ou "introjeção da moral patronal", dependendo do ponto de vista. Talvez, ainda certa forma de paternalismo e uma forte ideia de hierarquia esteja impregnada, mesmo com a introdução desta forma de organização racional do trabalho.

Um dos aspectos para incutir esta ideia de "família ferroviária" é unir a instrução, os laços de família e a promoção. Os que já tinham membros da família trabalhando na ferrovia, tinham preferência no ingresso. Na promoção, tinha-se preferência pelos funcionários casados aos solteiros, alegando que os primeiros eram mais responsáveis, e impunha-se boicotes à separação dos casais:

A introjeção desta 'moral patronal' imposta aos trabalhadores é observável através das entrevistas com ferroviários aposentados. Salientaram, com ênfase, comparando o comportamento exigido dos ferroviários nas décadas de 30 até 60 ao dos dias atuais que 'antigamente havia respeito na Paulista: ferroviário não entrava na sala da Diretoria, não bebia, não largava mulher, nem abandonava os filhos. Se não, já sabia: ou era repreendido ou mandado embora. Não era esta bagunça que é hoje. (TENCA, 2002)

$45 \quad$ É o que se constata no seguinte depoimento: "E a limpeza? E a limpeza dos carros?! O lema era o seguinte: conforto, rapidez e segurança. Era o lema da Companhia Paulista de Estradas de Ferro. O senhor nunca ouviu falar nessas três palavras? Ouviu falar, então não precisa dizer mais nada. (...) Não tinha acidente, não tinha nada. Nem com vagão de carga. Não existia isso. Isso era coisa muito difícil." (depoimento do Sr. Benedito Guilherme in TENCA, 2002, p. 167) 
Outro motivo para reforçar a ideia de "família ferroviária" era a de que os ferroviários passavam a maior parte do tempo no trabalho, habitando nas vilas ferroviárias, a separação entre o trabalho e a casa eram tênues, e o tempo livre também era passado com outros ferroviários e suas famílias. Sobre o tempo da jornada de trabalho, apesar da implementação da jornada de oito horas de trabalho, desde muito cedo, antes da legislação trabalhista, houve relatos de sobre-tempo em Zambello (2005:322), como também em Tenca (2002:137):

(...) Da Paulista, a única coisa que a gente tinha marcado é que ali a gente vivia mais com os colegas de serviço do que com a família. Porque o senhor vê o tempo que a gente tinha: entrar seis horas, seis e meia da manhã, e sair nove horas da noite! Em casa, chegava lá, era tomar banho e dormir. Então, a gente tinha mais convivência lá dentro, tinha mais amizade. Era considerado quase que um irmão um do outro. Não havia discussão, não havia briga...(...) (depoimento Clóvis Paes de Oliveira, in TENCA, 2002, p. 137)

O certo é que a partir dos anos 1950, nos períodos da crise ferroviária, alta inflacionária, e aumentos constantes do custo de vida, estas horas extras (sobre-tempo) eram mais constantes entre os ferroviários, inclusive para ajudar em sua renda familiar.

A ideia de "família ferroviária" ajudou também a reforçar a ideia de hierarquia, contraditoriamente com a de proximidade e de veneração; proximidade dos chefes e engenheiros em relação aos seus trabalhadores, que não eram meros burocratas, e de veneração dos trabalhadores para com seus chefes. Esta ideia de "família ferroviária” permaneceu até o final da existência da Companhia Paulista como empresa privada. Ao ser encampada pelo Estado, esta ideia se perdeu. Muitos cargos administrativos foram dados por apadrinhamento político, houve muita rotatividade de chefes, que não apresentavam conhecimento prático. Assim, parece ilustrativo o seguinte depoimento, de um funcionário sobre o Inspetor Geral da Companhia, um dos últimos da Paulista:

(...) Aquilo é que era organização! Financeiramente, para nós, não era bom, mas na parte da organização, meu Deus do céu! A diferença, era do dia para noite. O Dr. Jaime Cintra, aquele era...quantas vezes ele não vinha, quando eu fazia socorro, quando eu era novo em socorro. Ele estava lá. Ele chegava, eu via ele. E tinha chefe de turma, tinha tudo, e ele chegava direto para mim: "O mocinho, como é que vai o serviço aí? Não, eu quero saber com você." Vinham os outros, correndo, com o guarda-chuva para cobri-lo, e ele: 'Não, não! Cobre esse. Esse é que tem que cobrir, eu não. Ele está trabalhando, eu estou aqui olhando'. Falava assim para os homens. Para você ver que homem que era o Dr. Jaime, Jaime Ulhoa Cintra. Ele morava em Jundiaí - Jundiaí, São Paulo (...) (depoimento do sr. André Serrano in TENCA, 2002, p. 179) 
E ainda, também é coincidente o comentário que outro autor (ZAMBELLO, 2005) faz, sobre o depoimento de um ex-ferroviário de Bebedouro, sr. Milton, que era lenheiro, e teve a carteira assinada em 1955, vindo de uma família de ferroviários, falando da mudança de administração quando encampada:

O sr. Milton compreende que a queda no sistema ferroviário tem origem na forma como a empresa foi administrada. Não havia mais o superintendente, como nos tempos da Companhia Paulista. (...) A reestruturação tirou o Chefe de Tração dos antigos centros de manutenção e foi subtraída dos locais de trabalho a organização que tornava chefe o funcionário com longo tempo de trabalho em um determinado local. A valorização do trabalhador sustentada pela experiência foi abandonada e o desenvolvimento do sujeito nos locais de trabalho deixou de crescer naturalmente, como uma raiz. A relação que o chefe mantinha com os equipamentos e vagões foi vedada pelos cortes de cargos, remanejamentos e formas equivocadas de administração pública do trabalho. (ZAMBELLO, 200, p. 227)

Desse modo, debalde as críticas de "introjeção moral”, que aliás, poderiam ser válidas no começo da Paulista, e não no seu fim, dado que a empresa era de capital aberto, com vários acionistas, e uma diretoria que já não era composta pela elite de cafeicultores. Com a crescente regulação trabalhista, a administração feita pela Companhia Paulista, funcionou e até era vista com saudosismo por seus ex-ferroviários. Claro está, no entanto, que neste tipo de administração de pessoal, notam-se muitos resquícios paternalistas e a hierarquia bastante carregada.

A transferência dos professores das aulas teóricas para próprios funcionários das companhias, e com todas as aulas funcionando nas oficinas, ocorreu por volta de 1946. A Sorocabana foi a primeira ferrovia a ter esta iniciativa, seguida da Companhia Paulista, que possuía escolas nas oficinas de Jundiaí e Rio Claro. Assim, começa a dissolução do CFESP, e cada companhia passa a ter a sua própria escola de seleção e formação. Por essa mesma época, criava-se o SENAI, em 1942, e poucos anos mais tarde, são criados o SESI e o SESC, em 1946. Assim, arrisca-se a dizer que a CFESP deixa de ter sua função. Entretanto, as empresas ferroviárias para selecionar e formar seus próprios funcionários, mantiveram as escolas em suas oficinas, sem a interferência do Estado. Esta transferência surtiu efeito na formação dos trabalhadores, que segundo o depoimento dos ex-ferroviários (TENCA, 2002), preferiam os professores-funcionários, pois o ensino teórico tinha mais relação com o trabalho nas ferrovias, do que quando supridos pelos professores das escolas estaduais, que não tinham noção do trabalho ferroviário. Só no final dos anos 
1950, com a crise ferroviária, e a Companhia Paulista não mais em tempos áureos, é que os funcionários buscavam a formação, porém dirigiam-se a outras empresas, convidados por estas, como a Vale do Rio Doce e a Usina de Volta Redonda. (TENCA, 2002, p. 58).

Em 24 de janeiro de 1923, foi criada a lei federal $n^{\circ} 4682$, redigida pelo deputado de Jundiaí, Eloy Chaves, que prevê a criação de Caixas de Aposentadorias e Pensões para as estradas de ferro:

(...) Com essa lei, o trabalhador ferroviário, tanto o empregado mensalista, como o empregado diarista com serviço de caráter permanente, passou a ter direito: $\left(1^{\circ}\right)$ a socorros médicos em casos de doenças em sua pessoa e em todos os familiares; $\left(2^{\circ}\right)$ a medicamentos obtidos por preço especial determinado por conselho de administração da caixa; $\left(3^{\circ}\right)$ a aposentadoria; $\left(4^{\circ}\right)$ a pensão por herdeiros em caso de morte. (ZAMBELLO, 2005, p. 100)

Segundo Zambello (2005:100), a Caixa de Aposentadoria e Pensões (CAP), foi criada para minimizar os conflitos e atender o interesse da ferrovia, já que quem criou a lei, estava ligado à elite cafeeira paulista e as ferrovias. As CAPs, eram entidades públicas autônomas, reguladas pelo governo e, para este fundo, descontava-se 3\% do salário mensal dos empregados, e $1 \%$ da renda bruta das empresas. O governo federal entrava com uma soma arrecadada do público através de taxas dos serviços ferroviários. Esta lei começou com os ferroviários, mas depois estendeu-se aos trabalhadores do porto e de navegação fluvial e marítima, através da lei 5.109 de 20 de dezembro de 1926. Tais leis relativas às caixas de aposentadorias e pensões, já estavam implantadas na Europa do século XIX, por volta de 1820, e sobretudo entre 1840 e 1850.

Mais tarde, na década de 1930, o Sindicato Ferroviário de São Paulo apresenta uma proposta de unificar as caixas de aposentadorias e pensões em uma só. Esta medida foi possível com a criação do Instituto de Aposentadoria e Pensões, subordinado ao Ministério do Trabalho, Indústria e Comércio, no governo de Getúlio Vargas. Aliás, durante toda a década de 1930, Getúlio Vargas procurando ganhar os trabalhadores urbanos, vai criando, primeiramente, leis de reforma das CAPs, até criar os IAPs - Institutos de Aposentadorias e Pensões para os diferentes tipos de trabalhadores, marítimos (1933), comerciários (1934), bancários (1934), industriais (1936), etc... Assim, os fundos ficaram sob o controle do governo federal, e este dinheiro foi utilizado para construir habitações. Mesmo antes da criação dos IAPs, há o Decreto n 21.236, de 1932, que aprova o regulamento para a aquisição e construção de casas populares pela Caixa de Aposentadorias e 
Pensões.

No ano de 1937, foi aprovado um novo regulamento para aquisição de prédios destinados à moradia dos associados e a sede dos IAPs. Tanto as Caixas de Aposentadorias e Pensões, de 1923; como o IAPI, ao qual ficaram reunidos os ferroviários, junto com os demais trabalhadores industriais em 1936, irão mudar esta relação de benefícios e assistência, antes oferecidos pelas empresas, e que pouco a pouco vão sendo absorvidas pelo Estado; assim como o modo de provisão de casas para seus trabalhadores. Segundo Carpintéro (1997, p. 145):

Alguns autores só reconhecem uma participação efetiva do Estado no campo da construção de moradias para os trabalhadores a partir dos anos 40 no Brasil. Discordamos aqui destes autores porque todo processo de implantação dos programas habitacionais pós-30 foram, na verdade, decorrentes das medidas tomadas durante o período do "Governo Provisório".

Assim, diante dos fatos apontados, somos favoráveis à posição de Carpintéro (1997).

Relacionado às vilas ferroviárias, nesta terceira periodização, ressalta-se o Primeiro Congresso de Habitação, de 1931, no qual circulam ideias de organização científica entre os arquitetos e engenheiros, e que culminam na Jornada de Habitação Econômica, patrocinada pelo IDORT, em 1941. Nesta Jornada, além das apresentações das vilas operárias das diversas fábricas, foi importante o discurso de Roberto Simonsen, em que o empresário defende a ação do Estado no campo da moradia popular. Segundo Correia (2004, p. 100):

\begin{abstract}
A ação do IDORT se inscreve, ainda, em um momento especial da ação dos industriais no campo da moradia do trabalhador. Até os anos 1930, tal ação fundamentava-se sobretudo em iniciativas individuais, voltadas especialmente à construção de vilas operárias e núcleos fabris junto a plantas industriais, e a um esforço de promoção desses lugares perante a opinião pública como ilhas de ordem e bem-estar. A partir dos anos 30 - já ocupando posição hegemônica na sociedade brasileira -, os industriais vão se empenhar em ampliar esta ação. Agora não se trata apenas de construir vilas e núcleos fabris e de mostrá-las como indício de um progresso e de um bem-estar propiciados pela indústria, mas especialmente influir na ação de outros setores do capital e na do Estado em relação à questão da moradia operária (...)
\end{abstract}

Acredita-se que a ação do Estado referida na Jornada de Habitação Econômica deva ser entendida no sentido do financiamento e na produção da moradia operária, para 
a venda. Na ocasião da Jornada da Habitação de Econômica, Roberto Simonsen “alertava para o perigo de o pagamento da casa própria absorver elevadas parcelas dos rendimentos dos trabalhadores, sacrificando a satisfação de outras necessidades, e recomendava para os mais pobres casas adequadas com aluguel acessível às suas posses (Simonsen, 1942)” (CORREIA, 2004, p. 98). Posição semelhante a do presidente do Instituto dos Industriários, Plínio Castanhede, que recomendava uma análise caso a caso, de compra ou aluguel da casa pelo trabalhador. Entretanto, enfatizava-se a importância da propriedade da casa pelo trabalhador (CORREIA, 2004, p. 97). Entre os defensores da casa própria, questionava-se como garantir que fosse compatível com salários baixos. E "alguns defendiam que recursos provindos de economia popular - caixas econômicas, companhias de seguros, institutos de previdência - deveriam ser postos em disponibilidade para este fim" (D'AURIA, 1942 apud CORREIA, 2004, p. 97). Outros defendiam que não tratava de falta de recursos, mas em um certo comodismo por parte de alguns trabalhadores, por não saber poupar ou querer adquirir uma casa, pois os salários seriam suficientes para a amortização de uma casa em zona suburbana (ARAÚJO, 1942 apud CORREIA, 2004, p. 98). Nas décadas de 1940 e 1950, a propriedade da casa pelo trabalhador foi amplamente postulada por engenheiros, assistentes sociais e intelectuais, que nela apontavam uma "grande obra de alcance social", "um direito e uma esperança de todos aqueles que trabalham e lutam”, “a primeira e essencial das propriedades” (TELLES, 1951, p. 123; CORBUSIER, 1949, p. 58; SÁ, 1946, p. 150 apud CORREIA, 2004, p. 61).

Ressalta-se que a produção da moradia pelas Caixas de Aposentadorias e Pensões e, posteriormente pelos Institutos de Aposentadorias e Pensões, era para a venda, tornando assim o trabalhador proprietário. Após a Lei do Inquilinato em 1942, freia-se a produção rentista, muitos empreendedores imobiliários retiram-se da produção e dirigem-se para a venda de habitação (ainda que a produção rentista continue a existir).

Assim, baseando-se nos fatos apontados, colocamos a hipótese de que a construção das vilas ferroviárias, para aluguel, deu-se de maneira intensa durante a década de 1920, e depois desta data, a forma de provimento de habitações pela empresa muda, principalmente após a década de 1930. As premissas que pautam tal afirmação são as seguintes: devido ao estabelecimento das ferrovias, já que segundo Matos (1974), a carta ferroviária de São Paulo já estava praticamente terminada em 1920, e ano de 1940, seria o final da era ferroviária, não seria mais necessária a construção de vilas ferroviárias. Colocamos a década de 1920, pois há relatos da construção de 120 casas em Rincão em 1921, 
e outro relatório da Companhia Paulista atestando as construções em 1924. Colocamos ainda o ano de 1927, como sendo o ano de construção das vilas do ramal de Itirapina a Jaú, por causa da remodelação de traçados e mudança do lugar de algumas das estações.

O ano de 1932, com a aprovação de casas "populares" pela Caixa de Aposentadoria e Pensões, é o ano de mudança da forma de acesso à habitação, de aluguel à casa própria, ideologia que vinha sendo cultivada por muitos engenheiros, assistentes sociais e políticos. Além disso, a partir daí, haverá uma participação cada vez mais crescente do

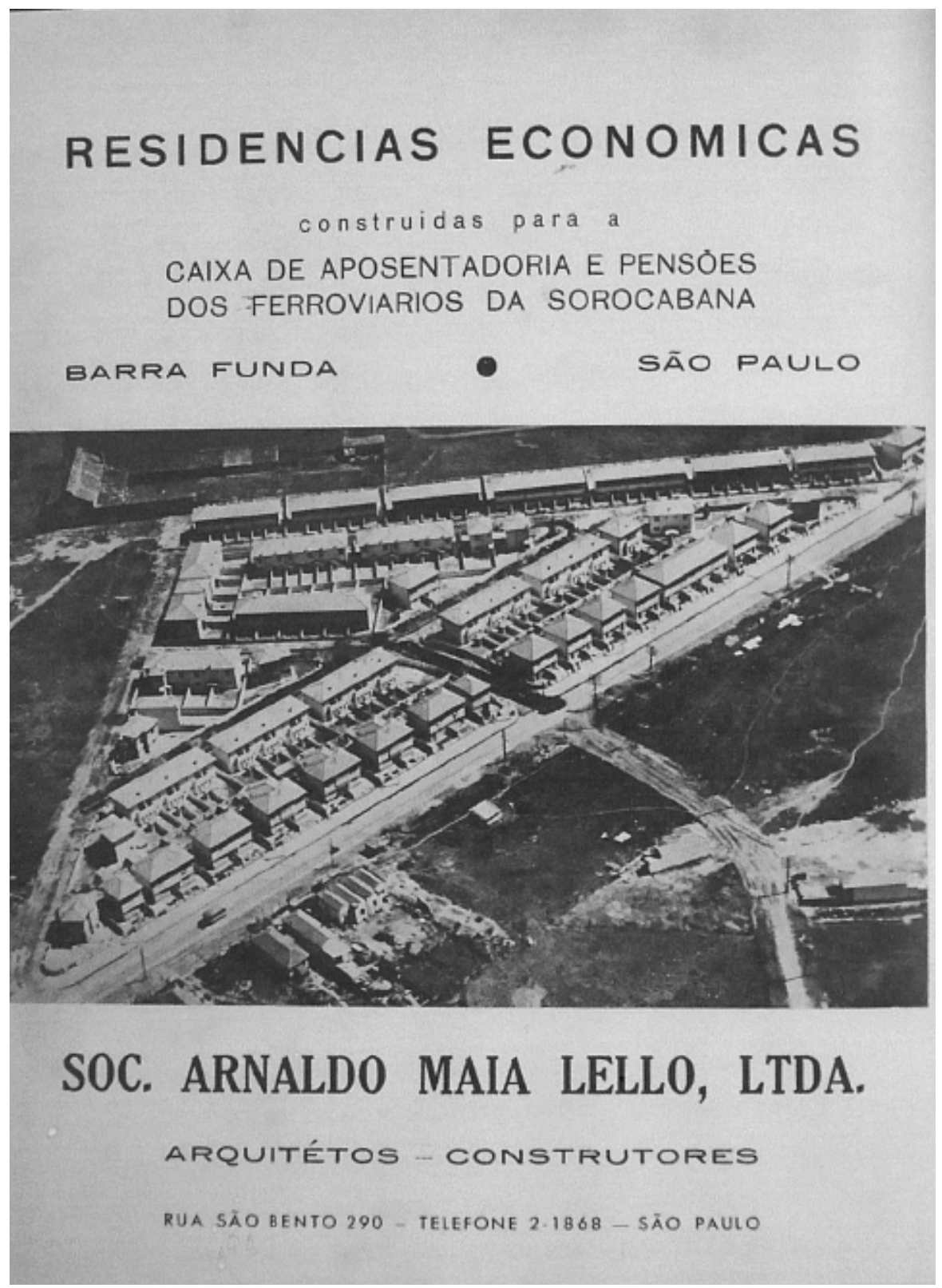

Foto 122 -Casas construídas através da CAP (Caixa de Aposentadoria e Pensões) da Companhia Sorocabana. Fonte: Revista Politécnica. No. 131, jul/ago 1939.

Estado no financiamento e construção, enquanto as empresas em geral e a Companhia Paulista entre elas, retira-se da produção de novas vilas ferroviárias nos moldes em que eram produzidas anteriormente ao ano de 1930. 
No entanto, segundo relatos de ex-ferroviários, nota-se a ajuda de fornecimento de materiais de construção e plantas, para a construção da casa, e a serem pagas em prestações mensais, no mesmo sentido de venda pela Companhia:

A Paulista fornecia, para todos, em geral, até a planta da casa mesmo. O funcionário fazia um rascunho do que queria e encaminhava para a seção técnica. E lá na seção técnica faziam o desenho, a planta da casa, e faziam o cálculo de material necessário: quanto ia de tijolo, quanto ia de... só areia e o saibro não davam. Mas o cal, cimento, mosaico, madeira... ela fornecia tudo, para pagar em prestações mensais, em quatro anos. Ficava pagando aquela parcela durante quatro anos. (...) O material, também, que era fornecido pela Paulista, era tudo de primeira. Caibros, de peroba, ipê, tudo de primeira, tudo material bom. Telha ela não dava. A única coisa que precisava comprar era telha. $O$ resto ela fornecia tudo, para pagar em parcelas. Já vinha descontado do salário. O funcionário fazia o contrato e já vinha descontada aquela parcela. (Depoimento do ex-ferroviária Sr. Clóvis Paes de Oliveira, in TENCA 2002, p. 141)

No mesmo sentido, outro depoimento coletado por outro autor:

Depois a própria ferrovia construiu um núcleo de casas e meu pai, com um sacrifício danado, conseguiu entrar, era casa pra ferroviário. As primeiras casas que foram construídas pra vender (grifo nosso) pra ferroviário foram construídas na Vila Paulista. Eu acho que essas casas foram construídas mais ou menos no ano de 53 e 54. Ela construiu esse núcleo de casa para vender pros ferroviários. Então meu pai, com muito custo e sacrifício, conseguiu comprar uma também e até hoje nós temos. E aí, depois, nós mudamos da roça e viemos morar na casa. Ela é aqui na Avenida Rodrigues Alves. Ainda tem a casa, inclusive quem mora nessa casa é minha irmã. (...) (depoimento Nelson Franco in LOSNAK, 2004, p. 246-7)

Parece que, na década de 1950, devido à inflação e à escassez de habitação, em muitas cidades, a Companhia Paulista construiu casas, para não ter que aumentar ainda mais os salários dos trabalhadores. Não se sabe, contudo, se foi uma atividade lucrativa, como o a venda de terras através da CAIC (Companhia de Agricultura, Imigração e Colonização), empresa subsidiária da Paulista. Tudo leva a crer que não, se o fosse, e conhecendo um pouco o perfil da Companhia, teria constituído uma empresa especializada para construção de casas, que seria sua subsidiária, porém não é deste modo que aparece nos relatórios da Companhia. Novamente, a venda de casas pela Companhia Paulista, era uma exceção e não regra. Então, como situar esta construção de casas? Clara está a responsabilidade do trabalhador em adquirir o terreno e construir. A Companhia auxiliava apenas 
com os materiais de construção e a planta. Seria uma forma de assistência social por parte da Companhia Paulista? Uma forma de fixação de mão-de-obra? Faltam-nos infelizmente, elementos para tal afirmação, mas tudo leva a afirmar que se deveu à possibilidade criada pela lei das Caixas de Aposentadorias e Pensões de 1932. Há outra explicação para esta construção de casas: quando o ferroviário deixava a posição de trabalhador para atender emergências ou manutenção das linhas, nos casos das "casas de turma", deveria deixar a casa; ou ainda era obrigado a deixar a vila, quando se aposentava. Por esse motivo, muitos trabalhadores prevenindo-se desta incômoda posição no futuro, garantiam-se, construindo a sua própria casa. Para aqueles que possuíam um filho ou parente na ferrovia, o mais corrente, era deixar a casa para este filho ou parente, daí perpetuando-se gerações de família na mesma vila ferroviária.

Nas diversas vilas ferroviárias, depois de seu desmonte, também ocorrerá a venda, muitas vezes a prestações. Porém a venda foi pequena, conforme dados fornecidos pela Superintendência do Patrimônio da União em São Paulo. No caso das cidades estudadas da Companhia Paulista, a cobrança de aluguéis continuou, mesmo depois de encampada pelo governo estadual em 1961, e que quando passou à FEPASA, em 1971, e depois que foi incorporada à Rede Ferroviária Federal S. A. Quando houve a extinção desta última em 2008, os bens imóveis foram transferidos à Superintendência do Patrimônio da União (SPU), sendo esta a responsável pela gestão das vilas remanescentes e a cobrança dos aluguéis. As vilas ferroviárias estão aguardando a definição deste último órgão, quanto à venda das casas. Alguns ex-ferroviários ou simplesmente ocupantes, não se sabe muito bem a origem destes, sendo que muitos não têm nenhuma relação com a ferrovia, pleitearam ou manifestaram interesse na compra à Superintendência do Patrimônio da União. Outros, por ter ciência de sua situação de irregularidade, pois simplesmente invadiram as casas, não manifestaram interesse, com medo de serem desalojados. Outros continuam pagando os DARFs ${ }^{46}$ emitidos pela União, com a esperança de um dia poderem comprar a casa da vila, na qual um dia, um parente ex-ferroviário residiu. Esta é a situação atual em relação à propriedade, agora pertencente à União, enquanto os habitantes das vilas ferroviárias continuam a ocupá-las, na esperança de verem regularizadas em seu nome, como proprietários. Para terminar, transcrevemos o trecho de Zambello (2005, p. 323), que bem descreve a situação atual das vilas ferroviárias, e a importância destas para a identidade e memória ferroviária:

46 DARF - Documento de Arrecadação das Receitas Federais. 
123
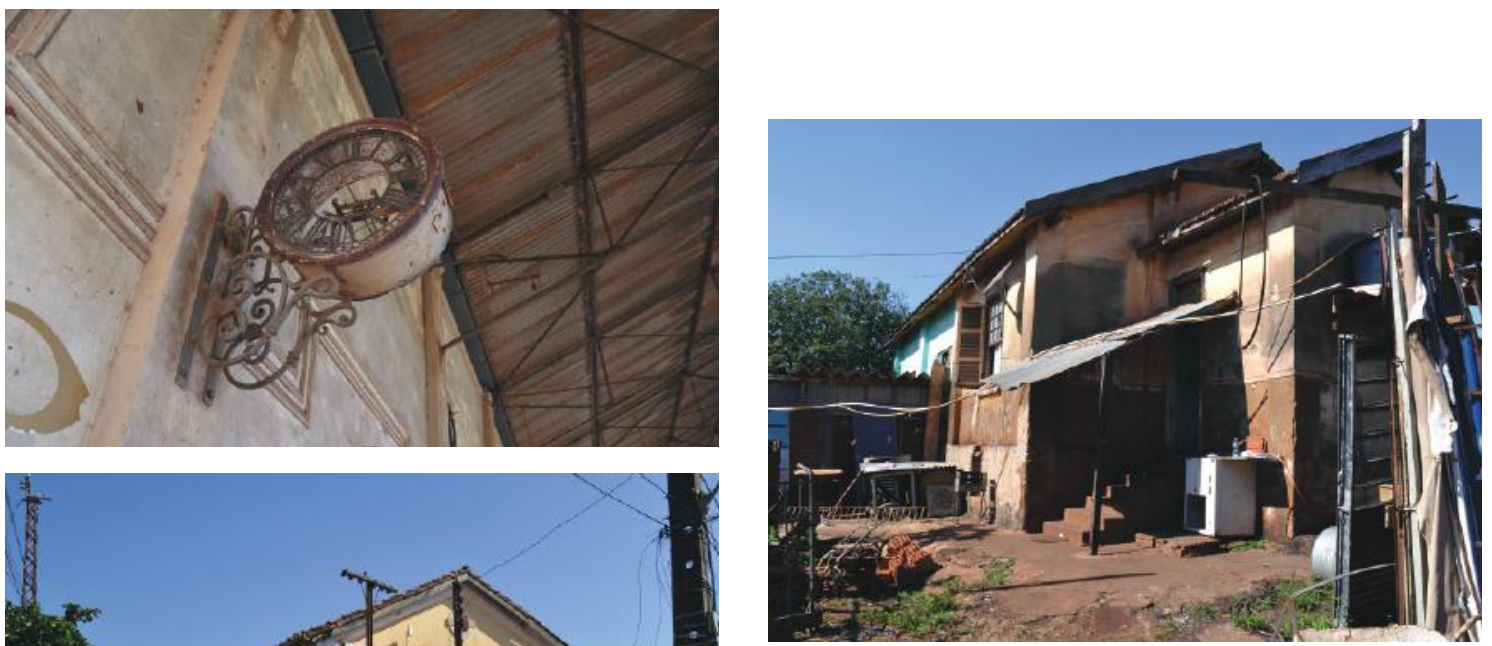

125

124

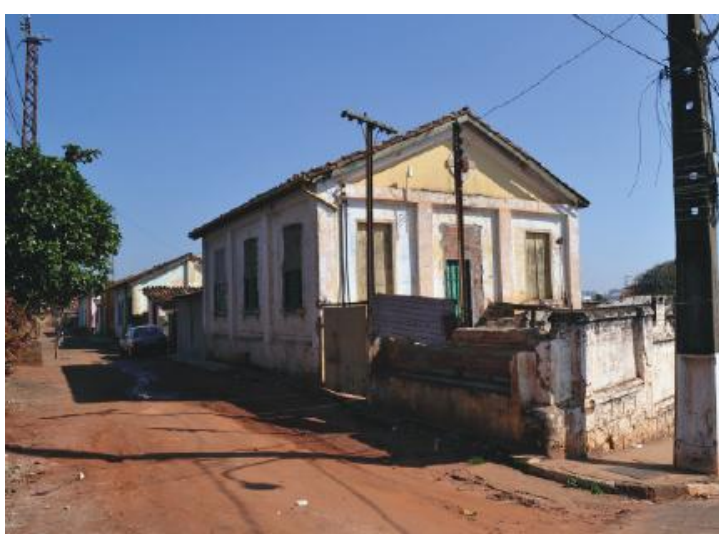

Foto 123 - Relógio da estação de Dois Córregos Foto 124- Casa da vila ferroviária de Dois Córregos. Foto 125 - Casa da vila ferroviária de Jaú. Fonte: autora, 2012.

Esse ferroviário que sempre viveu em vila ferroviária e ainda vive, porém a crise do sistema desestruturou a dinâmica da ocupação das casas da companhia: não são mais ferroviários que residem em grande parte delas, se estiverem desocupadas agora são invadidas por estranhos. $O$ abandono das estações ferroviárias é ressaltado quando o presente serve como referência para a rememoração do passado de trabalho. Os antigos ferroviários rememoram a ferrovia e a crise desencadeada pela estatização ganha significado, sobretudo porque, a ordem que existia no passado não existe mais.

\subsection{Cidades, trabalhadores e vilas ferroviárias}

As vilas ferroviárias são muito semelhantes às vilas operárias ${ }^{47}$, porque foram produzidas por uma empresa, e com os mesmos objetivos, atrair, reter, controlar, e de certa forma moldar o trabalhador qualificado ou necessário aos seus trabalhos. Como as vilas operárias, as casas das vilas ferroviárias passaram pelos mesmos debates em torno à casa operária, conceituações, programas, e ainda os vários estilos arquitetônicos. A seguir, e como, de alguma maneira, estas idéias, ideais e relações sociais tomaram forma nas vilas ferroviárias da Companhia Paulista.

47 Os vários sentidos que pode ter adquirido o conceito de vilas operárias no Brasil, recomendamos ver Correia (2004b). 


\section{Implantação}

Quanto à localização das vilas ferroviárias na cidade há duas possibilidades, ou a estação está no centro da cidade ou afastada do centro. No primeiro caso, é como alguns autores observam, a estação funciona como símbolo do progresso. Aos poucos, modifica-se a centralidade das cidades da igreja para a estação. Acontece que a centralidade da

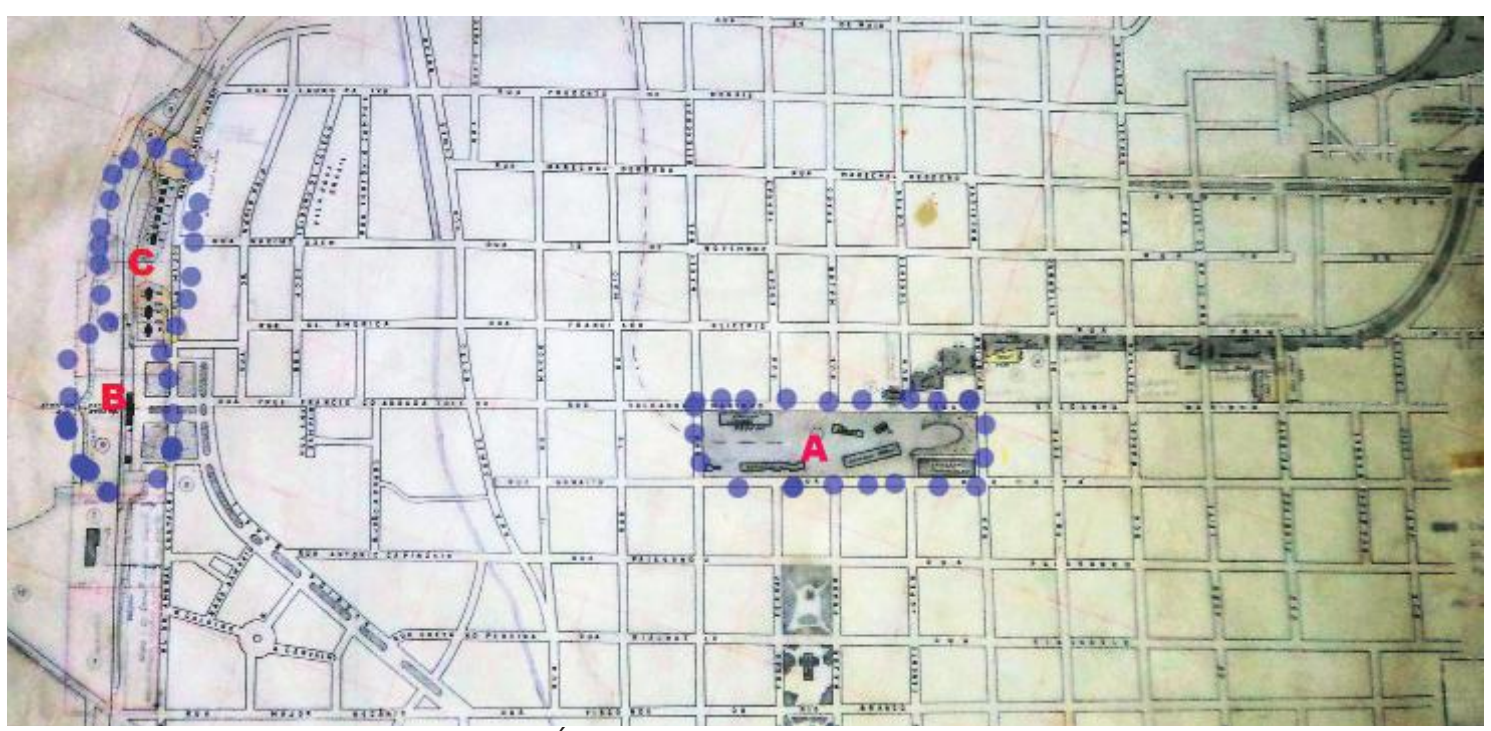

Mapa 10 - Implantação de Jaú. A - Área da antiga estação. B - Nova estação C - Vila ferroviária. Fonte: confeccionado pela autora sobre planta do arquivo da Inventariaça da ex-RFFSA.

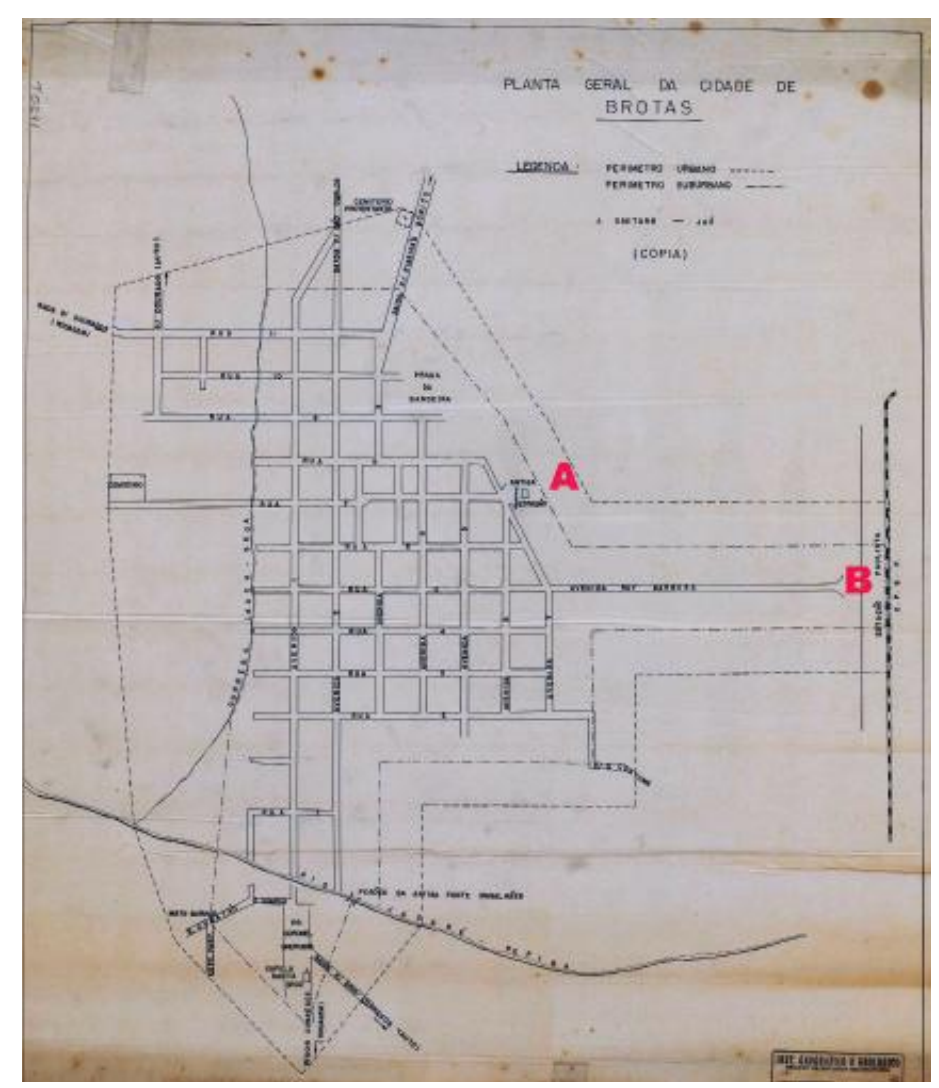

Mapa 11 - Mapa de Brotas. A Área da antiga estação. B - Nova estação Fonte: confeccionado pela autora sobre planta do IGC.

estação pode ser modificada com o tempo, o que aconteceu, por exemplo, com a cidade 
de Jaú. Hoje a antiga estação é ocupada pela rodoviária, e a estação foi para a periferia. Outras cidades objeto de nosso estudo passaram por uma retificação do traçado: o ramal de Itirapina a Jaú, desse modo, Brotas e provavelmente Dois Córregos. ${ }^{48}$ A centralidade da estação talvez não tenha se modificado também em Rincão, dada as suas pequenas dimensões.

Outra questão que pode ter influenciado a localização das vilas ferroviárias, é a conotação social e sanitária. Blay (1985) afirma que em um dado momento, por lei municipal, tais "vilas operárias" deveriam estar localizadas em determinados espaços urbanos, de preferência longe do perímetro urbano (o que era considerada a "cidade"), sugerem-se os bairros paulistanos de Santana, Pirituba, Água Branca, Campos das Perdizes, Ipiranga, São Caetano, São Bernardo, Penha, Aricanduva, Tatuapé, Santo Amaro, e servidos por bonde ou estação de trem. (BLAY, 1985, p. 75). Na utilização do meio de transporte para o trabalho, sugere-se que as "vilas operárias" referidas estão dissociadas da fábrica, portanto, sendo o termo utilizado em sentido amplo. ${ }^{49}$ Tal localização sugere uma segregação social no contexto referido. Era a época em que a burguesia do café queria transformar a cidade de São Paulo numa cidade européia, (BLAY,1985, p. 137). Era o tempo também do movimento "city beautiful", com planos de embelezamento da cidade. "Frequentemente, lançava-se mão da ideia de que a partir da habitação do pobre as doenças se propagavam para o resto da cidade, ameaçando toda a população urbana (...)” (CORREIA, 2004, p. 7). Tal momento coincide com a administração municipal de Antônio da Silva Prado, prefeito da cidade de São Paulo por 12 anos, entre 1895 e 1911. Recorda-se que Antônio da Silva Prado foi presidente do Conselho e um dos principais acionistas da Companhia Paulista de Estradas de Ferro, entre 1892 e 1928, afastando-se por motivos de saúde e falecendo no ano seguinte $(1929)^{50}$, conforme informa o Relatório da Companhia Paulista. Assim, os trabalhadores pobres deveriam ser afastados do perímetro urbano e dos bairros nobres. No caso das cidades do interior que estamos estudando, talvez não caiba falar em localização no perímetro urbano ou não, pelos seguintes motivos: as pequenas extensões das cidades, a introdução das primeiras infraestruturas urbanas, tais como abastecimento de água, esgoto, eletricidade, juntamente com as ferrovias, e o modo de vida urbano.

48 COMPANHIA PAULISTA DE ESTRADAS DE FERRO. Relatório da Diretoria da Companhia Paulista de Vias Férreas e Fluviais. Relatório n. 79. São Paulo, Casa Vanorden, 1928. p. 15.

49 Para saber mais as várias denominações e conotações do termo vila operária, ver CORREIA (2004b:10)

50 COMPANHIA PAULISTA DE ESTRADAS DE FERRO. Relatório da Diretoria da Companhia Paulista de Vias Férreas e Fluviais. Relatório n. 80. São Paulo, Casa Vanorden, 1928.

Relatório da Diretoria da Companhia Paulista de Vias Férreas e Fluviais. Relatório n. 81. São Paulo, Casa Vanorden, 1929. 
Talvez a mudança das estações e vilas ferroviárias podem ter ocorrido com o crescimento destas cidades do interior.

Quanto ao tamanho das vilas ferroviárias variam de tamanho, sendo pequenas, médias ou grandes, dependendo da demanda de trabalhadores. Mas existindo uma estação certamente haverá ali uma habitação para alguns trabalhadores. Sem dúvida, o local das oficinas demanda muitos trabalhadores, entre qualificados e não-qualificados. São os casos das vilas ferroviárias da Companhia Paulista, de Jundiaí e Rio Claro. Outros locais de grande demanda eram os locais de baldeação, seja por troca de bitolas (métrica, de 1,00m e larga, de 1,60m) seja entre eletrificada e não eletrificada. E conforme já visto, os locais de armazéns, sobretudo aqueles reguladores de café, construídos na década de 1920.

Outro aspecto relacionado à implantação, tem relação à simbiose indústria e ferrovias e os trabalhadores. Muitas indústrias procuram instalar-se próximo aos rios e às ferrovias. As ferrovias começam a construir casas para seus trabalhadores, e outras empresas também. Acontece que estas são para trabalhadores qualificados, no entanto, a demanda por casas é grande. Desse modo, outros empreendedores privados, não necessariamente ligados às ferrovias e outras indústrias, começam a construir casas para alugar e absorver tal demanda. Tal fenômeno ocorre em todos os lugares, desde a Inglaterra e nas vilas operárias e ferroviárias brasileiras. Como exemplo inglês, pode-se citar a vila ferroviária de Swindon, e como exemplos brasileiros, pode-se citar: a Vila Economizadora, em São Paulo e outra próxima à vila ferroviária de Campinas, que: “(...) foi fundada por dois irmãos que trabalhavam com transportes de cargas e que decidiram investir em habitações destinadas aos operários do bairro, acreditando ser mais lucrativo, considerando a localização sem obstáculos, o valor baixo da terra, a construção simples e barata." (ZAMBELLO, 2005, p. 66). Parece que os que moravam na vila ferroviária, pagavam o aluguel barato, e assim preferiam nela habitar. Para os que não habitavam as vilas, havia dificuldade de se encontrar casas para alugar ou o dinheiro gasto com habitação, consumia grande parte de seus salários. Tanto é assim que o aumento salarial era calculado com base naqueles empregados sem casa, com casa, e os não efetivos (SEGNINI, 1982, p.59). Em certos momentos de grande demanda, a própria Companhia Paulista construiu casas.

Quanto à implantação, as vilas ferroviárias estão localizadas imediatamente ao lado da estação, e conforme o tamanho da estação, se terminais, intermediárias ou de passagem, assim também varia o tamanho das vilas, podendo constituir duas ou no máximo quatro casas enfileiradas contíguas à estação, imediatamente atrás, isto é, do outro 
lado da linha; e as maiores chegando a constituir vários quarteirões. Neste último caso, incluem-se as vilas ferroviárias de Dois Córregos e Rincão. Geralmente as estações ferroviárias possuem um pátio em frente à estação, que proporciona uma boa perspectiva para sua apreciação. As vilas ferroviárias como estão ao lado, e muitas vezes atrás, acabam por configurar o que alguns chamam da área relegada ao mundo do trabalho. Ou ainda, a estação acaba definindo um eixo de ocupação dividindo entre o lado do cartão postal, símbolo do progresso, da praça em frente à estação, e o mundo do trabalho com seus armazéns, galpões e suas vilas ferroviárias, criando-se uma Right side e uma Wrong side (ARAKAKI, 2007, p. 124). As primeiras estações e, portanto, implantações da Compa-

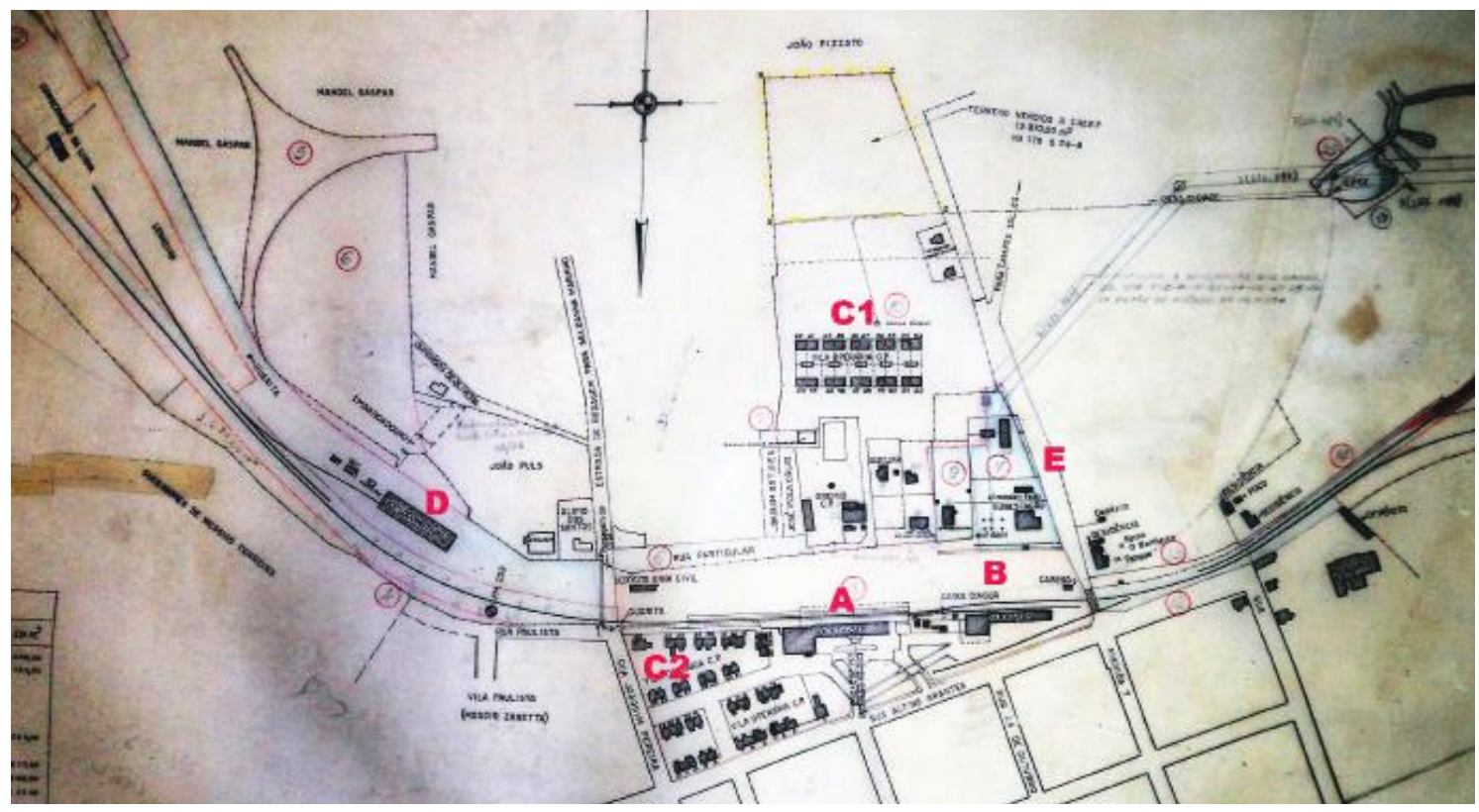

Mapa 12 - Implantação de Dois Córregos. A - Estação; B -Armazém; C1 e C2 - Vila ferroviária; D - Depósito de locomotivas; E - Subestação elétrica; Fonte: confeccionado pela autora sobre mapa do IGC (1951).

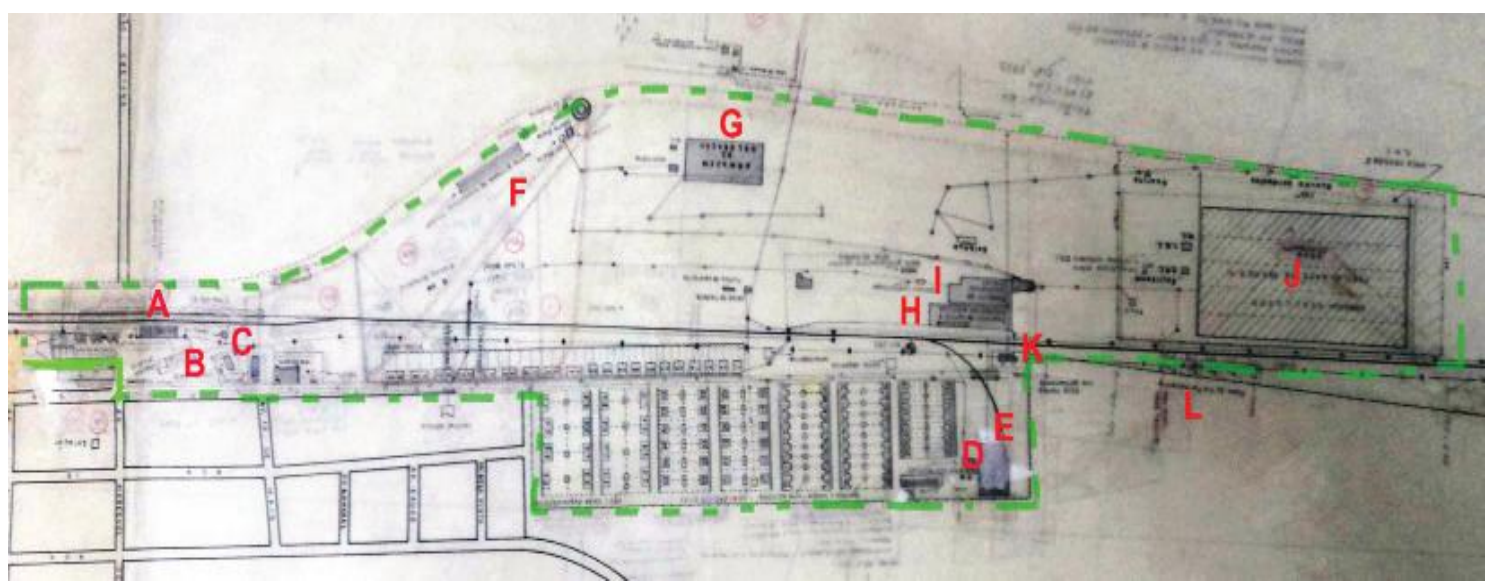

Mapa 13 - Implantação de Rincão. A - Estação; B - Armazém ; C- Casa do chefe da Estação; D - Casa do chefe da subestação; E - Subestação Elétrica; F - Local de limpeza das locomotivas; G - Armazém de Baldeação; H - Depósito de carros e locomotivas elétricas; I - Depósito de locomotivas à diesel; J - Armazém Regulador - Instituto do Café; K- Casa de turma de Via Permanente; L - Casas da Via Permanente. Os edifícios ou locais F, G, H, I, J, K e L não existem mais, foram demolidos. Fonte: Mapa realizado pela autora, tendo como base planta do arquivo da inventariança da ex-RFFSA. 


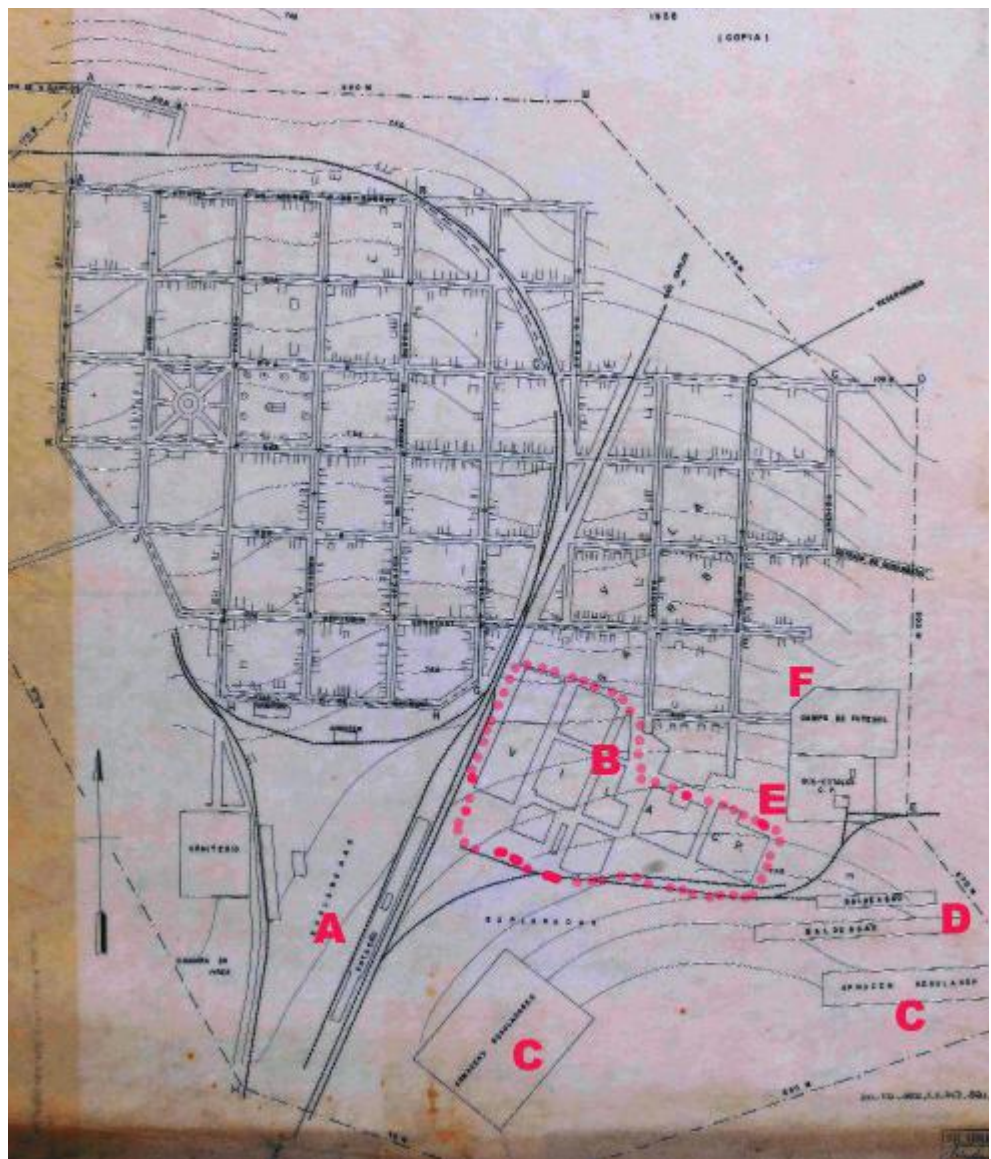

Mapa 14 - Mapa de Itirapina. A - Estação; B - Vila ferroviária; C - Armazém regulador de café; D - Baldeação; E - Subestação elétrica; F - campo de futebol. Fonte: confeccionado pela autora sobre mapa do IGC (1951).

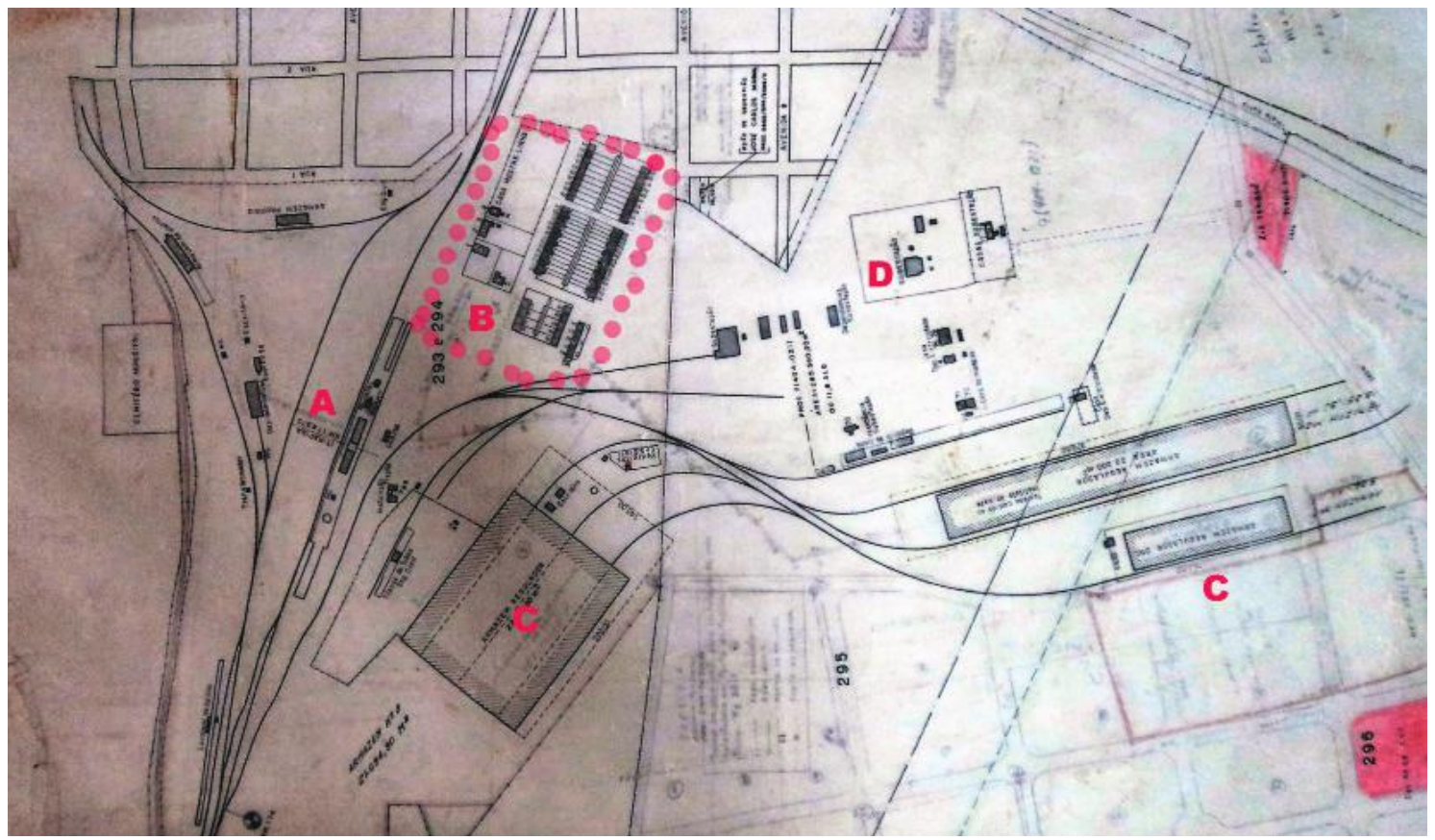

Mapa 15 - Implantação de Itirapina. A - Estação; B - Vila ferroviária; C - Armazém regulador de café; D - Subestação elétrica. Fonte: confeccionado pela autora sobre planta do arquivo da Inventariança da ex-RFFSA. 


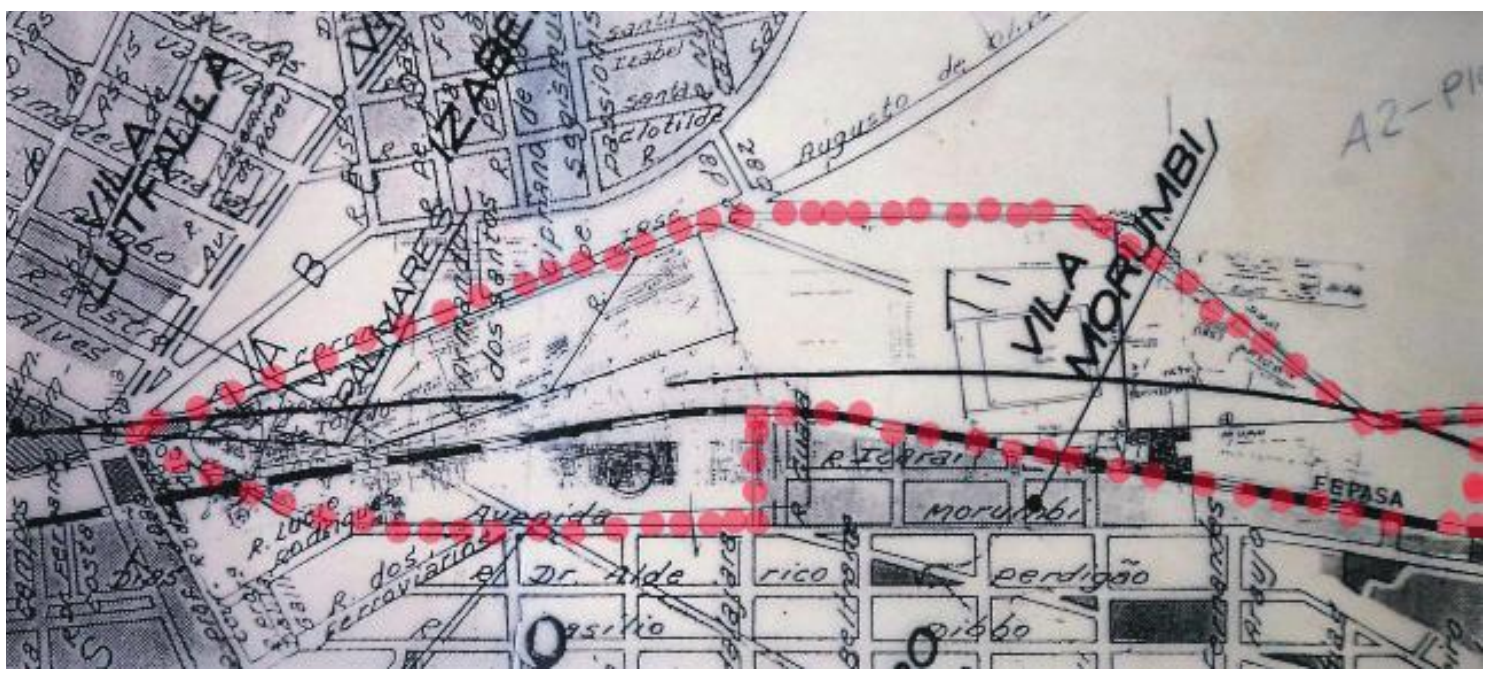

Mapa 16 - Mapa de São Carlos. Área delimitada corresponde a parte do complexo ferroviário de São Carlos. Fonte: confeccionado pela autora sobre planta do arquivo da Inventariança da ex-RFFSA.

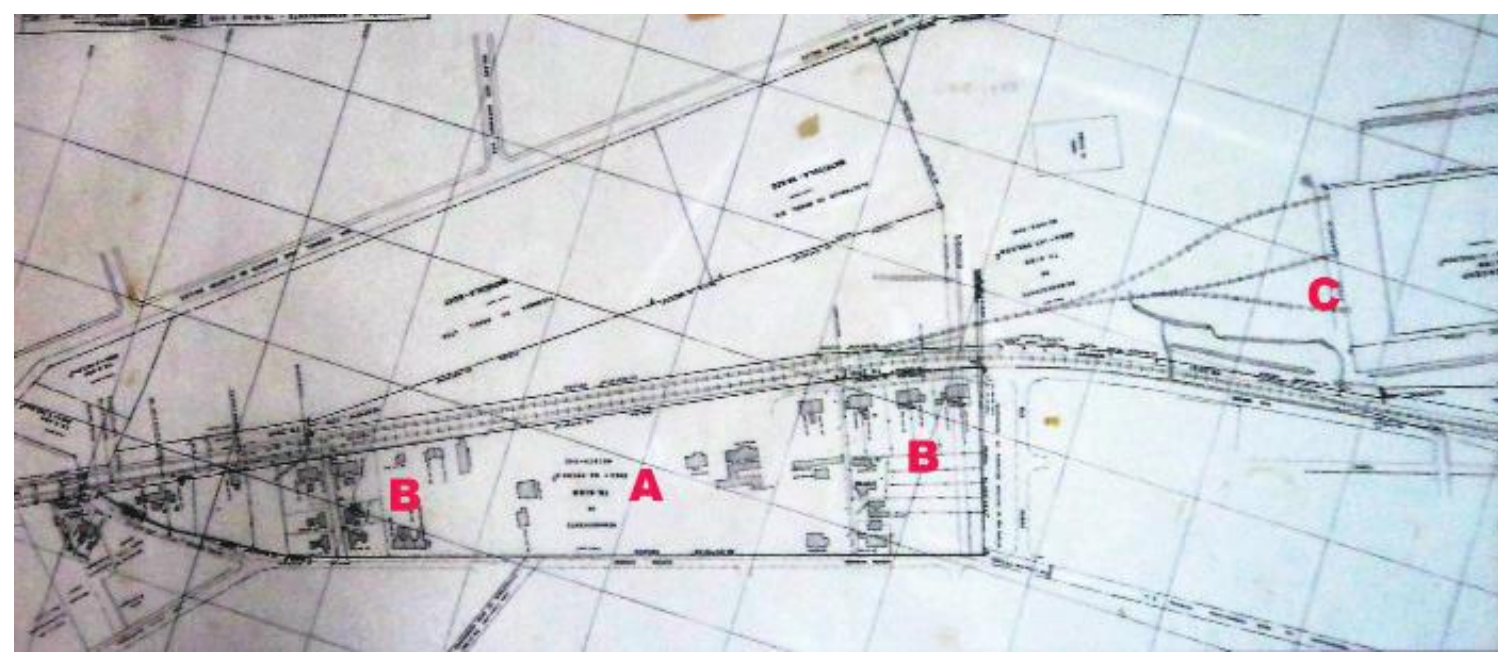

Mapa 17 - Implantação de São Carlos. A - Subestação elétrica; B - Vila ferroviária; C - Armazém Fonte: confeccionado pela autora sobre planta do arquivo da Inventariança da ex-RFFSA.

nhia Paulista foram Jundiaí e Campinas. Nesta última, a Companhia Paulista construiu casas entre 1890 e 1900, em dois núcleos diferentes: atrás da Estação, e outro, na mesma rua ao lado do bairro Ponte Preta, conforme observado por Zambello (2005, p. 67). Tal configuração foi identificada também nas cidades pesquisadas de Itirapina, Dois Córregos e Rincão. Nas cidades de Brotas e Jaú, estão localizadas ao lado da estação. Em São Carlos estão localizadas próximas de onde estava o armazém regulador de café, e constitui a atual Vila Morumbi

Nota-se fortemente na implantação das vilas, a hierarquia do trabalho espacializada. Não é algo específico das vilas ferroviárias, mas comum a várias vilas operárias. Um exemplo inglês é a vila operária da fábrica têxtil de Saltaire ${ }^{51}$, onde as casas dos engenhei- 


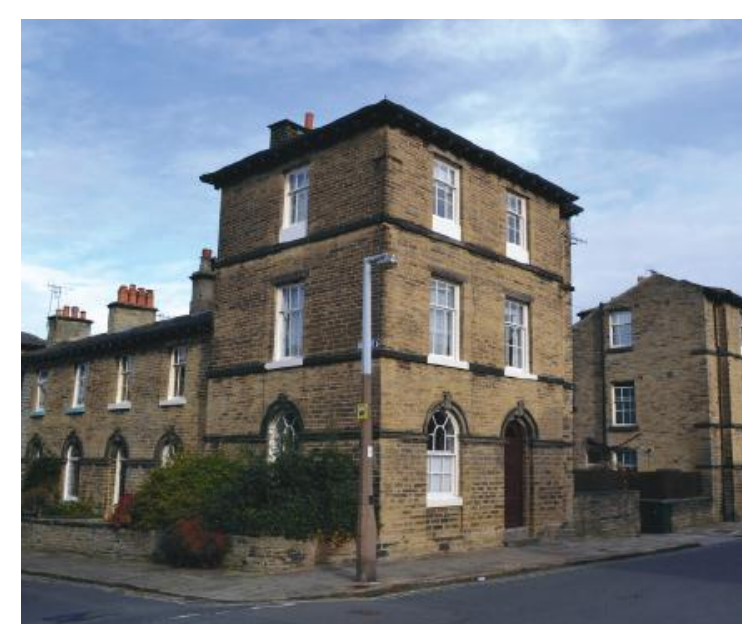

Foto126 - Vila operária de Saltaire. Fonte: autora, 2014. ros são maiores e afastadas das dos demais trabalhadores, e ainda nas esquinas das quadras destes, alguns encarregados viviam aí, para a vigilância. Na Vila de Paranapiacaba, os engenheiros além das casas maiores, estão situados nas partes mais altas. Nas vilas ferroviárias, há algumas peculiaridades quanto a como à hierarquia e à vigilância sobre os trabalhadores são espacializadas.

Diferentemente da vila operária da indústria, na qual para manter a vigilância era necessária a proximidade; no caso das companhias ferroviárias, excetuando-se os locais das oficinas de construção e reparo de vagões e locomotivas, há uma única indústria, porém dispersa, que possuía muitas unidades menores, e atingia várias cidades. Assim, em cada cidade, dispunha de uma estação e uma vila ferroviária. Deste modo, como assegurar a vigilância, o controle? Este tipo de organização reflete o sistema organizacional adotado pelas ferrovias norte-americanas desde 1850, mencionado por Chandler (1998) e adotada pela Companhia Paulista a partir de 1928, juntamente com os princípios tayloristas, separando funções técnicas das funções administrativas (GARCIA, 1992, p. 67-68). Desse modo, o controle era delegado aos engenheiros e nas cidades menores aos chefes de estações. Nas vilas ferroviárias estudadas não se encontrou a vila dos engenheiros ou as casas dos engenheiros, talvez por tratar-se de cidades pequenas. Como já dito anteriormente, sabe-se que havia engenheiros residentes em cidades importantes para a Companhia como: Jundiaí, Dois Córregos, São Carlos, Araraquara e Jaboticabal. Segundo Garcia (1992, p. 109): “O engenheiro chefe era o vínculo entre a direção da empresa e o ferroviário. Ele representava a empresa, mas ao mesmo tempo era de extrema importância para o trabalhador da oficina.". Müller (2006, p. 71) constatou que na Vila Ponte Preta, em Campinas, da Companhia Paulista, construída em 1919:

As casas dos engenheiros e chefes estão localizadas na extremidade do empreendimento, próximas às casas de áreas maiores; o restante das residências se dividem em outras duas quadras, contínuas ao arruamento. Instaladas de frente para uma rua secundária sem saída, essas moradias se isolam da malha urbana.

Segundo Garcia (1992, p. 76), que analisa a Companhia Paulista entre 1930 e 
1940, após a implementação dos princípios tayloristas, a companhia organizou-se em quatro divisões, cada uma delas por sua vez subdividia-se em seis departamentos. Desse modo:

A primeira Divisão com sede em Campinas, onde se situava a linha tronco de Jundiaí a Rio Claro, com os ramais de Descalvado, Santa Veridiana, Piracicaba, Santa Rita e Aurora, apresentando uma extensão de 386

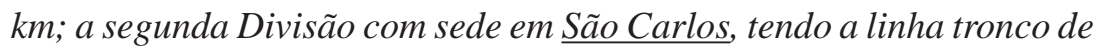
Rio Claro a Rincão, a linha de Rio Claro a Visconde, mais os ramais de Ribeirão Bonito e Água Vermelha, numa extensão de 310km; a terceira Divisão com sede em $\underline{\text { Bebedouro e a quarta sede em Dois Córregos, }}$ já saindo portanto, da zona de influência de Rio Claro. ( G A R C I A, 1992. p. 76. Grifo nosso)

E cada divisão destas possuía seis departamentos, a saber: Contabilidade, Almoxarifado, Tráfego, Engenharia Civil, Engenharia Mecânica e Conservação da Linha. Assim imagina-se a grande quantidade de trabalhadores nestas cidades, consideradas Divisões.

Também não se encontrou nas vilas ferroviárias os chefes de estação residindo na própria estação como Moreira (2007) identifica nas vilas ferrovi-
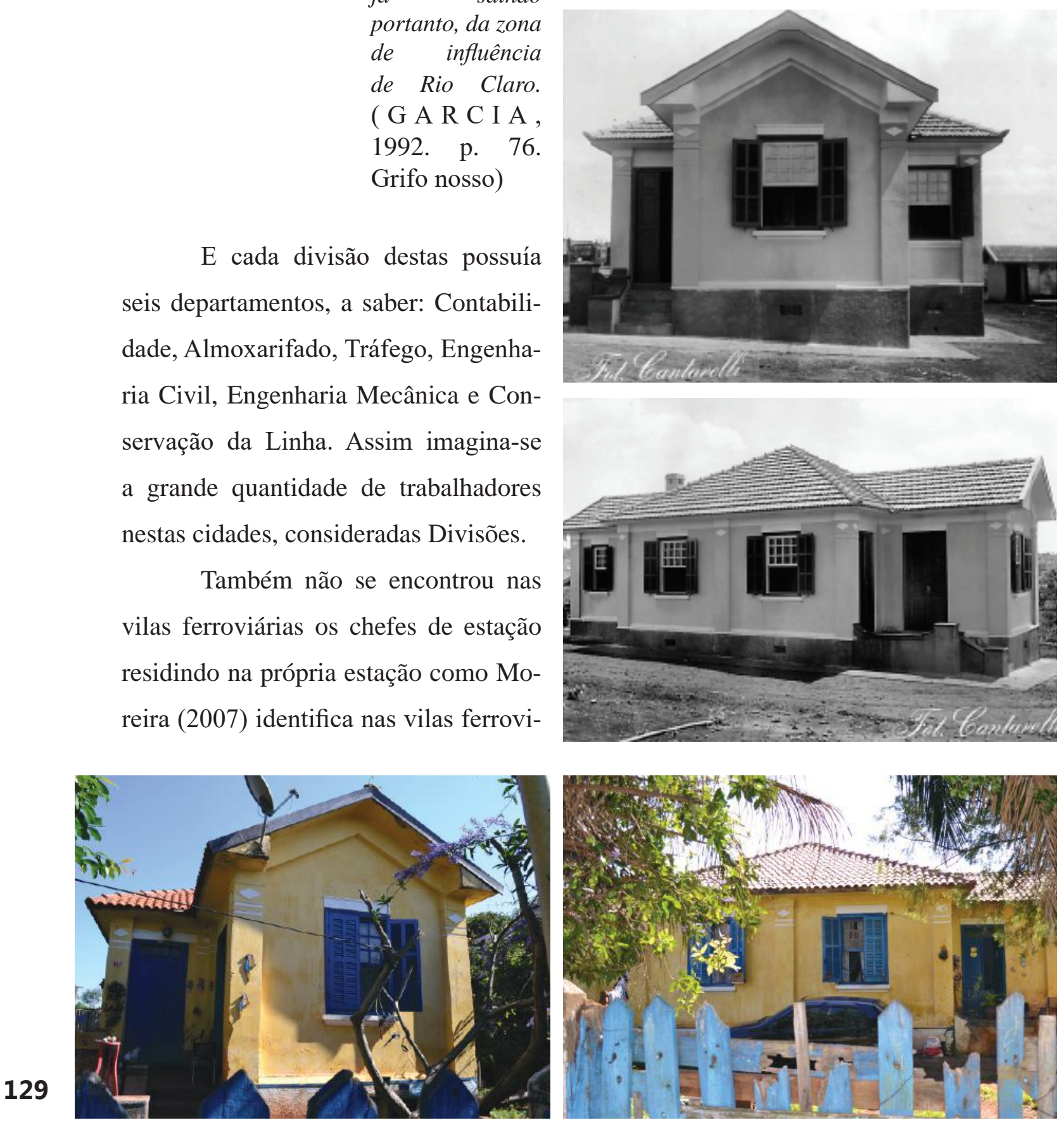

Fotos 127 e 128 - Fotos antigas da casa do chefe da estação de Jaú (s/d) Fonte: Museu ferroviário de Jundiaí, s/d. Fotos 129 e 130- Fotos atuais da casa do chefe da estação de Jaú (2013) Fonte: autora, 2013. 
árias em território mineiro. Lá ocorre a habitação do chefe da estação, situada no pavimento superior da edificação e uma habitação destinada ao maquinista. Desse modo, nas vilas da Companhia Paulista, a casa destinada ao chefe da estação ou ao chefe de tráfego (pois, ao que indica o relatório da Companhia Paulista, a mão-de-obra qualificada e requisitada, por isto, reservada a residência, era o pessoal de tráfego ${ }^{52}$ ) estava localizada juntamente a outras casas da vila, mas apresentando lotes, recuos, áreas maiores e alguns ornamentos a mais, e estrategicamente localizada ou ao lado ou na esquina. Outro lugar importante, era a casa do chefe ou o responsável pela subestação, quando da eletrificação das linhas da Companhia Paulista. A subestação de energia elétrica marca assim a paisagem ferroviária, e é possível datá-la sempre após 1922, o ano em que começam os trabalhos de eletrificação da Paulista. Aquelas para os demais trabalhadores, segundo diversos autores, destinavam-se a maquinistas, foguistas, guarda-trens, ajustadores e pessoal da
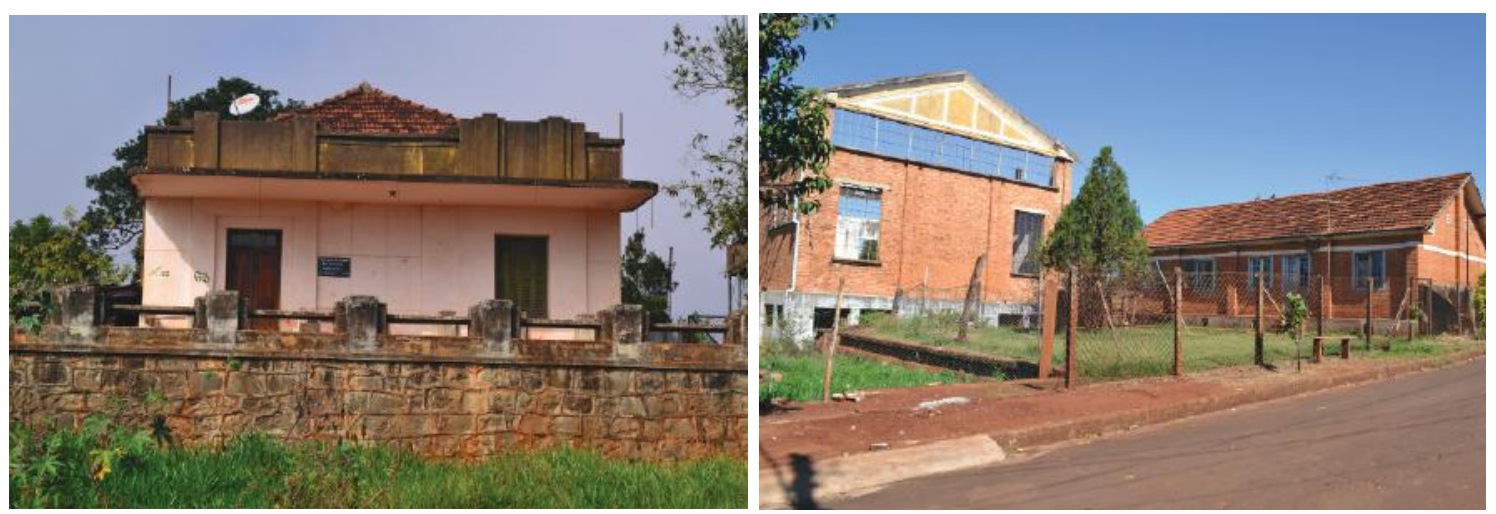

Fotos 131 (esq) - Casa do chefe da subestação elétrica de Dois Córregos. Fotos 132 -

Subestação elétrica de Rincão, e ao lado direito a casa do chefe da subestação. Fonte: autora, 2013.

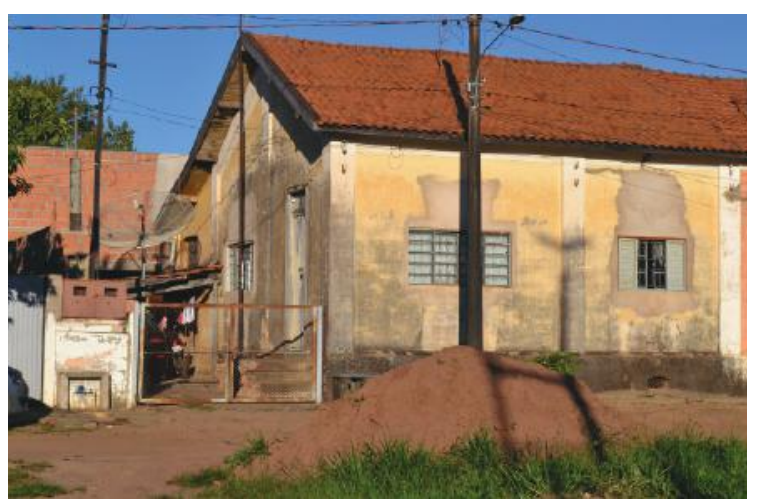

Foto 133 - Casa do Mestre de Linha de Itirapina. Fonte: autora, 2013. manutenção, para solução de problemas imediatos. Mesmo entre estes trabalhadores havia uma diferenciação através da tipologia das casas, sobretudo tamanho dos lotes, recuos, programa e área das casas. Isto pode ser verificado em Rincão, depois da casa do chefe da estação, as melhores casas eram destinadas aos maquinistas, e as menores casas ao pessoal da manutenção da linha.

52 Fala-se da escassez de casas, e portanto, a solução seria a construção de casas sobretudo nas localidades desprovidas de aluguel, dirigidas aos empregados, "não só de tráfego como de outras repartições.” (RCPEF, 1912, p. 148). 
Um outro aspecto que se quer ressaltar em relação à implantação é a existência de quintais, mesmo nas casas "em linha", sem recuo frontal, mas com a presença do quintal nos fundos, detectada em Itirapina e em Rincão. O quintal revestiu-se de aspectos moralizantes, pois se acreditava que o quintal ou o jardim, aproximaria o trabalhador do cultivo da terra, o afastaria de vícios, como o álcool. Parece que tal ideia permaneceu nos engenheiros e industriais por um longo tempo, tanto que se encontrou um artigo em um Congresso Pan-Americano de Estradas de Ferro, em finais da década de 1950, no qual um engenheiro uruguaio afirma a importância dos quintais, juntamente com as associações e clubes, para afastar os trabalhadores dos vícios. ${ }^{53}$

\section{Equipamentos}

A Companhia Paulista possuía Escolas, Cooperativas de Consumo, e ainda equipamentos de lazer. Nem todas as vilas ferroviárias da Companhia Paulista possuíam todos os equipamentos. Como motivo, apontamos que muitas vilas estavam inseridas na malha urbana na cidade, e não se apresentam como uma company town, isolada, como, por exemplo, a Vila de Paranapiacaba. Além disso, os funcionários podiam circular pelas linhas da Companhia Paulista e buscar os serviços que necessitavam. Serviços que poderiam ser escolas para os filhos dos ferroviários, hospitais e igrejas. A Escola de formação dos ferroviários estava localizada em Jundiaí e depois em Rio Claro. Pelos relatos de ferroviários, sabe-se que os exames médicos admissionais eram realizados em Jundiaí. As cooperativas de consumo

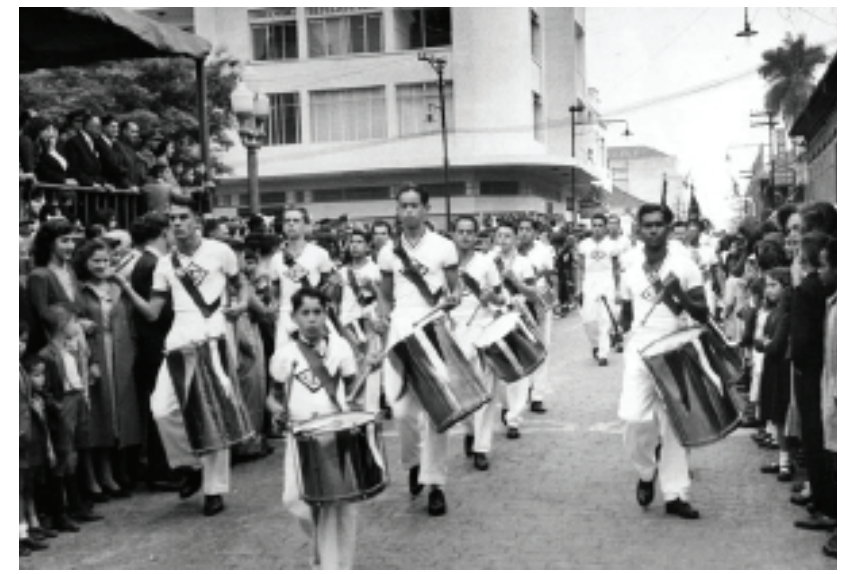

Foto 134 - Banda do Curso de Ferroviários. Fonte: Museu ferroviário de Jundiaí, s/d.

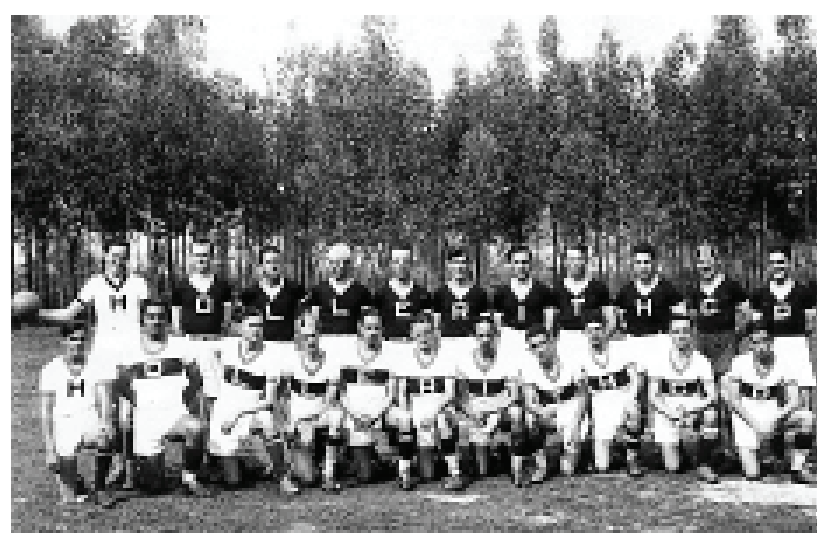

Foto 135 - Time de futebol da Companhia Paulista. Fonte: Museu ferroviário de Jundiaí, s/d.

53 “Bem estar e moral do pessoal”. In Revista Ferroviária. Rio de Janeiro, ano XIX, n. 12, p. 61-2, dezembro 1958. 
estavam localizadas apenas nas cidades com grandes armazéns como Jundiaí, Campinas, Dois Córregos e São Carlos.

E apesar do sobre-tempo, afirmado por Zambello (2005), os ferroviários possuíam algum tempo livre que era passado, com outros ferroviários, ou seja, a "família ferroviária”. Os principais passatempos eram o futebol e os grêmios recreativos. Nem os salões para os bailes, nem o campo de futebol, e em algumas cidades chegam a constituir um clube, eram iniciativa da Companhia Paulista. Tenca (2002) afirma que os clubes ou grêmios recreativos e esportivos eram iniciativa dos engenheiros e outros ferroviários. Os associados pagavam uma mensalidade. A iniciativa portanto, não era da Companhia, esta, quando muito, dava uma contribuição. Através do depoimento de um ex-funcionário, descobriu-se como foi reunido o dinheiro para a construção de uma piscina ${ }^{54}$. Nas cidades em que o número de funcionários era maior, estes clubes deviam ser maiores. Também Ferreira (2010, p. 193-4) conta como o Grêmio Recreativo Flor de Maio, em São Carlos, era frequentado não só pelos funcionários da Companhia Paulista, como pelos negros da região, e como reuniu dinheiro através da organização de bailes, comprou o terreno em 1927, com a fundação do Grêmio em 1928. Além deste Grêmio, em São Carlos, os funcionários organizaram a Associação Atlética Ferroviária de Araraquara.

Sobre o futebol, há um trabalho de conclusão de curso da Faculdade de Esportes, da Universidade de São Paulo, escrito por Ferreira (2008), que defende que a difusão do futebol no interior paulista deu-se pelas ferrovias. É interessante como o autor relaciona urbanização e industrialização, e atribui a criação de clubes de futebol graças a estes dois fatores, já por si inter-relacionados. O autor considera a ferrovia como:

(...) extensão da industrialização, pois ela transmite valores culturais e altera o já existente meio interiorano, alterando então o cenário e a vida deste. Também ocorre uma inserção de objetos e símbolos vindos da capital industrial desenvolvida. Defender um brasão, uma ou duas cores, o nome da agremiação futebolística é muito importante hoje em dia, inclusive ocorrem agressões físicas e verbais por essa divergência de símbolos no país do futebol. (FERREIRA, 2008, p. 44)

Pode-se discordar do autor, considerando a ferrovia não só como extensão, mas sendo ela mesma uma indústria. $\mathrm{O}$ autor vê a mesma como criadora de cidades, levando

54 "A criação do Grêmio Recreativo foi de iniciativa de funcionários da Companhia Paulista de Estradas de Ferro. James Blake, juntamente com outros, cujos nomes, agora, me fogem à memória, foi o fundador. Foi iniciativa de funcionários da Companhia. Funcionários de alto escalão das oficinas, não da Companhia em si, ou da diretoria da Companhia Paulista. Funcionários aqui, das oficinas." (depoimento do Sr. Benedito Guilherme in TENCA, 2002, p. 170). 
a urbanização e os valores urbanos, um destes valores, o futebol. Interessante ainda como Ferreira (2008) também recorda a introdução deste esporte no Brasil, e acrescenta que os clubes serviram para organizar esta prática esportiva, e que a profissionalização deu-se em 1933.

Em 1894, o jovem de 20 anos de idade, Charles Muller, chega a São Paulo vindo da Europa com o intuito de disseminar a prática do futebol. Como é sabido, na "terra da garoa" havia muitas indústrias e empresas ainda relacionadas ao capital inglês, e que eram compostas em seu quadro de funcionários por maioria de ingleses. (FERREIRA, 2008, p. 33)

Algumas delas eram a Companhia de Gás, a São Paulo Railway e o London Bank. Em 1901, surge a Liga Paulista de Football, cujo objetivo seria regulamentar competições entre as equipes, que naquele momento eram apenas cinco: São Paulo Athletic (clube criado pelo próprio Charles Muller), o Germânia (atual Esporte Clube Pinheiros), Mackenzie e a Internacional. (FERREIRA, 2008, p. 33-4). Inicialmente, o esporte era praticado apenas pela elite paulista, mas paralelamente, os operários das fábricas se organizavam e disputavam seus campeonatos de várzea.

Nessa perspectiva, a criação de clubes de futebol a partir das empresas se torna comum com o passar dos anos, e muitos clubes surgiram por interesse associativo de funcionários de empresas que administravam algumas ferrovias. Vejamos exemplos de alguns clubes do interior de São Paulo que surgiram entre 1900 e 1950 e tiveram relação direta ou indireta com as ferrovias. (FERREIRA, 2008, p. 40-1).

Cita ainda a difusão do esporte na Estrada de Ferro Noroeste, a AFE (Associação Ferroviária de Araraquara), fundada por engenheiros e funcionários da EFA (Estrada de Ferro Araraquarense), em 1950; e a Paulista Futebol Clube, da Companhia Paulista de Estradas de Ferro, em 1909. Sobre ela:

O Paulista Futebol Clube da cidade de Jundiaí foi talvez um dos clubes mais antigos a ser fundado sob influência das ferrovias. $O$ clube foi fundado a 17 de maio de 1909 por funcionários da Companhia Paulista de Estradas de Ferro (CPEF), contudo o clube sucedia ao Jundiahy Foot Ball Club fundado por um escocês em 1903, chamado Thomas Scott. O próprio estádio do Paulista chama-se Jayme Cintra, em homenagem ao engenheiro que trabalhou por décadas na CPEF e era muito agraciado pelos funcionários da empresa por seu respeito adquirido durante anos de dedicação a empresa. (FERREIRA, 2008: 41) 


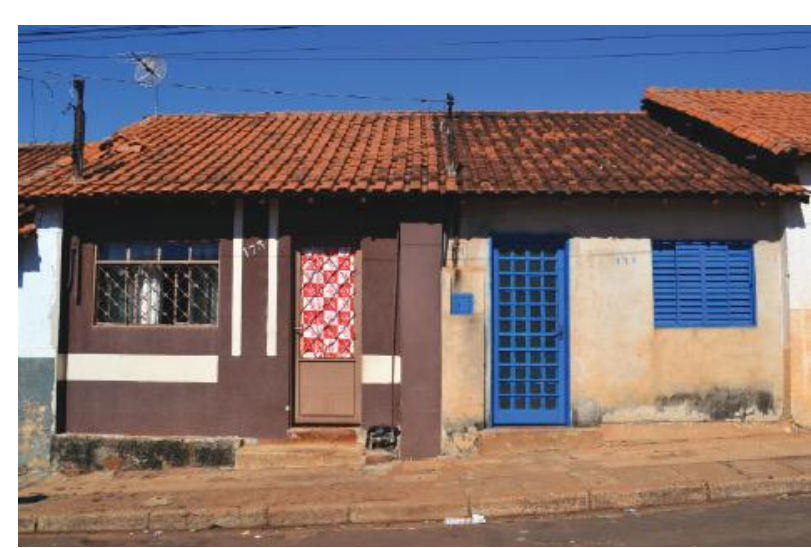

Foto 136 - Fachada de casa ("porta e janela") em linha, em Rincão. Fonte: autora, 2013.

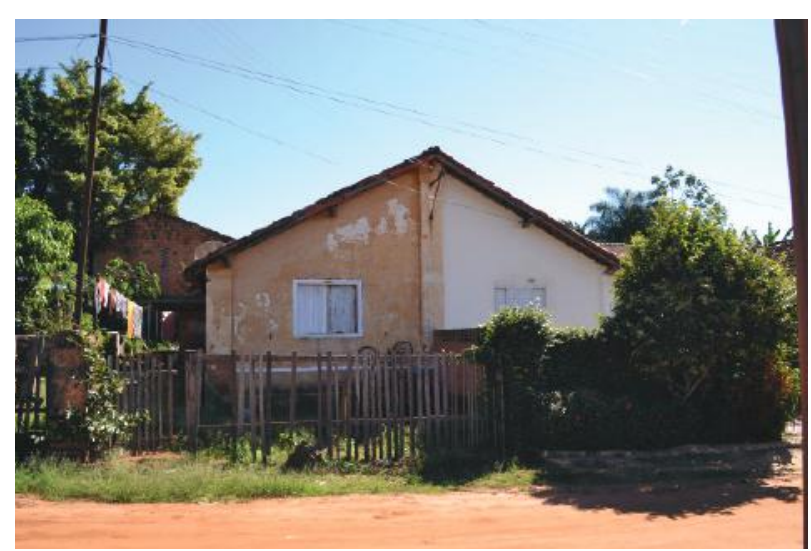

Foto 138 - Casas geminadas em Brotas.

Fonte: autora, 2013

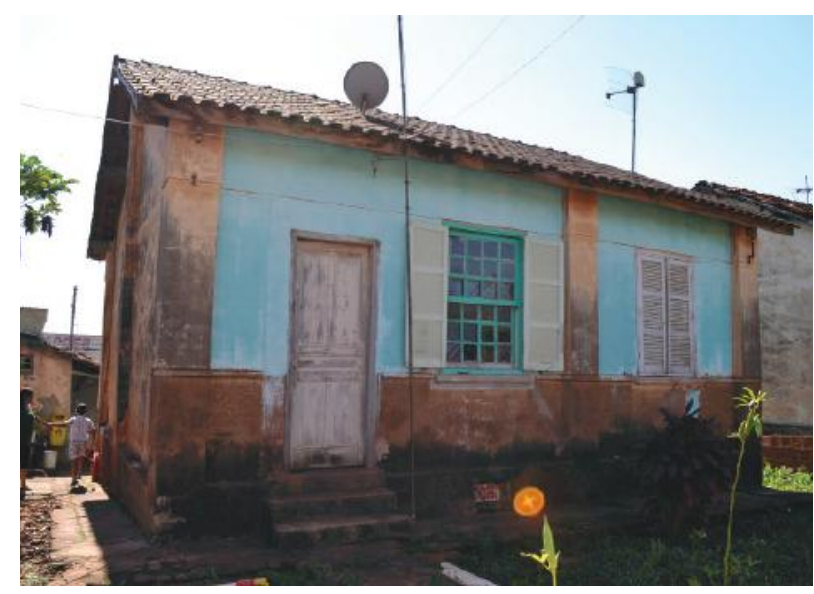

Foto 140 - Casas isolada no lote, em Jaú. Fonte: autora, 2013.

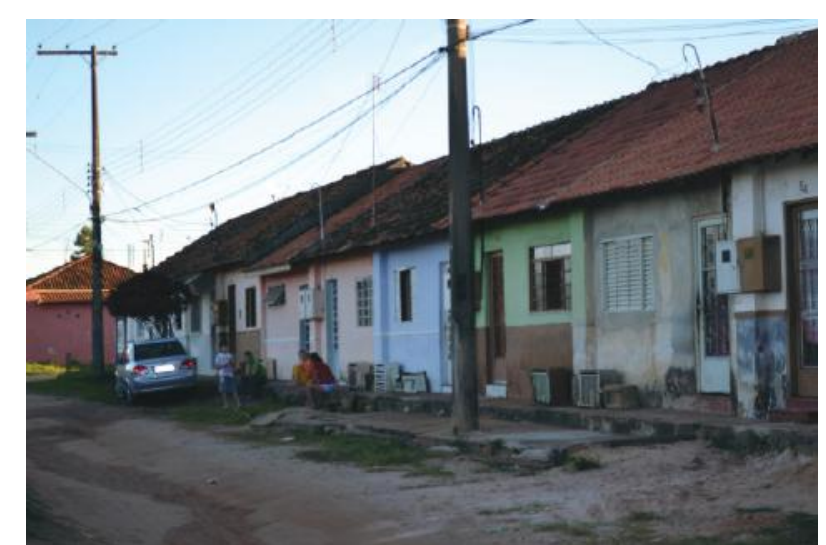

Foto 137 - Casas "em linha", em Itirapina. Fonte: autora, 2013.

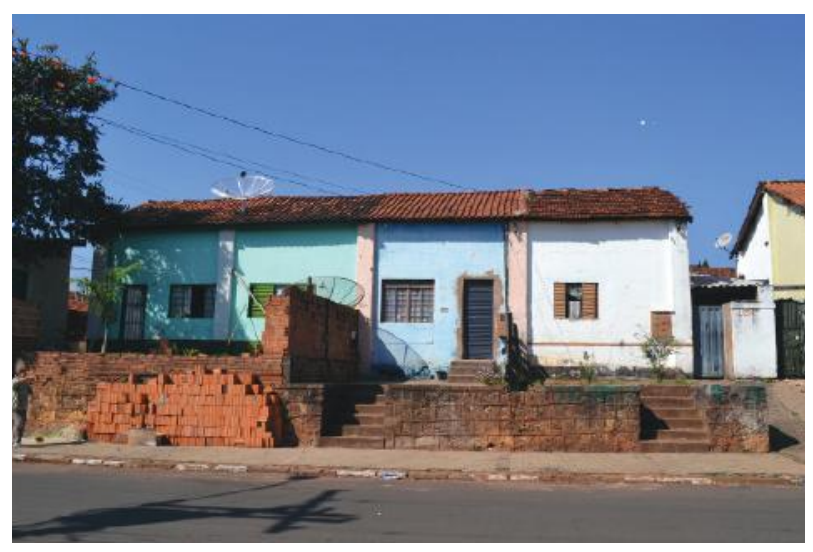

Foto 139 - Casas geminadas em Dois Córregos. Fonte: autora, 2013.

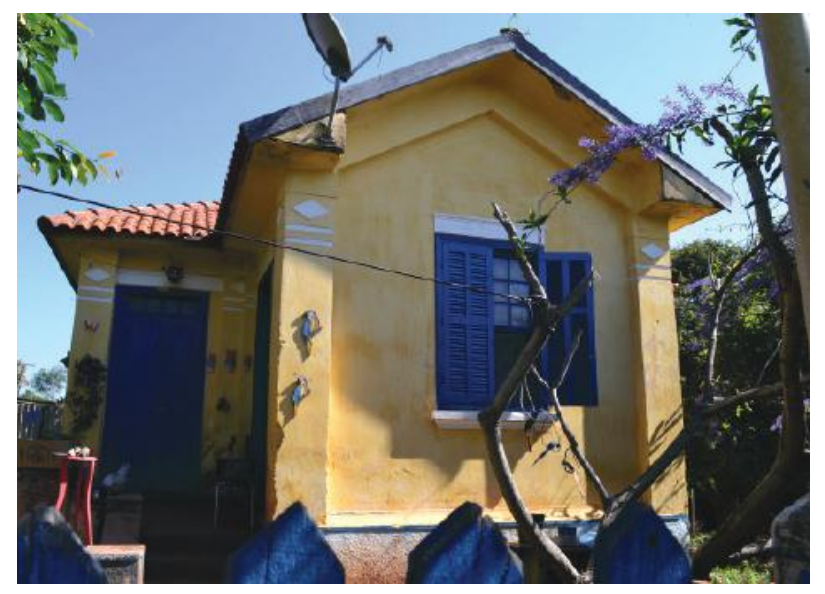

Foto 141 - Casa isolado no lote, casa de chefe de estação, em Jaú. Fonte: autora, 2013.

\section{Tipologias}

As tipologias das vilas ferroviárias são as mesmas encontradas nas vilas operárias, e que tem estreita relação com a implantação na lote, são: 1. Casas em linha ou em renque;

2. Casas geminadas 3. Casas isoladas no lote. As casas da primeira tipologia podem ser 
observadas nas vilas ferroviárias de Itirapina e Rincão. A tipologia do segundo grupo, em todas as cidades estudadas, com exceção de Itirapina. E as casas da terceira tipologia, encontramos nas seis cidades estudadas, geralmente eram destinadas aos chefes da estação.

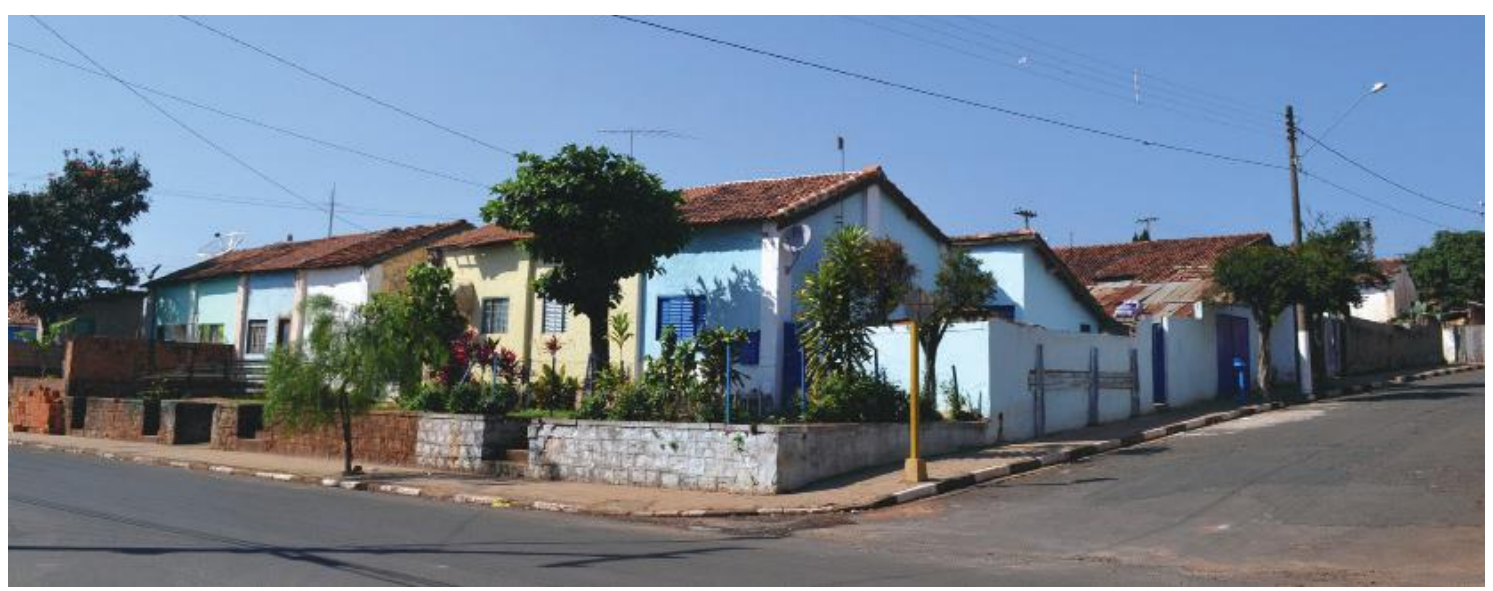

Foto 142 - Conjunto de casas geminadas em Dois Córregos. Fonte: autora, 2013.

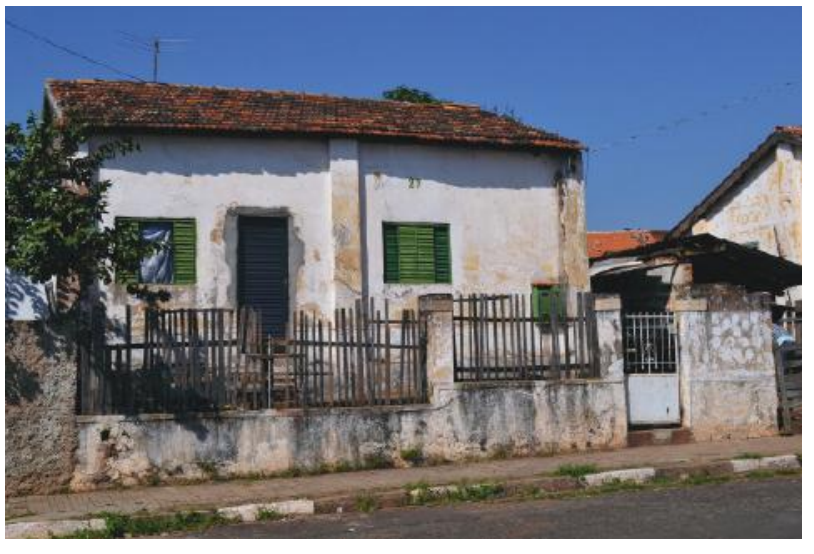

Foto 143 - Casas geminadas com muros frontais baixos, em Dois Córregos. Fonte: autora, 2013.
Um outro elemento que se quer destacar aqui, é a ausência de muros ou muros altos. Os muros não fazem parte da paisagem das vilas ferroviárias. Contudo, principalmente, em cidades um pouco maiores, como Jaú e São Carlos, são elementos que dificultam a leitura da paisagem ferroviária atualmente, chegando inclusive a ser um elemento de descaracterização. Em Dois Córregos, os muros frontais conservam-se baixos. Em Rincão, não há recuos frontais, apenas laterais, e nestes recuos, pode-se observar um certo padrão ainda conservado de muros e portões de madeira baixos, de não mais que 1,60 metros de altura.

Uma última particularidade que se gostaria de colocar em relação à vila ferroviária, e que se relaciona bastante o trabalho ferroviário e a habitação: uma tipologia tipicamente ferroviária, ainda que se encontre afastada da vila (pois esta encontra-se geralmente ao lado da estação) porém que pertence a este complexo ferroviário, são as chamadas "casas de turma". As "casas de turma", construídas ao longo da linha, entre estações, envolvem uma ou duas casas geminadas, para abrigar os trabalhadores responsáveis pela manuten- 


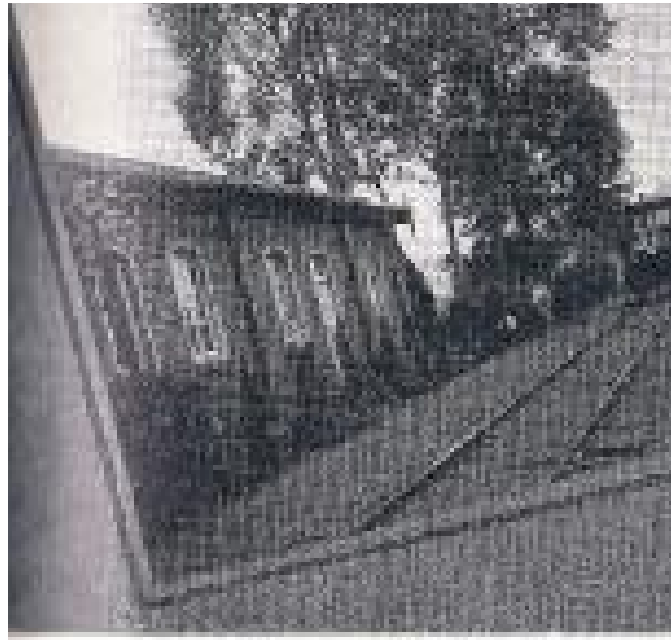

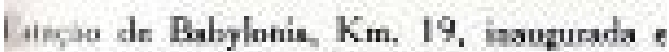
Abri de 1892 Cims of Tums nn Km, 17

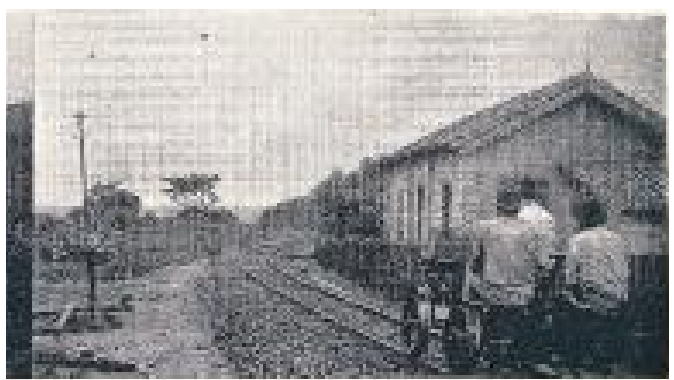

Estez̧ăo de Espraizdo, km. 62

145 liecho do linha ns mocemo eerm Can de turma ne $\mathrm{km}$. 6.6
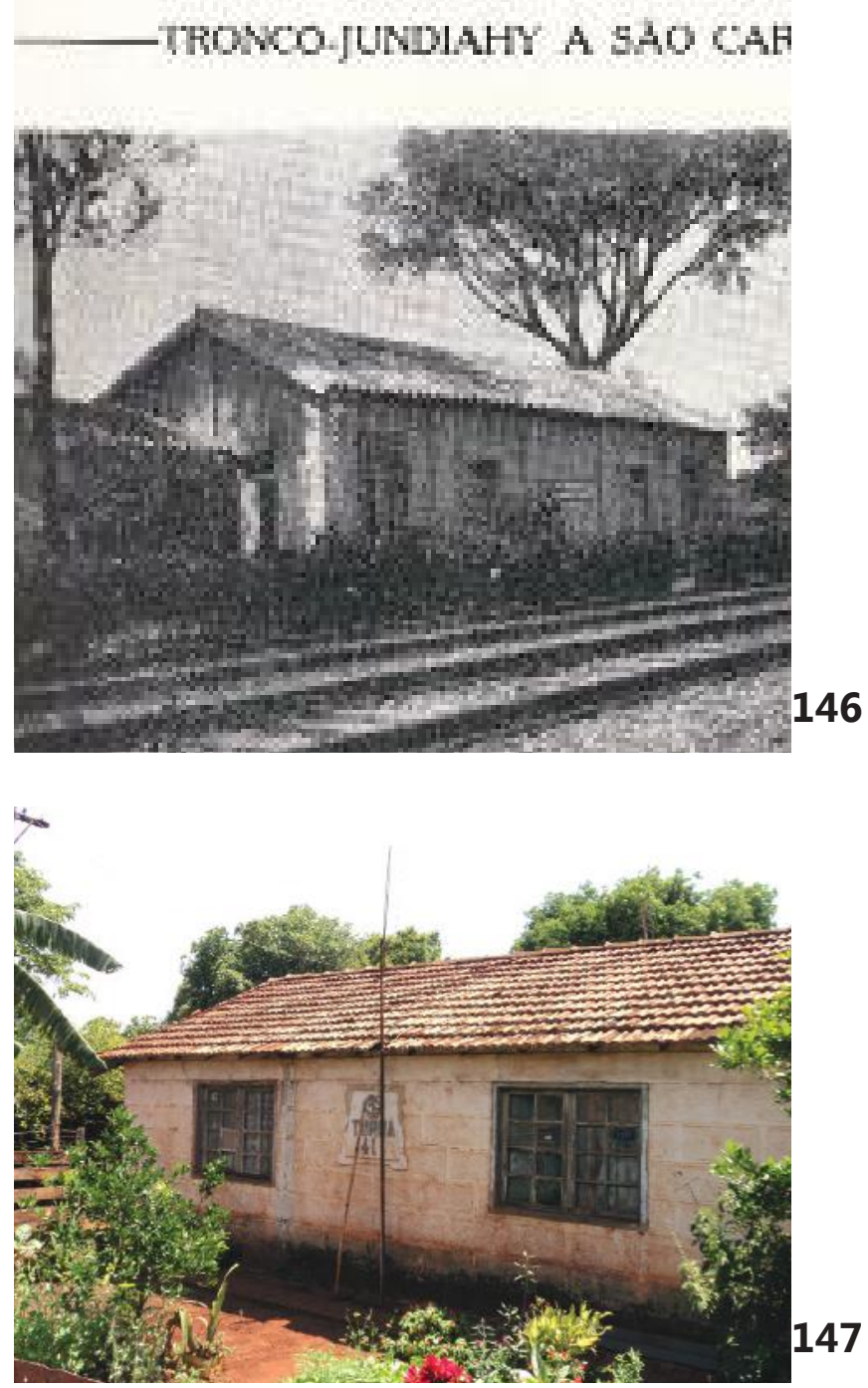

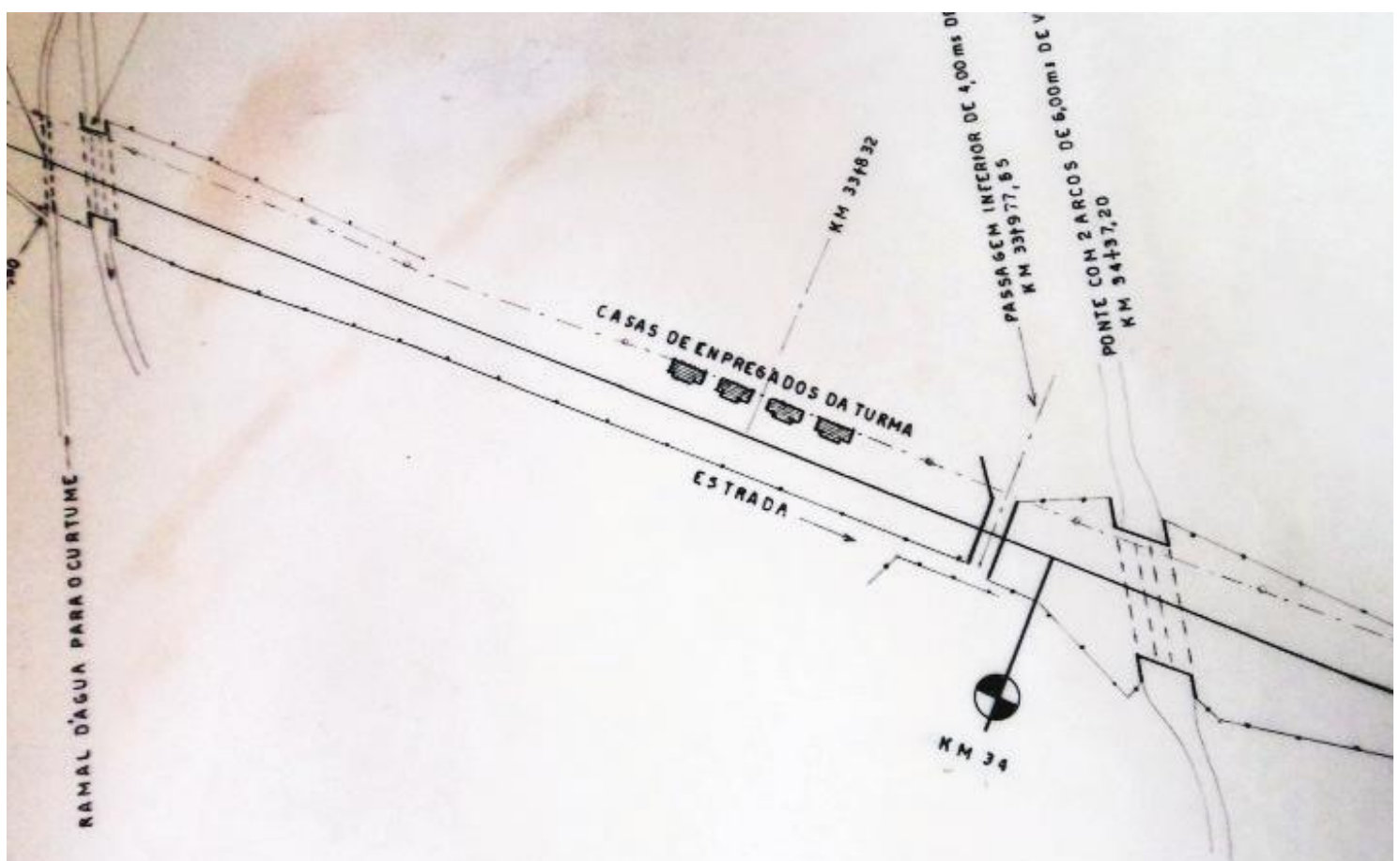

Foto 144 - Casa de turma da CP, no ramal São Carlos e Santa Eudóxia. Foto 145 e 146 - Casas de turma da CP. Fonte: Álbum Ilustrado da CP, 1918. Foto 147 - Foto atual de casa de turma em Pederneiras, da CP. Fonte: autora, 2011.

Mapa 18 - Uma implantacação de casa de turma. Fonte. Arquivo da Inventariança da RFFSA s/d. 
ção da linha. Finger (2009), em seu estudo da vila ferroviária Belga, no Rio Grande do Sul, afirma que a distância entre as "casas de turma" era de $20 \mathrm{~km}$. No caso da Companhia Paulista, não foi verificada exatamente a distância. Atualmente o acesso a elas, em alguns lugares fica mais difícil, e impossibilitado, quando o único de acesso a elas era a ferrovia, muitas vezes, suprimida, desativada ou utilizada apenas pelo transporte de cargas.

\section{Programa}

Morais (2002) que estuda as vilas ferroviárias que compunham a FEPASA, reuniu dados comparativos importantes entre as ferrovias. Entre eles, há dados comparativos entre a média das metragens das casas das vilas ferroviárias das companhias, assim temos: Estrada de Ferro Araraquara, 114,61 m2; Estrada de Ferro Sorocabana, 98,62m2; Companhia Paulista, 78,42m2; Companhia Mogiana, 68,91 m2; e Estrada de Ferro São Paulo - Minas, 61,60m2. (MORAIS, 2002, p. 181-2). Outro dado comparativo importante são os números de unidades habitacionais construídas, por cidade e ferrovia. Em número totais, têm-se o seguinte: Estrada de Ferro Sorocabana, 2784 unidades; Companhia Paulista, 1666 unidades; Companhia Mogiana, 809 unidades; Estrada de Ferro Araraquara, 412 unidades; Estrada de Ferro São Paulo - Minas, 81 unidades. Segundo estes dados, a Estrada de Ferro Sorocabana foi a que mais construiu, seguida da Companhia Paulista.

Os programas mais elaborados e, portanto, apresentando maiores áreas eram dirigidos aos chefes de estação ou aos chefes responsáveis pelo tráfego. Desta forma, a hierarquia do trabalho, é também observada nas áreas das casas. Quanto ao programa, podemos dizer que possuem programas muito semelhantes, mesmo o dos chefes da estação e que variaram pouco no tempo. Compõe-se de um a três dormitórios, sala, cozinha e banheiro. A simplicidade do programa também é constatada por Zambello (2005, p. 67) em Campinas: "Essas moradias geralmente contavam com uma sala de 2m2, uma copa contígua, onde há acesso para dois dormitórios, seguida pela cozinha e pelo banheiro.”. Müller (2006) que estuda a vila ferroviária da Ponte Preta em Campinas, fala de uma padronização das casas construídas pela Companhia Paulista, contudo, não fornece dados. Saia (1989, p. 111) que estuda a arquitetura fabril, não incluindo as vilas operárias, mostra alguns catálogos de companhias americanas e inglesas, da década de 1920, que sugerem alguma padronização para as plantas das fábricas. O fato é que, dada a escassez de fontes primárias, fica difícil afirmar uma padronização das vilas ferroviárias, e tudo o que o termo traz consigo. Arrisca-se a dizer que dada a simplicidade do programa, materiais 
e estilos, pode-se falar em uma não variação, admitindo-se a reprodução de uma planta, adaptando-se apenas a implantação nas diversas cidades operadas pela Companhia Paulista, e conforme o tempo, a adaptação da fachada aos estilos da época.

Durante as visitas de campo, pode-se detectar algumas particularidades quanto à cozinha e ao banheiro. Nas vilas operárias em geral, a cozinha localizava-se em uma parte transitória entre o banheiro e a casa. É o que se constata, por exemplo, na vila ferroviária em Santa Maria (RS), conhecida como Vila Belga (FINGER, 2007, p. 129, 131 e 133).
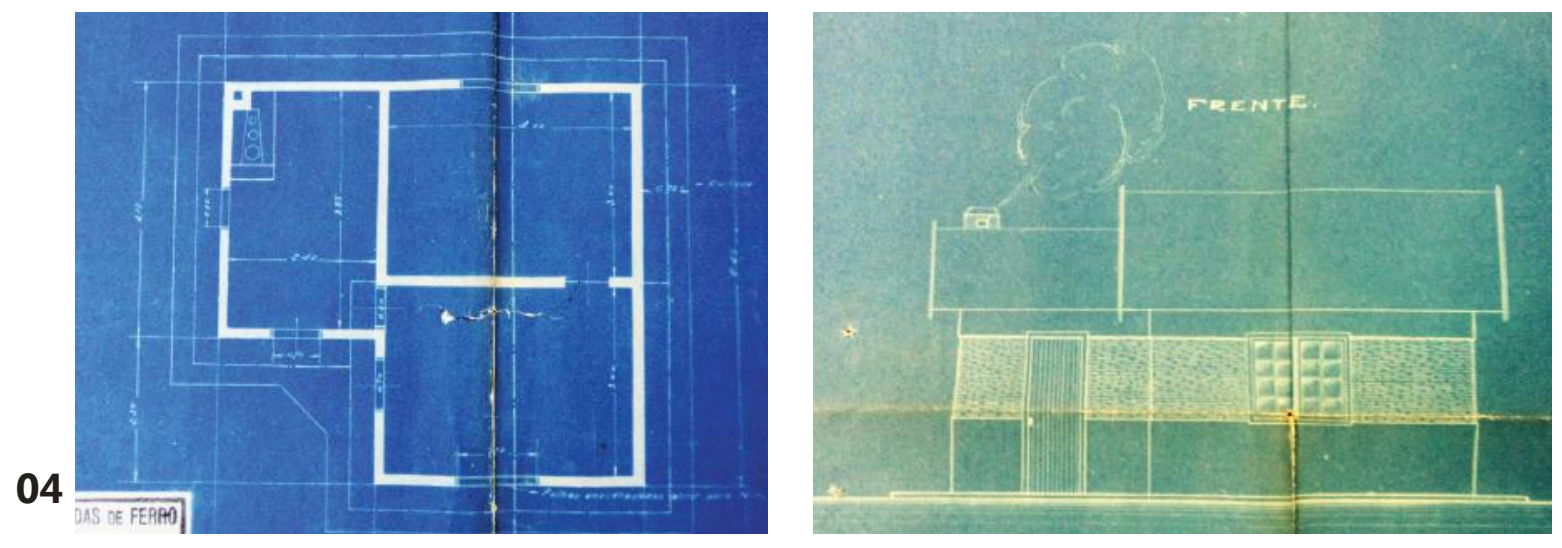

\section{8}

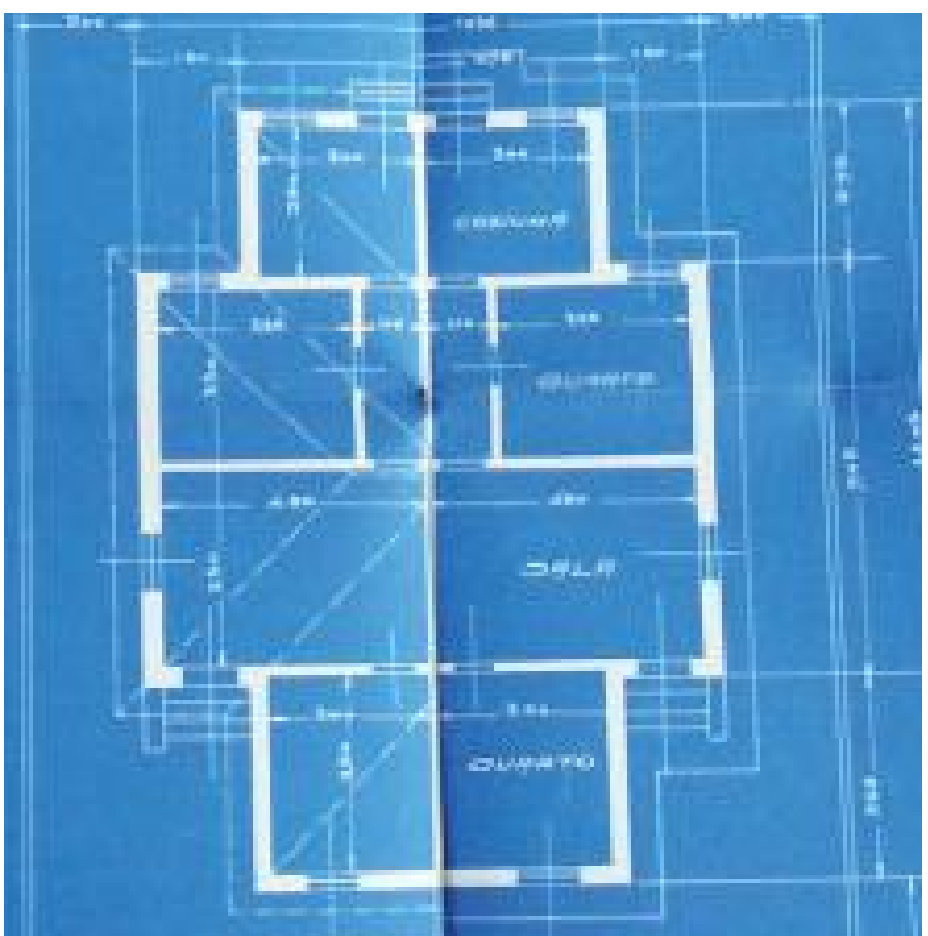

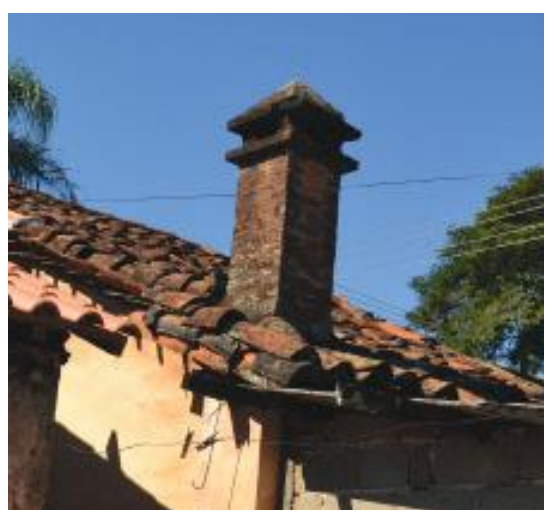

Foto 04, 05 e 08 - Fotos apresentadas anteriormente, das únicas plantas encontradas de vilas ferroviárias da CP. Fonte: Museu Ferroviário de Jundiaí; Arquivo Municipal de Campinas.

Foto 148 - Chaminé de uma das casas da vila ferroviária de Rincão. Fonte, autora, 2013.

A cozinha e o banheiro estão localizados na parte externa, que se comunica com a frente da casa através de um corredor. Quanto às vilas ferroviárias da Companhia Paulista, com relação à cozinha, ela se apresenta no corpo principal da casa, e pode-se dizer que as mais antigas, possuíam forno à lenha. Tal aspecto foi registrado nas poucas plantas encontradas nos arquivos, como também na visita de campo, em que se constatou a presença da cha- 
miné, ainda que na cozinha atual não exista mais o fogão à lenha.

Quanto à localização do banheiro, por seus aspectos construtivos, higiênicos e de fabricação das peças sanitárias, variou no tempo. Cruz (2007, p. 10) que estuda a Vila de Paranapiacaba (SP) faz o seguinte comentário:

Sobre a influência dos hábitos britânicos de conforto e de higiene doméstica, o que se alterou no Brasil foi principalmente a localização das casas burguesas, passando os ingleses a preferir as residências isoladas entre arvoredos, perto dos rios ou ainda à beira-mar, aos sobrados geminados. (...) A essas casas os ingleses acrescentaram pelo menos duas instituições britânicas que se incorporaram à arquitetura doméstica aos brasileiros: o hall e o water-closet (wc) (FREYRE, 1977).

(...) Geralmente o wc era contíguo à cozinha por causa da economia de tubulação que ainda era importada. Chuveiro, latrina e bidê, equipamentos destinados à higiene, acomodavam-se num mesmo espaço, diferente do costume francês, que isolava a latrina em um cômodo separado.(LEMOS, 1999b).

Desse modo, Cruz (2007) identifica que, na vila inglesa de Paranapiacaba, nas casas mais ricas e dirigidas aos funcionários mais qualificados, como engenheiros, o banheiro era incorporado ao espaço interno da casa, devido aos aparelhos sanitários e as tubulações importadas, e também segundo afirmado no trecho acima, pela influência inglesa. Nas demais tipologias para os outros trabalhadores, há a existência do banheiro externo.

$\mathrm{Na}$ vila ferroviária inglesa de Swindon, constatou-se que ao início, antes da construção da piscina, os trabalhadores iam ao prédio do Mechanic Institute para tomar banho, que era cobrado. Além disso, as casas não possuíam cozinha, o que leva a crer que cozinhavam na lareira; a sala e a cozinha eram o mesmo ambiente. Possuíam uma escada que levava para os dormitórios no andar superior, e um quintal de $21 \mathrm{ft}(6,40$ metros $)$

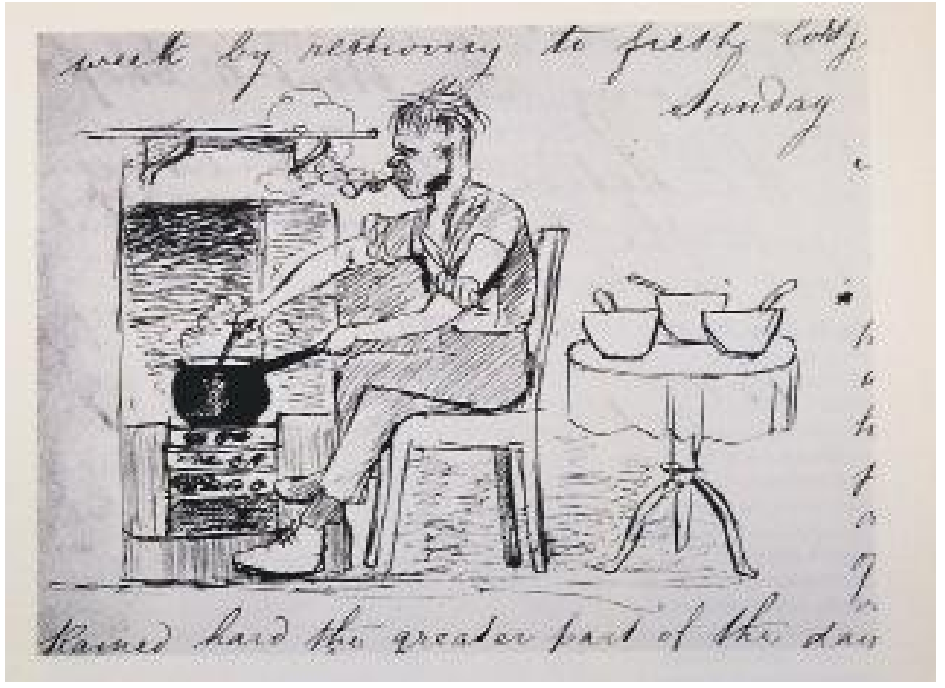

Figura 05 - Desenho, maio de 1843, tirado de um diário de ferroviário, cozinhando na lareira. Fonte: CATELL\&FALCONNER, 1995 p.55. 

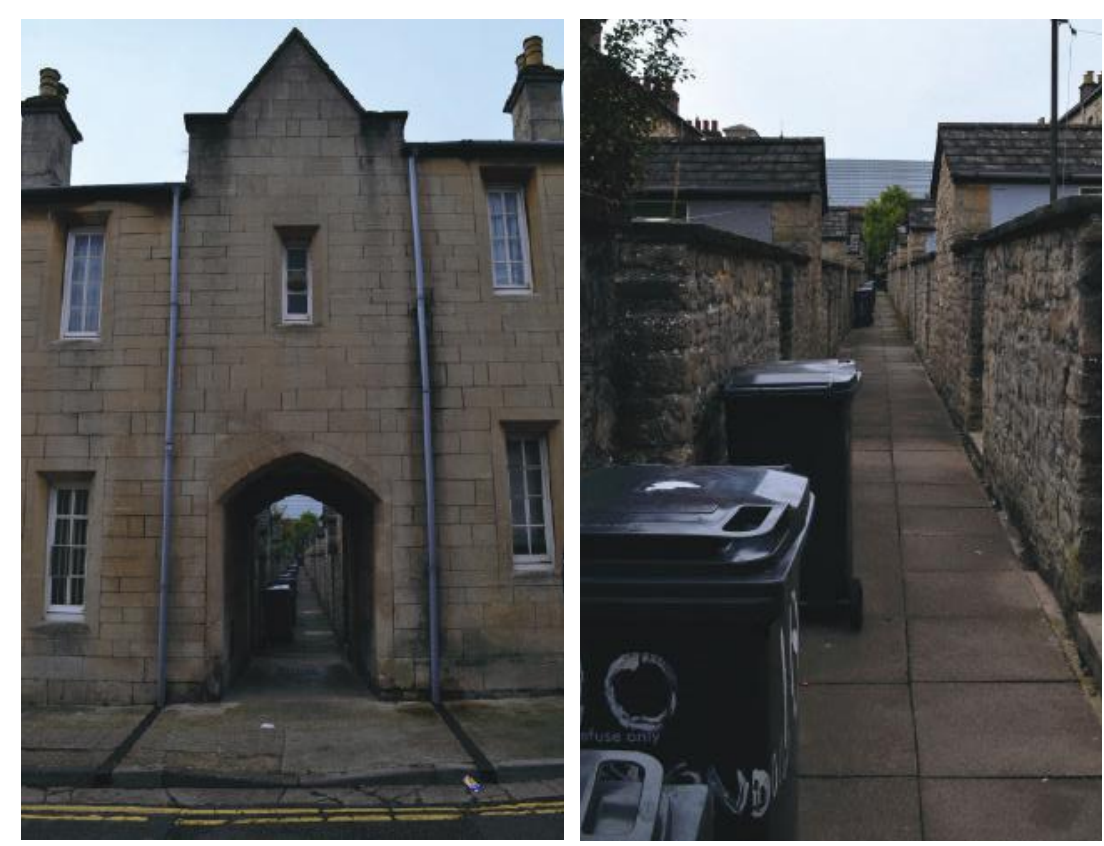

Foto 149 (esq) - Entrada da alameda ou back-alley em Swindon.

Foto 150 - Alameda ou back-alley em Swindon. Fonte: autora, 2013. de comprimento. No fundo do quintal, estavam localizados o banheiro e um buraco que servia de lixo. Entre as duas fileiras de casas, no fundo do quintal há uma alameda (back-alley), e debaixo dela, a mais ou menos $8 \mathrm{ft}(2,44 \mathrm{~m})$ a fossa séptica, ou o sistema de drenagem do esgoto. Contudo,

o sistema de abastecimento de água e esgoto da vila era defeituoso, e responsável pelas doenças. As mais comuns eram tifo e varíola, causados pelo entupimento ou vazamento da fossa localizada no fundo dos quintais. A situação era crítica, tanto que em 1849, o superintendente Gooch, ordenou que as casas fossem purificadas, e as tubulações limpas. A companhia proveria o material e os moradores fariam a própria manutenção das casas. (CATELL\&FALCONER, 1995, p. 65).

Numa segunda etapa, as casas possuíam uma configuração diferente, eram de dois andares, cada andar ocupado por uma família, com entradas diferentes. Este programa permitia que os moradores pudessem escolher, entre um, dois e quatro dormitórios, dependendo de quanto pudessem pagar. Deveriam, no entanto, compartilhar o único banheiro, e a cozinha era inexistente. Em 1847, mais um conjunto de casas foi construído, com uma pequena dispensa debaixo da escada, e três quartos, mas ainda sem cozinha. Em 1861, chegaram mais operários de Gales, primeiramente solteiros, o que levou a companhia a construir um alojamento para estes, chamado "barracks". Este aumento levou os empreendedores privados a construir para estes novos operários com as suas famílias. Estas casas possuíam uma lavanderia e um banheiro no quintal, e local para guardar carvão e cinzas, e cozinhas equipadas com fornos, desenhadas pelo arquiteto Thomas Smith Lansdown. (CATELL\&FALCONER, 1995, p. 106 -7).

De volta às vilas operárias brasileiras, há uma afirmação de Carpintéro (1997) que 


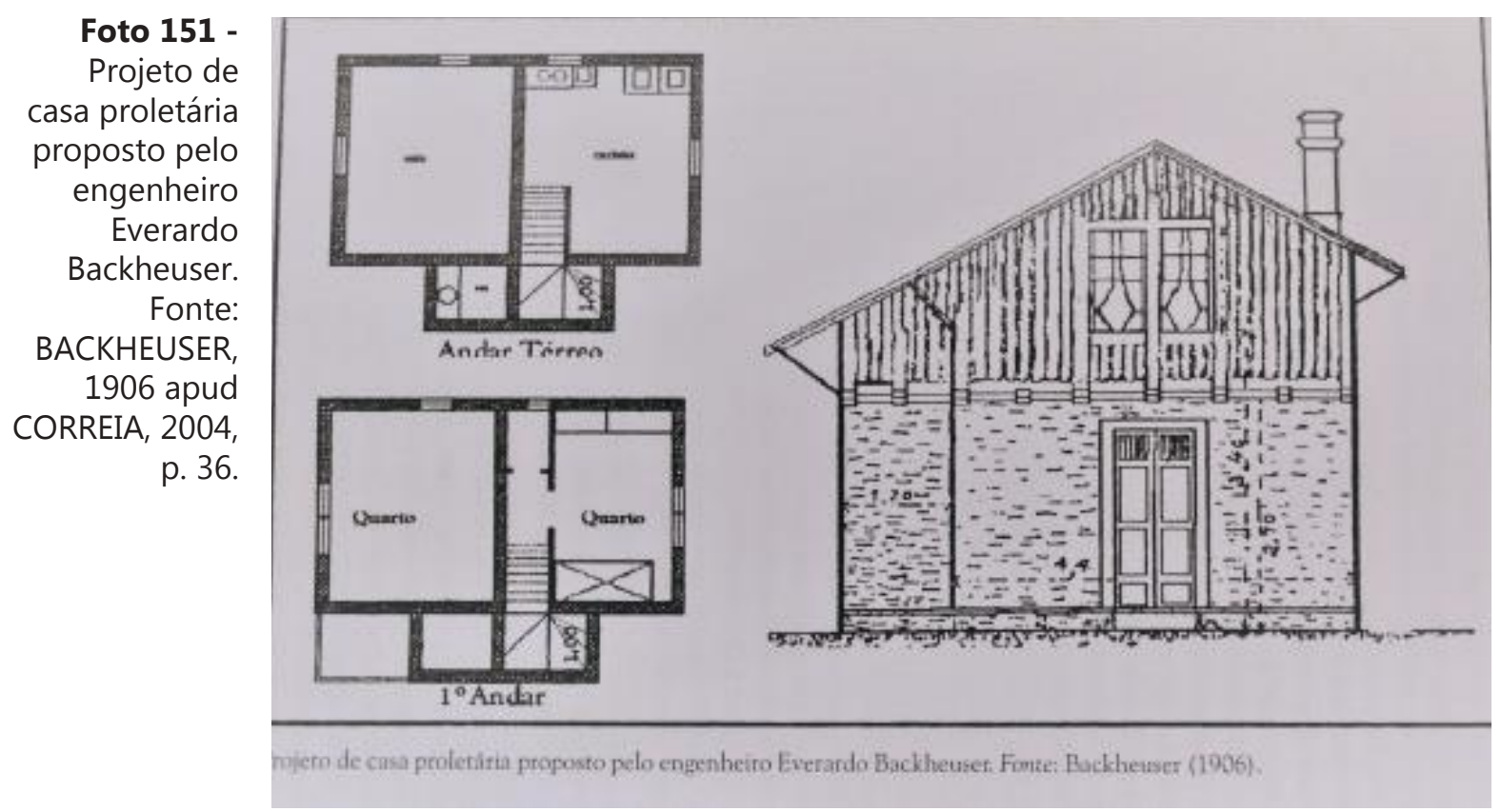

conta que o engenheiro Beckheuser, em 1906, recomendava a construção do banheiro fora, por dificuldade de construção, e que este foi incorporado posteriormente "apesar de mais oneroso, possibilitava, na opinião dos técnicos, modificar determinados hábitos considerados 'prejudiciais' ao bom funcionamento da casa” (CARPINTERO, 1997, p. 111-112).
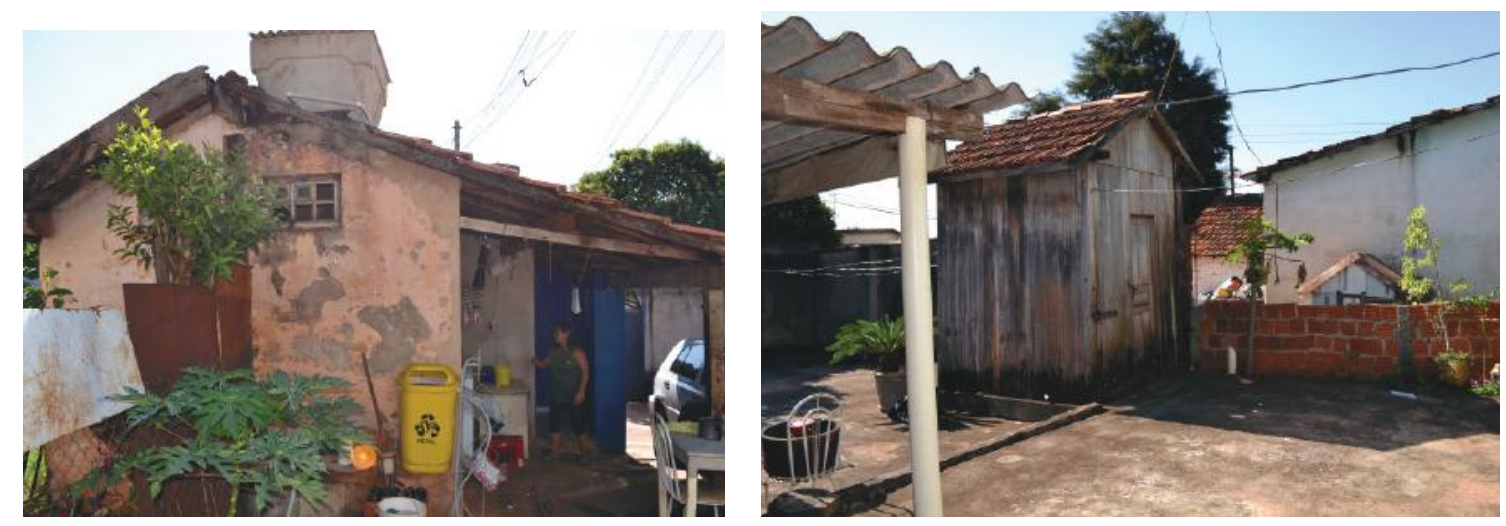

Foto 152 (esq.) - Anexo externo em casa da vila ferroviária de Rincão. Fotos 153 - Anexo externo, em madeira, em casa da vila ferroviária de Jaú, Fonte: autora, 2013.

Nas vilas ferroviárias estudadas, que já se encontram bastante descaracterizadas, o banheiro se encontra adaptado no interior da casa. Contudo, acredita-se que originalmente havia as duas tipologias: uma com o banheiro incorporado ao corpo principal, e outra com o banheiro externo, que seria o mais provável nas áreas rurais, para a construção de fossas sépticas. Como exemplos, que apontam indícios de banheiro externo, tem-se 
Jaú e Rincão, cujas plantas realizadas pelo levantamento da Prefeitura mostram que todas as casas possuíam banheiro externo associado ao tanque de lavar roupas.

Com relação ao encanamento, também se pode fazer referência à coleta de águas pluviais, pois a presença de calhas poderia encarecer as casas. Deste modo, a maior parte das casas das vilas operárias eram de telhas de barro, em duas águas, ou geminadas em quatro águas. Uma exceção encontrada na bibliografia estudada é a vila operária da Companhia Industrial São Joannense, em São João del Rey, em Minas Gerais, estudada por Moreira (2007:230). Nela encontramos algumas casas com platibanda. Em nosso estudo, a platibanda está presente em algumas das casas, e imagina-se que eram dirigidas a funcionário de hierarquia maior dentro do conjunto dos trabalhadores, em Dois Córregos. A presença da platibanda é também justificada para compôr o estilo Art Decó da construção, localizando-se temporalmente as casas entre 1930 e 1940 . Um detalhe relacionado ao encanamento e fornecimento de água, e que, dentre as vilas pesquisadas, só se encontrou em Rincão, foi a caixa d'água em ferro, construída para o abastecimento da vila. É um outro elemento, que além das caixas

Foto 156 - Forro em madeira de uma das casas de Rincão. Fotos 157 Assoalho em madeira de uma das casas de Rincão. Fonte: autora, 2013.
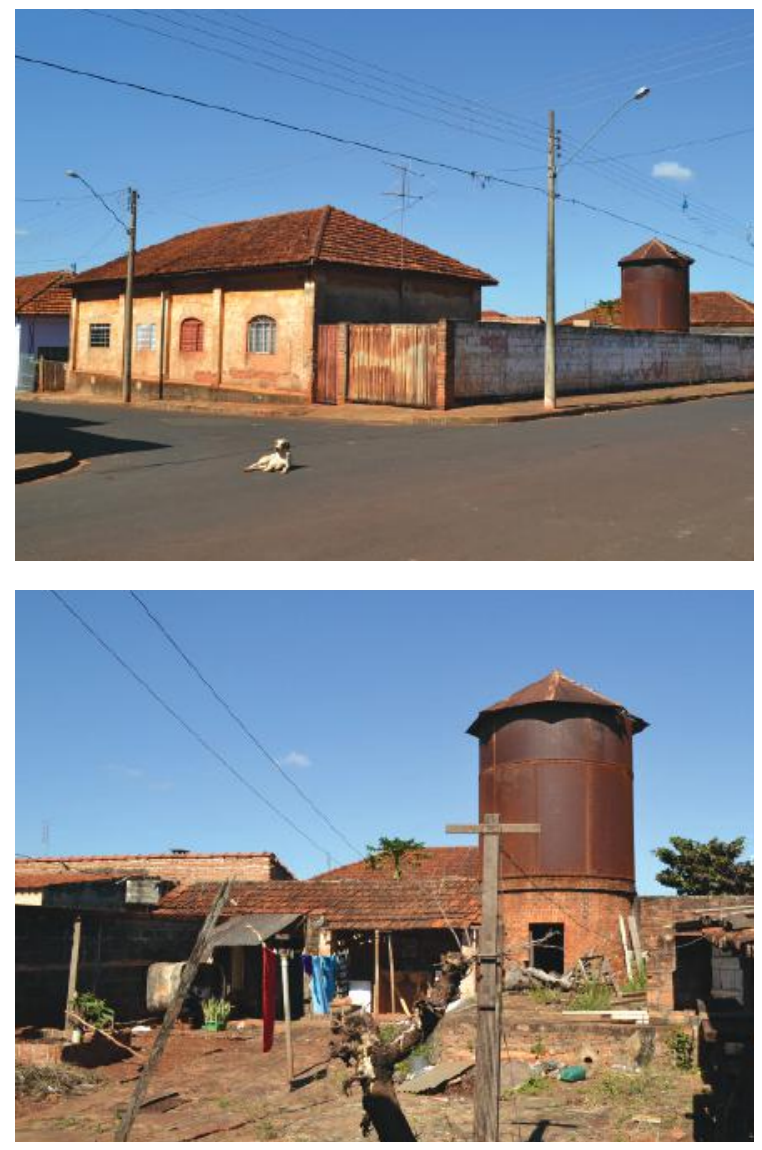

Foto 154 - Vila ferroviária de Rincão e a caixa d'água. Fotos 155 - A caixa d'água localizada em um dos quintais. Fonte: autora, 2013.
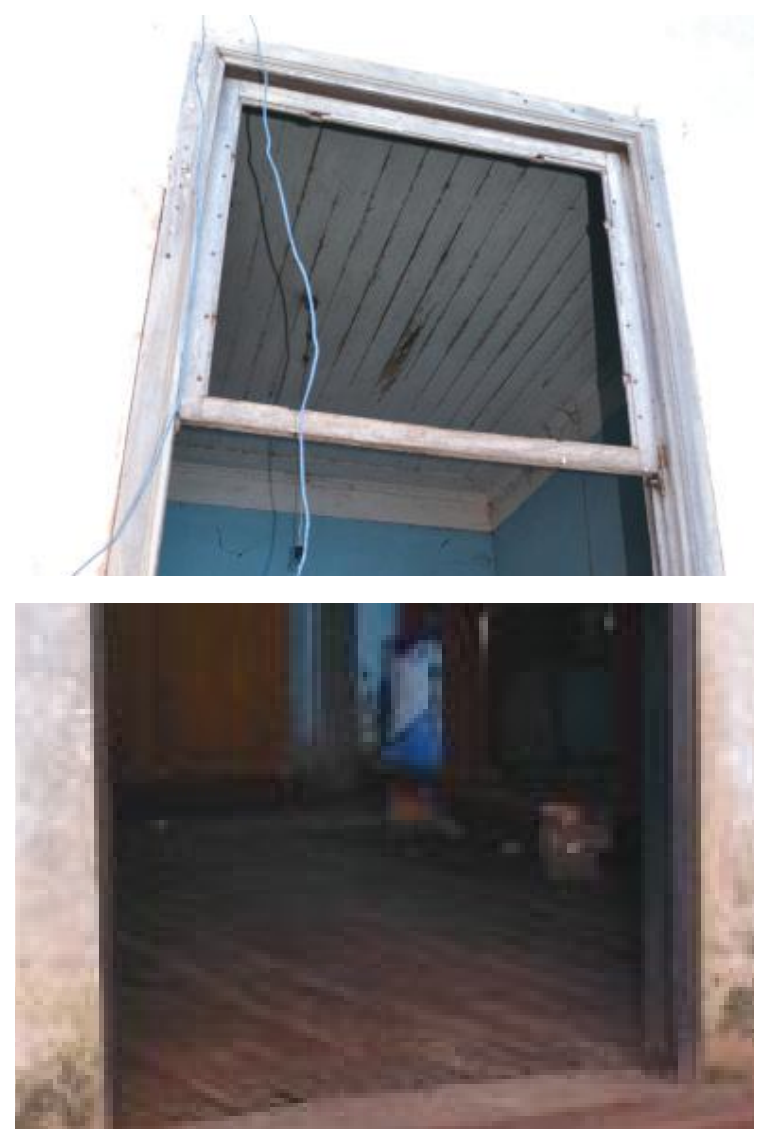
d'água das estações da fase das locomotivas a vapor - faz parte do complexo e marcam a paisagem ferroviária que se está procurando estabelecer.

Outro detalhe que denota um alinhamento com as questões higienistas das casas operárias do período, é a presença de recuos laterais e porão em algumas. Acredita-se que são resultantes também de códigos sanitários, porque nas vilas inglesas não existem tais detalhes construtivos. A presença de recuos é benéfica para a circulação de ar, entre as casas. Geralmente nas casas em linha ou em renque, dificilmente encontramos tais características construtivas. É constatada em algumas das casas geminadas em Rincão, onde se encontrou também o assoalho e o forro em madeira.

\section{Material}

Quanto ao material, podemos dizer que a maior parte das vilas ferroviárias da Companhia Paulista foram construídas em alvenaria. A icônica Vila de Paranapiacaba foi construída em sua maior parte em madeira, porém não é a única. Foram encontrados exemplos em Ourinhos, da Estrada de Ferro Sorocabana, com muitas casas construídas com este material, praticamente a vila inteira. Em São Carlos, encontrou-se um único exemplar em meio a outros materiais. Saia (1979, p. 213-221) afirma que a técnica e os materiais do ciclo ferroviário eram: o tijolo, a telha francesa, o concreto armado, a madeira que passa a ser serrada em bitolas comerciais, e os diversos tipos de materiais e mobiliá-

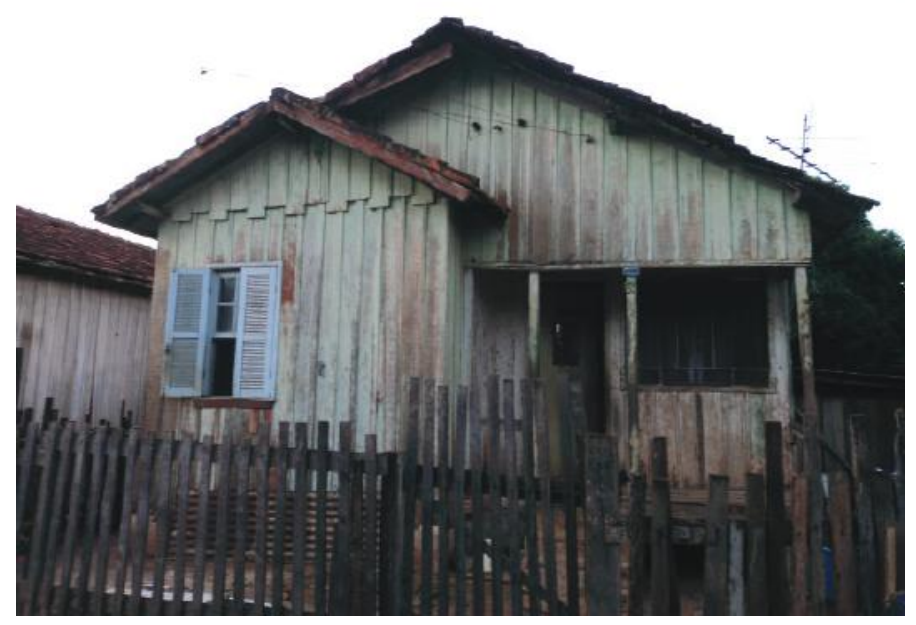

Foto 158 - Casa em madeira da Companhia Sorocabana em Ourinhos. Fonte: autora, 2011.

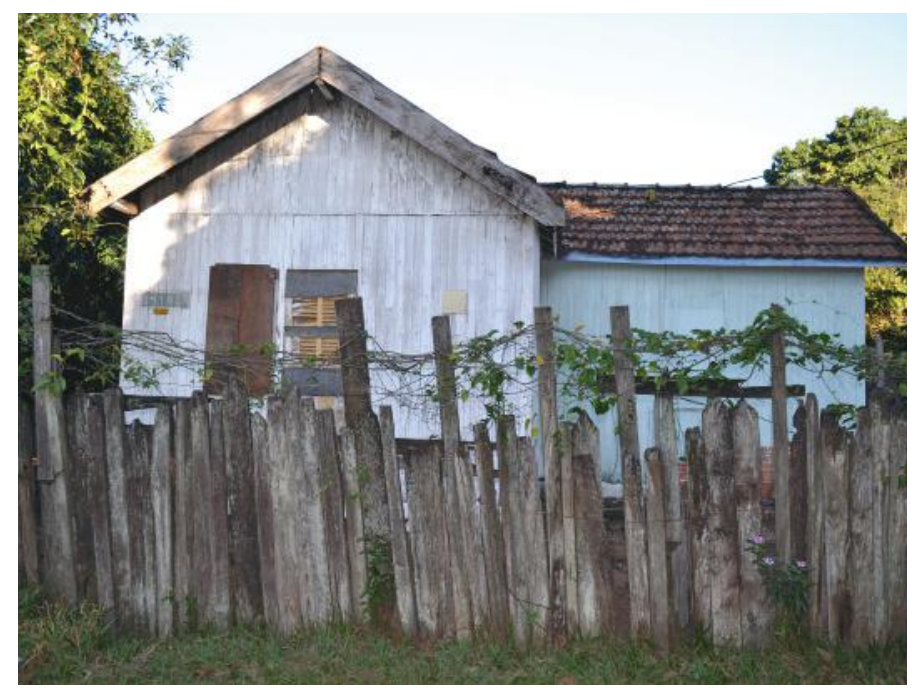

Foto 159 - Casa em madeira da Companhia Paulista em São Carlos. Fonte: autora, 2013. 
rios importados. Lemos (1989), ao estudar a arquitetura do café, que de certa forma encontra-se interligada com a da ferrovia, afirma que a arquitetura do café é a arquitetura do tijolo, o que ele chama de "alvenaria burguesa". Segundo o autor, o emprego do tijolo foi possibilitado pela riqueza do café, que trouxe consigo a

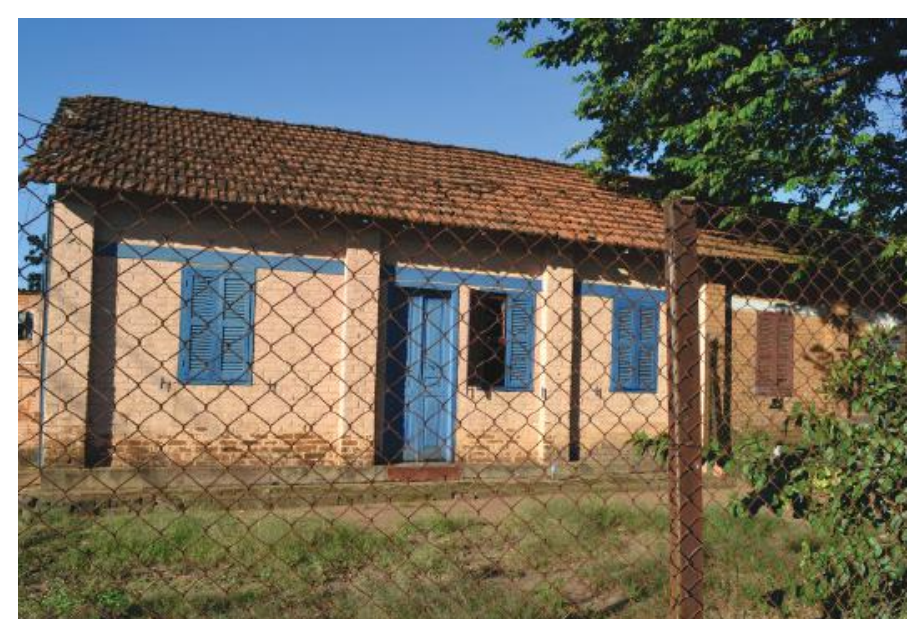

Foto 160 - Casa em tijolo aparente da Companhia Paulista em São Carlos. Fonte: autora, 2013. imigração italiana e a industrialização. Muitas fazendas de café utilizaram o tijolo para suas construções, e inclusive no revestimento dos terreiros de secagem de café. D'Alambert (1993) afirma que há registros de uso de tijolos desde 1840, porém que a sua difusão deu-se a partir de 1870, com a industrialização do material, possibilitada pelas olarias a vapor.

\begin{abstract}
Em São Paulo, no final da década de 1870, eram comuns os anúncios nos jornais locais de olarias a vapor, oferecendo tijolos de boa qualidade a preços acessíveis. No bairro do Bom Retiro, localizavamse as grandes olarias de Ribeiro \& Clavel, de Manfred Meyer \& Paiva entre outras." (D'ALAMBERT,1993, p. 33).
\end{abstract}

Aliás, quanto a todos os outros materiais, anteriormente mencionados, como a telha e a madeira serrada em bitolas comerciais, o uso só foi possibilitado em larga escala, após a industrialização no Brasil. Segawa (2000, p. 160) afirma que “(...) Nos anos 1910, as técnicas construtivas não eram socialmente tão seletivas: burgueses ou remediados, todos moravam em casas em tijolo, cerâmica e madeira (...)” e que a distinção era feita pelo maior número de cômodos e nas áreas. Nas vilas ferroviárias estudadas, como dito anteriormente, a maior parte das casas foram construídas em tijolo e, em geral revestidas. Em São Carlos, encontrou-se um exemplar de casa em madeira, e também encontramos uma casa em tijolo aparente. E também em Rincão, encontramos apenas a casa do chefe da subestação elétrica e a própria subestação elétrica em tijolo aparente, as demais edificações em alvenaria revestida.

Pelo que se pode observar, há um tratamento diferente dado às estações e às vilas ferroviárias. As estações, muitas vezes representavam o ícone do progresso e cartão postal da cidade, recebiam um tratamento arquitetônico melhor que as vilas ferroviárias. 
Além de utilizarem materiais diferentes como o ferro e o vidro, assumiam os diversos estilos arquitetônicos. Porém, em geral, era o eclético, neoclássico ou neorrenascentista, conforme denominações que se queira dar. Moreira (2007) ao tratar da arquitetura fabril e ferroviária de Minas Gerais, identificou o estilo eclético. A autora também tenta sistematizar os modelos industriais brasileiros, utilizando-se da classificação dada por Hardman\&Leonardi (1982, p. 142). Assim, existem os seguintes modelos: "padrão colonial" referindo-se às "fábricas têxteis do Império, apresentava fachadas similares à das casas grandes de fazendas de açúcar e café. Localizadas especialmente em fazendas, tais fábricas geralmente empregavam trabalho escravo, possuíam culturas de algodão e surgiram como prolongamento da atividade agrícola”. Como exemplos deste padrão: fábrica Cedro em Minas Gerais, fábrica São Bento em Jundiaí, e fábrica São Luís, em Itu, estas duas últimas no estado de São Paulo. Outro padrão é "britânico manchesteriano", devido aos tijolos vermelhos e simetria de planos, citando como exemplos as Fábricas Reunidas Matarazzo, na Água Branca, a Cervejaria Antártica, ambas na cidade de São Paulo.

Ao mesmo tempo, Moreira (2007) cita um “quadro comparativo" entre os modelos europeus e norte-americanos para o cenário do estado de São Paulo, utilizado por Saia (1989), que adota a seguinte classificação, para o cenário brasileiro, e somente para as fábricas têxteis: oficinas manufatureiras (1813 a 1869); edifício fabril com uso industrial camuflado (1869-1881), edifício fabril com tipologia específica (1881-1920), edifício fabril com padronização parcial (1920-1930), padronização total (após1930). Não tendo como foco da pesquisa as estações, e alertando que houve mudanças do lugar das estações e as reformas que podem ter sofrido ao longo do tempo, as estações estudadas seguem um estilo eclético. Ainda que em outras ferrovias possa ser encontra-

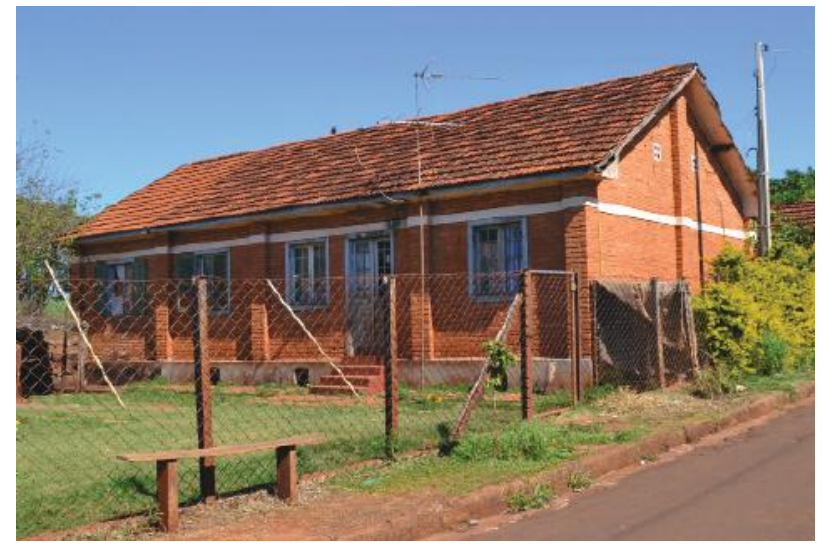

Foto 161 - Casa do chefe da subestação elétrica de Rincão, em tijolo aparente. Fonte: autora, 2013.

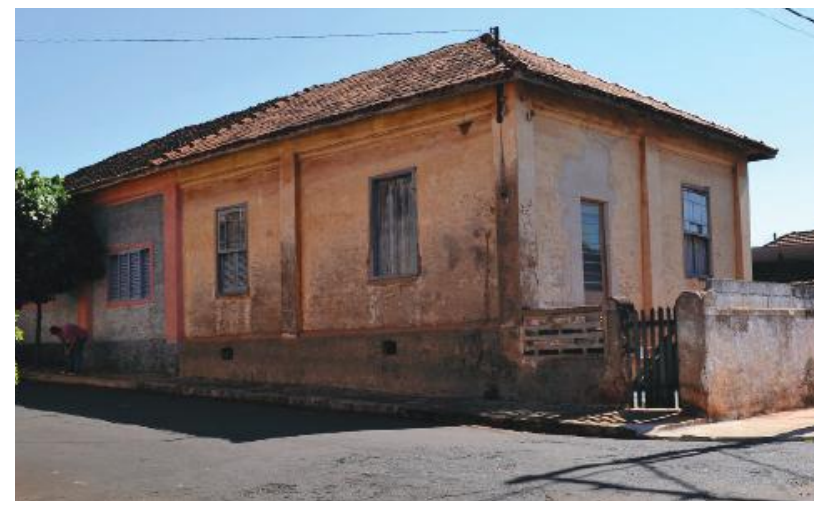

Foto 162- Uma das tipologias em Rincão, em alvenaria revestida. Fonte: autora, 2013. 
do estilo que se enquadraria no chamado "padrão colonial" podemos observar que em estações mais recentes houve inclusive o estilo Art-Decó ou proto-modernista, dependendo dos autores, como é o caso da estação de Mairinque, da Estrada de Ferro Sorocabana.

As vilas ferroviárias por serem construções pertencentes ao mundo do trabalho, e por questões de economia, são extremamente simples, e parcas de ornamentação. O detalhe máximo de ornamentação encontrado entre as vilas estudadas foi a presença de pilastras nas fachadas ou molduras nas janelas. Além de apresentarem uma área maior, as casas dos chefes costumam apresentar algum outro pequeno detalhe a mais, de ornamentação, em relação as demais casas. Nas vilas estudadas por Correia (2004), observa-se que há uma variação dos estilos, apresentando casas em estilo "missões" ou "missiones", "bangalô"55 (CORREIA, 2004b: 63), "Art Decó", entre os anos 1930 e 1940; e estilo modernista a partir de $1940^{56}$, como foi o caso da vila operária para a Usina de Volta Redonda, projetada pelo arquiteto modernista Attílio Côrrea Lima ${ }^{57}$ (CORREIA, 2004b, p. $105 ; 119)$.

A profusão de estilos durante o período é verificada por vários autores como Saia (1979, p. 211), Lemos (1989), Moreira (2007) e Balleiras (2003). Lemos (1989) afirma, em Alvenaria Burguesa, que os estilos arquitetônicos na época do café, são sobretudo, o neoclássico, neorenascentista devido à influência de arquitetos italianos e do neocolonial, inventado por Ricardo Severo. Ao final da época do café, surge um novo estilo: o art déco, que segundo o autor, foi deflagrado por Warchavchick e Rino Levi, e ao final deste, surge como nova técnica, o concreto. Balleiras (2003, p. 297) afirma que os diversos estilos “(...) eram divulgados no cinema, pelas revistas e manuais de construção do período. Aracy Amaral (1994) aponta o período entre 1920 e 1940, como um momento de transição entre os cânones clássicos e a arquitetura tradicional, e a afirmação do estilo

$55 \quad$ O estilo "missiones" e "bangalôs" são bastante omitidos nos livros de arquitetura brasileira, talvez por serem consideradas uma "arquitetura menor", porém amplamente divulgada em jornais e revistas, e aparece como um chamariz nas propagandas de jornais da época. No conjunto fabril da Companhia Industrial Fiação e Tecidos Goyana, Correia (2004b, p. 63) identifica casas neste estilo, voltadas para os técnicos mais especializados: "Há ainda um grupo de doze casas - conhecidas na cidade como os 'bangalôs' - que são colocadas duas a duas, dispondo de terraço e recuo lateral. São casas amplas, cujos interiores reúnem duas salas, cozinha, quatro quartos, sanitário, dois terraços, lavanderia, 170 metros quadrados de área construída e 170 metros quadrados de área não construída.".

56 Antes de 1940, houve um concurso para a vila industrial de Monlevade em 1934, com a apresentação de três propostas, incluindo-se a do arquiteto modernista Lúcio Costa, cuja proposta para as casas eram geminadas sobre pilotis, mas sua proposta não foi a vencedora do concurso. (CORREIA, 2004b) (LIMA, 2004).

57 Que entretanto “é mais um projeto urbanístico inspirado nas company towns e nas vilas de Tony Garnier, porém não estabelece um estilo arquitetônico para as casas. (CORREIA, 2004b, p.105). Após a morte de Attílio Corrêa Lima "um novo projeto, concluído em 1945, para a Cidade Operária da F. N. M. foi formulado pelos arquitetos Paul Lester Wiener e Josep Lluis Sert.(...)” . (CORREIA, 2004b, p. 105; 119). 
nacional (...)”.

Apesar da simplicidade do programa e da fachada das casas, pode-se dizer que foi encontrada uma casa, de dimensões maiores, isolada no lote, provavelmente pertencente a algum chefe de estação ou de outra seção, em estilo Art Decó, na cidade de Jaú. Correia (2008) aponta um volume expressivo de arquitetura fabril e, especialmente vilas operárias neste estilo, localizadas no estado de São Paulo: Companhia de Fiação e Tecelagem São Pedro (Itu); Argos Industrial (Jundiaí); portarias da Fiação, Tecelagem e Estamparia Ypiranga Jafet (São Paulo, SP, fundada em 1893), creche da Condessa Marina Crespi, no Cotonifício Rodolfo Crespi (São Paulo) (CORREIA, 2008, p. 74, 78-9). Em Piracicaba, há em Art Decó, a Vila Boyes. Vale lembrar que as fábricas e as vilas passaram por várias fases. Assim, se foram construídas em um estilo, quando partes do complexo industrial é ampliado, novas edificações recebem plantas e fachadas no próximo estilo em voga. Um outro exemplo analisado por Correia (2004b, p. 62) é a Companhia Industrial Fiação e Tecidos Goyana, fundada em 1893 com início da produção em 1895. Nos anos 1930, alguns de seus edifícios assumem a linguagem Art-Decó. Segundo Correia (2004b)
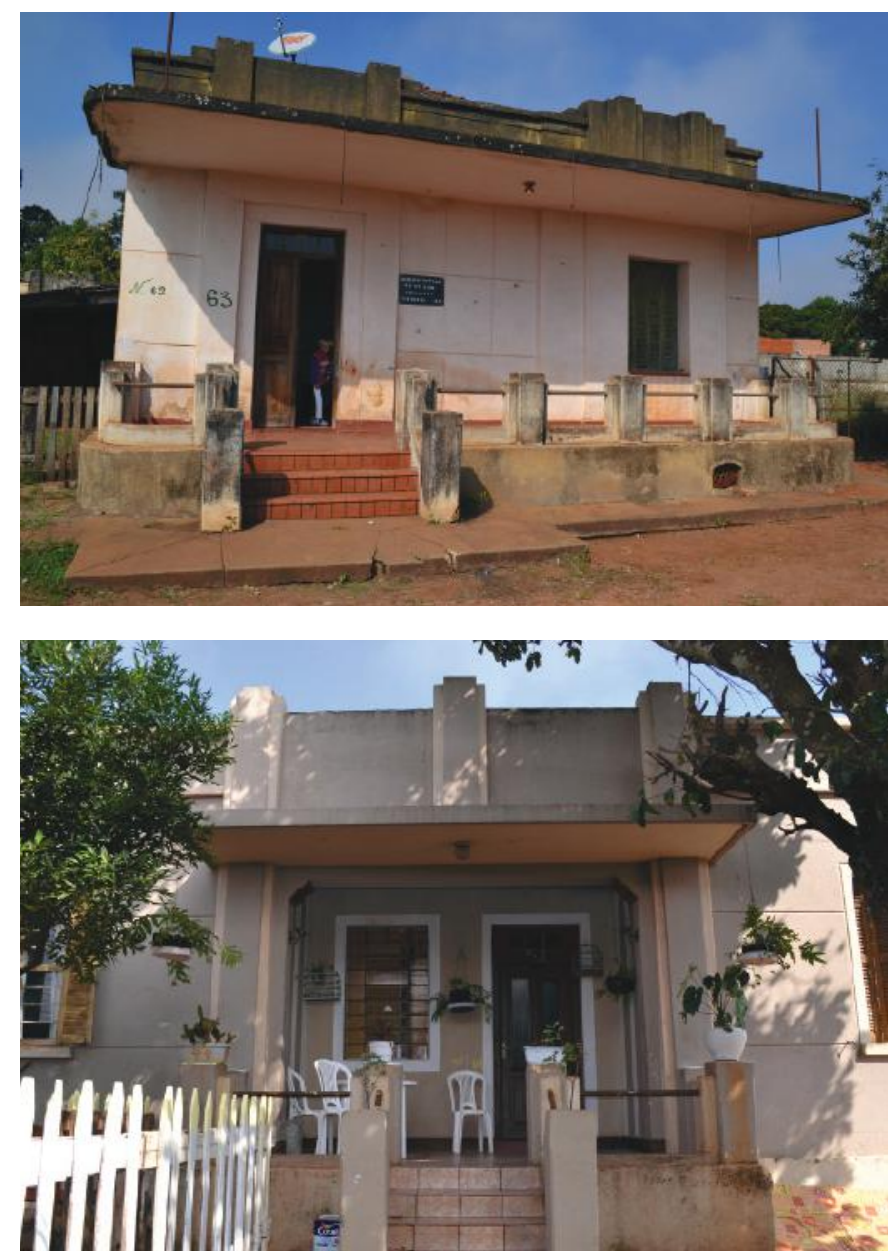

Foto 163 e 164- Casas em estilo Art-Déco, próximas $O$ Art-Decó á subestação elétrica em Dois Córregos. Fonte: autora, consistiu 2013.

em um

conjunto de

manifestações artísticas que se propagou a partir dos anos vinte e viveu seu apogeu nas décadas de 1930 e 1940. Foi formalmente lançado na Exposição Internacional de Artes Decorativas e Industriais Modernas, ocorrida em Paris, em 1925. Da Europa, o estilo se difundiu para as Américas, onde imprimiu marcas profundas no cenário das cidades 
como Miami, Montevideo e Rio de Janeiro. (CORREIA, 2004b, p. 59)

O Art-Decó foi muito divulgado por revistas e pelo cinema. Em outro artigo, Correia (2008) fala de algumas características construtivas encontradas nestes edifícios fabris que caracterizam o estilo, como volumes, platibandas e ornatos de formas escalonadas, conforme "uma tendência conhecida como zigzag modern. Alguns casos mais raros adotam formas arredondadas que remetem à tendência streamlined”. (CORREIA, 2008, p.99). A técnica utilizada para execução, é o tijolo revestido de reboco. "Com exceção das igrejas e de algumas das instalações fabris, nelas a estética déco é evidenciada, sobretudo, na forma de detalhes ornamentais das fachadas, que, por sua vez, são empregados de forma bastante parcimoniosa.” (CORREIA, 2008, p. 99). Nas habitações operárias, são identificados tais elementos nas fachadas das casas geminadas, com repetição de elementos "de um modelo único (buscando unidade compositiva ao conjunto) e na demarcação dos limites de fachada das casas (buscando individualizar cada uma das moradias que compõem o conjunto).” (CORREIA, 2008, p. 100). Tais elementos de formas escalonadas, algumas lajes arredondadas, e o uso de platibandas, é o que encontramos em algumas casas da vila ferroviária de Dois Córregos.

Debates sobre o estilo à parte, não é isto o que caracteriza as vilas ferroviárias. As vilas ferroviárias são muito mais caracterizáveis pela sua simplicidade, o que levaria a enquadrá-las no que se chama de "arquitetura modesta". Um dos caminhos que encontramos para caracterizá-las é a morfotipologia, ou seja, sua implantação (tamanho dos lotes, configuração em quarteirões, logradouro, alinhamento e recuos), seus edifícios (tipologias, subtipologias, fachadas, materiais, cores), seus equipamentos (mobiliários urbanos, árvores, etc...), monumentos, praças, etc.. Questão à qual pretende-se analisar ao final deste trabalho.

Revista a história da Companhia Paulista e seus trabalhadores, nota-se que as relações sociais, incluindo-se o trabalho, encontram-se "espacializadas", isto é, tais relações sociais tomam forma no espaço. Esta história social contribui para ler os complexos industriais com as suas vilas, e dar novo significado aos diferentes elementos e espaços, conformando-se em uma paisagem industrial ferroviária. 


\title{
Capítulo 3 - A Paisagem cultural ferroviária e as áreas de conservação
}

\begin{abstract}
"En nuestros mismos días, el interés de las más bellas de sus ciudades depende, no ya de la riqueza aislada de sus palacios, sino de la exquisita y celosa decoración de las habitaciones, aun en las más pequeñas, de sus orgullosas épocas." (RUSKIN, John in "La lámpara del recuerdo", Las siete lámparas de la arquitectura )
\end{abstract}

"As pequenas coisas parecem em si ser nada, mas elas trazem paz, assim como as flores dos campos que acreditamos não terem perfume, mas que juntas perfumam.”. (GHANDI)

Por tudo que já foi falado sobre a importância das ferrovias na economia brasileira, e principalmente na configuração do território paulista, a estreita ligação das ferrovias e do café, da riqueza de uma única ferrovia, que foi Companhia Paulista (imaginem-se as outras companhias que não fazem parte deste estudo), seus engenheiros, diretores e seus ferroviários, a relação entre vilas operárias e ferroviárias, toda a transformação da legislação trabalhista, e as teorias de gestão científica, a educação e a moradia dos trabalhadores, enfim por toda esta história social, e ainda hoje existem atores sociais, tais como alguns moradores, os últimos ex-ferroviários, pesquisadores, associações de ferroviários, apaixonados por ferrovias, acredita-se que as vilas ferroviárias sejam um lugar de memória bastante forte.

Se tomadas isoladamente, parece que as vilas ferroviárias são insignificantes. As vilas ferroviárias teriam mais sentido se tomadas em conjunto e conectadas à história da Companhia Paulista, e ao conjunto do patrimônio industrial ferroviário. Para uma política de preservação, gostaríamos de sublinhar aqui o conceito de "paisagem cultural". A utilização deste conceito, parece não se chocar com o de patrimônio industrial ferroviário, e permite uma nova abordagem. O conceito de paisagem cultural, possui vantagens e desvantagens, como veremos a seguir. Entre as vantagens, está a visão sistêmica que pode conferir aos diversos bens móveis e imóveis, e materiais e imateriais, que cercam à Companhia Paulista. Além disso, pelo fato das ferrovias paulistas terem contribuído grandemente para o desenho do território paulista, parece bastante compatível esta nova abordagem, em que a história da Companhia Paulista, liga-se ao patrimônio industrial. 
O conceito de "paisagem cultural" poderia ser aplicado a outras ferrovias que cruzaram e ajudaram a construir a história do estado de São Paulo, tais como: a Estrada de Ferro Sorocabana, Estrada de Ferro Mogiana, a Estrada de Ferro Noroeste e outras. ${ }^{1}$ Entre as desvantagens pode se adiantar que estão: o estabelecimento de limites para estas paisagens, o destaque dado a uma das camadas de tempo em detrimento de outras, e o que aqui se sublinha, são problemas de gestão. Para os problemas de gestão, propõe-se aqui aliar o conceito de paisagem cultural ao de áreas de conservação. Novamente volta-se a recordar que não são conceitos novos, porém através da bibliografia brasileira estudada, raramente são vistos em conjunto. Talvez pela legislação patrimonial brasileira, valorizar o tombamento, em detrimento dos outros instrumentos. A ideia de unir a preservação ao ordenamento territorial, deu-se com o alargamento do conceito de patrimônio, sendo uma tendência mundial, pelo que pode ser constatado nas cartas patrimoniais. ${ }^{2}$

\subsection{Paisagem cultural ferroviária}

O conceito de paisagem é um dos mais difíceis de consensuar na comunidade científica, já que vários campos do saber trabalham com o conceito, como a geografia, o paisagismo, a história, a biologia e as artes. Dependendo do conceito de paisagem, haverá uma metodologia para abordá-la, que orientará os resultados do processo de identificação e preservação da paisagem (RIBEIRO, 2007). A leitura de estudos de casos, de como o IPHAN vem aplicando o conceito em alguns de seus dossiês, como o de Cananéia (NASCIMENTO\&SCIFONE, 2010), as minas de ouro nas capitanias do sul (REIS FILHO, 2013), e o da imigração de Santa Catarina (REIS FILHO, 2013), bem como a leitura do texto de Ribeiro (2007) são interessantes para entender o conceito de paisagem cultural e sua aplicação.

Há um certo consenso sobre o que é "paisagem cultural" como: "testemunho do trabalho do homem, de sua relação com a natureza, como um retrato da ação humana sobre o espaço ou ainda como panorama e cenário." (RIBEIRO, 2007, p. 14). Contudo ain-

\section{1}

As ferrovias poderiam ser classificadas como rotas culturais, considerada um tipo específico de paisagem cultural pela UNESCO, como a Rhaetian Railway in the Albula e Bernina Landscapes (esta inclusive envolve dois países, a Itália e a Suíça) ou Mountain Railway of India. Em nosso presente trabalho, apenas utilizaremos o termo paisagem cultural, já se subentendendo as rotas culturais neste termo.

2 Ver Colenbrader, B. J. F., Roders, A. R. P. \& Veldpaus, L. (2013). 
da, persiste um antagonismo entre paisagem e intervenção humana e um "essencialismo", "que a transforma em um dado natural"3, que segundo Cauquelin (2007) é uma crença bastante arraigada, esta naturalidade da paisagem. Há diferentes concepções de paisagem dependendo da área de conhecimento, assim, o conceito de paisagem para o biólogo é diferente do geógrafo. Mesmo dentro da geografia, pode-se encontrar diferentes escolas. Conforme apresentado por Ribeiro (2007), na geografia, há duas escolas americanas: a Escola de Berkeley que de certo modo, separa a paisagem natural e paisagem cultural, e os autores da Nova Geografia Cultural, como Duncan e Cosgrove, para se diferenciar de Berkeley. Há ainda uma matriz francesa, com grande influência na geografia brasileira, representada por Paul Vidal de la Blache (1845-1918), cuja “(...) ambição era explicar os lugares e não os homens, mas para ele a análise dos gêneros de vida mostraria como a elaboração das paisagens reflete a organização social do trabalho e as diferentes formas de relação do homem com o seu meio.” (CLAVAL, 1999:03 apud RIBEIRO, 2007, p. 28). Sua escola foi muito "influente e constituída por discípulos espalhados por todas as partes, influenciando também, posteriormente na história, a formação da Escola dos Annales, e nesta especialmente os trabalhos de Fernand Braudel (1902-1985)." (RIBEIRO, 2007, p. 29).

No Brasil, o conceito de paisagem definido pela Nova Geografia americana e a escola de Vidal de la Blanche, tem correspondência no conceito de paisagem definido por Santos (2008), para o qual a paisagem é produto e vetor das intervenções humanas, e sem estas, seria apenas espaço. Além disso, segundo Milton Santos (1994), a paisagem é um espaço de "rugosidades", mais que um "palimpsesto", pois as rugosidades do espaço, dos diferentes tempos permanecem, e interagem, fruto da ampla circulação de sujeitos, artefatos, ideias, formas e espécies da fauna e da flora, dos "encontros" (CERTEAU), "trocas" e "hibridismos" (BURKE), numa perspectiva da "história global" (BROTTON\&JARDINE, 2000; GOODY). Outro autor brasileiro, que trabalha com a paisagem, mas segundo um enfoque ambientalista é Aziz Ab'saber, que fala do tombamento da Serra do Mar, sob tal enfoque.

No campo do patrimônio, Ruskin já falava sobre a paisagem. Em sua obra "As sete lâmpadas da arquitetura", publicada em 1849, "além de considerar arquitetura e paisagem como elementos complementares e indissociáveis, confere-lhes uma dimensão

3 "De fato, parece que a paisagem é continuamente confrontada com um essencialismo que a transforma em um dado natural. Há algo como uma crença comum em uma naturalidade da paisagem, crença bem arraigada e difícil de erradicar, mesmo sendo ela permanentemente desmentida por numerosas práticas.". (CAUQUELIN,2007 apud RIBEIRO, 2007, p. 110). 
histórica e documental que residirá na base conceitual para a defesa de sua conservação.” (RUFINONI, 2009, p. 31), e ainda Ruskin “defende que a conservação do patrimônio cultural não deve limitar-se à tutela dos monumentos de arquitetura e sim se estender a todos os documentos da civilização humana, inclusive à paisagem e ao território transformados pelo homem.” (RUFINONI, 2009, p. 32). John Ruskin viveu em um contexto em que houve rápida transformação do meio ambiente, ocasionada pela expansão das indústrias na Inglaterra.

A questão da paisagem cultural e patrimônio, tanto no contexto internacional como nacional, é trabalhada pelo geógrafo Ribeiro (2007). No contexto internacional, o autor identifica que a paisagem, nas cartas patrimoniais, era tratada ou como ambiência ou entorno de um bem (Carta de Restauro de Atenas, 1931), ou então associa-se a paisagem com o ambiente natural ou o belo (Convenção de Washington, 1940). Na Recomendação de Paris (1962), ainda segundo Ribeiro (2007), fala-se em paisagem, porém não se conceitua. Na maior parte das cartas, a paisagem é vista como moldura e ambiência e não sendo considerada ela mesma como documento. Em 1972, durante a Conferência Geral da UNESCO, é criada a "World Heritage List", a lista do patrimônio mundial, que divide os lugares entre culturais e naturais. A mudança no conceito de paisagem, ocorrerá somente em 1992, quando a UNESCO instituiu a "paisagem cultural" como categoria para inscrição de bens na lista de patrimônio mundial, que antes eram divididos somente em bens naturais e culturais.

No contexto nacional, ocorre, de certa forma, um reflexo do que ocorria no contexto internacional. Ribeiro (2007) analisa os bens inscritos no livro do tombo Arqueológico, Etnográfico e Paisagístico do IPHAN, não ignorando os outros livros e também os processos arquivados, e verifica o processo de atribuição de valor. Ribeiro (2007) constata que há uma certa postura entre 1930 e 1960, que corresponde ao período em que Rodrigo Melo Franco de Andrade esteve frente à instituição. Em décadas posteriores, há uma crescente preocupação com os conjuntos, entre eles paisagísticos. A partir da década de 1960 e especialmente 1970, há um crescimento da relevância do patrimônio natural. O período compreendido entre 1930 e 1960 é também conhecido como o período do patrimônio "pedra e cal", por causa do predomínio de tombamentos da arquitetura colonial e barroca, em detrimento das demais, e também do predomínio do livro de tombo de Belas Artes. Ribeiro (2007), detecta que raramente o termo "paisagístico" é utilizado, sendo preferido o “conjunto arquitetônico e urbanístico". A paisagem é considerada nos casos dos jardins, 
elementos naturais ou molduras, como demonstram os tombamentos do Jardim Botânico do Rio de Janeiro (1938); jardim do hospital São João de Deus, Cachoeira, BA; Ilha de Boa Viagem, Niterói, RJ (1938) inscrito no livro de Artes, e depois no Livro Histórico; Aldeia de Carapicuíba, SP (1940) “desprovida de valor arquitetônico”, não poderia ser inscrito no livro de Belas Artes, sendo inscrito no livro Paisagístico.

A prática de inscrição de conjuntos no Livro Paisagístico, só viria a ser comum a partir de 1970. Uma das exceções foi Congonhas, MG, (1941) inscrito no Livro Arqueológico, Etnográfico, Paisagístico, talvez por ser distrito de Ouro Preto, e desprovida de valor arquitetônico na época. As demais cidades mineiras, como São João del Rei, Tiradentes, Mariana, Ouro Preto, Serro foram inscritas apenas no livro de Belas Artes (1938), sendo que Ouro Preto foi inscrita também no Livro paisagístico, somente em 1986. Pilar de Goiás, primeiro conjunto a ter "paisagístico" no título de tombamento, em 1954, mas inscrito no Livro de Belas Artes e no Livro Histórico, mas não no Arqueológico, Etnográfico e Paisagístico. Os exemplos são os mais variados, interessante por exemplo, foi o tombamento de Olinda, onde aparece a expressão “conjunto paisagístico", Ribeiro (2007, p. 84) transcreve parte do parecer do IPHAN sobre este tombamento:

Acho que não há possibilidade em ser Olinda tombada como conjunto arquitetônico na sua totalidade. Ela está muito deturpada. Assim, só paisagístico, poderá ser incluída a área litorânea, que ficará, desta forma, preservada, no que concerne a gabarito e a densidade de construções.(Cf Atas do Conselho Consultivo do IPHAN, 17 de maio de 1938).

Chama à atenção a valoração dada ao conjunto de Olinda, e a paisagem vista como elemento natural e moldura. Outros dois exemplos de inscrição no livro de tombo Paisagístico por causa da arborização do conjunto, novamente a paisagem vista como jardim ou elemento natural, foi o conjunto Arquitetônico e Paisagístico de Vassouras (1958) e o Cemitério da Soledade, Belém, PA (1964).

A partir dos anos 1960, no IPHAN, a prioridade de inscrição passa a ser transferida do Livro de Belas Artes para o Livro Histórico. A “cidade-monumento" passa a ser vista como "cidade-documento" (SANT'ANNA, 1995). Como motivos da mudança de enfoque, Ribeiro (2007) aponta para a Carta de Veneza de 1964, que impulsiona os estudos de "ambiência" histórica e sócio-cultural do bem tombado. Além disso, há o crescimento de centros históricos urbanos, antes considerados estagnados como Ouro Preto (RIBEIRO 
2007, p. 92) que passam a ter a preservação ameaçada pelo “desenvolvimento". Outra influência foi a valorização dos centros históricos aliada ao potencial turístico. A paisagem é vista neste período como "vestígio do homem com relação ao meio", considerada ela mesma um bem e não apenas como moldura, e ainda "o aspecto de monumentalidade e excepcionalidade dando lugar à ideia do bem como um documento, registro da história nacional e da relação do homem com seu ambiente.” (RIBEIRO 2007, p. 94). Tem-se as inscrições de: Natividade, TO, (1987), inscrita em três livros, porém só o conjunto urbano foi inscrito, ao invés da cidade e da serra; Monte Santo, no Sertão da Bahia (1982). Ao mesmo tempo, há os arquivamentos de processos, alegando-se problemas de extensão como a Serra da Barriga (AL) e Zumbi dos Palmares e o Pantanal. Ribeiro (2007) aponta que anteriormente, o IPHAN já havia enfrentado problemas de extensão e de complexidade, em Salvador e São Luís, não impedindo o tombamento. Também foram tombados, Paraty e Porto Seguro, cujo tombamento está ligado a movimentos exteriores ao IPHAN: Paraty foi inscrita nos livros de Belas Artes e Arqueológico, Etnográfico e Paisagístico em 1958, e Porto Seguro, também em ambos os livros em 1974, entre os motivos para o tombamento, sugerem-se a abertura de ferrovias e o turismo em massa.

Entretanto, nas décadas posteriores a 1970, com a crescente preocupação ecológica, volta-se a entender a paisagem somente como elemento natural. Na década de 1980, com o crescente interesse em relação ao meio ambiente, foi criada a Coordenadoria de Patrimônio Natural dentro do IPHAN, operando entre 1985 e 1990 (RIBEIRO 2007, p. 104). Em suas diretrizes para a classificação do patrimônio, propõe a divisão da paisagem em: sítios naturais e sítios alterados pelo homem. (RIBEIRO 2007, p. 105). Somente em 2009 , há a chancela da “paisagem cultural” pela portaria IPHAN, No 127 que define:

A paisagem cultural é o meio natural ao qual o ser humano imprimiu as marcas de suas ações e formas de expressão, resultando em uma soma de todos os testemunhos resultantes da interação do homem com a natureza e, reciprocamente, da natureza com o homem passíveis de leituras especificas e temporais. (Art. $2^{\circ}$, Portaria No. 127, de 2009 também conhecida como Carta de Bagé)

Contudo, apesar de alguns projetos de tombamento realizados sob o conceito, ainda é pouco utilizado pelo IPHAN, e traz mais desafios que soluções. Ribeiro (2007, p.113) afirma em sua conclusão que:

A categoria de paisagem cultural aplicada à preservação do patrimônio no Brasil ainda coloca muitas dúvidas e aventa muitas possibilidades de uso. Trata-se de um caminho a ser trilhado, ainda pouco explorado. E é aí que reside a riqueza da abordagem da paisagem cultural no 
processo de renovação dos trabalhos sobre o patrimônio cultural nesse começo do século XXI.

Na conclusão o autor questiona: "Apesar de a legislação permitir a inscrição de paisagens no Livro do Tombo adequado, é necessário ainda que se discuta a validade do instrumento do tombamento aplicado a uma grande área como aquela que, quase sempre, abarca uma paisagem cultural” (RIBEIRO 2007, p. 113), e estimula a pensar "ações conjuntas da Instituição, valorizando exatamente o aspecto integrador e holístico das abordagens a partir da paisagem cultural.” (RIBEIRO 2007, p. 113), cuja “grande tarefa é a de identificar quais paisagens devam ser objeto de atribuição de valor e de preservação a partir de quais critérios". A importância do trabalho de Ribeiro (2007) reside ainda na conceituação da paisagem cultural, que pode ser bastante variada, e dependendo da conceituação haverá uma metodologia para abordá-la e que por sua vez orientará os resultados de identificação e preservação da paisagem.

Esta diferenciação fica clara, quando o autor aponta de que forma a paisagem cultural foi adotada pela UNESCO, e a Convenção Européia da Paisagem. Ambas tomam a paisagem cultural como um bem, e reconhecem a interação entre o ambiente natural e as ações humanas, no entanto, os objetivos são diferentes. Enquanto a UNESCO, tem como objetivo principal fazer uma lista de bens de valor excepcional, a Convenção Européia não tem a valoração de "excepcionalidade" como objetivo principal, mas sim o de "introduzir regras de proteção, gerenciamento e planejamento para todas as paisagens baseadas num conjunto de regras, constituindo um elemento fundamental da gestão do território.” (RIBEIRO, 2007, p. 52). Dado que os objetivos dos dois organismos são diferentes, os critérios de valoração e classificação se diferenciam: a UNESCO, além do valor de excepcionalidade, possui entre outros critérios, a integridade e a autenticidade do bem, enquanto que para a Convenção Européia da Paisagem, estes não são critérios importantes, tanto que classifica as paisagens em: de considerável importância, ordinárias e degradadas. Além disso, as escalas em que cada organismo trabalha são diferentes. $\mathrm{Na}$ UNESCO a escala é mundial, na Convenção é regional. Aplicado ao caso nacional, resta saber quais critérios o IPHAN pretende adotar: se o da $\mathrm{UNESCO}^{4}$, ou algo mais relacio-

$4 \quad$ Na época em que o livro de RIBEIRO (2007) foi escrito, ele analisa a lista indicativa da UNESCO até o ano de 2005, com 18 indicações para paisagens culturais, sendo duas delas brasileiras: o Caminho do Ouro de Paraty, em que o parecer da UNESCO de 2004, julgou o relatório incompleto (pois não foram englobados de maneira consistente elementos necessários para constituir-se numa paisagem cultural. Uma das questões foi a ausência de manifestações culturais populares) e sugeriu alterações. A outra indicação, foi a Paisagem cultural do Rio de Janeiro, na qual pairava a dúvida sobre a inclusão ou não das favelas. 
nado ao ordenamento do território, como a Convenção Européia.

Parece que uma das grandes vantagens do conceito "paisagem cultural" no campo do patrimônio seria, tomar a paisagem como um bem em si, isto é, paisagem como produto e vetor das intervenções humanas, e não como moldura, ou separando a paisagem natural e cultural, como outrora a paisagem foi tomada dentro do IPHAN. Outras grandes vantagens do conceito "paisagem cultural" são: "seu caráter relacional e integrador de diferentes aspectos que as instituições de preservação do patrimônio no Brasil e no mundo trabalharam historicamente de maneiras apartadas" (RIBEIRO, 2007, p. 111) e a valorização da integração entre material e imaterial, cultural e natural. Tal antinomia entre material e imaterial, é criticada por Meneses (2010, p. 31), pois:

o patrimônio cultural tem como suporte, sempre, vetores materiais. Isso vale também para o chamado patrimônio imaterial, pois se todo patrimônio material tem uma dimensão imaterial de significado e valor, por sua vez todo patrimônio imaterial tem uma dimensão material que lhe permite realizar-se. As diferenças não são ontológicas, de natureza, mas basicamente operacionais.

Contudo, apesar desta unificação do conceito, o IPHAN ainda parece operar dividindo o patrimônio material e imaterial, a começar pelos diferentes livros de tombo, e separando os bens imateriais em Registros. Não necessariamente deveria se operar assim pois, por exemplo, há países que operam com uma lista única de bens tombados, o que facilita a proteção, e evita questionamentos sobre a jurisdição de proteção, se federal, estadual ou municipal. Além disso, abre caminho para unificação de critérios de gestão e intervenção, o que hoje não ocorre na situação brasileira. Se há no IPHAN uma vontade de introduzir um novo conceito, talvez seja necessário repensar mais a fundo os instrumentos, incluída a legislação e os procedimentos de gestão, que até hoje vem operando.

Apesar da vantagem do conceito, a "paisagem cultural" aplicada ao "patrimônio" apresenta problemas e questões em aberto. Um deles é a compatibilidade entre os conceitos. Acredita-se que serão compatíveis se o conceito de patrimônio, respeitar àquela dimensão contemporânea, e adentrar em uma lógica de ordenamento do território, nos moldes da Convenção Européia, mais do que uma lista indicativa. Como nos lembra Ribeiro (2007, p. 59): “Não devemos esquecer o processo vivo e perpétuo que está na base de elaboração de paisagens, porque ele condiciona fortemente as atuais escolhas econômicas, produtivas, culturais e sociais.". O conceito de "paisagem cultural" pode funcionar como metodologia de análise e estudo, porém sua operacionalidade deve ser 
melhor refletida, se aplicada a uma política de patrimônio. Além disso, unir o conceito de paisagem cultural ao de patrimônio, seria considerar a paisagem como valor cultural. E novamente, quanto mais se alarga o conceito do patrimônio, inclusive territorialmente, maior o embate de forças e o jogo de valoração aí envolvidos. Segundo Meneses (2010) há outros valores envolvidos no valor cultural: formais, afetivos, pragmáticos, que não existem isolados, agrupam-se de forma variada, produzindo combinações, recombinações, superposições, hierarquias diversas, transformações, conflitos. O grande dilema e desafio, para os órgãos de preservação, numa sociedade contemporânea, está em mediar, equilibrar, estes vários desígnios e valores, e transformá-los em uma política de preservação, para melhor gerir o patrimônio ou os patrimônios.

A segunda questão é: ao se fazer um recorte de uma paisagem, uma questão é o estudo, a análise, e outra questão é a "preservação" ou a "patrimonialização" desta paisagem. Sem querer, não se está priorizando uma das camadas do tempo (uma de suas "rugosidades") em detrimento das demais? Talvez o tempo não se constitua em camadas e as "rugosidades" da paisagem tampouco, elas estão em constante interação e transformação. Conforme lembra Ribeiro (2007, p. 58):

Igualmente, o território é um palimpsesto, isto é, um documento em perpétua transformação, onde encontramos alguns traços, mas não todos, que as diferentes épocas deixaram e que se misturam aos traços que o presente deixa à sua volta e que o modifica continuamente, de maneira contrária a uma simples estratificação.

Quando o patrimônio abarca não apenas o edifício isolado, mas outras áreas, ainda existem poucos critérios e instrumentos definidos, pelo menos no Brasil. Um deles está em como definir os limites destas áreas de paisagens. Uma vez delimitadas, posto que cobrem grandes áreas (vide os dossiês citados anteriormente ${ }^{5}$ ), a segunda questão é como gerir tais áreas, pois como se viu na primeira parte deste trabalho não se dispõem de mecanismos e procedimentos para a manutenção e monitoramento contínuos e documentação precisa e atualizada (ainda que recomendada há tempos por Cartas Patrimoniais) para monumentos isolados, imaginem-se extensas paisagens. Com relação a priorização ou não de uma parte da paisagem cultural em detrimento das demais, o que acaba invariavelmente acontecendo (por exemplo, o dossiê da imigração, priorizou a imigração européia, mas não os indígenas ou as minas. Ou ainda, pode-se questionar onde estão os $5 \quad$ Vale do Ribeira (NASCIMENTO\&SCIFONE, 2010), as minas de ouro nas capitanias do sul (REIS FILHO, 2013), e o da imigração de Santa Catarina (REIS FILHO, 2013). 
açorianos em Santa Catarina na política de preservação), uma saída seria operacionalizar através de circuitos coexistentes, como existem roteiros turísticos temáticos diversos em algumas cidades. Talvez a operação em circuitos coexistentes pode ser uma saída, cuja aplicabilidade merece ser estudada.

Dentro desta perspectiva e dos conceitos expostos com relação à paisagem, acredita-se que o patrimônio ferroviário pode ser analisado como uma paisagem cultural, definido pela geografia, como produto e vetor das intervenções humanas, recordando-se que se trata de apenas umas das camadas do tempo, sem esquecer das diversas rugosidades do espaço. Concorda-se com seu caráter integrador, entre os bens materiais e imateriais do patrimônio ferroviário, inclusive ao considerar como patrimônio não apenas edifícios isolados como as estações ferroviárias, mas todo seu complexo, considerando o que se chama de arquitetura modesta e pertencente ao mundo do trabalho, como as vilas ferroviárias, as oficinas, as "casas de turma", etc., como definidas pela Carta do Patrimônio Industrial. Contudo, para operacionalizar tal conceito, e transformá-lo em uma efetiva política de preservação, é necessário um maior aprofundamento e definição de critérios para estabelecer limites da paisagem cultural e para gerir tais áreas, nas quais estão inseridos estes bens. Parece que o conceito de paisagem cultural, não resolve os problemas de gestão do patrimônio. Vemos assim a necessidade de subdividi-los em unidades menores para facilitar tal gestão.

Para suprir essa desvantagem de gestão, propõe-se aqui uma mescla de conceitos, o de paisagem cultural com o de áreas de conservação. Assim, somada ao conceito de Paisagem Cultural, no qual o Complexo Ferroviário da Companhia Paulista poderia ser tombado em nível federal, porém em nível municipal, as estações e vilas ferroviárias, bem como outros equipamentos relacionados a ferrovia, poderiam ser protegidos através de "áreas de conservação". Ou ainda, mesmo que não fossem protegidas em nível federal ou estadual, poderiam ser protegidas em nível municipal e/ou local, através das áreas de conservação. O poder local, envolvendo a sociedade civil, poderia auxiliar os órgãos de preservação estadual e federal neste processo de gestão do patrimônio, e os órgãos auxiliariam os poderes locais no tocante às diretrizes de preservação. É claro que isto só funcionará, se antes os órgãos de preservação se pusessem de acordo quais são estes critérios e diretrizes; e quais funções compete a cada um e estabelecessem procedimentos em comum. O sentido, a re-significação, apoiados no contexto maior de paisagem cultural, porém a gestão será melhor garantida, se dividida e compartilhada, ao mesmo tempo, 
que auxiliada pelos órgãos de preservação estadual e, se for o caso, federal. Resta uma definição dos papéis de cada órgão. Unir a questão do patrimônio com o de ordenamento territorial é uma tendência mundial e, nossa proposta de ressaltar as áreas de conservação, vem do estado de conservação das vilas ferroviárias inglesas, que comentaremos a seguir.

\subsection{Preservação, patrimônio urbano e áreas de conservação}

Se no primeiro capítulo, constatou-se por visitas técnicas pelo interior do estado de São Paulo, que muito do patrimônio ferroviário encontra-se abandonado e em ruínas, e no caso das vilas ferroviárias, invadidas e descaracterizadas, diverso panorama encontrou-se em relação ao patrimônio ferroviário inglês. É claro, que isto não significa que não tenha havido perdas e demolições, e deve-se levar em conta que o processo de preservação deste patrimônio iniciou-se antes lá do que aqui. ${ }^{6}$ Acredita-se que o estado de preservação do patrimônio inglês deve-se, ao modelo de preservação anglo-saxão, aos esforços das sociedades inglesas de patrimônio industrial, dos trusts e às áreas de

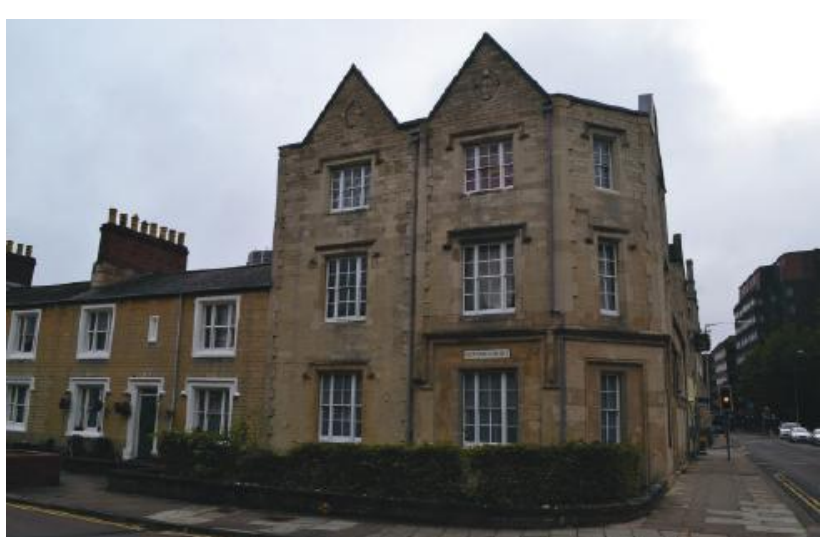

Foto 165 - Vila ferroviária de Swindon (Reino Unido) Fonte: autora, 2013.

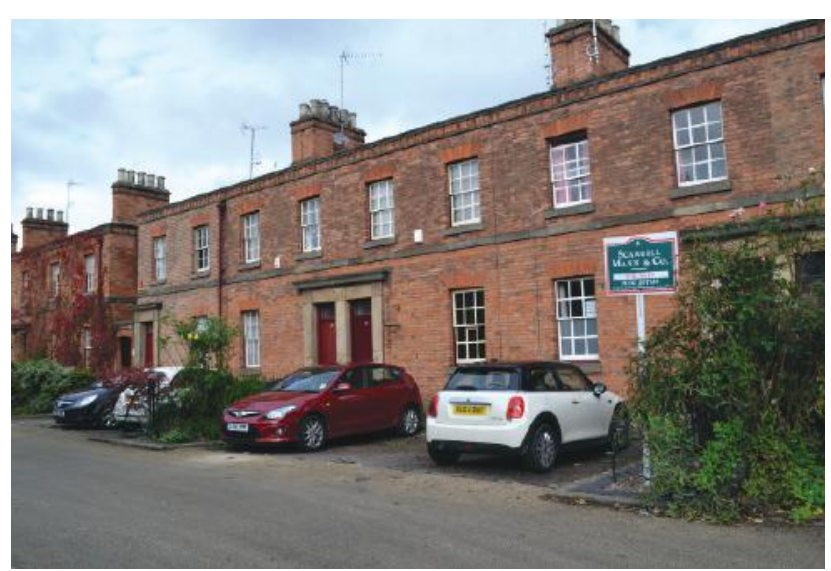

Foto 166 - Vila ferroviária deDerby (Reino Unido). Fonte: autora, 2013. Leicester, 1995. 


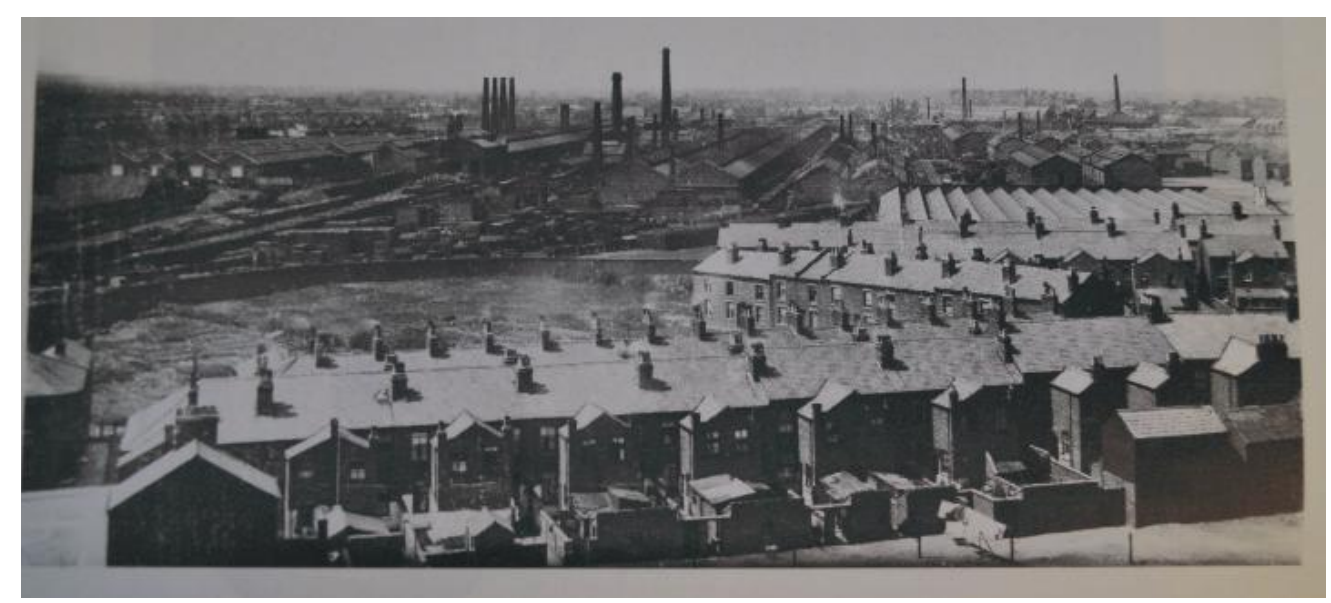

Foto 167

- Visão

geral do

complexo

ferroviário de Crewe, em 1895.

Fonte:

Arquivo

National

Railway

Museum, York, UK.
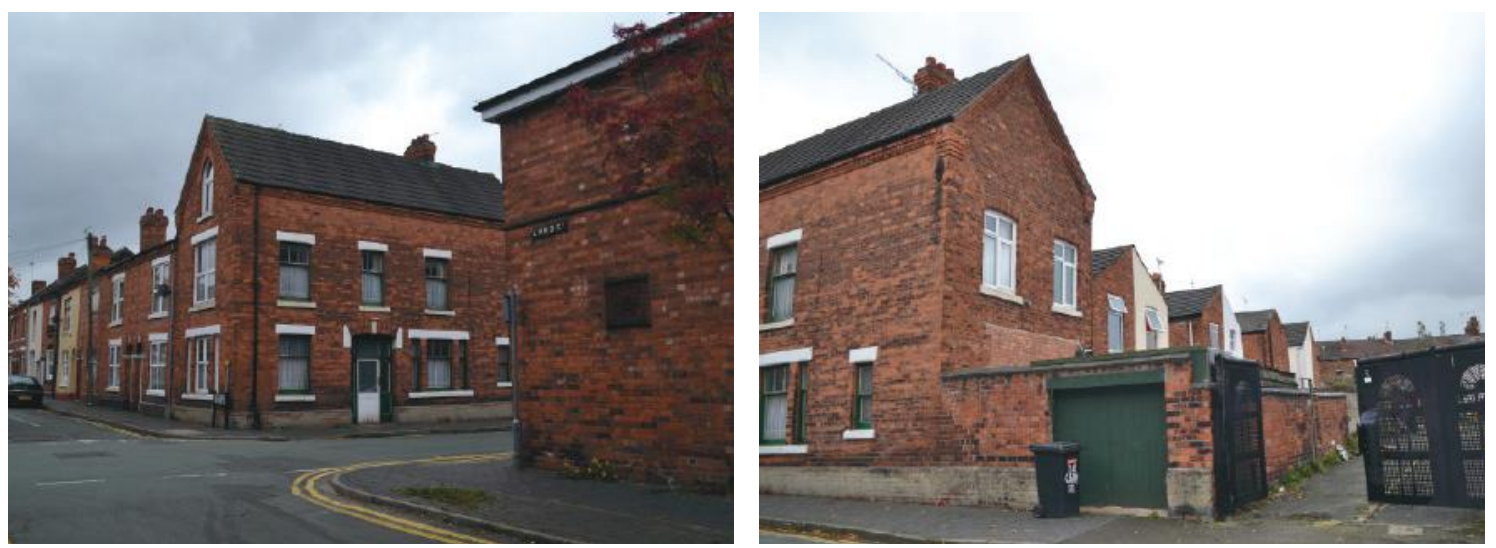

Foto 168 e 169 - Fotos atuais de Crewe (Inglaterra). Fonte: autora, 2013.

planos de áreas de conservação estabelecidos e seguidos, e que são revistos a cada dez anos.

Segundo Miller (2004, p. 4), todas as vilas ferroviárias de todas as companhias inglesas chegariam a 56.500 unidades em 1920. A partir de 1930, este número diminui por causa do fechamento de alguns ramais e a venda de algumas propriedades e demolição de outras. Em 1948, acontece a nacionalização das ferrovias inglesas. Este processo acelera-se na década de 1960, chegando a 37.000 unidades, enquanto que na década de 1980, este número não chegava a 1000 unidades. Não todas foram demolidas, mas segundo a sua fonte, um número considerável foi vendido, impossível de contabilizar. Por isso, mesmo Miller, tendo listado algumas vilas ferroviárias da London North Western Railway, aponta que muitas vilas ferroviárias ainda estão por descobrir. $\mathrm{O}$ interessante no Reino Unido, também é que novos edifícios muitas vezes, mimetizam características das antigas construções, assim fica difícil identificar o que é novo e o que é antigo.

De maneira geral, muitas vilas ferroviárias foram demolidas durante a década de 1960, mesmo com o funcionamento de algumas oficinas e da nacionalização das ferrovias britânicas, que passaram a pertencer à British Railway. E muitos esforços de conservação 
deram-se a partir de 1970, através de delimitações de áreas de conservação e movimentos preservacionistas. Dois exemplos são Swindon e Derby. A vila ferroviária de Swindon foi pela primeira vez designada como área de conservação em 1975. Em novembro de 1977, o Secretário de Estado nomeou a área de conservação como de "extraordinário interesse”. Em 1987, a área foi re-designada e ampliada para incluir os outros edifícios da Great Western Railway, entre a vila e a linha para o norte; alguns destes edifícios já foram listados entre os graus II* e II. ' Já em Derby, Billson (1996, p.7) conta que o livro teve início nas pesquisas de 1978, seguindo a publicação do Derby City Council sobre a notícia de tentativa de demolir o Bruswick Inn, um edifício tombado (listed building), pois a municipalidade local e os proprietários das casas adjacentes à vila, queriam demolir para a construção de uma nova rua e um estacionamento. Contra estes, estava a Derby Civic Society. Assim, podemos observar que o Inn já estava listado antes da década de 1970. A partir da campanha para salvar o Inn e as demais casas da vila, foi estabelecido o Derbyshire Historic Building Trust. A área de conservação foi estabelecida e reconhecida em 1980. Ironicamente, apesar dos esforços de preservação, a Midland Railway Station, a estação já pertencente à British Railway foi demolida em 1985. (BILLSON, 1996, p. 7). Observa-se que as áreas de conservação não excluem a demolição, pois claramente também são levadas em conta as forças de valoração e as políticas do patrimônio. No caso citado, tais forças são representadas por um lado a municipalidade e os proprietários, e por outro, a Derby Civic Society.

Pelo exposto acima, vimos que os esforços de conservação começam a partir de 1970. Não por acaso, é a época que coincide com a Civic Amenities Act, de 1967 que estabelece as "conservation areas" ou áreas de conservação. Vimos no primeiro capítulo que houve esforços em diversos países do que se chama de "conservação integrada", unir o patrimônio aos órgãos de planejamento urbano, ou seja, o que se pode chamar de patrimônio urbano, cujos princípios já existiam desde o século XIX, e que serão ratificados na Declaração de Amsterdã em 1975. E é claro, tal movimento coincide também com o alargamento do conceito de patrimônio, que de edifício isolado passa a todo o contexto urbano, inclusive largas porções do território, mesclando-se a paisagem natural a seus aspectos culturais.

No primeiro capítulo, vimos como se deu o alargamento do patrimônio, a partir da teoria de Riegl, sobre o valor de antiguidade dos bens, como aponta Choay (2006). Foi $7 \quad$ Na Inglaterra os graus de proteção são três: graus I, II* e II. O grau I é o mais restritivo, não podendo ser modificado interiormente, e o grau II, aplica-se apenas ao exterior do edifício. Na Escócia, há apenas dois graus: A e B, sendo o primeiro mais restritivo. 
visto que apesar do caminho teórico aberto para o alargamento do patrimônio no início do século XX, existe uma lacuna para a difusão dos chamados novos patrimônios que se difundem grandemente a partir dos anos 1960. O patrimônio urbano apesar de ser tratado por teóricos como Sitte, Buls e Giovannoni, e os ensinamentos deste último serem incorporados numa das primeiras cartas patrimoniais a Carta de Restauro de Atenas de 1931, a difusão do patrimônio urbano só ocorrerá a partir da Carta de Veneza, de 1964. Ainda assim, o patrimônio urbano não era visto como um bem em si, mas ambiência, entorno e paisagem de um monumento. Aliás a noção de monumento e documento, sendo o tecido urbano considerado documento também ocorrerá apenas a partir da década de 1960. Nesta mesma década, há tentativas de unir a preservação de áreas urbanas dentro do planejamento urbano, tanto na França como na Itália, e baseados nestes, no Brasil. Cada vez mais, tal estratégia é recomendada nas cartas patrimoniais. Paralelamente, são introduzidas questões sociais e de natureza imaterial na salvaguarda do patrimônio, e a partir da década de 1990, o crescimento da preocupação do ambiente natural. Acredita-se que um conceito omni abarcante seria o conceito de paisagem cultural, que une aspectos materiais e imateriais do patrimônio, como os aspectos naturais e sua interação com o homem, que são os aspectos culturais. Assim, depois de termos visto brevemente a gênese do conceito de patrimônio urbano e do alargamento do conceito, vejamos o que dizem as principais cartas patrimoniais, em relação ao patrimônio urbano. Seguiremos a ordem cronológica das cartas e recomendações, e analisando principalmente as internacionais, citando uma e outra carta patrimonial brasileira.

Na Carta de Restauro de Atenas, de 1931, não se fala em patrimônio urbano, porém fala-se em vizinhança, e sublinha-se o respeito ao caráter histórico e artístico do monumento, do qual tal vizinhança faz parte. A próxima carta que toca a questão do patrimônio urbano, sem utilizar, no entanto, o termo, é a Recomendação de Paris de 1962, um documento da UNESCO e do ICOM (International Council of Museums), que ainda que dirigida a paisagens naturais, trata de paisagens e sítios urbanos. Na Carta de Veneza (1964), em seu primeiro artigo, afirma que a noção de monumento histórico: “Estende-se não só às grandes criações, mas também às obras modestas, que tenham adquirido, com o tempo, significação cultural. ” Nota-se, portanto, que os termos, ambiência, vizinhança, entorno e paisagem das primeiras cartas estão relacionadas com o patrimônio urbano, porém apenas o edifício isolado é considerado monumento (valor excepcional) ou documento (valor histórico), a mudança só será sentida a partir da Carta de Veneza. 
A próxima carta patrimonial a tratar do patrimônio urbano é a Norma de Quito, um documento da OEA (Organização dos Estados Americanos). Nesta carta recomenda-se que os planos de valorização monumental devem ser vistos juntamente com planos de desenvolvimento nacional, além disso, recomenda-se zonas de proteção tanto para conjuntos monumentais urbanos ou ambientais. O ponto negativo desta carta é que se recomenda o uso dos sítios históricos para o turismo, sem antever os efeitos nocivos que possam ter e ser evitados. Recomendações neste sentido, serão feitas apenas na década seguinte na Carta do Turismo Cultural, documento do ICOMOS (International Council on Monuments and Sites) de 1976. No ano seguinte, a Recomendação de Paris (1968 UNESCO), também atenta para que os planos de urbanização tenham em consideração a preservação dos monumentos: “(...) Os arredores e o entorno de um monumento ou de um sítio protegido por lei deveriam também ser objeto de disposições análogas para que seja preservado o conjunto de que fazem parte e seu caráter(...)” (p. 9) O patrimônio urbano aparece neste documento ainda sob a forma de entorno ou conjunto.

Gostaria de citar aqui duas cartas patrimoniais brasileiras, o Compromisso de Brasília (1970 - assinada por Lúcio Costa) e o Compromisso de Salvador (1971), este último trata o patrimônio urbano ainda sob o conceito de ambiência: "Recomenda-se a criação de legislação complementar, no sentido de ampliar o conceito de visibilidade de bem tombado, para atendimento do conceito de ambiência.”, como também fala da necessidade de estudos e planos diretores, e que contem com apoio do IPHAN, IBDF (Instituto Brasileiro de Desenvolvimento Florestal), órgãos estaduais e municipais com obras públicas que afetem áreas de valor natural e cultural. Recorda-se que em 1973, foi criado junto à Secretaria do Planejamento- SEPLAN-, o Programa Integrado de Reconstrução das Cidades Históricas, mais conhecido como PCH (Programa de Cidades Históricas), que durou até o ano de 1987, mas sem já vigor dos anos iniciais. ${ }^{8}$ Nota-se que estes documentos, bem como a criação do PCH, deram-se mesmo antes da Declaração de Amsterdã (1975), considerada a carta do patrimônio urbano, já se menciona a necessidade da preservação do monumento e seu entorno, ou conjunto urbano, dentro do planejamento urbano e regional, como dos planos de desenvolvimento, e o PCH seria uma tentativa de concretizar tais diretrizes. Experiências neste sentido, já vinham sendo testadas tanto na França como na Itália desde a década de 1960, e inspiradas nestes modelos, também 8 Mais sobre a sua criação e um balanço crítico pode ser visto em: SANT'ANNA, Marcia. A herança do PCH: balanço crítico e desdobramentos 40 anos depois. Anais do Museu Paulista, São Paulo, v. 24, n. 1, p. 59-74, abr. 2016. Disponível em <http://www.scielo.br/scielo.php?script=sci_arttext\&pid=S010147142016000100059\&lng=pt\&nrm=iso $>$. acessos em 07 out. 2016. http://dx.doi.org/10.1590/1982$02672016 \mathrm{v} 24 \mathrm{n} 0102$. 
foram aqui testadas. ${ }^{9}$ Uma última carta antes de citar a Declaração de Amsterdã: a Recomendação de Paris, de 1972, um documento da UNESCO que traz medidas para proteção do patrimônio cultural e natural, de valor excepcional (mundial). O patrimônio urbano é contemplado nos chamados conjuntos, na parte de patrimônio cultural, porém de valor excepcional. Ainda que não seja objetivo deste trabalho, uma questão a ser levantada é a seguinte: dependendo dos critérios de valoração ao considerar o que é patrimônio ou não, leva a tratamento e gestão diferentes dos bens patrimoniais.

A Declaração de Amsterdã, resultado da reunião do Conselho da Europa e Congresso do Patrimônio Arquitetônico Europeu, em 1975, é claramente a carta do patrimônio arquitetônico urbano, juntamente com a Carta de Washington que veremos a seguir. Nela utiliza-se o termo "conservação integrada", no qual se mescla conservação do patrimônio e o planejamento urbano, sendo este confiado aos poderes locais juntamente com a participação da população. A novidade desta carta é reforçar o aspecto de unir a preservação aos planos urbanos, e ao mesmo tempo, trata da participação popular. A próxima carta é a Recomendação de Nairóbi, de 1976, da UNESCO, que se autodenomina "Recomendações relativas à salvaguarda dos conjuntos históricos e sua função na vida contemporânea”. Em toda a carta fala-se muito em ambiência e da necessidade de planejamento urbano, e planejamento físico-territorial. De maneira geral, quando se fala da dimensão contemporânea do patrimônio, nota-se a tendência de uni-lo ao planejamento urbano e físico-territorial.

A Carta de Burra, é uma carta do ICOMOS de 1980, traz várias definições, não utiliza o termo "patrimônio urbano", porém o faz indiretamente ao definir o que é um bem: "O termo bem designará um local, uma zona, um edifício ou outra obra construída, ou um conjunto de edificações ou outras obras que possuam uma significação cultural, compreendidos, em cada caso, o conteúdo e o entorno a que pertence.” E acrescenta: “(...) o termo significação cultural designará o valor estético, histórico, científico ou social de um bem para as gerações passadas, presentes ou futuras.”. Diferentemente da UNESCO, não se fala nesta carta de "valor excepcional", mas sim em "significação cultural", acredita-se muito mais adequada para abarcar "arquiteturas modestas" e outros

9 Como já apontamos anteriormente, um balanço crítico do PCH encontra-se em Sant'Anna (2016), e estamos de acordo com a autora quando afirma que: "talvez o 'calcanhar de Aquiles' do programa tenha sido sua atuação por meio de intervenções arquitetônicas pontuais e não mediante um conjunto de ações articuladas a planos de preservação dotados de dimensões normativas e propositivas, e a instrumentos eficientes de gestão, financiamento e monitoramento. Além disso, havia muita dependência de investimentos públicos e pouca promoção do investimento privado." (SANT'ANNA, 2016, p. 67). Concordamos que deve haver uma independência de investimentos públicos, e que a sustentabilidade econômica do patrimônio urbano nas políticas de preservação brasileiras ainda está por realizar. 
conjuntos, porém, por outro lado, contribui-se ainda mais para o alargamento do conceito de patrimônio.

A Carta de Washington (1986), documento do ICOMOS, juntamente com a Declaração de Amsterdã (1975), são consideradas as cartas relativas ao patrimônio urbano. A de Washington difere e de certa maneira ultrapassa esta última, por possuir caráter internacional. A carta busca complementar, retomando os princípios e objetivos da Carta de Veneza (1964) bem como a Recomendação de Nairóbi (1976) e, novamente reforça que para a eficácia da preservação das cidades e bairros históricos, deve estar conectado às políticas de desenvolvimento econômico social e considerada nos planos urbanos e planejamento físico-territorial em todos os níveis. Acompanha esta carta no contexto brasileiro, a Carta de Petrópolis, de 1987, resultado do $1^{\circ}$ Seminário Brasileiro para Preservação e Revitalização dos Centros Históricos, nela define-se o que é "sítio urbano histórico" (SHU), como:

parte integrante de um contexto amplo que comporta as paisagens natural e construída, assim como a vivência de seus habitantes num espaço de valores produzidos no passado e no presente, em processo dinâmico de transformação, devendo os novos espaços urbanos ser entendidos na sua dimensão de testemunhos ambientais em formação.

É pois, quase uma definição de paisagem cultural, e ainda nota-se a presença da dimensão contemporânea do patrimônio. Outro aspecto interessante desta carta é a polifuncionalidade:

Sendo a polifuncionalidade uma característica do SHU, a sua preservação não deve dar-se à custa de exclusividade de usos, nem mesmo aqueles ditos culturais, devendo necessariamente, abrigar os universos do trabalho e do cotidiano, onde se manifestam as verdadeiras expressões de uma sociedade heterogênea e plural. Guardando essa heterogeneidade, deve a moradia construir-se na função primordial do espaço edificado, haja vista a flagrante carência habitacional brasileira. Desta forma, especial atenção deve ser dada à permanência do SHU das populações residentes e das atividades tradicionais, desde que compativeis com sua ambiência.

Porém não é o que aconteceu na maioria dos casos dos projetos de revitalização realizados no Brasil, nos quais predominou o uso turístico, e afugentando a população original, nos tão conhecidos processos chamados de "gentrificação". Acredita-se que o trecho acima encaixa perfeitamente na questão da preservação das vilas ferroviárias, que além de edificações de uso habitacional, pertenceram ao mundo do trabalho e do cotidiano. Também o trecho acima, pode vir a questionar o uso cultural dado a vários bens patrimoniais e neste caso, especialmente estações de algumas cidades. 
As demais cartas internacionais, de maneira geral, tratam de aspectos específicos do patrimônio: como a autenticidade, Conferência de Nara (1994) e a correspondente brasileira, a Carta de Brasília (1995); e cada vez mais consideram as dimensões sociais do patrimônio. Um exemplo disso é a Declaração de Sofia, de 1996, do ICOMOS. E a partir da década de 1990, a partir das questões ambientais e de desenvolvimento sustentável, o conceito de patrimônio ganha novos matizes, ganhando força o conceito de paisagem cultural.

Já se passaram quase vinte anos da publicação da Carta de Washington(1986), documento do ICOMOS. Gostaríamos de aqui comentar que há um documento internacional, ainda pouco comentado no ambiente brasileiro, e que pretende ser a atualização da Carta de Washington, elaborado pelo CIVVIH (International Committee on Historic Towns and Villages), comitê estabelecido em 1982, que vinha elaborando a carta desde 2005. Tal documento foi adotado na $17^{\mathrm{a}}$. Assembléia Geral do ICOMOS, em novembro de 2011, conhecido como Princípios de Valleta. Em sua essência, os Princípios de Valleta possuem os mesmos critérios e definições da Carta de Washington, porém parecem ser mais estruturados e detalhados, que a carta de 1986. Os Princípios de Valleta estão estruturados em quatro grandes partes: 1. Definições 2. Aspectos de mudança 3. Critérios de intervenção 4. Propostas e estratégias. O que era "método e instrumento" na Carta de Washington, é incorporado e detalhado nas duas últimas grandes partes "Critérios de intervenção" e "Propostas e estratégias" dos Princípios de Valletta. Os Princípios trazem dez critérios de intervenção, e que devem ser utilizados nos doze pontos das propostas e estratégias. Os critérios de intervenção, de maneira geral, sublinham os valores culturais, a qualidade de vida dos habitantes e o meio ambiente. Retomam o que foi dito na Carta de Washington sobre método e rigor científico nas análises para elaboração do plano de salvaguarda e da necessidade de estudos multidisciplinares. Os doze pontos das propostas e estratégias, mais que propostas, são pontos, com exceção do plano de conservação ou salvaguarda e o plano de gestão, as demais "propostas e estratégias" são pontos como: a questão da autenticidade e integridade das cidades e áreas históricas, as novas funções, a arquitetura contemporânea, o espaço público, os equipamentos e "acondicionamento" urbano (na versão em inglês: "facilities and modifications"), mobilidade, turismo, riscos, economia de energia (este um ponto novo em relação as demais cartas) e participação.

A novidade desta carta patrimonial está em suas duas primeiras partes: das definições e a segunda parte intitulada "aspectos de mudança". A novidade da primeira parte 
reside em que ao definir vários conceitos, como meio, salvaguarda, zona urbana protegida, zona de amortecimento ("buffer zone”), plano de gestão e espírito do lugar, acaba por destacar alguns conceitos que o comitê julgou importantes e, de uma maneira, ressalta a dimensão contemporânea dos mesmos. A novidade da segunda parte reside no próprio título: "Aspectos de mudança". De certa maneira, dá a entender que se busca romper a dialética entre a dimensão museal do patrimônio e sua dimensão contemporânea. Busca-se assim, um caminho de abertura do patrimônio à mudança, justamente por sublinhar na primeira parte da carta, a sua dimensão contemporânea. A segunda parte começa afirmando que as cidades e as áreas urbanas históricas, são "organismos vivos, que estão submetidos a mudanças contínuas. Estas mudanças afetam a todos os elementos constitutivos da cidade (naturais e humanos, materiais e imateriais)” (p. 24) Também é interessante a seguinte afirmação: “A mudança dirigida adequadamente, pode oferecer oportunidades para melhorar a qualidade das cidades e áreas urbanas históricas a partir de suas características históricas.” (p. 25). Creio que a observação de Veldpaus e Roders (2014, p. 246), resume a essência dos Princípios de Valleta e também com relação à abordagem baseada na paisagem, pois toca em questões de gestão do patrimônio:

Em resumo, isto é o que os especialistas chamam agora de abordagem baseada na paisagem (landscape-based approach), uma abordagem que considera a reutilização, e mantém o patrimônio não apenas de uma perspectiva do objeto, mas também de uma perspectiva cultural, sócio-econômica, ecológica e urbana. Nesse processo, a preservação tornou-se o condutor do desenvolvimento sustentável. Assim, partindo de uma forte intolerância à mudança, a mudança é agora gerida usando o patrimônio como o motor de desenvolvimento urbano.". ${ }^{10}$ (tradução nossa)

Acredita-se que seja importante, a dimensão contemporânea e ao considerar a mudança como algo positivo, contudo, deve-se tomar cuidado para que tais mudanças não sejam justificativas para novos projetos que desconsideram a cidade e suas pré-existências, como o tecido urbano e os critérios de intervenção em edifícios, largamente estabelecidos desde a Carta de Veneza. Tal afirmação não é redundante, pois já ocorreu na prática, conforme alertaram Kühl (2008) e Rufinoni (2009) em relação às intervenções realizadas no patrimônio industrial. Como já foi comentado, há um certo distanciamento

10 "In short, this is what experts would now call a landscape-based approach, an approach that reconsiders, reuses, and retains heritage not only from an object perspective, but also from a cultural, socioeconomic, ecological, and urban perspective. In this process, preservation became a driver for sustainable development. Thus, departing from a strong intolerance to change, change is now being managed using heritage as a driver for urban development." (RODERS\&VELDPAUS, 2014, p. 246) 
entre arquitetos e urbanistas e aqueles profissionais "conservacionistas", ou envolvidos com patrimônio ou preservação dos monumentos.

É certo que tal distanciamento tem raízes históricas, no distanciamento que alguns arquitetos modernistas fizeram com relação ao tecido urbano, e tais pré-existências urbanas e sociais só serão recuperadas com a crítica ao Movimento Moderno, com o aparecimento dos Novos Urbanismos, e a volta dos estudos de morfologia urbana. As cartas patrimoniais, concretamente a Declaração do Quebéc (2008) e os Princípios de Valleta (2011) também parecem apontar ultimamente para isso, ao mencionar sobre o espírito do lugar, caráter do lugar ou genius ou spiritu loci.

Acredita-se que o diálogo é possível, assim, por um lado, arquitetos e planejadores urbanos deveriam estar mais atentos e considerar as pré-existências, recordando que se tratam tanto de pré-existências físicas como sociais, do edifício como do tecido urbano como um valor a ser agregado no projeto. De outro lado, os profissionais "conservacionistas", dado o alargamento do conceito do patrimônio, seja conceitual e seja territorialmente, considerá-los como organismos vivos, ou seja, sua dimensão contemporânea, e em constante mudança, como bem lembram os Princípios de Valleta. Tais posturas contribuiriam para diminuir a distância entre os profissionais e, ao mesmo tempo, criar uma cultura de preservação participada com a sociedade. Afinal, não se deve perder de vista o fim último da preservação que é a sociedade: pois não se preservam apenas coisas, preservam-se coisas para as pessoas, as chamadas gerações futuras.

Acredita-se que assim, a preservação das vilas ferroviárias possa funcionar: re-significação através da paisagem cultural, e para a gestão deste patrimônio, a proposta é o estabelecimento de áreas de conservação. Tal estabelecimento das áreas de conservação deveria ser confiado aos poderes locais, juntamente com a participação da sociedade civil local, em uma espécie de inventário participativo, que poderia ser feito conjuntamente pelo IPHAN e pelo CONDEPHAAT, ou melhor, sob a supervisão destes, que atuariam como consultores dos municípios que desejassem ver suas estações e vilas ferroviárias preservadas e restauradas. Para tal estabelecimento, além da demarcação de áreas, um estudo sobre a estrutura, morfologia (materiais, cores e detalhes do lugar), tipologias, ${ }^{11}$ etc,

11 Miarelli Mariani recomenda um profundo conhecimento da cidade pré-existente, com acurada leitura da realidade urbana, com seus dados funcionais, estruturais e formais, "bem como abarcar a compreensão do tecido histórico, sua estrutura fundiária, processo formativo e os materiais, técnicas, padrões cromáticos e tipos construtivos que o compõem. Na escala do território, deve-se ainda atentar para os modos de formação e fruição desses espaços ao longo do tempo, ou seja, para os mecanismos inicialmente espontâneos e progressivamente intencionais com os quais comunidades tradicionais moldaram esses espaços de acordo com suas necessidades e interesses." (MARIANI, Miarelli. Restauro e territorio.p. 64 apud RUFINONI,2009, p. 204). Saverio Muratori, no final dos anos de 1940, falava da 
como definidos na Declaração do Québec em 2008, e ratificados nos Princípios de Valleta $(2011)^{12}$, ambos documentos do ICOMOS, que falam de "spiritus loci”, "espírito do lugar", ou ao caráter do lugar a que se referem muitos autores, para estabelecer um guia de transformação para os futuros projetos na área. Tais guias de transformação devem ser revistos de tempos em tempos, como são revistas as áreas de conservação inglesas, pois as sociedades mudam, como também as suas necessidades.

\section{3. O caso concreto das vilas ferroviárias escolhidas}

Depois de verificado o estado atual das vilas ferroviárias, seu possível lugar nas políticas de preservação, dada a importância histórica da Companhia Paulista, dos seus trabalhadores e das vilas no âmbito do patrimônio industrial e da configuração do território paulista, volta-se à pergunta inicial: todos os edifícios da Companhia Paulista devem ser preservados ou somente alguns? As vilas ferroviárias escolhidas - Itirapina, Dois Córregos, Brotas, Jaú, Rincão e São Carlos - merecem ser todas preservadas? Se preservadas, quais critérios e estratégias a adotar de forma a garantir uma preservação eficaz, isto é, respeitando o valor cultural das edificações e, ao mesmo tempo, o contexto urbano, e de modo que a população original permaneça, além disso, reconheça e usufrua? Tentaremos responder uma a uma, tais questões ainda neste capítulo.

Sobre a primeira pergunta - se todos os edifícios da Companhia Paulista devem ser preservados ou somente alguns - pelo levantamento histórico que fizemos neste trabalho, foi verificada a importância do complexo industrial ferroviário. Portanto, a resposta é "sim", devem ser preservados. E ao mesmo tempo, por enquadrar-se no que se refere a carta do patrimônio industrial, abarcando não somente as estações como as vilas ferroviárias, as oficinas, as pontes, rotundas (giradores), hortos florestais, como também os bens móveis, como locomotivas, vagões, e outros tipos de maquinários. O modo de fazer esta preservação é que deve ser discutido. Como já vimos, a preservação é um conceito maior

necessidade de compreender "o processo histórico de formação desses conjuntos, de onde derivaram e como se transformaram, para que possa garantir a integridade de identidades formais únicas." (RUFINONI, 2009, p. 216). Cervelatti (1976, p. 19-20) para o Plano de Bolonha, também se refere a necessidade de estudos históricos e análise estrutural e tipológica do lugar, antes de qualquer plano de intervenção.

12 É do mesmo ano (2011), "Joint ICOMOS - TICCIH Principles for the Conservation of Industrial Heritage Sites, Structures, Areas and Landscapes", ou também conhecido como os "Princípios de Dublin", cidade onde ocorreu a 17 . Assembléia Geral do ICOMOS, em 28 de novembro de 2011. 
que o tombamento. Tomando os casos concretos das vilas ferroviárias, e já respondendo a segunda pergunta formulada, se as vilas ferroviárias de Itirapina, Dois Córregos, Brotas, Jaú, Rincão e São Carlos, merecem ser preservadas, a resposta é: “sim”, merecem ser preservadas no âmbito do conjunto da história da Companhia Paulista. Individualmente, elas não possuem sentido, e muito da história da ferrovia perdeu-se da memória dos atuais ocupantes.

Faz-se necessário um trabalho de re-significação destes edifícios sob o ângulo da história da Companhia Paulista, e ao mesmo tempo, no conjunto do patrimônio industrial ferroviário. Se tomadas em conjunto, ganham maior força de significação, daí o percurso realizado nesta tese pela história da Companhia Paulista e de seus trabalhadores, e pela leitura morfotipológica destes espaços, constituindo-se no que se poderia chamar de paisagem cultural ferroviária. Se a pergunta em relação às vilas, fosse, ao invés de utilizar a palavra "preservadas", fosse utilizada a palavra "tombadas", a resposta seria: "não, pois na atual conjuntura de organização e política de preservação brasileiras, dependerá em que nível será o tombamento". Como se disse ao início deste trabalho, não se trata de “patrimonializar" tudo, conforme levanta Choay (2006, p. 237) $)^{13}$, porém também não se deve tomar a posição oposta, isto é, não é o caso de destratar patrimônios e demoli-los. ${ }^{14}$ Assim, mesmo os complexos ferroviários (estações, vilas ferroviárias, etc...) do interior do estado de São Paulo, que não fossem preservados em nível federal ou estadual, mas em que que houvesse poderes locais e sociedades civis interessados em sua preservação, poderiam estabelecer as áreas de conservação, mas sempre conectadas ao um conjunto

13 “(...) qual é o fundamento em que repousa a conservação do patrimônio histórico arquitetônico num mundo que se muniu de recursos científicos e técnicos para guardar na memória e interrogar seu passado sem a mediação de monumentos ou de monumentos históricos reais? Com efeito, quer se trate das funções econômicas e dos recursos de entretenimento oferecidos pelo patrimônio na sociedade de lazer, quer se trate de valores cognitivos, pedagógicos e artísticos, nenhuma das motivações institucionalmente reconhecidas ou reivindicadas permite interpretar o fervor com o qual o culto patrimonial é celebrado e se difunde no mundo inteiro." (CHOAY, 2006: 237)

14 Aqui gostaria de citar os projetos desenvolvidos pelo arquiteto e professor da Universidade de Delft, Prof. Paul Meurs. Certamente, um dos projetos de seu escritório que mais guardam relação com o meu projeto de pesquisa, é o projeto "Dutch railway NS (Nederlandse Spoorwegen): the collection", por se tratar de uma avaliação do patrimônio de 50 estações ferroviárias. O projeto foi encomendado conjuntamente pelas empresas: de trens holandesa, Nederslandse Spoowegen, ProRail (empresa de infraestrutura holandesa) e Bureau Spoorbouwmeester (o departamento do governo responsável pelas ferrovias). As primeiras ferrovias holandesas datam da metade do século XIX, e muitas das antigas estações ainda operavam no século XXI, com ou sem ajustes. O projeto feito pelo escritório consistiu na seleção de 50 estações que pudessem ilustrar a história da evolução das ferrovias holandesas. "Para garantir que estas estações refletissem a história das ferrovias e ao mesmo tempo mantivessem a função como as contemporâneas áreas ferroviárias." Para tanto, foram feitas avaliações do patrimônio e dos valores destes edifícios, para "estabelecer qualidades, valores essenciais e conceitos. E desse modo, oportunidades para futuras extensões, ajustes e desenvolvimento das áreas tornarem-se claras.". Talvez tal estratégia de trabalho, estabelecendo critérios de seleção, avaliando e estabelecendo valores essenciais e conceitos, possam ser aproveitados para as vilas ferroviárias. 
maior que chamamos paisagem cultural ferroviária.

Seguem ainda algumas considerações sobre a política de preservação do patrimônio industrial e paisagem ferroviária. Depois de ter visto outras formas de gestão, penso que as políticas de preservação podem pautar-se por três aspectos: que a sociedade perceba a necessidade de preservar, a sustentabilidade financeira do patrimônio edificado e a reutilização. Estes três elementos intimamente relacionados, devem possuir, a dimensão contemporânea do patrimônio e a necessidade de ligar a preservação aos planos de desenvolvimento e ordenamento do espaço. Com relação ao envolvimento da sociedade na preservação, Marins (2013, p. 170-173) ao tratar da preservação do patrimônio rural, propõe três eixos de fomento: o primeiro seria do envolvimento da população, através, por exemplo, dos inventários participativos; um segundo eixo seriam as ações geradas pelas universidades ${ }^{15}$; e ainda um terceiro eixo, que seria a "consolidação de iniciativas advindas de entidades não-governamentais, como proprietários e associações”.

Os três eixos podem ser aplicados à preservação do patrimônio ferroviário. O envolvimento da população poderia se dar através dos inventários participativos, como os realizados no Vale do Ribeira e nos Roteiros Nacionais de Imigração (MARINS, 2013, p. 170). A importância desta participação, reside em não contrapor o valor técnico ao valor social, conforme apontado por Meneses (2010, p. 34). Tal participação da sociedade é importante na valoração dos bens a serem preservados, que como foi visto anteriormente são os mais variados e conflitantes, e como afirma Meneses (2010, p. 30): “É preciso introduzir outros critérios para avaliar os círculos concêntricos de pertinência e de interesse do bem, que possam antes de mais nada definir seu potencial de interlocução, começando sempre com os interlocutores locais. ”. Ainda assim tal participação social, seria uma tarefa juntamente de educação e informação, pois esperar simplesmente pela participação social não sei se funcionaria.

Outra forma seria, estimular e envolver as associações existentes de preservação e de organizações de ferroviários ou dos apaixonados pelas ferrovias, como há em São Carlos e Brotas, em uma estrutura mais profissional e eficaz. O exemplo inspirador seria o dos

15 "Um segundo eixo de fomento à preservação do patrimônio rural paulista deriva de ações geradas pelas universidades, especialmente por seus programas de pós-graduação. À exceção dos textos de Luis Saia, servidor do IPHAN em São Paulo, todos os demais trabalhos de relevo que refletiram sobre a arquitetura rural paulista foram gerados em meio acadêmico. (...)" (MARINS, 2013:170) "Tal estreitamento de relações com a sociedade civil leva-nos, por fim, ao terceiro direcionamento de ações para a preservação do patrimônio cultural. Trata-se da consolidação de iniciativas advindas de entidades não-governamentais, como proprietários e associações. Nesse âmbito, o Estado de São Paulo pode ser considerado um espaço relativamente recente de ações de cooperação voltadas à preservação do vasto patrimônio rural nele existente, especialmente aquele oriundo da produção cafeeira.” (MARINS, 2013: 173) 
trusts ingleses. De certa maneira, os vários núcleos da Associação Brasileira de Preservação de Ferroviária (ABPF) que mantém as marias-fumaças em funcionamento em Jaguariúna e na Móoca (Museu do Imigrante) funcionam de maneira semelhante, pois são economicamente independentes, e não pertencem aos museus públicos. Quanto à ação gerada pelas universidades, chama a atenção o convênio que o National Railway Museum estabeleceu com a Universidade de York. Vários armazéns das antigas companhias ferroviárias espalhados pelo estado de São Paulo poderiam ser usados para abrigar um museu do gênero. E o arquivo existente, atualmente no Museu Ferroviário
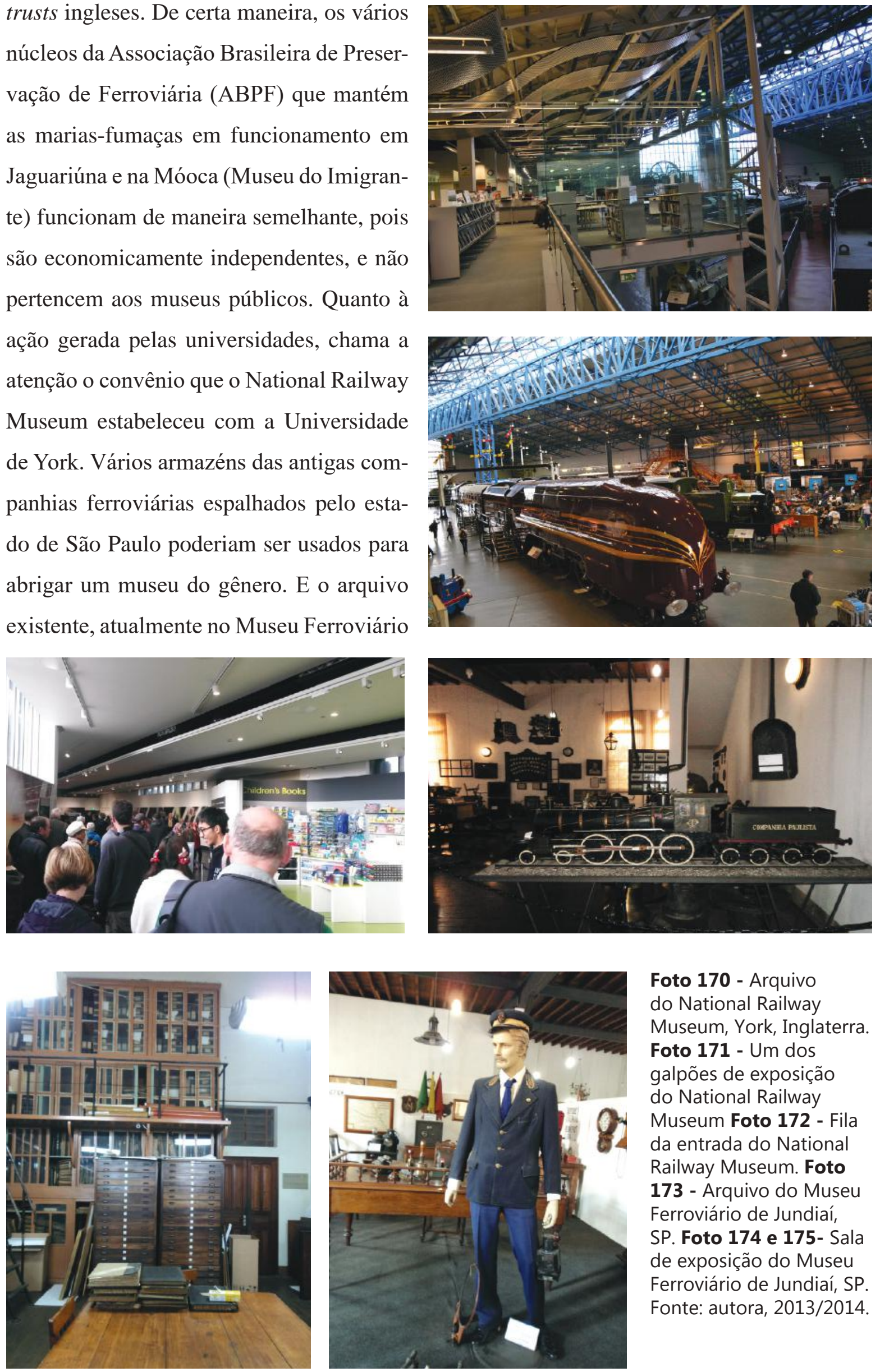

Foto 170 - Arquivo do National Railway Museum, York, Inglaterra. Foto 171 - Um dos galpões de exposição do National Railway Museum Foto 172 - Fila da entrada do National Railway Museum. Foto 173 - Arquivo do Museu Ferroviário de Jundiaí, SP. Foto 174 e 175- Sala de exposição do Museu Ferroviário de Jundiaí, SP. Fonte: autora, 2013/2014. 
de Jundiaí, mereceria uma catalogação e mais profissionais, para o qual as universidades poderiam contribuir mais. ${ }^{16}$ Além disso, tal museu poderia abrigar os bens móveis ferroviários espalhados pelo Brasil. Acredita-se que havendo uma grande quantidade de bens móveis, não se vê problema em deixá-los em suas respectivas estações, como locomotivas, relógios, etc... que funcionariam como os bens móveis integrados das arquiteturas religiosas.

Aliar as iniciativas de sociedades não governamentais, associações ou fundações, não somente à valoração dos bens, isto é, ao inventário, como também à sustentabilidade financeira seria desejável. O Estado agiria como um conselheiro e incentivador fiscal, mas não tanto como o executor das ações, como ocorre no modelo anglo-saxão de preservação. Meneses (2010, p.37) não vê contraposição entre valor econômico e valor cultural:

Para finalizar estas reflexões sobre valor, penso oportuno dizer algo sobre antinomia corrente que opõe o valor cultural ao valor econômico (valor de troca). Na perspectiva que desenvolvi, não há qualquer antagonismo. Há uma dimensão econômica do bem cultural, assim como uma dimensão cultural do bem econômico. (...) A oposição existe, sim, entre a lógica da cultura (que é uma lógica de finalidade, em que a produção do sentido e da comunicação é que constitui prioridade, como acentua García Canclini) e a lógica de mercado (que tende a instrumentalizar a cultura, na obtenção do lucro) (MENESES, 2010, p. 37).

Afinal de contas, o bem cultural, seja ele o edificado ou a paisagem, para manter-se como estão, dependem de intervenções materiais, e demandam investimentos. Investimentos que não devem ser apenas dos órgãos públicos, mas contar com a participação da sociedade. Da mesma maneira, quando se fala em educação patrimonial, esta não deve ser dirigida apenas a crianças e grupos escolares, aos técnicos de prefeituras locais, à população local, mas também à sociedade em geral, com a iniciativa privada também incluída. E dado o contexto brasileiro, antes da educação patrimonial, o país necessita de educação básica.

Com relação aos usos dos edifícios do complexo ferroviário da Companhia Paulista, acredita-se que as vilas ferroviárias não devam ser transformadas em museus, e não é preciso muita criatividade como sugere Choay (2006, p. 220), ao comentar sobre uma casa de operários das minas de Hénin-Beaumont, em Lévin: “(...) Como estes poderão permanecer, a não ser como marcos simbólicos, sob a forma de museus? Para ir mais longe, é necessária uma imaginação que não possa ser substituída por mera nostalgia.”

16 Há um projeto da UNESP e o Museu Ferroviário, um bom começo, porém mais contribuições seriam necessárias, não só para São Paulo, como para outras regiões. 
(CHOAY, 2006, p. 220). Não há dúvida que para as vilas ferroviárias, o uso deve permanecer o original, o residencial. Havendo vilas ferroviárias abandonadas, ou ainda, com grande potencial turístico, não se vê problemas em transformá-las em hotéis, desde que a população original seja alocada em outro lugar de maneira justa e adequada. Há que se levar em conta a realidade das vilas ferroviárias escolhidas, muitas delas são localizadas em cidades pequenas - com exceção de Jaú e São Carlos - a população não chega aos 30.000 (trinta mil) habitantes.

Apesar de muitas cartas patrimoniais referirem-se a centros históricos, acredita-se que não seja o caso das vilas ferroviárias. Muitas delas estão localizadas nas periferias das cidades do interior paulista, cidades que não possuem recursos financeiros ou uma indústria geradora de empregos, dependentes de outras, algumas inclusive são apenas cidades dormitórios. Deste modo, uso residencial ou uso turístico, dependerá dos planos de desenvolvimento dos municípios, estabelecidas as áreas de conservação. E ainda, devem ser previstas formas de informação, de manutenção e reformas para os moradores locais, podendo ou não ser sob a forma de cartilhas, como as vistas nas vilas inglesas e na Vila Economizadora na cidade de São Paulo. Além desta forma de educação patrimonial, é necessária de tempos em tempos, a fiscalização e monitoramento adequados. Com relação à situação fundiária, as casas devem ser ven-

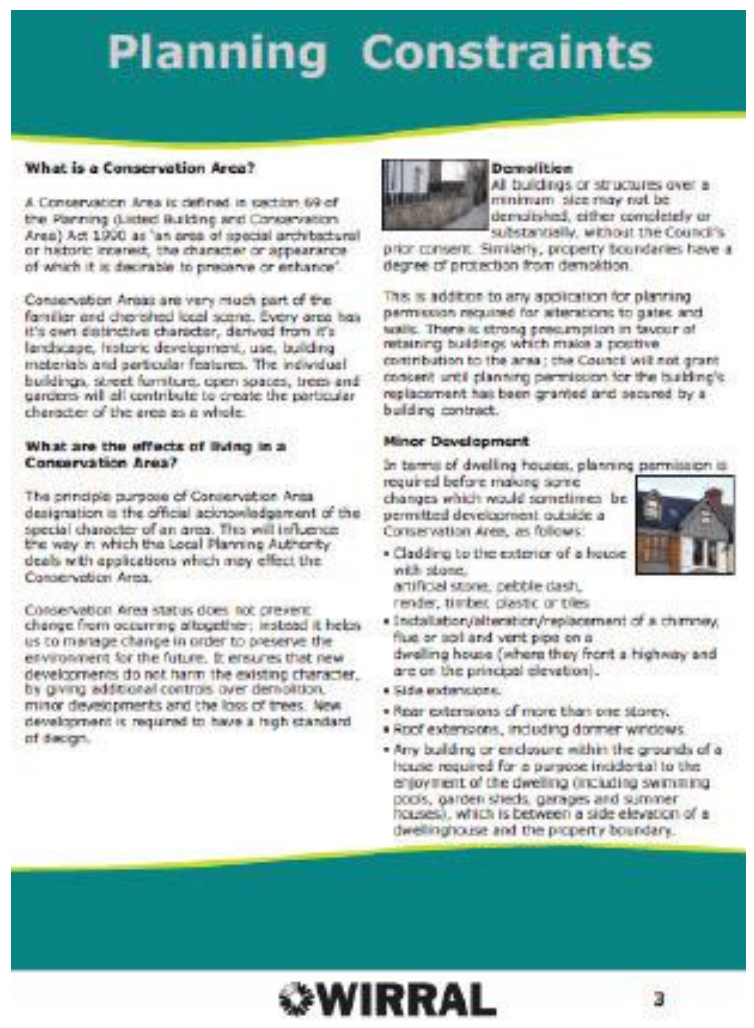

Figura 6 - Página de folheto explicativo, de Bromborough Conservation Area, explicando aos moradores sobre o que é uma área de conservação e o que eles podem ou não fazer em suas casas. Fonte: autora, 2013. didas aos ocupantes atuais, ou então compradas pelas prefeituras, que administrarão os locais, alugando seus imóveis.

Após observar a diversidade de usos nos complexos ferroviários ingleses e do patrimônio industrial internacional, acredita-se que para as estações e outros edifícios maiores, como armazéns e oficinas, o uso deve estar de acordo com as necessidades locais, bem como os planos diretores e de desenvolvimento, estabelecidos através das áreas de 
conservação. Atualmente, as estações de Brotas e Rincão possuem usos administrativos, pelas prefeituras locais. A estação de Jaú possui um uso cultural e um comercial, pois existe um restaurante, porém que ocupa o imóvel irregularmente. Não se vê problemas quanto a estes usos, inclusive o comercial, que poderá inclusive dar sustentabilidade financeira à conservação. São Carlos possui um uso cultural, que parece pouco frequentado. Itirapina, mesmo sendo concessão do DNIT à ALL, o edifício da estação encontra-se desocupado, provavelmente por ser uma estação apenas de passagem. Em Dois Córregos, o edifício da estação encontra-se vazio.

Não há problemas quanto ao uso museal, desde que a cidade comporte um museu, e os museus sejam atraentes, dêem um verdadeiro significado aos bens móveis e imóveis do patrimônio ferroviário, e sejam instrumentos ativos de educação patrimonial. Cooper (2002) faz um estudo de dez museus ferroviários brasileiros e compara a cultura "museística" européia e a brasileira. E afirma que, por ser um país novo, os brasileiros estão ligados mais ao presente e ao futuro, do que ao passado. E o autor conclui que não há uma proporção da população brasileira que está com o passado disposto nas vitrines dos museus ferroviários. Para o autor, as pessoas que vão a estes museus ferroviários é porque tem memórias pessoais relacionadas às ferrovias. (COOPER, 2002, p.100). É verdade, que na Inglaterra, há bem mais amantes das ferrovias que no Brasil. Porém, no Brasil, é possível ver algumas associações de ex-ferroviários espalhadas aqui e acolá, sendo verificadas em Brotas, e outra associação de ferromodelismo em São Carlos. Diversas dissertações e teses são feitas por pessoas que tiveram familiares ligados a ferrovia.

Discorda-se da posição de Cooper (2002), ao afirmar que o brasileiro não tem cultura museística. A começar, não temos um museu ferroviário devidamente organizado e atrativo, como os ingleses possuem. Devíamos nos questionar como estão expostos os objetos e como estão montadas as exposições, e como funcionam os museus. Lowenthal $(1985$, p. 68) afirma que se pode neutralizar o passado apenas o exibindo (displaying) em vitrines, fazendo dele apenas ornamentos, pois desse modo o passado não pode nos machucar e destrói o seu potencial, e dá exemplo de instrumentos agrícolas pendurados na parede, que podem ser admirados por aqueles que não sabem, nem se importam para que eram utilizados. Por outro lado, questiona-se a inserção dos mesmos nos circuitos turísticos e como são divulgados. Houve algumas exposições em São Paulo, em que certamente as pessoas nunca haviam ouvido falar da artista, mas devido a propaganda e a divulgação feitas, formavam-se filas aos finais de semana. Claro que São Paulo, não tem o atrativo 
da praia concorrendo com o museu, mas também não se pode afirmar que o brasileiro não tem cultura museística. A cultura museística pode ser criada, assim como o respeito ao patrimônio. É um problema também de comunicação.

Há alguns anos, em Pernambuco, como turista fiquei curiosa a respeito de como seria um engenho de açúcar, perguntei à guia turística se havia algum para visitar, mas ela não soube informar. Será por falta de engenhos restaurados? Será por que os turistas preferem a praia? Por que o engenho não está no circuito turístico? Concordo com Cooper que a memória ferroviária está ligada a uma memória afetiva, a pessoas que trabalharam na ferrovia, menos do que pessoas que buscam o conhecimento das ferrovias. Mas será que o problema não está em como se apresenta o patrimônio ao público? O patrimônio não deve ser tema apenas para técnicos e especialistas, nem algo só para pessoas com memória afetiva ligado aos trens, mas aberta ao público, e para isto é necessária a comunicação, pois dele depende sua própria sobrevivência. Como vimos anteriormente e, volta-se a recordar: a preservação deve ser compartilhada com a sociedade.

O patrimônio ferroviário não necessariamente deve estar voltado ao passado. Deve certamente, ter um elo com o passado, porém para sua sobrevivência e manutenção, necessariamente conecta-se com o presente, e não pode se fechar a especialistas ou apaixonados pela ferrovia, mas projetar-se ao futuro. Lowenthal (1985, p. 412) estimula a pensar sobre esta dimensão contemporânea do passado, ou esta conexão entre passado, presente e futuro, quando afirma que o lugar do passado não é simples trazê-lo de volta, como “um país separado e estrangeiro, mas sim, assimilá-lo nós mesmos, e ressuscitá-lo em um sempre cambiante presente. ${ }^{17}$ Assim, devem ser vistos tanto os edifícios, ou bens imóveis, como os objetos, bens móveis ligados ao patrimônio ferroviário, e não devem ser vistos de maneira separada. Um exemplo que me vem à mente, seria o estudo do funcionamento das oficinas, e o estudo de cada tipo de locomotiva e vagão poderia dar significado ao material remanescente em muitos museus ferroviários, que hoje parecem desconexos. Talvez trazendo o significado destes objetos, e com um projeto museográfico atualizado, poder-se-ia reconectar passado, presente e futuro da preservação. ${ }^{18}$ Fazem-se necessárias exibições atrativas, e interativas, que demandam estudos de museologia. Fala-se muito em educação patrimonial, acredito que o museu seja uma de suas vertentes. Talvez assim, a cultura museística brasileira pudesse se renovar.

17 "But their place is not simply back there, in a separate and foreign country; it is assimilated in ourselves, and resurrected into an ever-changing present." (LOWHENTAL, 1985, p. 412).

18 Existe o Museu Ferroviário de Jundiaí, mas o mesmo infelizmente ainda não atingiu estas condições. 
Dois autores possuem posições diferentes com relação ao patrimônio, aos museus e ao turismo. Schouten (2006) ${ }^{19}$ afirma que para conciliar o turismo cultural e o desenvolvimento sustentável, ou a base do desenvolvimento cultural, é preciso ter em consideração quatro elementos-chave, segundo os alvos ou objetivos que estão descritos entre parênteses: qualidade de experiência (visitantes), qualidade de recursos (cultura), qualidade de uso (reabilitação) e qualidade de vida (habitantes). O ponto de vista do autor é do turismo, e segundo ele:

Patrimônio como uma realidade histórica pode apenas existir pela virtude da interpretação e se isso não é fornecido, os visitantes farão suas próprias interpretações, baseados em suas próprias ideias, juízos falsos e julgamentos. A realidade histórica não aparece dos restos do passado por si mesma, deve ser criada (...) Informação histórica não é suficiente, é preciso ser traduzida para os visitantes. Interpretação é a arte que faz a história 'real'”. ${ }^{20}$ (SCHOUTEN, 2006, p. 81. Tradução nossa)

Daí a necessidade de fornecer uma "linha narrativa" (story line) para os lugares e bens patrimoniais, para o "patrimônio" ser "palatável" e mais facilmente acessado pelas pessoas, ou visitantes ou turistas. ${ }^{21}$ Já o autor inglês Fowler (1992) sublinha a questão do passado como commodity, como produto a ser consumido, porém ele vê isso de maneira negativa, e questiona o lugar da história e como ela vem sendo ensinada pelos profes19 SCHOUTEN, Frans "Sustainable Cultural tourism planning" in MEURS, P. \& VERHOEF, LGW. World heritage site in Olinda in Brazil: Proposals for Intervention. Amsterdam: IOS Press, 2006. Frans Schouten é professor associado da NHTV Breda University of Applied Sciences.

20 "Heritage as a historical reality can only exist by virtue of interpretation and if this is not provided, the visitors will make their own interpretations, based on their own ideas, misconceptions and prejudgements. The historical reality does not peep up from the remains of the past of itself, it has to be created. (...) Historical information is not enough, it needs to be translated to the visitors. Interpretation is the art that makes history 'real'." (SCHOUTEN, 2006, p. 81).

21 "During the development of a heritage site, the development of a story line is a useful aid to the provision of interpretations for the visitors. The physical remains of the past, whether landscapes, sites, or objects, have many layers of signification, which it may be important to present to the visitors. From the point of view of communications, which of these should be chosen to will depend on the objectives and the target audience. A building or an artefact is always more than it seems to be. A palace is not only the dwelling place of a monarch, but is also built of impress, to ensure that the subject are duly impressed and have to look (both figuratively and literally) up to their king. The layout expresses the differences in status of the activities to be perfomed in and around the place. The interior and decorations tell us something about the relationship between the monarch, his court and his subjects; all these different aspects can offer a clue for the development of a story line." (SCHOUTEN, 2006, p. 83). "To facilitate the consumption of experiences by the visitors, product development is necessary, in particular within the field of heritage and cultural tourism. Visitors have a both a profound lack of knowledge of history and a biased preconception of the past. To accommodate the visitors we need to actualise the interpretation strategies. Fruitful cooperation between the custodians of our past and product developers can jointly deliver a strong concept for a strategy for communication with visitors." (SCHOUTEN, 2006, p. 84) 
sores e sobretudo pelos museus, existindo um apelo para o emocional. Ao mesmo tempo, Fowler (1992) reconhece que existe uma linha tênue entre uso e exploração do "passado". Creio que as posições dos dois autores devem ser balanceadas. Os museus podem contribuir para a educação patrimonial, contudo, ao mesmo tempo, considerando a História como construção, ao invés de apenas uma "linha narrativa", poderiam ser apresentadas mais "linhas narrativas". Novamente, sublinha-se a importância da dimensão contemporânea do patrimônio, de conectar-se com o grande público do presente, com vistas a sua sobrevivência no futuro.

Mais detalhadamente sobre cada uma das vilas, e assim chegamos ao final deste capítulo: pode-se dizer que Rincão é a que possui grandes qualidades e características morfotipológicas preservadas, ainda que, como se pode observar durante esta pesquisa, vem ano a ano perdendo tais características. Na sequência, estão Itirapina, Brotas, Dois Córregos e Jaú. São Carlos é a vila que se encontra mais descaracterizada, e é de difícil leitura como complexo ferroviário à primeira vista. ${ }^{22}$ Contudo, São Carlos apresenta aspectos interessantes como a existência de casas com materiais diversos, e um aspecto positivo é a existência de uma associação de ferromodelismo, que poderia contribuir para a preservação do complexo. Uma associação de ferroviários também foi encontrada em Brotas, conforme citado anteriormente. Além disso, Brotas já sendo turística, poderia integrar o patrimônio 22 É esta dificuldade de leitura das vilas ferroviárias dentro de um complexo ferroviário, aliada a conflitos fundiários, é que a nosso ver, não tem poupado as vilas de demolições nas diversas partes do estado de São Paulo.
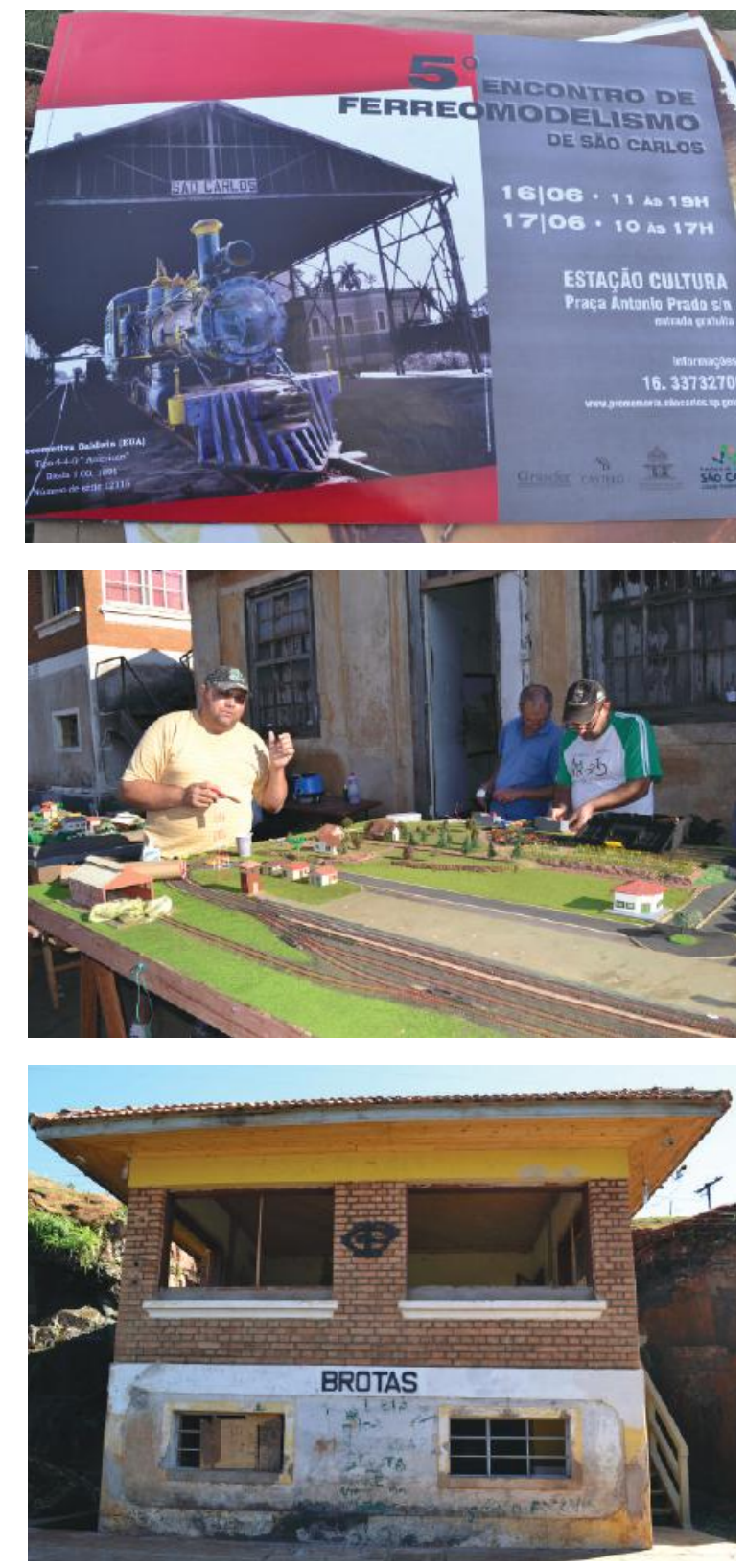

Foto 176 - Foto do cartaz de um dos encontros de ferromodelismo em São Carlos. Foto 177 - Associação de ferromodelismo, que se reúne em um dos armazéns da estação de São Carlos. Foto 178 - Edifício que a Associação de Preservação Ferroviária Brotense pretende utilizar como sede. Fonte: autora, 2013. 
ferroviário ao circuito turístico. Acredita-se que mesmo uma cidade aparentemente sem grande potencial turístico, em função da história da Companhia Paulista, e pela reativação de algumas das linhas para turismo, poderia desenvolver tal potencial.

Chega-se ao final do capítulo, tendo percorrido diversas escalas: a) a da paisagem cultural ferroviária, para a re-significação destes espaços e conferir uma visão sistêmica aos seus mais variados bens; b) a das áreas de conservação, numa tentativa de propôr uma solução de gestão, uma vez que o conceito de paisagem é limitado neste sentido; c) e agora chega-se a escala da morfologia urbana, ensaia-se ler estes espaços, e apreender o seu caráter, enfim, o seu genius ou spiritus loci. Acredita-se que somente após esta apreensão do passado, suas pré-existências físicas e sociais, é que se pode conectá-las com o presente e o futuro, seja por projetos urbanos ou elaboração de guias de transformação. 


\section{Capítulo 4 - Um ensaio de leitura morfotipológica da vila ferroviária de Rincão}

O estudo da morfologia urbana demandaria uma outra tese, mas para situar o leitor e fazer uma leitura de pelo menos uma das vilas ferroviárias, recorreu-se a algumas referências bibliográficas existentes. Procurou-se notar convergências e divergências entre os vários autores, elegeu-se tópicos em comum, e colocou-se os autores em diálogo.

Komorowski (2007), identifica três principais linhas de estudo morfotipológico, sendo os demais derivados delas (GAUTHIER and GILLIAM, 2006 apud KOMOROWSKI, 2007), são elas: a escola italiana ou Muratoriana; a escola britânica ou Conzeniana e a escola francesa ou de Versailles. Segundo o autor elas surgiram quase ao mesmo tempo (as italianas e inglesas um pouco antes da escola francesa) por volta de 1950 e de forma independente, mas com mais força a partir de 1980. As diferenças entre as escolas expressam ambientes acadêmicos nas quais elas se desenvolveram. Os fundadores da escola italiana eram arquitetos, (Muratori, e seus discípulos e continuadores mais próximos Canniggia\&Maffei) e seus trabalhos eram orientados para informar o projeto da forma urbana.

Os fundadores da escolabritânica eramgeógrafos(CONZEN, 1975; WHITEHAND, 1981) e os trabalhos estavam orientados para entender o processo da morfogenética urbana, o desenho de uma nova forma urbana não era uma preocupação importante, tal preocupação é de época mais recente. Já os fundadores da escola francesa ou escola de Versailles eram um grupo misto de arquitetos e cientistas sociais de diferentes disciplinas, como a sociologia, a história e a antropologia entre outros (Henri Lefebvre e Phillipe Panerai entre outros), e estavam preocupados em compreender a relação entre a forma urbana e vários fenômenos sociais. Mas, como a escola italiana, também com o projeto da nova forma urbana. (KOMOROWSKI, 2007, p. 8). Ainda segundo Komorowski (2007, p. 16) parece que a escola italiana estava mais preocupada com a forma por si mesma, enquanto a escola francesa, preocupava-se com a forma e os fenômenos sociais, tal como seus usos e significados no espaço urbano. Como se pode ver, há diversas linhas, e dentro destas linhas, diversos autores que trabalham a questão da morfologia urbana, porém, para este trabalho utilizarei bastante o trabalho de Lamas. Ao ler o trabalho de Lamas, parece-me quase evidente que o autor, apesar de analisar diversos autores que trabalham com a ques- 
tão da morfologia urbana, centra-se no trabalho de Aldo Rossi.

Há entretanto algumas considerações a serem feitas aqui, antes de prosseguirmos. Segundo Komorowki (2007, p. 12), Aldo Rossi e Carlos Aymonino rejeitavam os trabalhos de Muratori e Cannigia, não se sabe em que medida havia esta rejeição. O certo é que Savério Muratori, foi posto em isolamento tanto em Veneza, onde lecionou por quatro anos (1950-1954) e também em Roma. Por outras fontes, sabe-se que havia um conflito entre Savério Muratori e Bruno Zevi, que o retratava como acadêmico e tradicionalista. (CATALDI, MAFFEI\&VACCARO, 2002, p. 6). O certo é que havia um conflito entre modernistas e não-modernistas. Ainda assim, a referência principal deste trabalho será Lamas (2011), pois faz referência a outros autores que não filiados às três linhas abordadas por Komorowski.

Para a morfologia urbana, utiliza-se a definição dada por Lamas (2011), pois este analisa alguns autores anteriores como Lynch (1960), Cullen (1961), Rossi (1966). Como a questão da morfologia urbana refere-se à leitura e percepção dos diferentes lugares, Lamas inclui outros autores, como Norberg-Schulz, que trabalha aprofundadamente a questão do "genius loci", termo também chamado "spiritus loci”, que quer dizer espírito ou caráter do lugar. No âmbito brasileiro, encontra-se o trabalho de Gunter e Maria Elaine Kohlsdorf, que tratam da leitura ou dimensão topoceptiva. E também no sul do Brasil, encontramos os trabalhos de morfologia urbana desenvolvidos por de Krafta \& Faria (2016). Os autores citados fazem referência uns aos outros. A definição de Lamas para a morfologia urbana (2011) é a seguinte:

O termo <<morfologia〉> utiliza-se para designar o estudo da configuração e da estrutura exterior de um objeto. É a ciência que estuda as formas, interligando-as com os fenómenos que lhes deram origem.

A morfologia urbana estudará essencialmente os aspectos exteriores do meio urbano e as suas relações recíprocas, definindo e explicando a paisagem urbana e a sua estrutura.

O conhecimento do meio urbano implica necessariamente a existência de instrumentos de leitura que permitem organizar e estruturar os elementos apreendidos, e uma relação objeto-observador. Estes dois aspectos defrontam-se com questões de objectividade na medida em que dependem de fenómenos culturais. (LAMAS, 2011 p. 37. Grifo nosso)

Além da definição acima de morfologia urbana, como "ciência que estuda as formas, interligando-as com fenômenos que lhes deram origem", também acrescenta que a 
morfologia urbana é "conjunto de objetos arquitetônicos ligados entre si por relações espaciais (idem, p. 41)". Trataremos mais adiante a importância que Lamas, como também Rossi, dá à arquitetura na leitura da cidade. Apreciamos a maneira como Lamas (2011) define a leitura polissêmica das formas urbanas, que engloba outras disciplinas, como também considera não apenas as características físicas como sua evolução no tempo, o que alguns autores chamam de diacronia. Ainda sobre a morfologia urbana, Lamas (2011) acrescenta:

A morfologia urbana supõe convergência e a utilização de dados habitualmente recolhidos por disciplinas diferentes - economia, sociologia, história, geografia, arquitetura, etc. - a fim de explicar um facto concreto: a cidade como fenómeno físico e construído. Explicação essa que visa a compreensão total da forma urbana e do seu processo de formação. Com imprecisão de linguagem, no calão arquitectónico, muitas vezes as palavras morfologia e forma são usadas indistintamente e sem diferenciação de significado. Importa clarificar que a morfologia urbana é a disciplina que estuda o objeto - a forma urbana - nas suas características exteriores, físicas, e na sua evolução no tempo. (LAMAS, 2011 p. 38)

Com relação a estes instrumentos de leitura das formas urbanas, é que os autores divergem e apresentam várias metodologias.

\subsection{Morfologia urbana}

Uma crítica que poderia ser dirigida aos autores que estudam a morfologia urbana é que haveria uma preocupação apenas com a forma pela forma, ou apenas com o sentido estético da cidade, descuidando-se de outros aspectos como o histórico ou o social. Como vimos, em Lamas, esta crítica não se aplica, pois a leitura da cidade é feita através da forma, com recurso às múltiplas disciplinas que se debruçam ao urbano e no decorrer do tempo. Esta visão de Lamas, muito deve à visão que Rossi tinha da cidade, e sobretudo da arquitetura da cidade como podemos ver no extrato a seguir:

A forma da cidade corresponde à maneira como se organiza e se articula a sua arquitetura. Entendendo por 'arquitetura da cidade' dois aspectos: Uma manufatura ou obra de engenharia e de arquitetura mais ou menos complexa, que cresce no tempo, e igualmente os factos urbanos caracterizados por uma arquitetura própria e por uma forma própria'. Este é também o ponto de vista mais correto para afrontar o 
problema da forma urbana, porque é através da arquitetura da cidade que melhor se pode definir e caracterizar o espaço urbano. (ROSSI apud LAMAS, 2011, P. 41)

A cidade é para Rossi (1996, p. 185): "uma grande manufatura arquitetônica", e a arquitetura como "um dos princípios da cidade" (ROSSI, 1996, p. 187), como também uma obra de arte. Rossi parece não desprezar os aspectos sociais e coletivos da cidade, mas em sua obra (1966) parece querer colocar o papel da arquitetura em evidência. Tampouco a Lynch esta crítica se aplica, pois em seu livro A imagem da cidade (1960), afirma que a imagem ambiental possui uma função social, psicológica e estética. Portanto, não é a forma pela forma, nem o estético pelo estético. Além disso, através de sua metodologia, tenta captar a percepção coletiva e não a individual.

Parece haver uma imagem pública de qualquer cidade que é a sobreposição de muitas imagens individuais. Ou talvez exista uma série de imagens públicas, cada qual criada por um número significativo de cidadãos. Essas imagens de grupo são necessárias sempre que se espera que um indivíduo atue com sucesso em seu ambiente e coopere com seus concidadãos. Cada imagem individual é única e possui algum conteúdo que nunca ou raramente é comunicado, mas ainda assim ela se aproxima da imagem pública que, em ambientes diferentes, é mais ou menos impositiva, mais ou menos abrangente. (LYNCH, 1960, p. 51)

Rossi também toca na questão da psicologia coletiva, citando a apropriação dos estudos da Gestalt pela Bauhaus e também cita a escola norteamericana de Kevin Lynch (ROSSI, 1996, p. 167). Além disso, trata da questão da memória coletiva, e neste sentido há uma citação interessante que faz ligação com a questão da paisagem urbana:

Ampliando a tese de Halbwachs, direi que a cidade mesma é a memória
coletiva dos povos; e como a memória está ligada a fatos e a lugares, a
cidade é o locus da memória coletiva.
Esta relação entre o locus e os cidadãos chega a ser, pois, a imagem,
preeminente, a arquitetura, a paisagem; e como os fatos voltam a
entrar na memória, novos fatos crescem na cidade. Neste sentido
completamente positivo as grandes idéias recorrem a história da cidade
e a conformam. (ROSSI, 1996, p. 191. Tradução nossa.)

Rykwert (2004), em seu livro sobre história urbana, observa a cidade como obra de arte e como também obra coletiva, tanto que descreve várias fábricas e vilas operárias do século XIX, o interesse dos arquitetos na construção de casas operárias e a habitação da classe média no capítulo "Casa e Lar". E igualmente quando Rykwert comenta sobre 
os arquitetos austríacos Otto Wagner e Camillo Sitte:

Apesar de seus enfoques serem diferentes, Wagner e Sitte partiram de uma mesma antipatia pelo Ringstrasse de Viena. Wagner desprezava o seu carnaval de estilos históricos, Sitte abominava os seus espaços excessivamente abertos e sujeitos ao vento, que isolavam os monumentos em meio ao tráfego e dificultavam o acesso. Quaisquer que fossem as diferenças de opinião entre eles, Wagner e Sitte tinham em comum o entendimento de que a cidade é uma obra de arte coletiva." (RYKWERT, 2004, p. 169. Grifo nosso.)

É claro que a cidade é polissêmica, e é possível lê-la a partir de diversas perspectivas, contudo, acreditamos que a querela se a cidade é um artefato artístico ou social, fica resolvida entendendo-se que a cidade é uma obra de arte, porém uma obra de arte coletiva. A leitura da cidade como obra de arte e o campo das teorias de percepção é infinito. Ao mesmo tempo, se pode fazê-las a partir da sociologia, psicologia, antropologia e da geografia. Mais que conflitantes, tais leituras serão agregadoras, se cada disciplina respeitar seu âmbito. Considerar a cidade como obra de arte coletiva, também abre espaço para entendê-la como algo vivo, em que as infinitas leituras e releituras poderão ocorrer, ao longo do tempo.

A importância da morfologia urbana está na consideração das pré-existências físicas e sociais, o que nos remete à polêmica dos modernistas que desprezam a tradição e dos pós-modernistas que voltam à tradição. Lamas divide a história do urbanismo em três períodos, que ele chama sucessivamente de: urbanismo formal, seguido do Modernismo e o Novo Urbanismo. O autor observa que a crítica à arquitetura moderna, e o retorno à cidade antiga pelos pós-modernistas é um pouco exagerada. O autor não condena os arquitetos modernistas, e possui uma visão mais ponderada. Para Lamas a importância da morfologia urbana reside em dois vetores principais, a saber:

- o interesse pela cidade antiga, sua preservação, conservação, restauro e revitalização, entendendo-a e recuperando-a na sua integridade física, funcional e social;

- a reavaliação das relações morfológicas existentes na cidade tradicional para o desenho do crescimento e expansão ou para intervenções no seu interior. (LAMAS, 2011, p. 390)

Assim, a morfologia urbana é importante tanto para as atividades de preservação como para o desenho urbano. Este último é o enfoque do livro de Lamas, mas não será o do presente trabalho. Nosso enfoque será bem mais o da preservação, e de como a partir 
da leitura morfológica, é possível estabelecer guias de transformação, na tentativa de evitar descontinuidades abruptas. Ainda quanto ao desenho urbano são interessantes as seguintes afirmações de Lamas:

Qualquer arquitecto terá de saber que não trabalha sobre tábua rasa, mas sobre um território que já existe. Isto é válido para o edifício que substitui num lote a construção degradada, para a modificação de uma construção degradada, como para os novos bairros ou novos edifícios. Há que procurar no território os elementos estimulantes e geradores do partido arquitectónico, e também os elementos que deverão ser mantidos. (LAMAS, 2011, p. 116)

A paisagem humanizada e a cidade são o resultado de centenas de anos de atividade do homem; constituem uma herança cultural que não pode ser dilapidada. Como tal, o controlo das transformações do território assume a maior importância na disciplina arquitetônica e urbanística. Implica a existência do plano (a ideia) e do planeamento (a ação de concretização e implementação do plano). (LAMAS, 2011 p. 116)

Lamas, para a leitura da morfologia, traz os elementos morfológicos ou morfotipológicos (parece que o autor utiliza os dois conceitos indistintamente), falaremos deles adiante.

Lynch na tentativa de captar a imagem da cidade, uma imagem coletiva, também tem como objetivos a preservação e o planejamento urbano, mas sobretudo a qualidade dos espaços e acrescenta que o olhar dos cidadãos pode ser informado. É o que se pode ver nos extratos a seguir:

(...) Essas imagens de grupo, consensuais a um número significativo de observadores, é que interessa aos planejadores urbanos dedicados à criação de um ambiente que venha a ser usado por muitas pessoas. (LYNCH, 1960, p. 8)

O objetivo final de tal plano não é a forma fisica em si, mas a qualidade da imagem inscrita na mente do usuário. Portanto, será igualmente útil aperfeiçoar essa imagem através do treinamento do observador, ensinando-o a olhar para a sua cidade, a observar a multiplicidade de suas formas e perceber de que modo elas se misturam. Para tanto, poder-se-iam levar os cidadãos às ruas, programar aulas nas escolas e universidades, a cidade poderia transformar-se no animado museu de nossa sociedade e de suas esperanças. Tal educação poderia ser usada não apenas para desenvolver a imagem urbana, mas para reorientála depois de uma transformação perturbadora. Uma arte do design urbano terá de ser o resultado do surgimento de um público informado e crítico. A educação e a reformulação física são partes de um processo contínuo.(...) (LYNCH, 1960, p. 131)

Para Norberg-Schulz que trata da questão do "genius loci", a importância da lei- 
tura serve para que arquitetos e planejadores urbanos criem espaços que sejam significativos para o homem, que ele possa habitar, e chamar de lugar. Também toca na questão da preservação do caráter do lugar, utilizando o termo "stabilitas loci", como uma necessidade psicológica e antropológica para o homem. Novamente, a questão da morfologia urbana para a preservação, o projeto e o desenho urbano, estão presentes.

\subsection{Morfologia urbana, paisagem e "genius loci"}

Não entraremos aqui no mérito do conceito de paisagem, que como já foi visto dependerá da disciplina a que está referido. Mas, resumidamente, a paisagem é uma construção, e não existiria paisagem se não houvesse observador. Já comentamos que há um certo consenso sobre o que é "paisagem cultural" como: "testemunho do trabalho do homem, de sua relação com a natureza, como um retrato da ação humana sobre o espaço ou ainda como panorama e cenário." (RIBEIRO, 2007, p. 14). E novamente para explicar a relação entre a morfologia urbana e a paisagem, recorreremos a Lamas (2011, p. 37): “ $A$ morfologia urbana estudará essencialmente os aspectos exteriores do meio urbano e as suas relações recíprocas, definindo e explicando a paisagem urbana e a sua estrutura.". Assim havendo espaço e ação humana (um simples observador inclusive) haverá leitura, percepção, um “alguém” colocando um valor (podendo este ser estético ou não) um sentido, um significado, e assim poderá haver morfologia urbana. E mais uma vez, o modo como é feita a leitura deste espaço humanizado é que marca a divergência dos autores.

O espaço não se limita à cidade, inclui extensões maiores ou menores do território. "O campo de estudo da morfologia será então a totalidade do território como lugar de transformações produzidas pelo homem, ou, por outras palavras, todo o território como lugar de intervenção da arquitetura." (LAMAS, 2011, p. 70) Lamas alarga a noção de "forma urbana" a todo o território, o que alarga a percepção das paisagens. Ainda segundo a visão de Lamas, que é basicamente emprestada de Rossi, tais paisagens (cidades ou não) são tratadas como objeto estético e como arquitetura, são obras de arte sociais coletivas com processo de formação no tempo.

Lamas recorre à Rossi para falar de "genius loci'. Mas certamente quem mais recorreu ao termo foi Norberg-Schulz (1980). Vejamos o que estes autores falam sobre 
"genius loci". A definição é dada por Rossi que afirma que "genius loci" ou simplesmente "locus" é a <<relação singular que existe entre certa situação local e as construções que estão nesse lugar >>, mas não é o sítio geográfico, tampouco o ambiente. A origem do termo vem de tempos antigos quando se acreditava que o sítio era governado pelo "genius loci”, pela divindade do local que presidia a tudo o que se desenvolvia nesse mesmo lugar. Ainda segundo Rossi (1966):

O conceito de locus sempre esteve presente na tratadística clássica, antes em Palladio e depois em Milizia seu tratamento toma cada vez. mais um aspecto de tipo topográfico e funcional; mas nas palavras de Palladio há ainda em forma viva o estremecimento do mundo antigo, o segredo desta relação que é mais evidente, por cima da cultura especifica arquitetônica, em certas obras suas como em Malcontenta ou a Rotonda, as quais devem precisamente à <<situação >> algumas das condições para sua compreensão. (ROSSI, 1966, p. 157.Tradução nossa.)

Lamas em outro momento faz a relação do "genius loci" e as pré-existências do lugar, ou também se pode chamar de "situação". O que nas cartas patrimoniais chama-se também de "spiritus loci" ou caráter do lugar:

É frequente, em determinadas metodologias de projecto, o recurso sistemático a qualquer preexistência como suporte da forma a criar. Recordo a obsessão das preexistências, evidente no discurso de alguns arquitectos do Porto e Lisboa. (...) $O$ processo criativo utiliza sempre, a preexistência como apoio, e elemento e condicionador da forma arquitetônica. Por outras palavras, e como nos exemplos apresentados por Rossi, o sítio é um $<$ génio $>>$ determinante e inseparável da arquitectura que o ocupará - no fundo, é já a génese da arquitetura. (LAMAS, 2011, p. 64)

Rossi diferencia "locus" (como ponto singular e da situação) e o ambiente, porque entende que o ambiente "parece extraordinariamente vinculado à ilusão", como um cenário que "imobiliza a vida e entristece como todas as falsidades turísticas de um mundo desaparecido." (ROSSI, 1966, p. 179). Rossi abomina a ambientação:

Não por causalidade este conceito de ambiente é aplicado muitas vezes e recomendado por aqueles que pretendem conservar as cidades históricas mantendo as fachadas antigas ou reconstruindo de modo tal que se mantenham todos os perfis e as cores e as coisas deste gênero; e que encontramos depois destas operações, supondo que sejam 
sustentáveis e realizáveis? Uma cena vazia, com frequência repugnante. (ROSSI, 1966, p. 179. Tradução nossa.)

Nesse mesmo livro, Rossi comenta que o conceito de "locus" deve ser objeto de investigações particulares, aplicadas a toda a história da arquitetura. Inclusive deve se analisar a relação entre locus e o projetar, pois: "Somente à luz destas investigação se poderá resolver o contraste aparentemente irremediável entre o projetar como elemento racional e como imposição e a natureza do lugar que participa na obra". Resta saber se tais investigações foram realizadas e quais são elas. Neste sentido encontramos uma obra, a de Norberg-Schulz, Genius Loci: towards a phenomenology of Architecture (1980), que foi publicada pela primeira vez em italiano sob o título "Genius loci - paesaggio, ambiente, architettura”, em 1979. Norberg-Schulz faz uma leitura fenomenológica da arquitetura, apoiando-se na filosofia de Heidegger. Ele afirma que:

O conceito de espaço existencial é aqui dividido nos termos complementares 'espaço'e 'caráter', de acordo com as funções básicas de 'orientação' e 'identificação'. Espaço e caráter não são tratados em um modo puramente filosófico (como realizado por O. F. Bollnow), mas são diretamente relacionados à arquitetura, seguido da definição da arquitetura como uma 'concretização do espaço existencial'. 'Concretização' é além disso explicado por meio dos conceitos de 'gathering' e 'coisa'. A palavra 'coisa' originalmente significava uma reunião (gathering), e o significado de qualquer coisa consistia no que ela reúne. Então Heidegger disse: 'Uma coisa reúne o mundo' (...) (NORBERG-SCHULZ, 1980, p. Tradução nossa.).

OutroconceitoqueNorberg-SchulzdeveaHeidegger,éoconceitodehabitar(dwelling) como o propósito da arquitetura. O homem habita, pois ele consegue orientar-se e identificar-se com o ambiente, quando ele o experimenta como algo significativo. ( NORBERG-SCHULZ, 1980, p. 5). Habitar implica algo mais que abrigar, pois implica que os espaços onde a vida ocorre são lugares. "Um lugar é um espaço no qual há um caráter distinto.". Este caráter distinto é o "genius loci" ou "espírito do lugar". E segundo Norberg-Schulz (1980, p.5), “Arquitetura significa visualizar o 'genius loci', e a tarefa do arquiteto é criar espaços significativos, onde ele ajude o homem a habitar.

Estas palavras introdutórias de Norberg-Schulz são muito significativas, e resumem a essência do livro. Gostaria de fazer um paralelo com o que vimos antes de Rossi e Lamas, antes de prosseguir com Norberg-Schulz. Há muitos paralelismos e pequenas diferenças entre Rossi e Norberg-Schulz. O que Rossi chama de 'locus', podemos per- 
feitamente intercambiar por 'lugar', e o que chama de 'situação', relaciona-se o 'caráter distinto', de Norberg-Schulz, que nada mais é que o 'genius loci' e o 'espírito do lugar'. Como ambos são arquitetos, falam da arquitetura e da importância do 'genius loci' no processo de criação. Aqui há matizes distintos entre os dois, pois para Norberg-Schulz é mais um analisar lugares que auxiliem nesse processo de projetar, e não tanto o lugar do projeto. Um pequeno matiz acrescentado por Norberg-Schulz ao termo lugar (ou “locus"), é a questão das duas funções psicológicas envolvidas, a orientação e a identificação, remetendo a certa proximidade ao trabalho de Lynch. Se bem que este último aproxima-se mais da linha da Gestalt, enquanto Norberg-Schulz é existencialista fenomenológico.

Apesar de concordarem na conceituação do "genius loci”, Rossi e Norberg-Schulz parecem divergir no modo de leitura e nas categorias e elementos de análise. Enquanto Rossi, parece estar ligado com categorias tradicionais de leitura de cidade, como bairro, tipologias e ruas, Norberg-Schulz parece estar com categorias mais abertas, aplicáveis a qualquer tipo de lugar. Vamos apresentar rapidamente quais são os elementos que estruturam um lugar.

Norberg-Schulz, inicialmente, ao tratar da fenomenologia do lugar, coloca a distinção do natural ou fenômeno humano, ou em termos concretos entre 'paisagem'(landscape) e 'assentamento'(settlement), e depois fala das categorias terra-céu (horizontal-vertical) e fora-dentro (outside-inside). (NORBERG-SCHULZ, 1980, p. 12) Desse modo, o habitar sempre ocorrerá entre terra-céu, e "settle" é mais que uma relação econômica, mas um conceito existencial que denota a habilidade de atribuir significado. Assim, quando o meio-ambiente é significativo, o homem está em casa, ele habita. O autor afirma que todos os lugares marcam presença ('presencing') sempre em relação à terra e ao céu, como os edifícios ficam de pé sobre a terra e sobem ao céu (sentido horizontal e vertical), como é sua silhueta.(NORBERG-SCHULZ, 1980, p. 50; 58). Além disso, de uma relação significativa entre horizontais e verticais também depende a forma da cobertura. O caráter do lugar ou "genius loci" leva em conta esta relação do edifício com a terra e o céu, um modo de estar na Terra que permite a identificação humana. As categorias dentro-fora tem relação com o grau de abertura destes lugares, como eles permitem abertura ou interioridade, como desmaterializam as edificações e criam interação entre exterior e interior, e também como deixam transmitir a luz. Tudo isso determina o caráter da arquitetura. (NORBERG-SCHULZ, 1980, p. 65-67) 
Orientação e identificação significam a experiência do lugar feito pelo homem (man-made place) dentro deste lugar. "O 'genius loci' depende de como estes lugares são em termos de espaço e caráter, isto é, em termos de organização e articulação." (NORBERG-SCHULZ, 1980, p. 69. Grifo do autor. Tradução nossa.).

Também fala de três arquétipos de lugares feitos pelo homem, que são a arquitetura romântica (topológica mais que geométrica e eminentemente local, como exemplo cita a arquitetura de casas medievais e o art-noveau) (NORBERG-SCHULZ, 1980, p. 69-71), a arquitetura cósmica (abstrata, geométrica, labiríntica, e como exemplo cita a cidade islâmica), e a arquitetura clássica (que unifica os traços topológicos e geométricos; como exemplo cita a arquitetura grega). Segundo Norberg-Schulz, estes três arquétipos de arquitetura - romântica, cósmica e clássica - ajudam a interpretar o genius loci de qualquer assentamento, porém eles nunca aparecem em formas puras mas em vários tipos de síntese. (NORBERG-SCHULZ, 1980, p. 73-74)

Para entender o "genius loci", o autor introduz os conceitos de significado e estrutura. O significado de qualquer objeto consiste na relação com os outros objetos, o fato de que o objeto reúne (the object 'gathers'). A estrutura são as propriedades formais de um sistema de relações. Estrutura e significado são aspectos de uma mesma totalidade, e ambos abstrações de um fluxo de fenômeno, com estáveis relações que permanecem mais que acontecimentos transitórios. (NORBERG-SCHULZ, 1980, p. 166). Creio que o autor toca em um aspecto importante para as questões de patrimônio que são a constância e a mudança dos lugares (NORBERG-SCHULZ, 1980, p. 180). Transcrevemos uma parte interessante sobre isso:

The structure of a place is not a fixed, eternal state. As a rule places change, sometimes rapidly. This does not mean, however, that the genius loci necessarily changes or gets lost. Later we shall show that taking place presupposes that the places conserve their identity during a certain stretch of time. Stabilitas loci is a necessary condition for human life. How then is this stability compatible with the dynamics of change? First of all we may point out that any place ought to have the 'capacity' of receiveing different 'contents', naturally within certain limits. A place which is only fitted for one particular purpose would soon become useless. Secondly it is evident that a place may be 'interpreted' in different ways. To protect and conserve the genius loci in fact means to concretize its essence in ever new historical contexts. We might also say that the history of a place ought to be its 'self-realization'. What was there as possibilities at the outset, is uncovered through human action, illuminated and 'kept' in works of architecture which are simultaneously 'old and new'. A place therefore comprises properties having a varying degree of invariance. (NORBERG-SCHULZ, 1980, 


\section{p. 18. Grifo nosso.)}

Desse modo, a "stabilitas loci", o preservar a essência do lugar, seu "genius loci" é importante para a condição humana. Porém como fazê-lo em novos contextos históricos, o autor não diz. Será possível? E como fazê-lo? Creio que o autor deixa esta questão em aberto. Certo que seguindo sua linha de raciocínio, o trabalho de arquiteto seria preservar este "genius loci", ou agregar seu lugar no projeto, e além disso criar espaços significativos, espaços em que o homem possa habitar e chamar de lugar, em processos contínuos, e em novos contextos.

Outra questão que aparece em discussão é se o genius loci, fruto de construção e percepção sociais, muda com o tempo. É o que parece apontar um dos pontos da Declaração de Quebéc (2008), documento do ICOMOS sobre spiritu loci:

Como o espírito do lugar é um processo em permanente reconstrução, que corresponde à necessidade por mudança e continuação das comunidades, nós afirmamos que pode variar ao longo do tempo e de uma cultura para outra, em conformidade com suas práticas de memória, e que um lugar pode ter vários espíritos e pode ser compartilhado por grupos diferentes. (ponto 3. Grifo nosso)

Desse modo, introduziu-se apenas algumas questões relativas ao genius loci/ spiritus loci que merecem posterior aprofundamento.

\subsection{Métodos e leitura morfotipológica da vila ferroviária de Rincão}

Existe uma grande gama de metodologias para a leitura do ambiente, mencionou-se as abordagens de Lamas e de Rossi, e brevemente a metodologia de Lynch. Apesar das diferenças, estas abordagens possuem pontos em comum, e parecem aplicáveis. Preferiu-se adotar metodologias que se aproximam. Também por diferir na metodologia, e não por não considerarmos importante, deixamos de lado as metodologias de NorbergSchulz, e de Gordon Cullen e as sequências visuais. Busca-se resumir e aplicar o método ao nosso objeto de estudo, as vilas ferroviárias. Ou seja, um método que seja viável para aplicação neste estudo, já que a questão da morfologia urbana mereceria um estudo à parte. O método de Lynch é trabalhoso, por se basear em uma imagem coletiva, por en- 
trevistas. Não será possível aplicar neste projeto. Utilizamos Lamas por ter elementos em comum com a abordagem de Rossi.

A metodologia de Rossi é baseada no sistema descritivo dos geógrafos franceses e tratadistas clássicos que inclui questões tipológicas, áreas de estudo (bairros e residências) e elementos primários. As questões da tipologia dos edifícios tem origem nos teóricos de arquitetura da Ilustração: "Nas aulas da Escola Politécnica, Durand escrevia: 'De mêmme que les murs, les colonnes, etc., sont les éléments dont se composent les édifices, de même les edifícices sont les éléments dont se composent les villes. ’'(ROSSI, 1966, p. 66). Assim a cidade é composta por tipologias de edifícios. Existe uma relação binária entre tipologia edificatória e morfologia urbana, cujo conhecimento é importante para o conhecimento da estrutura dos fatos urbanos, segundo Rossi (1966, p. 101).

Para o estudo da cidade, esta deverá ser subdividida em unidades menores que Rossi, chama de áreas de estudo:

Este contorno urbano mínimo está constituído pela área-estudo; com este termo entendo designar uma porção da área urbana que pode ser definida ou descrita recorrendo a outros elementos da área urbana tomada em seu conjunto; por exemplo o sistema viário. (ROSSI, 1966, p. 100. Tradução nossa).

Umas das áreas de estudo seria o bairro, uma unidade morfológica e estrutural. Tais unidades devem ser estudadas tanto do ponto de vista formal como histórico e social. E dentro destas áreas de estudo encontram-se os elementos primários ou fatos urbanos primários. Rossi não especifica quais são, mas dentre eles, destaca os monumentos, por seu caráter de permanência, por desenvolver uma ação precisa, funcionando como núcleos de agregação e por sua individualidade. Acredito que Lamas dá continuidade à metodologia de Rossi, e especifica tais elementos.

Lynch é mais pragmático que Rossi, e para seu estudo de três cidades, elencou os seguintes elementos imagéticos, nos quais se podem dividir a imagem da cidade: Ruas, Limites, Bairros, Pontos Nodais e Marcos. A nosso ver, tais elementos encontram correspondência com as categorias de Rossi. Novamente encontramos as áreas de estudo de Rossi presente como Bairros, que possuem Limites. Os demais elementos Ruas, Pontos Nodais e Marcos, seriam o que Rossi chama de elementos primários. Lynch assim define os bairros: 
Os bairros são áreas relativamente grandes da cidade, nas quais o observador pode penetrar mentalmente e que possuem algumas características em comum. Podem ser reconhecidos internamente, às vezes usados como referências externas - como, por exemplo, quando uma pessoa passa por eles ou os atravessa. (...) (LYNCH, 1960, p. 75)

E continua:

As características físicas que determinam os bairros são continuidades temáticas que podem consistir numa infinita variedade de componentes: textura, espaço, forma, detalhe, símbolo, tipo de construção, usos, atividades, habitantes, estados de conservação, topografia. Numa cidade edificada de modo tão fechado e compacto, como Boston, as homogeneidades de fachada-material, modelos, ornamentação, cores, a linha do horizonte e, em especial, o modo de dispor as janelas - eram, todas, indicações básicas para a identificação dos bairros principais. Beacon Hill e a Avenida Commonwealth são dois exemplos disso. Os indicadores não eram apenas visuais: o barulho era igualmente importante. Na verdade, às vezes a própria confusão podia ser um indicador, como no caso de uma mulher para quem o fato de começar a se sentir-se perdida era um sinal de que estava no North End. (LYNCH, 1960, p. 75)

Assim, dentro de um bairro, além dos elementos citados, como limite, rua, pontos nodais e marcos, pode-se distinguir várias características físicas ou indicadores, não necessariamente visuais que ajudam na orientação e identificação dos bairros, e que constituem a imagem desta parte da cidade.

Lamas, como sabemos, dá continuidade aos estudos de Rossi. As áreas de estudo de Rossi, são ampliadas e ele chama de dimensões espaciais da morfologia urbana, e encontram-se assim divididas: dimensão setorial - a escala da rua; dimensão urbana - a escala do bairro, e dimensão territorial - a escala da cidade (que compreende certamente bairros, grandes infraestruturas e áreas verdes). Nas diferentes dimensões espaciais ou escalas é possível observar e analisar os diferentes elementos morfológicos ou morfotipológicos, que apesar de serem as mesmas nas diferentes escalas, se articulam de maneira diferente e estruturam os espaços. Lamas cita e define cada um dos seguintes elementos morfotipológicos:

a) O SOLO - O PAVIMENTO

\section{b) OS EDIFÍCIOS - O ELEMENTO MÍNIMO}

Não seria possível continuar a abordar esta questão sem referir os estudos de Aymonino, Rossi e outros, da Faculdade de Arquitetura de Veneza, sobre as relações entre a < morfologia urbana e a tipologia edificadas $>>$. Nesses trabalhos, os elementos primários da forma urbana são identificados com os tipos construtivos. Os edificios 
agrupam-se em diferentes tipos, decorrentes da sua função e forma, estabelecendo relações biunívocas e dialécticas com as formas urbanas. A questão dos tipos edificados, tem sido abordada por vários autores: desde Palladio, em que os tipos se identificam com as villas residenciais, às propostas classificativas de Quatremère de Quincy ou de Durand. Para este último, < <o tipo é um esquema que respeita as necessidades funcionais e permite elaborar um projecto $>>$, distinguindo-se do <〈modelo>>, que será a representação de uma outra realidade. (LAMAS, 2011, p. 86)

\section{c) O LOTE - A PARCELA FUNDIÁRIA}

\section{d) O QUARTEIRÃO}

O quarteirão foi (e é) um instrumento de trabalho urbanístico na produção da cidade tradicional, permitindo a localização e definição da arquitetura e relacionando-a com a estrutura urbana. Foi um elemento morfológico sempre presente nas cidades até ao período moderno, constituindo elemento da estética urbana.

O Movimento Moderno imprimiu ao quarteirão um processo de transformações sucessivas que culminaram no seu abandono, num quadro mais vasto de profundas modificações na maneira de pensar e organizar a cidade. (LAMAS, 2011, p. 94)

\section{e) A FACHADA, O PLANO MARGINAL}

(...) A fachada é o invólucro visível da massa construída, e é também o cenário que define o espaço urbano. (LAMAS, 2011, p. 96)

(...) a fachada admitia graus de autonomia em relação ao interior do edifício, obedecendo leis de simetria, repetição, equilíbrio, hierarquia e enfatização de alguns elementos mais significantes (a porta principal, o andar nobre, o eixo de simetria e a parte central, etc.), evidentes nas arquiteturas eruditas e tantas vezes nas arquiteturas populares. Tais regras eram aplicadas em função de uma imagem exterior pretendida, a que por vezes se subordinava o interior dos edifícios. (LAMAS, 2011, p. 96)

f) O LOGRADOURO : é o espaço privado do lote não ocupado por edificações. É o que vemos muitas vezes designado como "vazios", sendo o edificado, os "cheios".

O logradouro constitui o espaço privado do lote não ocupado por construção, as traseiras, o espaço privado, separado do espaço público pelos contínuos edificados.

O logradouro foi, também, na cidade tradicional, um resíduo, ou resultado dos acertos de loteamentos e de geometria de ocupações dos lotes.(LAMAS, 2011, p. 98)

É através da utilização e desenho do logradouro que se faz parcialmente

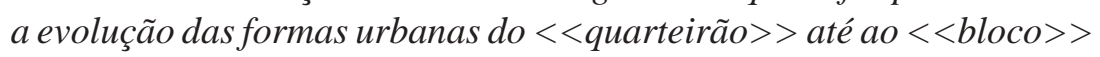
construído. (LAMAS, 2011, p. 98). 


\section{h) A PRAÇA}

Nas cidades islâmicas, a praça não existe. Quando muito, o cruzamento de ruas produz uma área mais larga no ponto de confluência. A praça é um elemento morfológico das cidades ocidentais e distingue-se de outros espaços, que são resultado de alargamento ou confluência de traçados - pela organização espacial e intencionalidade de desenho. (LAMAS, 2011, p. 100)

\section{i) O MONUMENTO}

A ampliação do conceito de monumento desenvolvida nas últimas décadas partiu do elemento singular arquitetônico ou escultórico para abranger conjuntos urbanos, centros históricos ou as próprias cidades. A evolução destes conceitos e um novo olhar sobre a cidade do passado como $<<$ cidade do presente $>>$ alteraram a $<<$ maneira de pensar o urbanismo $>>$, recolocando o patrimônio edificado na vida da sociedade. (LAMAS, 2011, p. 104)

\section{j) A VEGETAÇÃO \\ k) O MOBILIÁRIO URBANO}

(...) A imagem de Las Vegas é constituída em boa parte pela presença dos elementos parasitários e móveis: anúncios e letreiros, luzes, etc. Mas este é, sem dúvida, um caso extremo, que não pode ser generalizado. (LAMAS, 2011, p. 110)

Situados os conceitos e metodologias para a leitura morfotipológica, acredita-se que agora pode-se adotar uma fusão de metodologias, ou melhor uma fusão das metodologias para a leitura das vilas ferroviárias, com base em Rossi e Lamas. Não será utilizada a leitura diacrônica, isto é evolução da morfologia urbana no tempo. No caso de Rincão, esta leitura não caberia porque a vila ocupa apenas parte do tecido urbano da cidade, que sabemos que teve até agora, apenas dois momentos - antes do complexo ferroviário e depois - da constituição deste complexo. Quando muito, a leitura diacrônica poderia ser feita segundo os diferentes momentos nos quais as casas foram construídas, mas infelizmente nos faltam dados. Só conseguiu-se a seguinte cronologia geral: a) primeiras casas junto à estação; b) construção do armazém regulador e as centenas de casas c) construção da subestação elétrica e unidades.

Apesar de nosso trabalho ter fundamentos histórico-sociais, reconhecem-se os limites do mesmo, assim, foi escolhida apenas uma das seis vilas ferroviárias para esta leitura. Das três dimensões ou escalas de análise da morfologia urbana apontadas por Lamas, certamente a escala de Rincão é a escala do bairro. No capítulo 2, analisamos os seguintes itens: implantação, tipologias, equipamentos, programas, estilos, como também 
de maneira geral e comparativa, as seis vilas ferroviárias escolhidas. Aqui retoma-se os referidos aspectos, porém à luz da revisão bibliográfica sobre morfologia urbana, e analisa-se apenas a vila ferroviária de Rincão, escolhida por apresentar riqueza de tipologias arquitetônicas e características morfotipológicas preservadas. Recorda-se que muitas das características observadas em Rincão só foram detectadas graças ao método comparativo. Portanto, um ponto a se ter em conta nas futuras pesquisas: a escolha de um conjunto de casos para a utilização do mesmo. Aqui não voltaremos ao significado histórico e social da vila de Rincão, para não ser repetitivo. Contudo, é de extrema importância na leitura morfotipológica, retomar tal significado. Ao analisar mais detidamente a vila de Rincão, apontamos paralelamente possíveis direcionamentos ou elementos a se ter em conta para um possível "guia de transformação" ou estabelecimento de uma "área de conservação".

\section{LOCALIZAÇÃO:}

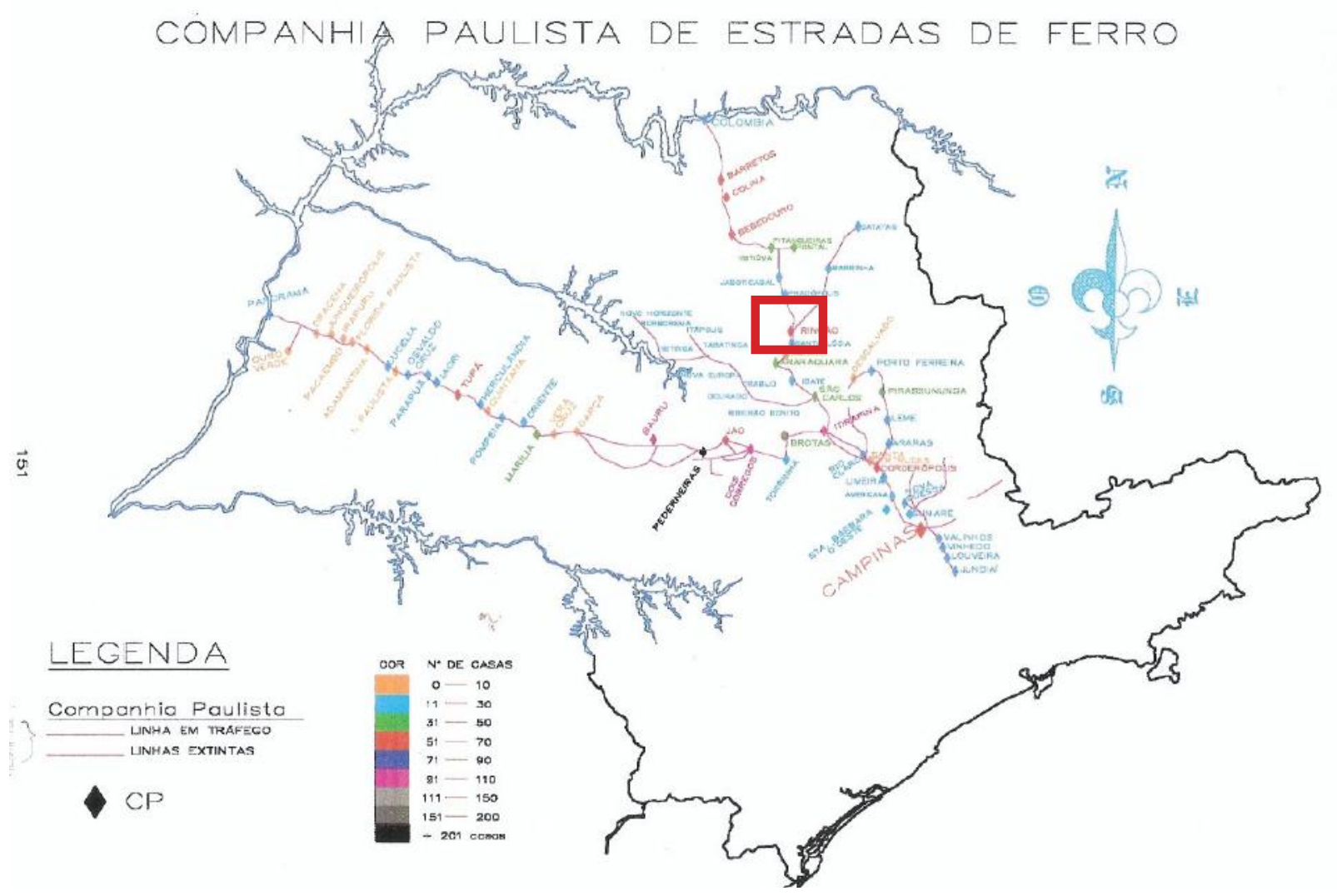

Mapa 2 - Linhas e as vilas ferroviárias da Companhia Paulista. No local circulado em vermelho encontra-se Rincão. Fonte: MORAIS, 2002. 

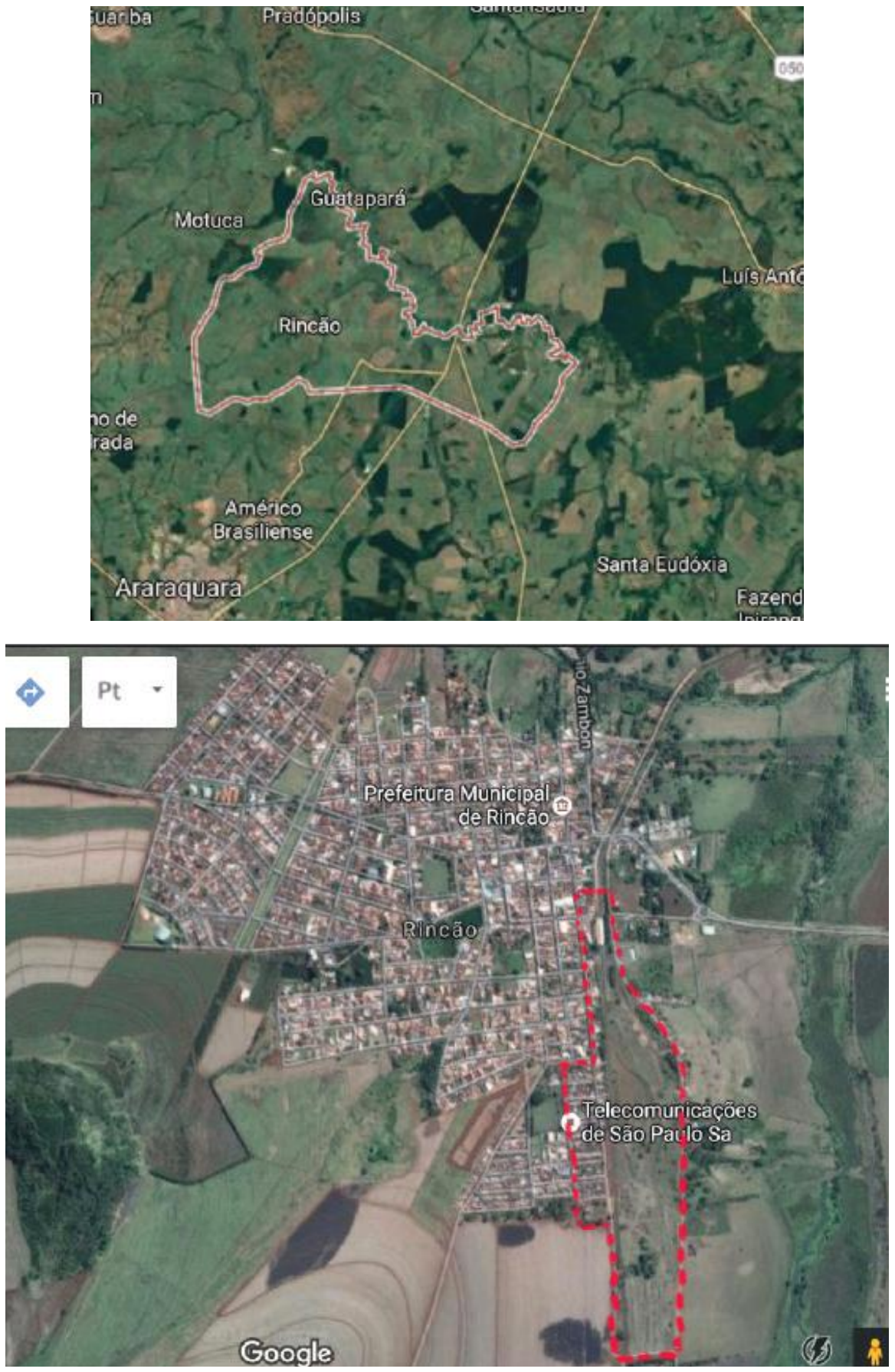

Mapa 19 - Foto aérea do município de Rincão e arredores. Mapa 20 Foto aérea do município e a área assinalada corresponde ao complexo ferroviário de Rincão. Fonte: Google, 2011.

\section{DESENVOLVIMENTO HISTÓRICO:}

Ano de construção: a cidade surgiu com os rumores da ferrovia, e portanto, a história de ambas se confundem, cidade e estação do mesmo ano de 1884. A hipótese para Rincão é que houve dois momentos de construção de unidades na vila ferroviária. Um primeiro núcleo surgiu juntamente com a estação e, portanto, é de 1884, e outro núcleo surgiu com a 
construção do armazém de café, em 1922. Infelizmente, o edifício do armazém não existe mais. No Relatório da Companhia Paulista de 1921, fala-se na construção de 120 unidades em Rincão. Segundo o Inventário da ex-RFFSA e SPU, a vila ferroviária hoje possui 72 unidades. Em nossa última visita de campo, contabilizamos 206 unidades. Sobre a divergência de números, a hipótese é a de que o Relatório de 1920, somente refere-se à construção de casas aprovadas em 1920, não considerando as unidades já existentes, estas localizadas mais próximas à estação. O número divergente entre ex-RFFSA e SPU é devido a forma de realização das visitas de campo, e também talvez não foram contabilizadas aquelas unidades vendidas pela FEPASA ou RFFSA, antes de sua extinção. Descobriu-se ainda que algumas casas, ou foram desmembradas, como aquelas próximas à estação, ou então, nos demais quarteirões, dois terrenos foram remembrados.

Infelizmente não se encontrou plantas originais nem da vila nem das casas, portanto, não sabemos nem as datas de construção, nem a autoria. Apenas sabemos que a seção de Linhas e Edifícios da Companhia Paulista, era a responsável por sua construção e manutenção. A planta mais antiga encontrada é a de implantação, datada de 1967, já portanto, a Companhia Paulista integrada à empresa estadual FEPASA. A planta encontra-se no arquivo da Inventariança da ex-RFFSA. E também encontramos um levantamento realizado pela Prefeitura Municipal de Rincão, da década de 1980.

Situação fundiária: pertenceu a Companhia Paulista, integrando a FEPASA (Ferrovias Paulistas S.A.) em 1961, e depois à RFFSA - Rede Ferroviária Federal S.A). Os bens imóveis operacionais (estação e linhas) pertencem ao DNIT, que administra a concessão à Ferroban/ALL. E os bens imóveis não operacionais, que incluem a vila ferroviária são pertencentes à SPU, que passou a administrá-la desde 2007. Em algum momento, unidades da vila ferroviária foram vendidas e compradas por alguns moradores. Outras foram compradas pela Prefeitura Municipal de Rincão, mas esta não saldando a dívida, as casas retornaram para a União. Portanto, a situação fundiária das casas é diversa. A parte dos armazéns pode ser bem operacional ou não operacional, o que merece verificação junto ao DNIT ou SPU.

Darei mais atenção à leitura da vila ferroviária, do que à estação e aos armazéns. Mas, é claro, as vilas ferroviárias devem ser consideradas dentro de um complexo ferroviário, e o complexo deve ser lido em seu conjunto.

Preservação: A cidade emancipou-se em 1948, antes era distrito do município de Arara- 
quara. Seus dados estatísticos aparecem apenas em 1950, no IBGE, e nesta mesma década possuía em torno de cinco mil habitantes. Em 2010, a cidade possuía 10 (dez) mil habitantes, e a projeção do IBGE para 2015 não era muito maior. Portanto, a cidade não é obrigada a possuir um plano diretor. A cidade não possui um departamento de planejamento e a cultura está ligada ao departamento de educação, portanto não há um departamento específico para cuidar das questões da preservação.

Há um estudo de 1978, realizado pela PLANART para várias estações da FEPASA. Tal estudo teve como responsável técnico o Prof. Dr. Nestor Goulart Reis Filho. Infelizmente, tal projeto de preservação não foi realizado. O interessante é que nos relatórios da PLANART as vilas ferroviárias encontram-se descritas, e não apenas as estações.

\section{OS EDIFÍCIOS}

Como vimos no capítulo 2, em relação aos edifícios de maneira geral, os programas são simples: sala, um a três dormitórios, cozinha e banheiro, este último geralmente externo e junto uma lavanderia ou área de serviço. O principal material é a alvenaria revestida. Com exceção da casa do chefe da estação e do chefe da subestação elétrica, quase não há ornamentação, e portanto, não há como enquadrá-las em estilo arquitetônico. Também com exceção da casa do chefe da estação e da subestação elétrica, as áreas e lotes são exíguos. As três tipologias principais são: A. Casas isoladas no lote; B. Casas geminadas, com recuos; C. Casas em linha, que em Rincão descreveremos mais detalhadamente, inclusive com o que podemos chamar de subtipologias, em relação às dimensões do lote e algumas outras características.

Rincão é, entre as vilas ferroviárias analisadas, a que mais apresenta riqueza tipológica, com 9 subtipologias diferentes incluídas as casas dos chefes da estação e da subestação elétrica. Seriam em realidade 11 subtipologias diferentes, mas duas delas não existem mais. Segundo a prancha de implantação de 1967, havia 10 unidades chamadas "casas de via permanente", e 2 unidades chamadas "casas de turma de via permanente".

Descreveremos a seguir, cada uma das nove tipologias encontradas atualmente em Rincão. 


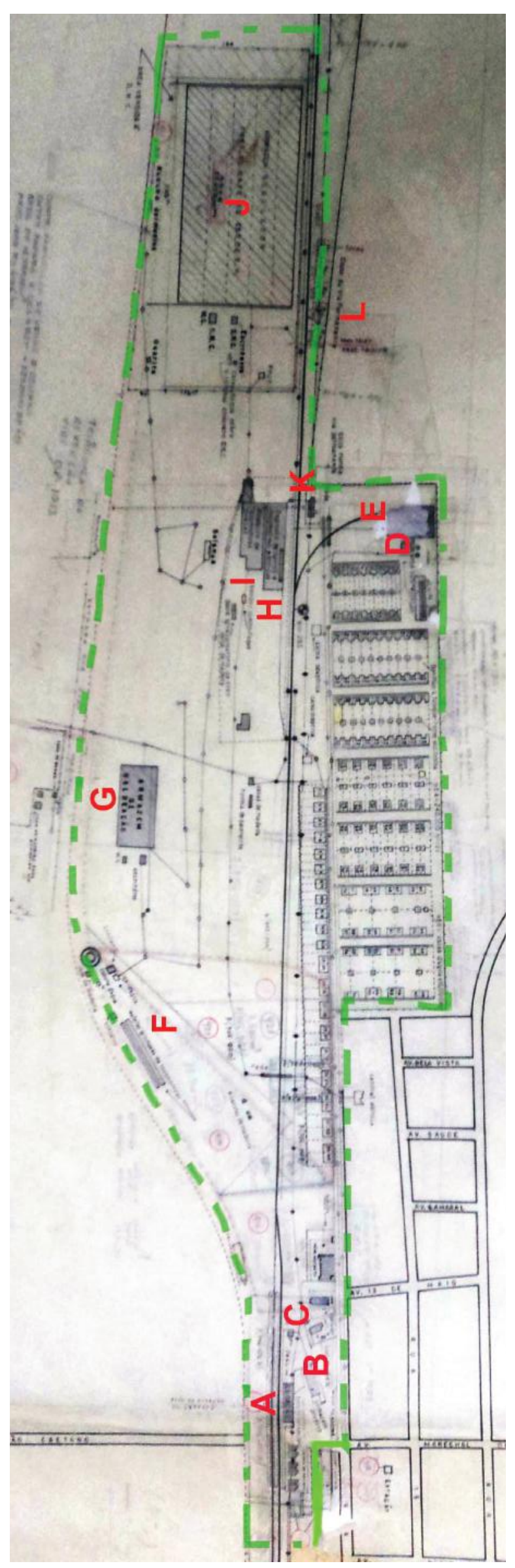

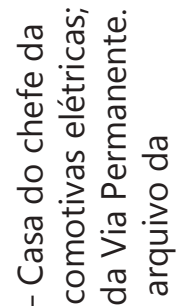

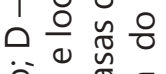

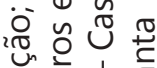

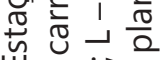

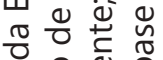
ㄴ.

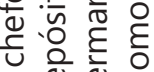
응 ๑ั กี ชั่ ن हो 岂 N हᄐ ब 广 $\frac{\pi}{0}$ U ๑ N

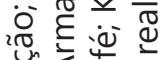

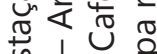
니율 《 i

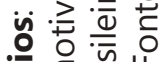
는 过 응 으으응 으

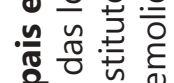
은 . 를응 흄 (1) $\frac{0}{0}$

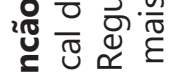
드 오 ह O . 든 है है 语皆造 은 它 윰 爻茙, 을은

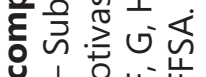
는 崩 응 ய

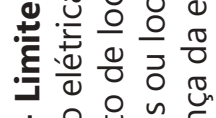

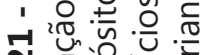
검을

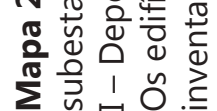




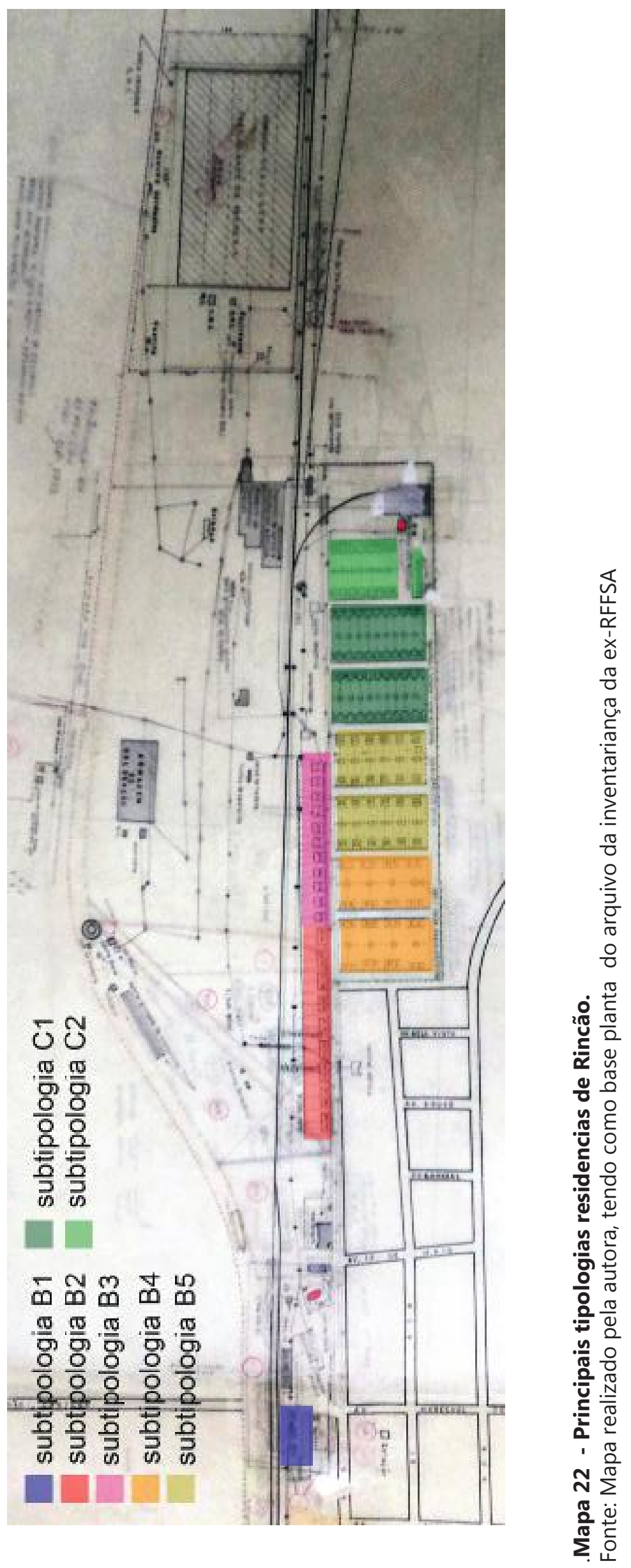



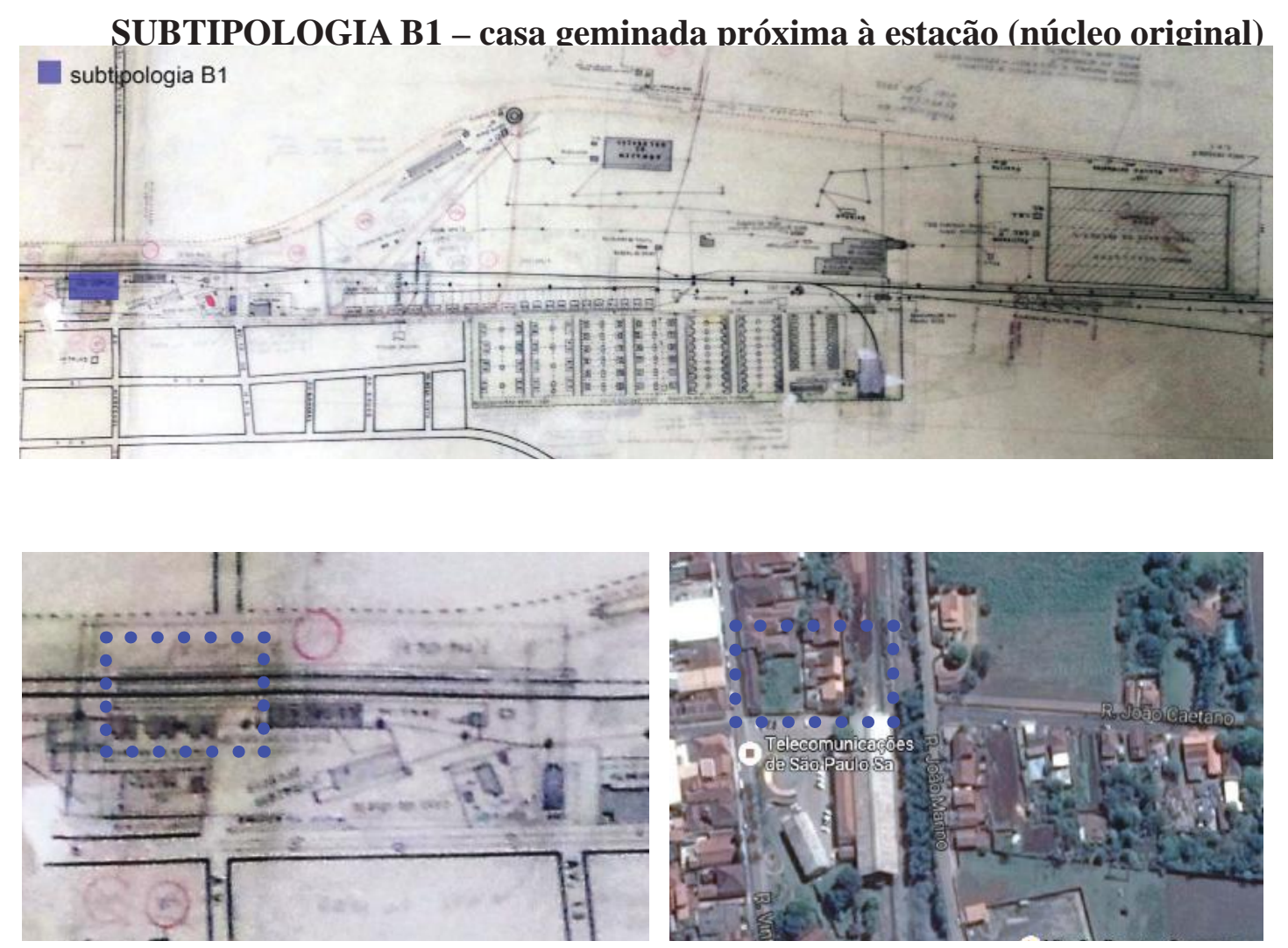

Área: 77m2, segundo Relatório "Avaliação de Edifícios e Dependências”, da RFFSA, de 31 de dezembro de 1991. Segundo o levantamento da Prefeitura, as áreas das casas desmembradas variam entre $63 \mathrm{~m} 2$ e $59 \mathrm{~m} 2$.

Pé-Direito: $3,50 \mathrm{~m}$.

Programa: Dois dormitórios (a unidade maior) ou um dormitório, sala, cozinha, banheiro e área de serviço externa.

Materiais: Cobertura: de duas águas e telhado de barro, porém não é possível saber quais são as telhas originais. A estrutura é provavelmente de tijolos, alvenaria revestida. As esquadrias externas, portas (dimensões $1,00 \mathrm{~m}$ x 2,70m, com duas folhas e bandeira) e janelas (dimensões $1,00 \times 1,70 \mathrm{~m} /$ peitoril 1,00m) originais são provavelmente de madeira. As janelas são de duas folhas, envidraçadas, e com persianas externas. Sobre a cor, não é possível saber sem um exame mais aprofundado. O piso original era de taco, segundo depoimento de moradores.

Estilo: trata-se de arquitetura modesta, sem propriamente um estilo.

Fachadas: Provavelmente a entrada seria pela parte posterior (contrário ao lado da estação) onde há um corredor que lembram as back alleys das vilas operárias inglesas. É na parte posterior da casa que também se encontram o banheiro e a lavanderia, na forma 
de um anexo. O quintal é exíguo em relação às demais tipologias. A fachada frontal é voltada para a linha do trem. Apresenta pilastras, características às várias casas das vilas ferroviárias da Companhia Paulista, sendo um elemento da estrutura posto em evidência, e posteriormente revestida. É umas das tipologias que apresenta chaminé, provavelmente para o fogão à lenha.

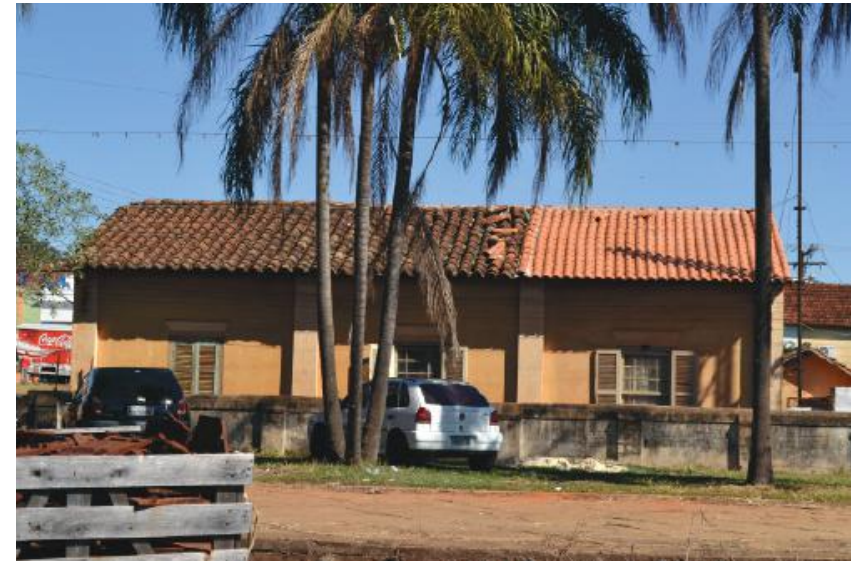

Em sentido horário, começando pela esquerda: Foto $\mathbf{1 7 9}$ - Fachada frontal. Foto $\mathbf{1 8 0}$ - fachada lateral. 181 - anexo com banheiro e tanque. Foto 182 detalhe da chaminé. Fonte: autora, 2013.
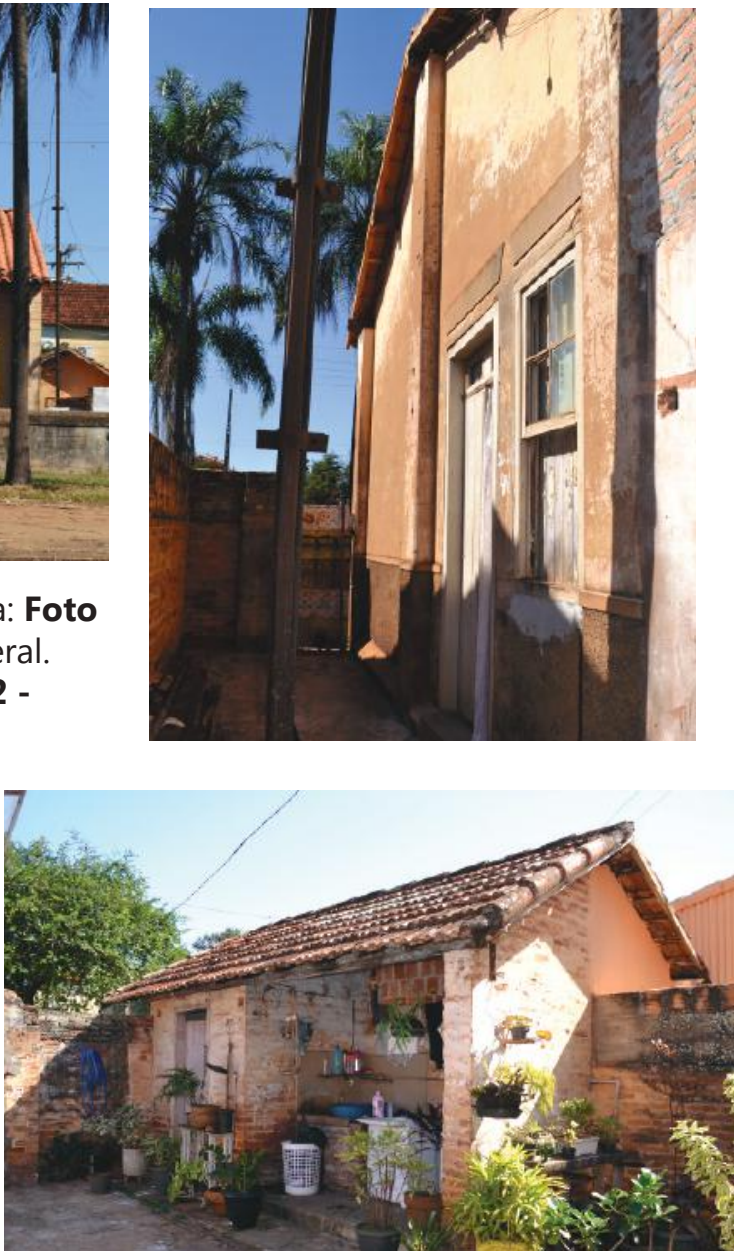

Conservação: Encontram se bastante descaracterizadas na parte posterior, e sobretudo a fachada, com a substituição da caixilharia, e modificação das aberturas das janelas e portas. Algum padrão com abertura originais das portas e janelas deverá ser observado em um possível "guia de transformação". A ocupação do terreno também foi modificada ao longo do tempo, juntando-se o anexo

Foto 183 -corredor de acesso às casas, pelos fundos do terrreno. Fonte: autora,

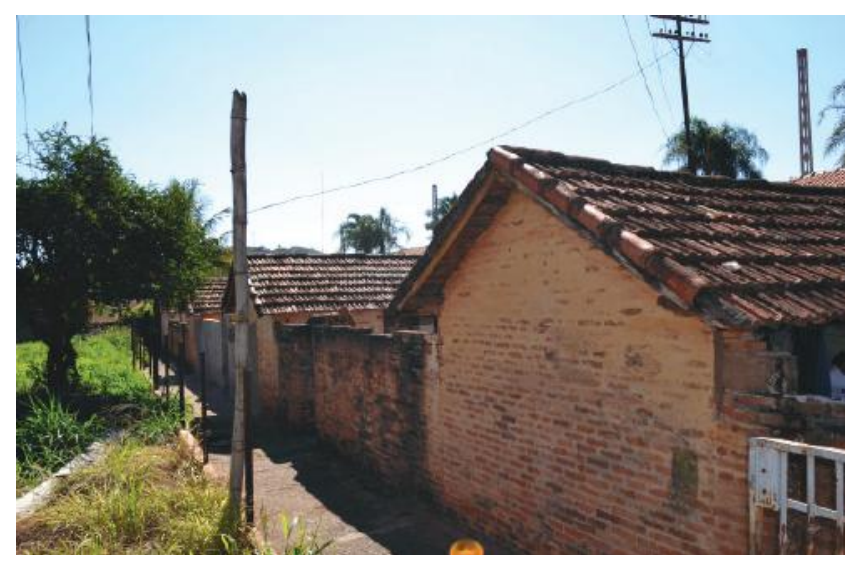



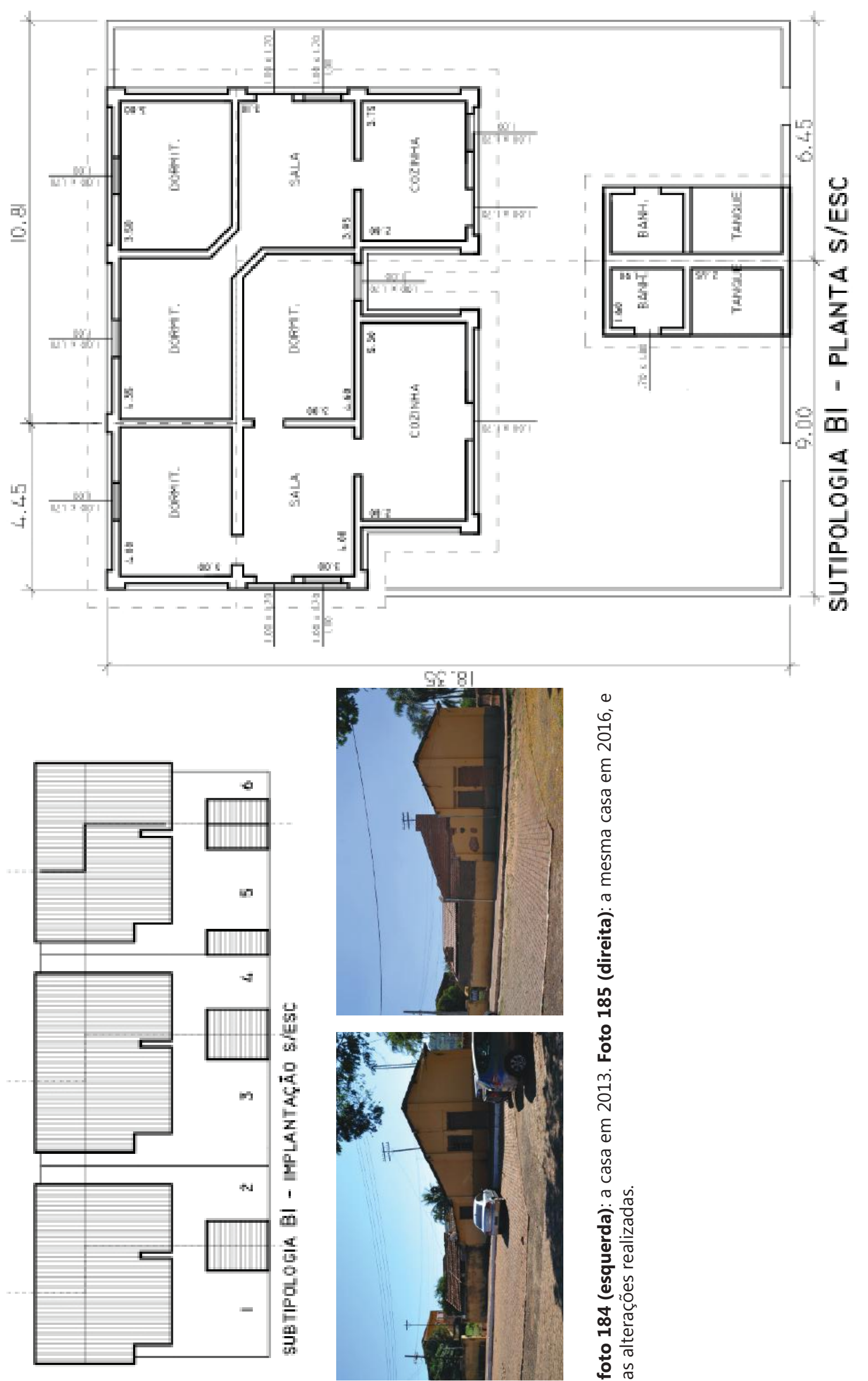

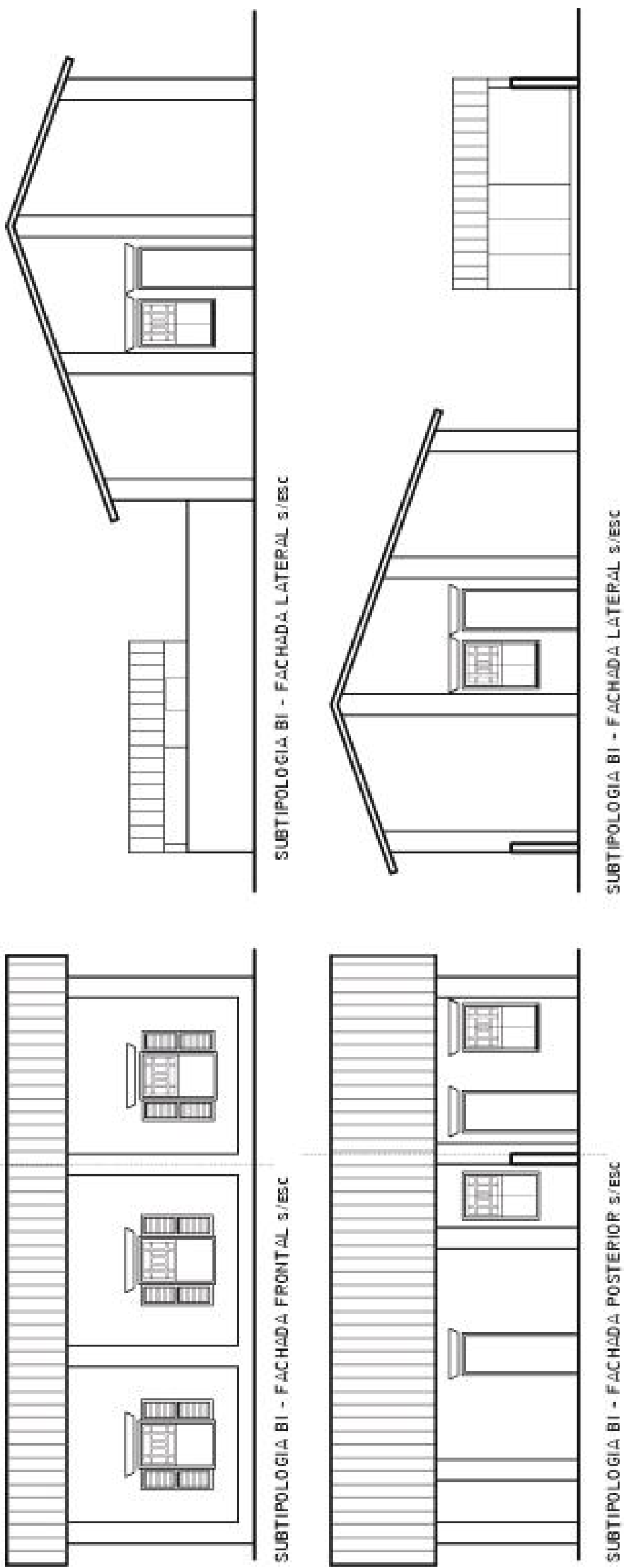
SUBTIPOLOGIA B2 - casa geminada ao longo da rua principal
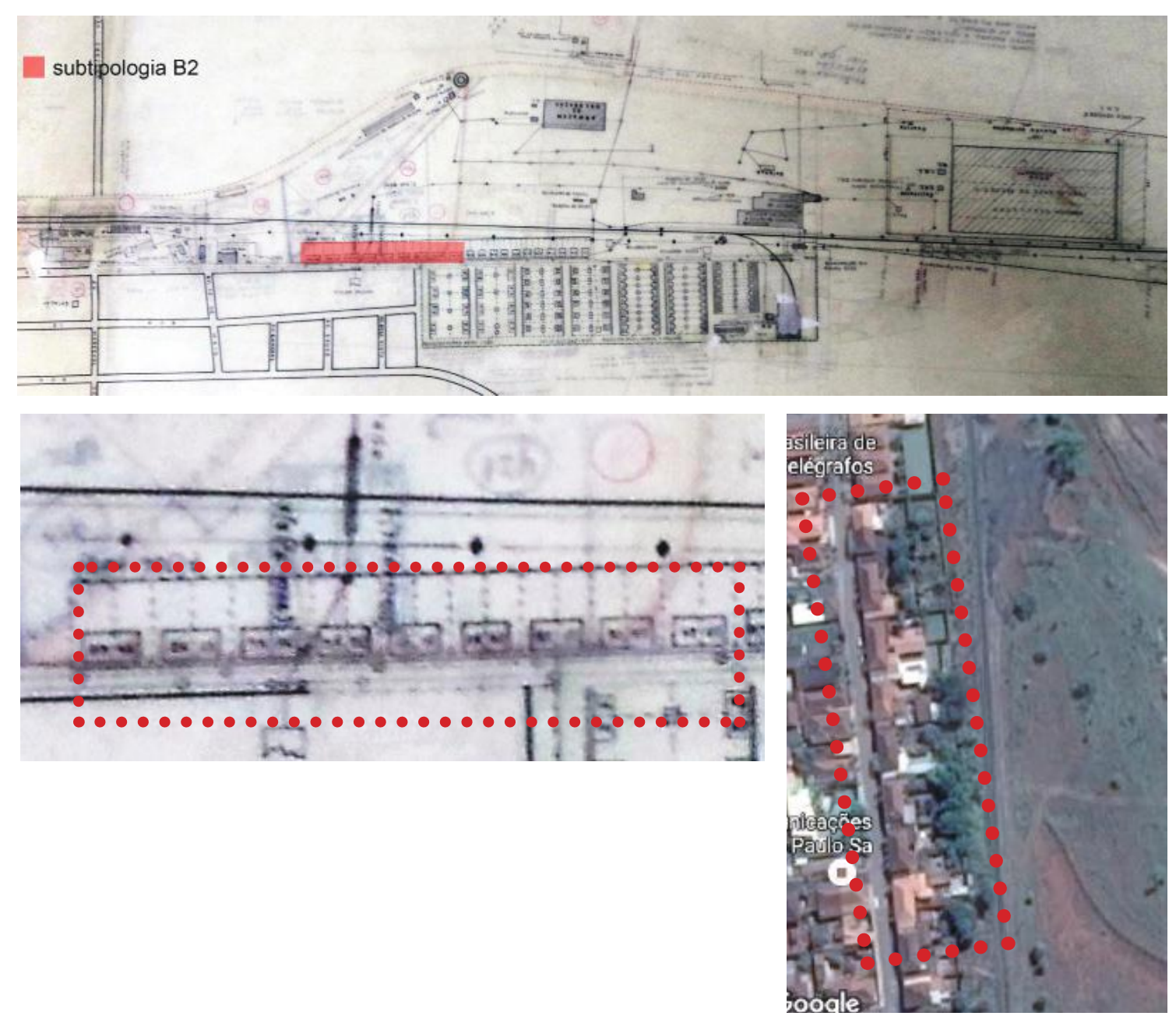

As subtipologias B2 e B3 são as únicas tipologias que não apresentam um banheiro externo na implantação realizada em 1967, porém através do levantamento da Prefeitura e da visita de campo pode-se detectar a presença deste anexo com área de serviço externo. Área - 48 m2, segundo Relatório “Avaliação de Edifícios e Dependências”, da RFFSA, de 31 de dezembro de 1991. Segundo levantamento da Prefeitura, existem 6 unidades (subtipologia B2A) com 72,01m2 (mais banheiro e área de serviço com 9,50m2) e 18 unidades (subtipologia B2B) com 59,46 m2 (mais banheiro e área de serviço com aproximadamente $9,50 \mathrm{~m} 2$ )

Pé-Direito: $3,50 \mathrm{~m}$.

Programa: Três dormitórios (subtipologia B2A) e dois dormitórios (subtipologia B2B), sala, cozinha, banheiro e área de serviço externa. 
Materiais: Cobertura: forma com a casa ao lado um telhado de quatro águas e telhado de barro, porém não é possível saber quais são as telhas originais, se as telhas francesas ou as de capa e canal. A estrutura é provavelmente de tijolos. A parede é de alvenaria revestida. As esquadrias, portas externas (dimensões $1,00 \mathrm{~m}$ x 2,70m, com duas folhas e bandeira) e janelas (dimensões $1,00 \times 1,70 \mathrm{~m} /$ peitoril 1,00m) originais são provavelmente de madeira. As janelas são de guilhotina de duas folhas, envidraçadas, e com persianas internas. Sobre a cor, não é possível saber sem um exame mais aprofundado. Apresentam porão, portanto, piso elevado, sendo o assoalho de madeira.

Estilo: trata-se de arquitetura modesta, sem propriamente um estilo.

Fachadas: Geminada. Não há recuo frontal, apenas lateral. A fachada principal dá para a rua principal, atual r. 21 de novembro, e a entrada para a casa é feita pela lateral. A parte posterior é quase paralela à linha do trem. O quintal é de proporções razoáveis. E encontra-se um anexo de banheiro e área de serviço. As fachadas apresentam pilastras, características às várias casas das vilas ferroviárias da Companhia Paulista, sendo um elemento da estrutura posto em evidência, e posteriormente revestido. Também apresentam as aberturas dos porões. A fachada frontal é composta por uma janela e portão. A entrada da casa é feita pela lateral que, por causa do porão, possui degraus.

Conservação: As fachadas frontais, em sua parte estrutural e de fechamento encontram-se em razoável estado de conservação. Algumas das portas e janelas foram substituídas por alumínio, com modificação do tamanho das aberturas, prejudicando a uniformidade das fachadas. Algum padrão com tamanho e desenho das aberturas originais das portas e janelas deverá ser observado em um possível "guia de transformação", sendo possível uma adaptação no material utilizado. A adaptação para um banheiro interior deve ser permitida. Esta tipologia possui como peculiaridade o recuo. Em um possível "guia de transformação", os casos em que o recuo não existe mais, deverão ser estudados.
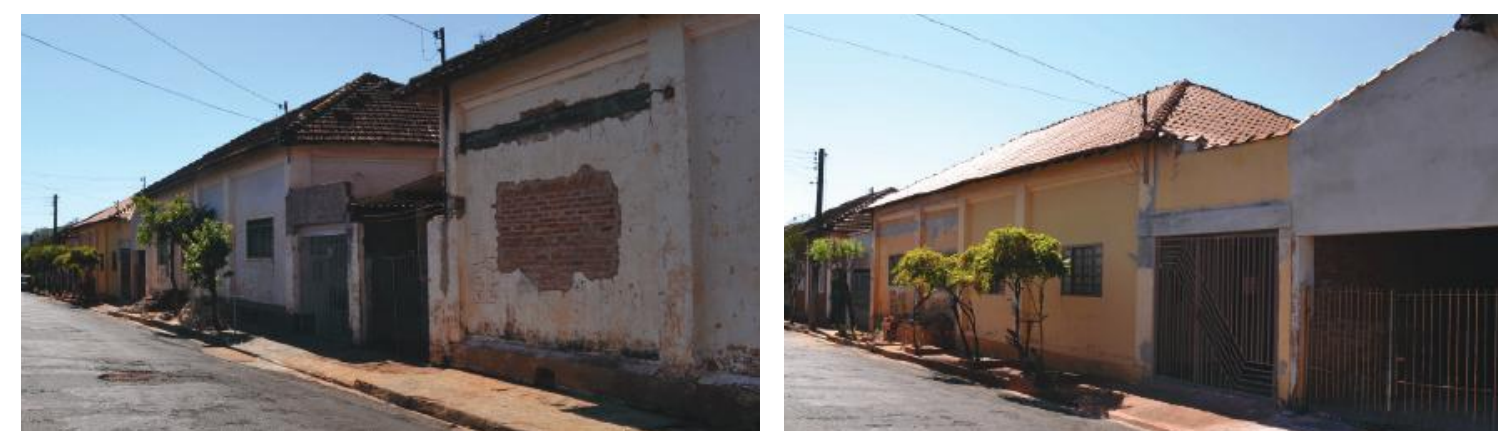

Fotos 186 e 187: Visão geral das subtipologias B2. Observa-se a substituição de caixilhos e o fechamento do recuo lateral. Foto: autora, 2013. 

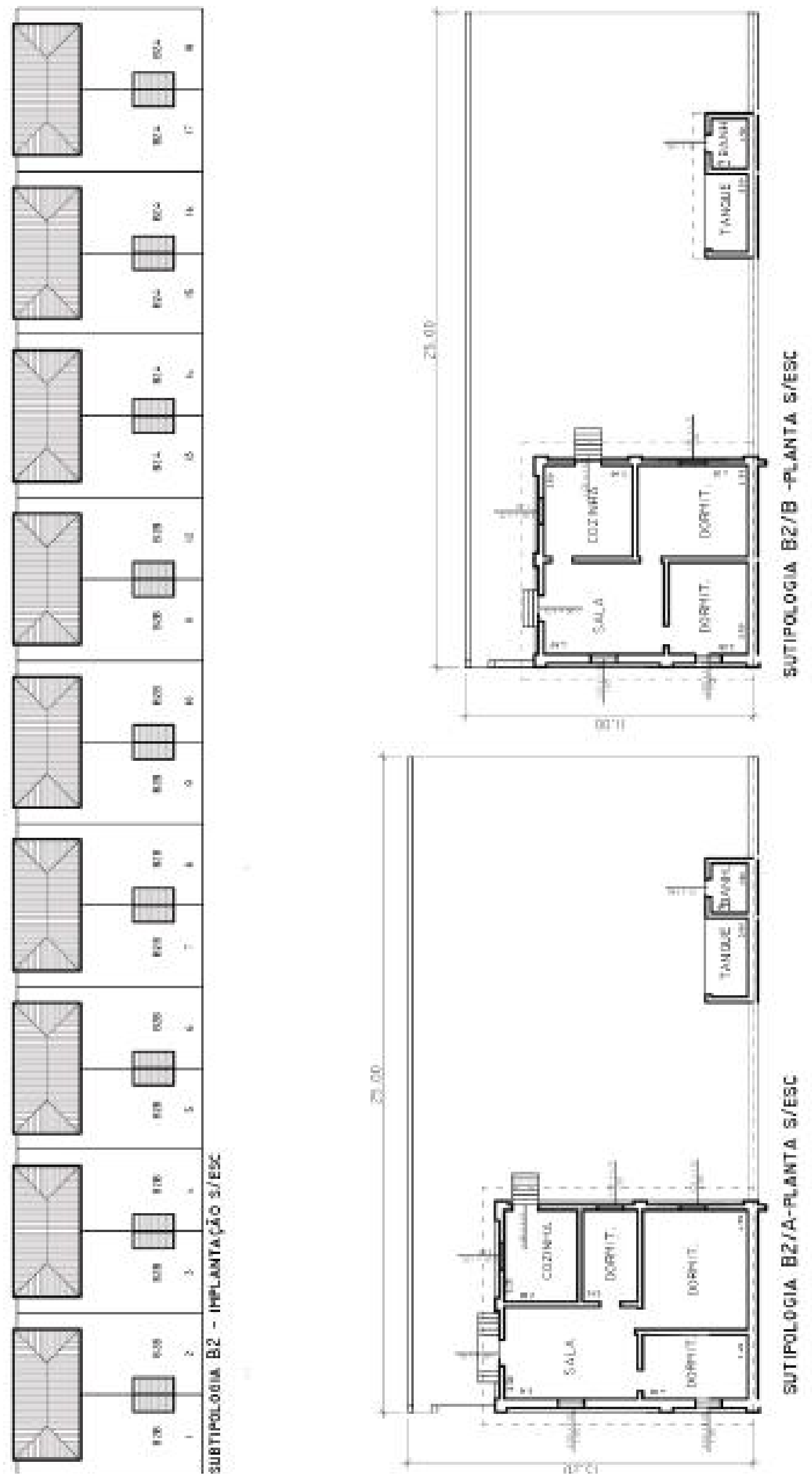

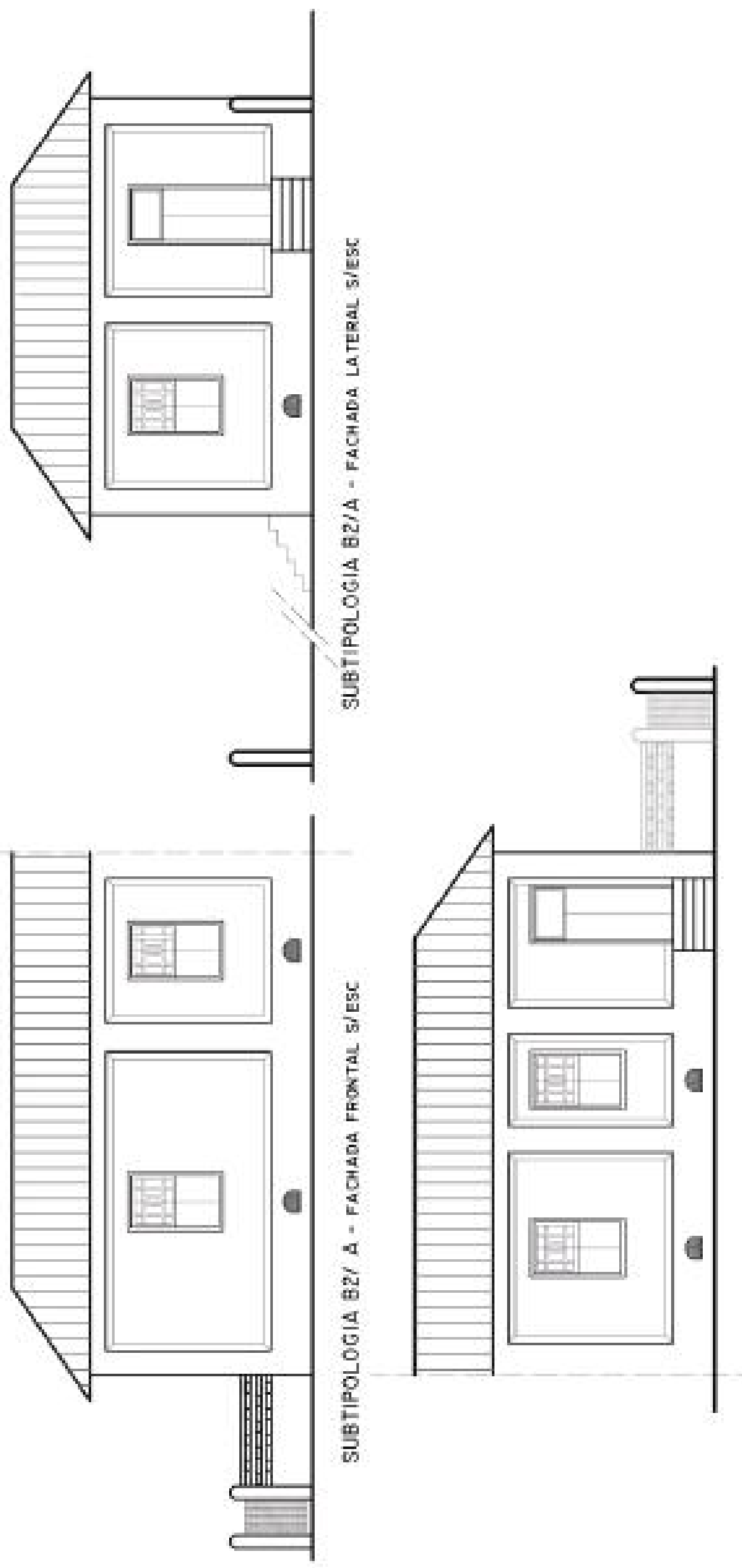

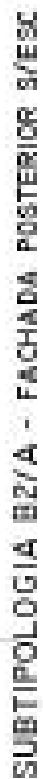



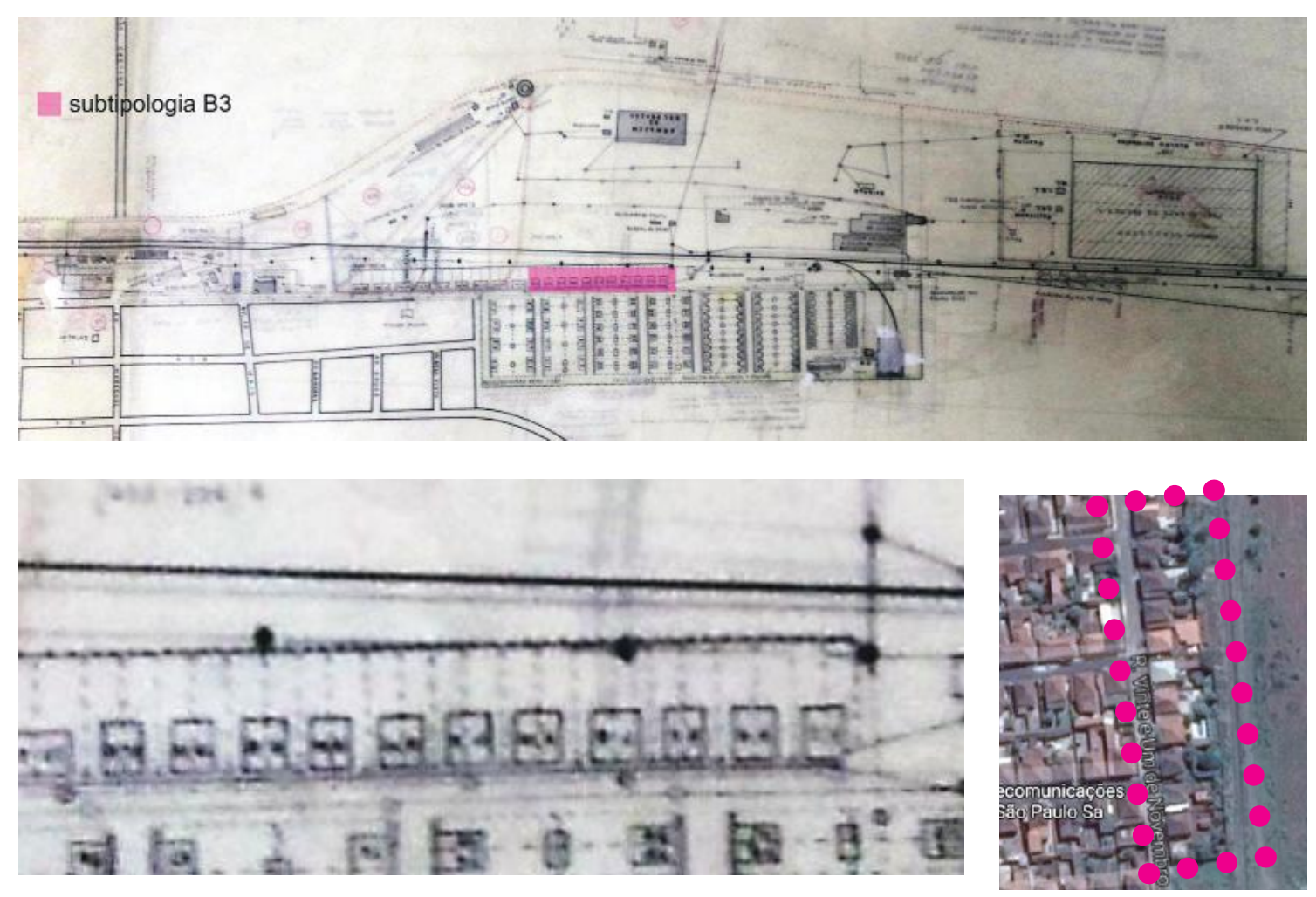

\section{SUBTIPOLOGIA B3 - casa geminada ao longo da rua principal}

Muito semelhante à subtipologia B2, sendo menor em área. Também é uma das tipologias, juntamente com a subtipologia B2, que não apresentava banheiro externo na planta de 1967, mas que no levantamento da Prefeitura e na visita de campo foi verificado.

Área: 48 m2, segundo Relatório "Avaliação de Edifícios e Dependências”, da RFFSA, de 31 de dezembro de 1991. Segundo levantamento da Prefeitura, são 22 unidades com $45 \mathrm{~m} 2$ (mais anexo externo de aproximadamente 9,90m2)

\section{Pé-Direito: 3,50m}

Programa: Um dormitório, sala, cozinha, banheiro e área de serviço externa.

Materiais: Cobertura: forma com a casa geminada ao lado um telhado de quatro águas e telhado de barro, porém não é possível saber quais são as telhas originais, se as telhas francesas ou as de capa e canal. A estrutura é provavelmente de tijolos. A parede é de alvenaria revestida. As esquadrias, portas externas (dimensões 1,00m x 2,70m, com duas folhas e bandeira) e janelas (dimensões $1,00 \times 1,70 \mathrm{~m} /$ peitoril 1,00m) originais são provavelmente de madeira. A porta possui uma bandeira de vidro. As janelas são de guilhotina de duas folhas, envidraçadas, e com persianas internas. As portas e janelas encontram-se alinhadas na fachada. Sobre a cor, não é possível saber sem um exame mais aprofundado. Apresentam porão, portanto, piso elevado, com um assoalho de madeira. 
Estilo: trata-se de arquitetura modesta, sem propriamente um estilo

Fachadas: Geminada. Não há recuo frontal, apenas lateral. A fachada principal dá para a rua principal, atual r. 21 de novembro, e a entrada para a casa é feita pela lateral, que por causa dos porões, apresenta degraus. A parte posterior é quase paralela à linha do trem. O quintal possui proporções razoáveis. E encontra-se um anexo de banheiro e área de serviço. As fachadas apresentam pilastras, características às várias casas das vilas ferroviárias da Companhia Paulista, sendo um elemento da estrutura posto em evidência, e posteriormente revestido. Também apresentam as aberturas dos porões. A fachada frontal é composta por uma janela e portão.

Conservação: As fachadas frontais, em sua parte estrutural e de fechamento encontram-se em razoável estado de conservação. Algumas das portas e janelas foram substituídas por alumínio, com modificação do tamanho das aberturas, prejudicando a uniformidade das fachadas. Algum padrão com tamanho e desenho das aberturas originais das portas e janelas deverá ser observado em um possível "guia de transformação", sendo possível uma adaptação no material utilizado. Adotar o mesmo padrão de telhas. A adaptação para um banheiro interior deve ser permitida. O recuo lateral não deverá ser fechado, e a altura de portões bem como seu fechamento deverá ser estudado para um possível projeto de conservação.
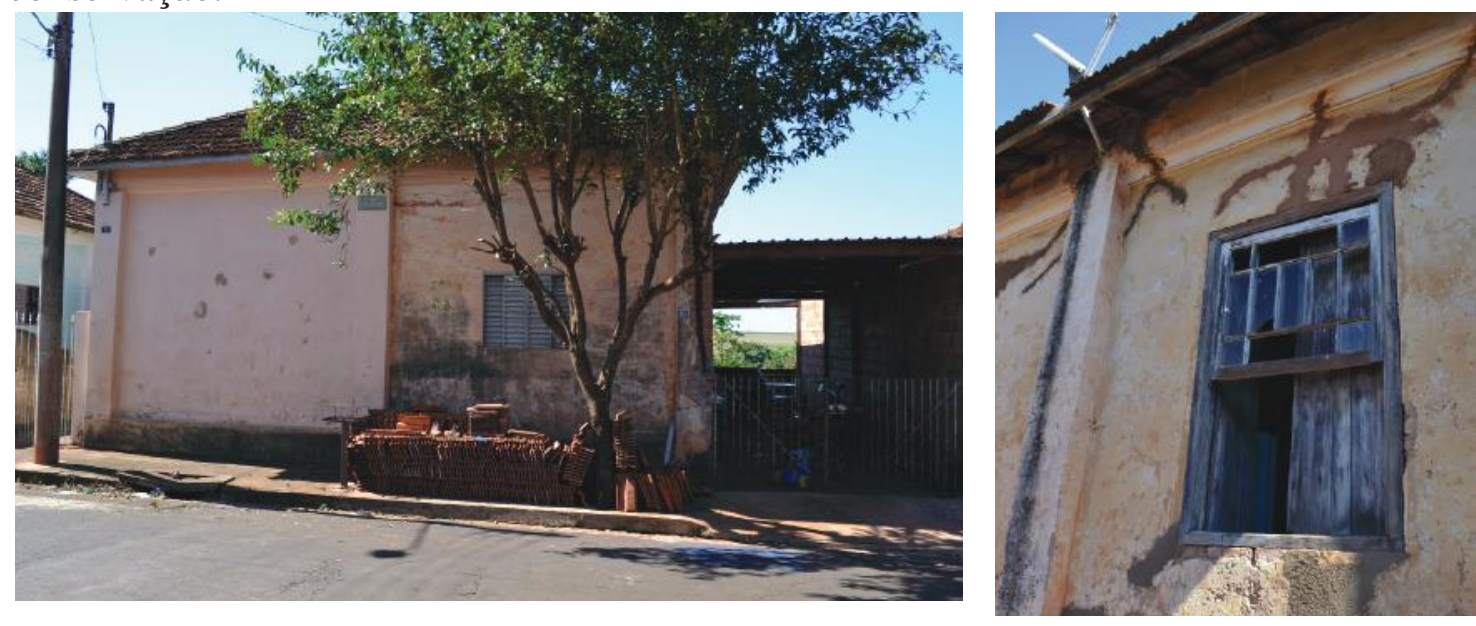

Em sentido horário, iniciando-se pela foto acima: Foto $\mathbf{1 8 8}$ - Fachada frontal, nota-se o fechamento e a substituição de caixilhos. Foto $\mathbf{1 8 9}$ -Janela provavelmente original. Foto 190 - Fachada frontal, o recuo e o muro baixo foram mantidos, porém os caixilhos foram substituídos. Foto: autora, julho 2013.

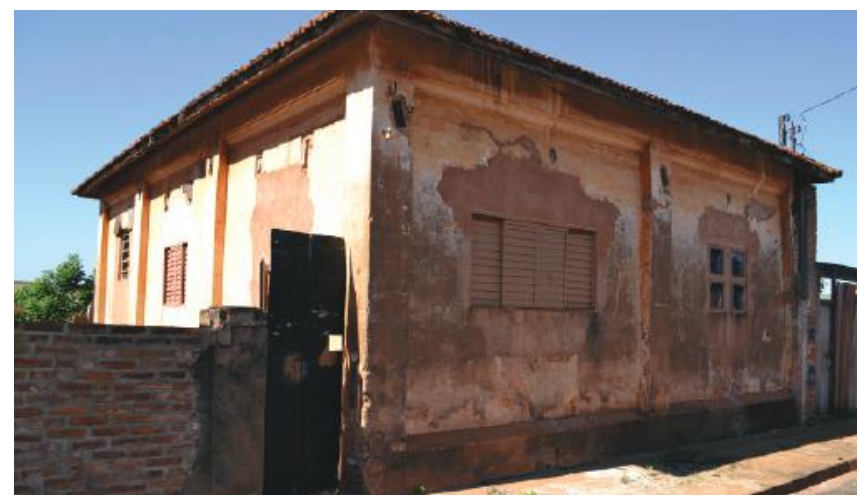



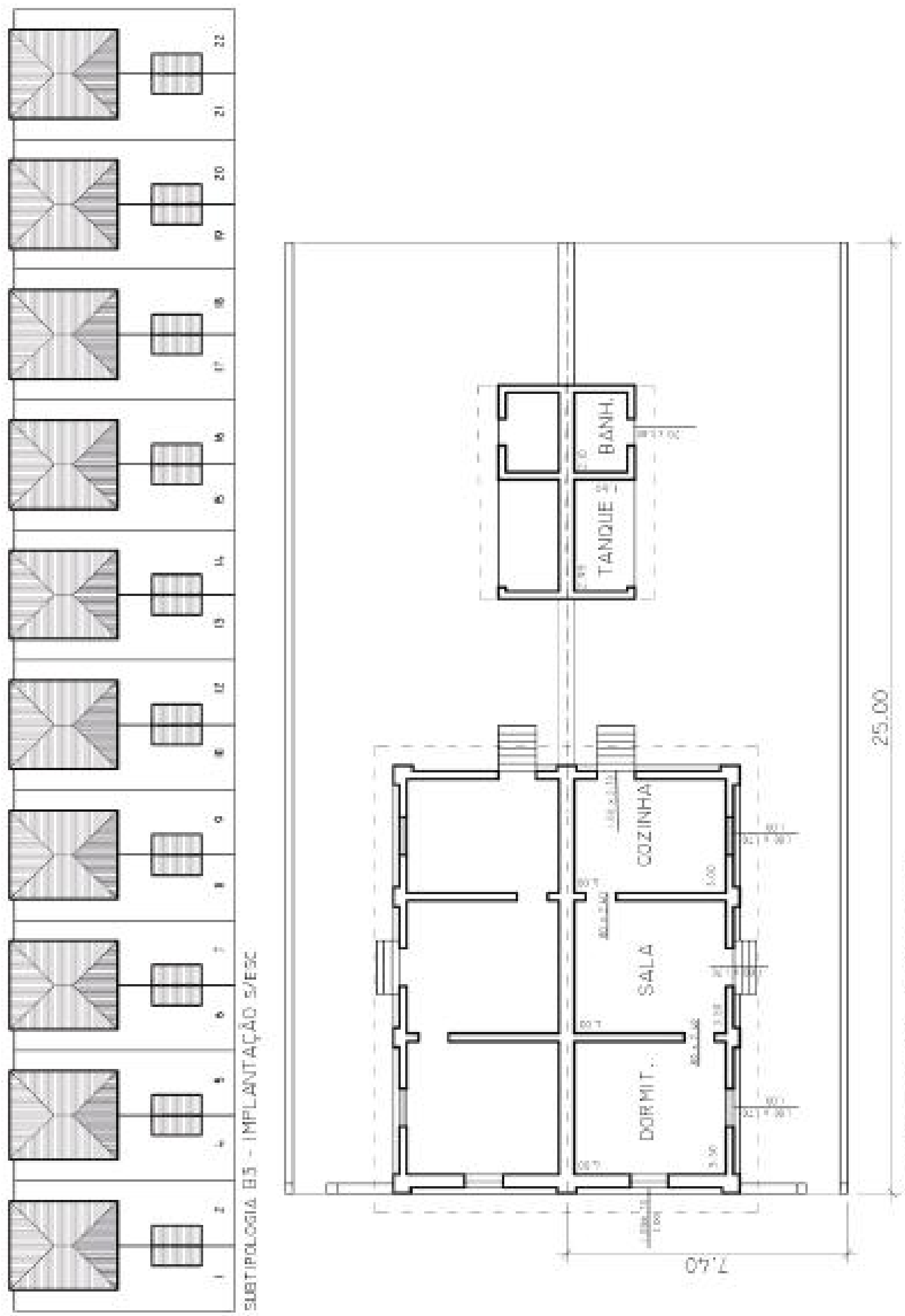

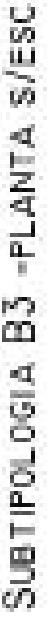



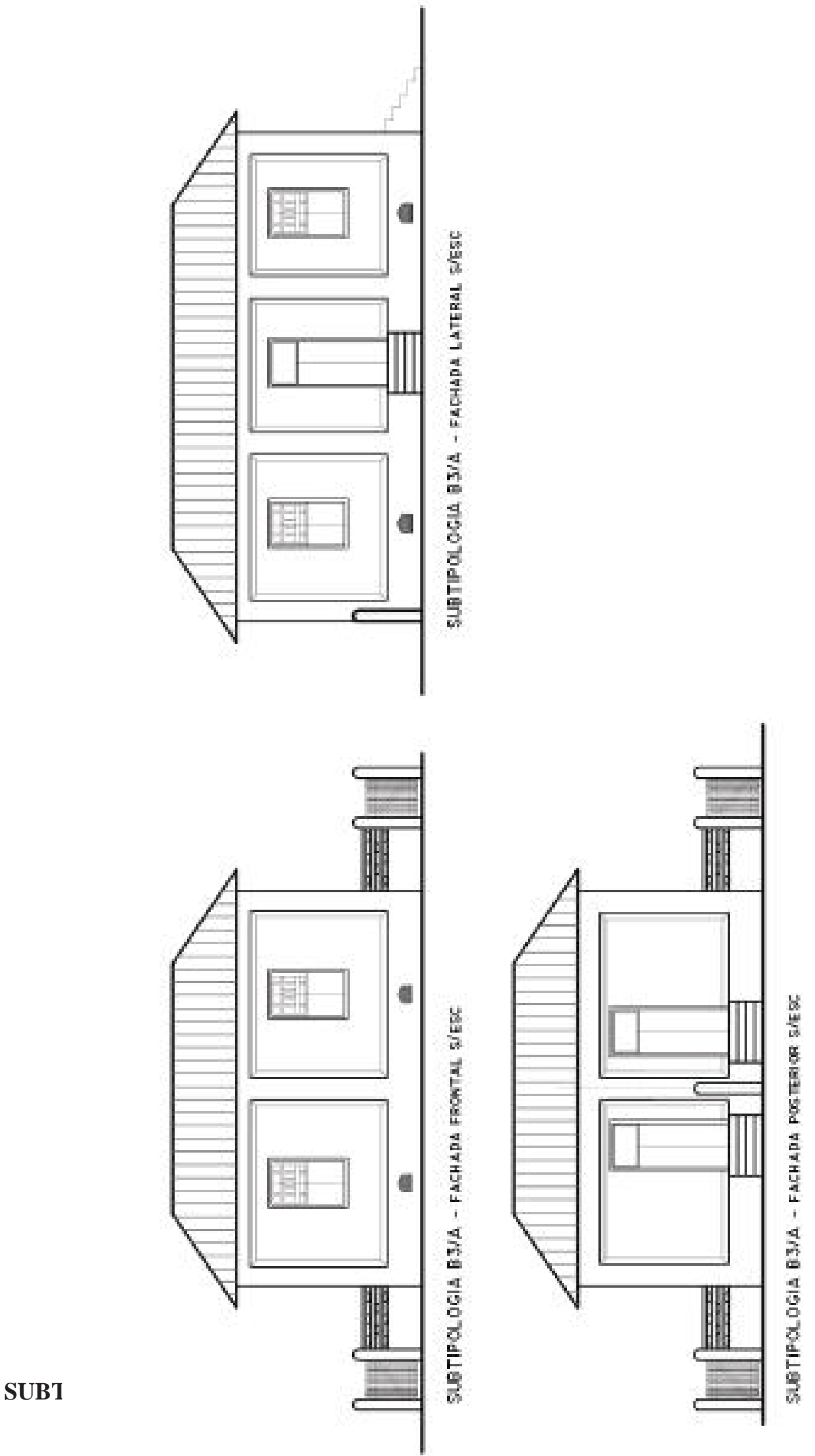
SUBTIPOLOGIA B4- casa geminada em lotes maiores, com grandes recuos
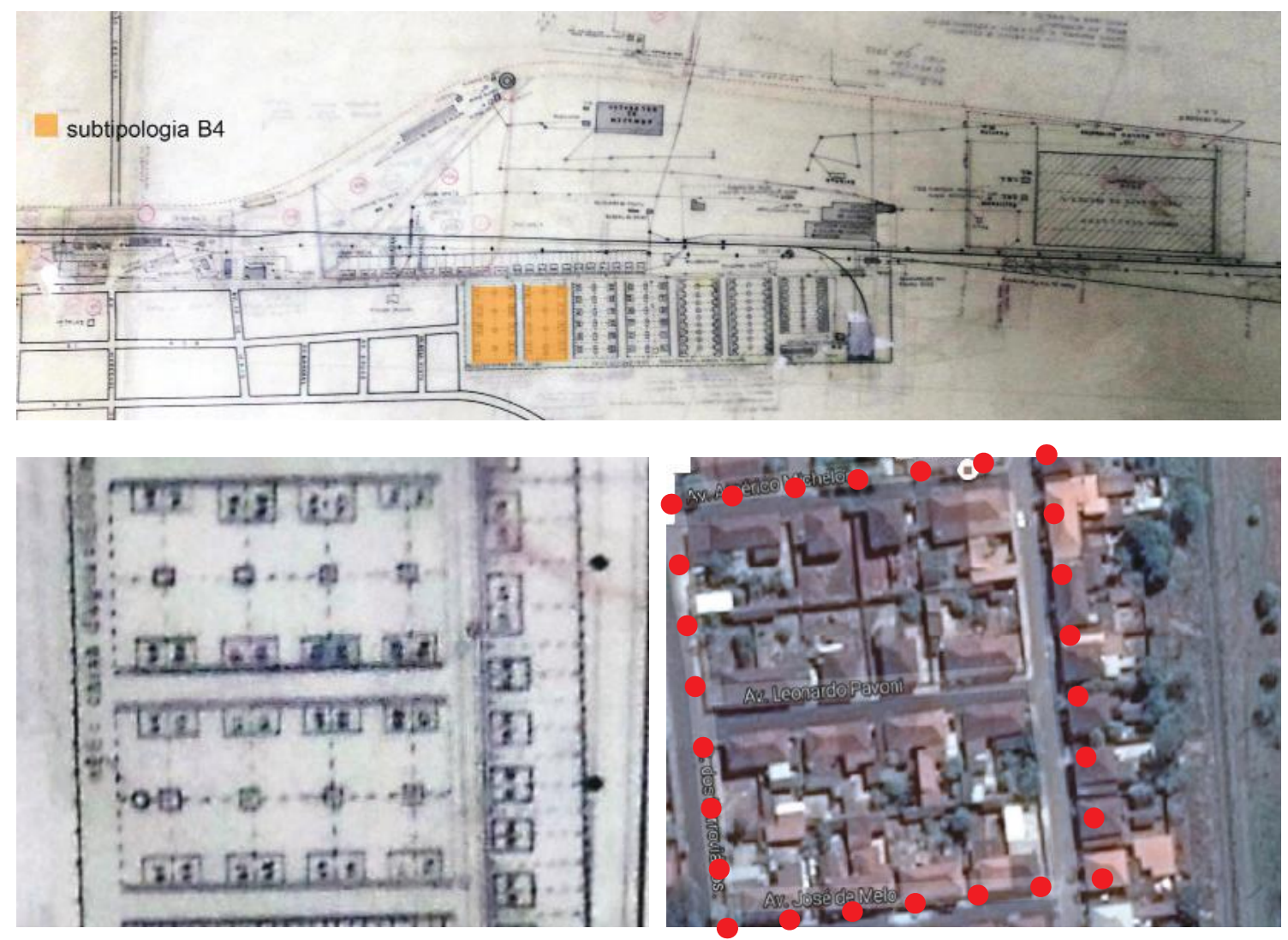

Área - 48 m2, segundo Relatório “Avaliação de Edifícios e Dependências”, da RFFSA, de 31 de dezembro de 1991. Segundo o levantamento da Prefeitura, 16 unidades possuem $72,20 \mathrm{~m} 2$ (subtipologia B4A) com área externa de aproximadamente 7m2, e 16 unidades (subtipologia B4B) com área externa também aproximadamente $7 \mathrm{~m} 2$.

Pé-Direito: $3,50 \mathrm{~m}$.

Programa: Três (subtipologia B4A) e dois (subtipologia B4B) dormitórios, sala, cozinha, banheiro e área de serviço externa.

Materiais: Cobertura: formam com a casa geminada ao lado um telhado de quatro águas e telhado de barro, porém não é possível saber quais são as telhas originais, se as telhas francesas ou as de capa e canal. A estrutura é provavelmente de tijolos. A parede é de alvenaria revestida. As esquadrias, portas externas (dimensões $1,00 \mathrm{~m}$ x 2,70m, com duas folhas e bandeira) e janelas (dimensões 1,00 x 1,70m/ peitoril $1,00 \mathrm{~m}$ ) originais são provavelmente de madeira. As janelas são de guilhotina de duas folhas, envidraçadas, e com persianas internas. Sobre a cor, não é possível saber sem um exame mais aprofundado. Algumas dos caixilhos em madeira que consideramos originais apresentam a cor desgastada em tons azulados. 
Conservação: As fachadas frontais, em sua parte estrutural e de fechamento encontram-se em razoável estado de conservação. Algumas das portas e janelas foram substituídas por alumínio, com modificação do tamanho das aberturas, prejudicando a uniformidade das fachadas. Algum padrão com tamanho e desenho das aberturas originais das portas e janelas deverá ser observado em um possível "guia de transformação", sendo possível uma adaptação no material utilizado. A adaptação para um banheiro interior deve ser permitida, porém o anexo original deverá ser mantido. A manutenção de anexos posteriores à planta de 1967, deverão ser estudados. O recuo lateral não deverá ser fechado, e a altura de portões bem como seu fechamento deverá ser estudado para um possível projeto de conservação.

Ao lado: Foto 191-fachada com recuo lateral fechado, mas caixilhos provavelmente originais. Abaixo: Foto 192 -as unidades geminadas, e ao fundo a caixa d'água em ferro fundido. fotos: autora, 2013.
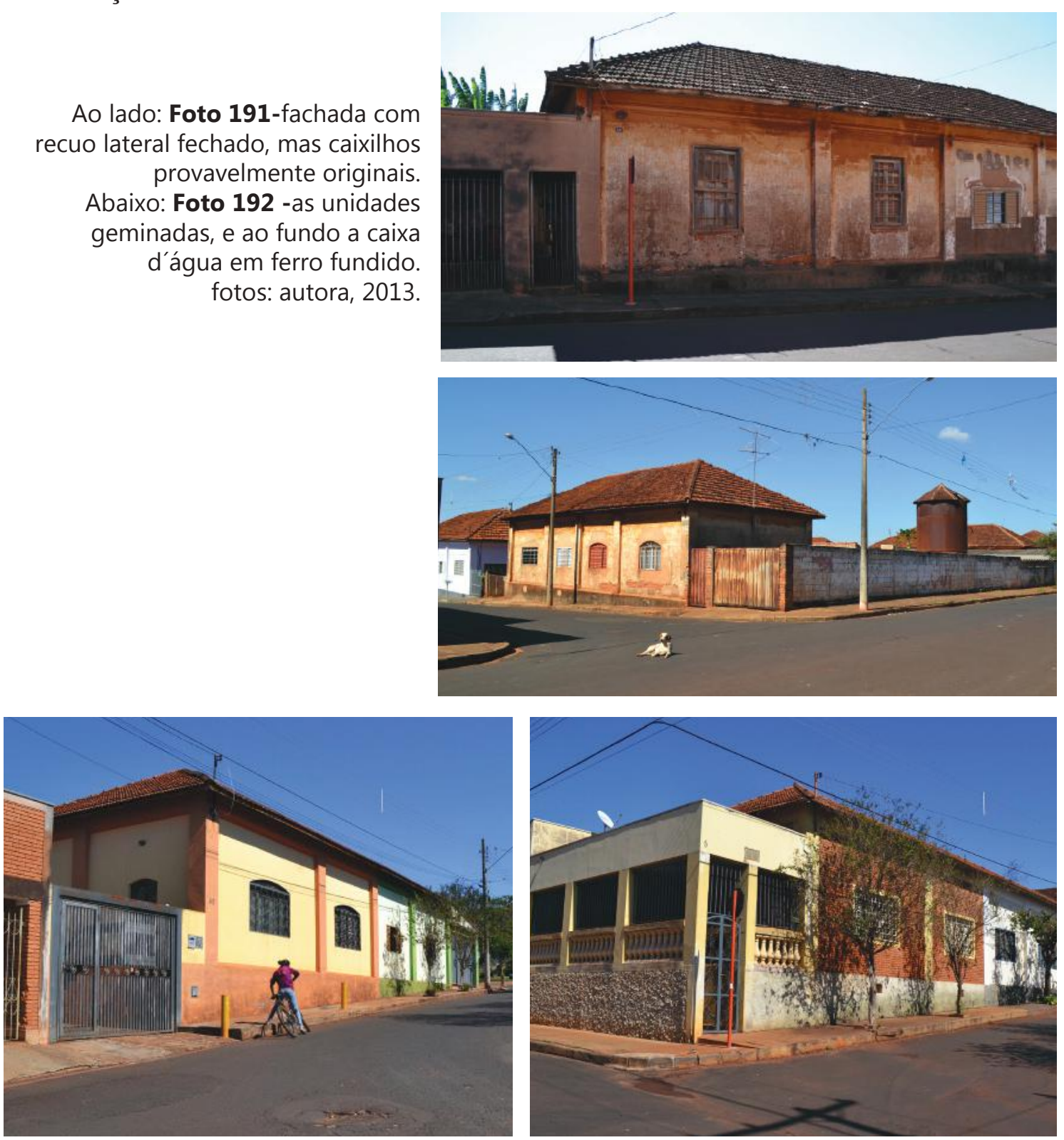

Foto 193 (Esquerda): Fachada frontal: nota-se a substituição de caixilhos. Foto 194 (Direita): o fechamento do recuo lateral, modificando a volumetria original. Foto: autora, 2013. 

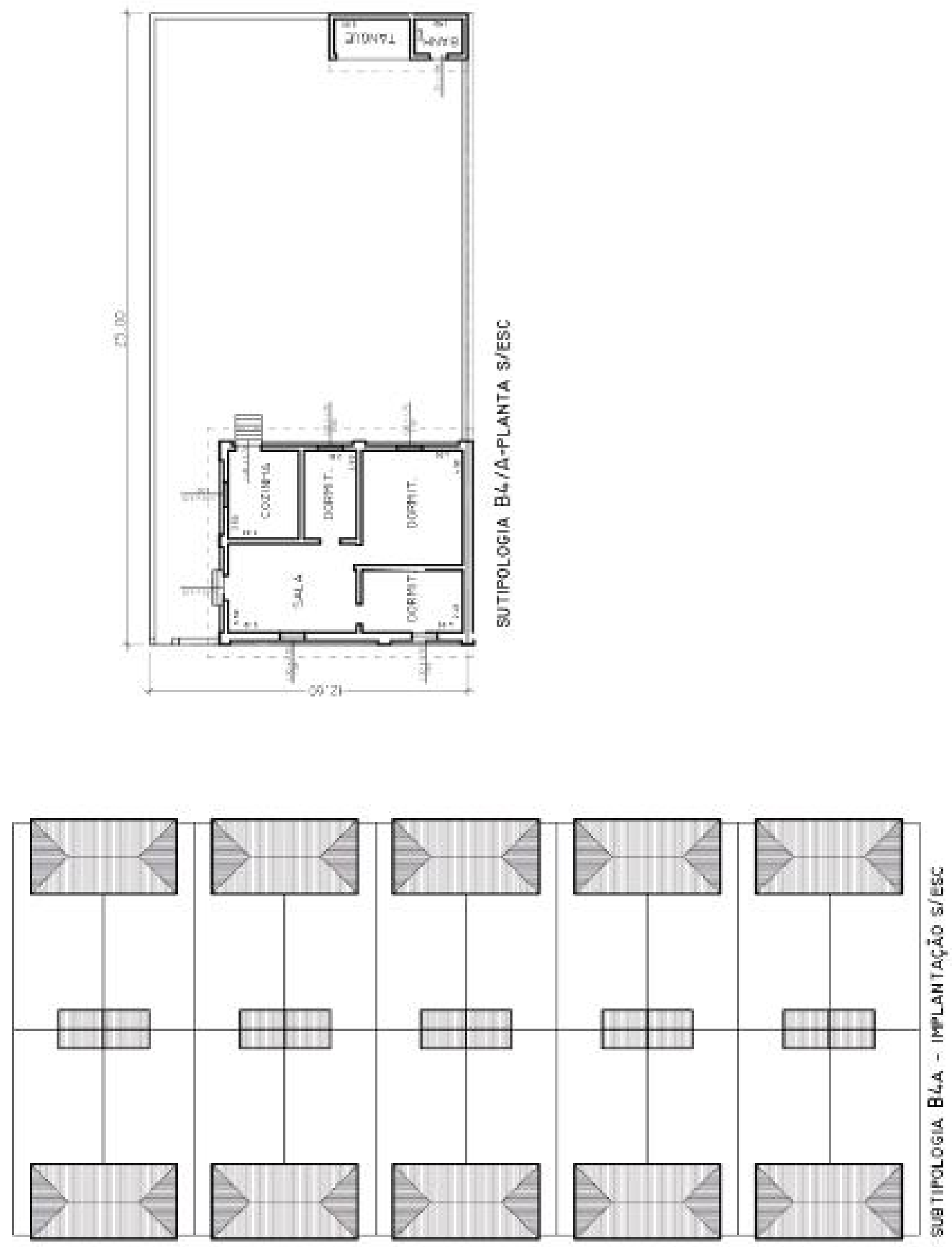

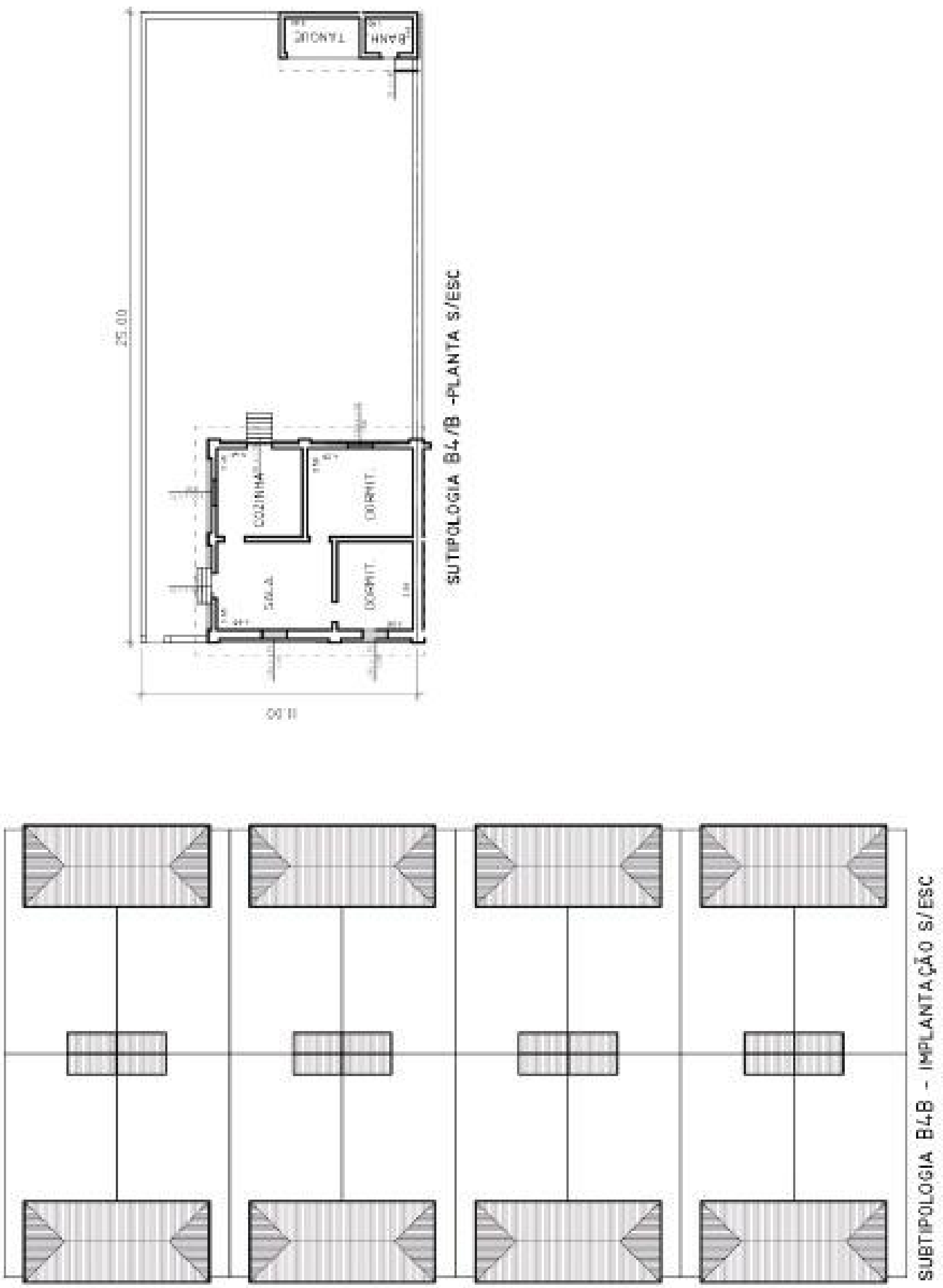


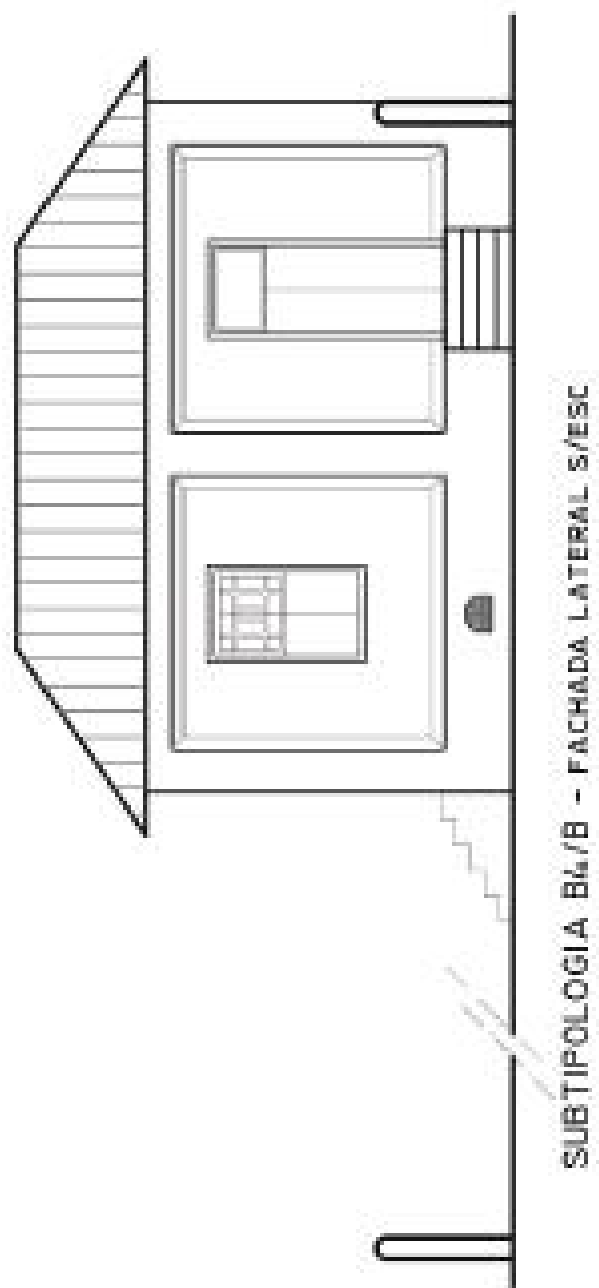

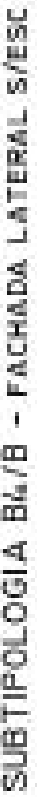
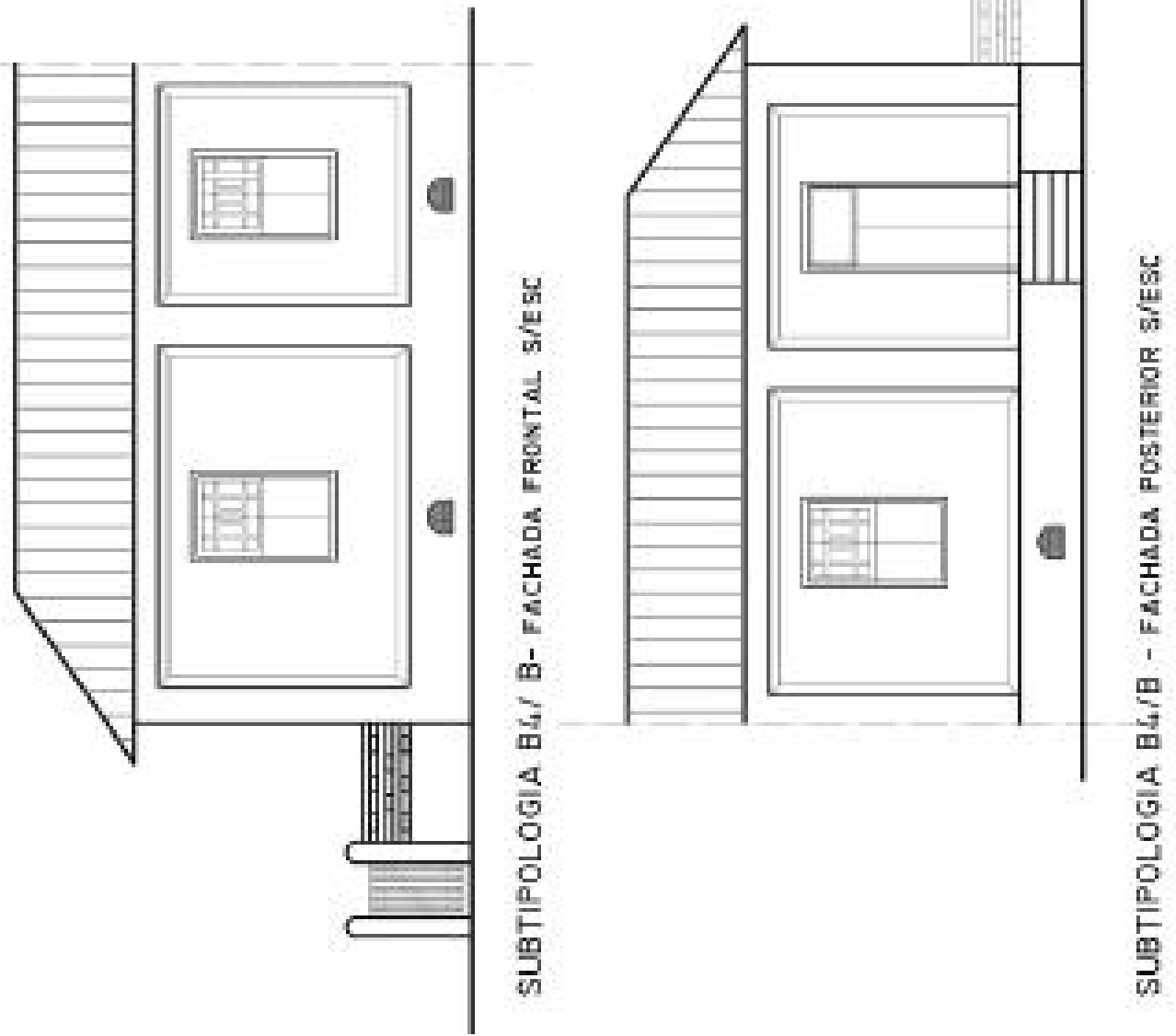
SUBTIPOLOGIA B5 - casa geminada em lotes menores, com recuos
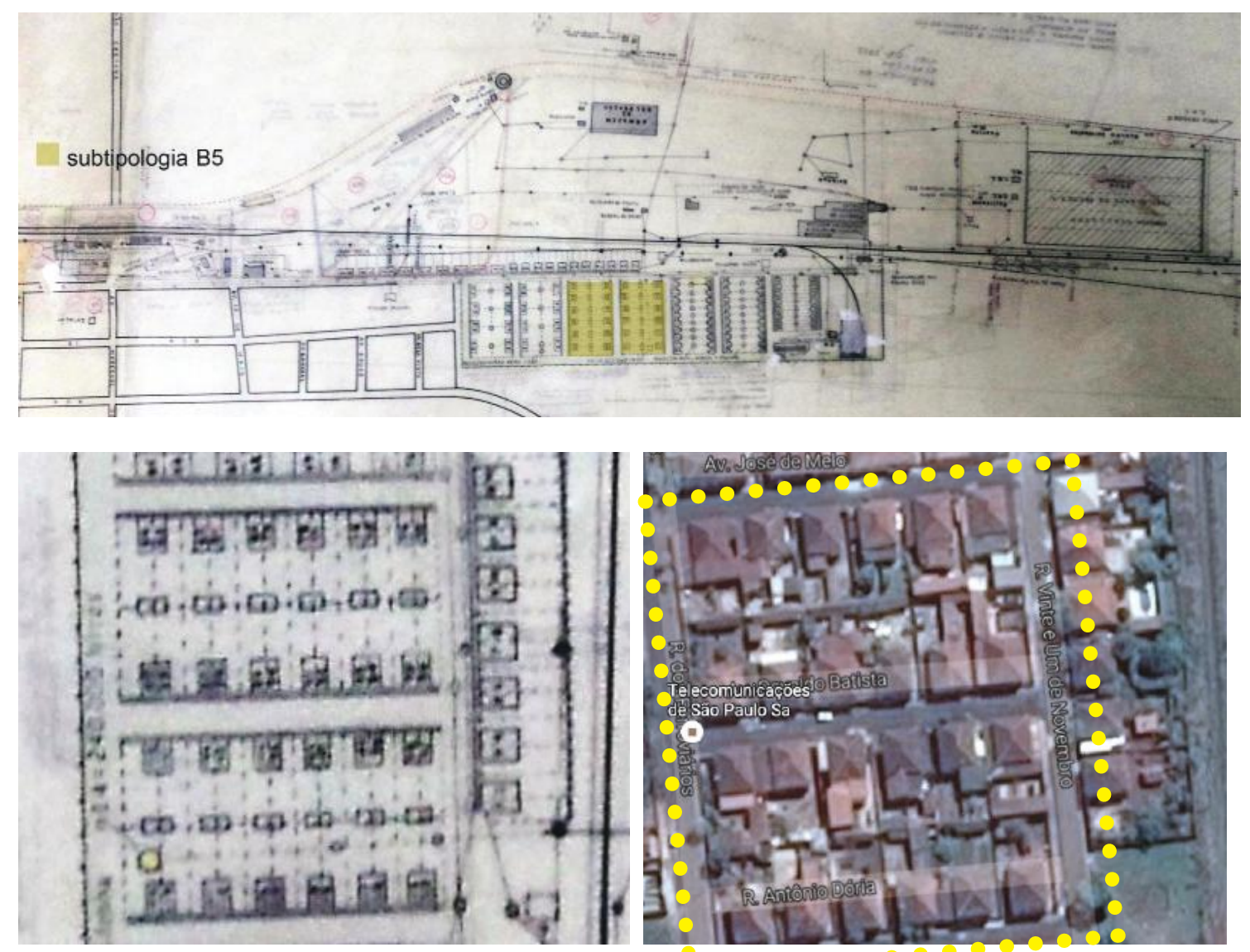

As fachadas desta tipologia são muito semelhantes à tipologia B4, porém mais retangulares e em lote menor. Os demais elementos são muito semelhantes.

Área - 48 m2, segundo Relatório “Avaliação de Edifícios e Dependências”, da RFFSA, de 31 de dezembro de 1991. Segundo levantamento da Prefeitura, são 48 unidades com $60 \mathrm{~m} 2$, mais o anexo com aproximadamente $7 \mathrm{~m} 2$.

\section{Pé-Direito: $3,50 \mathrm{~m}$.}

Programa: Um dormitório, sala, cozinha, banheiro e área de serviço externa.

Materiais: Cobertura: formam com a casa geminada ao lado um telhado de quatro águas e telhado de barro, porém não é possível saber quais são as telhas originais, se as telhas francesas ou as de capa e canal. A estrutura é provavelmente de tijolos. A parede é de alvenaria revestida. As esquadrias, portas externas (dimensões 1,00m x 2,70m, com duas folhas e bandeira) e janelas (dimensões 1,00 x 1,70m/ peitoril 1,00m) originais são provavelmente de madeira. As janelas são de guilhotina de duas folhas, envidraçadas, e com persianas externas e outras com fechamento interno. Sobre a cor, não é possível saber sem um exame mais aprofundado. Alguns dos caixilhos em madeira que considerei originais apresentam a cor desgastada em tons azuladas, porém é necessário um exame aprofunda- 
do. Apresentam porão, com fechamento em ferro fundido ornamentado. O piso é portanto elevado, sendo o assoalho de madeira. O forro também de madeira.

Estilo: trata-se de arquitetura modesta, sem propriamente um estilo.

Fachada: Geminada. Não há recuo frontal, apenas lateral. A fachada principal dá para a rua perpendicular à rua principal, e a entrada para a casa é feita pela lateral. Existem pilastras características de outras vilas ferroviárias da Companhia Paulista, e também há uma base de quase meia parede sobressalente no mesmo nível da pilastra, e que deixa evidente o desnível do terreno. Difere da tipologia anterior, pois geralmente a fachada é composta de apenas uma janela e um portão. Algumas das casas possuem muretas vazadas, a ser verificado o ano de sua construção.

Conservação: As fachadas frontais, em sua parte estrutural e de fechamento encontram-se em razoável estado de conservação. Algumas das portas e janelas foram substituídas por alumínio, com modificação do tamanho das aberturas, prejudicando a uniformidade das fachadas. Algum padrão com tamanho e desenho das aberturas originais das portas e janelas deverá ser observado em um possível "guia de transformação", sendo possível uma adaptação no material utilizado. A adaptação para um banheiro interior deve ser permitida, porém o anexo original deverá ser mantido. A manutenção de anexos posteriores à planta de 1967, deverão ser estudados. O recuo lateral não deverá ser fechado, e a altura de portões bem como seu fechamento deverá ser estudado para um possível projeto de conservação.
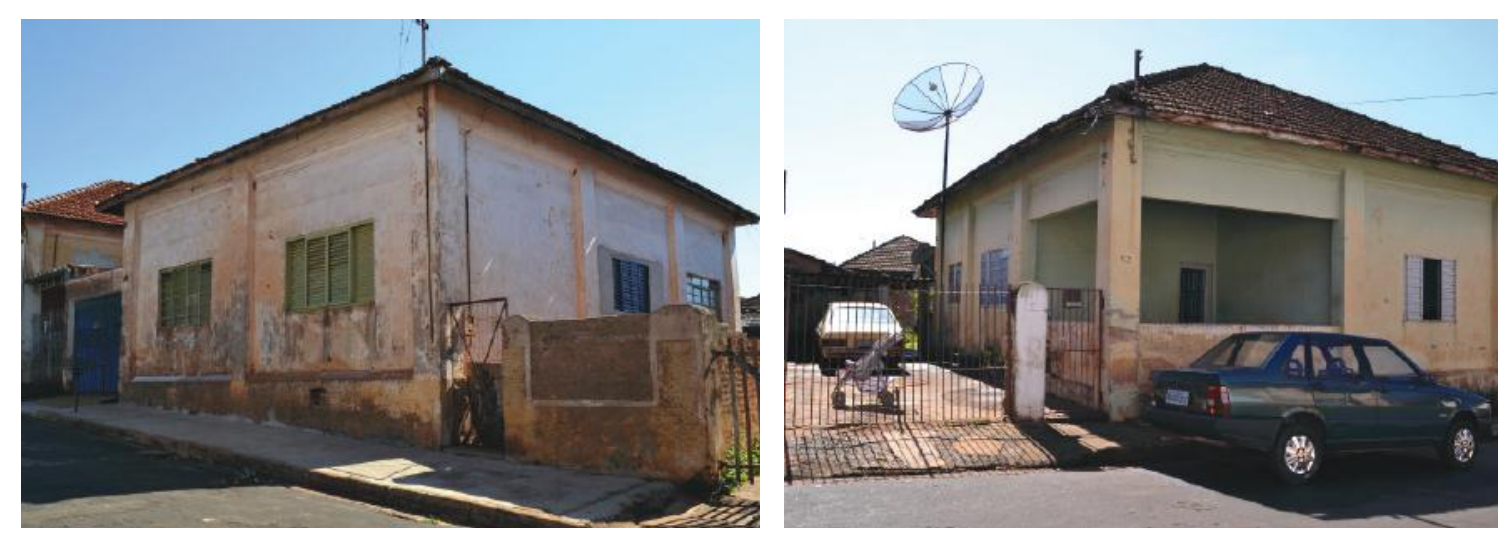

Foto 195 (Esquerda) - fachada com recuo lateral, e muros baixos. Foto 196 (Direita) - Modificação da fachada frontal. Fotos: autora, 2013. 

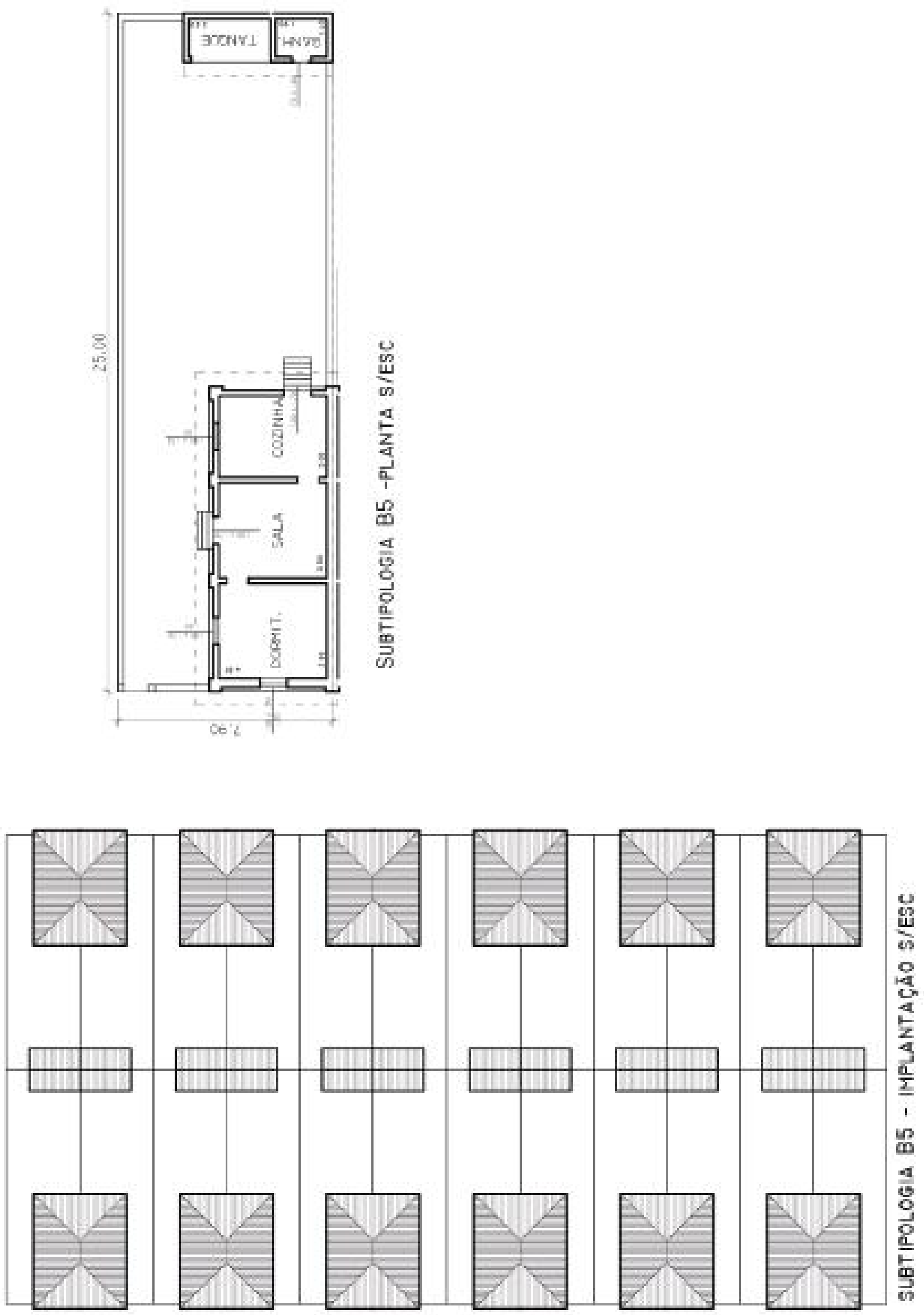

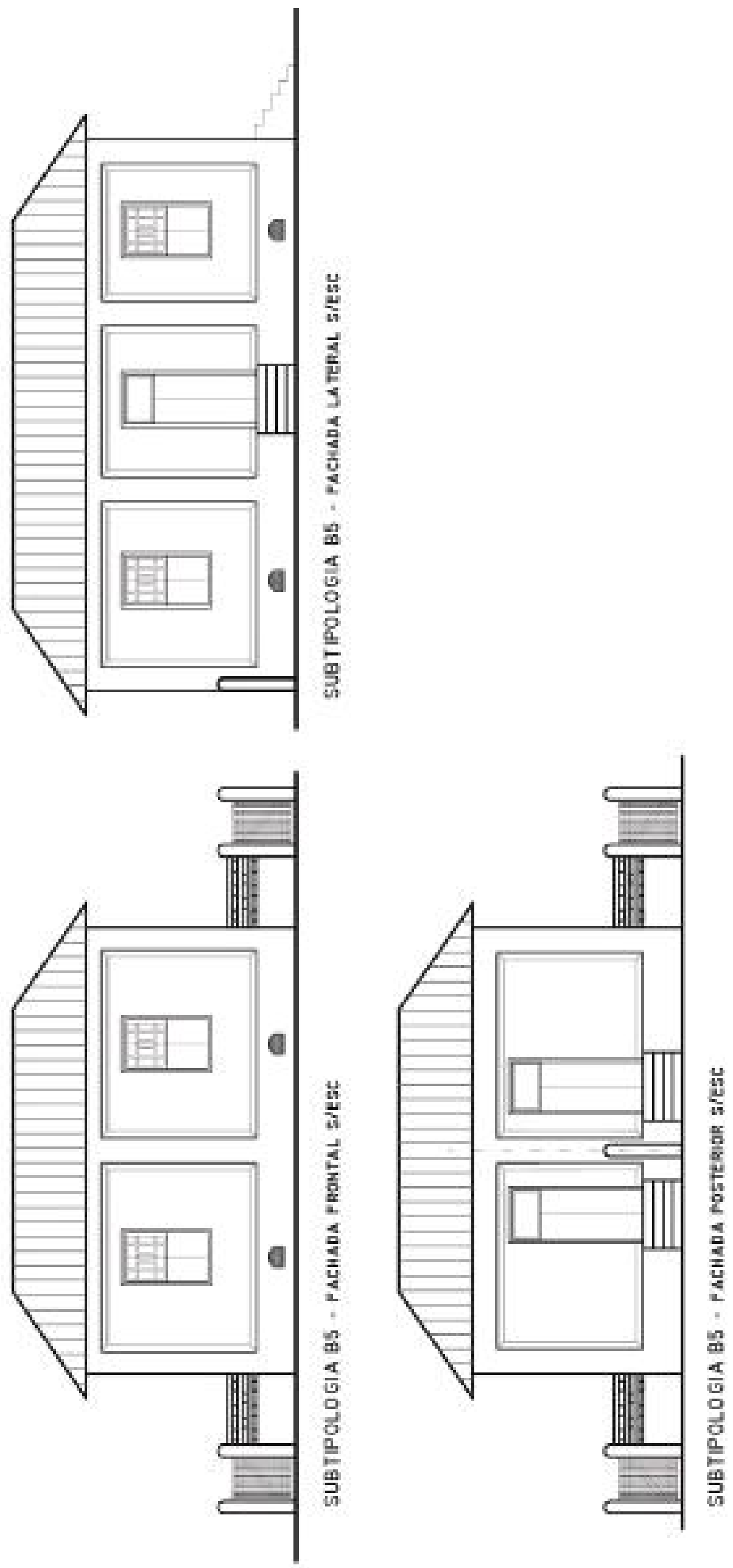


\section{SUBTIPOLOGIA C1 - casas em linha, sem recuos, em lotes maiores que a subtipo-}

\section{$\operatorname{logia} \mathrm{C2}$}
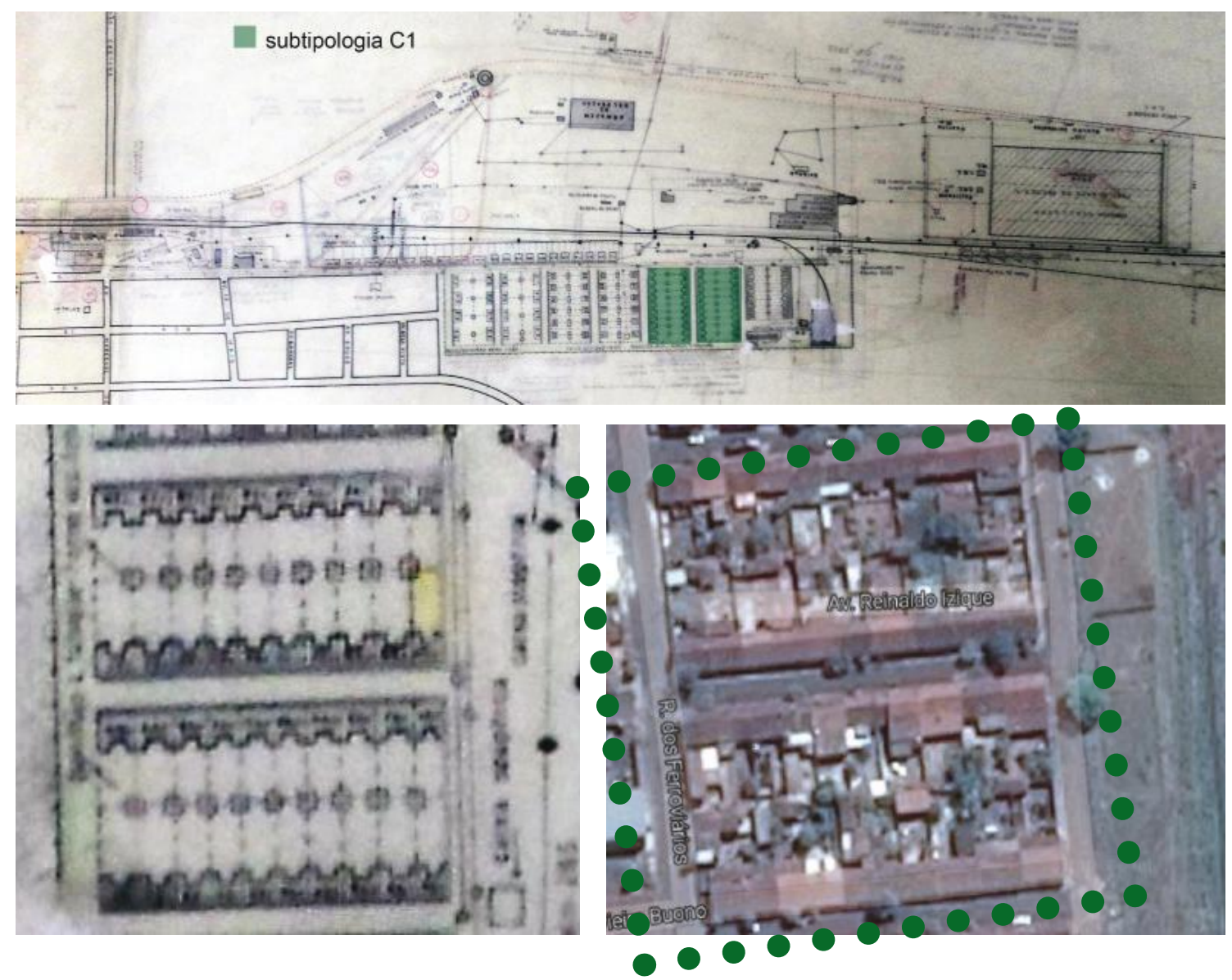

As subtipologias C1 e C2 são as que inicialmente denominamos casas em linha, pois não apresentam recuos frontais ou laterais, e tampouco porão. Elas diferem na área e no tamanho do lote. E segundo depoimento recolhido na prefeitura de Rincão, eram subtipologias dedicados aos trabalhadores responsáveis pela manutenção da linha.

Área - 48 m2, segundo Relatório “Avaliação de Edifícios e Dependências”, da RFFSA, de 31 de dezembro de 1991. Segundo levantamento da Prefeitura, são 16 unidades (subtipologia C1A) com aproximadamente $80 \mathrm{~m} 2$ e anexo de $8 \mathrm{~m} 2$, e 29 unidades com aproximadamente $60 \mathrm{~m} 2$ e anexo de $8 \mathrm{~m} 2$.

Pé-Direito: 2,50m a 3,00m.

Programa: Quatro dormitórios (subtipologia C1A) ou 2 dormitórios (subtipologia C1B), sala, cozinha, banheiro e área de serviço externa.

Materiais: Cobertura: de duas águas. Novamente, não é possível saber quais são as telhas originais, se as telhas francesas ou as de capa e canal. A estrutura é provavelmente de tijolos. A parede é de alvenaria revestida. As esquadrias, portas externas (dimensões 
$1,00 \mathrm{~m}$ x 2,10m, com duas folhas e bandeira) e janelas (dimensões 1,00 x 1,30m/ peitoril $0,80 \mathrm{~m}$ ) originais são provavelmente de madeira. Inclusive encontramos algum exemplar delas. As portas são de duas folhas. As janelas são de duas folhas, envidraçadas, e com persianas externas e outras com fechamento interno também em madeira. Sobre a cor, não é possível saber sem um exame mais aprofundado. Alguns dos caixilhos em madeira que consideramos originais apresentam a cor desgastada em tons azulados, porém é necessário um exame mais aprofundado. Não apresentam porão. Por causa do desnível do terreno, algumas apresentam degraus.

Estilo: trata-se de arquitetura modesta, sem propriamente um estilo.

Fachada: Não há nenhum tipo de recuo, estando a fachada no alinhamento da rua. Existem pilastras características de outras vilas ferroviárias da Companhia Paulista, e também há uma base de quase meia parede sobressalente no mesmo nível da pilastra, e que deixa evidente o desnível do terreno e apresentam degrau. Geralmente a fachada apresenta uma porta e três janelas.

Conservação: A fachada em sua parte estrutural e de fechamento encontra-se em razoável estado de conservação. Algumas das portas e janelas foram substituídas por alumínio, com modificação do tamanho das aberturas, prejudicando a uniformidade das fachadas. Algum padrão com tamanho e desenho das aberturas originais das portas e janelas deverá ser observado em um possível "guia de transformação", sendo possível uma adaptação no material utilizado. A adaptação para um banheiro interior deve ser permitida, porém o anexo original deverá ser mantido. A manutenção de anexos posteriores à planta de 1967, deverá ser estudada.
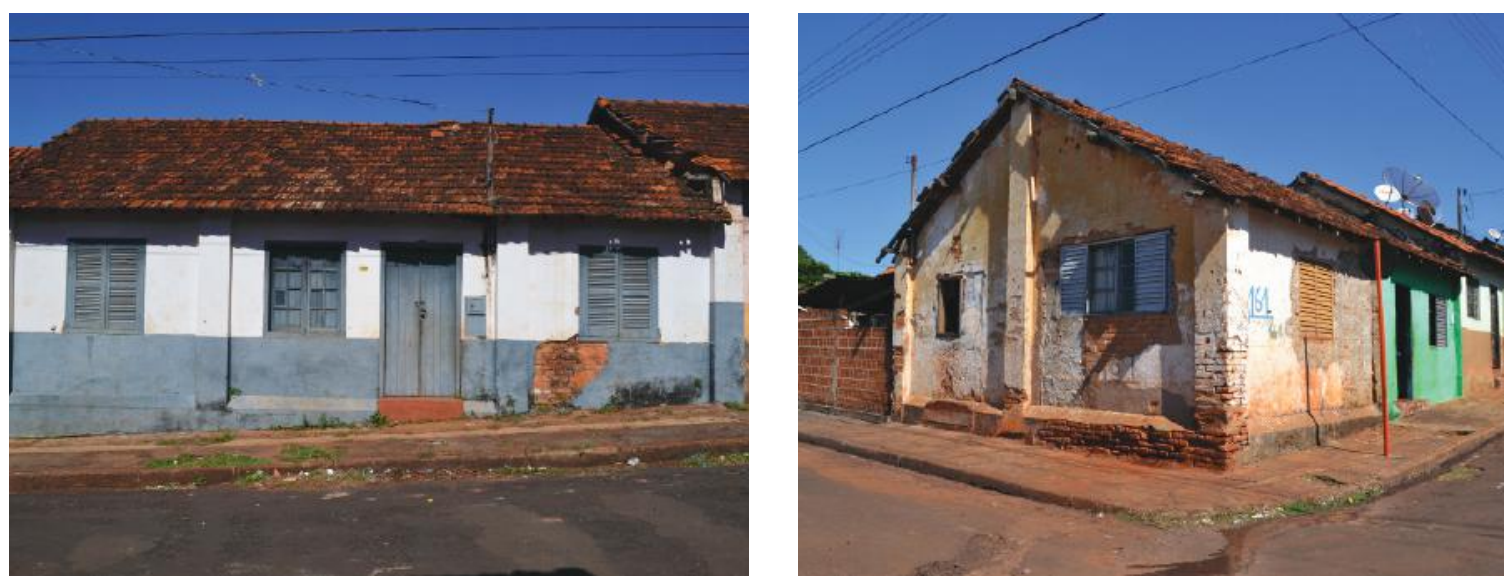

Foto 197 (Esquerda): Fachada da subtipologia C1 em relativo estado de conservação. Foto 198 (Direita): unidade de esquina, onde se pode ver duas fachadas, em mau estado de conservação. Fotos: autora, julho 2013. 


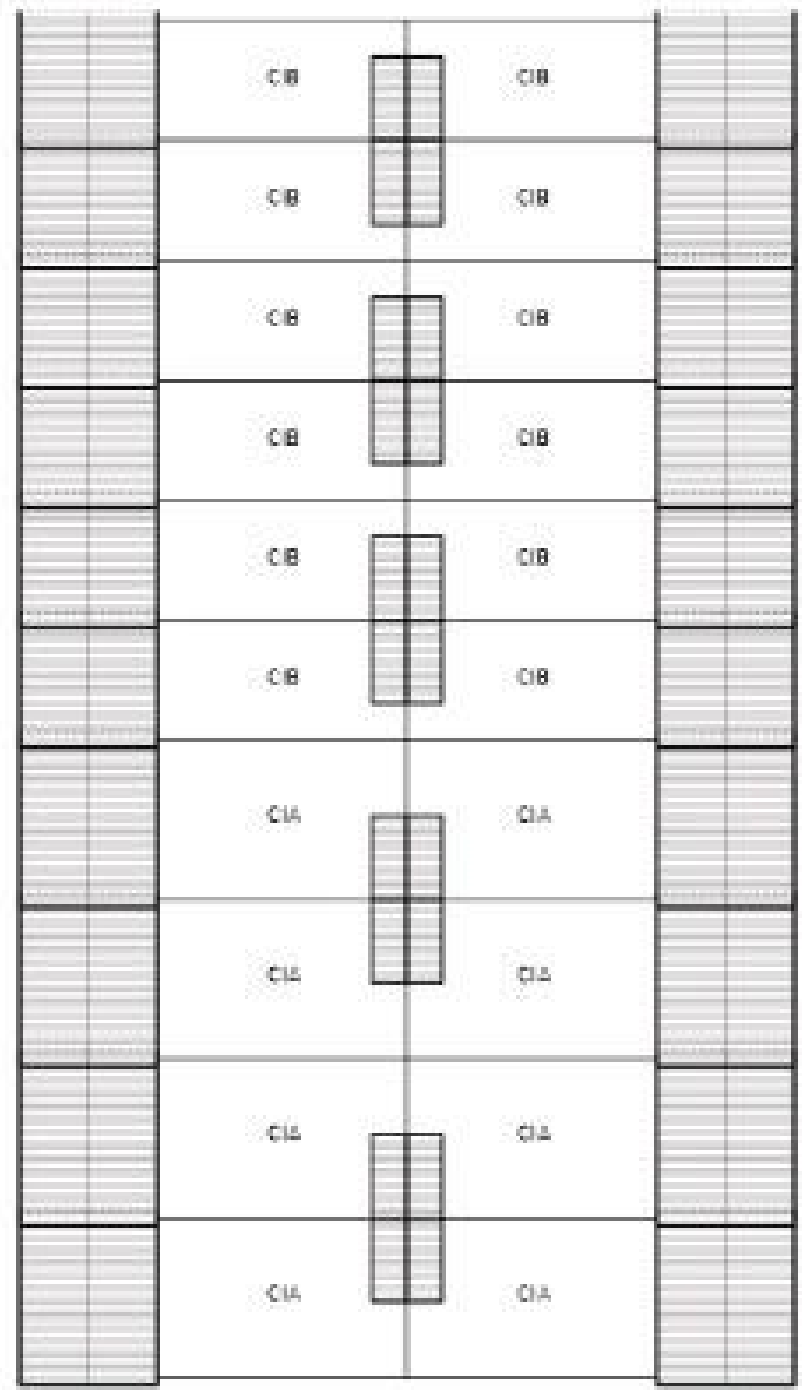

SURTIFOLOGIAS CI - IMPLANTAÇĂO S/ESC
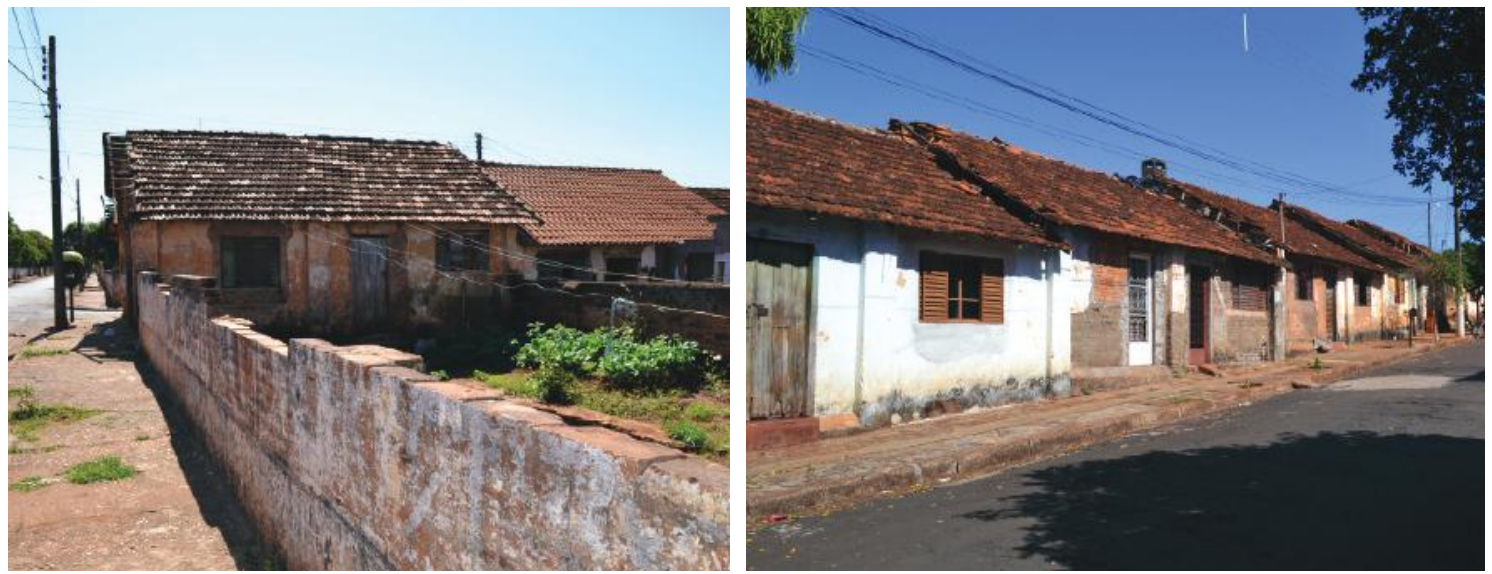

Foto 199(Esquerda): Fachada posterior e quintal. Foto 200 (Direita): Visão geral da rua. Fotos: autora, julho 2013. 

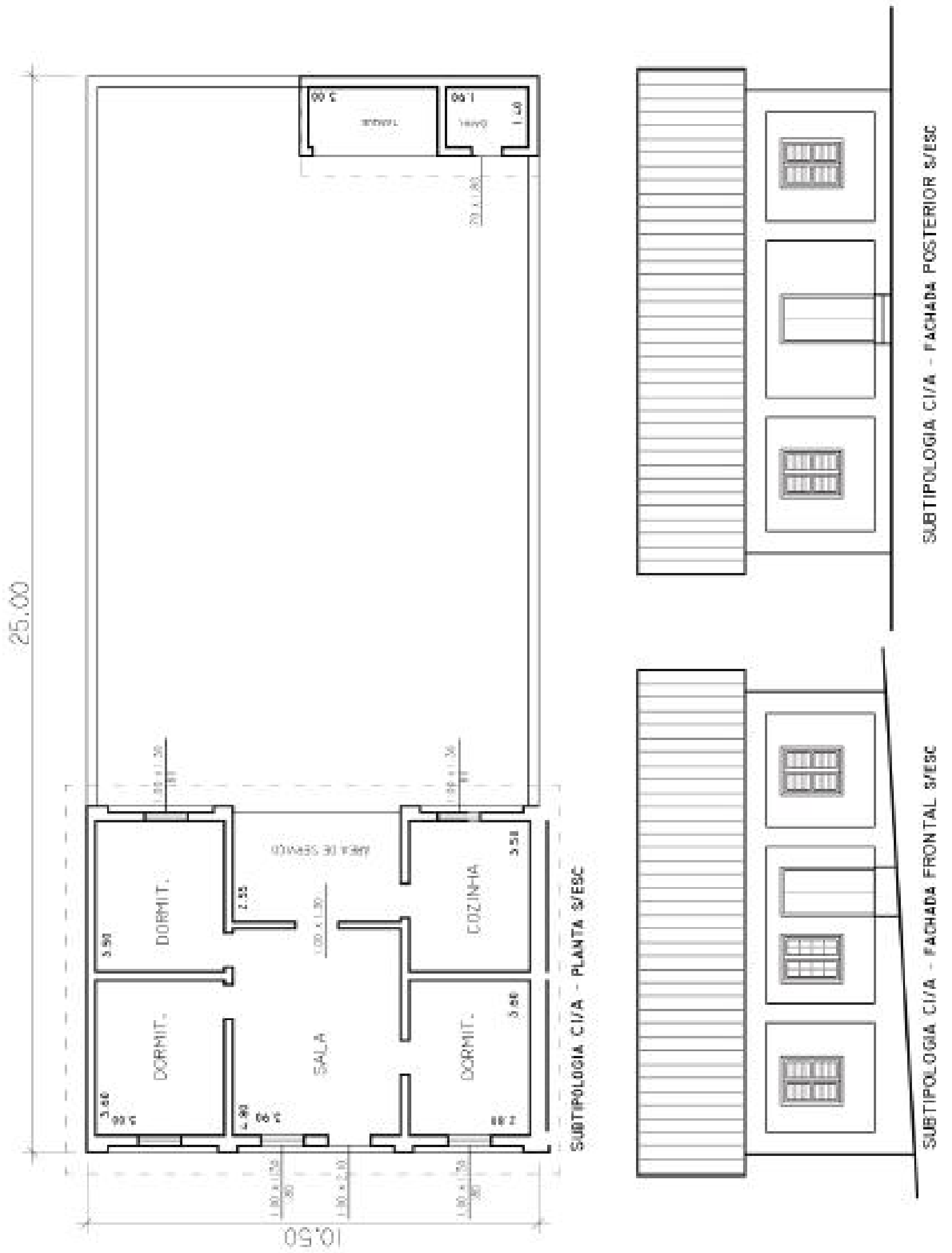

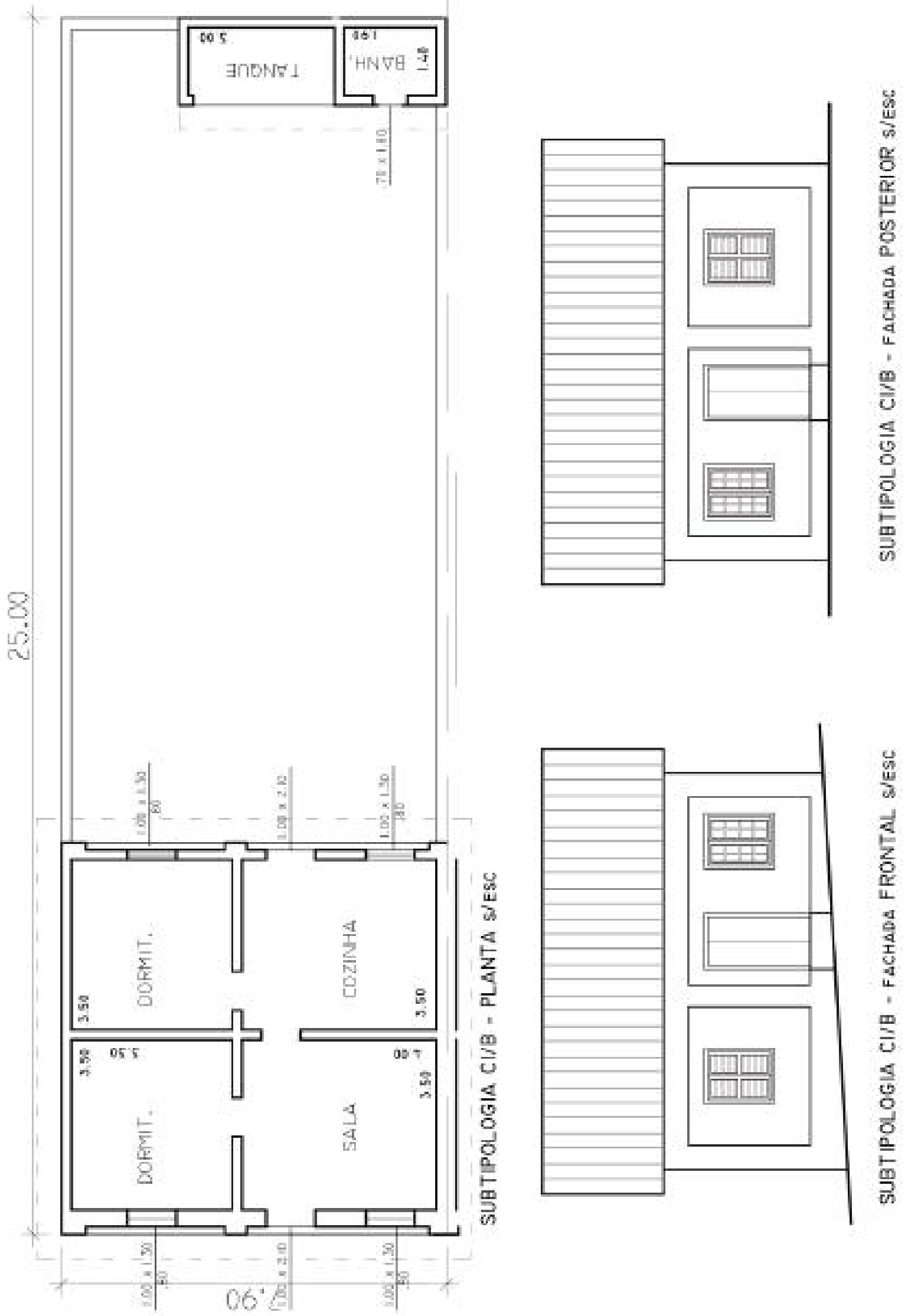
SUBTIPOLOGIA C2- casas em linha, sem recuos, em lotes menores

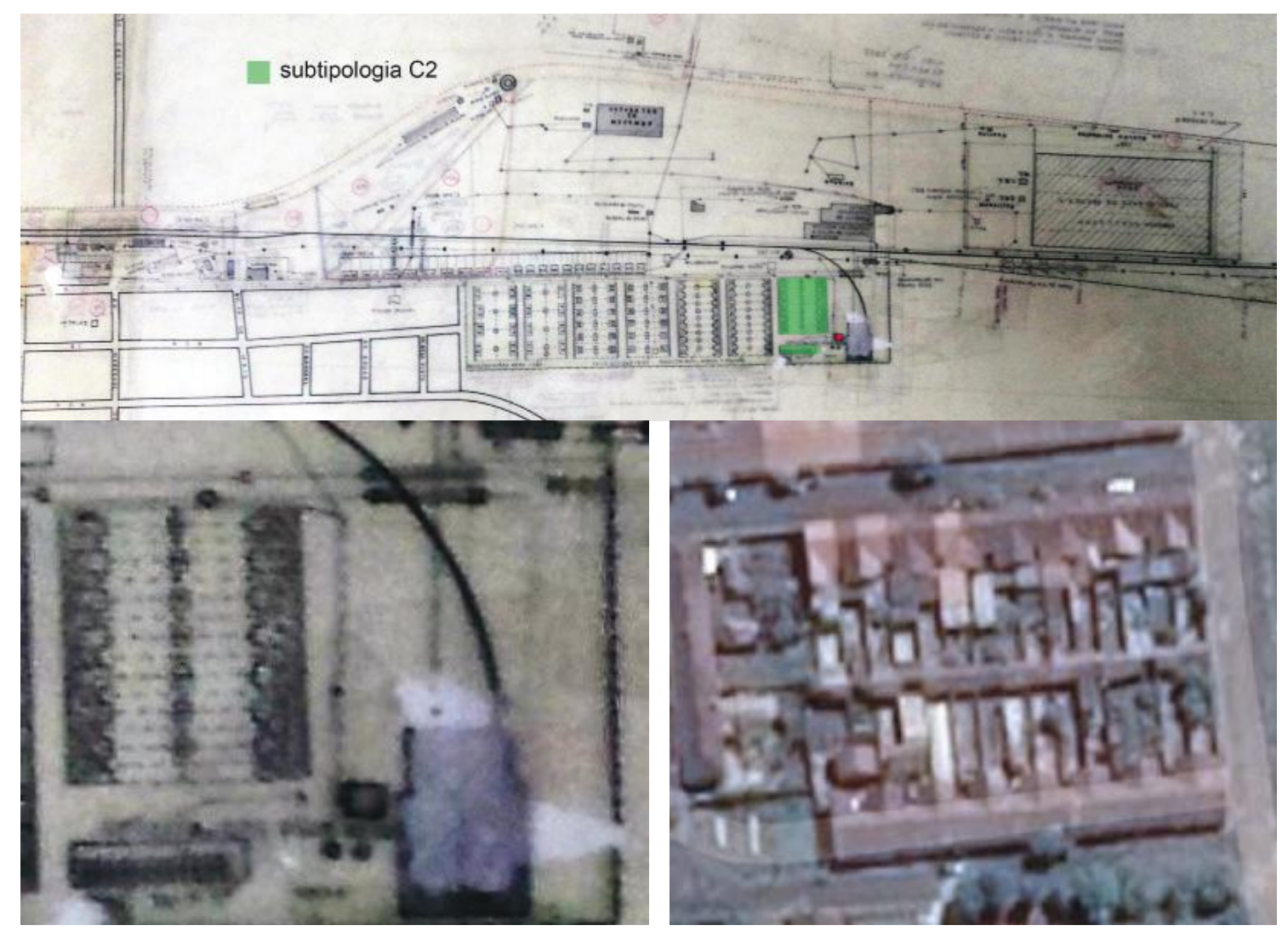

As subtipologias C1 e C2 são as que inicialmente denominamos casas em linha, pois não apresentam recuos frontais ou laterais, e tampouco porão. Elas diferem na área e no tamanho do lote, sendo a subtipologia C2, a menor das tipologias.

Área - 48 m2, segundo Relatório “Avaliação de Edifícios e Dependências”, da RFFSA, de 31 de dezembro de 1991. Segundo levantamento da prefeitura, 32 unidades de aproximadamente $40 \mathrm{~m} 2$ e anexo de 7,00 m2.

Pé-Direito: aprox. de 2,50m a 3,00m.

Programa: Um dormitórios, sala, cozinha, banheiro e área de serviço externa.

Materiais: Cobertura: de duas águas. Novamente, não é possível saber quais são as telhas originais, se as telhas francesas ou as de capa e canal. A estrutura é provavelmente de tijolos. A parede é de alvenaria revestida. As esquadrias, portas externas (dimensões $1,00 \mathrm{~m}$ x 2,10m, com duas folhas e bandeira) e janelas (dimensões $1,00 \times 1,30 \mathrm{~m} /$ peitoril $0,80 \mathrm{~m}$ ) originais são provavelmente de madeira. Inclusive encontramos algum exemplar delas. As portas são de duas folhas. As janelas são de duas folhas, envidraçadas, e com persianas externas e outras com fechamento interno também em madeira. Sobre a cor, não é possível saber sem um exame mais aprofundado. Alguns dos caixilhos em madeira 
que consideramos originais apresentam a cor desgastada em tons azulados, porém é necessário um exame mais aprofundado. Não apresentam porão. Por causa do desnível do terreno, algumas apresentam degrau.

Estilo: trata-se de arquitetura modesta, sem propriamente um estilo

Fachada frontal: Não há nenhum tipo de recuo, estando a fachada no alinhamento da rua. Existem pilastras características de outras vilas ferroviárias da Companhia Paulista, e também há uma base de quase meia parede sobressalente no mesmo nível da pilastra, que deixa evidente o desnível do terreno e apresentam degrau. Geralmente a fachada apresenta uma porta e uma janela.

Conservação: A fachada em sua parte estrutural e de fechamento encontra-se em razoável estado de conservação. Algumas das coberturas estão com problemas de estrutura e faltam telhas, mas no geral estão em estado razoável de conservação. Algumas das portas e janelas foram substituídas por alumínio, com modificação do tamanho das aberturas, prejudicando a uniformidade das fachadas. Algum padrão com tamanho e desenho das aberturas originais das portas e janelas deverá ser observado em um possível "guia de transformação", sendo possível uma adaptação no material utilizado. A adaptação para um banheiro interior deve ser permitida, porém o anexo original deverá ser mantido. A manutenção de anexos posteriores à planta de 1967, deverão ser estudados.
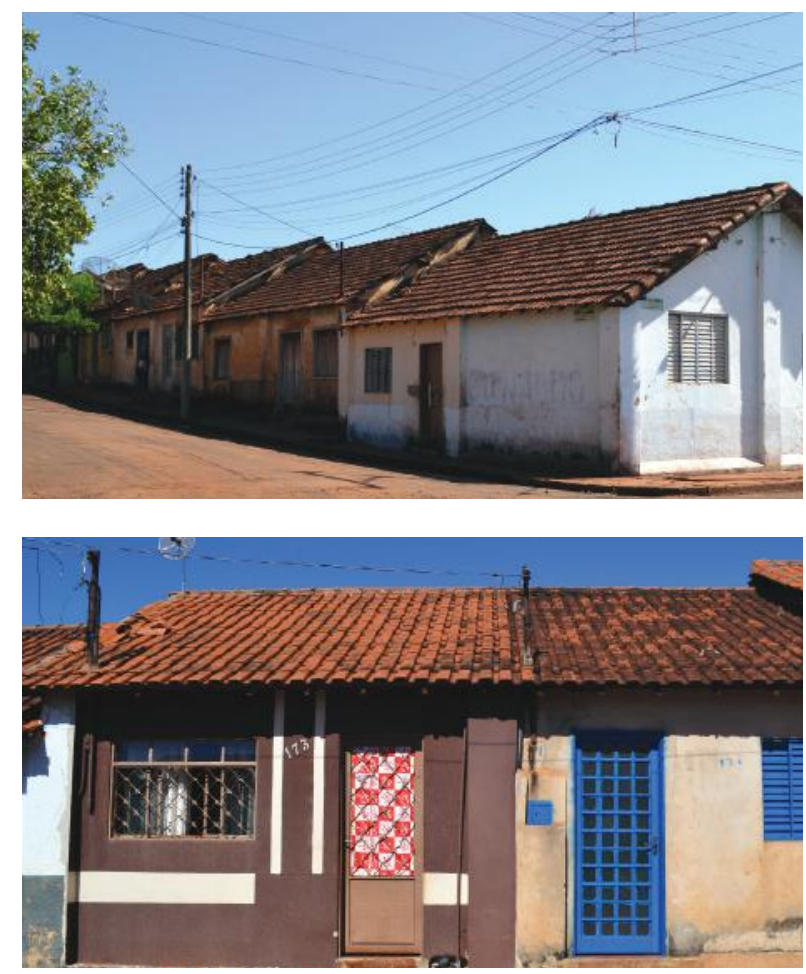

Foto 201 - Visão geral da rua.

Foto 202 - Fachada frontal da subtipologia C2. Fotos: autora, julho 2013.

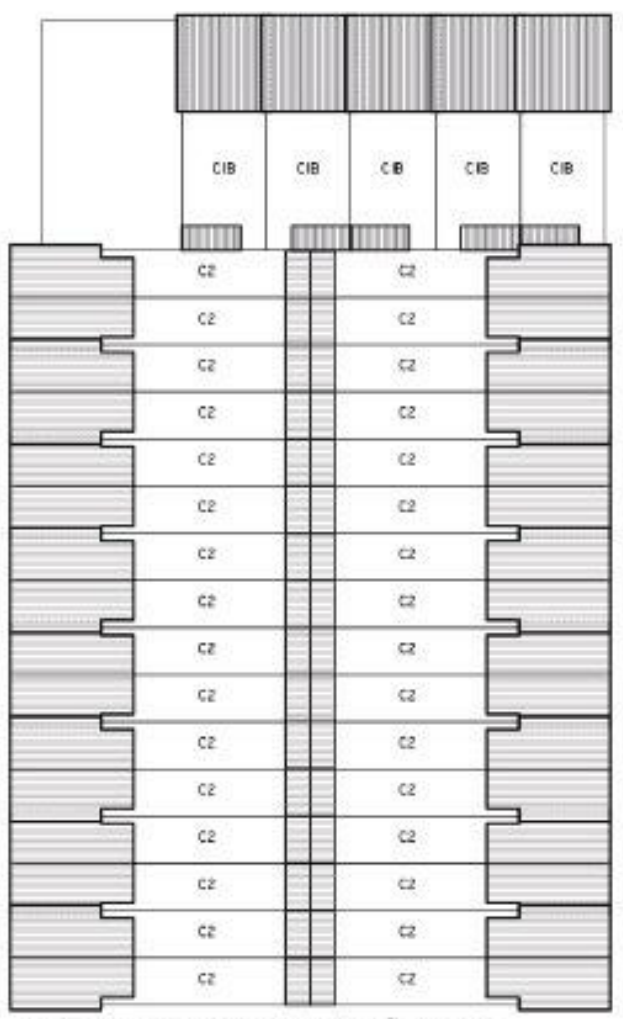

SUBTIPOLOGIAS C2- IMPLANTAÇÃO S/ESC 

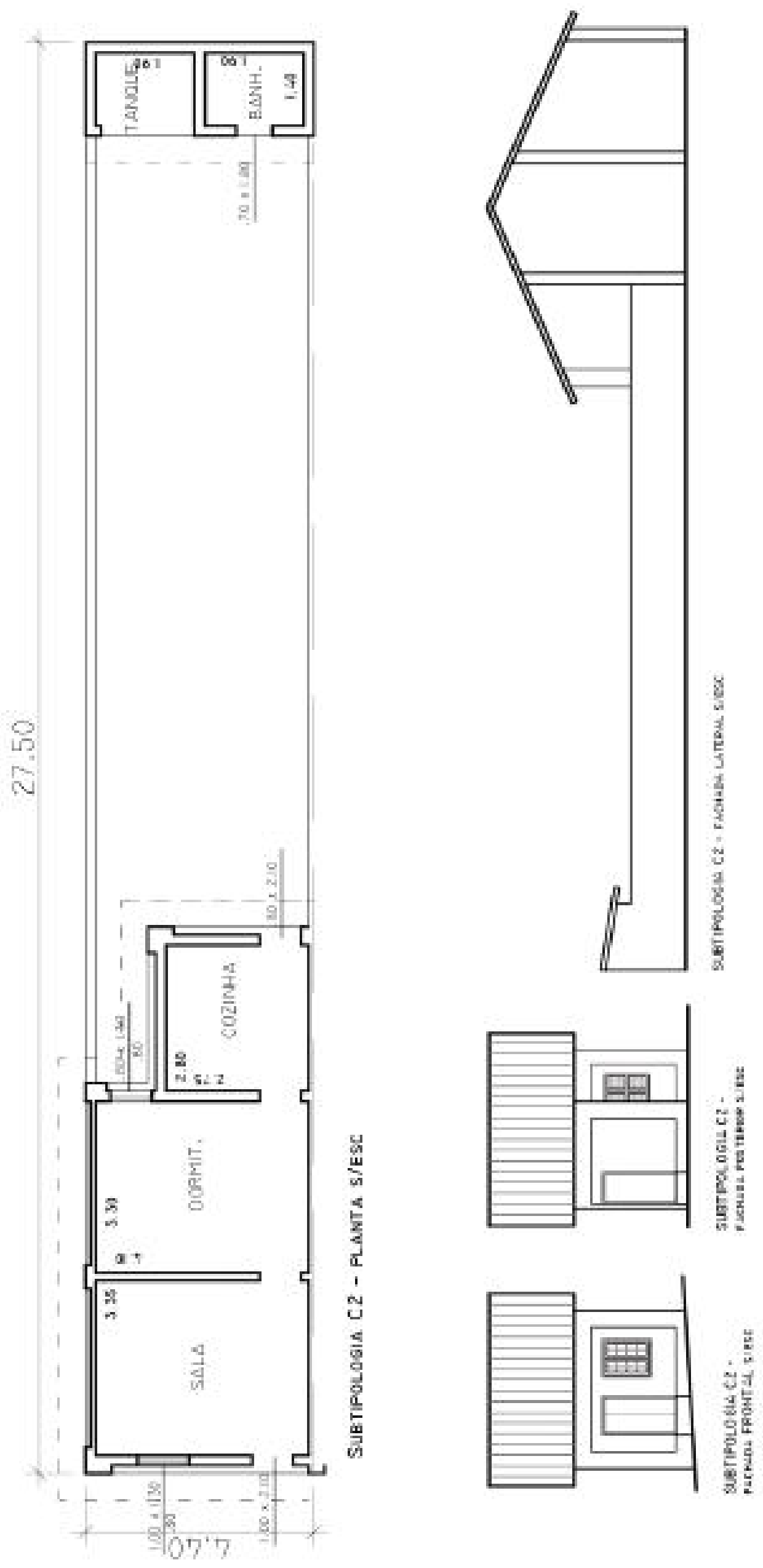


\section{CASA DO CHEFE DA ESTAÇÃO}

É uma tipologia à parte. Também de alvenaria revestida. Infelizmente, não tivéssemos acesso à casa, apenas a observamos pela parte externa, que já se encontra bastante descaracterizada. Também tivemos acesso a uma planta realizada pela prefeitura, na década de 1980.

Como não tivemos acesso à casa, a descrição em alguns itens ficará incompleta.

Área - ??? m2

Pé-Direito: (seguindo o padrão das outras casas, provavelmente terá 3,50m)

Programa: Dois dormitórios, escritório, sala, copa, cozinha, banheiro e área de serviço desta vez internos. Ainda assim, pela planta pode-se identificar dois anexos: um tanque e uma edícula, que não se sabe bem a função. Destaca-se neste programa, o escritório, espaço fundamental na casa do chefe da estação, verificado em programas de outras companhias.

Materiais: Cobertura: de quatro águas. Novamente, não é possível saber quais são as telhas originais, se as telhas francesas ou as de capa e canal. A estrutura é provavelmente de tijolos. A parede é de alvenaria revestida.

Estilo: trata-se de arquitetura modesta, sem propriamente um estilo

Fachadas: Existem pilastras características de outras vilas ferroviárias da Companhia Paulista.

Conservação: Pelo que se pode observar, os caixilhos foram modificados. De original, apenas as paredes.
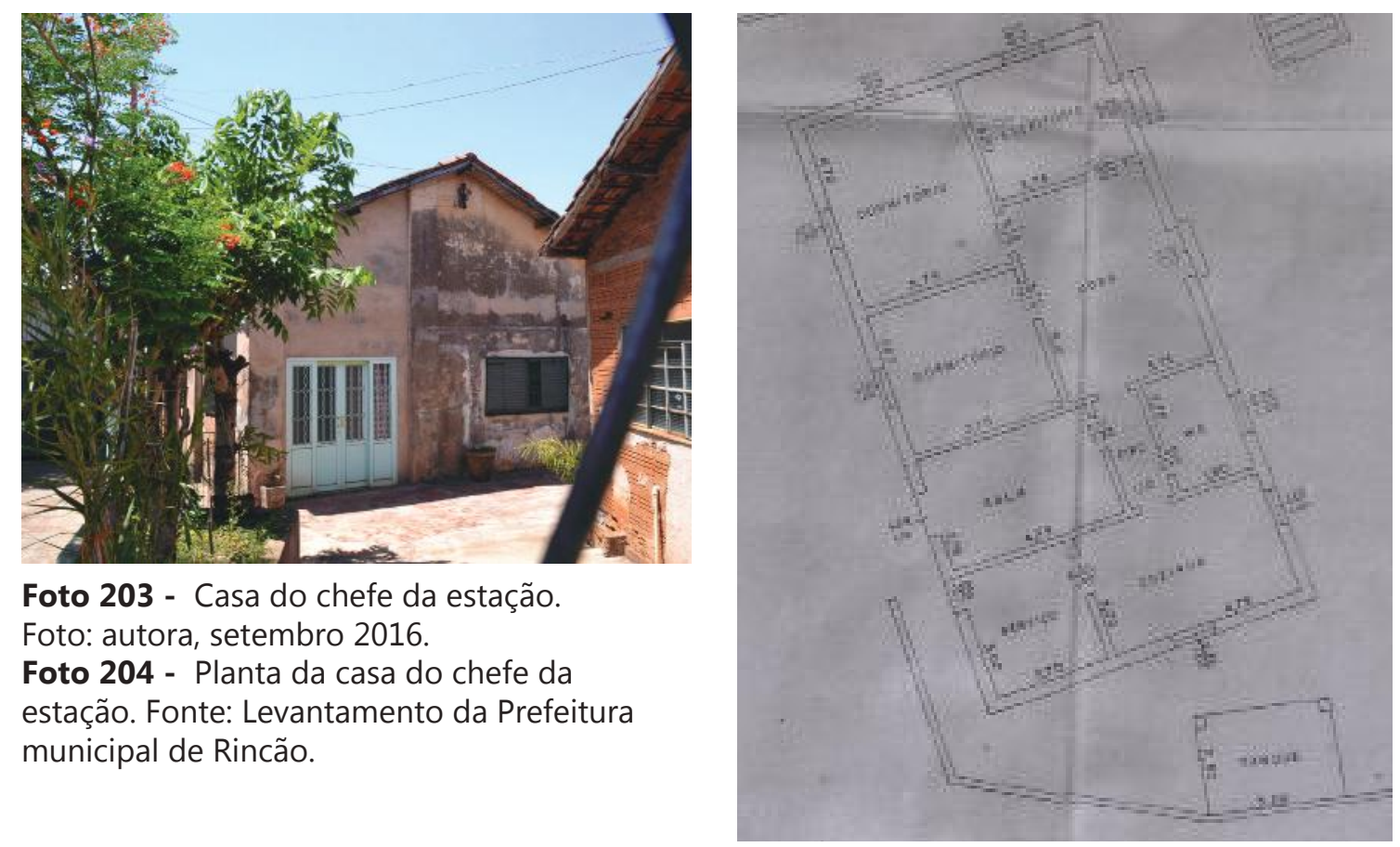

Foto 203 - Casa do chefe da estação. Foto: autora, setembro 2016.

Foto 204 - Planta da casa do chefe da estação. Fonte: Levantamento da Prefeitura municipal de Rincão. 


\section{CASA DO CHEFE DA SUBESTAÇÃO ELÉTRICA}
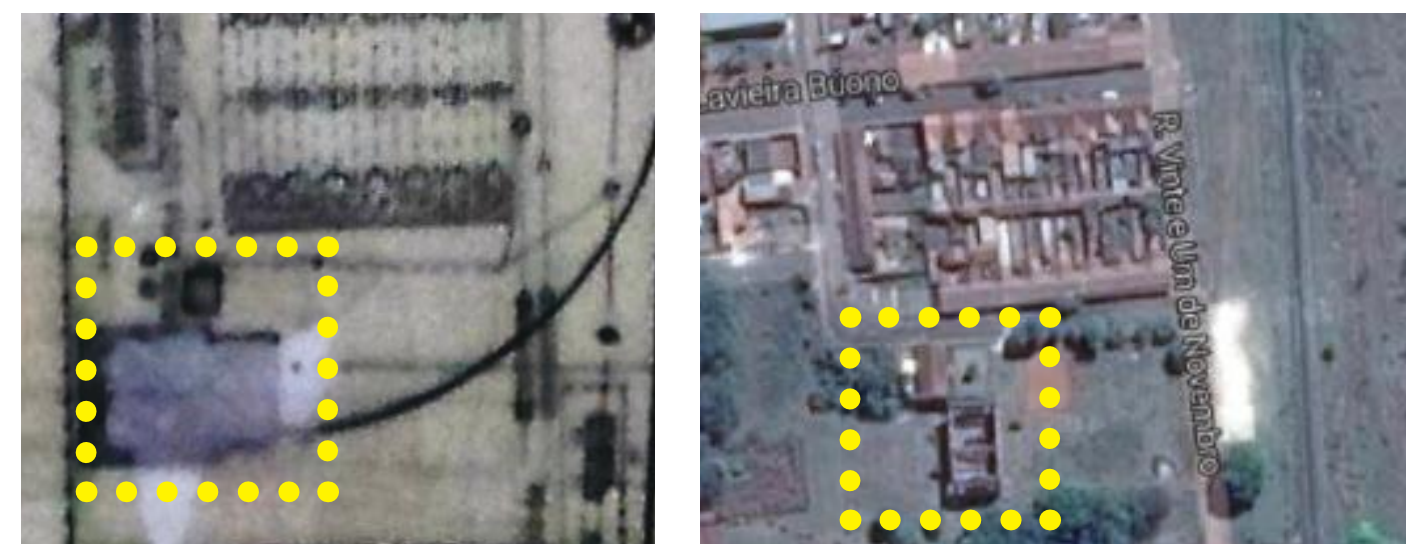

Como a casa do chefe da estação, é uma tipologia à parte, nem todas as casas dos chefes das subestações elétricas são iguais em todas as cidades. A de Dois Córregos, possui ornamentação em estilo Art-Decó. A de Rincão é em tijolo aparente, e assemelha-se a de São Carlos. Atualmente a subestação encontra-se abandonada e destelhada, porém a casa do chefe da subestação está habitada, com uso residencial.

Como não tivemos acesso à casa, a descrição em alguns itens ficará incompleta.

Área - 48 m2, segundo Relatório “Avaliação de Edifícios e Dependências”, da RFFSA, de 31 de dezembro de 1991.

Pé-Direito: Provavelmente, conforme observado em outras casas, 3,50m.

Programa: Podendo haver escritório.

Materiais: Cobertura: de duas águas. Novamente, não é possível saber quais são as telhas originais, se as telhas francesas ou as de capa e canal. A estrutura é provavelmente de tijolos. A parede é de tijolo aparente. As portas são de duas folhas e parcialmente envidraçadas. As janelas são de duas folhas, envidraçadas, e com persianas externas e outras com fechamento interno também em madeira. Os caixilhos estão desgastados pelas intempéries, e possuem a cor azulada, porém é necessário um exame mais aprofundado sobre a cor. Apresentam o piso elevado, inclusive com aberturas que lembram um porão. Provavelmente, o piso seria de assoalho e o forro de madeira.

Estilo: trata-se de arquitetura modesta, sem propriamente um estilo.

Fachadas: As casas dos chefes geralmente possuem uma implantação mais livre no terreno. A implantação da casa ou escritório do chefe da subestação de Rincão está muito próxima à subestação. Há uma fachada frontal e outra posterior, porém a fachada voltada para a rua, é uma empena cega. Existem pilastras características de outras vilas ferrovi- 
árias da Companhia Paulista, porém desta vez aparentes. Há uma base de nivelamento do terreno, e que se encontra revestida. Há também um friso revestido que se destaca da fachada. A fachada posterior espelha a frontal.

Conservação: Coberturas, estruturas e fechamentos encontram-se em bom estado de conservação. Assim como as portas e janelas parecem que são originais, e encontram-se em razoável estado de conservação. Em um possível "guia de transformação", sublinhar que se devem manter a caixilharia, e o tijolo aparente. Quanto ao uso residencial, dependendo do uso dado à subestação poderá ser mantido ou modificado.

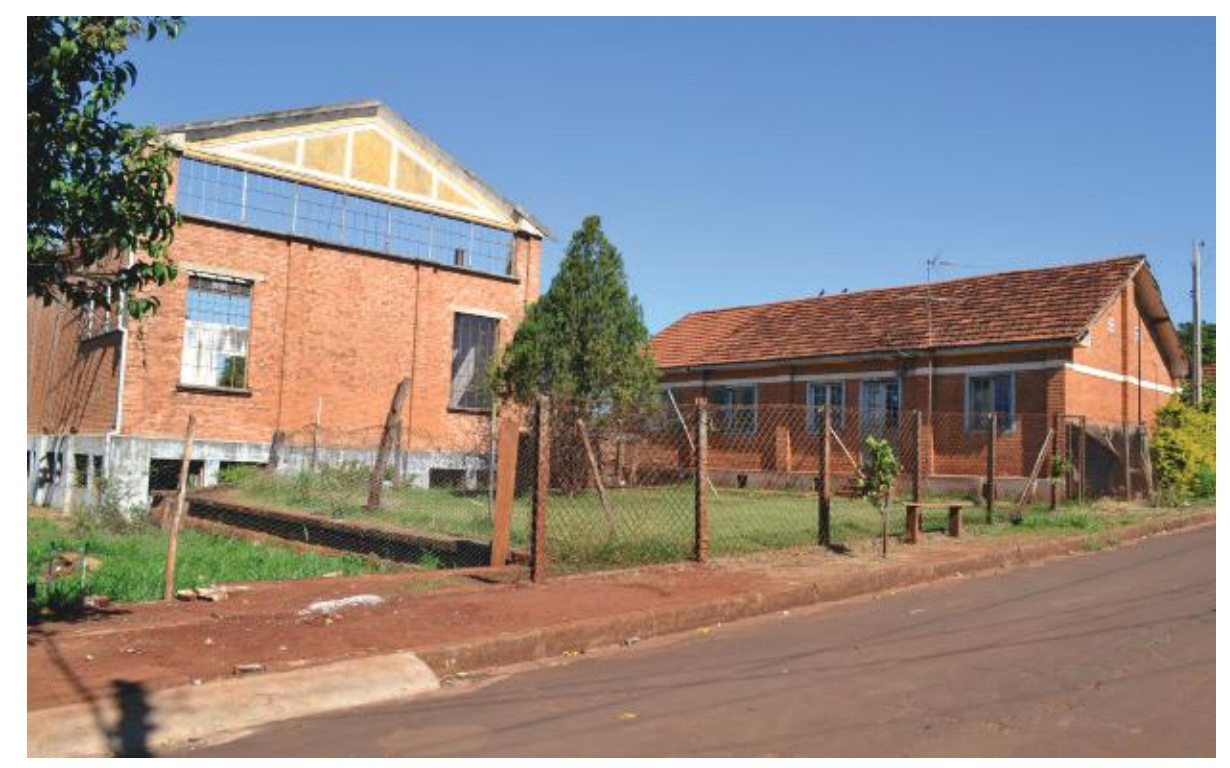

Foto 205 - Subestação elétrica abandonada, e sem a cobertura. Ao lado a casa do chefe da subestação. Foto: INOUE, julho 2013.

A seguir, prossegue-se com a análise de outros elementos morfotipológicos.

\section{A FACHADA (O PLANO MARGINAL)}

As fachadas frontais ou as que faceiam as ruas parecem ser de grande importância para manter o caráter local. Há algumas descaraterizações com relação ao tamanho das aberturas de portas e janelas, porém ainda se pode perceber como deveriam ser as originais e fazer alguns esboços. Não existem fachadas em Art-Decó, como em Dois Córregos, apenas a casa do chefe da subestação elétrica, como também a própria subestação, são em tijolo aparente. Como não há propriamente estilo, é extremamente 
importante manter o padrão das fachadas, com o tamanho de suas aberturas originais, para manter o caráter da vila. Aliás, a perspectiva da leitura morfotipológica é justamente a de valorizar a forma e não tanto o estilo, dada a simplicidade das unidades. Um outro aspecto importante é o não fechamento dos recuos existentes. A altura dos muros e portão, como também seu desenho, seria um outro aspecto a conferir o caráter do lugar e a se ter em conta nos guias de transformação.

Um detalhe relacionado às fachadas é manter as placas dos números de bens patrimoniais onde há, e também o logotipo da Companhia Paulista, onde houver.

\section{O SOLO - O PAVIMENTO}

A questão do solo pode ter vários sentidos. Um deles é o tratamento da superfície, as texturas que podem conferir caráter ao lugar. O segundo sentido tem relação com sua ocupação. Poderíamos falar em usos do solo (comercial, institucional, residencial), a ocupação densa ou não, etc... Deste segundo sentido, derivam-se os itens seguintes: lote, quarteirão, logradouro, traçado da rua, cada um dos quais, comentaremos a seguir. Outro aspecto já discutido anteriormente é a implantação.

Sobre a implantação, vale lembrar que a vila ferroviária não teria sentido sem a estação e todo seu complexo, como já discutido. O tamanho da vila é remete à demanda de trabalhadores. Desse modo, oficinas, armazéns e locais de baldeação e entroncamentos possuem maiores vilas ferroviárias. A vila ferroviária de Rincão era um local de baldeação de bitolas diferentes, e depois, de linhas elétricas e não elétricas. Também já foi mencionado anteriormente que na vila ferroviária, foram encontrados elementos que refletem a hierarquia social do trabalho: casas dos chefes das estações em lotes maiores, e em locais estratégicos, próximos às estações ou nas esquinas de quarteirões. Ainda neste complexo ferroviário, vale recordar que não encontramos equipamentos institucionais mais ligadas à vila ferroviária que propriamente à estação, que são encontrados em algumas vilas operárias, tais como escolas, igrejas, hospitais e lugares recreativos. Apenas o campo de futebol e a associação dos ferroviários, ambas iniciativas destes, situados na Rua dos Ferroviários.

De maneira geral, a ocupação do solo não é densa, nem horizontalmente, nem verticalmente, como pode ser observado nos mapas, sendo o gabarito bastante plano. A vila ferroviária é obviamente residencial, e isto não se alterou ao longo do tempo. Recorda-se isto pois, em alguns lugares, em que as vilas ferroviárias estão localizadas em áreas 

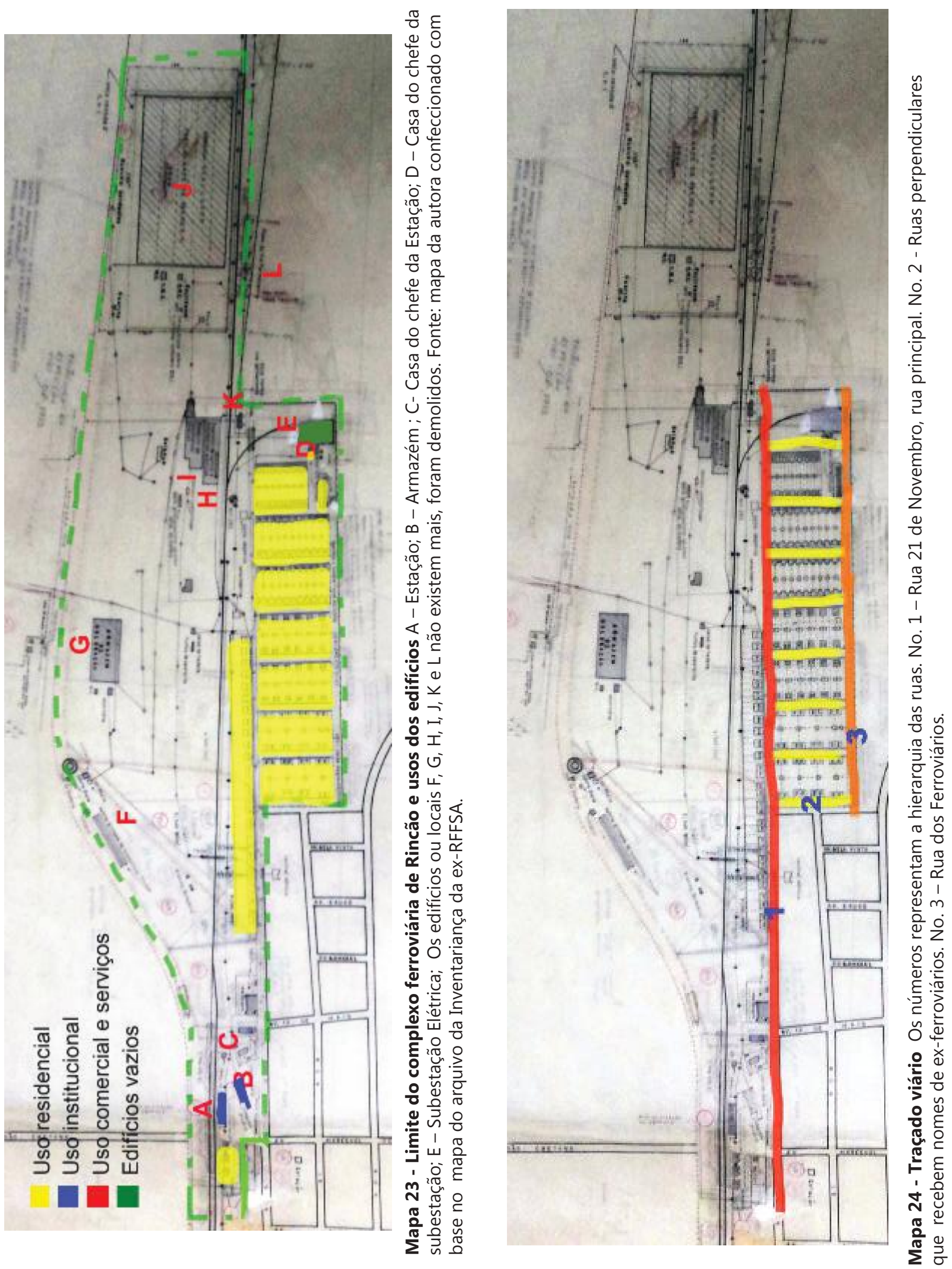
centrais ou valorizadas, sofrem demolições ou são substituídas por usos comerciais ou outros. Os edifícios das estações e armazéns, perdendo a sua função original, encontram-se muitas vezes vazios. Novamente, em áreas onde o terreno é valorizado, por pressões imobiliárias, tais edifícios acabam sendo demolidos. As estações e armazéns que estudamos encontram os mais variados usos, mas geralmente cultural (o que levanta a questão da sustentabilidade financeira), ou uso institucional ou comercial. No caso de Rincão, a Prefeitura Municipal instalou-se na estação e no armazém ao lado.

Falando em futuro, ou apontando caminhos para guias de transformação, não vemos problemas no uso institucional dado à estação e ao armazém. À vila ferroviária, obviamente, caberia a continuidade do uso residencial.

Quanto ao tratamento da superfície, atualmente as ruas são asfaltadas e de domínio público. Segundo testemunho de um professor de Sociologia da UNESP de Araraquara $^{1}$, que chegou a morar na vila em sua infância, quando seu pai era ferroviário já da FEPASA, as ruas foram de terra, assim o asfaltamento é recente. Quando pertenciam à Companhia Paulista, as ruas poderiam ser de domínio privado, delimitado por alguma barreira física, que separasse o tecido da cidade do tecido da vila ferroviária. Mas até o presente momento, e segundo relatos, tudo indica que as vilas ferroviárias se mesclavam com o tecido da cidade em que se instalaram. No caso de Rincão, a vila ferroviária inclusive pode ter sido o núcleo inicial da cidade, já que esta surgiu com a ferrovia.

Ainda de domínio público são as calçadas. Em algumas partes, como elas se encontram desgastadas pode-se ver que eram feitas com tijolos. Certamente, tais calçadas seriam as originais e construídas pela Companhia Paulista. Uma questão a ser descoberta é se a Companhia Paulista possuía uma olaria própria. Contudo, segundo o testemunho do professor, a calçada da rua que morou era de pedras de arenito (como se vê na foto).
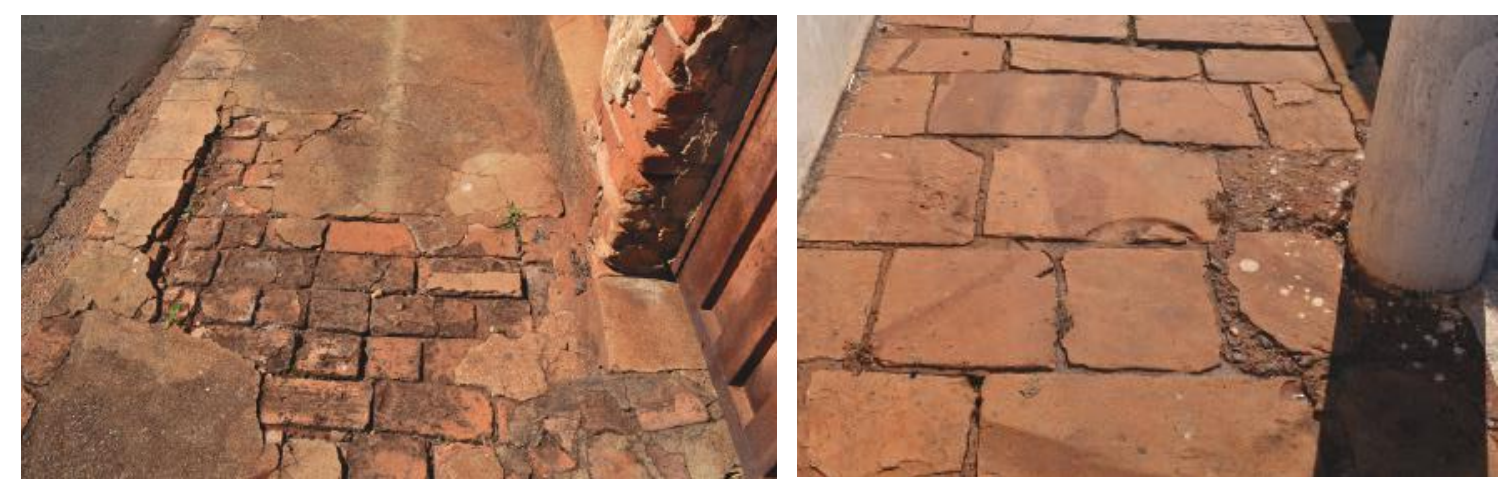

Foto 206 (Esquerda) - calçada com tijolos. Foto 207 (Direita) - calçada com revestimento em arenito. fotos: autora, 2013.

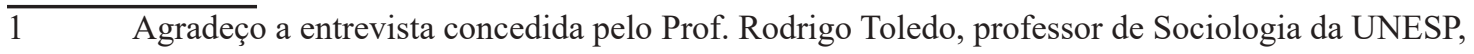
campus Araraquara, realizada em Rincão, em outubro de 2016. 


\section{O TRAÇADO, A RUA}

Existe uma rua principal, quase paralela à linha de trem (hoje denominada rua 21 de novembro), que pode ser considerada um dos eixos estruturantes da vila ferroviária, e encontra-se na cota mais baixa. Dela partem oito ruas perpendiculares, em ligeiro aclive, e ainda existe uma via paralela que hoje é denominada Rua dos Ferroviários. As ruas perpendiculares possuem nomes de pessoas (R. Américo Michelon, Leonardo Pavoni, José de Melo, Osvaldo Batista, Antônio Dória, Reinaldo Izique, e Lavieira Buono), são nomes de ex-ferroviários.

As casas encontram-se ao longo da rua principal, como dos sete quarteirões que conformam. Além de um pequeno núcleo de 3 unidades residenciais próximas à estação, hoje subdividas em seis unidades.

\section{O QUARTEIRÃO}

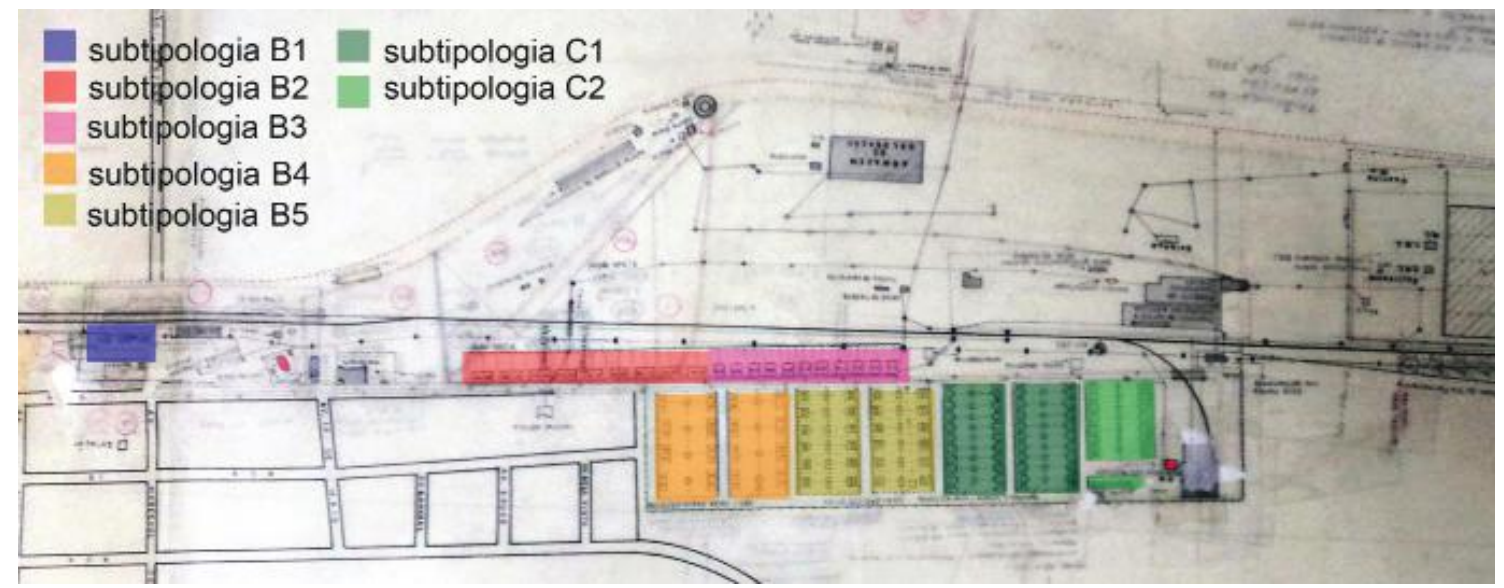

Mapa 22 - Principais tipologias residenciais de Rincão. Fotos: autora, 2013.

Rincão é uma das vilas ferroviárias que mais apresentam unidades residenciais, e portanto, as unidades residenciais estão agrupadas em vários quarteirões. Na planta encontrada, de 1967, pode-se identificar um núcleo residencial, somado a sete quarteirões, que estão assim conformados, segundo tipologias residenciais:

Núcleo próximo à estação, com subtipologia B1: 6 unidades.

Casa do chefe da estação: 1 unidade

Casa o chefe da subestação: 1 unidade

Quarteirão ao longo da rua principal (atual R. 21 de novembro), com 6 unidades da subtipologia B2A, e 12 unidades da subtipologia B2B, totalizando 18 unidades

Quarteirão ao longo da rua principal (atual R. 21 de novembro), com 22 unidades da 


\section{subtipologia B3.}

Um quarteirão com 20 unidades da subtipologia B4A e outro quarteirão com 16 unidades com a subtipologia B4B. Os dois quarteirões juntos, totalizam 36 unidades.

Dois quarteirões com a subtipologia B5 : cada quarteirão possui 24 unidades. Os dois quarteirões totalizam 48 unidades.

Dois quarteirões com subtipologias C1A e C1B: cada quarteirão possui 8 unidades subtipologia C1A e 12 unidades da subtipolgia C1B. Os dois quarteirões totalizam 40 unidades.

Um quarteirão com 32 unidades da subtipologia C2, e mais 5 unidades da subtipologia C1A, totalizando 37 unidades.

Segundo as unidades citadas acima, haveria no total 209 unidades construídas, dado que diverge dos números do Relatório da Companhia Paulista, e da Inventariança, e inclusive pode variar conforme o tempo segundo desmembramentos, remembramentos e demolições.

\section{O LOTE - A PARCELA FUNDIÁRIA}

Em geral, os lotes são regulares e ortogonais. As tipologias e os lotes estão relacionados, assim, de modo geral, segundo a tipologia, o tamanho do lote é distinto, nas tipologias que apresentam recuos ou são isoladas. As dimensões aproximadas dos lotes segundo as subtipologias:

Lote $\mathrm{B} 1=15 \times 18.35 \mathrm{~m}=275,25 \mathrm{~m} 2$

Lote $\mathrm{B} 2=11 \times 25=275 \mathrm{~m} 2$

Lote $\mathrm{B} 3=7,40 \times 25=185 \mathrm{~m} 2$

Lote $\mathrm{B} 4 \mathrm{~A}=12,60 \times 25=315 \mathrm{~m} 2$

Lote $\mathrm{B} 4 \mathrm{~B}=11 \times 25=275 \mathrm{~m} 2$

Lote $\mathrm{B} 5=7,90 \times 25=197,50 \mathrm{~m} 2$

Lote $\mathrm{C} 1 \mathrm{~A}=10,50 \times 25=262,50 \mathrm{~m} 2$

Lote $\mathrm{C} 1 \mathrm{~B}=7,90 \times 25=197,50 \mathrm{~m} 2$

Lote $\mathrm{C} 2=4,40 \times 27,50=121 \mathrm{~m} 2$

\section{O LOGRADOURO}

O logradouro constitui o espaço privado do lote não ocupado por construção, as traseiras, o espaço privado, separado do espaço público pelos contínuos edificados. O logradouro foi, também, na cidade tradicional, um resíduo, ou resultado dos acertos de loteamentos e de 
geometria de ocupações dos lotes. (LAMAS, 2011, p. 98)

Constitui o que se costuma chamar em muitos mapas de "cheios", ocupado por edificações e "vazios", o espaço privado do lote não ocupado.

Pode-se perceber que na planta original, possuía um longo quintal (cujos aspectos moralizantes da época, foram discutidos no capítulo 2) e um anexo ao fundo, que provavelmente seria o banheiro conjugado a uma lavanderia. Atualmente esta configuração está bastante descaracterizada, pois os moradores já fizeram suas extensões ao longo do terreno, como se pode observar por uma foto aérea do "Google Earth".

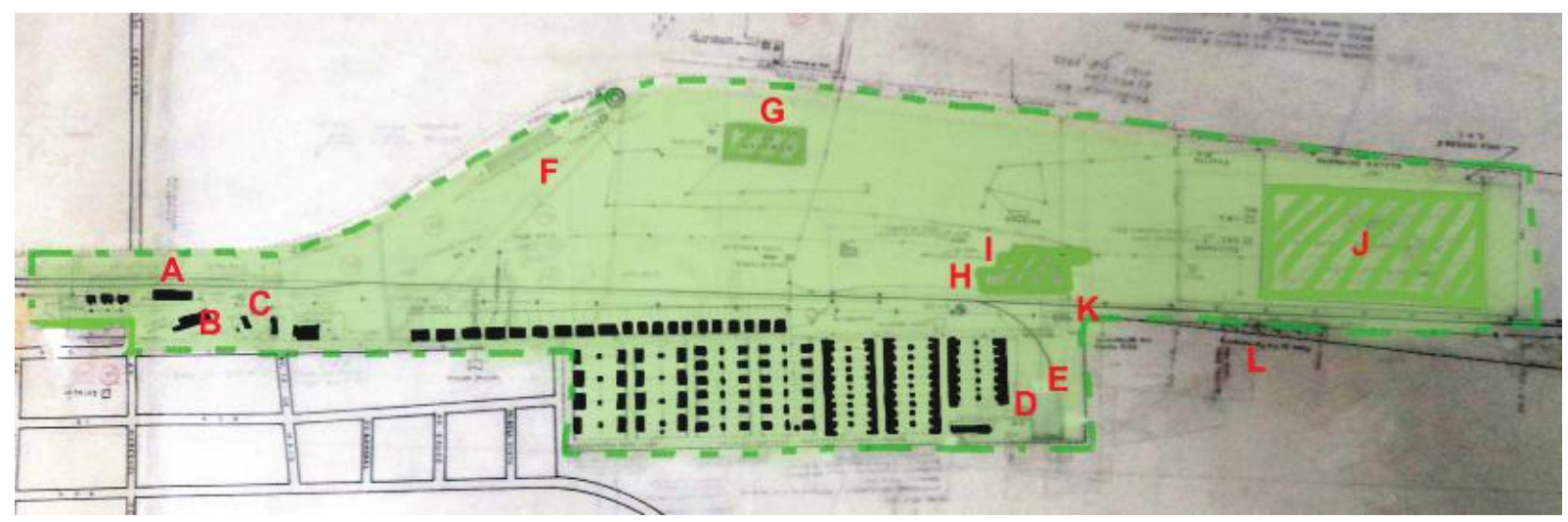

Mapa 25 - Logradouro - As formas em preto são os edifícios. O restante são os "vazios". Os edifícios G, H, I e J (armazém regulador de café) com hachuras não existem mais, foram demolidos. Assim como os edifícios F,K e L não existem mais. A - Estação; B - Armazém ; CCasa do chefe da Estação; D - Casa do chefe da subestação; E - Subestação Elétrica. Fonte: mapa confeccionado pela autora tendo como base planta da Inventariança da ex-RFFSA.

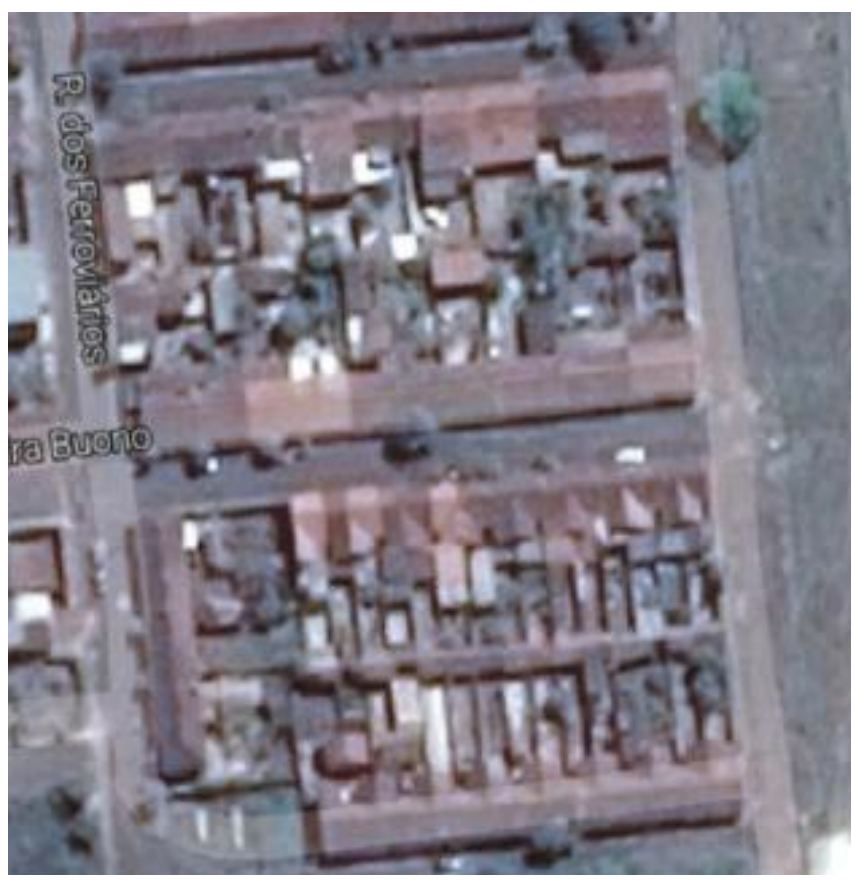

Foto 208 - Foto aérea que mostra como os terrenos estão ocupados atualmente. Fonte: Google Earth. 
8. A PRAÇA - Não existe propriamente uma praça, mas pelo que foi notado em relação as demais estações e vilas ferroviárias estudadas, existe sempre uma grande esplanada em frente à estação. Em muitas das situações atuais, tais esplanadas foram transformadas em praças, com ruas em paralelepípedos, jardins e bancos.

9. O MONUMENTO - Ao visitar as vilas ferroviárias das cidades estudadas, é comum a população saber onde está localizada a estação. Considera-se, portanto, a própria estação como um marco ou um monumento, facilmente identificável pelos observadores. Em Rincão, a cidade nasceu com a estação, é facilmente identificável não apenas pela população como qualquer um que passe pela cidade, pois ela encontra-se logo na entrada.

Outro elemento que se destaca na paisagem, e poderia ser considerado um monumento ou marco é a caixa d'água. A caixa d'água é feita em ferro fundido, cuja construção provavelmente é datada em torno de 1920.
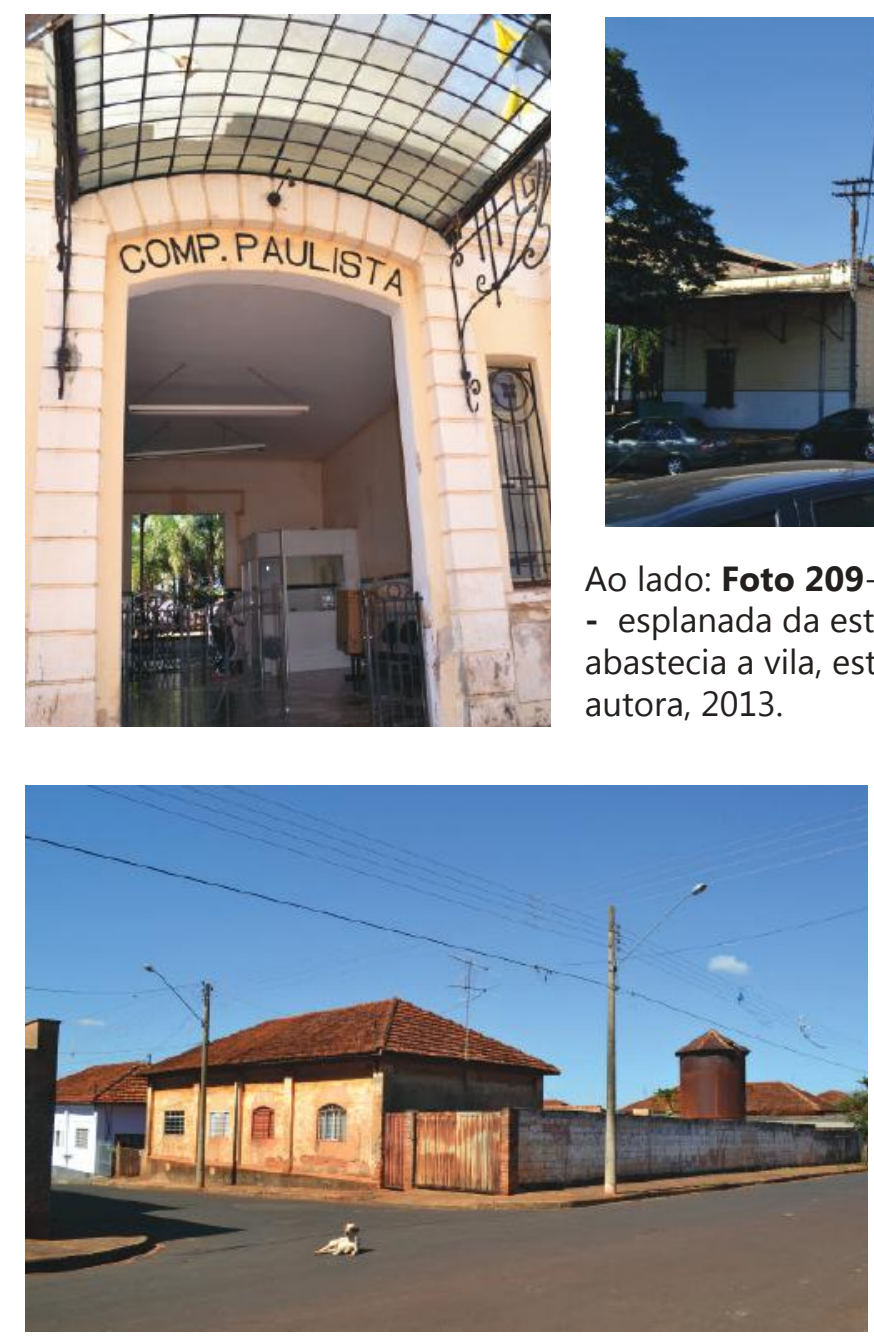

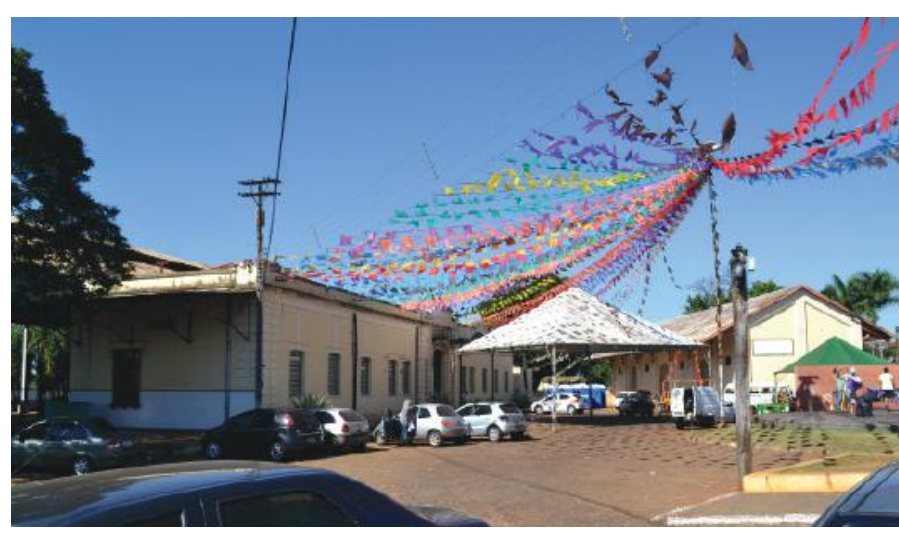

Ao lado: Foto 209- entrada da estação. Acima: Foto 210 - esplanada da estação. Foto 211 - Caixa d'água que abastecia a vila, está localizada entre dois lotes. Foto: autora, 2013. 


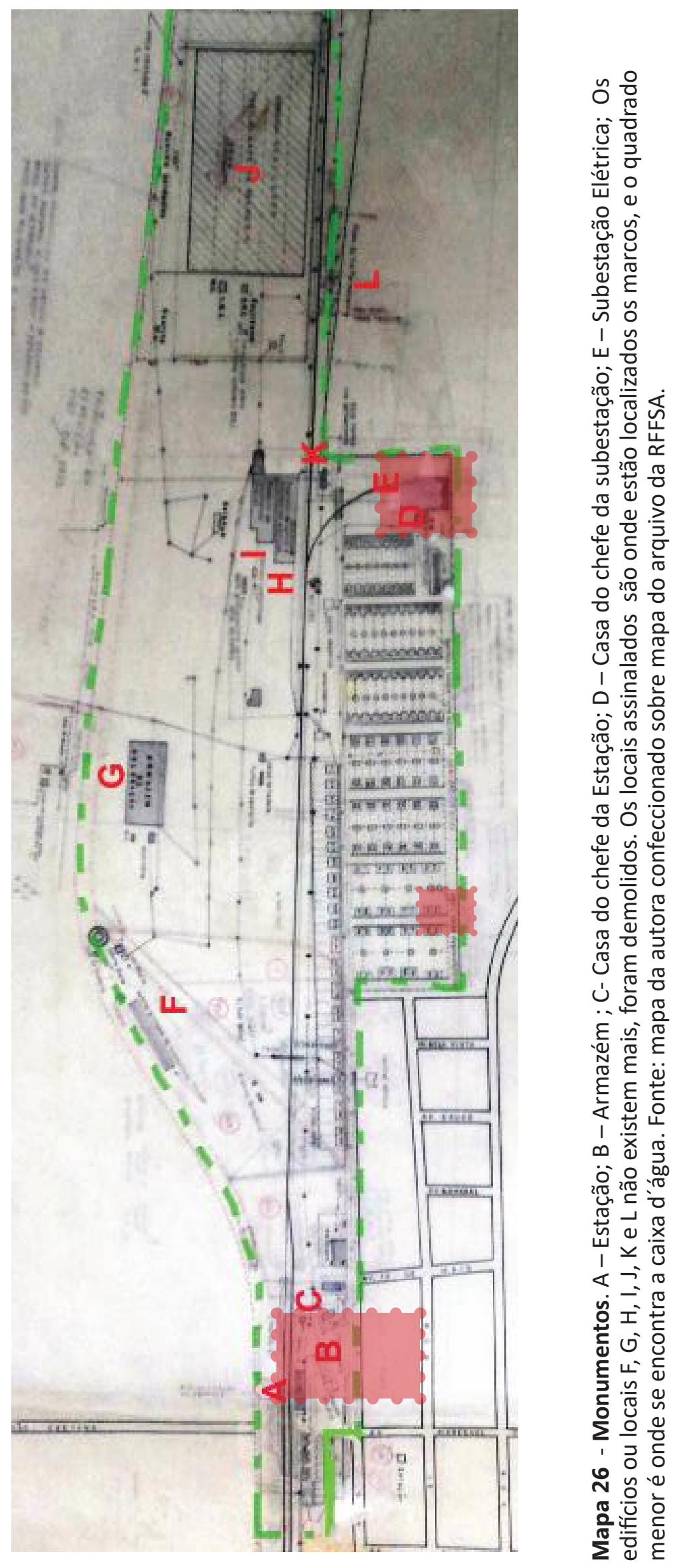



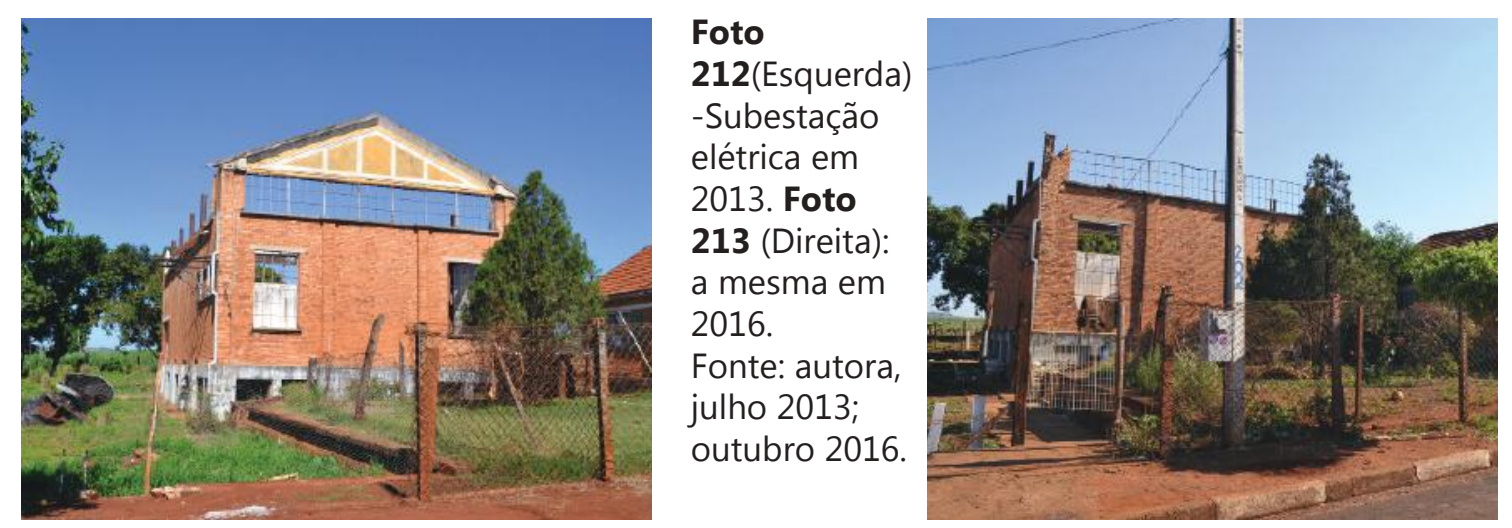

\section{A VEGETAÇÃO}

As vilas ferroviárias estudadas em geral são parcas em vegetação, e Rincão não foge à regra. Há sim, algumas árvores plantadas nas calçadas mas acredita-se que sejam de épocas mais recentes.

Existe a possibilidade de área verde nos quintais de todas casas, com exceção da tipologia mais próxima da estação por sua exiguidade. Outra possibilidade de área verde seriam os campos de futebol, muito comuns em vilas ferroviárias maiores. Mas na única prancha de implantação encontrada, da década de 1960, não existe indicação de nenhuma quadra de futebol ou outro equipamento de recreação dos ferroviários. ${ }^{2}$ Onde hoje existe um campo de futebol, em realidade, era a área que era ocupada pelos armazéns reguladores de café e outros depósitos de máquinas.
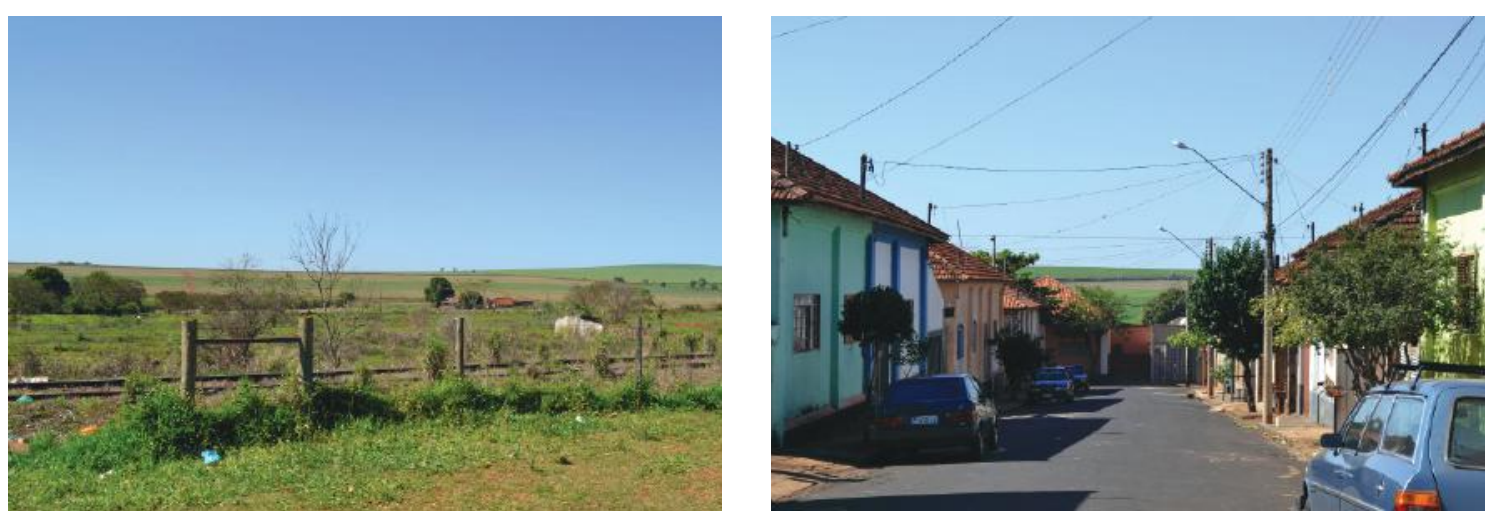

Foto 214 - Área verde livre deixada pela demolição do armazém regulador de café.

Foto 215 - Visão geral da rua, com algumas árvores plantadas nas estreitas calçadas.

Foto: autora, julho 2013.

\section{O MOBILIÁRIO URBANO}

No capítulo 2, falávamos em equipamentos que eram introduzidos com a implantação das vilas operárias e ferroviárias, como escolas, hospitais e clubes recreativos. $2 \mathrm{Na}$ visita de campo, descobriu-se que há um campo de futebol na rua dos Ferroviários, mas na planta não está indicada. 
Em Rincão, durante a visita de campo encontramos uma antiga sede da associação dos ferroviários, iniciativa destes e com alguma ligação com o sindicato. Porém, na maior parte das vilas ferroviárias estudadas não encontramos nenhum destes equipamentos, que mesmo não sendo propriamente mobiliário urbano, modificam a paisagem. Um elemento urbano já citado é a caixa d'água, que é comum nas estações mais antigas, quando as locomotivas eram movidas à vapor. Porém em Rincão, a caixa d'água foi construída para 0 abastecimento da vila.

Como mobiliário urbano podemos considerar placas, letreiros, sinalizações, bancos, postes de luz. Assim como as árvores e a vegetação, o mobiliário urbano é extremamente parco. Apenas alguns elementos chamam atenção em Rincão, e em algumas vilas ferroviárias, um deles é a placa com a indicação da vila dos ferroviários. Outro elemento é a placa com o número de bem patri-

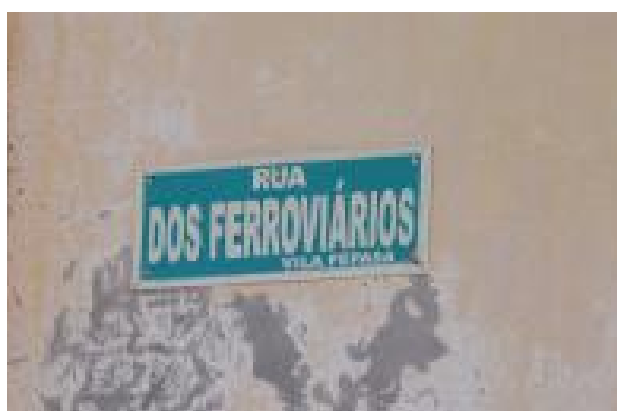

Foto 216 - Placa da rua. Foto: autora, 2013. monial, que deve remontar à época da Companhia Paulista, e quando incorporada à RFFSA, ganha nova placa. E além disso, é possível identificar a companhia ferroviária que pertenceu a vila, pois em algumas fachadas, existe a marca da ferrovia.

\section{FATORES NEGATIVOS}

Visão geral: Rincão é, das vilas ferroviárias estudadas, a que possui mais unidades, e também diversidade de tipologias. Por este motivo, para o estudo de outras vilas ferroviárias da Companhia Paulista pode servir de modelo.

Desenvolvimento recente: Ao contrário de outras cidades, não apresentou um grande crescimento. Talvez por isso, é que a vila ferroviária pode se manter ao longo do tempo, com poucas demolições e alterações. O fator negativo, em uma cidade tão pequena, é a dificuldade em lidar com a sustentabilidade econômica, face à preservação. Talvez uma saída, seria engajar a prefeitura, oferecendo suporte técnico pois a mesma não conta com um departamento de planejamento ou preservação, e esta engaje a população local.

Extensões e alterações não empáticas: Há as extensões e anexos construídos nos quintais dos banheiros, e mesmo a demolição do anexo original que compreendia banheiro e 
lavanderia. Há casos de desmembramento (subtipologia B1) e remembramento, porém sem alteração da edificação.

Outra alteração que se ressaltou bastante e que influi na fachada, e portanto o caráter do lugar, foi a substituição das portas e janelas com alteração do tamanho das aberturas, bem como o fechamento de recuos laterais com muros e portões altos, e mesmo o fechamento com outro volume construído.
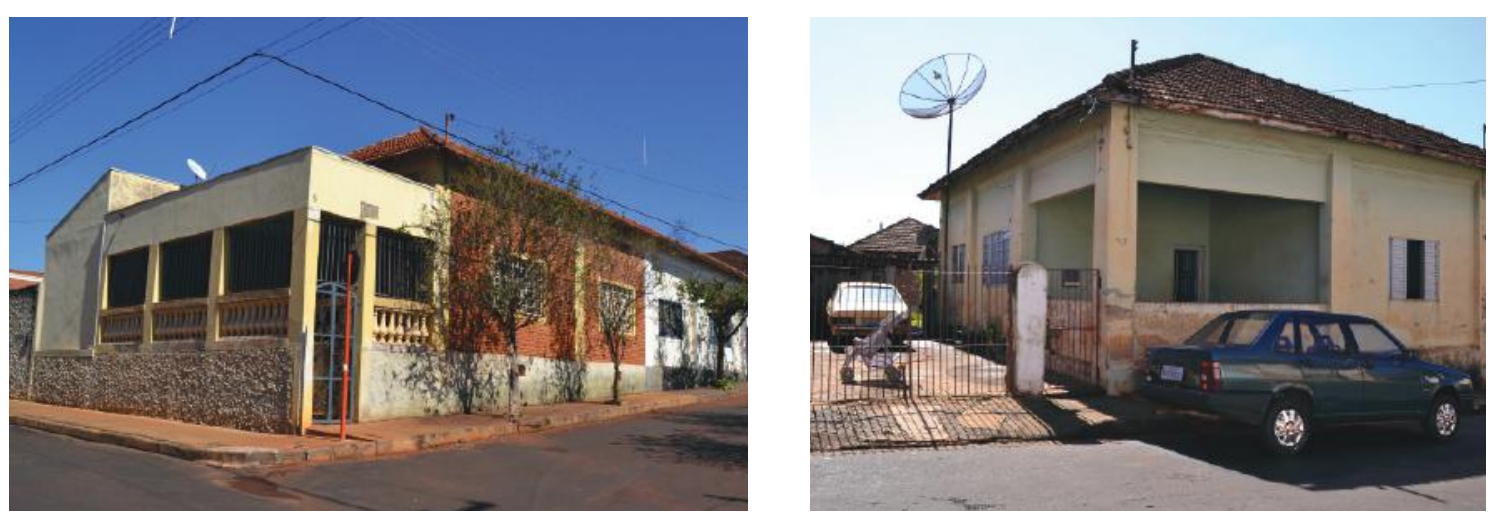

Foto 217 e 218 - Exemplos de alterações da volumetria e da fachada. Fotos: autora, 2013.

\section{SUMÁRIO DO CARÁTER ESPECIAL}

O caráter do lugar é dado pelo conjunto de todos os elementos morfotipológicos analisados. Porém sem dúvida, a volumetria e a uniformidade das fachadas de cada tipologia tem um papel importante para manter o caráter da vila ferroviária de Rincão.

Ao se estabelecer os guias de transformações, deve-se ter em conta as extensões e alteração não empáticas citadas acima. Não se deve permitir que se altere a volumetria do local, portanto, não se deverá permitir o fechamento dos recuos laterais nas casas geminadas (subtipologias B2, B3, B4 e B5), e manter os portões e muretas neste recuo com tamanho padrão (baixo). A adaptação para um banheiro interior poderá ser aceita, contanto que se mantenha o anexo original de banheiro e área de serviço no exterior. Com relação às fachadas, não se deverá permitir a alteração do tamanho e do alinhamento das aberturas de portas e janelas originais, podendo o material ser substituído.

A grande questão é o que fazer com as extensões e alterações já realizadas. Trata-se de um assunto bastante polêmico, no entanto, é necessário tentar envolver a comunidade na preservação, e assim talvez, a demolição de algumas alterações poderia ser negociada. Com relação às portas e janelas deverá ser feito o mesmo, mas acredita-se que a substituição de caixilhos será menos polêmica que as demolições de extensões dos quintais (que a meu ver são menos problemáticas para o caráter do local) e a modificação 
da volumetria com a construção nos recuos (mais problemáticas). Estas últimas sim, modificam bastante o caráter da vila ferroviária de Rincão.

A cor é outro assunto polêmico. Além de um estudo aprofundado, para descobrir a cor original, creio que certo padrão deverá ser mantido, com certa gama de cores. Não é recomendado uso de cores aberrantes como as utilizadas no Pelourinho (BA), nem diferentes cores para cada casa. Talvez cores padrões para cada tipologia, inclusive para que os visitantes possam identificar suas diferenças.

Para atrair visitantes e para a valorização da vila, poderia ser introduzido um sistema de arborização e de iluminação de todo o complexo ferroviário, incluindo-se obviamente a vila ferroviária, transformando-a em um equipamento de lazer e cultura, ou mesmo institucional. O terreno vazio deixado pelo armazém regulador de café e outras edificações demolidas poderia ser transformado em um parque. Alguns das locomotivas ou vagões poderiam ser trazidos de volta como equipamentos de lazer. A rua principal poderia ter algum nome significativo que remeta à ferrovia, assim como as ruas perpendiculares que já possuem nomes de ex-ferroviários. Poderiam ser colocados em algumas placas ou realizados murais, com a história da ferrovia, ou desenhos que fizessem referência à mesma, para que, de alguma forma a memória ferroviária permaneça viva.

Terminamos o presente trabalho com a leitura morfotipológica de Rincão, tentando descobrir suas características. Acreditamos que de algum modo ou outro, todas as vilas ferroviárias mereceriam ser preservadas dentro do complexo ferroviário, pelo viés da paisagem ferroviária e das áreas de conservação, pela leitura de sua morfotipologia, e pela elaboração de guias de transformação. Tudo dependerá de como e quem vai fazê-lo. Afinal, tudo depende de como se constrõem as linhas narrativas do patrimônio, que conectam passado, presente e futuro. Depois das questões iniciais da tese respondidas, e da longa viagem percorrida, pergunta-se: chegou-se ao final da linha? 


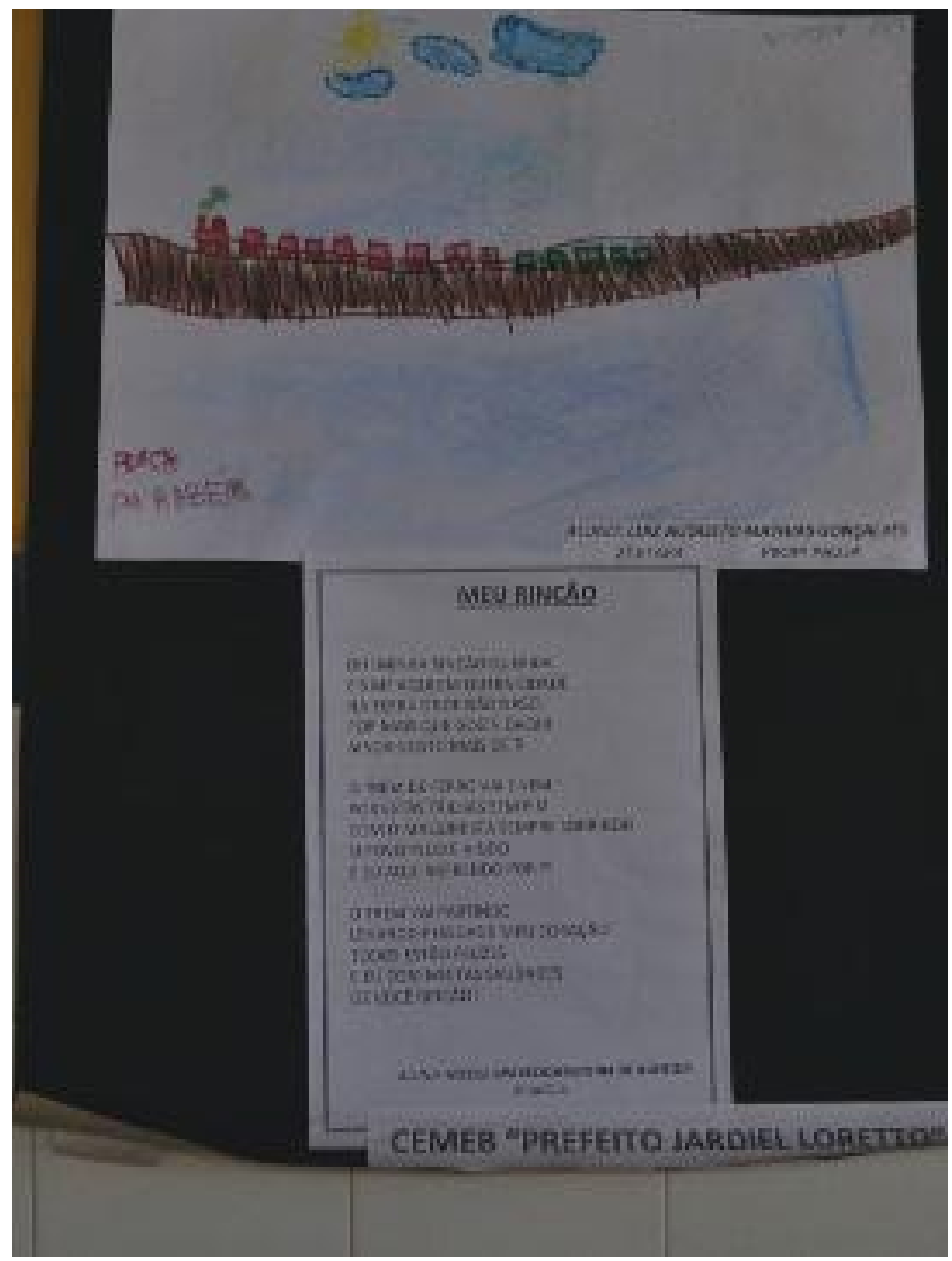

Foto 219 - Desenho e poesia feitos por alunos da escola municipal em comemoração ao aniversário da cidade. Ambos relacionam a cidade ao trem. Foto: autora, 2016. 


\section{Considerações Finais - Fim da linha?}

"Clearly, of the past there is no end, nor of its heritagisation.(...)"

(FOWLER, 1992, p. 76)

Esperamos que após todo este extenso percurso possamos ter respondido à questão problema que deu origem a este trabalho, no qual a preocupação foi evidenciar as vilas ferroviárias de uma das várias companhias, sendo a escolhida a Companhia Paulista, dentro do patrimônio industrial e do complexo ferroviário, mostrando seu estado atual e algo das políticas de preservação para apontar caminhos para a conservação das mesmas.

Assim foi visto que as vilas ferroviárias estão silenciadas não apenas no campo do patrimônio, e só tardiamente incluídas, como também são pouco mencionadas na bibliografia referente às ferrovias, sendo que apenas as estações ganham destaque. Seu estado atual de preservação foi levantado, e como a inclusão delas no complexo ferroviário é recente pelos órgãos de patrimônio, ainda se sublinhou que todo o patrimônio industrial não está sendo visto de forma sistêmica pelos órgãos. Apontou-se a falta de uma política de preservação claramente definida, principalmente pelo órgão central, federal. E problemas de gestão em todos os níveis. Vimos que há diversas formas de organização tanto das políticas como dos órgãos de patrimônio, se mais centralizados pelo Estado como o francês, ou com maior participação da sociedade civil, como o modelo anglo-saxão. Tentou-se esclarecer os diversos conceitos, de que o grande público chama de patrimônio: tombamento, preservação, conservação e gestão. Dado que as vilas ferroviárias são parte do tecido urbano, procurou-se entender a gênese do conceito de patrimônio urbano, tanto nos principais teóricos da conservação como nas cartas patrimoniais. Descobriu-se que o alargamento do conceito de patrimônio deu origem aos chamados novos patrimônios, nos quais encontram-se as vilas ferroviárias: como "arquitetura modesta", "memória ferroviária”, patrimônio urbano, patrimônio industrial.

Optou-se por este último por ser o alargamento apontado por Choay (2006), como outros autores, um caminho sem volta e por ser um corpo teórico bastante consolidado. Além disso, por constatarmos o estado das vilas existentes, em contraste com o estado de conservação das vilas operárias e ferroviárias de outros países, propõe-se uma política de preservação que, além de incluir as vilas ferroviárias no que se chama de patrimônio in- 
dustrial, adote o conceito de paisagem cultural ferroviária mesclada ao conceito de áreas de conservação. Não são conceitos novos, como dizia-se ao início, mas os vemos poucos utilizados conjuntamente na bibliografia brasileira, portanto, quis-se voltar a recordá-los. Sabe-se que o termo paisagem cultural, tem sua origem aproximadamente na década de 1990. No ambiente brasileiro, passou a se falar em paisagem, no IPHAN, em 2009. Dados os limites do conceito, principalmente no estabelecimento de áreas e consequente gestão, propõe-se fortemente aliá-lo ao conceito de áreas de conservação. Cabe conferir mais atenção aos poderes e às sociedades locais no cuidado do patrimônio, bem como associá-lo ao planejamento urbano. Aproxima-se ao que se chama de dimensão contemporânea do patrimônio, tão necessária inclusive para sua sobrevivência. Vê-se assim solucionado, o problema de re-significação desta "arquitetura modesta" das vilas ferroviárias, fundamentada na história social da Companhia Paulista, seus trabalhadores e vilas ferroviárias. Vimos que merecem ser preservadas, porém nem todas tombadas. E para solucionar os problemas de gestão, envolver mais ativamente a população local na preservação.

Como um sumário de contribuição da presente pesquisa pode-se apontar: evidenciou-se as vilas ferroviárias dentro do complexo ferroviário, mostrando a existência destas e não apenas as estações, como mostram os estudos. Também se mostrou que além da Vila de Paranapiacaba, a produção de vilas ferroviárias era comum a todas as companhias ferroviárias, e haverá outras que merecem ser preservadas. Quer se evidenciar também que a ferrovia era um complexo industrial, e como as demais indústrias do período produzia casas para seus trabalhadores. Há várias relações que podem ser estabelecidas com as vilas operárias do período, como a produção, a hierarquia especializada através da implantação e das tipologias, como os debates sobre a casa operária, a intervenção do Estado e a retirada da inciativa privada, bem como a chamada organização racional do trabalho, que penetrou o processo de trabalho como em outros aspectos da vida dos trabalhadores, inclusive a habitação. As vilas ferroviárias são parte deste patrimônio industrial, ressaltando que o patrimônio ferroviário não é a mais importante parte do mesmo, para não se perder a visão sistêmica do patrimônio brasileiro. Também se arrisca a dizer que a metodologia percorrida por este trabalho, poderia ser adotada para as outras vilas ferroviárias da Companhia Paulista, inclusive fazendo as necessárias adaptações, para outras companhias ferroviárias.

Como futuras pesquisas, ou questões que poderão ser aprofundadas em trabalhos posteriores a este, apontamos: no campo da história, acredita-se na investigação do pa- 
pel dos engenheiros ingleses no início da ferrovia, pois a presença destes, é inicialmente detectada nos Relatórios da Companhia Paulista, mas depois desaparece. Retornaram à Europa? O que foi feito deles? Outra interessante pesquisa seria explorar cada uma das empresas subsidiárias da Companhia Paulista: os quatorze Hortos Florestais ${ }^{1}$; a CAIC - Companhia de Agricultura, Imigração e Colonização; o matadouro de Barretos que depois foi vendido para a companhia inglesa Brazil Meat Company. Outra pesquisa poderia focalizar os acionistas da Companhia Paulista, que circulavam pelos meios políticos e técnicos da época, sendo um dos mais citados Antônio Prado. ${ }^{2}$ Outro que mereceria estudo seria o Barão do Pinhal. ${ }^{3}$ No campo da preservação, acredita-se que a questão da valoração e significação dos diversos patrimônios, ainda parece ser uma questão em aberto e de difícil solução para determinados casos. Outro assunto ainda pouco levantado seria a sustentabilidade tanto econômica como ambiental da conservação dos conjuntos, comprovados ou descomprovados em número. Mereceriam um estudo à parte questões relacionadas à leitura morfotipológica e morfologia urbana, no estabelecimento tanto da paisagem cultural e quanto das áreas de conservação, que o presente trabalho apenas tangencia. No campo da preservação do patrimônio ferroviário, um assunto pouco pesquisado e que mereceria um estudo são os bens móveis, vagões, locomotivas, etc..., sobre os quais existem desenhos e inúmeros arquivos aparentemente ainda pouco explorados no Museu Ferroviário de Jundiaí.

Retomando a terceira pergunta feita ao início desta pesquisa: verificado que o tombamento não garante a preservação, sendo apenas um dos instrumentos, quais seriam os critérios e estratégias a adotar de forma a obter uma preservação eficaz para os casos concretos? Apontamos dificuldades existentes nos órgãos e políticas de preservação brasileiras, e mesmo o patrimônio industrial inglês sofreu perdas. Contudo, acredita-se no valor do exemplo anglo-saxão de preservação, no qual há mais participação da sociedade 1 Existe um trabalho sobre o criador dos hortos, Edmundo Navarro de Andrade, de MARTINI, Augusto Jerônimo. Edmundo Navarro de Andrade: o plantador de eucaliptos e a questão da preservação florestal no Brasil. São Paulo: Humanitas, 2008.

2 Existe o trabalho do norte-americano LEVI, Darrel E. The Prados of São Paulo: an elite Brazilian Family in a changing society, 1840-1930. Traduzido para o português: LEVI, Darrel E. A família Prado. São Paulo: Cultura, 1977.

3 Foram encontrados três trabalhos: MORAES, Marcos Antônio. "O conde do Pinhal em dois tempos epistolares”. Calendário de Cultura e Extensão. São Paulo, p. 2-3, dez. 2002.; CARVALHOSA, Helena (curadoria) Fazenda Pinhal: 100 anos de fotografia. São Carlos: SESC, 19--. ; RIBEIRO, M.A.R.;CAMPOS, C. "História da riqueza na economia cafeeira paulista: a família Arruda Botelho (18541901). Resgate: Revista Interdisciplinar de Cultura, Centro de Memória da UNICAMP, Campinas, v. XX, p. 59-73,2012. 
na preservação do patrimônio, inclusive financeiramente, e também nas áreas de conservação estabelecidas. Talvez não haja uma resposta definitiva para a questão, e mesmo a nossa proposta de mesclar os conceitos de paisagem cultural e áreas de conservação ainda precisa ser ensaiada, pois como citamos Choay (2006, p. 149) ao início deste trabalho: “(...) uma lei não basta. Hoje isso é patente. A preservação dos monumentos antigos é antes de tudo mentalidade.” E recorda-se o que se propõe hoje como solução e como patrimônio, poderá não valer amanhã, pois a valoração é cambiante tal qual é a sociedade, e suas necessidades. Hoje, no Brasil, fala-se em inventário participativo, uma inovação face a outros tempos, em que o Estado e o órgão de preservação definiam o que era o patrimônio. Na Inglaterra, tal processo de patrimonialização sempre foi compartilhado com a sociedade. Hoje nas Cartas Patrimoniais internacionais, concretamente nos Princípios de Valleta, fala-se na dimensão contemporânea e palavras de mudança são introduzidas. Assim cita-se a Fowler (1992, p. 176) ao início destas considerações, o passado nunca terá fim por causa desta patrimonialização, e hoje o que se propõe poderá, quiçá, não ser válido no futuro.

\section{O Trenzinho do Caipira ${ }^{4}$}

música: Heitor Villa Lobos

letra: Ferreira Gullar

Lá vai o trem com o menino

Lá vai a vida a rodar

Lá vai ciranda e destino

Cidade noite a girar

Lá vai o trem sem destino

Pro dia novo encontrar

Correndo vai pela terra, vai pela serra, vai pelo ar

Cantando pela serra do luar

Correndo entre as estrelas a voar

No ar, no ar, no ar... (...)

\footnotetext{
$4 \quad$ A música "O trenzinho do caipira" é uma composição de Heitor Villa Lobos, e parte integrante da peça Bachianas Brasileiras No. 2. A música imita o movimento de uma locomotiva com os instrumentos da orquestra. Anos mais tarde, a música recebeu a letra de Ferreira Gullar em Poema Sujo. Sobre a letra ver a entrevista de Ferreira Gullar: <http://www1.folha.uol.com.br/fsp/ilustrad/fq0612200923.htm>. Acesso em 29/10/2014 23:11.
} 


\section{Referências Bibliográficas}

ALASMAR, Pedro Piccino. Ferro sobre terra roxa - Avaliação e Proposta de Conservação e Restauro para a Estação Ferroviária de Jaú. Monografia. Curso de Pós-graduação lato sensu. Universidade Católica de Santos, Santos, 2008.

ANGELO, Cláudio Felisoni de. Estrutura do mercado de transportes: a conduta e o desempenho das empresas ferroviárias brasileiras. Tese de Livre Docência. São Paulo, FEA-USP, 1998.

ARAKAKI, Elizabeth Mie. A Paisagem e os Trilhos no Oeste Paulista: o caso de Presidente Prudente. Tese (doutorado) - Faculdade de Arquitetura e Urbanismo, Universidade de São Paulo, São Paulo, 2010.

ARANTES, Antônio Augusto. "Documentos históricos, documentos de cultura". Revista do Patrimônio Histórico e Artístico Nacional. Brasília, 22, 1987, p.48-55.

ARAÚJO NETO, Adalberto Coutinho de. Entre a revolução e o corporativismo a experiência sindical dos ferroviários da E. F. Sorocabana nos anos 1930. Dissertação (mestrado). São Paulo, FFLCH, 2006.

BALLEIRAS, Mary Helle Moda. Indústria e habitação: arquitetura fabril no interior de São Paulo. Dissertação (Mestrado) - Faculdade de Arquitetura e Urbanismo, Universidade de São Paulo, São Carlos, 2003.

BAPTISTA, D. M. T.; GAGLIARDI, C. M. R. Intervenções urbanas em centros históricos. São Paulo: EDUC:CAPES, 2012.

BEM, Sueli Ferreira de. Contribuição para estudos das estações ferroviárias. Dissertação (mestrado) - Faculdade de Arquitetura e Urbanismo, Universidade de São Paulo, São Paulo, 1998.

BERNARDINI, Luis Felipe Jorge. Cultura e cidade na trajetória do Eng. Adolfo Augusto Pinto. Fontes para uma história social da introdução do concreto em São Paulo. Relatório de Iniciação Científica, Faculdade de Arquitetura e Urbanismo, Universidade de São Paulo, São Paulo, 2004.

BERNARDINI, Sidney P. Consolidação do grande capital cafeeiro e planejamento territorial do estado de São Paulo na Primeira República. Primeiro Trabalho Programado, doutoramento, Faculdade de Arquitetura e Urbanismo, Universidade de São Paulo, São Paulo, 2001.

BESSA, Altamiro Sérgio Mol. A construção das paisagens turísticas nos descaminhos da Estrada Real. Tese (doutorado). São Paulo, Faculdade de Arquitetura e Urbanismo, Universidade de São Paulo, São Paulo, 2011.

BINNEY, Marcus; MACHIN, Francis; POWELL, Ken. Bright Future. The Re-use of 
Industrial Buildings. London: Save Britain's Heritage, 1990.

BLAY, Eva Alterman. Eu não tenho onde morar: vilas operárias na cidade de São Paulo. São Paulo: Nobel, 1985.

BOITO, Camillo. Os Restauradores. São Paulo, Ateliê, 2002.

BONDUKI, Nabil. Intervenções urbanas na recuperação de centros históricos. Brasília, DF: IPHAN/Programa Monumenta, 2012.

BORSOI, Diogo F. Nos traços do cotidiano: Cunha entre as vilas de serra acima e os portos da marinha (1776-1817). Dissertação (Mestrado) - Faculdade de Arquitetura e Urbanismo, Universidade de São Paulo, São Paulo, 2013.

BORTOLUCCI, Maria Ângela P.C.S. \& CORREIA, Telma de Barros. Lugares de produção: arquitetura, paisagens e patrimônio. São Paulo: Annablume, 2013.

BRANDI, Cesare. Teoria de Restauração. São Paulo, Ateliê, 2004.

BRUNA, Paulo Júlio Valentino. Os Primeiros Arquitetos Modernos: Habitação Social no Brasil 1930-1950. São Paulo: Editora da Universidade de São Paulo, 2010.

BULLEN, Peter A. \& LOVE, Peter. The rhetoric adaptive re-use or reality of demolition: views from the field. Cities, n. 27, p. 215-224, 2010.

BURMAN, Peter \& STRATTON, Michael. Conserving the railway heritage. London: E\&FN Spon, 1997.

CACHIONI, Marcelo. Londres, Lisboa e São Paulo: vigilância, ordem, disciplina e higiene nos espaços de sobrevivência operária. Tese (doutorado). São Paulo, Faculdade de Arquitetura e Urbanismo, Universidade de São Paulo, São Paulo, 2013.

CAMPOS, Cristina. Ferrovias e Saneamento - O engenheiro Antonio Francisco de Paula Souza e a construção da rede de infraestrutura territorial e urbana paulista, 1870-1893. Tese (doutorado) - Faculdade de Arquitetura e Urbanismo, Universidade de São Paulo, São Paulo, 2007

CANNIGGIA, G.; MAFFEI, G.L. (1979) Composizione architettonica e tipologia edilizia: Lettura dell'edilizia di base .Venezia : Marsilio, 1979.

CANNIGGIA, G.; MAFFEI, G.L. Architectural composition and building typology: Interpreting basic building. Firenze : Alinea, 2001.

CANNIGGIA, G.; MAFFEI, G.L. 'Continuità tipologica e manutenzione consepevole:metodi e tecniche per la mutazione fisiologica de la città' in Restauro e città, anno II, 127-144, 1986.

CARPINTÉRO, Marisa Varanda T. A construção de um sonho. Os engenheiros-arquitetos e a formulação da política habitacional no Brasil (São Paulo 1917-1940). 
Campinas, SP: Editora da UNICAMP, 1997.

CARDOSO, Antonio Carlos. Contribuição ao estudo da eletrificação das linhas da Companhia Paulista. Jundiaí: sn, 1922.

CARVALHO, Diego Francisco de. Trabalho e conflito na Noroeste do Brasil. Dissertação (mestrado) - Faculdade de Filosofia, Letras e Ciências Humanas, Universidade de São Paulo, São Paulo, 2009.

CASTRIOTA, Leonardo. Paisagem cultural: novas perspectivas para o patrimônio. Arquitextos, Vitruvius, São Paulo, ano 14, n. 162.02, nov. 2013. Disponível em: <http:// www.vitruvius.com.br/revistas/read/arquitextos/14.162/4960>. Acesso em: 15 set.2016.

blume, 2009.

Patrimônio cultural - conceitos, políticas e instrumentos. São Paulo: Anna-

CASTRO, Sonia R. O Estado na Preservação de Bens Culturais: o Tombamento. Rio de Janeiro, Renovar, 1991.

CATALDI, G.; MAFFEI G.L.; VACCARO, P. (2002) 'Saverio Muratori and the Italian school of planning typology', Urban Morphology 6, 3-14.

CATELL, John and FALCONER, Keith. Swindon: the legacy of a railway town. London: HMSO, 1995.

CAUQUELIN, Anne. A invenção da paisagem. São Paulo: Martins Fontes, 2007.

CAVAlCANTI NETO, J. R. ; CARNEIRO, F. G.; GIANNECCHINI, A. C. Avanços e desafios na preservação do patrimônio ferroviário pelo Instituto do Patrimônio Histórico e Artístico Nacional. In VI Colóquio Latino Americano sobre Recuperação e Preservação do Patrimônio Industrial. São Paulo, TICCIH/Faculdade Belas Artes, jul. 2012.

CERVELLATI, Pier Luigi. La Cittá Bella. Il Recupero dell’Ambiente Urbano. Bologna, Mulino, 1991.

CHIURATTO, Agnes Helena. Paisagem cultural e a experiência urbana latino-americana Buenos Aires/Rio de Janeiro. Dissertação (mestrado) - Faculdade de Arquitetura e Urbanismo, Universidade de São Paulo, São Paulo, 2015.

CHOAY, Françoise. A Alegoria do Patrimônio. São Paulo, Estação Liberdade: UNESP, 2006.

CHUVA, Márcia Regina Romeiro. Os arquitetos da memória: sociogênese das práticas de preservação do patrimônio cultural no Brasil (anos 1930-1940). Rio de Janeiro: Ed. UFRJ, 2009.

COLENBRADER, Bernard J. F., RODERS, Ana R. Pereira \& VELDPAUS, Loes. Urban Heritage: Putting the Past into the Future. In The Historic Environment, vol. 4, No. 1, p. 3-18, april 2013. 
CONGRESSO DE ENGENHARIA E LEGISLAÇÃO FERROVIÁRIAS. (Resenha). São Paulo: Empresa Graphica da Revista dos Tribunais, 1936.

COOPER, Martin Steam railways in Brazil: their cultural context and preservation. Master of Arts in Railway Studies, Institute of Railway Studies of York, September, 2002.

CORREIA, Telma de Barros. Pedra: plano e cotidiano operário no sertão. O projeto urbano de Delmiro Gouveia. Tese (doutorado). Faculdade de Arquitetura e Urbanismo, Universidade de São Paulo, São Carlos, 1995.

. "A indústria e a moradia operária: as diferentes formas de acesso a casas em vilas operárias e núcleos fabris.” Sinopses. São Paulo, n. 28, p. 9-18, dezembro 1997.

2004.

A construção do habitat moderno no Brasil 1870 - 1950. São Carlos: Rima,

Vilas operárias e núcleos fabris e de mineração no Brasil: a construção e o desmonte. Tese de Livre-Docência - Faculdade de Arquitetura e Urbanismo, Universidade de São Paulo, São Carlos, 2004.

; GUNN, P. O. M. “A organização do território pelo capital: o caso das vilas e núcleos gerados por empresas”. .In: SIMPÓSIO: A ORGANIZAÇÃO DO TERRITÓRIO PELO CAPITAL: O CASO DAS VILAS E NÚCLEOS GERADOS POR EMPRESAS. São Paulo: Universidade de São Paulo, setembro de 2004.

“Brasil, suas fábricas e vilas operárias." Pós: Revista do Programa de Pós-Graduação da Faculdade de Arquitetura e Urbanismo. São Paulo, n. 20, p. 10-32, dez. 2006.

. “Art decó e indústria: Brasil, décadas de 1930 e 1940”. Anais do Museu Paulista. São Paulo, v. 16, n. 2, p. 47-104, jullho/dez 2008.

COSTA, Emília Viotti da. Da monarquia à República: momentos decisivos. 5a. ed. São Paulo: Brasiliense, 1987.

CONZEN, M.R.G. Alnwick, Northumberland: a study in townplan analysis, Institute of British Geographers Publication 27. London : George Philip, 1960.

. 'The use of town plans in the study of urban history', in DYOS, H.J.

(ed.) The study of urban history. London : Edward Arnold, 1968. p. 113-30.

. 'Geography and townscape conservation' in UHLIG, H. and LIENAU, C. (eds.) AngloGerman Symposium in Applied Geography, GiessenWürzburhMünchen. Giessen : Lenz, 1975, p. 95-102.

CRUZ, Thaís Fátima dos Santos. Paranapiacaba: a arquitetura e o urbanismo de uma vila ferroviária. Dissertação (mestrado) - Faculdade de Arquitetura e Urbanismo, Universidade de São Paulo, São Paulo, 2007. 
CULLEN, Gordon. Paisagem urbana. Lisboa, Edições 70, 1993.

D'ALAMBERT, Clara Correia. O tijolo nas Construções Paulistanas. Dissertação (mestrado) - Faculdade de Arquitetura e Urbanismo, Universidade de São Paulo, São Paulo, 1993.

DEBEN, L., SALET, W. \& VAN THOOR, M.T.(Eds.). Cultural heritage and the future of the historical inner city of Amsterdam. Amsterdam: Aksant Academic Publishers, 2004.

DIOGO, Érica. Habitação social no contexto da reabilitação urbana da Área Central de São Paulo. Dissertação (mestrado) - Faculdade de Arquitetura e Urbanismo, Universidade de São Paulo, São Paulo, 2004.

DIAS, Adriana Custódio. O Bairro da Móoca: traços culturais para projetos de requalificação urbana. Dissertação (mestrado) - Faculdade de Arquitetura e Urbanismo, Universidade de São Paulo, São Paulo, 2008.

DUARTE JUNIOR, Romeu. Sítios históricos brasileiros: monumento, documento, empreendimento e instrumento. Tese (doutorado) - Faculdade de Arquitetura e Urbanismo, Universidade de São Paulo, São Paulo, 2012.

FERREIRA, Lania Stefanoni. Entroncamento entre raça e classe: ferroviários no Centro Oeste Paulista 1930-1970. Tese (doutorado)- Instituto de Filosofia e Ciências Humanas, Universidade Estadual de Campinas, Campinas, 2010.

FERREIRA, Ricardo P. Futebol e ferrovia: o trem da industrialização que para o interior. Trabalho de Conclusão de Curso - Faculdade de Educação Física, Universidade Estadual de Campinas, Campinas, 2008.

FIGUEIREDO, Vanessa Gayego B. Da tutela dos monumentos à gestão sustentável das paisagens culturais complexas: inspirações à política da preservação cultural no Brasil. Tese (doutorado) - Faculdade de Arquitetura e Urbanismo, Universidade de São Paulo, São Paulo, 2014.

FINGER, Anna Eliza. Vilas ferroviárias no Brasil: os casos de Paranapiacaba em São Paulo e da Vila Belga no Rio Grande do Sul. Dissertação (mestrado) - Faculdade de Arquitetura e Urbanismo, Universidade de Brasília, Brasília, 2009.

FINGER, Anna Eliza. Um século de estradas de ferro: arquiteturas das ferrovias no Brasil entre 1852 e 1957. Tese(doutorado) - Faculdade de Arquitetura e Urbanismo, Universidade de Brasília, Brasília, 2009.

FONSECA, Maria Cecília Londres. O patrimônio em processo. Trajetória da política federal de preservação no Brasil. Rio de Janeiro: Ed. UFRJ, IPHAN, 2005.

FOWLER, Peter J. The past in Contemporay Society. London, Butler\&Tanner Ltd., 1992. 
. "World Heritage Cultural Landscapes" World Heritage Paper. N ${ }^{\circ}$ 6, Paris, UNESCO, 2003. Disponível em: <http://whc.unesco.org/en/series>. Acesso em: 15 setembro 2016.

FRANCISCO, Rita de Cássia. As oficinas da Companhia Mogiana de Estradas de Ferro: arquitetura de um complexo produtivo. Dissertação (mestrado) - Faculdade de Arquitetura e Urbanismo, Universidade de São Paulo, São Paulo, 2007.

GARCIA, Liliana Bueno dos Reis. Rio Claro e as Oficinas da Companhia Paulista de Estradas de Ferro: trabalho e vida operária 1930-1940. Dissertação (mestrado) - Instituto de Filosofia e Ciências Humanas, Universidade Estadual de Campinas, Campinas, 1992.

GAUTHIER, P.; GUILLIAND, J. (2006) 'The study of urban form in Canada', Urban Morphology 10, p. 51-66.

GERIBELLO, Denise Fernandes. Habitar o patrimônio cultural: o caso do ramal ferroviário Anhumas-Paraibuna. Dissertação (Mestrado), Instituto de Filosofia e Ciências Humanas, Universidade Estadual de Campinas, Campinas, 2011.

GHIRARDELLO, Nilson. À beira da linha - formações urbanas da Noroeste Paulista. São Paulo: Editora UNESP, 2002.

GIANESELLA, Rubens. Gêneses urbanas do colonialismo: síntese de encontros culturais. Anais do Museu Paulista, v. 20, n. 1, p. 165-200, 2012.

GIOVANNONI, Gustavo. Vecchie città ed edilizia nuova. Milano: CittàStudiEdizioni, 1995. (Primeira Edição: Torino: UTET, 1931).

Textos escolhidos. Cotia, SP: Ateliê Editorial, 2013. Tradução de Renata Campello Cabral, Carlos Roberto M. de Andrade, Beatriz Mugayar Kühl. Organizado por Beatriz K. Kühl.

GITAHY, M. L. C. “Qualificação e urbanização em São Paulo: A experiência do Liceu de Artes e Ofícios de São Paulo, 1873-1934”. In RIBEIRO, M. A. R. Trabalhadores urbanos e ensino profissional. Campinas: Ed. UNICAMP, 1986.

GOUVEIA, Maria Alice; MICELI, Sérgio. Política cultural comparada. Rio de Janeiro: FUNARTE/ Instituto de Estudos Econômicos, Sociais e Políticos de São Paulo/ Financiadora de Estudos e Pesquisas-FINEP, 1985.

GRANDI, Guilherme. Café e expansão ferroviária: a Companhia Rio Claro (18801903). São Paulo: Annablume, FAPESP, 2007.

Estado e capital ferroviário em São Paulo: a Companhia Paulista de Estradas de Ferro entre 1930 e 1961. São Paulo: Alameda, 2013. 
GUAZELLI, Bárbara. "Vila Ponte Preta. Ferrovia e habitação" Habitação e ferrovia: vilas operárias de Campinas. Programa de Pós-graduação do Instituto de Arquitetura e Urbanismo, Universidade de São Paulo, São Carslo, s/d.

HOMEM, Maria Cecília Naclério. Cozinha e Indústria em São Paulo: Do Rural ao Urbano. São Paulo: Editora da Universidade de São Paulo, 2015.

KANTOR, Iris. Cartografia e diplomacia: usos geopolíticos da informação toponímica (1750-1850). Anais do Museu Paulista, v. 17, n. 2, p. 39-61, 2009.

KEMPTER, Eloísa Dezen. O lugar do patrimônio industrial. Tese (doutorado) -Instituto de Filosofia e Ciências Humanas, Universidade Estadual de Campinas, Campinas, 2011.

KOHLER, André Fontes. Políticas públicas de regeneração urbana, preservação do patrimônio e lazer e turismo: padrões de intervenção pública e avaliação de resultados no Pátio de São Pedro, Recife, 1969-2008. Tese (doutorado) - Faculdade de Arquitetura e Urbanismo, Universidade de São Paulo, São Paulo, 2011.

KOHLSDORF,G; KOHLSDORF, M. E. "Dimensão topoceptiva" in Dimensões Morfológicas dos Lugares. Brasília: (?), 2005. Disponível em: www.ufscar.br/ cec/arquivos/ referencias/Texto\%20Maria\%20Elaine.doc. Acesso em: 27 julho 2016.

KOMOROWSKI, Bartek. The Death and Life of Local Buidling Traditions. Typomorphological Analysis as a Basis of Urban Design in Montreal. Research Project Montreal, School of Urban Planning, McGill University. 2007.

KÜHL, Beatriz M. Preservação da arquitetura do ferro em São Paulo. Tese (doutorado) - Faculdade de Arquitetura e Urbanismo, Universidade de São Paulo, São Paulo, 1996.

Arquitetura do ferro e arquitetura ferroviária em São Paulo: reflexões sobre a sua preservação. São Paulo: Ateliê Editorial: Fapesp: Secretaria da Cultura, 1998.

Preservação do Patrimônio Arquitetônico da Industrialização: Problemas teóricos de Restauros. Cotia, Ateliê Editorial, 2008.

. "Patrimônio industrial: algumas questões em aberto." Revista Eletrônica de Arquitetura e Urbanismo, São Paulo, n. 3, p. online, 2010. Disponível em: < http://www. usjt.br/arq.urb/numero_03/3arqurb3-beatriz.pdf>. Acesso em: 15 outubro 2016.

O legado da expansão ferroviária no interior de São Paulo e questões de preservação. São Paulo, 2010. In BORTOLUCCI, Maria Ângela P.C.S. \& CORREIA, Telma de Barros. Lugares de produção: arquitetura, paisagens e patrimônio. São Paulo: Annablume, 2013.

LAMAS, José Ressano Garcia. Morfologia urbana e desenho da cidade. Lisboa: Fundação Calouste-Gulbekian, 2011.

LANDRIANI, Loris; POZZOLI, Matteo. Management and Valuation of Heritage Assets. A comparative analysis between Italy and USA. NY, London: springer, 2014. 
LANNA, Ana Lúcia Duarte. Ferrovias, cidades, trabalhadores 1870-1920. Tese de livre docência - Faculdade de Arquitetura e Urbanismo, Universidade de São Paulo, São Paulo, 2002.

LARKHAM, P.J. Conservation and the city. London : Routledge, 1996.

LARKHAM, P. J.; JIVÉN, G. 'Sense of Place, Authenticity and Character: A commentary'. in Journal of Urban Design, vol 8, No. 1, 2003, p. 67-81.

LEITE, Rogério Proença. Contra-usos da cidade - lugares e espaço público na experiência urbana contemporânea. Campinas: Editora da Unicamp, 2004.

LEMOS, Carlos A. Cerqueira. Alvenaria Burguesa: breve história da arquitetura residencial de tijolos em São Paulo a partir do ciclo econômico liderado pelo café. São Paulo: Nobel, 1989.

LEPETIT, B. Arquitetura, Geografia, História: Usos da Escala. In: SALGUEIRO, H. (org.). Por uma nova História Urbana. Bernard Lepetit. São Paulo: EDUSP, 2001, pp. 191-226.

LIMA, Fábio José Martins de. "Por uma cidade moderna: ideários de urbanismo em jogo no concurso para Monlevade e a realização da nova cidade operária (1934-1960)". In: SIMPÓSIO: A ORGANIZAÇÃO DO TERRITÓRIO PELO CAPITAL: O CASO DAS VILAS E NÚCLEOS GERADOS POR EMPRESAS. São Paulo, Universidade de São Paulo, setembro de 2004.

LYNCH, Kevin. A imagem da cidade. São Paulo, Martins Fontes, 1997. Versão original em inglês: The Image of the City. MIT Press, Cambridge, MA. 1960.

LOSNAK, Célio (coord.). Nos trilhos da memória: ferro e sangue: histórias de vida de ferroviários da Estrada de Ferro Noroeste do Brasil e RFFSA. Bauru, Secretaria Municipal de Cultura, 2004.

LO TURCO, Ivanise. "Exemplo de reconversão arquitetônica: da Estação Sorocabana ao Museu do Imaginário do Povo Brasileiro: 1914 a 2002”. In: Pós Revista do Programa de Pós-Graduação da FAU. São Paulo, n. 16, p. 114-130, dez. 2004.

LOUREIRO, Juliana C. Quintais de Olinda - uma leitura indiciária sobre sua gênese. Anais do Museu Paulista, v. 20, n. 1, p. 231-281, 2012.

LOWENTHAL, David. The past is a foreign country. Cambridge University Press, Cambridge, 1985.

LUZ, Luciano Ferreira da. Os trilhos nas áreas urbanas: conflitos, desafios e oportunidades em dez cidades paulistas. Dissertação (mestrado) - Departamento de Geografia, Faculdade de Filosofia, Letras e Ciências Humanas, Universidade de São Paulo, São Paulo, 2006. 
-Campinas/SP. Dissertação (mestrado) - Faculdade de Arquitetura e Urbanismo, Universidade de São Paulo, São Paulo, 2008.

MANFRÉ, Maria Alzira Marzagão. Elementos de urbanização: quintalões de Brasital e os modelos de composição urbana. Tese (doutorado) - Faculdade de Arquitetura e Urbanismo, Universidade de São Paulo, São Paulo, 2009.

MANGE, Roberto. Formação e seleção profissional do pessoal ferroviário. São Paulo: CFESP, 1941.

MANNA JUNIOR, Dante della. Mayrink: conjunto de habitações ferroviárias. São Paulo, FAU-USP, 1981.

MARINS, Paulo César Garcez. "Do Luz Cultural ao Monunenta: sobre a opção pela escala monumental na preservação de uma área de São Paulo. In : GAGLIARDI, Clarissa Rosa (org). Intervenções urbanas em centors históricos: casos da Itália e São Paulo em discussão. São Paulo: EDUC, 2012, p. 145-169.

- "Preservação do patrimônio rural no estado de São Paulo: entre ação governamental e práticas sociais" in BORTOLUCCI, M. A. P.C.S. \& CORREIA, T.B. Lugares de produção: arquitetura, paisagens e patrimônio. São Paulo: Annablume, 2013.

MARTINS, Margareth Guimarães. Caminhos tortuosos: painel entre o estado e as empresas ferroviárias brasileiras, 1934-1956. Tese (doutorado) - Faculdade de Filosofia, Letras e Ciências Humanas, Universidade de São Paulo, São Paulo, 1995.

MARX, Murilo. Nosso chão: do Sagrado ao Profano. São Paulo: Edusp, 1989.

MATOS, Odilon Nogueira de. Café e ferrovias: a evolução ferroviária de São Paulo e o desenvolvimento da cultura cafeeira. São Paulo: Alfa-Omega. 1974.

MAUTNER, Yvonne. "A era das estradas de ferro: o trabalho assalariado na indústria da construção.”. Espaço\&Debates. São Paulo, n. 36, p. 62-8, 1992.

MEEKS, Carrol Louis Vanderslice. The railroad station: an architectural history. New Heaven: Yale University Press, 1964.

MELLO, Zélia Maria Cardoso de. "Características dos núcleos urbanos em São Paulo". Estudos Econômicos, São Paulo, v. 15, n. 2, p. 307-37, mai/ago, 1985.

MENEGUELLO, Cristina. Da ruína ao edifício neogótico, reinterpretação e preservação do passado na Inglaterra vitoriana. São Paulo, Annablume, 2008.

MENESES, Ulpiano Toledo Bezerra de. O campo do Patrimônio cultural. Conferência Magna. In: I Fórum do Patrimônio Cultural. Sistema Nacional do Patrimônio Cultural: Desafios, estratégias e experiências para uma nova gestão. Brasília: IPHAN, 2010. P. 25-39. 
for Intervention. Amsterdam: IOS Press, 2006.

MEURS, Paul \& VAN THOOR, Marie-Thérèse (eds). Zonnestraal Sanatorium: the History and Restoration of a Modern Monument. NAI Publishers, Rotterdam, 2011.

MICELI, Sérgio (org.) Estado e cultura no Brasil. São Paulo: DIFEL Difusão Editorial S. A., 1984.

"SPHAN: refrigério da cultura oficial.". Revista do Patrimônio Histórico e Artístico Nacional, Rio de Janeiro, n. 22, 1987.

MINAMI, Issao. Vila Martin Smith, no Alto da Serra, em São Paulo, um exemplo típico de 'Model Company Town'. Tese (doutorado) - Faculdade de Arquitetura e Urbanismo, Universidade de São Paulo, São Paulo, 1994.

MORAIS, Marcelo de. Arquitetura e as relações urbanas nos núcleos habitacionais ferroviários. Dissertação (mestrado) - Instituto de Arquitetura e Urbanismo, Universidade de São Paulo, São Carlos, 2002.

MORATELLI, Thiago. Os trabalhadores da construção da Estrada de Ferro Noroeste do Brasil: experiências operárias em um sistema de trabalho de grande empreitada (São Paulo e Mato Grosso). Dissertação (mestrado) - Instituto de Filosofia e Ciências Humanas, Universidade Estadual de Campinas, Campinas, 2009.

MOREIRA, Danielle. Couto. Arquitetura ferroviária e industrial: o caso das cidades de S. João del Rei e Juiz de Fora (1875-1930). Dissertação (mestrado) - Instituto de Arquitetura e Urbanismo, Universidade de São Paulo, São Carlos, 2007.

MOREIRA, Maria de Fátima Salum. Ferroviários, trabalho e poder. São Paulo, Editora da UNESP, 2008.

MORINAGA, Carlos Minoru. Áreas contaminadas e a construção da paisagem pósindustrial de São Paulo. Tese (doutorado) - Faculdade de Arquitetura e Urbanismo, Universidade de São Paulo, São Paulo, 2013.

MULDER, André. A place to be proud of: heritage and social inclusion in shrinking cities (Germany and United Kingdom). Demographic and Social Development: shrinkage, regeneration and social dynamics. OECD, 2012. P. 273-9.

Heritage and its role in revitalising the housing market. Department of Real Estate \& Housing. Faculty of Architecture, Delft University of Technology. s/d.

MÜLLER, Christine. Vila ferroviária Ponte Preta - Campinas, SP. Passado e Futuro. Dissertação (mestrado) - Faculdade de Arquitetura e Urbanismo, Pontifícia Universidade Católica, Campinas, 2006.

NASCIMENTO, Flávia Brito \& SCIFONE, Simone. A paisagem cultural como novo paradigma para a proteção: a experiência do Vale do Ribeira-SP. Revista CPC. São Paulo, n. 10 , p. 29-48, maio/out 2010. 
NICHOLAS; LORRAINE, THAPA, BRIJESH, YONG JAE. Residents's perspectives of a World Heritage site. The Pitous Management Area, St. Lucia. Annals of Tourism Research. Vol. 36, n. 3, 2009. P. 390-412.

NORBERG-SCHULZ, C., Genius Loci: towards a phenomenology of Architecture. NY, Rizzoli. International Publications, 1980.

NOZOE, N. H. São Paulo: economia cafeeira e urbanização. São Paulo: IPE-USP, 1984.

OLIVEIRA, Elisa Haddad de. Piratininga, entrada da Alta Paulista: o projeto de um entreposto comercial e ferroviário no interior paulista, 1905-1908. Iniciação Científica, Faculdade de Arquitetura e Urbanismo - Universidade de São Paulo, 2011.

PALMER, Marylin; NEAVERSON, Peter. Managing the industrial heritage; its identification, recording and management. School of Archaeological Studies, University of Leicester, 1995.

PANERAI, P. Éléments d>analyse urbaine. Bruxelles : Archives d'architecture moderne, 1980.

PANERAI, P. ; DEPAULE, J.-C. ; DEMORGON, M. Analyse Urbaine. Marseille :

Parenthèses, 1999.

PATRÍCIO, Karina Pavão. Percorrendo os trilhos da ferrovia rumo às associações entre longevidade humana e fatores ambientais. Tese (doutorado) - Faculdade de Saúde Pública, Universidade de São Paulo, São Paulo, 2006.

PAULETO, Ludmilla Sandim T L. Diretrizes para intervenções em edificações ferroviárias de interesse histórico no Estado de São Paulo: as estações de Estrada de Ferro Noroeste do Brasil. Dissertação (mestrado) - Faculdade de Arquitetura e Urbanismo, Universidade de São Paulo, 2006.

PICKARD, R. D. Conservation in the Built Environment. Essex: Addison Wesley Longman Limited, 1996.

PINHEIRO, André et al. Paisagem fabril: Matte Leão e Matadouro Modelo. Identificação e Registro. Curitiba: Fundação Cultural de Curitiba, 2012.

PINTO, Adolfo A. História da Viação Pública em São Paulo, 1903. Introdução e notas de Célio Debes, 2. Ed. São Paulo, Governo do Estado, 1977. (Coleção paulística, v.2)

PLANART - Planejamento e Arquitetura Ltda. Relatório Técnico para as obras de recuperação da estação de Brotas. São Paulo, 1978.

Relatório Técnico para as obras de recuperação da estação de Dois Córregos. São Paulo, 1978. 

Paulo, 1978.

Relatório Técnico para as obras de recuperação da estação de Jaú. São

. Relatório Técnico para as obras de recuperação da estação de Rincão. São Paulo, 1978.

. Relatório Técnico para as obras de recuperação da estação de São Carlos. São Paulo, 1978.

POZZER, Guilherme Pinheiro. A antiga estação da Companhia Paulista em Campinas: estrutura simbólica transformadora da cidade (1872-2002). Dissertação (mestrado) - Instituto de Filosofia e Ciências Humanas, Universidade Estadual de Campinas, Campinas, 2007.

PRATA, Juliana Mendes. Patrimônio cultural e cidade: práticas de preservação em São Paulo. Tese (doutorado) - Faculdade de Arquitetura e Urbanismo, Universidade de São Paulo, 2009.

REIS FILHO, Nestor Goulart. Estação cultura: patrimônio ferroviário do povo de Campinas. São Paulo: Via das Artes, 2004. Artes, 2013.

As minas de ouro e a formação das Capitanias do Sul. São Paulo: Via das

REVISTA FERROVIÁRIA. Rio de Janeiro: Empresa Jornalística dos Transportes, 1941 - 1961 - mensal.

RIBEIRO, Rafael Winter. Paisagem Cultural e Patrimônio. Rio de Janeiro: IPHAN, 2007.

RODERS, A.P.; VELDPAUS, L. Learning from a Legacy: Venice to Valetta. in Change over time. Vol. 4, No. 2, Fall 2014. Pennsylvania: University of Pennsylvania Press, 2014.

RODRIGUES, Ângela R. Estudo do patrimônio industrial com uso fabril da cidade de São Paulo. Dissertação (mestrado) - Faculdade de Arquitetura e Urbanismo, Universidade de São Paulo, 2011.

RODRIGUES, Marly. Imagens do passado. A instituição do patrimônio em São Paulo. 1969-1987. São Paulo: Editora UNESP: Imprensa Oficial do Estado: Condephaat: FAPESP, 2000.

ROGIC, Tamara. Converted Industrial Buildings: Where Past and Present Live in Formal Unity. PhD Thesis. Faculty of Architecture and the Built Environment. TU Delft University, Delft, 2009.

ROSSI, Aldo. La arquitectura de la ciudad. Editora Gustavo Gilli S. A.,, Barcelona, 1966. 
RUFINONI, Manoela Rossineti. Preservação e Restauro Urbano. Teoria e Prática de Intervenção em Sítios Industriais de Interesse Cultural. Tese (doutorado) - Faculdade de Arquitetura e Urbanismo, Universidade de São Paulo, 2009.

RUSKIN, John. Cap. VI "La lámpara del recuerdo" in Las siete lámparas de la arquitectura. Buenos Aires: Libreria El Ateneo Editorial, 1956.

RYKWERT, Joseph. A sedução do lugar. A História e o Futuro da Cidade. São Paulo, Martins Fontes, 2004.

SAES, Flávio Azevedo Marques de. Grandes empresa de serviços públicos na economia cafeeira: um estudo sobre o desenvolvimento do grande capital em São Paulo: 1850-1930. São Paulo:sn, 1979.

As ferrovias de São Paulo 1870-1940. São Paulo: Editora Hucitec, 1981.

SAIA, Helena. Arquitetura e Indústria. Dissertação (mestrado) - Faculdade de Arquitetura e Urbanismo, Universidade de São Paulo, São Paulo, 1989.

SAIA, Luís. Morada paulista. São Paulo, Perspectiva, 1972.

SANT'ANNA, Márcia. Da cidade-monumento à cidade-documento - a trajetória da norma de preservação de áreas urbanas no Brasil (1937-1990). Dissertação (Mestrado) - Faculdade de Arquitetura e Urbanismo, Universidade Federal da Bahia, Salvador, 1995.

A herança do PCH: balanço crítico e desdobramentos 40 anos depois. Anais do MuseuPaulista. SãoPaulo, v.24,n.1,p.59-74, abr. 2016. Disponívelem <http://www.scielo.br/scielo.php?script $=$ sci_arttext\&pid $=$ S0101-47142016000100059\&lng $=$ pt\&nrm=iso $>$. Acesso em 07 out. 2016. http://dx.doi.org/10.1590/1982-02672016v24n0102.

SANTOS, Milton. A natureza do espaço. 4ª .ed. São Paulo: EDUSP, 2008.

SANTOS, Rodrigo Amado dos. A rotunda no município de Lins: para além da materialidade, memória e significado. Dissertação (mestrado) - Faculdade de Filosofia, Letras e Ciências Humanas, Universidade Estadual de São Paulo, Marília, 2009.

SCHMIDT, Leo. Architectural Conservation: An Introduction. Berlin, Bonn: WBG, 2008.

SCHOUTEN, Frans “Sustainable Cultural tourism planning” in MEURS, P. \& VERHOEF, LGW. World heritage site in Olinda in Brazil: Proposals for Intervention. Amsterdam: IOS Press, 2006.

SEGAWA, Hugo. Prelúdio da Metrópole. Arquitetura e Urbanismo em São Paulo na passagem do século XIX ao XX. São Paulo: Ateliê Editorial, 2000.

SEGNINI, Liliana R. Petrili. Ferrovia e ferroviários: uma contribuição para a análise 
do poder disciplinar na empresa. São Paulo: Editora Autores Associados: Cortez Editora, 1982.

SILVA, Roberto Simoens Toffoli da. Preservação e sustentabilidade: restaurações e retrofits. Dissertação (mestrado) - Faculdade de Arquitetura e Urbanismo, Universidade de São Paulo, São Paulo, 2013.

SOMEKH, Nadia (org). Preservando o patrimônio histórico: um manual para gestores municipais. São Paulo: CAU-SP/Mack-Pesquisa/DPH. 2016.(?)

SOUKEF JUNIOR, Antônio. A ferrovia e a cidade: a experiência de Bauru. Tese (Doutorado). - Faculdade de Arquitetura e Urbanismo, Universidade de São Paulo, São Paulo, 2005.

A preservação dos conjuntos ferroviários da São Paulo Railway em Santos e Jundiaí. São Paulo: FAUUSP, Relatório de Pós-Doutorado (FAPESP), 2010.

STRIKE, James. Architecture in Conservation. Managing Development at Historic Sites. London and New York, Routledge Press, 1994.

SYNTKO, V. A. \& TYUTYUNNIK, Yu G. Industrial heritage in culture and landscape. Geography and Natural Resources 29 (2008). p. 97-8.

TAVERNOR, Robert. Visual and cultural sustainability: the impact of tall buildings a London. Landscape and Urban Planning 83 (2007) p. 2-12.

TENCA, Álvaro. Senhores dos trilhos: racionalização, trabalho e tempo livre nas narrativas de ex-alunos do curso de ferroviários da antiga Paulista. São Paulo, Editora UNESP, 2006.

TWEED, Christopher \& SUTHERLAND, Margareth. Built cultural heritage and sustainable urban development. Landscape and Urban Planning (83), 2009. P. 62-9.

UNITED NATIONS EDUCATIONAL, SCIENTIFIC AND CULTURAL ORGANIZATION (UNESCO). Operational Guidelines for the Implementation of the World Heritage Convention. Disponível em: < http://whc.unesco.org/en/guidelines/> Acesso em: 15 setembro 2016.

Cultural Landscapes: the challenges of conservation. World Heritage Papers, n. 7. Paris: UNESCO, World Heritage Centre, 2003. Disponível em: $<$ http://whc.unesco. org/en/series/7/>. Acesso em: 15 setembro 2016.

Managing Historic Cities. World Heritage Papers, n. 27. Paris: UNESCO, World Heritage Centre, 2010. Disponível em: <http://whc.unesco.org/en/series/27/>. Acesso em: 15 setembro 2016.

VERHOEF, LGW \& R OERS, R. (Eds.) Proceedings of the second international symposium on restoration Dutch involvement in the conservation of cultural heritage 
overseas. Delft: Dup science, 2005.

VIANNA, Mônica. Barra Bonita e Bariri: de núcleo residencial a centro de lazer. In: SIMPÓSIO: A ORGANIZAÇÃO DO TERRITÓRIO PELO CAPITAL: O CASO DAS VILAS E NÚCLEOS GERADOS POR EMPRESAS. São Paulo, Universidade de São Paulo, setembro de 2004.

VICHNEWSKI, Henrique Telles. As indústrias Matarazzo no interior paulista: arquitetura fabril e patrimônio industrial (1920-1940). Dissertação (mestrado) - - Instituto de Filosofia e Ciências Humanas, Universidade Estadual de Campinas, Campinas, 2004.

VITALE, Letizia. Áreas industriais na orla ferroviária: valorização imobiliária ou valor urbano? Tese (doutorado) - Faculdade de Arquitetura e Urbanismo, Universidade de São Paulo, São Paulo, 2014.

VITORINO, Bruno Bonesso. Patrimônio ameaçado: os grupos residenciais construídos até 1930 no Brás, Móoca e Belém. Dissertação (mestrado) ) - Faculdade de Arquitetura e Urbanismo, Universidade de São Paulo, São Paulo, 2008.

XIE, Philip Feifan. Developing industrial heritage tourism. A case study of proposed jeep museum in Toledo, Ohio. Tourism Management 27 (2006). P. 1321-1330.

WHITEHAND, J.W.R. (ed.) The urban landscape: Historical development and Management. London : Academic Press, 1981.

WHITEHAND, J.W.R. ; LARKHAM, P.J. Urban landscapes: international perspectives. London : Routledge, 1992.

WHITEHAND, J.W.R. 'From Como to Alnwick: in pursuit of Caniggia and Conzen', Urban Morphology 7, 2003, p. 69-72.

YUNG, Esther \&CHAN, Edwin HW. Implementation challenges to the adaptive reuse of heritage buildings: towards the goals of sustainable, low carbon cities. Habitat International 36 (2012) p. 352-361.

ZAIA, I. B. Ferrovias, cidades e trabalhadores: os funcionários da Companhia Paulista de Estrada de Ferro: 1870-1920. In: SIMPÓSIO DE INICIAÇÃO CIENTÍFICA DA UNIVERSIDADE DE SÃO PAULO. Resumos... São Paulo, USP: 1999. v. 2, p. 323.

ZAMBELLO, Marco Henrique. Ferrovia e memória: estudo sobre o trabalho e a categoria dos antigos ferroviários da Vila Industrial de Campinas. Dissertação (mestrado) - Faculdade de Filosofia, Letras e Ciências Humanas, Universidade de São Paulo, São Paulo, 2005.

\section{COLEÇÕES DE REVISTAS E DOCUMENTAÇÃO OFICIAL}

Arquivo da Inventariança da extinta Rede Ferroviária Federal S. A. RFFSA 


\section{Relatórios da Companhia Paulista de Estradas de Ferro 1885 -1954 \\ Termos de Transferência - Superintendência do Patrimônio da União - SPU}

\section{LEGISLAÇÃO}

BRASIL. Decreto No. 4682, de 24 de janeiro de 1923. "Crea, em cada uma das emprezas de estradas de ferro existentes no paiz, uma caixa de aposentadoria e pensões para os respectivos ernpregados.". Disponível em: < http://www.planalto.gov.br/ccivil_03/decreto/Historicos/DPL/DPL4682.htm>. Acesso em 17 out. 2016.

BRASIL. Decreto-lei No. 25, de 30 de novembro de 1937. Organiza a proteção do patrimônio histórico e artístico nacional. Diário Oficial da União, Rio de Janeiro, 06 dez. 1937.

BRASIL. Lei 8.987, de 13 de fevereiro de 1995. Dispõe sobre o regime de concessão e permissão da prestação de serviços públicos previsto no art. 175 da Constituição Federal, e dá outras providências. Disponível em: $<$ http://www.planalto.gov.br/ccivil_03/leis/ L8987cons.htm>. Acesso em 17 out. 2016.

BRASIL. Lei 11.483, de 31 de maio de 2007. Dispõe sobre a revitalização do setor ferroviário, altera dispositivos da Lei No. 10.233, de 05 de junho de 2001, e dá outras providências. Disponível em: < http://www.planalto.gov.br/ccivil_03/_ato2007-2010/2007/lei/ 111483.htm>. Acesso em: 16 set. 2016.

BRASIL. Decreto No. 6.018, de 22 de janeiro de 2007. Regulamenta a Medida Provisória no 353, de 22 de janeiro de 2007, que dispõe sobre o término do processo de liquidação e a extinção da Rede Ferroviária Federal S.A. - RFFSA, altera dispositivos da Lei no 10.233, de 5 de junho de 2001, e dá outras providências. Disponível em: $<$ https://www. planalto.gov.br/ccivil_03/_ato2007-2010/2007/decreto/d6018.htm>. Acesso em: 16 nov. 2016.

BRASIL. Ministério da Cultura. Instituto do Patrimônio Histórico e Artístico Nacional IPHAN, Portaria No. 127, de 30 de Abril de 2009. Estabelece a chancela da paisagem cultural. Diário Oficial da União, Brasília, DF, 5 mai. 2009, Seção 1, p. 17

BRASIL. Ministério da Cultura. Instituto do Patrimônio Histórico e Artístico Nacional IPHAN, Portaria No. 407, de 21 de dezembro de 2010. Dispõe sobre o estabelecimento dos parâmetros de valoração e procedimento de inscrição na Lista do Patrimônio Cultural Ferroviário, visando à proteção da memória ferroviária, em conformidade com o art. $9^{\circ}$. da Lei No. 11.483/2007. Disponível em:< http://portal.iphan.gov.br/uploads/legislacao/ Portaria_Iphan_407_de_21_de_dezembro_de_2010.pdf>. Acesso em: 16 set 2016.

BRASIL. Ministério da Cultura. Instituto do Patrimônio Histórico e Artístico Nacional - IPHAN/ Ministério do Planejamento, Orçamento e Gestão. Superintendência do Patrimônio da União. Portaria Interinstitucional No. 1, de 14 de setembro de 2011. Dispõe sobre o estabelecimento de procedimentos conjuntos entre o Instituto do Patrimônio 
Histórico e Artístico Nacional -IPHAN e a Secretaria do Patrimônio da União - SPU em relação a bens imóveis não operacionais oriundos da extinta Rede Ferroviária Federal S. A. - RFFSA que possam ter valor histórico, artístico e cultural, visando à proteção da memória ferroviária, em conformidade com o art. $9^{\circ}$ da Lei 11.483/07. Diário Oficial da União, Brasília, DF, 14 de setembro de 2011, Seção 1, p. 11.

\section{CARTAS PATRIMONIAIS}

CONSELHO DA EUROPA. CONGRESSO DO PATRIMÔNIO EUROPEU. Declaração de Amsterdã, out. 1975. Disponível em:< http://portal.iphan.gov.br/uploads/ckfinder/ arquivos/Declaracao\%20de\%20Amsterda\%CC\%83\%201975.pdf $>$. Acesso em: 16 set. 2016.

CONSELHO DA EUROPA. COMITÊ DE MINISTROS. Recomendação da Europa. 11 set. 1995. Disponível em: <http://portal.iphan.gov.br/uploads/ckfinder/arquivos/Recomendacao\%20Europa\%201995.pdf>. Acesso em: 16 set. 2016.

ICCROM; ICOMOS; UNESCO. Conferência de Nara, 1994. Disponível em:< http:// portal.iphan.gov.br/uploads/ckfinder/arquivos/Conferencia\%20de $\% 20 \mathrm{Nara} \% 201994$. pdf>. Acesso em: 16 set. 2016.

ICOMOS. Carta de Atenas. 1931. Disponível em: < http://portal.iphan.gov.br/uploads/ ckfinder/arquivos/Carta\%20de\%20Atenas\%201931.pdf >. Acesso em: 16 set. 2016.

ICOMOS. Carta de Veneza. 1964. Disponível em: < http://portal.iphan.gov.br/pagina/ detalhes/226>. Acesso em: 16 set. 2016.

ICOMOS. Carta de Turismo Cultural. 1976. Disponível em: < http://portal.iphan. gov.br/uploads/ckfinder/arquivos/Carta\%20de\%20Turismo\%20Cultural\%201976.pdf>. Acesso em: 16 set. 1976.

ICOMOS. Carta de Burra. 1980. Disponível em: < http://portal.iphan.gov.br/uploads/ ckfinder/arquivos/The-Burra-Charter-2013-Adopted-31_10_2013.pdf $>$. Acesso em: 16 set. 2016.

ICOMOS/IFLA. Carta de Florença 1981. Disponível em: < http://portal.iphan.gov.br/ uploads/ckfinder/arquivos/Carta\%20de\%20Florenc\%CC\%A7a\%201981.pdf $>$. Acesso em: 16 set. 2016.

ICOMOS. Declaração de Tiaxcala. 1982. Disponível em: < http://portal.iphan.gov.br/ uploads/ckfinder/arquivos/Declaracao\%20de\%20Tlaxcala\%201982.pdf>. Acesso em: 16 set. 2016.

ICOMOS. Declaração do México. 1985. Disponível em: < http://portal.iphan.gov.br/ uploads/ckfinder/arquivos/Declaracao\%20do\%20Mexico\%201985.pdf>. Acesso em: 16 set. 2016.

ICOMOS. Carta de Washington. 1987. Disponível em: <http://portal.iphan.gov.br/ 
uploads/ckfinder/arquivos/Carta\%20de\%20Washington\%201987.pdf>. Acesso em: 16 set. 2016.

ICOMOS. Declaração de Sofia. 9 out. 1996. Disponível em:< http://portal.iphan. gov.br/uploads/ckfinder/arquivos/Declaracao\%20de\%20Sofia\%201996.pdf>. Acesso em: 16 set. 2016.

ICOMOS. Québec Declaration. On the Preservation of the Spirit of Place. Québec, October, 2008. Disponível em: <http://www.icomos.org/quebec2008/quebec_declaration/ pdf/GA16_Quebec_Declaration_Final_EN.pdf>.Acesso em: 16 set. 2016.

ICOMOS. The Valletta Principles for the Safeguarding and Management of Historical Cities, Towns And Urban Areas. CIVVIH, april, 2010. Disponível em: $<$ http:// civvih.icomos.org/sites/default/files/Valletta\%20Principles\%20Book\%20in $\% 205 \% 20$ languages.pdf $>$. Acesso em: 16 set. 2016.

IPHAN. Compromisso de Brasília, 1970. Disponível em: < http://portal.iphan.gov.br/ pagina/detalhes/226>. Acesso em: 16 set. 2016.

IPHAN. Compromisso de Salvador, 1971. Disponível em: < http://portal.iphan.gov.br/ pagina/detalhes/226>. Acesso em: 16 set. 2016.

IPHAN. Carta de Petrópolis. 1987. Disponível em: < http://portal.iphan.gov.br/ uploads/ckfinder/arquivos/Carta\%20de\%20Petropolis\%201987.pdf $>$. Acesso em: 16 set. 2016.

IPHAN. Carta de Brasília (Documento Regional do Cone Sul sobre autenticidade). 1995. Disponível em: < http://portal.iphan.gov.br/uploads/ckfinder/arquivos/Carta\%20 Brasilia\%201995.pdf>. Acesso em: 16 set. 2016.

IPHAN. Declaração de São Paulo II (Recomendações brasileiras à XI Assembléia Geral do ICOMOS). 1996. Disponível em: http://portal.iphan.gov.br/uploads/ckfinder/arquivos/Declaracao\%20de\%20Sao\%20Paulo\%201996.pdf. Acesso em: 16 set. 2016.

ITÁLIA. Mínistério de Instrução Pública. Carto do Restauro. 1972. Disponível em: < http://portal.iphan.gov.br/uploads/ckfinder/arquivos/Carta\%20do\%20Restauro\%201972. pdf>. Acesso em: 16 set. 2016.

OEA. Normas de Quito, 1967. Disponível em: <http://portal.iphan.gov.br/pagina/detalhes/226>. Acesso em: 16 set. 2016.

TICCIH. Carta de Nizhny Tagil sobre o Patrimôno Industrial. Julho 2003. Tradução: APPI. Disponível em: < http://ticcih.org/wp-content/uploads/2013/04/NTagilPortuguese. pdf $>$. Acesso em: 16 set. 2016.

TICCIH. The Dublin Principles. Joint ICOMOS - TICCIH Principles for the Conservation of Industrial Heritage Sites, Structures, Areas and Landscapes. $28^{\text {th }}$ November 2011. Disponível em: <http://ticcih.org/wp_content/uploads/2013/10/GA2011_ICOMOS_TICCIH_joint_principles_EN_FR_final_20120110.pdf>. Acesso em: 16 set. 2016. 
UNESCO. Recomendação de Paris. Paisagens e sítios. 1962. Disponível em: < http:// portal.iphan.gov.br/uploads/ckfinder/arquivos/Recomendacao\%20de\%20Paris\%201962. pdf>. Acesso em: 16 set. 2016.

UNESCO. Recomendação de Paris. Obras Públicas ou Privadas. 1968. Disponível em: $<$ http://portal.iphan.gov.br/uploads/ckfinder/arquivos/Recomendacao $\% 20 \mathrm{de} \% 20$ Paris\%201968.pdf>. Acesso em: 16 set. 2016.

UNESCO. Declaração de Estocolmo. 1972. Disponível em: < http://portal.iphan.gov.br/ uploads/ckfinder/arquivos/Declaracao\%20de\%20Estocolmo\%201972.pdf>. Acesso em: 16 set. 2016.

UNESCO. Recomendações de Nairóbi 1976. Disponível em: < http://portal.iphan. gov.br/uploads/ckfinder/arquivos/Recomendacao\%20de\%20Nairobi\%201976.pdf>. Acesso em: 16 set. 2016.

UNESCO. Declaração de Nairóbi. Quênia, 1982. Disponível em: < http://portal.iphan. gov.br/uploads/ckfinder/arquivos/Declaracao\%20de\%20Nairobi\%201982.pdf $>$. Acesso em: 16 set. 1982.

\section{WEBSITES}

ESTAÇÕES FERROVIÁRIAS DO BRASIL. Disponível em: $<$ http://www.estacoesferroviarias.com.br>. Acesso em: 11 jun. 2013.

PREFEITURA MUNICIPAL DE BROTAS. Disponível em: < http://www.brotas.sp.gov. br/page.php? $p=$ aspectos_historicos.php>.Acesso em: 11 jun. 2013.

PREFEITURA MUNICIPAL DE DOIS CÓRREGOS. Disponível em: <http://pmdoiscorregos.conexaosegura.net>. Acesso em: 10 jun. 2013.

PREFEITURA MUNICIPAL DE ITIRAPINA. Disponível em: $<$ http://www.camaraitirapina.sp.gov.br/historico.html.> Acesso em: 06 jun. 2013.

PREFEITURA MUNICIPAL DE JAÚ. Disponível em: < http://www.jau.sp.gov.br/conhecajau_historia.php.> Acesso em: 13 jun. 2013.

PREFEITURA MUNICIPAL DE RINCÃO. Disponível em: < http://www.rincao.sp.gov. br/historia.html.> Acesso em: 12 jun. 2013.

PREFEITURA MUNICIPAL DE SÃO CARLOS. Disponível em: < http://www.saocarlos.sp.gov.br/index.php/historia-da-cidade/115269-historia-de-sao-carlos.html.> Acesso em: 17 jun. 2013. 
Apêndice

APÊNDICE A - Algumas informações das cidades pesquisadas

APÊNDICE B - População das cidades pesquisadas entre 1907 à 2010, segundo dados do IBGE 


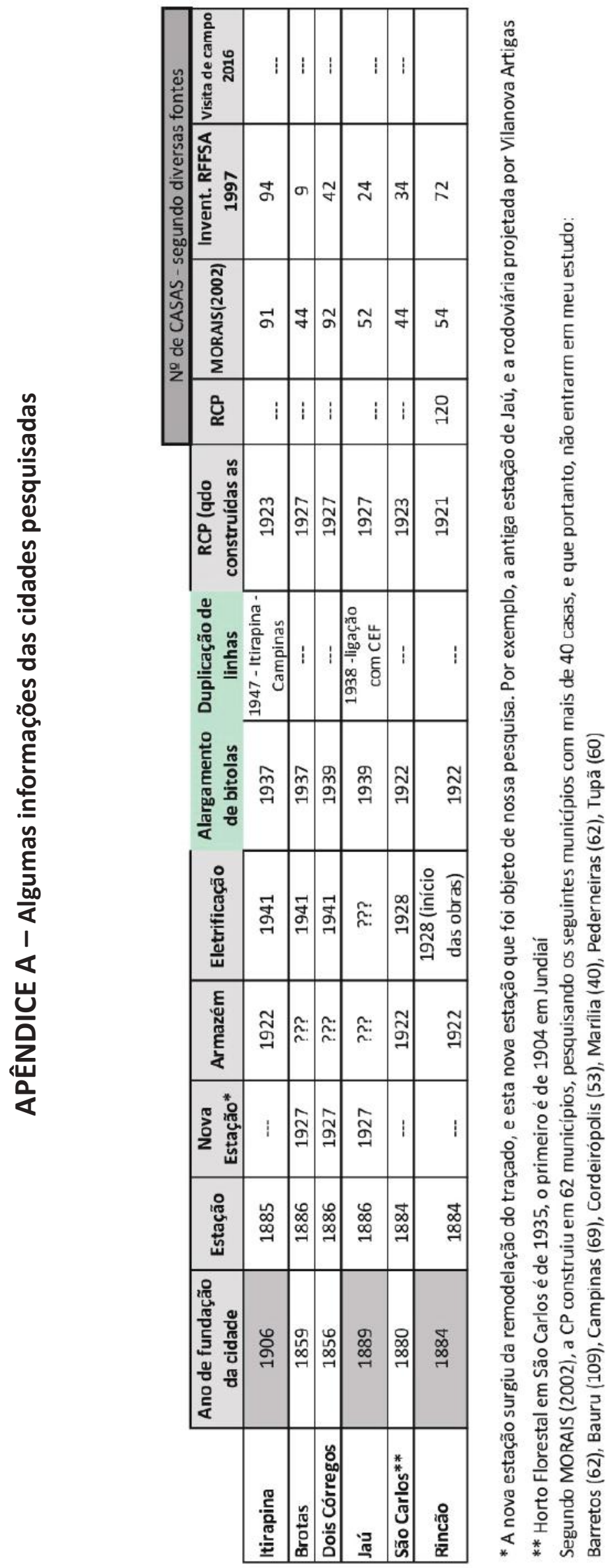




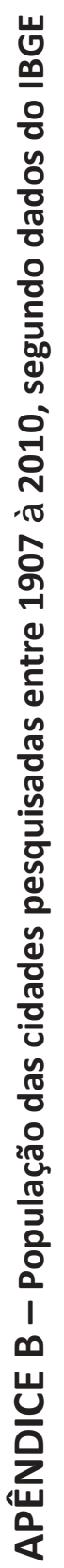

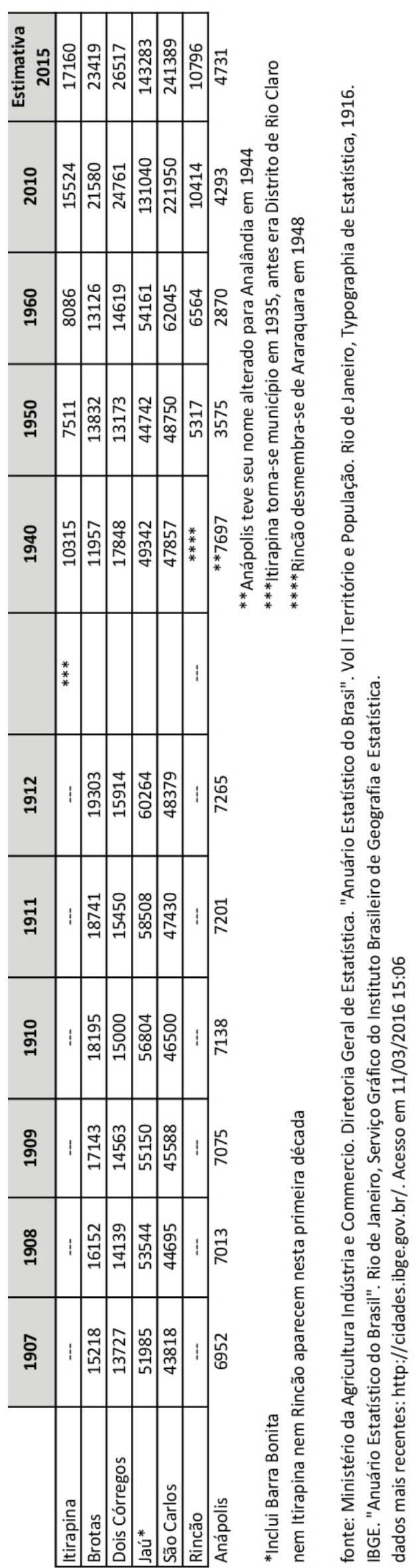

